\title{
Volgens de regelen van de kunst : de strafrechtelijke aansprakelijkheid van de medicus voor professioneel uitgevoerde handelingen
}

Citation for published version (APA):

Wöretshofer, J. (1992). Volgens de regelen van de kunst : de strafrechtelijke aansprakelijkheid van de medicus voor professioneel uitgevoerde handelingen. [Doctoral Thesis, Maastricht University]. Gouda Quint. https://doi.org/10.26481/dis.19920605jw

Document status and date:

Published: 01/01/1992

DOI:

10.26481/dis.19920605jw

Document Version:

Publisher's PDF, also known as Version of record

Please check the document version of this publication:

- A submitted manuscript is the version of the article upon submission and before peer-review. There can be important differences between the submitted version and the official published version of record.

People interested in the research are advised to contact the author for the final version of the publication, or visit the DOI to the publisher's website.

- The final author version and the galley proof are versions of the publication after peer review.

- The final published version features the final layout of the paper including the volume, issue and page numbers.

Link to publication

\footnotetext{
General rights rights.

- You may freely distribute the URL identifying the publication in the public portal. please follow below link for the End User Agreement:

www.umlib.nl/taverne-license

Take down policy

If you believe that this document breaches copyright please contact us at:

repository@maastrichtuniversity.nl

providing details and we will investigate your claim.
}

Copyright and moral rights for the publications made accessible in the public portal are retained by the authors and/or other copyright owners and it is a condition of accessing publications that users recognise and abide by the legal requirements associated with these

- Users may download and print one copy of any publication from the public portal for the purpose of private study or research.

- You may not further distribute the material or use it for any profit-making activity or commercial gain

If the publication is distributed under the terms of Article $25 \mathrm{fa}$ of the Dutch Copyright Act, indicated by the "Taverne" license above, 
Volgens de regelen van de kunst 



\title{
Volgens de regelen van de kunst
}

De strafrechtelijke aansprakelijkheid van de medicus voor professioneel uitgevoerde handelingen

\author{
Proefschrift
}

ter verkrijging van de graad van doctor aan de Rijksuniversiteit

Limburg te Maastricht, op gezag van de

Rector Magnificus, prof. mr. M.J. Cohen, volgens het besluit van het College van Dekanen, in het openbaar te verdedigen, op vrijdag 5 juni 1992 om 16.00 uur

door

Jürgen Wöretshofer

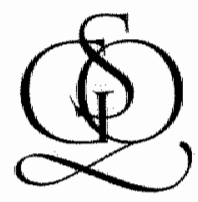

Gouda Quint BV

(S. Gouda Quint - D. Brouwer en Zoon)

Arnhem 
Promotores:

Prof. mr. G.P.M.F. Mols

Prof. mr. F.B.C. van Wijmen

Beoordelingscommissie:

Prof. mr. Th.A. de Roos (voorzitter)

Prof. mr. T.M. Schalken (Vrije Universiteit Amsterdam)

Prof. mr. B. Sluyters (Rijksuniversiteit Leiden) 


\section{Inhoudsopgave}

\section{De Hüzer veearts en de medicus}

1 Het eerste Huizer veearts-arrest

2 Het tweede Huizer veearts-arrest

3 De betekenis van de Huizer veearts-arresten 14

3.1 Inleiding

3.2 Het ontbreken van de materiële wederrechtelijkheid als exceptief verweer

3.3 Het ontbreken van de materiële wederrechtelijkheid als kwalificatieverweer

3.4 De concretisering van de wederrechtelijkheid

3.5 De medische exceptie respectievelijk het beroepsrecht 18

4 Conclusie

\section{Mishandeling}

$1 \quad$ Inleiding

2 De wetsgeschiedenis van mishandeling en van dierenmishandeling 24

2.1 Dierenmishandelling

2.1.1 De totstandkoming van art. 254-oud $\mathrm{Sr}$ in 1881

2.1.2 Jurisprudentie en literatuur over art. 254-oud $\mathrm{Sr} \quad 26$

2.1.3 Wetswoorstellen tot wijziging wan art. 254-oud $\mathrm{Sr} \quad 27$

$\begin{array}{ll}2.2 & \text { Mishandeling } 28\end{array}$

2.2.1 Inleiding 28

2.2.2 Parlementaire behandeling van de mishandeling 29

2.2.3 Mishandeling in de novelle-Cort van der Linden, 1900

2.3 Conclusie 32

3 De strafrechtelijke aansprakelijkheid van de medicus 32

$3.1 \quad H e t$ voor mishandeling vereiste opzet 32

3.1.1 Formele en materiële opzetdelicten 32

3.1.2 Opzet 33

3.1.3 Opzet en oogmerk 33

3.1.4 Oogmerk en delictsomschrijving 35

3.1.5 Geen mishandeling, omdat het vereiste opzet ontbreekt 35

$\begin{array}{lll}3.1 .6 & \text { Conclusie } & 38\end{array}$

3.2 Een medlische behandeling is geen mishandeling 39

3.2.1 Inleiding 39 
3.2.2 De aard van de handeling 39

3.3 Toestemming en verzoek 41

3.3.1 Inleiding 41

3.3.2 Twee benaderingen 41

3.3.3 Twee belangen $\quad 42$

3.3.4 Rechtsgeldige toestemming 43

3.3.5 Drie opvattingen over toestemming bij mishandeling 43

3.3.6 Conclusile 46

3.4 Ontbreken van de (materiële) wederrechtelijkheid 46

3.5 Medische exceptie en beroepsrecht 48

3.5.1 Inleiding 48

3.5.2 De medische exceptie 48

3.5.3 Het beroepsrecht 51

3.5.4 Een medische exceptie in het WvSr? 52

3.5.5 De medische exceptie bij mishandeling en de Hoge Raad 53

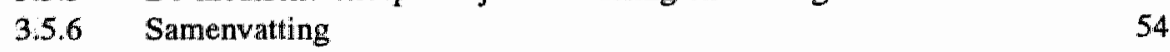

4 Conclusie $\quad 54$

\section{Abortus}

$1 \quad$ Inleiding 57

2 De wetsgeschiedenis van de artt. $295-298 \mathrm{Sr} \quad 58$

$2.1 \quad$ Inleiding 58

2.2 De tekst van de artikelen $295-298 \mathrm{Sr}$

2.3 De totstandkoming van de artikelen $295-298 \mathrm{Sr} \quad 60$

2.4 Conclusie $\quad 64$

3 Opvattingen van juristen over de strafbaarheid van abortus 65

4. Opvattingen van medici over de strafwaardigheid van abortus 66

$5 \quad$ Straffeloosheid vanwege overmacht? $\quad 67$

6 De abortusbepalingen in de novelle-Cort van der Linden, $1900 \quad 68$

7 De abortusbepalingen in de novelle-Loeff, $1904 \quad 70$

8 De opvattingen van medici over abortus $\quad 72$

9 Het standpunt van Simons $\quad 74$

10 De Gemengde Commissie van $1909 \quad 75$

11. Abortus en de zedelijkkheidswetgeving 1911

11.1 Inleiding 76

11.2 Art. 451ter en het beroepsrecht van de medicus 77

11.3 Art. 251 bis en het beroepsrecht van de medicus 78

11.4 Een verschil van mening over de erkenning van het beroepsrecht 84

11.5 De voorgestelde abortusbepaling in de Eerste Kamer 85

11.6 Conclusie 86

12 Beroepsrecht, medische exceptie en abortus 86

13 Rechtspraak over art. 251bis $\mathrm{Sr} \quad 88$

14 Opvattingen over abortus door een medicus 89

14.1 Na 1911 tot de jaren vijftig 89

14.2 In de jaren vijftig en de beginjaren zestig 92

14.3 Vanaf het midden van de jaren zestig 92

15 Rechtspraak over abortus lege artis door een medicus 96

16 De opvatting van Enschedé 99 
18 Straffeloosheid vanwege medische indicatie 101

19 De verschillende wetswoorstellen inzake abortus 102

19.1 Inleiding

19.2 Het wetsvoorstel 10719 (Lamberts/Roethof) 104

19.3 Het wetsvoorstel 11890 (Stuyt/Van Agt) 106

19.4 Het wetsvoorstel 13253 (Van Schaik/Van Leeuwen) 108

19.5 Het wetsvoorstel 13302 (Veder-Smit/Geurtsen) 109

19.6 Het wetsvoorstel 13909 (Geurtsen/Lamberts/Roethof/Veder-Smit) 111

19.7 Het wetsvoorstel 15476 (Abma/Verbrugh) 112

$\begin{array}{lll}19.8 \text { Conclusie } & 113\end{array}$

20 De Wet Aforeking Zwangerschap (WAZ) 114

20.1 Inleiding 114

20.2 Structuur van de nieuwe abortusregeling 115

20.3 De aansprakelijkheid van de medicus vanwege het WvSr $\quad 116$

$\begin{array}{ll}20.3 .1 & 116 \\ 20.3 .2 & 116\end{array}$

20.3.2 De strafbaarstelling $\quad 116$

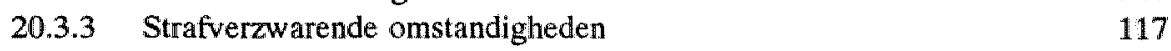

$\begin{array}{ll}\text { 20.3.4 De strafuitsluitingsgrond } & 11.8\end{array}$

20.3.5 Het afdrijven van een levenswatbare vrucht 119

$\begin{array}{ll}\text { 20.3.6 De overtijdsbehandeling } & 121\end{array}$

20.4 De aansprakelijjkheid van de medicus vanwege de WAZ 122

$\begin{array}{ll}20.5 & \text { Geen materiële normstelling } \\ 20.6 & 124\end{array}$

20.6 Geen medische exceptie bij abortus door een medicus 124

21 Samenvatting 125

\section{Thanasie}

Inleiding

$1 \quad$ De wetsgeschiedenis van de artt. 293 en $294 \mathrm{Sr} \quad 129$

$\begin{array}{lll}1.1 & \text { De totstandkoming van art. } 293 \mathrm{Sr} \text {, levensberoving op verzoek } & 129\end{array}$

1.2 De totstandkoming van art. $294 \mathrm{Sr}$, hulp bij zelfmoord $\quad 130$

$\begin{array}{lll}1.3 & \text { Conclusie } & 132\end{array}$

2 Gedachten over thanasie vanaf $1880 \quad 133$

$\begin{array}{lll}2.1 & \text { Inleiding } & 133\end{array}$

$2.2 \quad$ Gedachten over thanasie tot $1910 \quad 134$

2.3 Gedachten over thanasie tussen 1910 en $1960 \quad 136$

$2.4 \quad$ Gedachten over thanasie in de jaren zestig 140

2.5 Gedachten over thanasie vanaf de jaren zeventig 141

2.6. Het woorlopig standpunt inzake euthanasie van het Hoofdbestuur van de KNMG in 1973

2.7 De discussienota Euthanasie van de Werkgroep Euthanasie van de KNMG

2.8 Het Standpunt wan het Hoofdbestuur van de KNMG van 1984 inzake euthanasie 
3.2 "Vrijwillige" en "onvrijwillige euthanasie"

3.3 "Directe" en "indirecte euthanasie"

3.4 "Passieve euthanasie"

3.4.1 Inleiding 154

3.4.2 De patient verleent geen toestemming tot de behandeling 155

3.4.3 Medisch zinloos handelen 157

$3.5 \quad$ Een vierde schijngestalte? 158

4 Conclusie 159

\section{B Euthanasie}

1 Voorstellen tot wetgeving 160

1.1 Inleiding 160

$\begin{array}{ll}1.2 \text { Voorgeschiledenis } & 160\end{array}$

13 Het initiatiefvoorstel 161

1.4 Het eindrapport van de Staatscommissie Euthanasie 162

$\begin{array}{lll}1.5 & \text { De Proeve } & 165\end{array}$

1.6 Een wettelijke regeling van euthanasie en het EVRM 167

1.7 Onderlinge vergelijking van het (gewijzigd) initiatiefvoorstel, $\begin{array}{ll}\text { het advies en de Proeve } & 170\end{array}$

1.7.1 De strafbepaling van levensbeëindiging op verzoek $\quad 170$

1.7.2 De constructie van de bijzondere rechtvaardigingsgrond 170

1.7.3 De constructie van de bijzondere schulduitsluitingsgrond in de Proeve 172

$\begin{array}{ll}\text { 1.7.4 Uitvoering door een arts } & 173\end{array}$

$\begin{array}{ll}1.7 .5 & \text { De situatie van de patiẽnt } \\ 1.73\end{array}$

1.7.6 De relatie tot de zorgvuldigheidseisen $\quad 176$

$\begin{array}{ll}1.7 .7 & 176 \\ 1.7 .8 & 176\end{array}$

$\begin{array}{lll}1.7 .8 & \text { De voorlichtingseis } & 177\end{array}$

1.7.9 De uitzichtloze noodsituatie en de (gezamenlijke) besluitvorming 178

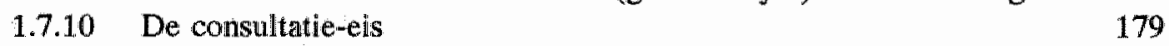

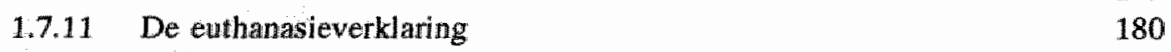

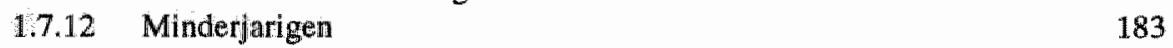

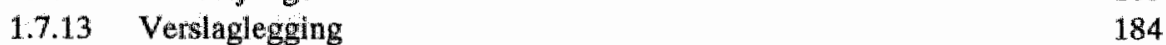

1.7.14 De verklaring van overlijden $\quad 185$

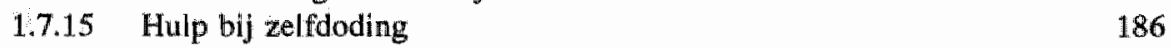

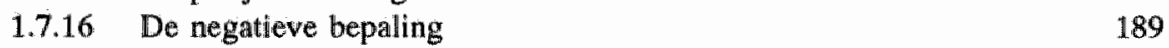

$\begin{array}{lll}1.8 & \text { Het kabinetswoorstel } & 191\end{array}$

$\begin{array}{ll}19 & \text { Het rapport van de Commissie Onderzoek Medische Praktijk } \\ \text { inzake Euthanasie } & 195\end{array}$

1.10 Het kabinetsstandpunt inzake medische beslissingen

1:11 Samenvatting 201

2 Strafuitsluiting bij euthanasie 203

2.1 Inleiding 203

2.2 De gedraging voldoet niet aan de bewoordingen van

$\begin{array}{ll}2.2 .1 & \text { Inleiding } 204\end{array}$ 
2.2.2 "Van het leven beroven"

2.2.3 "Van het leven benemen"

2.3 Ontbreken van de materiële wederrechtelijkheid 208

2.3.1 Inleiding 208

2.3.2 Betere naleving van de strekking van de wet 208

2.3.3 De materiële wederrechtelijkheid ontbreekt

vanwege de rechtsiontwikkeling

2.3.4 Het ontbreken van de materiële wederrechtelijkheid bij euthanasie in de jurisprudentie

$2.4 \quad$ Medische exceptie en beroepsrecht 216

2.4.1 Inleiding

2.4.2 De wetgever heeft de medische exceptie ten aanzien van euthanasie niet erkend

2.4.3 De medische exceptie in de jurisprudentie over euthanasie

2.4.4 Samenvatting

$2.5 \quad$ Noodtoestand

2.5.1 Inleiding

2.5.2 Culpa in causa

2.5.3 Proportionaliteit en subsidiariteit

2.5.4 Samenvatting

2.6 Psychische overmacht, gewetensdrang en gewetensbezwaren

2.6.2 Culpa in causa

2.6.3 "Garantenstellung"

2.6.4 Gewettensdrang en gewetensberwaren

2.6.5 Conclusie

$\begin{array}{lll}2.7 & \text { Voorwaarden voor euthanasie } & 229\end{array}$

2.7.1 Inleiding

2.7.2 Voorwaarden aan de kant van de patiënt 231

2.7.3 Voorwaarden aan de kant van de hulpverlener 233

2.7.4 Voorwaarden en de Hoge Raad 236

$\begin{array}{ll}2.7 .5 & \text { Voorwaarden voorwaardelijk? } \\ 2.88\end{array}$

$\begin{array}{lll}2.8 & \text { De vervolging van euthanasie } & 238\end{array}$

3 Conclusie

2 Recente medisch-ethische benaderingen van "levensbeëindiging"

2.2 Medisch zinloos handelen bij zwar-defecte pasgeborenen

2.4 Medisch en ethisch zinlloos handelen bij irreversibel comateuze patiënten

2.5 Morele rechtvaardiging van nalaten van ethisch zinloos handelen bij zwaar-defecte pasgeborenen

2.6 Morele rechtvaardiging van nalaten van medisch/ethisch zinloos handelen bij irreversibel comateuze patiënten 
2.8 Besluitvorming bij irreversibel comateuze patiënten $\quad 262$

2.9 Vormen van levensbeeindiging 263

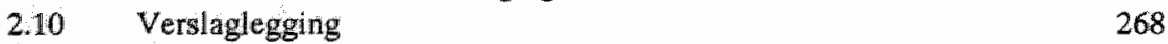

211 De overlijdenswerklaring. 269

2.12 De wenselijkheid van een regeling ten aanzien van levensbeëindiging bij pasgeborenen $\quad 270$

213 Lewensbeêindiging bij emstig geestelijk gehandicapten 271

2.14 Samenvatting 275

3 Voorstellen tot een wettelijke regeling met betrekking tot

4. Strafuitsluiting bij levensbeëindiging 281

$\begin{array}{lll}4.1 & \text { Inleiding } & 281\end{array}$

$\begin{array}{ll}4.2 & \text { Toepasselijke strafbepalingen } \\ 4.3 & 282\end{array}$

4.3 Omissiedelicten en zorgplicht 283

4.4 Levensbeeindiging en strafuitsluiting 285

$\begin{array}{ll}4.4 .1 & \text { Inleiding } \\ 4.4 .285\end{array}$

4.4.2 Medische exceptie $\quad 286$

4.4.3 Overmacht in de zin van noodtoestand 286

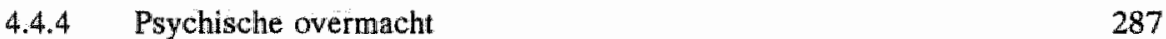

$\begin{array}{ll}4.4 .5 & \text { De omstandigheden } \\ 4.4 .6 & 289\end{array}$

$\begin{array}{lll}4.4 .6 & \text { Conclusie } & 291\end{array}$

4.4.7 Een uitstap naar de burgerlijke rechter 291

4.4.8 De zaak "baby Ross" 293

5 Conclusie $\quad 304$

\section{Slotbeschouwing}

$1 \quad$ Mishandeling $\quad 307$

2 De problematiek van omstreden handelen van de medicus 307

$\begin{array}{lll}2.1 & \text { Abortus } & 308\end{array}$

2.2 Thanasie 309

$\begin{array}{lll}2.2 .1 & \text { Algemeen } & 309\end{array}$

2.2.2 Wat moet en wat kan de wetgever doen? 313

$\begin{array}{lll}2.2 .3 & \text { Thanasie bij wilsbekwame patiēnten } & 314\end{array}$

2.2.4 Thanasie bij wilsonbekwame patiënten 316

3 Samenvatting $\quad 317$

$\begin{array}{lr}\text { Samenvatting } & 319\end{array}$

Zusammenfassung $\quad 333$

$\begin{array}{ll}\text { Lijst van aangehaalde literatuur } & 341\end{array}$

$\begin{array}{ll}\text { Jurisprudentieregister } & 357\end{array}$

$\begin{array}{ll}\text { Register aangehaalde auteurs } & 361\end{array}$

$\begin{array}{ll}\text { Curriculum vitae } & 367\end{array}$ 


\section{Lijst van afkortingen}
AA
Ars Aequi
$A-G$
Adwocaat-Generaal
BUPO
$\mathrm{CAL}$
DD
Internationaal Verdrag inzake Burgetlijke en Politieke Rechten
Doen of laten
KNMG-Commissie Aanvaardbaarheid levensbeeindigend handelen
Delikt en Delinkwent
EVRM
G.O.
Nederlandse Vereniging voor Kindergeneeskunde, Doen of laten?
Europees Verdrag tot bescherming van de rechten van de mens en de fundamentele vrijheden
G.V.
Gewijzigd ontwerp
GW
Gewijzigd voorstel van wet
$\mathrm{H}$
Grondwet
Hoofdstuk
HEK
HR
Handelingen Eerste Kamer
HTK
KNMG
$\mathrm{MC}$
Hoge $\mathbb{R a a d}$
Handelingen Tweede Kamer
Koninklijke Nederlandsche Maatschappij tot bevordering der Genees- kunst
Medisch Contact
MvA
MvJ
MvT
NJ
NJB
NLR
NMG
NTvG
Memorie van Antwoord
Minister van Justitie
Memorie van Toelichting
Nederlandse jurisprudentie
Nederlands Juristenblad
T.J. Noyon, Het Wetboek van Strafrecht, zevende druk, 1977, losblaw dig, bewerkt door J. Remmelink
Nederlandsche Maatschappij tot bevordering der Geneeskunst
Nederlands Tijdschrift voor Geneeskunde
OM
Openbaar Ministerie
O.R.O.
Oorspronkelijk regeringsontwerp
OvJ
P-G
P.v.J.
Officier van Justitie
Procureur-Generaal
Rb.
Paleis van Justitie
Arrondissementsrechtbank
RR
Tijdschrift voor Rechtstheorie en Rechtsfilosofie
RvS Raad van State
$\mathrm{Sr}$
Wetboek van Strafrecht
Stb.
Staatsblad
Sv Wetboek van Strafvordering
TVGR
Tijdschrift voor Gezondheidsrecht 
TwS

W

WLB

WvSr

WvSv

W.V.

WUG
Tijdschrift voor Strafrecht

Weekblad van het Recht

Wet op de lijkbezorging.

Wetboek van Strafrecht

Wetboek wan Strafvordering

wetsvoorstel

Wet op de tittoefening van de geneeskunst 


\section{Inleiding}

In dit boek wordt de strafrechtelijke aansprakelijkheid van de medicus voor professioneel uitgevoerde handelingen jegens patienten beschreven.

Dag in dag uit verrichten medici handelingen die een strafbaar karakter lijken te hebben, namelijk telkens wanneer zij aan een patiënt pijn of letsel toebrengen. Dat betreft zowel kleine handelingen, bijvoorbeeld een prik voor een bloedonderzoek als ingrijpende handelingen, zoals een zware operatie.

Wanneer iemand anders dan een arts aan een derde pijn of letsel toebrengt, dan verdenken we hem van mishandeling. Bij het handelen van de arts denken we daar echter pas aan, als zich bijzondere omstandigheden hebben voorgedaan.

Onder mishandelling wordt begrepen het opzettelijk toebrengen van pijn of letsel. Een medische ingreep lijkt daarmee aan de delictsomschrijving van mishandeling te beantwoorden. Indien de delictsomschrijving zelf niet reeds de ruimte biedt om het aldus bedoelde medisch handelen van de aansprakelijkheid uit te zonderen, dan zou een medicus in beginsel wellicht enkele keren per dag een strafbare handeling verrichten, tenzij een rechtvaardigingsgrond het wederrechtelijk karakter van de handeling wegneemt.

Uit het Wetboek wan Strafrecht (Sr) blijkt niet, waarom de medicus voor deze handelingen niet strafbar zou zijn. Weliswaar kan hij, zoals leder ander, een beroep doen op de wettelijke strafuitsluitingsgronden, maar die gronden zijn eigenlijk bedoeld voor uitzonderlijke omstandigheden, die een inbreuk vormen op het uitgangspunt dat ledereen die een handeling verricht die aan een delictsomschrijving beantwoordt zich schuldig maakt aan een strafbaar feit en deswege strafbaar is.

Het doet geforceerd aan, om te stellen dat een medische behandeling geen strafbaar feit oplevert, doordat bijvoorbeeld in overmacht in de zin van noodtoestand is gehandeld. Dan zou geredeneerd moeten worden, dat de medicus zich in een noodsituatie bevindt en dat hij in die situatie de juiste keuze maakt tussen het belang dat de strafbepaling beschermt en het belang van de patient. Het belang van de gezondheid van de patient zou dan een meerwaarde bezitten ten opzichte van het belang dat met de naleving van de strafbepaling wordt nagestreefd.

Noodtoestand is een rechtvaardigingsgrond. Voor zover de straffeloosheild van de medicus met behulp van een schulduitsluitingsgrond geconstrueerd zou moeten worden, is de oplossing nog minder in overeenstemming met de realiteit. Want de consequentie hiervan zou zijn, dat de alledaagse beroepsuitoefening van de medicus in beginsel een strafbaar karakter heeft. Toegesneden op het medisch handelen, houdt een schulduitsluitïngsgrond immers in, dat de medicus wel wederrechtelijk heeft gehandeld, marr dat hem het strafbare feit om hem moverende redenen niet in die mate verweten kan worden dat hij strafbaar is. Daarmee zou de beroepsuitoefening van de medicus gestigmatiseerd en gecriminaliseerd zijn. 
Het algemeen gevoelen dat medisch handelen in beginsel niet strafrechtelijk relevant is, vindt niet alleen bewestiging in geneeskundige wetten, maar tevens in de Grondwet en in initernationale verdragen.

Volgens art. $221 \mathrm{id} 1 \mathrm{GW}$ treft de owerheid" "maatregelen ter bevordering van de volksgezondheid". Art. 5 onder d Internationaal Verdrag inzake de uitbanning van rassendiscriminatie, noemt als een wan de burgerrechten: "het recht op openbare gezondheidszorg, geneeskundige verzorging, sociale zekerheid en sociale diensten" ."

Art. 12 Internationaal Verdrag inzake economische, sociale en culturele rechten bepaalt in lid 1: "De Staten die partij zijn bij dit Verdrag erkennen het recht van een ieder op een zo goed mogelijke lichamelijke en geestelijke gezondheid" en in lid 2 onder meer" De door de Staten die partij zijn bij dit Verdrag te nemen matregelen ter vollledige verwezenlijking van dit recht omvatten onder meer die welke nodig zijn om te komen tot: ... $\mathbb{d}$. Het scheppen van omstandigheden die een ieder in geval van ziekte geneeskundige bijstand en verzorging waarborgen".

Terwijl op de overheid de verplichting rust de gezondheidszorg in algemene zin te bevorderen, kenmerkt zich de beroepsuitoefening van de medicus door handelen ten dienste van de gezondheid van zijn patiënten.

Het strafrecht heeft tot taak de rechtsorde te beschermen. Door het strafrecht zwaar beschermde rechtsgoederen zijn het menselijk leven en de lichamelijke integriteit van de mens: De hierop betrekking hebbende strafbepalingen zijn vooral te vinden in het Tweede Boek van het Wetboek van Strafrecht en wel in de Titels XIX en XX, die luiden "Misdrijven tegen het leven gericht" en "Mishandeling".

De bescherming van de lichamelijke integriteit en het recht op leven zijn grondrechten, die zowel in de Grondwet als in internationale regelgewing zijn neergelegd. Art. $11 \mathrm{GW}$ bepaalt: "Ieder heeft, behoudens bij of krachtens de wet te stellen beperkingen, recht op onaantastbaarheid van zijn lichaam",

Art. 3 van de Universele Verklaring van de Rechten van de Mens luidt: "Everyone has the right to life, liberty and security of person" en art. 5 luidt: "No one shall be subjected to torture or to cruel, inhuman or degrading treatment or punishment."

Voor de juridische praktijk zijn daamaast van belang de bepalingen met een daarmee vergelijkbare strekking in het Europees Verdrag tot bescherming van de rechten van de mens en van de fundamentele vrijhedien (EVRM) en in het Internationaal Verdrag inzake Politieke Rechten en Burgerrechten (BUPO). Beide verdragen hebben in Nederland rechtstreekse werking, zodat ledere burger zich daarop kan beroepen.

In art. 2 EVRM en in art. 6 BUPO wordt het recht op leven benadrukt. De aanhef van art. 2 lid 1 EVRM luidt: "Everyone"s right to life shall be protected by law" "Art. 6 lid 1 BUPO bepaalt: "Every human being has the inherent right to life. This right shall be protected by law. No one shall be arbitrarily deprived of his life".

De artikelen 3 EVRM en 7 BUPO verbieden onmenselijke behandelingen. Volgens art. 3 EVRM mag niemand "be subjected to torture or to inhuman or degrading treatment or punishment". In dezelfde zin spreekt art. 7 BUPO van: "No one shall be subjected to torture or to cruel, inhuman or degrading treatment or punishment. In particular, no one shall be subjected without his free consent to medical or scientific experimentation".

De voomaamste doelen van de medische beroepsuitoefening zijn het herstel of instandhouden van de gezondheid en het behoud van het menselijk leven. 
Daar het strafrecht onder meer tot taak heeft het leven en de gezondheid van de mens te beschermen, schijnt het niet goed mogelijk dat de medische beroepsuitoefening in strijd zou komen met het strafrecht. Wanneer desondanks medisch handelen dat in het belang van de gezondheid van de patiënt geschiedt aan een delictsomschrijving beantwoordt, dan rijst de vraag langs welke weg straffeloosheid woor het medisch handelen kan worden bereikt.

Terwijl het voor de hand ligt dat de medicus niet strafrechtelijk aansprakelijk is wanneer hij volgens de regelen der kunst operatieve ingrepen verricht, is dat niet of althans minder vanzelfsprekend bij abortus en thanatische gedragingen, zoals euthanasie.

Bij abortus is het probleem dat de arts die een $z$ wangerschap afbreekt daarmee tevens het afsterven van de vrucht bewerkstelligt. In de samenleving is moreel onstreden of en zo ja, onder welke omstandigheden hij daartoe gerechtigd is. Dat geldt eveneens voor thanatische gedragingen. Ook lijken deze handelingen in strijid met de doelen van de medische beroepsuitoefening. Als grondslag van de medische ethiek wordt immers de eerbied voor het leven genoemd.

"In wezen is euthanatisch handelen in strijd met het werk van de arts. Hij immers tracht voortdurend het leven te behouden en heef de dood eerder als vijand dan als bondgenoot ${ }^{\text {". }}{ }^{1}$

\section{De regelen van de kunst}

In dit proefschrift wordt de strafrechtelijke aansprakelijkheid van de medicus voor een aantal gedragingen onderzocht, waarbij uitgegaan wordt wan de veronderstelling dat de medicus deze gedragingen "volgens de regelen van de kunst" uitvoent. Dat will zeggen, dat zowel de besluitvorming als het gevolg geven aan de beslissing op zorgvuldige wijze plaatsvinden.

Hoewel het strafrecht zich - op een enkele uitzondering na - slechts bezighoudt met begonnen of voltooide gedragingen, is de aandacht in dit onderzoek derhalve op de vraag gericht, of de medicus de juiste beslissing neemt, en beslissing aan welke hij vervolgens uitvoering geeft.

Terecht spreekt de Commissie Onderzoek Medische Praktijk inzake Euthanasie daarom van "Medische beslissingen rond het levenseinde", om aldus "dodelijke complicaties van medisch handelen en medische fouten" van haar onderzoeksgebied uit te sluiten. ${ }^{2}$ in die zin zijn hier de uitdrukkingen "volgens de regelen van de kunst" en "professioneel witgevoerde handelingen" gebezigd.

In plaats van "regelen van de kunst" wordt ook wel gesproken van "lege artis". Volgens Leenen is voor handelen "lege artis" vereist een indicatie, een behandelingsdoel en een zorgvuldige uitvoering. Als daaraan is voldaan, dan heeft de medicus medisch-professioneel gehandeld. Hij omschrijft de medisch-professionele standaard als:

"zorgvuldig volgens de inzichten van de medische wetenschap en ervaring handelen als een redelijk bekwaam arts van gelijke categorie in gelijke omstandigheden met middelen die in redelijke verhouding staan tot het concrete behandelingsdoel". 
Daaraan woorafgaande merkt hij op dal het medisch-professioneel handelen aan een tweetal vereisten moet voldoen:

"de handeling moet medisch zijn geindiceerd met bet oog op een concreet behandelingsdoel; de handeling moet volgens de regelen van de kunst worden uitgevoerd". Van de medisch-professionele standaard onderscheidt hij de professionele standaard. Deze latste heeft betrekking op handelingen die mede genormeerd zijn door andere dan medisch-ethische normen. Het begrip professionele standaird is ruimer dan het begrip medisch-professionele standaard.

"De normen voortvloeiend uit de aard van het medisch handelen (medisch-professionele standaard), die normen voortvloeiend uit de rechten van de patiënt en de maatschappelijke normen, wormen samen de professionele standaard voor het handelen van de arts."

Ten opzichte van het door Leenen gemaakte onderscheid wordt in dit boek het begrip "volgens de regelen van de kunst" of "lege artis" in de betekenis gebruikt, die hij aan het begrip "professionele standaard" toekent. Dat geschiedt met het doel de veronderstelling te beklemtonen dat de medicus op deskundige en zorgvuldige wijze te werk is gegaan en zich geen complicaties of medische fouten voordoen.

Leenen verbindt aan het door hem gemaakte onderscheid in de normering van het medisch handelen straftechtelijke consequenties. Medisch-professioneel handelen is vanwege de medische exceptie niet strafbaar, terwijl op professioneel handelen de medische exceptie niet van toepassing is, wanneer het handelen mede onderworpen is aan niet medischprofessionele normen. Tot die handelingen rekent hij abortus en euthanasie. Deze handelingen moeten volgens hem maatschappelijk en juridisch genormeerd worden, omdat zij ethische vraggstukken betreffen."

Het bijzondere van niet slechts aan de medische ethiek, maar tevens aan de algemene ethiek onderworpen handelingen is, dat over de geoorloofdheid daarvan in een pluriforme samenleving verschillend wordt gedacht. Of de betreffende handeling geoorloofd wordt geacht, wordt bepaald door de levensbeschouwing. Kenmerkend voor door de levensbeschouwing bepaalde oordelen is dat zij zich slecht woor compromissen lenen. Vanwege het ontbreken wan consensus over de geoorloofdheid van deze handelingen verschaffen maatschappelijke normen en waarden de medicus onvoldoende houvast over het hoe te handelen. Een tweede consequentie is dat wetgeving die ten aanzien van deze vraagstukken duidelijkheid kan verschaffen, moeilijk te realiseren is. Het ontbreken van consensus en wan een toereikende wettelijke regeling kan voor de medicus (rechts) onzekerheid leweegbrengen.

\section{Onderzoeksdoelen}

Het onderzoek, waarvan hier verslag wordt gedaan heeft twee doelen. Het ene doel is na te gaan hoe het strafrecht reageert op medische handelingen die ethisch omstreden zijn. Het andere doel is te onderzoeken welke mogelijkheden het strafrecht kan bieden 
om een ethisch omstreden gedraging die, althans op het eerste gezicht, aan een delictsomschrijwing beantwoondt, van de strafbaarheid uit te sluiten.

Aangezlen in het onderzoek de gedraging van de medicus centraal staat; wordt aan schulduitsluitingsgronden - die immers naar hun aard dadergericht werken - slechts in zoverre aandacht besteed dat deze een bijdrage leveren tot verheldering van rechtsgnonden die de wederrechtelijkheid van de gedraging kunnen opheffen. Schulduitsluitingsgronden zijn onvoldoende in staat aan de medische stand duidelijkheid over de strafrechtelijke ansprakelijkheid te verschaffen. Evenmin kunnen zij bijdragen tot rechtszekerheid voor artsen en (potentiële) patiènten.

Als algemene term voor een grond die de strafbaarheid uitsluit, wordt hier van rechtsgrond gesproken. Daarmee wordt bedoeld een strafrechtelljk relevant argument op grond waarvan de gedraging van de medicus niet strafbaar is, althans niet strafbaar behoort the zijn.

\section{De afbakening van het onderzoek}

Het onderzoek richt zich op de strafrechtelijke aansprakelijkheid woor een viertal typen gedragingen: ingrepen waarbij aan een patiênt pijn of letsel wordt toegebracht, abortus provocatus, euthanasie en levensbeeindiging zonder verzoek van de patiënt.

Het opzettelijk toebrengen van pijn of letsel is als mishandeling in de artt. 300 e.v. van het Wetboek van Strafrecht strafbaar gesteld. Daarom kan verdedigd worden dat een medische handelling die pijn of letsel aan de patiënt toebrengt onder een van de delictsomschrijvingen van mishandeling valt. Daarwan uitgaande zouden er rechtsgronden aan te wijzen moeten zijn die de strafbaarheid uitsluiten.

In de benadering van Leenen worden de normen voor een dergelijk handelen in beginsel bepaald door de medische beroepsgroep. Voor zover de medicus volgens de medischprofessionele standaard heeft gehandeld, ontvalt volgens Leenen vanwege de medische exceptie aan de gedraging het strafbaar karakter.

Een onderzoek naar rechtsgronden op grond waarvan de medicus straffeloos aan een patiënt pijn of letsel mag toevoegen, is op zichzelf voor de medische noch voor de juridische praktijk relevant. Voor zover mij bekend bestaat geen jurisprudentie, waarbij een medicus voor deze handeling strafbaar werd geacht. Datarentegen is de vraag naar de strafuitsluitende rechtsgrond wel val rechistheoretisch belang. Uit het onderzoek zal blijken dat strafrechtjuristen een keur van oplossingen hebben aangedragen om de straffeloosheid wan de medicus voor deze handelwijze te funderen. De meeste daarvan kunnen evengoed worden aangevoerd ter verdediging van de straffeloosheid van handelingen als abortus, euthanasie en levensbeëindiging en dat gebeurt ook. Bij die handelingen wordt echter een zuiver strafrechtelijke benadering van de rechtsgronden bemaeilijkt vanwege met die handelingen verband houdende ethische vragen.

Het onderzoek naar de strafrechtelijke aansprakelijkheid van de medicus voor mishandeling heef derhalve tot doel materiaal voor een vergelliking te leveren tussen de strafrechtelijke benadering van gewoon medisch handelen en bijzonder medisch handelen. Met "gewoon medisch handelen" wordt bedoeld, hetgeen Leenen "medisch-professioneel handellen" noemt. Bijzonder medisch handelen betreft hier drie gedragingen: abortus, euthanasie en levensbeẽindiging. 
Dit onderzoek is primair strafrechtelijk van aard. Vanwege de morele implicaties van de behandelde problematiek wrordt ook daaraan aandacht besteed.

Aan het woord komen vooral medici en strafrechtjuristen en daarnaast ethici en politici. Vanaf de jaren zestig hebben ethici zich in toenemende mate met de morele implicaties van het medisch handelen beziggehouden, terwijl woordien het terrein van de zogenaamde medische ethiek vooral een zaak van de medische beroepsuitoefening zelf was. De gezondheidsethicus Dupuis spreekt van een "gilde-component" van de medische professie. "Van ouds is in het medisch beroep sprake van een specifieke medische moraal, een set van regels, die de arts dient te hanteren in zijn rol als arts".

In het door de Koninklijke Nederlandsche Maatschappij tot bevordering der Geneeskunst (KNMG) in 1959 uitgegeven boekje "Medische ethiek en gedragsleer" wordt erkend dat in "de beroepsuitoefening wan de arts (...) de laatste jaren zeer veel veranderingen (zijn) opgetreden en (komt) de medicus (...) bovendien steeds meer in contact met de samenleving" "Het verlies van de exclusiviteit van de medische ethiek blijkt ook uit de verandering van de titel van deze leidraad voor artsen. Eerst luidde deze "Medische Ethiek", vervolgens "Medische Ethiek en Gedragsleer" en in 1978 "Gedragsregels voor artsen ${ }^{\text {*1 }}$.

Voor politici is van belang of de hier besproken problematiek wettelijk geregeld dient the worden en zo ja, hoe een wettelijke regeling eruit zou moeten zien.

Daar drie van de vier gedragingen levensbeschouwelijke onderwerpen betreffen, $k a n$ ervan worden uitgegaan dat de verschillende levensbeschouwelijke stromingen in de samenleving ook in de zojuist genoemde groepen vertegenwoordigd zijn. Het belang van de levensbeschouwelijke stromingen woor dit onderzoek is gelegen in de gebezigde argumenten en niet in kwantitatieve gegevens.

Per gedraging wordt het verloop van de discussie over de geoorloofdheid van de gedraging met name onder medici en strafrechtjuristen vanaf 1881 beschreven. In dat jaar kwam het Wetboek van Strafrecht tot stand. Daarbij richt de discussie van de medici zich vooral op de ethische toelaatbaarheid van de gedraging en die van de juristen in het bijzonder op de strafrechtelijke geoorloofdheid. Nagegaan wordt hoe tijdens de totstandkoming van het Wetboek van Strafrecht over de geoorloofdheid van deze gedragingen is gedacht en in hoeverre daarbij een verschuiving heeft plaatsgevonden in de morele waardering van deze gedragingen. Het onderzoek geschiedt chronologisch per gedraging. Op deze wijze kan worden achterhaald of veranderingen in het denken en in de houding onder medicil en onder strafrechtjuristen ten opzichte van de hiler besproken problematiek hebben plaatsgevonden.

Van een rechtsvergelijkend onderzoek is afgezien. Dit wordt wel nodig geacht. Allereerst dient echter aandacht besteed te worden an de situatie in eigen land. Daarover bleek zoveel materiaal beschikbaar, dat voor rechtsvergelijking onvoldoende numte overbleef: 
Voor het onderzoek werd gebruik gemaakt van schriftelijk materiaal, Van het bestuderen en verwerken van alle beschikbare literatuur moest al spoedig worden afgezien wanwege de grote hoeveelheid die over dit onderwerp beschikbatr is. Wel is de medische en strafrechtelijke literatuur in de periode tot rond 1950 zo volledig mogelijk verwerkt. Voor de selectie van de nadien verschenen literatuur is ernaar gestreefd verschillende opvattingen en stromingen zo veel mogelijk aan bod te laten komen.

Voor de kennisname van opvattingen van medici (en wan ethici die over de hier behandelde problematiek uitspraken hebben gedaan) zijn met name van belang het Nederlands Tijdschrift voor Geneeskunde (NTvG) en Medisch Contact (MC). Hel NTwG was tot 1945 tevens mededelingenorgaan van de (Koninklijke) Nederlandsche Maatschappij tot bevordering der Geneeskunst; die functie werd vanaf die tijjd door MC overgenomen.

Voor de strafrechtelijke benadering werd gekozen voor het Weekblad van het Recht (W), het Tijdschrift voor Strafrecht (TvS), sinds 1975 voortgezet als Delikt en Delinkwent (DD) en het Nederlands Juristenblad (NJB).

In de tweede helft van de zestiger jaren heeft het gezondheidsrecht zich als zelfstandige specialisatie binnen het recht doen kennen. Artikelen over het gezondheidsrecht zijn vooral te vinden in het Tijdschrift voor Gezondheidsrecht (TvGR).

\section{Indeling}

In het eerste hoofdstuk worden de Huizer veearts-arresten in verband met de strafrechtelijke aansprakelijkheid van de medicus voor professioneel handelen in het algemeen beschreven. Deze arresten vervullen in de navolgende hoofdstukken een spillfunctie in de jurisprudentiële benadering van de onderzochte problematiek.

Het tweede hoofdstuk betreft de aansprakelijkheid voor operatieve ingrepen, die aan de delictsomschrijving van mishandeling (lijken te) voldoen. Medische handelingen die pijn of letsel veroorzaken worden hier als operatieve ingrepen aangeduid, waarmee dit begrip in een beperkte betekenis wordt gebezigd. Er bestaat in de samenleving in het algemeen overeenstemming over de opvatting dat de medicus tot handelen mag overgaan. De legitimatie daarvoor kan zijn, dat in het belang van de gezondheid van de patiënt wordt gehandeld.

In het derde hoofdstuk wordt ingegaan op de problematiek van abortus. Abortus is, althans op sommige indicaties, levensbeschouwelijk omstreden. In het algemeen bestaat well instemming dat de medicus in uitzonderlijke gevallen tot abortus mag overgaan. Het bijzondere bij abortus is dat de arts niet slechts met een patiënt te maken heeft; maar tevens met een menselijke vrucht en dat de vrucht in het belang van de vrouw wordt gedood. Daarmee is een conflict gegeven tussen de patiënt (de vrouw die abortus wenst) en de vrucht. Zonder bijzondere wetgeving is een rechtsgrond voor de straffeloosheid moeilijk aan te wijzen en ook is - zoals in het derde hoofdstuk zal blijken - goede wetgeving op dit gebied lastig te verwezenlijken.

De legitimatie voor abortus zou gelegen kunnen zijn in de wens wan de vrouw in verband met haar situatie en in verband met het feit dat bij abortus een menselijke vrucht en niet een geboren mens wordt gedood.

Welliswaar is abontus vanwege een bijzondere rechtvaardigingsgrond sinds 1984 voor de medicus onder bepaalde omstandigheden niet meer strafbaar, maar de "lijdensweg" 
tot de Wet Afbreking Zwangerschap (WAZ) ten gevolge waarvan de bijzondere rechtvaardigingsgrond in het Wetboek van Strafrecht is terecht gekomen, toont, evenals de WAZ het problematische karakter van strafrechtellijke regelgeving bij ethisch omstreden vraagstukken aan.

In het vierde hoofdstuk wordt levensbeëindigend handelen van de medicus besproken. Dat handelen kan al dan niet op verzoek geschieden. Levensbeëindiging op verzoek word: euthanasie genoemd. De levensbeeindigende gedraging zonder verzoek bij een patiênt die zijn will niet kenbaar kan maken, wordt kortweg als "levensbeëindiging" aangeduid.

Het vierde hoofdstuk bestaat wit drie delen. In het eerste deel wordt nagegaan hoe de euthanasie-discussie in Nederland onder de medici is verlopen. Dat deel sluit af met een bespreking van de zogenaamde "schijngestalten" van euthanasie. Dit begrip is door Leenen ge introduceerd om gedragingen aan te duiden die op euthanasie lijken, maar niet daaronder vallen." Als schijngestalten beschouwt hij het staken van medisch zinloos handelen, de levensverkortende pijnbestrijding en het weigeren van toestemming voor medisch handelen. Schijngestalten behoren zijns inziens tot het gewone medisch handelen. Dat is anders met de levensbeëindiging, die betrekking heeft op wilsonbekwame patienten.

In overeenstemming met het verloop van de euthanastediscussie wordt pas aan het eind van eerste deel van dit hoofdstuk een terminologisch onderscheid gemaakt tussen de verschillende thanatische gedragingen.

Het verloop van de discussie over de toelaatbaarheid van euthanasie vertoont een ander karakter dan die over abortus. Het meest opvallende is, dat over euthanasie door de hier aan het woord zijnde groepen lange tijd buitengewoon weinig naar buiten is gebracht. Dat is vooral frappant, omdat in andere landen in dezelfde tijd het onderwerp wel ter discussie stond. Uit de weinige witlatingen gedurende de eerste tientallen jaren na 1881 kan worden afgeleid dat euthanasie, begrepen als levensbeëindiging op verzoek bij een patiënt in een uitzichtloze noodsituatie, werd afgewezen. Vermoedelijk bestond in de medische wereld instemming, dat de medicus to de zogenaamde schijngestalten van euthanasie mocht overgaan.

Bij euthanasie bestaat een conflict tussen het belang van de patiënt en bepaalde levensbeschouwingen in de samenleving. Medisch-ethisch en strafrechtelijk is van belang een antwoord te krijgen op de vraag waaraan de medicus een legitimatie tot handelen zou kunnen ontlenen. Die legitimatie zou kunnen berusten zowel op de situatie van de patiënt als op diens toestemming tot de gedraging.

Nog meer dan euthanasie is lewensbeeindiging levensbeschouwelijk omstreden. Het bijzondere bij levensbeëindiging is dat de patient geen wilsuiting omtrent de omstreden gedraging heeft gedaan, omdat hij daartoe niet in staat was. In dat geval zou levensbeëindiging uitsluitend gelegitimeerd kunnen worden door de situatie waarin de patiënt zich bevindt.

In de slotbeschouwing wordt getracht een antwoord te geven op de hier opgeworpen vragen. 


\section{Terminologie}

Met "medicus" of "arts" wordt hier een behandelende arts bedoeld, die tot de uitoefening van de geneeskunst bevoegd is en die de geneeskunst als beroep uitoefent. Degene die als medicus in Nederland werkzaam wil zijn, moet het artsexamen met goed gevolg hebben afgelegd. ${ }^{10}$ Het onbevoegd uitoefenen van de gemeeskunst als beroep of bedrijf is in strijd met art. $436 \mathrm{Sr} .{ }^{11}$ De behandelende arts is degene die de behandelingsovereenkomst met de patiënt aangaat en die voor de behandeling verantwoordelijk is.

De medicus neemt in de gezondheidszorg een centrale positie in. Hij is de enige die de geneeskunst in volle omvang mag uitoefenen. ${ }^{12}$ Dat wil niet zeggen, dat een medicus elke medische handeling mag verrichten. Voor sommige medische handelingen zijn bijzon* dere vaardigheden en specialistische kennis vereist. Wanneer dat het geval is, dan wordt er hier van uitgegaan dat de medicus deze bezit.

Soms is datgene wat over de strafrechtelijke aansprakelijkheid van de medicus opgemerkt gaat worden ook (analoog) van toepassing op andere in de gezondheidszorg werkende personen. ${ }^{13}$ Daarop wordt in het vervolg niet expliciet de aandacht gevestigd.

In plaats van medisch handelen of behandelen wordt hier meestal van handelen gesproken. Daarmee wordt in het algemeen zowel een actief optreden als een nalaten te handelen bedoeld. Taalkundig gezien is het juister van een "zich gedragen" te spreken, maar dat zou veelal tot gewrongen zinsconstructies leiden.

10 Art. 1 van de Wet van 1 juni $1865,5.60$, regelende de uitoefening der geneeskunst in verband met de arth.. 1 en 3 wan de Wet van 25 dec. 1878, s 222 , houdende regeling der woorwaarden to verkrijging der bevoegdheid van arts, tandarts, apotheker, verloskundige en apothekersbediende.

11 Zie Remmelunk, 1951 , p. $47-68$.

12 Vgl. art. 1 Wet van 25 dec 1978, S 222; "De hoedanigheid van arts geeft de bewoegdheid de gemeeskunst uit the oefenen in hatar wollen omwang ....

13 Vgl. Gevers, 1991, p. 13. 
$\therefore$ 


\section{De Huizer veearts en de medicus}

\section{Het eerste Huizer veearts-arrest ${ }^{\mathrm{A}}$}

In het begin van de jaren dertig werd een veearts verweten dat hij "zeven koeien, welke niet lijdende waren aan mond-en klauwzeer noch ook werden verdacht gevaar op te leveren voor besmetting met die ziekte, opzettelijk in verdachten vestand heeft gebracht, ...", doordien hij die koeien liet vervoeren van een wei naar een stal. In die stal bevonden zich enkele koeien, die aan mond- en klauwzeer leden. Dat was de veearts bekend.

In art. 82 Veewet was strafbaar gesteld het "opzettelijk vee in verdachten toestand brengen". Uitgaande van de bewoordingen van dit artikel, voldeed het handelen van de veearts aan de delictsomschrijving.

De veearts ontkende het telastegelegde niet. Hij wees echter op het volgende: "Ik heb gehandeld, omdat het uit veterinair oogpunt beter is, dat koeien die droog staan, met mond- en klauwzeer besmet worden, dan koeien die melk geven, in wellk geval de ziekte gepaard gaat met ziekte van de uiers enz., terwijl droog staande koeien de ziekte sneller doormaken. In het onderhavige geval betrof het droogstaande koeien die kalveren moesten".

Verder had hij, volgens zijn zeggen, alvorens het vee in verdachte toestand te brengen, toestemming gevraagd en verkTegen van de verantwoordelijke inspecteur van de Veeartsenijkundige Dienst. In een vergelijkbaar geval, dat zich eerder had afgespeeld, had hij eveneens toestemming verkregen van de inspecteur. Toen had bovendien de inspecteur op aanraden van hem advies ingewonnen bij het Departement van Landbouw. Het antwoord luidde: "Art, 82 is in het door U gestelde geval niet van toepassing. Voor Minister, Frederiks".

Volgens de A-G Wijnveldt beriep de veearts zich in deze "eigenaardige zaak" op een rechtvaardigingsgrond, die "(...) een figur (geeft), welke niet nieuw is, maar zich o.a. bij de gewone geneeskunde herhaaldelijk voordoet", waarmee hij op het beroepsrecht van de medicus respectievelijk de medische exceptie zinspeelde. Het beroepsrecht houdt in algemene zin in, dat een medicus in zijn beroepsuitoefening straffeloos handelingen mag verrichten die voor anderen strafbarar zijn.

Volgens de Hoge Raad kon het door de veearts aangevoerde op twee wijzen worden begrepen. In het verweer kon een beroep op een wettelijke strafuitsluitingsgrond opgesloten liggen, die de strafbaarheid van de verdachte uitsloot. Mocht daarvan geen sprake zijn, werd "in elk geval" daarbij betoogd, dat hij tot wat hij deed gerechtigd was, omdat hij "heeft gehandeld als veearts ter behartiging van den algemeenen gezondheidstoestand van den veestapel".

Als het door de veearts gestelde juist was, dan kon volgens de Hoge Raad geen veroordeling volgen, omdat "niet kan worden aangenomen, dat de Veewet, in art. 82 het opzette- 
lijk vee in verdachten toestand brengen strafbaar stellende, op handelingen als door ... (de veearts, J.W.) met woorgeschreven bedoeling (dat hij heeft gehandeld als veearts ter behartiging van den algemenen gezondheidstoestand van den veestapel, J.W.) verricht, het oog heeft gehad".

De Hoge Raad wernietigde het wonnis van de rechtbank en verwees de zaak naar het Hof Amsterdam. Daar verklaarde de veearts nog het volgende: "dat, bij het plegen van het feit slechts hebben woorgezeten juiste veterinaire overwegingen in dezen zin, dat .... de verspreiding van mond- en klauwzeer ... van dien aard was, dat met zeer grote waarschijnlijkheid was te verwachten, dat bedoelde zeven koeien, blijvende in de wei ..., aan de ziekte njet zouden ontkomen". Volgens hem was hij vanwege "het belang van den eigenaar der koeien, het gevoel van deernis met de koeien, ... en eindelijk het belang van den veestapel in het algemeen" gehouden te handelen zoals hij had gedaan.

Het Hof Amsterdam kwam tot een veroordleling. Het was van mening dat het beroep van de veearts op analogie met het beroepsrecht van de medicus niet opgaat, omdat bij dit recht de niet-strafbaarheid haar reden heeft in het uitzonderlijk karakter van het rechtsgoed: "behoud voor een bepaald persoon van een gezond lichaam, ..., waarmede niet gelijk is te stellen het rechtsgoed: behoud voor een bepaalden eigenaar van een gezonden veestapel".

\section{Het tweede Huizer veearts-arrest ${ }^{2}$}

Vervolgens kwam de zaak voor de tweede keer bij de Hoge Raad terecht. In het tweede Huizer veearts-arrest stelt de Hoge Raad eerst vast dat "de genees- en heelkundige zorg voor het vee wettelijk is geregeld en door de wet van waarborgen van deugdelijkheid is voorzien", waartoe hij verwijst naar art. 1 van de veeartsenijkundige wet ${ }^{3}$.

In die bepaling leest de Hoge Raad een aanwijzing voor de juistheid van de stelling dat "een veearts, die, naar juist wetenschappelijk inzicht, in het welbegrepen belang van het vee, op dat vee een zekere behandeling toepast, zich niet schuldig maakt aan een strafbare gedraging". Dat is alleen anders als "de wet uitdrukkelijk het tegendeel bepaalt".

Daarna overweegt de Hoge Raad dat art. 82 Veewet verbiedt het opzettelijk vee in verdachten toestand te brengen, waaronder "valt het opzettelijk brengen van gezonde of niet verdachte koeien in een verblijfplats van aan mond- en klauwzeer lijdend vee".

Terwijl enerzijds uit de veeartsenijkundige wet een aanwijzing geput kan worden dat de handeling van de veearts niet strafbaar is, voldoet die handeling anderzijds aan de tekst van de delictsomschrijving van art. 82 Veewet. Dat houdt echter niet noodzakelijkerwijs in dat de wet aan de veearts uitdrukkelijk deze handeling verbiedt. Want vervolgt de Hoge Raad, "niet kan worden aangenomen, dat volgens genoemd artikel zoude kunnen worden gestraft de veearts, die, bij het toepassen van een zekere behandeling van het aan zijne zorg toevertrouwde vee - ... - handelt niet slechts volgens hetgeen naar eigen inzicht geoorloofd en wetenschappelijk aangewezen is, doch ook volgens in zijn wetenschap algemeen als juist erkende richtsnoeren, en die daarbij, ook alweder volgens algemeen erkend deskundig inzicht, door voorkoming van ernstig lijden, het heil van het in verdachten toestand gebracht vee bevordert". 
Hiertegen zou weliswaar kunnen worden ingebracht, "dat tenrand, die een met straf bedreigde handeling verricht, in elk geval strafbar is, wanneer niet de wet zelf met zoovele woorden een strafuitsluitingsgrond aanwijst". Maar dit argument kan volgens de Hoge Raad niet met vrucht worden aangevoerd, omdat de mogelijkheid bestaat "dat de wederrechtelijkheid in de delictsomschrijving zelve geen uitdrukking heef gevonden en niettemin geen veroordeeling zal kunnen volgen op grond dat de onrechtmatigheid der gepleegde handeling in het gegeven geval blijkt te ontbreken en derhalve dan het betrokken wetsartikel op de letterlijk onder de delictsomschrijving vallende handeling niet van toepassing is ${ }^{n}$.

In hoeverre dat mogelijk is, hangt af van de wijze warop de delictsomschrijving is geformuleerd. Het geval kan zich voordoen, zo overweegt de Hoge Raad: "dat de strafwet zich wel in de deliktsomschrijving van zoodanige bewoordingen kan bedienen, dat voor dergelijke, buiten den tekst der wet zelve liggende beschouwingen, geen ruimte wordt gelaten, doch zulks hier niet het geval is".

Ter vaststelling dat art. 82 Veewet zich niet van "zoodanige bewoordingen" bedient, interpreteert de Hoge Raad echter niet de tekst van de delictsomschrijving, maar leidde hij uit andere bepalingen van de Veewet af dat de tekst van de betreffende bepaling de nodige ruimte liet.

Volgens de Hoge Raad blijkt "o.m. ... dat de Veewet ...., ook ingeënt vee, gedurende zekeren tijd, als verdacht aanmerkt, zoodat het inenten is te beschouwen als het in verdachten toestand brengen van het vee, waarop deze behandeling wordt toegepast". Daarom behoeft het inenten nog geen strafbare handeling te zijn. In de bewoordingen van de Hoge Raad: "dat echter de veearts, die volgens de in zijn wetenschap algemeen erkende regelen deze voorbehoedende behandeling (het inenten, J.W.) op het vee toepast; niet volgens art. 82 Veewet kan worden gestraft, niet, omdat in de wet zelve een bepaalde strafuitsluitingsgrond met zooveele woorden zoude zijn te vinden, - ...- maar omdat de onrechtmatigheid van het in verdachten toestand brengen van het vee zoude wegvallen".

De annotator van het tweede Huizer veearts-arrest Taverne, die tevens als raadsheer het arrest concipieerde, achtte de beslissing van de Hoge Raad van "zeer principieele beteekenis". Volgens hem heeft de Hoge Raad met een nieuwe buitenwettelijke strafuitsluitingsgrond, "het wegvallen van onrechtmatigheid der handeling" gewerkt. Dat houdt volgens hem niet noodzakelijk in dat de Hoge Raad daarmee de leer van het ontbreken van de materiële wederrechtelijkheid heeft toegepast. De nieuwe strafuitsluitingsgrond is volgens hem een "zelfstandige constructie van het wederrechtelijkheidsbegrip op buitenwettelijke en buitenrechtelijke gronden althans met erkenning van zulke elementen ${ }^{\text {"i }}$. Daarbij moet er wel op worden gelet dat de rechter niet in strijd komt met de wet end dat bij de constructie van deze strafuitsluitingsgrond zoveel mogelijk aansluiting wordt gezocht bij de wet.

Taverne noemt het inenten slechts én bepaald geval van het handelen zoals een goed weearts betaamt. "Om dezen meer algemeenen grond te motiveeren, heeft de H.R. ook aansluiting gezocht bij de wettelijke regeling van de uitoefening der veeartsenijkunst".

Uit de Veewet zelf blijkt volgens Taverne dat deze "niet elk opzettelijk in verdachten toestand brengen van het vee (behoudens dan de in de wet geregelde strafuitsluitingsgronden) strafbaar" wilde stellen. Als men dientengevolge geen veroordeling will, dan is het de "meest rationeele weg, om - wat het wezen der zaak betreft - de oplossing in het ontbreken der wederrechtelijkheid of onrechtmatigheid te zoeken"t. 


\subsection{Inleiding}

Vooral het tweede Huizer veearts-arrest leidde tot discussies over de vraag naar de betekenis van de overwegingen van de Hoge Raad in dit arrest. Vanwege deze aandacht voor het tweede arrest heeft de aanduiding "Huizer veearts-arrest" meestal slechts betrekking op dit arrest. Dit gebruik wordt ook hier gevolgd.

Gestelld kan worden dat de Hoge Raad het ontbreken van de materiële wederrechtelijkheid als exceptief verweer danwel als kwalificatieverweer heeft erkend ${ }^{4}$, dat hij langs interpretatieve weg en rekening houdend met de geschonden belangen een oplossing heeft aangedragen of dat hij de veterinaire/medische exceptie heeft erkend.

\subsection{Het ontbreken van de materiële wederrechtelijkheid als exceptief verweer}

Vanaf de jaren vijftig is een aantall keren een beroep gedaan op het ontbreken van de materiële wederrechtelijkheid. Daarbij richtte zich het beroep op de exceptieve kant van deze rechtsgrond. In dat geval wordt gesteld dat het feit weliswaar aan de delictsomschrijving beantwoordt, maar desondanks niet wederrechtelijk is, omdat daarmee een hoger belang wordt nagestreefd dan het door de strafbepaling beschermde belang. De Hoge Raad heeft een beroep van deze strekking vermoedelijk niet gehonoreerd. Dat is begrijpelijk, daar de rechter zich anders op het terrein van de wetgever begeeft. ${ }^{5}$

Een variatie van dit verweer houdt als additioneel argument in dat de dader zich in een noodsituatie bevond, waarin hij een gerechtvaardigde keuze heeft gemaakt. Deze inkleding van het beroep op het ontbreken van de materiële wederrechtelijkheid lijkt zozeer op de noodtoestand als belangenconflict dat bij aanvaarding de grenzen tussen beide strafuitsluitingsgronden verdwijnen, althans vervagen. Daarom bestaat er volgens Van Veen geen behoefte aan deze vorm van het ontbreken van de materiële wederrechtelijkheid als exceptief verweer."

Bovendien bieden de Huizer veearts-arresten geen aanknopingspunten voor verweren waarblj van een conflicterend rechtsbelang wordt uitgegaan.

\subsection{Het onibreken van de materiële wederrechtelijkheid als kwalificatieverweer}

Van Veen ${ }^{7}$, die het Huizer veearts-arrest als een erkenning van het ontbreken van de materiële wederrechtelijkheid als kwalificatieverweer opvat; spreekt in dat verband van een "geslaagd beroep op de bedoeling van de wetgever bij het redigeren van een strafbepa-

4 Zie over deze bendering: Van Veen, RR 1980, p. 1-22. Zie ook DD 1975, p. 189-207 en p. 27.4-290. Zie ook: Vermunt, DD 1984 , p. 109-120 en $712-724$.

5 Zie voor een "bijna-uitzondering" O.a. HR 11 mei 1976, NJ 1976, 538 mont. ThWvV, waarin de HR echter langs interpretatieve weg tot net-strafbaarheid kwam. Zie hiertoe: Schaffmeister en Hejider, in: Bij deze stand van zaken, $1983, p, 455-457$.

6 Van Veen, RR 1980, p. 18-19.

7 Van Veen, RR 1980, p. 12. 
ling $^{\text {"1 }}$. In de interpretatie van dat arrest als erkenning van de medische exceptie ziet hij parallellen met zijn zienswijze. ${ }^{8}$

Als kwalificatiewerweer kan het ontbreken van de materiele wederrechtelijkheid op twee wijzen worden ingekleed. In de ene wordt de delictsomschrijving zodanig geïnterpreteerd dat de wet op het feit niet van toepassing is. De gedraging is in overeenstemming met de bewoordingen van de delictsomschrijving, maar niet met de strekking ervan. De aanwezigheid van een moodsituatie is niet nodig. Aangevoend wordt dat de wet niet voor deze gedraging is geschreven en dat deze daarom niet in strijd is met de bedoeling van de wetgever.

In een variant daarop wordt erkend dat de gedraging niet alleen aan de bewoordingen van de delictsomschrijving voldoet, maar tevens in strijd is met de bedoeling van de wetgever. Vanwege een andere rechtsnorm zou de gedraging desondanks niet wederrechtelijk zijn.

Een andere inkleding van het ontbreken van de wederrechtelijkheid als kwalificatieverweer betwist bethalve de toepasselijkheid van de delictsomschrijwing ook de actuele juistheid van de achterliggende norm. In deze benadering wordt niet gesteld dat de wederrechtelijkheid op grond van een andere rechtsnorm ontbreekt, maar dat de wet werouderd is en daarom niet van toepassing is.

Evenals bij noodtoestand is er sprake van een conflict. Maar anders dan bij noodtoestand wordt hierbij de principiële geldigheid van de wettelijke norm met betrekking tot de hitigieuze gedraging bestreden. Bij een beroep op noodtoestand wordt echter de algemene geldigheid van de verbodsnorm niet betwist. Een tweede verschil met noodtoestand is dat het conflict van plichten of normen niet door een noodsituatie behoeft te zijn opgeroepen, terwijl bij noodtoestand gesteld wordt dat deze norm vanwege de uitzonderlijke omstandigheden in een concreet geval niet van toepassing is."

Daarom voelt Van Veen voor het ontbreken van de materiele wederrechtelijkhelld als kwalificatieverweer en will hij noodtoestand beperken tot acute noodsituaties. ${ }^{10}$

\subsection{De concretisering wan de wederrechtelijkheid}

Schaffmeister en Heijder hebben voorgesteld dat de rechter zich reeds bij de vraag of een gedraging aan een delictsomschrijving beantwoordt, dient af te vragen of de gedraging niet alleen formeel, maar ook materieel wederrechtelijk is. "1 De materielle wederrechtelijkheid wordt derhalve door hen als een impliciet bestanddeel beschouwd. Zij noemen dit de concretisering van de wederrechtelijkheid.

De door Schaffmeister en Heijder in wezen als ingelezen bestanddeel aanwezig geachte materiële wederrechtelijkheid is bedoeld ter beperking van de aansprakelijkheid in de gevallen waarin deze niet op haar plaats is. Een feit voldoet slechts dan aan de delictsom-

8 Later interpreteert hij het Huizer veearts-arrest als erkenning van de "beroepsexceptie" "Vgl, Van Bemmelen/Van Veen, $I$, 1989, p. 223-224. Zie ook Vermunt, DD 1984, p. 109-120 en p. 712-724.

9 Van Eikema-Hommes, in: Strafrecht in perspectief, 1980 , p. 169.

$10 \mathrm{Vgl}$. Van Bemmelen/Wan Veen, $I_{,}$1989, p. 186. Mulder woelt in zijn noot onder HR 21 okt. 1986, NJ 87, 607 niet voor om dit gewal als ontbreken wan de materiële wederrechtelijkheid alan to merken.

11. Schaffmeister en Heijder, in: Bij deze stand van zaken; 1983, p. 441-474. Zie woor een benadering die daarmee een antal overeenkomsten vertoont: Van Eikema-Hommes, in: Strafrecht in perspectief, 1980, p. $161-178$. 
schrijwing respectievelijk is slechts dan wederrechtelijk, wanneer een beschermd belang geschonden is. Beschermde belangen kunnen op drie niveaus worden aangetroffen. Zodoende kunnen worden onderscheiden belangen die aan de delictsomschrijving ten grondslag liggen, belangen uit andere rechtsgebieden of maatschappelijke belangen. Binnen de drie niveaus is doorslaggevend het niveau dat de meest beperkte grens trekt. ${ }^{12}$ Daarmee heeft, om thet Schalken te spreken, de "rechterlijke vindingrijkheid haar grens ... in de duidelijkheild van de wet ${ }^{\text {it. }}{ }^{13}$

Voor een interpretatieve benadering op het derde niveau lenen zich volgens Schaffmeister en Heijder "Jacuneuze" delictsomschrijvingen. ${ }^{14}$ Art. 82 Veewet beschowwen zij als een dergelijke delictsomschrijving. Volgens hen ${ }^{15}$ kunnen de Huizer veearts-arresten in die zin worden begrepen dat de Hoge Raad via een interpretatie van het bestanddeel "vee in verdachten toestand brengen" rekening heeft gehouden met het door art. 82 Veewet beschermde belang en dat belang heeft de veearts juist nagestreefd.

Een zelfde invalshoek kiest Nieboer. Hij constateert eerst dat in art. 82 Veewet ten onrechte een beperkend bestanddeel (wederrechtelijk) was weggelaten. Volgens hem heeft de Hoge Raad hier bepaald, dat de grond van de niet-strafbaarheid daarin ligt, dat de Wet op de uitoefening van de veeartsenijkunst een veearts exclusieve bevoegdheden verleent en dat een veearts die deze bevoegdheden op de juiste wijze gebruikt zich niet schuldig maakt aan een strafbare gedraging. Bij de veearts ontbrak de onrechtmatigheid en daarom was de delictsomschrijving niet van toepassing op de gedraging. Bovendien moest volgens de Veewet een inenting eveneens als een wijze van "in verdachten toestand brengen" worden begrepen, terwijl de inenting in art. 82 Veewet evenmin wordt uitgezonderd.

Dat alles leidt Nieboer tot de conclusie dat art. 82 Veewet te ruim was geformuleerd. Het ging bij de Huizer veearts om bevoegdheden die aan een (bijzondere) kwaliteit ontleend waren. Het doel van de Veewet en (het verder gelegen) doel van art. 82 Veewet werden met de gedraging gediend. Uit de Veewet zelf kon de te ruime formulering van art. 82 Veewet worden afgelleud.

In het Huizer veearts-arrest stonden de bevoegdheden centraal. Zowel de kwaliteit van de veearts, als de 'kwaliteit' van art. 82 Veewet (inenting niet uitgezonderd), brachten hiler een uitzonderlijke situatie mee.

Volgens Nieboer zal de Hoge Raad vermoedelijk thans minder moeite hebben met het aannemen van de niet-strafbaarheid. Want de veearts heeft een zorgplicht, zodat straffeloosheid via noodtoestand bereikt $\mathrm{kan}$ worden. ${ }^{16}$

In gelijke zin laat zich Strijards uit. Indien het duidelijk is dat de dader het door de strafwet beveiligde belang heeft gediend, dan is er geen strafrechtelijke zorgplichtschending en daarmee geen gedraging in strafrechtelijke zin. Nodig is en zo gebeurt het ook tegenwoordig, dat meteen naar het beschermde belang wordt gekeken en niet eerst naar de delictsomschrijving en pas dan naar dat belang. Thans zouden we zeggen, dat de arts

12 Schaffmeister en Heijder, in: Bij deze stand van zaken, 1983, p. 471 .

13 A-G Schalken, NJB 1984, p. 46.

14 Schaffmeister en Heijder, in: Bij deze stand wan zaken, 1983, p. 467.

15 Schaffmeister en Heijder, im: Bij deze stand van zaken, 1983, p. 45 ll en p. 472. In dezelfde zin: Vermunt, DD 1984, pn 115.

16 Nieboer, 1991, p. 139. 
stelt het vee niet in "die verdachte toestand" te hebben gebracht, die de wet, gelet op de strekking ervan, verbiedt. ${ }^{17}$

Wanneer wordt uitgegaan van deze benadering, dan behoort daar wel nog bij dat daartoe volgens de Hoge Raad een bijzondere aanleiding moet bestaan. Samen met de bijzondere aanleiding benadrukte hij immers het uitzonderlijke karakter van deze strafuitsluiting.

De bijzondere aanleiding kan gevonden worden in een in algemene bewoordingen omschreven wettelijke bevoegdheid, die tenminste hetzelfde terrein bestrijkt als de verbodsbepaling. Zo'n bijzondere aanleiding is uitzonderlijk omdat in het algemeen het feit strafbaar is wanneer het aan een delictsomschrijwing beantwoordt en een wettelijke rechtvaardigingsgrond niet aanwezig is. Het uitzonderlijke is niet gelegen in het specifieke karakter van het rechtsgoed in de zin als bijvoorbeeld door het Hof Amsterdam in het Huizer veearts-arrest met betrekking tot de medische exceptie werd gesteld:

"dat, indien de opheffing der strafbaarheid in het Nederlandsche strafrecht geldt, zij haar oordeel vindt in het uitzonderlijk karakter; dat aan het rechtsgoed; behoud voor een bepaald persoon van een gezond lichaam, moet worden toegerekend, waarmede niet gelijk is te stellen het rechtsgoed: behoud voor een bepallden eigenaar van een gezonden veestapel"

maar in de uitzonderlijke omstandigheden. ${ }^{18}$

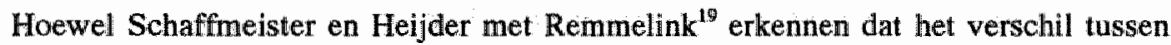
de leer van het ontbreken van de materiële wederrechtelijkheid en hun interpretatieve oplossing "niet levensgroot" ${ }^{110}$ is, geven zij an hun benadering de voorkeur. Daarvoor noemen zij als voordelen, dat de rechter aan de bewoordingen van de wettekst wordt gebonden, dat hij ten aanzien van de wetgeving een complementaire functie vervult, dat hun oplossing goed past in de opvatting dat strafrechtelijke geboden en verboden als uitzonderingsgevallen strikt uitgelegd moeten worden en tenslotte, dat het verschil tussen formele en materiële wederrechtelijkheid zich dan niet alleen bij geschreven strafbepalingen kan voordoen. ${ }^{21}$

Remmelink noemt terecht als bezwaar tegen deze benadering, dat de formele leer, waarbij het op het eerste gezicht voor de strafbaarheid voldoende is als de gedraging aan de delictsomschrijving beantwoordt, duidelijkheid en 'vastheid' biedt. Slechts wanneer toepassing van de formele leer tot "een volstrekt onbevredigende uitkomst" leldt, acht hij de door Schaffmeister en Heijder voorgestelde benadering aanvaardbaar. Maar dan wel met de beperking dat zoveel mogelijk aangesloten dient te worden bij de "typering wan het onrecht, dat de wetgever kennelijk heeft willen bestrijden" ${ }^{22}$ Dat betekent dat hij het niveau van de matschappelijke normen afwijst, waar deze in strijd komen met de bedoeling van de wetgever ${ }^{23}$

17 Strijards, 1987, p. 72-75.

18. Vi. A-G Schalken, NJB 1984, p. 46, die wijst op de vitzonderlijke omstandigheden van deze zakak.

19. Remmelink noemt in dit verband HR 28 nov. 1978, NJ 1979, $93 \mathrm{~m}$.nt. ThWwW. Hazewinkel-Suringa/Rernmelink, 1991, p. 330-331.

20 Haxewinkel-Suringe/Remmelink, 1991, p. 331.

21 Schaffrneister en Heijder, in: Bij deze stand van zaken, 1983, p. 474.

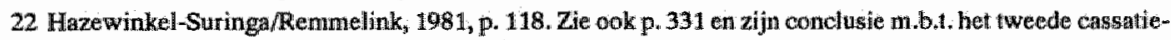
middel wór IR 27 nov. 1984, NJ 1985,106 mant. ThW w.

23 Dat is ook het geval bij het ontbreken van de materiêle whederrechtelijkheid. Vgl. Hazewinkel-Suringa/Remmelink, 1991, p. 330. Zie ook Van Benmelen/Van Veen, I, 1989, p. 99. 
Van een onaanvaardbare uitkomst had mijns irziens in hell geval van de Huizer veearts gesproken kunnen worden, als het toenmalige art. 82 Veewet volgens de letterlijke tekst op de gedraging van de veearts was toegepast.

\subsection{De medische exceptie respectievelijk het beroepsrecht}

De medische exceptie kan als verbijzondering van het ontbreken van de materiële wederrechtelijkheid worden beschouwd. ${ }^{24}$ Dan houdt zij in dat de gedraging van de medicus die aran (de bewoordingen van) een dellictsomschrijving voldoet, niet materieel wederrechtelijk is, voor zover de medicus lege artis handelt.. Evenals het ontbreken van de materiële wederrechtelijkheid wordt de medische exceptie wit het ongeschreven recht afgeleid. Daarentegen heeft het beroepsrecht van de medicus zijn grondslag in het geschreven recht. Maar de wijze waarop de medische exceptie en het beroepsrecht toegepast worden verschilt nilet van elkaar. In wezen betreft het twee varianten van dezelfde basisgedachte: een medicus die lege artis handelt; verricht geen strafbare gedraging, ondanks dat de gedraging aian een delictsomschrijving beantwoordt. Vanwege de gemeenschappelijke strekking worden de medische exceptie en het beroepsrecht hier in het algemeen tezamen besproken. ${ }^{25}$ Daarbij wordt meestal de aanduiding medische exceptie gebezigd, behalve als dle grondslag van deze rechtsgrond noodzaakt tot differentiẻring. Dat doet zich vooral bij bespreking van het medisch handelen in verband met de delictsomschrijvingen van mishandeling voor.

Het ontbreken van de materiẻle wederrechtelijkheid kan als kwalificatieverweer of als exceptief verweer worden ingeroepen. Dat is ook mogelijk ten aanzien van de medische exceptie.

Als kwalificatieverweer houdt de medische exceptie in, dat het handelen van de medicus weliswaar aan de delictsomschrijving beantwoordt, maar dat hij met zijn gedraging het belang dat met de delictsomschrijving beoogd wordt te beschermen, beter heeft gediend dan door van de gedraging af te zien.

Als exceptief verweer betreft de medische exceptie eveneens een handelen in strijd met de delictsomschrijving en bovendien met het daaraan ten grondslag liggende belang. Maar het belang dat de medicus met de handeling die tot normoverschrijding leidde nastreefde, bezit een evidente meenwarde ten opzichte van het door de delictsomschrijving beschermde belang.

Ten tijde van en vooral in verband met de abortusdiscussie wordt het Huizer veearts-arrest door sommigen aangehaald om aan te tonen dat een medicus die aborteert zich met succes kan beroepen op het ontbreken van de materiële wederrechtelijkheid.

Enschedé merkt over de Huizer veearts op:

24 Leenen bespreekt de medische exceptie onder het kopje "Ontbreken van de materiële wederrechtelijkheid"; Leenen, 1991, p. 107-108. Zie ook Hazewinkel-Suringa/Remmelink, 1991, p. 231.

25 Onder andere Enschede, 1985 , p. 48, gebruikt beide termen, maar bedoelt telkens een recht van de medicus dat afgeleid is wit de medische wetgeving. 
"De Huizer veearts is een unicum gebleven, een hapax. Zodat we nu, na viffig jaar, kunnen zeggen: de leer wan het ontbreken van de materielle wederrechtelijkheid is dood en begraven. ${ }^{\text {in } 26}$

Naar zijn mening ${ }^{27}$ heeft de Hoge Raad in de Huizer veearts-arresten beslist dat de medische exceptie zich als veterinaire exceptie ook uitstrekt over veeartsen. ${ }^{28}$ Met deze interpretatie kan ik meegaan, maar dan wel met de kanttekening dat voor de werking van de medische exceptie niet kan worden volstaan met de constatering dat de desbetreffende persoon aan zijn beroep een algemene bevoegdheid tot handelen ontleent. Biovendien is nodig dat het handelen niet in strijd is met de bedoeling van de (straf)wetgever.

Het gaat or om, zoals Vermunt zegt ${ }^{29}$, dat bij de veearts het

"handelen vanuit zijn kwaliteit 'bevoegd veearts', waaraan een bijzondere relatie tot het beschermde rechtsgoed inherent is, (...) een gegeven (is) dat bij de normconcretisering niet gemist kan worden"; of zoals hij het in het algemeen formuleert: "Wanneer - ... - een norm verbiedt om een bepaald rechtsgoed onheus te benaderen, dan hangt het mede van de sociale positie (en de daaraan inherente bijzondere relatie tot het rechtsgoed) van het handelend subject af welke handelswijzen voor het predikaat "onheus' in aanmerking komen". ${ }^{30}$

Volgens Vermunt betreft het Huizer veearts-arrest de geoorloofdheid of ongeoorloofdheid van de methode van handelen en niet die van het doel waarmee wordt gehandeld. ${ }^{31}$

Volgens Enschedé is de arts "buiten het bereik van de strafwet" als hij "handelt binnen de grenzen van het medisch normstelsell warvan hij deel uitmaakt". ${ }^{32}$ Dat lijikt mij juist, voor zover de uitoefening van de geneeskunst als geheel is bedoeld. Zodra naar de concrete gedraging van een medicus wordt gekeken, spelen ook andere factoren een rol. Deze brengen mee, dat handelen volgens de normen van het beroep een amnwijzing is dat het handelen niet strafbaar is. Het is de strafrechter die bepaalt of de medicus in overeenstemming met die normen heeft gehandeld. Als de rechter tot die vaststelling komt, dan kan de gedraging desondanks strafbaar zijn; namelijk als deze in strijd is met het door de delictsomschrijving beschermde belang.

Of, in de woorden van Van Eikema-Hommes ${ }^{33}$ :

"dat de medische norm hier noodzakelijke voonwaardle is (...), maar geen toereikende rechtsgrond (...). Däárvoor was nodig beoordeling van het handelen in het licht van het materiële strafrechtelijke beginsel, dat in de Veewet positieve gestalte heeft gekregen; t.w. dat de algemene gezondheidstoestand van de veestapel beschermd wordt en besmettelijke ziekten worden geweerd en bestreden" ,

Het is nodig dit scherp te stellen, omdat de medische exceptie soms, ook door Enschede, gezien wordt als een zelfstandige strafuitsluitingsgrond, warbij in wezen de medische lezing bepaalt of een gedraging die aan een delictsomschrijving beantwoordt, ook strafbaar is.

26 Vgl. Enschedé, 1985, p. 29.

27 Enscheddé, 1985, p. 48. Ook Remmelink leest in het Huizer veearts-arrest een erkenning van de medische excoptie. Zie Hazewinkel-Suringa/Renmelink, 1991, p. 321 e.v.

28 Ensichede, 1985, p. 31-32.

29 Vermunt, DD 1984, p. 715.

30 Vermunt, tha.p.

31 Vermunt NJB $1985, \mathrm{p} .810$.

32 Enschedé, 1985, p. 32.

33 Van Eikema-Honmes, in: Strafrecht in perspectief, 1980, p. 178. 
Wanneer is volgens de Hoge Raad in de Huizer veearts-arresten sprake van handelen binnen de grenzen van het veeartsenijkundig normstelsel? In het Huizer veearts-arrest overwoog de Hoge Raad:

"nitet kan worden aangenomen, dat volgens genoemd artikel zoude kunnen worden gestraft de veearts; die, bij het toepassen van een zekere behandeling wan het aan zijne zorg toevertrouwde vee - ... - handelt niet slechts volgens hetgeen naar eigen inzicht geoorloofd en wetenschappelijk aangewezen is, doch ook volgens in zijn wetenschap algemeen als juist erkende richtsnoeren, en die daarbij, ook alweder volgens algemeen erkend deskundig inzicht, door voorkoming van ernstig lijden, het heil van het in verdachten toestand gebracht vee bevordert".

De Hoge Raad constateerde dat de veearts een zorgplicht had ten opzichte van het vee. Derhalve behoorde het tot zijn taak het wel en wee van dat vee te bevorderen. Daarbij diende hij dusdanig te handelen als volgens zijn eigen inzicht als veearts ${ }^{34}$ geoorloofd en wetenschappelijk aangewezen is. De subjectieve beoordeling door de veearts is echter niet toereikend. Zijn inzicht over de geoorloofdheid behoort in overeenstemming te zijn met het in de veeartsenijkunde algemeen erkend deskundig inzicht. Met dat inzicht is een veeartsenijkundig ethisch inzicht bedoeld. Het betreft de vraag of het om een veeartsenijkundige behandeling gaat. "Veeartsenijkundig-ethisch" gezien dient volgens de veearts en volgens algemeen deskundig inzicht de handelling geoorloofd te zijn. Als dat geconstateerd kan worden, dan dient bovendien de concrete handeling volgens zijn eigen oordeel wetenschappelijk geschikt te zijn om het beoogde resultaat te bereiken. Dit wetenschappelijk oordeel moet bevestigd worden doondat het handelen volgens in zijn wetenschap algemeen als juist erkende richtsnoeren plaatsvindt. Of daarvan sprake is bepaalt de rechter.

\section{Concilusite}

De Huizer veearts-arresten bieden weliswaar de mogelijkheid daarin slechts een erkenning van de medische exceptie te lezen, maar de overwegingen van de Hoge Raad wijzen eerder in de richting van een rechtsgrond die in meer algemene zin de wederrechtelijkheid kan opheffen. Deze rechtsgrond kan als het ontbreken van de materiële wederrechtelijkheid worden aangeduid. Vanwege de verschillende mogelijkheden voor een interpretatie van de Huizer veearts-arresten en in verband met de tenughoudendheid van de Hoge Raad om arresten met een zelfde strekking te wijzen, wordt hier gepleit voor een beperkte strekking van het ontbreken van de materiële wederrechtelijkheid.

Bij een gedraging, die aan de bewoordingen wan een delictsomschrijving beantwoordt, kan de materiële wederrechtelijkheid ontbreken, wanneer

1. evident in hetzelfde belang is gehandeld, dat de delictsomschrijving beoogt te beschermen,

2. de wetgever juist niet de omstreden gedraging van de strafbaarheid wilde uitsluiten,

34 In HR 27 nov. 1984, NJ 1985, 106 m.nt. ThWvV, las de Hoge Raad de overweging van het Hof: "omdat zij navir zijn oordeel ..." als: "naar zijn vakkundig oordeel als medicus" . Vermoedelijk bedoelde hijj hetzelfie met de uitdrukking "naar eigen inzicht". 
3. de wijze waarop het belang wordt nagestreefd meer aangewezen is dan de wet na te leven. ${ }^{35}$

$35 \mathrm{Vgl}$. Strijards, 1987, p. 49: Bij het ontbreken van de materiêle wederrechtelijkheid dient de gedraging het door de: strafwet veilig gestelde rechtsbelang. 



\section{Mishandeling}

\section{Inleïding}

Toen in 1978 de strafrechtjuristen De Doelder en 't Hart over "Medicus en mishandeling" schreven $^{\text {}}$, ontlokten zij de gezondheidsjurist Schuurmans Stekhoven de reactie, dat zij het voor de praktijk veel belangrijker probleem van de medische kunstfouten over het hoofd zagen. ${ }^{2}$ In dit hoofdstuk gaat het evenwel juist over de door De Doelder en 't Hart aangesneden problematiek.

Een operatieve ingreep lege artis is een medische handeling die tot de beroepsuitoefening van de medicus behoort. Met "operatieve" of "chinurgische" ingreep wordt hier elke gedraging van een medicus bedoeld, die aan de objectieve bestanddelen van eên van de delictsomschrijvingen van (zware) mishandeling beantwoordt en die derhalve pijn en/of (zwaar) lichamelijk letsel veroorzaakt. Vanzelfsprekend leidt deze ingreep niet tot strafrechtelijke aansprakelijkheid van de medicus. Er is een medische indicatie aanwezig en de professioneel uitgevoerde handeling geschiedt in het belang van de gezondheid van de patiënt. In de benadering van Leenen is er sprake van een medisch-professionele handeling, die volgens hem vanwege de medische exceptie straffeloos mag geschieden. ${ }^{3}$

In dit hoofdstuk wordt nagegaan op welke rechtsgrond de straffeloosheid van de medicus voor dit handelen berust. Daanit zal blijken dat ondanks de vanzelfsprekendheid juristen, vooral in de eerste tientallen jaren na invoering van het Wetboek van Strafrecht, getracht hebben een antwoord op deze vraag te vinden. ${ }^{4}$

Het belang van het vraagstuk ligt daarin, dat het hierbij niet gaat om een levensbeschouwelijk onderwerp. Verondersteld wordt dat de in dit hoofdstuk verkregen inzichten kunnen bijdragen tot verheldering van de problematiek van de strafrechtelijke benadering van medisch handelen waarbij dit well het geval is. Daartoe behoren abortus, euthanasie en levensbeëindiging.

In de praktijk hebben zich, bij mijn weten, omtrent de strafrechtelijke aansprakelijkheid van de medicus vanwege mishandeling voor een lege artis uitgevoerde handeling nooit problemen voorgedaan. Dat heeft waarschijnlijk tot gevolg gehad dat medici nauwelijks belangstelling voor de problematiek toonden. Hun belangrijkste bijdrage beperkt zich tot een standpuntbepaling van een op initiatief van de strafrechtjurist Simons door de Nederlandsche Maatschappij ter Bevordering van de Geneeskunst (NMG) ingestelde commissie van medici en rechtsgeleerden - verder de Gemengde Commissie van 1909 genoemd - die juridische knelpunten van handelen door medici onderzocht en daarbij

1 De Doeldar en 't Hart, TVGR 1978, p. 57-68.

2 Schumrmans Stekhoven, TwGR 1978, p. 159 .

3 Leenen, 1991, p. 26.

4 Vgl. Hazewinkel-Suringa/Rernmelink, 1991, p. 338: "De juristen hebben de vraag echter wel eefn antwoord wardig geacht en boekdelen vol geschrewen om dat al genene gevoelen, dat een chirurg wel behandelt, mar miet mishardelt, al steekt of snijdt hij in het levende vlees en brengt hil aldus opzentelijk letsel toe, juridischa te funderen". 
in het bijzonder aandacht besteedde aan dat handelen in verband met de delictsomschrijvingen van mishandeling en abortus. ${ }^{5}$

In dit hoofdstuk wordt eerst ingegaan op de wetsgeschiedenis van de strafbepallingen voor dierenmishandeling, art. 254-oud Sr en voor mishandeling, artt. 300 e.v. Sr. Bij de totstandkoming van de strafbepalingen omtrent mishandeling werd verwezen naar opmerkingen gemaakt bij de vaststelling van art. 254-oud $\mathrm{Sr}$, omdat daar een vergelijkbare problematiek speelde ${ }^{6}$ Vervolgens wordt nagegaan, op welke wijze in de literatuur en jurisprudentie getracht is de straffeloosheid van de medicus voor chirurgische ingrepen te funderen.

\section{De wetsgeschiedenis van mishandeling en van dierenmishandeling}

\subsection{Dierenmishandeling}

Bij de formulering van ant. 254-oud Sr zag de wetgever zich voor het probleem geplaatst dat hij het straffen van dieren en het verrichten van vivisectie, dat wil zeggen het doen van proeven op levende dieren, in het algemeen niet onder de strafbepaling van art. 254-oud $\mathrm{Sr}$ wilde laten vallen.

In het kader van dit onderzoek is wooral de wijze waarop de wetgever tracht tot strafuitsluiting voor vivisectie te komen van belang ${ }_{4}$ omdat vivisectie een gedraging is die door beroepsbeoffenaren wordt uitgeoefend en die in dat opzicht overeenkomsten vertoont met chirurgische ingrepen bij de mens. Echter, terwijl een chirurgische ingreep in het belang van de patiënt wordt verricht, geschiedt vivisectie niet in het belang van het betrokken dier.

\subsubsection{De totstandkoming van art. 254-oud $\mathrm{Sr}$ in 1881}

$\mathrm{Bij}$ de door de wetgever behandelde delictsomschrijving van dierenmishandeling, art. 254-oud Sir, was in plaats van de feitelijke omschrijving in art. 272 Oorspronkelijk Regeringsontwerp (O.R.O.): "Hij die opzettelijk een dier wreed behandelt, wordt gestraft met ..." , een meer kwalificatieve aanduiding gekomen: "Mishandeling van een dier wordt gestraft met ...".

Van een wrede behandeling was volgens de MvT sprake als het handelen geen "rechtmatige, geoorloofde oorzaak" heeft. "Alleen noodeloos aangedane smart, die niet door eenig matschappelijk doel of wetenschappelijk belang geboden wordt, is strafbaar". Of een handeling jegens een dier wreed is, wordt in die opvatting objectief bepaald. Bij een rechtmatig, geoorloofd doel was de wijze waarop het dier werd behandeld nimmer wreed, char de handeling slechts middel tot dat doel was. Ontbrak een zodanig doel, dan kon de handeling wreed zijn. Voor het vervullen van de dellictsomschrijving van art. 272 O.R.O. was bovendien nodig, dat het opzet op de wreedheid was gericht. ${ }^{?}$

5 Genengde Cormmissie van 1909, NTVG 1909, 1, p. 71-83.

6 Aan de overtredingswariant wan art. $254 \mathrm{Si}$, art. $455 \mathrm{Sr}$ (kwelling van dieren) wordt hjeronder geen aandacht besteed; daar deze bepaling woor het signaleren van de hier beschreven problematiek slechts wan marginale betekenis is:

7 Snidr, II, 1891, p. 367 . 
De Commissie van Rapporteurs merkte hiertoe op:

"Deze redenering is, ..., niet juist en in strijd met het systeem wan het ontwerp. Het opzet moet gericht zijn op de wreede behandeling; dit is voldoende on het misdrijf te constitueren. Of de wreedheid middel is of doel, is volkomen onverschillig; de opzettelijk gepleegde objectieve wreedheid is al wat vereischt wordt, zonder dat bovendien mag gevorderd worden de subjectieve wreedheid of het doel om te mishandelen. De Regering ziet over het hoofd, dat volgens haar eigen stelsel het opzet nimmer het oogmerk insluit". ${ }^{8}$

De Commissie stelde voor de wreedheid als geobjectiveerd bestanddeel in de delictsomschrijving op te nemen en wilde daarom het artikel lezen als: "Hij die ... een dier uit wreedheid mishandelt ..." , zodat slechts het mishandelen door het subjectieve schuldverband zou worden bestreken.

In het Regeringsantwoord werd bevestigd,

"dat het niet voldoende is dat de behandeling èn opzettelijk èn wreed is, maar dat het opzet op de wreedheid gericht moet zijn. Meent men dat dit zelfde denkbeeld nog duidelijker zou worden uitgedrukt door het woord 'mishandeling', de Minister zal zich tegen deze wijziging niet verzetten".

Daarmee gaf de regering te kennen dat zij aan 'opzettelijk wreed behandelen' en 'mishandelen' dezelffe betekenis toekende: De bijvoeging "uit wreedheid" werd als overbodig en in strijd met het systeem van het Ontwerp beschouwd, daar dan het motief in de delictsomschrijving zou zijn opgenomen.

Tevens protesteerde de toenmalige Minister van Justitie Modderman "ten sterkste" tegen de bewering van de Commissie dat "volgens het eigen stelsel der Regeering het opzet nimmer het oogmerk insluit". "Of 'opzet' formeel of materieel is op te vatten, hangt af van het verband waarin het voorkomt"."

De Commissie kon zich wel vinden in de gewijzigde bepaling "Mishandeling van een dier...", maar was niet overtuigd door het antwoord.

"Ook na de nadere toelichting der Regeering blijft de Commissie van gevoelen dat 'opzettelijk wreede behandeling', volgens de terminologie van het Wetboek altijd aanwezig is wanneer de opzettelijke handeling (objectief) wreed is, ook al ontbreekt de wreedheid als animus (subjectief), zoodat tegen de bedoeling de vivisectie strafbaar zou worden". ${ }^{10}$

Tijdens de parlementaire behandeling kwam Modderman op dit twistpunt terug.

"Het woord "mishandeling' is in de plaats gekomen wan 'opzettelijk-wreede behandeling'. Dit is echter geschied onder uitdrukkelijke verklaring dat slechts verduidelijking, geenszins verandering van de bedoeling beoogd wordt.

De Commissie meende dat het woord 'mishandeling' de bedoeling nog duidelijker uitdrukte, en ik heb mij bij haar wensch om dit laatste woord te kiezen, nedergelegd. De bedoeling echter - ... - is geheel dezelfde gebleven. Het is dus niet voldoende dat de handeling is èn opzettelijk èn wreed, maar zij moet zijn opzettelijk-wreed. ... Wanneer daarentegen de smart van het dier niet DOEL maar MIDDEL is voor een rationeel doel, dan is het artikel niet van toepassing. De vivisectie zal dus in

8 Smidt, II, 1891 , p. 369.

9 Smidt, IT, 1891 , p. 370 .

10 Smidt, II, 1891, p. 371. Zie ook Simons, I1, 1923, p. 199-200, volgens wie dierenmishandeling aarwezig was, zodra het opzettelijk toebrengen wan pijn of letsel niet in het belang van het behandelde dier was, zodat voor them vivisectie onder de delictsomschrijwing viel. 
den regel valten buiten dit artikel. In den regel, dat wil zeggen wanneer zij werkelijk geschiedt net een wetenschappelijk doel, door een wetenschappelijk man, binnen de grens van de behoefter der wetenschap" .

Uit de wetsgeschiedenis blijkt daarmee, dat de Commissie de niet-strafbaarheid van de vivisectie zocht in het ontbreken van subjectieve bestanddelen, terwijl de regering de straffeloosheid in het objectief geoorloofde doel gelegen zag. Een handeling jegens een dier was geen dierenmishandeling, wanneer deze geschiedde ter bereiking van een rationeel doel, "omdat de rechtmatigheid niet in het gedrang komt" ${ }^{12}$ Een bepaald doel kon in beginsel rationeel zijn, maar dan moest er wel aan bepaalde voorwaarden zijn voldaan. Voor een geoorloofde vivisectie noemde Moddlerman als voorwaarden, dat zij door een wetenschapper, binnen de grenzen wan de beroepsuitoefening en met een wetenschappelijk doel geschiedt.

\subsubsection{Jurisprudentie en literatuur over art. 254-oud $\mathrm{Sr}$}

Volgens de Hoge Raad was niet elke wrede behandeling van een dier dierenmishandeling. Hij eiste dat het opzet op de wreedheid was gericht en dat de wreedheid doel wan de handeling was en niet slechts middel tot een rationeel doel. Voor de strafbaarheid werd derhalve ondermeer geêist dat de wreedheid doel op zichzelf was, althans geen middel was tot bereiking van een rationeel doel. ${ }^{13}$ De Hoge Raad verwarde daarmee de vraag naar het materiele opzet en de vraag naar de onrechtmatigheid, met als gevolg dat vivisectie nooit strafbaar kon zijn. ${ }^{14}$

Deze uitspraken riepen kritiek op, omdat dientengevolge niet onder dierenmishandeling viel het opzettelijk wreed behandelen van een dier, waarbij de wrede behandeling als middel tot een geoorloofid doel diende."

In de literatuur werd gepleit voor een geobjectiveerde benadering van middel en doel. ${ }^{16}$ Wttewaall merkte op dat onder "wreed behandelen" weliswaar verstaan kon worden, het pijn doen lijden zonder gegronde reden, zodat de dader om strafbaar te zijn de bewustheid moest hebben zonder gegronde reden te handelen. Hiertegen voerde hij aan, dat de strafbaarheid daarmee afhangt van het subjectieve oordeel van de dader over zijn bevoegdheid een dier leed toe te voegen. ${ }^{17}$ Hij gaf er de voorkeur aan om "wreed behandelen" te lezen als: pijn veroorzaken, tenzij uit gegronde reden. De strafbaarheid hangt dan af van de objectieve aanwezigheid van een gegronde reden. Naar zijn mening werd

11 Smidi, II, 1891, p. 379 .

12 Semplonius, 1920 , p: 104-108. Zie m.n. p. 108.

13 HIR 30 april 1888 , W 5555. Zie b.w. ook: IIR 31 okt. 1887, W 5489 en HR 12 dec. 1898, W 7216.

14 Vgl. Van Hamel, 1913 , pi 311.

15 Zito voor kritiek: Sinuons, II, 1923, p. 199-200: "Deze ook naar mijn meening onjuiste uitlegging, berustende op eene verkeerde opvatting wan het begrip 'mishandeling' ontmoette van verschillende zijden ernstige bestrijding". Noyon, 1904, aant. 1 op art. 254; Wttewall, TVS 1898, p. 118-126; W 10105; W 10109.

16 Vgl. Simons, II, 1923, p. 200; Semplonius, 1920, p. 110 e.v.; Noyon, 1926, want, 1 op art. 254 en De Beneditty, TVS 1935, p. 177: "ieder werd wrijgesproken, wien thet te doen was om een geoorloofd maatschappelijk doel te bere"lken, ook al werd bet dier hierdoor nog zooveel leed toegebracht" Zie ook NLR, aant. 2 op art. 254 .

17 Witewaall, TuS 1898, p. 125 . 
bij mishandeling deze opvatting gevolgd en verdiende zij ook bij dierenmishandeling aanbeveling. ${ }^{18}$

In latere arresten stelde de Hoge Raad niet meer de eis dat de wreedheid doel op zichzelf behoorde te zijn. ${ }^{19}$ Was de wreedheid echter middel tot een geoorloofd doel, dan was volgens hem van dierenmishandeling nog steeds geen sprake. Als het doel geoorloofd was, dan mocht elk middel gebezigd worden, dat ter bereiking van dat doel nodig was. De jurisprudentie van de Hoge Raad schoot daarmee in zoverre nog tekort, dat niet werd gesteld, dat een rationeel doel een redelijk doel behoort te zijn dat zijn redelijk karakter door het gebezigde middel kan verliezen. Hierop had Modderman gewezen, toen hij in verband met de vivisectie opmerkte, dat een doel slechts rationeel is voor zover zekere grenzen in acht worden genomen. Maar doordat daartegenower de misleidende uitlatingen van hem over middel en doel stonden, bood de wetsgeschiedenis voor de verschillende benaderingen door de Hoge Raad aanknopingspunten.

\subsubsection{Wetsvoorstellen tot wijziging van art. 254-oud $\mathrm{Sr}$}

Voordat het in 1920 tot een wijziging van art. 254-oud Sr kwam; werden in de novelle-Cort van der Linden in $1900^{21}$ en in de novelle-Loeff in $1904^{22}$ voorstellen tot wijziging van deze bepaling gedaan.

Cort van der Linden had voorgesteld de aanhef van art. 254 te lezen als: "Hij die opzettelijk een dier wreed behandelt of noodeloos pijnigt of kwelt, wordt gestraft ..." De novelle-Cort van der Linden werd door zijn opvolger Loeff ingetrokken. In de novelle-Loeff werd vastgehouden aan de in de novelle-Cort van der Linden voorgestelde wijziging. De novelle-Loeff onderging een zelfde lot als de novelle-Cort van der Linden. $\mathbf{Z i j}$ werd ingetrokken door Minister Van Raalte, de opvolger van Loeff. ${ }^{23}$

Ook de latere Minister van Justitie Heemskerk achtte een wijziging van art. 254-oud Sr geboden. Daarom werd op 28 juli 1919 bij de Tweede Kamer een wetsvoorstel tot wijziging van art. 254 -oud $\mathrm{Sr}$ ingediend. ${ }^{24}$ In $1920^{25}$ kwam het eerste lid van art. 254 $\mathrm{Sr}$ als volgt te luiden:

"Met .... wordt gestraft:

1. hij die, zonder redelijk doel of met overschrijding van hetgeen ter bereiking van zodanig doel toellatbaar is, opzettelijk een dier pijn of letsel veroorzaakt of de gezondheid benadeelt;

18 Wttewall, TwS 1898, p. 126.

19 Vermoedelijk gaf hiertoe een circulaire van de MvJ van 12 dec. 1917 de arnzet. De tekst wara deze circullaire is te vinden in W 10180. Zie over deze circulaire: Semplonius, 1920, p. $117-120$.

$20 \mathrm{MR} 13$ mei 1918 , W $10252 \mathrm{~m} . n$. D.S.; HR 11 Hov. 1918, W $10347 \mathrm{~m}$.nt. D.S. (Zie hiertoe ook: Semplonius 1920, p. 119-120); HR 13 jan. 19 19, W 10385 m.nt. D.S. Vgl. Nieboer, 1991, p. 108: Volgens HR 11 mov. 1918, W 10347, NJ 1918, 1245 en 11 okt. 1920, W 10635, NJ 1920, 1096, heiligde het doel het gebruikte middlel, ook als dit niet proportioneel was.. Deze uitleg was uit een oogpunt van dierenbescherming "hoogsi ongewenst". Daarom greep de wetgever in.

21. Handelingen der Siaten Generaal 1900-1901, Eijlagen 100, p. 1-61.

22 Handelingen der Statten-Generaal 1904-1905. Bijlagen 80, p. 1-38.

$23 \mathrm{Wgl}$. Semplonits, 1920 ; p. 133 .

24. TK 1918-1919, 528, no. 1 .

25 Wet van 16 april 1920, Stb.194. 
2. hij die, zonder redelijk doel of met overschrijding van hetgeen ter bereiking van zodanig doel toelaatbaar is, opzettelijk aan een dier dat geheel of ten dele aan hem toebehoort en onder zijn toezicht staat, of aan een dier tot welks verzorging hij verplicht is, de nodige verzorging onthoudt".

Van dierenmishandeling vanwege art. $254 \mathrm{Sr}$ is sindsdien volgens de delictsomschrijving geen sprake als het doel objectief gezien redelijk is en als het middel proportioneel is ain het doel. ${ }^{26}$

\subsection{Mishandeling}

\subsubsection{Inleiding}

Titel XX van Boek II van het Wetboek van Strafrecht draagt het opschrift "Mishandeling". In art. $300 \mathrm{Sr}$ is de eenvoudige mishandeling strafbaar gesteld en in art. $302 \mathrm{Sr}$ de zware. In de strafbaarstelling van de eenvoudige en de zware mishandeling met "voorbedachten rade" voorzien de artt. 301 en $303 \mathrm{Sr}$.

Art. 300 lid 1 Sr luidt:" "Milshandeling wordt gestraft met ..." , zonder dat nader wordt aangegeven wat onder mishandeling dient te worden verstaan. De zware mishandeling is wel feitelijk omschreven. Art. 302 lid 1 Sr luidt: "Hij die aan een ander opzettellik zwaar lichamelijk letsel toebrengt, wordt, als schuldig aan zware mishandeling, gestraft met..."

In het Oorspronkelijk Regeringsontwerp werd ook de eenvoudige mishandeling omschreven. Ant. 324 O.R.O. sprak van: "Hij die door eenige daad aan een ander opzettelijk lichamelijk leed toebrengt of opzettelijk diens gezondheid benadeelt, wordt, als schuldig aan mishandeling, gestraft met ..."

De Commissie van Rapporteurs van de Tweede Kamer stelde voor om in plaats van deze omschrijwing te volstaan met de aanduiding "mishandeling". Volgens haar bracht de tekst van art. 324 O.R.O. onder andere mee, dat bepaalde niet strafwaardige handelingen onder de delictsomschrijving zouden vallen. Met name noemde zij daarbij medische ingrepen en het ouderlijk tuchtigingsre cht, zonder de niet strafwaardige handelingen hiertoe te willen beperken: ${ }^{27}$

De regering nam dit voonstel in het Gewijzigd Ontwerp (G.O.) over. In haar voorstelling viel onder "mishandeling" echter niet de "opzettelijke benadeling van de gezondheid". Daarom werd een vierde lid aan art. 300 G.O. toegevoegd, luidende: "Met mishandeling wordt gelijkgesteld opzettelijke benadeling van de gezondheid".

26. Vgli. m.b.t. de bedoeling van de wetgever wan 1920: Simons, 1I, 1923, p. 200; Noyon, 1926, aant. 1 op art. 25.4 en Van Bemmelen/Van Hattum, $\mathbb{1 1}$, 1954 , p. 503-504 en NLR, aant. 2 op art. 254. In HR 16 jan. 1922 , W $10870, \mathrm{NJ} 1922,345$, overwoog de Hoge Raad dat voor de strafbaarheid niet wordt vereist, dat de dader opzettelijk zonder redelijk doel handelt, waarmee hij te kennen gaf, dat het redelijk doel een geobjectiveerd doel was.

27 Smidt, II, $1891, p, 475$. 
Bij de beraadslagingen in de Tweede $\mathrm{Kamer}^{28}$ over de eenvoudige mishandeling werd opgemerkt, dat het woord mishandeling aanleiding zou kunnen geven tot misverstanden omdat bij de dierenmishandeling het woord mishandeling in de plaats was gekomen van het "opzettelijk wreed behandelen", terwijl het bij de eenvoudige mishandeling in de plaats van "opzettelijk lichamelijk leed aandoen" kwam. Daarom werd in overweging gegeven om de eenvoudige mishandeling in die bewoordingen te omschrijven.

Hiertegen bracht Patijn, lid van de Commissie van Rapporteurs, in dat voor eenvoudige mishandeling niet altijd nodig is een opzettelijk wrede behandeling, een gedachte die door Modderman werd bevestigd. Met andere woorden: een gedraging die jegens een mens mishandeling oplevert, behoeft jegens een dier verricht nog geen dierenmishandeling te zijn.

Een tweede bezwaar van Patijn tegen de terugkeer naar een feitelijke omschrijving was, dat "er dan zouden kunnen zijn die er zelfs heelkundige operatien onder begrepen". Hij voegde daaraan toe:

"Een chirurgijn bijv. die een persoon behandelt brengt deze dikwijls opzettelijk leed toe, maar een leed dat tot genezing moet strekken en dus nimmer als 'mishandeling' zou kunnen worden gequalificeerd".

Volgens Modderman was de strekking van de delictsomschrijwingen van dierenmishandeling en mishandeling dezelfde, namelijk:

"dat het niet voldoende is dat men opzettelijk leed doet, maar daarenboven een vereischte dat dit leed doel was. Dit wordt dan ook reeds in het spraakgebruik van het dagelijksch leven erkend. Wie zijn kind kastijdt of, als chirurgijn, iemand een operatie doet ondergaan, veroorzaakt opzettelijk leed, maar wordt, daar leed daarbij geen doel, maar middel is voor een rationeel doel, niet gezegd te mishandelen. Komt deze verklaring nu niet precies overeen met hetgeen gisteren door mij gezegd werd ter toelichting van art. $254 ?^{\prime \prime 29}$.

Na deze verklaring werd het wetsartikel in zijn huidige redactie in de Tweede Kamer aangenomen.

De aanduiding van het doel als 'rationeel' is een aanwijzing dat Modderman geen subjectieve waardering van het doel bedoelde. Wezenlijk is of - objectief gezien - met de gedraging een objectief gerechtvaardigd doel wordt nagestreefd. Noch intentie, noch oogmerk spelen hierbij een rol.

Volgens de regering viel het opzettelijk toebrengen van pijn of letsel niet onder mishandeling, wanneer het doel gerechtvaardigd was. Een gerechtvardigd doel brengt mee dat de handeling niet onder de delictsomschrijving valt, omdat zij niet als onrecht wordt aangemerkt.

28 Smidt: II, 1891, p. 476-478.

29. Smidi, 1,1891, p. 477. Zie bovendien in dezelfde zin: hel Antwoord der Regering op het Verslag van de Eerste Kamer, Smidt, II, 1891, p. 380: "Van verschillende beteekenis is geen sprake. En bij menschen, èn bij dieren valt thet veroorzaken van pijn als middel tot een geoorloofd doel buiten het begrip" .

Valgens Nieboer, 1991, p. 107-108, ontkende Modderman met behulp van een finale omschrijwing de toepasselijkheid van de gedragsnorm. Volgens hem was hell beter geweest als Modderman duidlelijk had gesteld dat behandelen geen misthandelen is. Als kritick op de finale omschrjying noemt Nieboer, dat daardoor de noodweerbepaling van art. $41 \mathrm{Sr}$ onkacht dreigt te worden. Blj noodweer is immers het wentuele leed evermin doel maar slechls middel voor een rationeel doel. 
"De mensch pleegt onrecht, zoo dikwerf hij, zijne macht misbruikende, zonder eenig rationeel doel, in.a.w. noodeloos, opzettelijk doet lijden eemig wezen dat lijden $\mathrm{kan}^{\prime \prime}$. 30

Een gedraging die letterlijk aan een delictsomschrijwing beantwoordt, behoeft derhalve niet onrechtmatig te zijn. Er kan immers, zo zouden we thans zeggen, de wederrechtelijkheid ontbreken. ${ }^{31}$

Steun voor deze interpretatie kan worden gevonden in uitlatingen van de wetgever ower opzet in het WvSr. In de MVT op het oorspronkelijk ontwerp werd het afhankelijk stellen van de strafbaarheid van de daad van "hare zedelijke waarde" afgewezen.

"De strafwet verliest op die wijze alle objectiviteit, hare toepassing wordt afhankelijk van de min of meer juiste zedelijke en verstandelijke inzigten en waarderingen harer overtreders, ... De wet stempele dus alleen als misdrijf opzettelijk gepleegde handelingen, van welke het ieder normaal ontwikkelde mensch duidelijk moet zijn dat zij in strijd zijn mel de zedelijke en maatschappelijke orde. Maar waar de wetgever, na rijp beraad, een feit onder de misdrijven heeft opgenomen, daar vrage men niet naar de subjectieve inzigten des daders over het geoorloofde of ongeoorloofde dier handeling, ten einde daarvan de strafbaarheid te doen afhangen " ${ }^{32}$

Misdrijven waren voor de wetgever van 1881 rechtsdelicten en overtredingen wetsdelicten. Een rechtsdelict is een strafwaardige gedraging, omdat deze door de samenleving als afkeurenswaardig wordt beschouwd, ook zonder dat zij strafbaar is gesteld. ${ }^{33}$ (Zware) mishandeling is in deze opvatting het strafwaardig opzettelijk toebrengen van (zwaar) lichamelijk letsel. ${ }^{34}$

De wetgever wilde het handellen met een gerechtvaardigd doel niet nader afbakenen. In beginsel liet hij daarmee de wetenschappers, de ouders en de artsen de vrije hand, voor zover geoorloofde doelen (vivisectie ten behoeve van de mens, opvoeding van het kind, geneeskundige doelen) - binnen de grenzen van het redelijke - werden nagestreefd. Als mocht blijken dat nadere grenzen gesteld dienden te worden, dan kon de wetgever die alsnog bepalen. ${ }^{3.5}$

30 Regeringsantwoord, Smidt, It, 1891, p, 370 .

31 Remmelink, Harewinkel-Suringa/Renmellink, 1901, p. 231, merkit op dat de wetgever van 1881 de aborterende arts varwege de medische exceptic niet straftaar achne. "Men kan derhive zeggen, dat de nitet-strafbaarbeïd van cen feit wegens bet ontbreken wan strafrechtelijk relevant onrecht (materièle wederrechtelijkheid) in het strafrecht eigenligk al van meet af (vanaf de totstindkoning wat bet wetboek) is erkend, zij het lang net herkend". Zie ook p. 321-322, was hij enerzjjds spreekt wan "het aanvankelijk gesloten systeem van de wetgever" en anderzijds in verband met het tuchtigingsrecht en het medisch handelen er op wijst, dat de rechtvatardiging van dit gedrag gezocht moet worden in normen "buiten de algemene en bijzondere straf fwetgeving derhalwe vooral uit de rondom het strafrecht gegroepeerde rechtsorde". Volgens Fonschedé, NJB 1966, p. 1112, stond de wetgever van 1881 op een "legalistisch standpunt".

32 Smid, I, 1891 , p. 7879.

33 Smidr, 1,1891 , p. 64. Vgli; Semplonius, 1920, p. 87: In de opvatting van de wetgevier van 1881 druisen rechtsdelicten in tegen het angeschreven recht en zijn reeds daaron de betreffende gedragingen op zichzelf strafwardig.

34 Dene alangevoerde grondslag woor de rongschikking wam delicten als misdrijf of als overtreding wordt in het a lgemeen a/gewezen. Zie daarover b.v. Van der Hoewen, 1884, p. 29 e.w. Dat neemt echter niet weg. dat de wetgever die opvatting verkondigde en dat er, zoals Mulder in: Recht en Praktijk, 1979, p. 88, schrijft, "met het critterium blijkbatar toch wel te werken valt". In dezelfde zim: Strijards, 1988 , p. 9 en p. 14.

35 Smidt, II, 1891, p. 379 . 
Art. 326 O.R.O. bleef ongewijzigd en daarmee kwam de feitelijke omschrijving van zware mishandeling in art. 302 Sr terecht. Terwijl juist chinurgische ingnepen vaker zwaar lichamelijk letsel kunnen veroorzaken, werd daaraan bij de behandeling van dit wetsartikel geen aandacht besteed. In de opvatting van de regering was dat ook miet nodig. Volgens haar viel medisch handelen dat lichamelijk letsel veroorzaakte buiten de delictsomschrijving, zowel wanneer deze feitelijk is omschreven als wanneer wordt vollstaan met de aanduiding mishandeling.

Daarentegen was in de opvatting van degenen die de aanduiding mishandeling in plaats van de feitelijke omschrijving wensten, om onder andere medische ingrepen niet onder de delictsomschrijving te laten vallen, de straffeloosheid voor ingrijpende chirurgische ingrepen niet verklaarbaar. Deze voldeden immers, in deze benadering, aan de delictsomschrijving van de zware mishandeling.

Afhankelijk van het gewicht dat toegekend wordt aan de uitlatingen door de bij het wetgevingsproces betrokkenen, kan derhalve verdedigd worden, óf dat een zware chirurgische ingreep - gezien de delictsomschrijving - zware mishandeling oplevert, óf dat die ingreep - vanwege het objectief gerechtvaardigde doel - niet onder de delictsomschrijving van art. $302 \mathrm{Sr}$ valt.

\subsubsection{Mishandeling in de novelle-Cort van der Linden, 1900}

In 1900 werd in de novelle van de toenmalige MvJ , Cort van der Linden, tot herziening van het Wetboek van Strafrecht woorgesteld mishandeling, in navolging van de jurisprudentie van de Hoge Raad $^{36}$, feitelijk te omschrijven als "het opzettelijk toebrengen van pijn of lichamelijk letsel", daar het woord mishandeling te kwalificatief zou zijn en niet het feit zelf zou uitdrukken. Het voorstel betekende in wezen een terugkeer naar de redactie van art. 324 O.R.O. In de MvT werd in dit verband geen aandacht besteed aan de positie van de medicus. ${ }^{37}$

Daarentegen werd wel voorzien in een bijzondere rechtvaardigingsgrond in verband met het tuchtigingsrecht van opvoeders. Daarin was het doel geobjectiveerd en tevens de eis van proportionaliteit verwerkt. ${ }^{38}$

"Niet strafbaar is hij die ter uitoefening der tucht over aan zijne tucht toevertrouwde minderjarigen een feit begat, voor zover het naar redelijk inzicht doelmatig is te achten".

Na wisseling van het kabinet werd de novelle-Cort van der Linden in 1901 door zijn opvolger Loeff ingetrokken en door een nieuwe novelle vervangen. ${ }^{39}$ De novelle-Loeff $\mathrm{f}^{\$ 0}$ behelsde geen voorstel om de delictsomschrijving van art. $300 \mathrm{Sr}$ te wijzigen. Uit de MvT blijkt niet waarom daarvan werd afgezien.

36 Vgl. HIR 25 juni 1894, W 6534 .

37 Handelingen Staten-Generaal, Bijlagen 1900-1901, p. 51.

38 Zie hiertoe: Simons, 1 ; 1927, p. $278-279$.

39 Handelingen Staten-Generaal, Bijlagen 1901-1902; Brief van 20 sept. 1901.

40 Handelingen der Staten-Generaal; Bijlagen 1904-1905, ars. 80 1-3. 
Uit de wetsgeschiedenis van de bepalingen omtrent mishandeling en dierenmishandeling valt niet af te leiden dat de wetgever voor de straffeloosheid van de medicus aan een bijzondere rechtsgrond dacht. Wel vond hij het kennelijk vanzelfsprekend, dat medisch handelen in het algemeen met een gerechtvaardigd doel geschiedt. Maar dat veronderstelde hij ook bij dierproeven en bij de uitoefening van het tuchtigingsrecht ten aanzien van minderjarigen.

In de opvatting van de regering neemt een handelen met een objectief gerechtvaardigd doel het anders onrechtmatige van dat handelen weg. ${ }^{41}$ Daarmee heeft zij te kennen gegeven, dat een handelen dat aan de letter van een delictsomschrijving beantwoordt, miet onder de delictsomschrijving valt wanneer de wederrechtelijkheid ontbreekt. De reden woor de straffeloosheid is niet gelegen in de hoedanigheid van de handelende persoon, maar in het gerechtvaardigde doel. De hoedanigheid is wel in zoverre van belang, dat zij aangeeft wie tot een bepaald handelen met een gerechtvaardigd doel bevoegd is.

\section{De strafrechtelijke aansprakelijkheid van de medicus}

\subsection{Het voor mishandeling vereiste opzet}

\subsubsection{Formele en materiële opzetdelicten}

Een opzetdelict kan formeel of materieel van aard zijn. Bij een formeel opzetdelict is het misdrijf met de handeling zelf voltooid. Een materieel opzetmisdrijf is pas voltooid wanneer de handeling een bepaald, in de delictsomschrijving aangegeven gevolg teweeg heeft gebracht. Delicten die in hun formulering een actief optreden veronderstellen, maar ook door een nalaten kunnen worden gepleegd - oneigenlijke omissiedelicten derhalve -, zijn steeds delicten met een materiële omschrijving. ${ }^{42}$ Mishandeling ${ }^{43}$, afdrijving

41. Vgl. Van Bemmelen/Vian Hattum, II, 1954, p. 226. Deze bendering acht Remmelink, zie NLR, gant. 1 op art. 300, "het meest rationele en consequente systeem", die meer dan andere benaderingen recht doet aan "de bedoelingen wan de wetgever". Volgens Strijards, 1987, p, 70-71, ontlenen de ouders aan hun hoedanigheid ate "hoogstpersoonlijke bewoegdheid" met een opvoedkundig doell leed toe te voegen. Hij kan zich voorstellen, dat een dergelijke bevoegdheid ook een rechtwatardigende werking in bepalde sport-, spel of wedstrijdsitwaties heef.

$42 \mathrm{Vgl}$. Hazewinkel-Suringa/Remmelink, $1991, \mathrm{p}$. 108. Over het belang van het onderscheid wordt werschillend gedecht. Van Hamel, 1927, p. 191 makt bezwaren tegen dit onderscheid. Remmelink, Hazewinkel-Suringa/Remmelink, 1991, p. 97-98, wijst erop dai het onderscheid slechts voortvloeit uit de delictsomschrijving, man acht halar belangrijk voor de poging, de causal iteit, de deelneming en, processueel, voor de bewijslast. Strijards, $1988, p .88$, woemt het in de materiele delicten genoemde gevolg een "bijkomende voorwaarde voor de ansprakelijkheid". Op p. 90 merkt hij op, dat bij forme le delicten aan de dader de gevolgen werweten worden. Maar die gevolgen zijn "niet apart tot bewijsthema (...) verheven". Het is volgens hem beter on we nus nceren. Zo heeft b.w. doodslag materiële trekken; het is meer een materieel dan een formeel delict. Volgens Nieboer, 1991, p. 90, wordt bij een materiêle delictsomschrijving de gedraging getyperd door de aantasting van een groot rechtsbelangen hanteert de wetgever formele dellictsomschrijvingen bij minder grote belangen. Deze delictsomschrijvingen benoemen explicjet de gevolg-veroorzakende gedragingen. Ook hij is wan mening dat het onderscheid tussen materiële en formele delicten niet scherp is, waatoe hij naar art. $310 \mathrm{Sr}$ verwijst.

43 Vgl. b.v. Van Bemmelen/Van Hattum, $I_{4}, 1953$, p. 162. 
en levensberoving (op verzoek) zijn materiële opzetdelicten. Pas wanneer is mishandeld, is afgedreven of het leven is beëindigd, zijn de respectieve misdrijven gepleegd.

\subsubsection{Opzet}

De wetgever omschreef opzet als "willens en wetens". Voorwardelijk opzet en oogmerk beschouwde hij als vormen van opzet. Als onderscheidend kenmerk tussen opzet en culpa diende het willen, zoals bijwoorbeeld blijkt uit Titel $\mathrm{XXI}$, die oorspronkelijk Wuidde: "Onwillig veroorzaken van den dood of van lichamelijk letsel". opzet bestaan verscheidene opvattingen. Enkele tientallen jaren geleden werd opzet vooral psychologisch ingevuld. ${ }^{45}$ Nadien werd opzet in het algemeen een psychisch neutralere inhoud toegekend. Ook werd voorgesteld om opzet normatief op te vatten. "Bij een normintieve opvatting wan het opzet komt duidelijk naar voren dat het steeds gaat om de sociale betekenis van het gedrag. De vraag is niet: wat denkt of wat wilde de dader toen his schoot? maar: pleegde hij een doodslag". ${ }^{46}$

Hoewel erkend moet worden dat het bewijs van opzet vaak geleverd wordt met overwegingen die wijzen op het hanteren van een normatief opzetbegrip ${ }^{47}$, verdient deze invulling geen navolging, omdat daarin aan het opzet een wederrechtelijkheidscomponent verbonden wordt. 48

In een andere benadering van opzet wordt de nadruk gelegd op de wetenscomponent van het opzet. ${ }^{49}$ Het bezwaar hiertegen is dat daardoor de scheidslijn tussen opzet en culpa onduidelijk is. ${ }^{50}$

\subsubsection{Opzet en oogmerk}

Bij opzet kan onderscheiden worden tussen formeel en materieel opzet. Formeel opzet is opzet gericht op de handeling. Materieel opzet is opzet gericht op een strafrechtelijk relevant resultaat van de handeling. In plaats van "materieel opzet" wordt meestal van "oogmerk" gesproken. Andere aanduidingen van oogmerk zijn: onmiddellijke doel, naaste doel, constitutief gevolg, naaste oogmerk en delictsoogmerk. De term "constitutief ge-

$44 \mathrm{Met}$ "onwillig" werd bedoeld dat de wil niet gerich behoefde te zijn en niet, zoals het woord "onwillig" ook kar worden begrepen: met tegenzin. Zie Smidt, 11, $1891, p_{.} 483$ en NLR, aant. 1 op Thtel XXI.

45 Vgl. Van Bemmelen/Van Hattum $l^{1}, 1953$, p. 312.

46 Peters, 1966, p. 117 . Zie verder p. 33-34 en p. 89 e.v.

$47 \mathrm{Vgl}$. Hazewinkel-Suringa/Remmelink, 1991 , p. 192 en p. 210 .

48 Brouns, 1988 , p. 292, noemt als ander bezwaar: doordat bij Peters de nadruk ligt op de relatie tussen daad en resultaat, verdwiint het onderscheid tussen opzet en berwuste sehuld. Zie ook Hazewinkel-Suringa/Remnelink, 1991, p. 155-156.

49 Nieboer, 1978 en Strijards, 1988, p. 95-97. Maar ook bij dexe suteurs blifft de willenscomponent cen rol spelen. Volgens Nieboer, 1991, p. 155, kan uit de combinatie van het weten en het toch doen, het willen doen afgeleid worden.

50 Vgl. Hazewinkel-Suringa/Remmelink, 1991, p. 185, noot 246; Politoff en Koopmans, 1991, p. 127. Op p. 128 merken Politoff en Koopmans op, dat onder "willen" hierbij verstaan dient te worden, hell "willen verwezenlijken". In de benadering van het opzet door Strijards, 1988, p. 106-107, verdwijn de scheidslijn tussen opzet en bewuste culpa echter niet helenial. Voor hem houdt bewuste culpa in een onvoldoende weten over de intredende gevolgen. 
volg $^{\text {nIst }}$ brengt tot uitdrukking, dat oogmerk zijn betekenis deels ontlleent aan de eigen aard van het delict. ${ }^{5}$

Onder resultaat van de handeling wordt begrepen een (noodzakelijk) gevolg dat aan een bepaald handelen verbonden is. Vanwege deze binding wordt dit resultaat ook het onmiddellijke of nasste doel genoemd. Dat doel behoeft niet hetzelfde te zijn als het doel dat met de handeling wordt nagestreefd, en is dat meestal ook niet. Het nagestreefde doel is datgene, wat de dader in wezen bereiken will. Dit doel wordt het middellijke doel genoemd, of in tegenstelling tot het naaste doel, het verwijderde doel ${ }^{53}$ of het einddoel. Zo is bij diefstal (art, $310 \mathrm{Sr}$ ) het (bijkomende) oogmerk gericht op de wederrechtelijke toeèigening - het resultaat, het onmiddellijke doel, van de handeling -, maar het nagestreefde doel kan bijwoorbeeld zijn zich te verrijken. ${ }^{54}$

Bij oogmerk gaat het om de eigenaardige richting van de wil, een beperking door nadere omschrijving van het resultaat, terwijl bij opzet het resultaat van de handeling open blijf: ${ }^{\text {is }}$

De Hoge Raad heeft in verschillende arresten met een omschrijwing van het oogmerk woor het bewijs op een met de opvatting van de wetgever overeenkomende wijze genoegen genomen. Zo spreekt hij in HR 5 jan. 1982, NJ 1982, 232 van: "naar hij besefte, als noodzakelijk en dus door hem gewild gevolg" ${ }^{56}$ Hieruit leidt Brouns af dat ook de Hoge Raad de betekenis van oogmerk niet beperkt tot opzet als oogmerk, waaronder hij verstaat: tot het naaste doel van de daad.

Opzet als oogmerk heeft een beperktere strekking dan oogmerk als materieel opzet. Wordt opzet als oogmerk telastegelegd, dan is voorwaardelijk opzet niet toereikend om het telastegelegde oogmerk te bewijzen, ondat de OvJ dan kennelijk het opzet een beperktere strekking wil toekennen. Eist daarentegen de delictsomschrijving materieel opzet, dat wil zeggen opzet op een resultaat van de handeling en is de telastelegging daarop afgestemd, dan kan voor het bewijzen van deze opzet met voorwardelijk opzet worden volstaan. Bij oogmerk als materieel opzet is voorwaardelijk opzet toereikend, bij opzet als oogmerk niet. ${ }^{\text {s7 }}$

51. Zie voor de Jatatste uiturukking: Vos, 1947 , p. 117-118.

$52 \mathrm{Vgl.}$ Vos, 1947 , p. 118; Hazewinkel-Suringa, 1964, p. 92-93; Hazewinkel-Suringa/Remmelink, $1991, \mathrm{p}$. 199 in Brouns, 1988, p. 175. Anders: Van Hawel, 1927, p. 297.

53 Noyon, 1,1904 , p. 7.

54 Als ifunctie van het bijkomend oogmerk noemen Politolf en Koopmans, 1991, p. 132, dat dit oogmerk wanuit eer crimineel-politiek standpunt vak is bedoeld oni de strafbaturbeid te beperken door hogere eisen aan de subjectieve participatie te stellen.

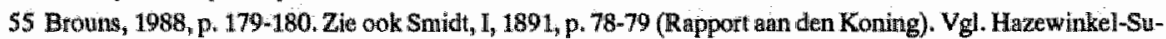
ringa/Remmelink, 1991, $\mathrm{p}_{\text {"1 }}$ 198: oogmerk is "special opzet . " ger icht op het met die handeling te bereiken gevolg. Wat gemeentijk een strafrechtelijk irtelewant motief is, is hierin verwer kt tot een subjectlef delictsbestanddeel. Dit (bijkoinende) oognerk ." Volgens Strijards, 1987, p. 11, moet onder oogmerk worden werstanan, hetgeen de dader als "tussendoel" (om íets anders te bereiken) accepteert. Hij ziet tussen oogmerk en het "gewone" opzet "niet veel verschill". Enigszins anders". Politoff en Koopmans, 1991, p. 130, noot 136" delictsonschrijwingen warin het woord "oogmerk" hetzelde betekent als "opzet" zijn een wizondering.

56 Zie b.w. ook HR 21 mei 1900, W 7461; HR 15 mart 1909, W 8842 en HR 14 okt. 1940, NJ $1941,87$. 57 zie Brouns, 1988, p 284. Vgl. Poltote en Koopnans, 1991, p. 133, nool 149. Hazewinkel-Suriuga/Remmelink, 1991, p. 199, merkt op, dat oogmerk soms eng en soms ruin moet worden opgevat.

Strijards, 1988 , p. 103, is van mening, dat de consiante jurisprutentie van de Hoge Raad, waarin deze bepaalt dat "kansweten" onvoldoende is om moogmerk" te bewijzen, niet steunt op enige wilsuiting van de wetgever. Daarbih is wel van belang, ten eerste, hoe het oognerk was telastegelegd en, ten tweede, dat deze jurisprudentie betrekking heeft op het expliciete bestanddeel oogmerk. 


\subsubsection{Oogmerk en delictsomschrijving}

Niet altijd heeft de wetgever in de delictsomschrijving oogmerk expliciet als bestanddeel opgenomen, hoewell in zijn voorstelling het handelen met oogmerk dient te geschieden. ${ }^{5 s}$ Bij materiële opzetmisdrijven, zoals mishandeling, afdrijing en levensberowing (op verzoek), is naast opzet op de gedraging altijd opzet op het gevolg (oogmerk) vereist, zonder dat daarvan uit de delictsomschrijving expliciet hoeft te blijken. ${ }^{59}$ In het algemeen heeft de wetgever het slechts nodig geacht oogmerk expliciet in een delictsomschrijving op te nemen, waar deze anders te ruim zou zijn geformuleerd.

"De functie van het woord 'oogmerk" in de delictsomschrijving is de strafbepaling te beperken tot strafbare handelingen door het resultaat van de handelingen (dat in andere gevallen vanzelf is gegeven) te noemen" ${ }^{\prime \prime}$.

Hoewel doodslag oogmerk vere ist, is het geen expliciet bestanddeel. Wie iemand anders opzettelijk doodt, heeft ook het oogmerk op de dood van de ander. De dood is immers als doel onlosmakelijk verbonden aan de dodingshandeling, zodat oogmerk in de delictsomschrijving impliciet verwerkt is. Hetzelfde geldt bijvoorbeeld voor afdrijving.

\subsubsection{Geen mishandeling, omdat het vereiste opzet ontbreekt}

Ook voor mishandeling is materieel opzet vereist. Wie iemand anders opzettelijk toetakelt heeft ook opzet op het gevolg van de gedraging en dat wil zeggen: oogmerk op pijn of letsel van de gelaedeerde. ${ }^{61}$ Deze invulling van mishandeling is geïnspireerd door de wetsgeschiedenis van art. $300 \mathrm{Sr}$ en de opmerking van de wetgever over opzet en oogmerk. De wetgever onderscheidde bij mishandeling tussen middel en doel. Tevens merkte hij op dat materiële opzetdelicten impliciet oogmerk vereisen, zodat het niet nodig is deze expliciet in de delictsomschrijving te verwerken. ${ }^{62}$

Volgens Brouns lijkt de wetgever van 1886 :

"I! ... bij medische handelingen ... te neigen naar een normatieve aanpak. $\left({ }^{63}\right)$... Het opzet behelst niet alleen een gevolgsgerichtheid, maar tevens een doelgerichtheid (bijvoorbeeld verminking of genezing) en het ondergeschikt maken van leed als middel voor dat doel, welk opzet niet bij een handelende kan bestaan zonder besef

Nieboer, 1991 , p. 181 zegt, dat er historisch en systematisch geen grond voor wfwifing van een "kansoogmerk" bestaat. Een complicatie is echter, dat de formule van hansopzet te beperkt is, "anmerkelijk" gat te ver; deze eis is hier weel te zwaar. "Tk parafraseer danrom "het nataste doel" ... alls "besseffen dat de gredraging gericht is op het in de wet genoemde doel', kortom: "wetsdoel-besef" ..." "Oogmerk is derhalve gewoon een vorn van zorgplicht-schending mits we zor gplicht niet uitsluitend betrekkem op de aanmer kelijke knans".

58 Dat geldt eveneers voor opzet. Vgl. b.v. Vos, 1947, p. 127 en Hazewinkel-Suringa/Remmelink, 1991, p. 195 e.w.

59 Smiidt, I, 1891, $\mathrm{p}_{n} 82$.

60 Brouns, 1988, p. 199. Vigl. Nieboer, 1991, p. 158-159.

61 B.v. Noyon, 1904, aant. 1 op art. 300 Sr; Van Bemmelen/van Fattum, 11, 1954, p. 224. Zje b.W. reeds Hazellhoff, Heemskerk en Polenaar, $1886, p_{*} 328$, die echter ten onrechte uitgan van het vereiste van boos opzet. Zie oolk HR 26 okt. 1908 , W 8759.

62 Smidi, I, 1891 , p. 82 .

63 Met verwijzing naar Smidt, 11, 1891, p. 477. 
van de handelingen. Afhankelijk van de zin die aan de handeling wordt gegeven, is er al dan niet sprake van mishandeling

Dit citaat doet denken alan het eerder genoemde en aldaar afgewezen concept van opzet als normatief opzet. Naar mijn mening wilde de regering van 1886 echter niet het opzet in de delictsomschrijving van mishandeling normatief anpakken, maar zocht zij de oplossing in een buiten het begrip "mishandeling" gelegen rationeel doel. Vanwege de meerduidige uitlatingen van de regering over dit onderwerp kon echter misverstand ontstaan en werden hatr uitlatingen over middel en doel ingekleurd door die over opzet en oogmerk. ${ }^{65}$

Waar een onderscheid wordt genaakt tussen opzet en oogmerk enerzijds en het doel van de handeling anderzijds, kunnen de wegen die tot straffeloosheid van de medicus leiden, verschillend zijn. Gewin was van mening dat een behandeling zowel subjectief, vanwege het ontbreken van het vereiste opzet, als objectief, vanwege de verschillende strekking van de handelingen, geen mishandeling is ${ }^{66}$ In de opvatting van de Gemengde Commissie van 1909 voldoet een medische handeling wel aan het subjectief vereiste. Zij valt daarmee, op zichzelf beschouwd, binnen het begrip mishandeling, maar daar een behandeling geen mishandeling is, gaat de medicus vrijuit. ${ }^{67}$

Hazelhoff, Heemskerk en Polenaar spraken enerzijds van een bij de dader bestaand einddoel dat die handelling al dan niet rechtvaardigt (subjectief). Anderzijds merkten zij op dat het doel om pijn te veroorzaken aanwezig is, zodra de pijniging nodeloos of nutteloos (d.i. doelloos) is (objectief). ${ }^{68}$

J.W. Smidt stelde, dat de medicus straffeloos is, omdat bij hem de "animus laedendi", het oogmerk op de mishandeling ontbreekt. ${ }^{69}$ Deze interpretatie treffen wre ook gedurende enige tijd bij de Hoge Rad aan. Mij is echter geen jurisprudentie bekend over een medicus die vanwege een mishandeling terechtstond, terwijl hij een operatieve ingreep lege artis had verricht.

In HR 5 nov. 1900, W 7513, was bewezenverklaard dat het opzet gericht was op het slaan wan de gelaedeerde. Volgens de Hoge Raad omvatte de bewezenverklaring het oogmerk om leed te doen. Daarmee kon het feit als mishandeling worden gekwalificeerd, indien niet van een geoorloofde beweegreden gebleken was. ${ }^{70}$ De rechter mocht echter de afwezigheid van een geoorloofde beweegreden veronderstellen, tenzij bepaalde aanwijzingen in een andere richting wezen. ${ }^{72}$ Ook had de verdachte geen recht op een uitdrukkelijk gemotiveerde verwerping als de rechter het beroep op een geoorloofde reden niet honoreerde.

In HR 10 febr. 1902, W 7723, beriep de verdachte zich op het tuchtigingsrecht. Dat beroep kon het hof opvatten als een ontkenning van het telastegelegde (materiele) opzet, watrover bij bewezenverklaring geen afzonderlijke beslissing was vereist. Uitdrukkelijk merkte de Hoge Raad nog op, dat een beroep op het tuchtigingsgrecht geen verweer in de zin van art. 358 lid 3 Sv betreft.

64 Brouns, $^{2} 988$, p. 56, noot 207.

65 Zo b.v. begreper door. De Doelder en "1 Hart, TVGR 1978, p. 61 en p. 64. Zie ook Leenen, 1991, p. 107-108, die naar het genoemde artikel verwijst.

66 Gewin, 1907, p. 145. In dezelfde zin: Noyon, 1 , 1904, p. 3-4 en aant. 1 op art. 300 .

67 Gemengde Commissive wan 1909, Nivg 1909, 1; p. 72-73. Vgl. Van Dam van Isselt, 1902, p. 60-61.

68 Hazelhof, Heenskerk en Polenaar, 1886, p. 375 . Zie ook p. 328: " Zoodra echter de pijn of het letsel doel wordt, dan is er sprake van mishandeling

69 J.W. Smidt, 1889 , p. $10-11$ en p. 64.

70 Zie hiertoe Noyon, 1904, alant. 4 op art. 300.

71 HR 23 febr. 1891, W 5999. 
Tevens stelde hij in dit arrest als eis, dat het middel (de toevoeging van pijn of letsel) proportioneel diende te zijn aan het geoorloofde doel, "als hoedanig eene binnen de grenzen der noodzakelijkheid beperkte kastijding van een kind door ouders of onderwijzers in aanmerking kan komen ${ }^{\text {an }}$.

Terwij] hieruit van een meer geobjectiveerde benadering wan het geoorloofde doel blijkt, overwoog de Hoge Raad in HR 10 juni 1924, W 11299, dat blijkens de totstandkoming van art. 300 Sr de wetgever voor het wettelijk begrip "mishandeling" veel gewicht toekende aan de bedoeling van de handelende persoon.

Wel maakte de Hoge Raad een onderscheid tussen het delictsoogmerk en een verder reikend oogmerk, dat wil zeggen het motief. ${ }^{2}$ Desondanks bood zijn invulling van het delictsoogmerk de mogelijkheid te stellen, dat hij oogmerk en motief verwarde, zoals bijvoorbeeld Van Dam van Isselt deed. Als een medicus een been afzet, dan is het oogmerk van zijn opzettelijke handeling om de patiènt letsel toe te brengen. Daarentegen is het zijn motief om de patiënt te genezen. Het motief speelt echter geen roll voor de strafbaarheid van het feit. Van Dam van Isselt demonstreerde het verschil tussen oogmerk en motief naar aanleiding van het hierboven genoemde arrest van de Hoge Raad van 10 febr. 1902, W 7723, over een onderwijzer die een jongen tuchtigt.

"Het oogmerk van de opzettelijke handeling was dus, den jongen pijn te doen. Maar waarom wilde hij dien jongen pijn doen, m.a.w. wat was het motief van die handeling. Het motief van die handeling was, 'den jongen bij het werk te houden". ${ }^{73}$ Of, zoals in het Regeringsantwoord werd opgemerkt:

"Het middellijk gevolg, met anderen woorden de vrucht die men woor zich zelf of een ander van de gebeurtenis verwacht, en dus ook de reden waarom de gebeurtenis gewenst wordt (drijfveer, motief) blijft buiten aanmerking en is, in het algemeen, voor het bestaan van een misdrijf volkomen onverschillig ${ }^{n / 74}$.

Oogmerk en motief kunnen wel samenvallen. Zo spreekt Van Hamel van mishandelen om te mishandelen. ${ }^{75}$ Voor de strafrechtelijke aansprakelijkheid is echter slechts het oogmerk van belang. Het motief kan wel een rol spellen bij de straftoemeting. Het motief, de drijfveer, de beweegreden, is de aanleiding tot een op een bepaald handelen gerichte willsvorming. ${ }^{76}$ Oogmerk is geconcretiseerde, doelgerichte wil. Bij materieel opzet is dat het opzet op het onmiddellijk resultaat van de handeling. Resultaat is daarbij te verstaan als een mogelijk gevolg "binnen het bereik van het delictstype". " Het woord 'mogelijk" brengt tot uitdrukking dat een handeling meerdere resultaten kan hebben die allemaal aangemerkt kunnen worden als een onmiddellijk resultaat. Bijvoorbeeld kan het toebrengen wan pijn of letsel in concreto verschillende resultaten opleveren, die allemaal onder het onmiddellijk resultaat pijn of letsel en daarmee "mishandeling" gebracht kunnen worden.

Het voor het bewijs niet relevante verwijderde oogmerk, het streven naar een einddoel, respectievelijk hes middellijke doel, wordt daarentegen wel bepaald door het motief. ${ }^{78}$

72 HIR 28 juni 1926, NJ 1926, 785 man. L.B. en HR 15 jan. 1934 , NJ 1934, 403 m.rit. W.P.

73 Van Dam van Iswelt, 1902, p. 48. Zie ook Van der Haka, 1883, p. 24-25.

74 Regeringsantwoord, Smidt, 1, 1891, p. 81 .

75 Van $\mathbb{H}$ iamel, 1927, p. 297-298.

76 Vgl. Brouns, 1988, p. 174.

77 Brouns, 1988 , p. 175 .

$78 \mathrm{Vgl}$. Van Hamel, $1927, \mathrm{p} .284$. Het is ook mogellijk te zeggen dat het verwijderde doel het notief bepaalt, zoalls Noyon, 1947, p. 29, doel. Anders Hazewinkel-Suringa, 1964, p. 91 en Hazewinkel Suringa/Remumelink, 1991, p. 198: "Wat gemeenlijk een strafrechtelijk irrelevant motief is, is thierin (in b.w. de artt. 225, 310 en $321 \mathrm{Sr}, \mathrm{J}$.W.) verwerkt tot een subjectief delictsbestanddeel". Zie ook Nieboer, 1991, p. 160 . 
De wisselende bewoordingen van de Hoge Raad ten aanzien wan de opzeteis bij mishandelinglaten geen duidelijke conclasie toe in hoeverre de Hoge Raad opzet op de geoorloofdheid van het doel eilste. ${ }^{79}$

Oogmerk bij mishandeling is opzet op het resultat mishandeling. Dat het een medicus niet te doen is om dit resultaat, maar om het genezen van de patiënt, neemt niet weg, dat hij opzettelijk het resultaat bewerkstelligt. ${ }^{80}$

De nadruk die de Hoge Raad voor het delictsoogmerk en voor het geoorloofde doel op de bedoeling van de handelende persoon legde, werd weerspiegeld in uitspraken van lagere rechters. Zo overwoog de rechtbank Rotterdam op 20 okt. 1925, NJ 1925, 1175 mint: L.B., dat het opzettelijk toebrengen wan lichamelijk letsel geen mishandeling oplevert, indien de dader een geoorloofd doel nastreefde en hij bij de toepassing van de middelen tot bereiking van dat doel niet bewust de grenzen van de redelijkheid overschrijdt. ${ }^{\text {si }}$

Ook beroepen op andere rechtvaardigingsgronden werden als ontkenning van de kwalificatie opgevat. De rechtbank Amsterdam 27 april 1938, NJ 1939, 554, overwoog "dat om het misdrijf van mishandeling te plegen niet voldoende is, dat men iemand opzettelijk leed toebrengt, doch bovendien een vereischte is, dat dit toebrengen van leed uitsluitend doell was en niet middel tot bereiking van een ander redelijk doel". In casu honoreerde de rechtbank het beroep op noodweer door niet aan de kwalificatie toe te komen en de verdachte te ontslaan van alle rechtsvervolging.

\subsubsection{Conclusie}

In de opvatting dat de medicus geen materieel opzet op mishandeling heef, wordt eerst het vereiste oogmerk ten onrechte door het motief bepaald en vervolgens gesteld dat het oogmerk van de medicus, maar eigenlijk zijn motief, gericht is op de genezing van de patiënt. Nu de wetgever het motief geen rol voor de strafbaarheid van het feit heeft toebedeeld ${ }^{82}$, is het bereiken van de straffelloosheid van de medicus via subjectieve bestanddelen niet goed te verdedigen. Formeel en materieel opzet zijn neutrale termen. Zowel ter bereiking van een geoorloofd doel als van een ongeoorloofd doel, kan opzettelijk worden gehandeld. De subjectieve, impliciet aanwezige bestanddelen opzet en oogmerk dienen ter vaststelling van de verantwoordelijkheid van de dader voor de "pure" gedraging. Zij sluiten echter een succesvol beroep op een strafuitsluitingsgrond niet uit, want ook al heeft de dader formeel en materieell opzettelijk gehandeld, daarmee staat de strafwaardigheid van de gedraging of van hem nog niet vast.

79. Vgl. Besier onder Rb. Rotterdam 20 okt. 1925, NJ 1925, 1175.

80 Remmelink - zie NLR, aan. 1a op art. 300 - wijst deze leer "vilt dogmatisch oogpunt af en ondat op deze wijze le gitimerende objectieve onstandigheden via bet opzet doorwerken. Vemoedelijk vanwege de misleidende uithatingen van Minister Modderman ower middel en doel, vindt hij deze opvatting wel "historisch sterk".

81 Zie ook: Rb. Den Bosch 7 jan. 1938, NJ 1938, 231.

82. Anders en uitzonderlijk: Hazelhoff, Heemskerk en Polenara, 1886, pi 113-115, die zich op de totstandkonting van de abortus- en mishandellingsbepalingen beroepen, om aan te tonen, dat de wetgever boos opzet eist, d.w.z. een wil in strijd nuet de voor ieder normasl ontwikkeld mens geldende beginselen wan de zedenwet. 


\subsubsection{Inleiding}

Op voorstel van de Commissie van Rapporteurs werd de feitelijke omschrijving van de eenvoudige mishandeling vervangen door het woord mishandeling, onder andere om medische behandelingen en de uitoefening van het ouderlijk tuchtigingsrecht niet onder de delictsomschrijving te laten vallen. Dit was aanleiding om te stellen dat een medische behandeling geen "mishandeling" in de zin van art. $300 \mathrm{Sr}$ is.

\subsubsection{De aard van de handeling}

"Wanneer men een zieke opzoekt, vraagt men niet: onder wiens mishandeling zijt ge? Wie mishandelt $U$ ? Altijd zal de vraag luiden: onder wiens behandeling zijt ge? of, wie behandelt $U$ ?" $^{\text {" }}$.

Met deze uitspraak wilde Van Dam van Isselt duidelijk maken, dat een medische behandeling naar zijn aard geen mishandeling is. ${ }^{84} \mathrm{Zij}$ is geen mishandeling omdat zij geen lichamelijk letsel teweeg brengt. In deze opvatting wordt niet ontkend dat aan een deel van het lichaam letsel wordt toegebracht, maar dat geschiedt ten bate van het hele lichaam, zodat het lichaam als geheel niet wordt mishandeld. Het verschil tussen mishandelen en behandelen is gelegen in de aard van de handeling. ${ }^{85}$ In de woorden van Van Dam van Isselt is het criterium tussen mishandelen en behandelen:

"geenszins of er pijn of stoomis wordt toegebracht of niet, neen, het criterium is of er pijn of stoornis wordt toegebracht, welke het lichaam baat of welke het lichaam schaadt: Baat ze het lichaam dan is er behandeling, schaadt ze het lichaam dan is er mishandeling"86, En, korter: "Mishandeling is, .... het opzettelijk toebrengen van voor het lichaam nadeelige pijn of stoornis".

Van Dam van Isselt sprak van "welke het lichaam schaadt". Maar in gevallen waarin een behandeling niet het verwachte resultaat oplevert, heeft het lichaam als geheel geen baat bij de behandeling van de medicus. Voor deze situaties is deze rechtsgrond ontoereikend. ${ }^{88}$ Dit bezwaar werd weggenomen door Simons, die schreef:

"Ik zou, ook met het oog op de geschiedenis van ons art. 300 en de vervanging van de vroegere omschrijving door het woord mishandeling, in verband met de aan dit woord te hechten betekenis, ...t en dus aan de ter genezing en in overeenstemming met de regelen zijner kunst verrichte handelingen van den geneeskundige het karakter

83 Van Dam van Isiselit, 1902, p. 55-56.

84. Van Dam van Isseln, 1902 , p. 60.

85 Van Dam van Isselt, 1902, p. 61; Domela Nieuwentuis, TvS 1917, p. 351. Vgl. Strijards, 1987, p. 3-4: bij en operatieve ingreep (lege artis) bepaalt en dekt "het medisch doel" de gedraging.

86. Van Dam van Isselt, 1902, p. 96. In origineel cursief. Hoewel het criterium van Van Dam van Isselt in zo verte onduidelijk is, cat dientengevolge elke handeling, warbij pijn of "stoornis" wordt toegebracht; door iedere derde niet als mishandeling beschouwd zou moeten worden, blijkt unt de context en uit bet gebruik van het woord behandeling, dat. Van Dam van Isselt slechts door een medicus verrichte handelingen bedoelt.

87 Van Dan van Isselt; 1902, p. 56. In origineel cunsief.

88 In deze zin: Gemengde Comnissie van $1909, \mathrm{Ntvg} 1909,1, \mathrm{~F} \cdot 73$; Hazewinkel-Swringa, 1964 , p. $196 \mathrm{en}$

De Doelder " 1 Hart, TVGR 1978, p. 64. 
van mishandeling willen ontzeggen, onverschillig of door de behandeling het voorgestelde doel bereikt wordt of niet ${ }^{\text {H99}}$,

zodat bij hem niet het resultaat maar de inspanning wooropstond. Hij signaleerde dat de tekst van art. $302 \mathrm{Sr}$ daarbij wel problemen oplevert, maar meende dat zowel de Titel ("Mishandeling") als de kwalificatie in art. $302 \mathrm{Sr}$ ("zware mishandeling") soelaas kunnen bieden. ${ }^{90}$ In het tweede deel van zijn Inleiding bevestigde Simons dit standpunt, waarbij hij opmerkte, dat een geoorloofd doel het begrip "mishandeling' niet uitsluit:" Wel kumnen, zo voegde hij daaraan toe, pijnveroorzakende handelingen van zeer lichte aard, die in een geoorloofd doel haar rechtvaardiging vinden, in overeenstemming met het spraakgebruik buiten het begrip "mishandeling" worden gelaten."

Ook als in deze opvatting het accent op het resultaat wordt gelegd, lijkt het mij waarschijnlijk dat een behoorlijke inspanning voldoende wordt geacht. Of een behandeling tot het gewenste resultaat leidt, kan immers niet altijd op voorhand worden gezegd. ${ }^{93}$ Daarom acht ik de aanduiding " resultaats' -opvatting" geschikt.

Volgens het door Van Dam van Isselt geformuleerde criterium is het voor de aansprakelijkheid van de medicus vanwege mishandeling niet van belang of de patiënt toestemming tot de handeling heeft verleend. Voldoende is dat de handeling met een geneeskundig doel geschiedt en dat dit doel wordt gerealiseerd. ${ }^{95}$

Als bezwaar tegen deze opvatting kan aangevoerd worden, dat zij zich beperkt tot rechtvaardiging van het medisch handelen. Een ander bezwaar is gelegen in de feitelijke omschrijving van de zware mishandeling in art. $302 \mathrm{Sr}^{96}$ en daamee verband houdend met de wijze waarop (zware) mishandeling ten laste wordt gelegd. Het valt niet goed te verdedigen dat een medische ingreep wel aan de delictsomschrijving van zware mishandeling voldoet of aan de oorspronkelijke omschrijwing van eenvoudige mishandeling - die ook voor de wiljze van ten laste leggen wordt gebezigd -, om vervolgens te concluderen dat deze gedraging niet als (zware) mishandeling gekwalificeerd kan worden.

Daar in deze opvatting gekeken wordt naar de aand van de handeling, speelt de toestemming geen rol voor de aansprakelijkheid vanwege mishandeling. Ook een medische ingreep zonder toestemming is immers een handeling die in het belang van de gezondheid van de patiënt kan zijn.

89 Sinons, I, 1927, p. 279-280.

90 Simons, $I, 1927$, p. 280; Noyon, $I_{4} 1904$, p. 3-4 en Van Bemmeten/Van Hattum, $I_{3}, 1953$, p. 370.

91 Simons, $\mathrm{I}, 1923, \mathrm{p} .17$.

92 Simons, $\mathrm{m}, 1923$, p. 18.

$93 \mathrm{Vgl}$. Leenen, 1991, p. 106: Het resulteat kwalsficert niet de (medische) handeling.

94 Zoals De Doelder en "I Hart, TrGR 1978, p. 64 bezigen.

95 Van Dam van Iswelt, 1902, p. 55. Anders: Leenen, 1991, p. 106 : "Hetl tegen de wil van de patiënt cen behandeling uitvoeren, kan we" degelijk mishandeling resulteren". Zie m.b.t. de toestemming verder: H. 1 , onder 3.1 .

96 Vgl. Van Loon, 1910, p. 143-145. 


\subsubsection{Inleiding}

In het strafrecht wordt in het algemeen van toestemming gesproken. Het woord omvat dan mede een verzoek. In die ruime betekenis wordt het begrip in beginsel ook hier gebezigd. Slechts daar war aan het verzoek een speciffek karakter toekomt of kan toekomen, wordt tussen toestemming en verzoek onderscheiden.

In thet $\mathrm{WvSr}$ is bij een aantal delicten rekening gehouden met toestemming. Deze delicten laten zich in drie groepen onderverdelen. ${ }^{97}$

Tot de eerste groep behoren de delicten waarbij het toestemmingsvereiste met zoveel woorden uit de delictsomschrijving blijkt. Hieronder vallen levensberoving op verzoek (art. $293 \mathrm{Sr}$ ) hulp bij zelfmoord (art. $294 \mathrm{Sr}$ ) en de oude abortusbepaling (art. $296 \mathrm{Sr}$ ). Toestemming neemt bij deze delicten niet de strafbaarheid weg, maar vergeleken met soortgelijke delicten zonder toestemmingsvereiste, geldt een lagere maximumstraf.

De tweede groep omvat de delicten watrin als bestanddeel wederrechtelijik is opgenomen en waarbij dat bestanddleel moet worden opgevat als: zonder gemachtigd te zijn door degene op wiens rechten een inbreuk wordt gemaakt. Toestemming van de gerechtigde ontneemt aan de handeling haar wederrechtelijk karakter. Indien het in de telastelegging verwerkte bestanddeel wederrechtelijk niet bewezen kan worden (omdat toestemming is gegeven), dient vrijspraak te volgen. Tot deze groep behoort bijvoorbeeld de bepaling over diefstal, art. $310 \mathrm{Sr}^{.99}$

Tenslotte is er een groep van delicten waarbij uit de aard van het delict blijkt dat deze tegen de wil van de gelaedeerde worden gepleegd. Hiertoe behoort art. 284 lid 1 sub $2 \mathrm{Sr}$, waarin strafbaar is gesteld het iemand onder dwang tot handelen brengen. ${ }^{100}$ Blijkt ter zitting van toestemming dan dient ook hier vrijspraak te volgen.

\subsubsection{Twee benaderingen}

In de literatuur bestaan twee tegenovergestelde opvattingen over de werking van de toestemming ten aanzien van delictsomschrijvingen die niet in ển van de hierboven genoemde categorieën vallen. Het eerste standpunt houdt in dat toestemming bij gedragingen waarbij (mede) een subjectief recht wordt geschonden tot straffeloosheid leidt, woor zover de wetgever dit niet expliciet heeft uitgesloten. Volgens het tweede standpunt is toestemming slechts van invloed op de strafbaarheid van het feit, als de wetgever dit heeft bepaald.

In de eerste opvatting wordt daartoe bijwoorbeeld als volgt geredeneerd:

"In de artt. onzer strafwet, waarin de wetgever over de kracht der toestemming handelde, wil ik zien voorschriften, ten doel hebbende uitvloeisels te zijn van een

$97 \mathrm{Vgl.m.b.t.} \mathrm{deze} \mathrm{onderverdeling:} \mathrm{Dorbeck,} \mathrm{1893,} \mathrm{p.} \mathrm{24-29;} \mathrm{Van} \mathrm{Hamel,} \mathrm{1913,} \mathrm{p.} 316$ en Hazewinkel-Suringa, 1964, p. 190-191. Enigszins anders: Nysingh, 1888, p $41-45$.

98 Zie bovendien nog art. 206 lid 1 sub 2 Sr (ongeschikt maken voor de krijgsdienst) en art. 281 lid 1 sub 1 Sr (schaking).

99 Zie verder: art. $282 \mathrm{Sr}$ (vrijheidsberoving), art. $321 \mathrm{Sr}$ (verduistering) en art. $350 \mathrm{Sr}$ (zaakbeschadiging).

100 Zie verder: art. $95 \mathrm{Sr}$ (alanslag tegen de regeringsraad), art. 239 sub 3-oud Sr (openbare schennis van de eerbaarheid), art. 281 lid 1 sub 2 Sr (schaking) en art. 317 Sr (afpersing). 
algemeene rechtsgedachte, van een algemeen den wetgever geleid hebbend beginsell" 101

Volgens de tweede opvatting brengt het feit dat de wetgever in een aantal artikelen rekening heeft gehouden met toiestemming mee, dat hij daarvan bij de andere delicten niet wilde weten.

"Heeft nu onze wetgever zich over onze vraag duidelijk uitgelaten? Nalar mijne meening ja, en wel in dien zin, dat overal, waar de wetgever hetzij de toestemming hetzij het niet-willen van den feitelijk benadeelde niet als element ${ }^{102}$ voor het delict vordert, aan dien will geene werking mag worden toegekend". ${ }^{103}$

\subsubsection{Twee belangen}

De rol die aan de toestemming wordt toegemeten, hangt af van het gewicht dat aan de onderscheiden belangen bij een delict wordt toegekend. Elke strafbararstelling geschiedt in het algemeen belang. Handelen dat aan een delictsomschrijving beantwoordt is derhalve in strijd met het algemeen belang. Bij een aantal delicten wordt tevens een inbreuk gemaakt op particuliere belangen, op subjectiewe rechten. Dan kan de vraag worden gesteld of in een delictsomschrijving het algemeen of het particuliere belang dominant is.

In 1904 kensichetste Noyon als de heersende opvatting dat strafbare feiten altijd de rechtsorde raken. Alleen daarom zijn zij stratbare feiten. Daarbij is onverschillig in hoeverre tevens particuliere belangen worden aangerand. ${ }^{104}$ Deze gedachtengang is tot in de jaren vijftig de gangbare. ${ }^{105}$

Nadien is een "teruggaande golfbeweging" ingezet ${ }^{106}$ De betekenis van het beginsel 'volenti non fit iniuria' is met de nadruk die de laatste jaren op de zelfbeschikking is komen te liggen, verder toegenomen. ${ }^{107}$

Dat de toestemming lange tijd niet werd erkend als rechtsgrond die de wederrechtelijkheid van een gedraging kon opheffen, heeft nog een andere reden. Over de hier bedoelde toestemming laat de wet zich niet uit. Zij moet derhalve uit het ongeschreven recht worden afgeleid. Maar vele strafrechtjuristen stonden in de eerste jaren na invoering van het WvSr ook ten aanzien van strafuitsluitingsgronden op een legalistischer standpunt dan thans het geval is. Voor zover ongeschreven strafuitsluitingsgronden niet werden erkend, kon reeds daarom aan de toestemming geen strafuitsluitende werking worden toegekend.

101. Dorbeck, 1893, p. 48.

102 Niet als onderdeel van de delictsomschrijwing. We zouden thans cerder zeggen: niet als bestanddeel.

103 Nysingh, 1888, p. 41 . Vgl. Lette van Oostwoorne, 1882 , p. 18.

104 Noyon, 1,1904, p. 22.

105 Zie biv: Tielboel wan den Ham, TrS 1893, p. 102; Simons, 1, 1927, p. 282, Vos, 1947, p. 197; Van Bemmelen/Van Hatum, I, 1953, p. 372-373; Noyon-Langemeijer, 1954, aant. 3 op wederrechtelijk.

106 Hazewinkel-Suringa/Renmelink, 1991, p. 311, noot 636. Renmelink verwijst voor deze gollfbeweging naar HR 28 now. 1978 , NJ 1979, 93 m.nt. ThWvV.

$107 \mathrm{Vgl.Strijards,} \mathrm{1987,} \mathrm{p.} \mathrm{69"} \mathrm{"Tegenwoordig} \mathrm{hebben} \mathrm{veel} \mathrm{mensen} \mathrm{nogal} \mathrm{wat} \mathrm{bedenkingen} \mathrm{dat} \mathrm{iemand} \mathrm{'zijns}$ ondanks" toch slachwoffer zou kunnen zijin". Volgens Strijards kan toestemming echter nooit een toereikende rechtsgrond voor straffeloosheid zijn, daar de benadeling van het individu niet een toereilkende rechitsgrond is om een bepaalde gedraging strafbar te stellen. Op p. 62 stett hij, dat het adagum "volenti non fit injuria" in het strafrecht niet geldt. 


\subsubsection{Rechtsgeldige toestemming}

Voor zover aan toestemming buiten de in de wet bepaalde gevallen rechtskracht wordt toegekend, kan deze slechts werken ten aanzien van delicten, waarbij ten eerste een individueel belang wordt geschonden en ten tweede het algemeen belang geen voorrang heeft op het individuele belang. Bijvoorbeeld kan toestemming tot een handeling in sirij met de goede zeden de strafbaarheid niet wegnemen. ${ }^{108}$ De toestemmingsgever is in dat geval niet "beschikkingsbevoegd" en evenmin kan daarbij van een redelijkerwijs opgewekt vertrouwen worden gesproken.

Naast "beschikkingsbevoegdheid" van het betrokken individu dient voor een rechtsgeldige toestemming in het strafrecht aan een aantal voorwaarden te zijn voldaan. Tussen de inwerkingtreding van het WvSr en nu blijkt niet van een verandering van de eisen die aan een rechtsgeldige toestemming worden gesteld. Het individu dient op grond van een vrije wilsbepaling en met besef van de draagwijdte van zijn beslissing toestemming te geven. Daarbij geldt dat niet de wilsbepaling, maar het door de toestemming redelijkerwijs opgewekte vertrouwen als rechtsgeldig moet worden beschouwd. ${ }^{109}$

Reeds honderd jaar geleden werd verdedigd dat meerderjarigheid geen absoluut vereiste voor een strafrechtelijk relevante toestemming is. Zo wil Nysingh in 1888 aan de rechter overlaten of een kind van beneden de tien jaar ${ }^{110}$ geldig toestemming kan verlenen. Dat hangt volgens hem immers af van de ontwikkeling van het individuele kind: Een standpunt dat ook thans nog wordt verdedigd. ${ }^{111}$

Indien de toestemming pas bij lemand bekend wordit nadat hij de handeling heeft verricht, is de objectieve toestand bepalend. ${ }^{112}$ Weliswaar heeft dan - strikt formeel gezien - een normovertreding plaatsgehad, maar van de schending van een rechtsgoed kan moeilijk worden gesproken. Een andere opvatting zou meebrengen, dat de kwade bedoelingen van de dader zijn strafbaarheid constitueren.

Soms eist de wel dat de toestemming schriftelijk wordt gegeven. In dat geval is een mondelinge toestemming niet toereikend. ${ }^{113}$

\subsubsection{Drie opvattingen over toestemming bij mishandeling}

Er kunnen drie opvattingen over de rol van de toestemming bij mishandeling onderscheiden worden. Volgens de eerste brengt toestemming mee, dat de handeling niet onder mishandeling valt. Deze opvatting komt tot uitdrukking in het adagium "volenti non fit iniuria". ${ }^{114}$ Volgens de tweede opvatting heeft de toestemming geen invloed op de strafbaarheid van de handeling: het blijft een mishandeling (volenti fit iniuria). ${ }^{115}$ De derde

$108 \mathrm{Vgl.} \mathrm{Hazewinkel-Suringa/Remmelink,} \mathrm{1991,} \mathrm{p.} 333$ en Strijards, 1987, p. 62.

109 Vgl. Van Hamel, 1913, p. 315 en Hazewinkel-Suringa/Remmelink, 1991, p. 333.

110 De toemmalige minimumgrens voor de strafrechtelijke aansprakelijkheid.

111 Nysingh, 1888, p. 13 en 50, en Hazewinkel-Suringa/Remmelink, 1991, p. 333.

112 Vgl. Hazewinke:-Suringa/Renmelink, 1991, p. 334 en p. 248.

113 Vgl. Hazewinkel-Suringa/Remmelink, 1991, p. 333-334.

114 Van der Haak, 1883 , p. 40.

115 Nysingh, 1888, p. 41 en p. 70; Van Loon, 1910, p. 147-148; Simons, 1 , 1927, p. 283; Noyon, 1926 , ant . 11 op inleiding; Strijards, 1987, p. 68-70 en p. 62 . 
opvalting houdt in dat toestemming tot het toebrengen van licht letsel uitsluit dat de handeling onder mishandeling valt. ${ }^{116}$

Degene die een rume werking van toestemming in het strafrecht voorstaat, kent niet noodzakelijk aan toestemming bij mishandeling een rechtvaardigende werking toe en degene die van mening is dat toestemming bij mishandeling de strafbaarheid opheft, zoekt daarin niet noodzakelijk de verklaring voor de straffeloosheid van de medicus. ${ }^{117}$

Dat toestenming tot (zware) mishandeling niet principieel het strafbare karakter van de handeling kan wegnemen, wordt verdedigd met de stelling dat toestemming geen bestanddeel van mishandeling is ${ }^{118}$, dat de wetgever "mishandeling met toestemming niet heeft toegestaan, noch kan toestaan, omdat de handeling ondanks toestemming in strijd blifft met het staatsbelang" "19", respectievelijk het algemeen belang.

Straffeloosheid van een operatieve ingreep vanwege toestemming wordt op dezelfde gronden afgewezen. ${ }^{120}$

Het feit dat de meeste schrijvers de rechtsgrond voor de straffeloosheid van de medicus niet in de toestemming zien, brengt echter niet mee, dat zij aan de toestemming bij een medische behandeling geen rol toekennen. Van Hamel noemt de toestemming van de patiënt "voorwaarde voor de rechtvaardiging door het beroep". ${ }^{121}$ Volgens Dorbeck wordt de rol van de toestemming hierbij bepaald door de ongeschreven regelen van het medisch beroep. ${ }^{122}$ Voor Van Hugenpoth tot Aerdt dekt "toestemming van de tot handelen bevoegde patiênt" de strafrechtelijke aansprakelijkheid van de medicus. Maar hij kent de toestemming slechts deze functie toe, voor zo ver de medicus "naar geweten en naar de regelen der wetenschap" handelt ${ }^{123}$, zodat de toestemming ook bij hem kennelijk één van meer voorwaarden is, waaraan de medicus moet voldoen, als hij niet strafrechtelijk aansprakelijk wil worden. Het verst hiervan verwijderd is de opvatting van Van Dam van Isselt, die de verkrijging van de toestemming welliswaar niet zonder bellang acht, maar die uitgaande van zijn standpunt dat een behandeling geen mishandeling is, stelde:

"Men mag aannemen, dat als een geneesheer iemand beter maakt, hij eene heilzame handeling verricht, onafhankelijk van het feit of dit den patiënt aangenaam is of niet. Genezen is genezen en daar kan de toestemming niets toe afdoen" ${ }^{124}$.

Wel achte Van Dam van Isselt behandelen zonder toestemming ongeoorloofd. Het ontbreken van toestemming maakt de handeling echter niet tot mishandeling, maar is een "inbreuk op onze vrijheid ${ }^{\text {t }}{ }^{125}$ Strafrechtelijke aanpak is via art. $284 \mathrm{Sr}$ mogelijk als met

116 Dorbeck, 1893, p. 75; Van Hamel, 1927, p. 262, Vos, 1947, p. 197; Noyon-Langemejier, 1954, amat. 3 op wederechtelijk; Van Bemmelen/Van Hattum, 1, 1953, p. 372-373; Van Bemmelen/Van Hattum, II, 1954, p. 227, Hazewinkel-Suringa, 1964, p. 191-192; Flazewinkel-Suringa/Remmelink, 1991, p. 334-336.

117 Zie b.w. Dorbeck, 1893, p. 85-87.

118 Nysingh, 1888, p. 64 .

119 Dorlbek, 1893 , p. 72 .

120 Nysingh, 1888 , p. 41. Lette van Oostwoorne, 1882, p. 18; Dorbeck, 1893, p. 48 e.w.; Van Hugerpoth tot Aerdt, in: De verantwoordelijkheid van den geneesheer, (1908), p. 74 .

121 Van Harmel, 1913 , p. 317.

122 Dorbeck, 1893, p. 87.

123 Van Hugenpoth tot Aerd, in: De verantwoordelijkheid wan den geneesheer, (1908), p. 74 .

124 Van Damu van Isselt, $1902, \mathrm{p} .55$.

125 Van Dam van Isseli, $1902, \mathrm{p} .77$. In origineel cursief. 
(bedreiging met) geweld gehandeld wordt ${ }^{126}$, mar niet als het geweld of de dreiging met geweld ontbreekt. Een aparte strafbepaling om de medicus die zonder toestemming behandelt te kunnen straffen achtte hij overbodig, daar zich volgens hem in Nederland dergelijke gevallen niet voordoen. ${ }^{127}$

De Gemengde Commissie 1909 ging uit van de stelling, "dat ieder individu de beschikking behoort te hebben over zijn eigen lichaam". Ter waarborging van dat recht stelde zij voor hieromtrent de volgende regeling in de WUG op te nemen. ${ }^{128}$

"In gevallen, waarin door den geneeskundige gewelddadig moet worden ingegrepen, waaronder mede wordi verstaan het brengen in een staat wan bewusteloosheid of onmacht, behoort hij zich vooraf te verzekeren van de uitdrukkelijke toestemming van dengene, die de behandeling moet ondergaan.

Is deze buiten staat zijn wil behoorlijk te verklaren, heeft hij den leeftijd van zestien jaar nog niet bereikt, of is hij, anders dan wegens verkwisting, onder curatele gesteld, dan wordt de uitdrukkelijke toestemming vereischt van den wettelijken vertegenwoordiger in burgerlijke zaken.

Bij ontstentenis van dezen of bij zijn weigering van toestemming kan door den geneeskundige de toestemming van den kantonrechter ${ }_{*}$ binnen wiens ressort de te behandelen persoon verblijft, worden gevraagd.

De beslissing van den kantonrechter is niet aan beroep onderworpen en wordt gesteld op het rekwest, waarbij zijn tusschenkomst is ingeroepen. Zij kan echter ook mondeling worden verleend.

Bij oogenblikkelijk dreigend gevaar voor leven of gezondheid is de geneeskundige tot dadelijk gewelddadig ingrijpen, ook zonder toestemming, bevoegd" "29

Vanwege de grote verscheidenheid aan opvattingen omtrent de rol van de toestemming in het strafrecht ${ }^{130}$ vond Van Dam van Isselt de toestemming als grondslag voor de straffeloosheid gevaarlijk. Een probleem doet zich bovendien voor indien geen toestemming is verkregen, want niet altijd mag terecht toestemming verondersteld worden. Van Dam van Isselt noemde in dat verband het geval van een "aspirant-zelfmoordenaar", wiens leven door behandeling wordt behouden. In de toestemmingstheorie zou er dan sprake zijn van mishandeling, mar dat achtte Van Dam van Isselt niet acceptabel. Als ander bezwaar tegen deze rol van de toestemming noemde hij dat dan ook toestemming tot niet-genezende handelingen mee zou brengen, dat de handeling niet als mishandeling kan worden aangemerki. ${ }^{\text {3: }}$

Leenen vertolkt de thans heersende opvatting waar hij schrijft dat toestemming voor een chirurgische ingreep een noodzakelijke, maar geen toereikende voorwaarde voor de straffeloosheid van de gedraging is. ${ }^{132}$

126 Van Dam wan Isselt, 1902, p. 78. Zie ook: Gemengde Commissie van 1909, NTwG 1909, I, p. 74.

127 Van Dam van Isselt, 1902, p. 81 .

128 Als reden daantoe geeft de Commissie op, dat aldus cok voor de civiele rechter een beroep op deze bepaling. karn worden gedman.

129 Gernergde Commussie van 1909 , NivG $1909,1, p_{i} 75-76$. Vgll, hiertoe instemmend: de arts Pinkhof NTVG 1910,1 , p. 62-63.

130 Vgl. Dorbeck, 1893 , p. 5.

131 Van Dam van Isselt, 1902, pr 16-19. Zie ook Hazewinkel-Suringa, 1964, p. 196.

132 Leenen, 1988 , p. 106-108. 


\subsubsection{Conclusie}

De opvatting dat toestemming buiten de door de wetgever bepaalde gevallen rechtvaardigend werkt is uitzonderlijk, hoewel in de literatuur een tendens waarneembaar is aan de rol wan de toestemming in het strafrecht een grotere betekenis toe te kennen. Uit de literatuur kan niet worden opgemaakt dat toestemming tot een medische ingreep deze kan rechtvaardigen. Wel wordt in het algemeen, zoals hier en bij de bespreking van andere mogelijke rechtsgronden blijkt, toestemming als ến van de voorwaarden voor geootoofd medisch handelen beschouwd. Slechts bjj de rechtsgrond 'een behandeling is geen mishandelling' is - in verband net mishandeling - het objectieve karakter van de gedraging doorslaggevend. Daardoor kan bij deze rechtsgrond verdedigd worden dat niet van belang is of all dan niet toestemming tot de behandeling is verleend, tenzij de toestemming als noodzakelijke voorwaarde voor de behandeling wordt beschouwd.

\subsection{Ontbreken van de (materiêle) wederrechtelijkheid}

In wezen wordt in elke opwatting, waarin gesteld wordt, dat medisch handelen niet aan de delictsomschrijving van mishandeling voldoet de wederrechtelijkheid van de gedraging ontkend.

Het merendeel van de discussie omtrent de grondslag van de straffeloosheid voor operatieve ingrepen door een medicus speelde zich af in de beginjaren van het WvSr. Toen werden in het algemeen ongeschreven strafuitsluitingsgronden niet erkend. Het gevolg daarvan was dat in die tijd de geoorloofdheid van het handelen van de medicus niet in het ontbreken van het element wederrechtelijkheid werd gezocht.

Maar ondanks grotere acceptatie van ongeschreven strafuitsluitingsgronden werd ook in latere jaren woor de straffeloosheid van de medicus voor operatieve ingrepen eerder naar andere rechtsgronden gegrepen. ${ }^{133}$ De materiële wederrechtelijkheid is daartoe te weinig bepaald, zodat de inhoud en de grenzen te vaag zijn.

Wel wordt de straffeloosheid van medisch handelen verdedigd met de stelling dat het bestanddeel "wederrechtelijk" niet te bewijzenis Daabjijwordt vande veranderstelling, uitgegaan, dat "wederrechtelijk" bestanddeel van de dellictsomschrijving van mishandeling is. ${ }^{34}$ Hiertoe wordt in hei praefix "mis" van mishandeling de wederrechtelijkheid gelezen. Vervolgens wordt betoogd, dat chirurgische ingrepen niet wederrechtelijk zijn.

De Doelder en 't Hart, die deze opvatting verdedigen, vatten 'wederrechtelijk' op als 'in strijd met het objectieve recht', waarbij zij - zoals gebruikelijk - "in de kern" aan wederrechtelijk dezelfde betekenis toekennen als het begrip 'onrechtmatig' in het civiele recht heeft. In hum benadering handelt de arts niet wederrechtelijk en pleegt hij derhalve geen mishandeling wanneer het toebrengen van pijn of letsel een middel is om een me-

133 Zie b.w. Hazewinkel-Suringi, 1964, p. 186.

134 Zie b. . Strjards, $1987, \mathrm{p}, 65$, wolgens welke een politieamblenaar, die ter handhaving van de openbare orde geweld bezigt, gen nuishande ling pleegt, ondat hij iniel wederrechtelijk handelt, maar ter uitvoering van de Poltuewet. Strijards leest hierbij art. $300 \mathrm{Sr}$ als "opzentelijh wederrechtellijk een ander leed of letsel toebrengen" "Deze interpretatie van de delictsonschrijving is echter niet toepastar bij art. 302 Sr. Nieboer, $1991_{\text {, }}$. 107, viudt het " opvallend" dat men vandaag "wederrechtelijk" als vanzelfsprekend leest in artikelen wala de wetgever dezterm kennelijk niet weriste te gebruiken. Als én van deze artikelen noemt hij nishandeling: 
disch doel na te streven en wanneer het middel en het daardoor veroorzaakte leed proportioneel zijn aan het medisch doel. ${ }^{135}$

Dat is in overeenstemming met het hierboven uit de wetsgeschiedenis afgeleide en verdedigde. Hun lezing van de delictsomschrijving van de eenvoudige mishandeling is echter ontoereikend, daar zij niet de straffeloosheid van de medicus ten aanzien van zware mishandeling verklaart. Bovendien komen in deze opvatting de subjectieve bestanddelen een belangrijke rol toe, zoals de schrijvers zelf erkennen:

"Men ziet hier de vervlochtenheid van het opzet- en het wederrechtelijkheidsvereiste, ..., en hoezeer de eísen welke via het bestanddeel opzet worden gesteld aan de mishandeling eigenlijk de vraag naar de wederrechtelijkheid betreffen". ${ }^{136}$

Tevens is de hier besproken opvatting niet goed te scheiden van het door De Doelder en 't Hart bekritiseerde standpunt, 'een behandeling is geen mishandeling', zoals blijkt uit de volgende zinsnede van Van Hugenpoth tot Aerdt:

"Het woord mis beteekent in het woord mishandeling slecht, verkeerd ... Indien dus de medicus den zieke pijn doet of letsel veroorzaakt met de bedoeling hem te genezen, het lichaam de gezondheid terug te geven, dan is dit op zich zelf geen slechte of verkeerde handeling, geen mishandeling maar een behandeling. En zulk een onderscheid heeft m.i. niets te maken met het strafbare feit mishandeling. Het spraakgebruik onderscheidt hier juist". ${ }^{137}$

Anderzijds doet zich al gauw een overlapping voor met de medische exceptie, die hierna besproken wordt:

"In mishandeling ligt het begrip onrechtmatig veroorzaken van lichamelijk leed opgesloten. ... Welke omstandigheden ... kunnen aan eene handeling, ..., haar onrechtmatig karakter ontnemen? Zeer zeker kan dit de omstandigheid, dat een wettelijk erkend beroep wordt uitgeoefend". ${ }^{138}$

Voor de opvatting dat wederrechtelijk bestanddeel is van mishandeling en het handelen van de arts niet wederrechtelijk is, spreekt dat een inhoudelijke verklaring voor de straffeloosheid van de medicus gegeven wordt, waarbij het handelen aan de civiele onrechtmatigheídseisen kan worden getoetst. ${ }^{139}$

135 De Doelder en 't Hart, TVGR 1978, p. 62 en p. 66. Zle ook "t Hart onder HR 21 febr. 1989, NJ'1989, 668 en Rb. Haarlem \& febr. 1984, NJ 1986, 133, waarin de politierechter Van Dorst overwovg, dat - gelet op de geschiedenis van art. $300 \mathrm{Sr}$ - de pijn of letsel toebrengende handeling voor de kwalificatie wederrechtelijk dient te zijn. Zie in dezelfde zin: De Doelder en Van Dorst, NJB 1977, p. 164-170.

136 De Doelder en " 1 Hart, TwGR 1978, p. 62. Zie ook Leenen, 1991, P. 107 e.w.

137 Van Hugenpoth tol Aerdt, in: De verantwoordelijkheid vain den geneesheer, (1908), p. 47.

138 Witsen, 1888, p. 30.

139 Zie ook Van Bemmelen, 1931, p. 9: "De ... omschrijving van onrechtmatig van den Hoogen Raad is ook voor bet strafrecht van groot belang, niet slechis voor de oneigenlijke omissiedelicten, maar bij alle strafbare feiten ter bepaling van de grenzen der rechtwaardigingsgronden". Deze eisen zijn hier derhalve niet bedoeld om de strafrechtelijke aminspakelijkheid vit te breiden. Zie daartoe kritisch: Hazewinkel-Suringa/Remmelink, 1991 , p. 153-154. 


\subsubsection{Inleiding}

In de literatuur wordt de medische exceptie vaker als rechtsgrond gebezigd om aan te tonen dat een operatieve ingreep door een medicus niet onder mishandeling valt, terwijl zoals in het hiena volgende hoofdstuk over abortus zal blijken de medische exceptie voor abortus door een medicus in het algemeen wordt afgewezen.

Hieronder worden de medische exceptie en het beroepsrecht afzonderlijk besproken, on zo ook voldoende aandacht aan de grondslagen van deze beide varianten van eenzelfde rechtsgrond te kunnen besteden. Helaas blijkt uit de gebezigde literatuur niet altijd voldoende duidelijk, of de betreffende auteur zich over de medische exceptie danwel over het beroepsirecht heeft uitgelaten.

\subsubsection{De medische exceptie}

Drie jaar na de invoering van het WvSr omschreef J.W. Smidt de medische exceptie als:

"... niet strafbaar is de bevoegde geneeskundige, die overeenkomstig de erkende regelen zijner wetenschap, middelen aanwendt of eene kunstbewerking verricht" ${ }^{\prime \prime 40}$ In deze omschrijving winden we alle kenmerken van de medische exceptie terug die ook door anderen gegeven worden. De medicus dient bevoegd te zijn en te handelen volgens de regelen zijner kunst.

Ter verdediging van de medische exceptie wordt, behalve door te verwijzen naar de parlementaire behandeling van de mishandelings- en abortusartikelen ${ }^{\mathbf{1 4 1}}$, een drietal argumenten gebezigd.

Volgens het eerste argument is de medicus niet strafbaar omdat hij in het belang van de maatschappij handelt. Bij het tweede argument wordt daaraan toegevoegd dat zijn handelen ook moreel verdedigbaar is. Het derde argument houdt in dat de medische exceptie uit het gewoonterecht kan worden afgeleid.

Het eerste argument komt erop neer, dat een medicus die beroepshandelingen verricht daarwoor niet strafrechtelijk alansprakelijk kan zijn, omdat hij in het belang van de maatschappij handelt. ${ }^{1 / 2}$

"De grond der straffeloosheid van medïci voor gewone operatiën is daarin gelegen,

dat het strafrecht bestaat in het maatschappelijk belang, dat ook de geneeskunst in hetzelfde belang wordt uitgeoefend en dus daarmede niet strijden kan". ${ }^{43}$

Dit argument doet denken aan de thans gangbare opvatting van het ontbreken van de materiële wederrechtelijkheid. Dientengevolge behoort bij een beroep op deze strafuitsluitingsgrond hetzelfde rechtsbelang te worden nagestreefd dat de overtreden bepaling beoogt te beschermen. Verder moet het rechtsbelang op deze wijze beter gerealiseerd kunnen worden, dan door de wet na te leven. Twee voorwaarden waaraan mijns inziens

140 J.W. Smidt, 1889 , p. 70 .

141 Zie Nysingh, 1888, p. 70.

142 Witsen, 1888, p. 31.

143 Lette vin Oostroome, 1882, p. 18. Vgl. Roessingh, TvS 1891, p. 312. 
het handlelen lege artis beantwoordt. Ex is well een verschil tussen deze twee benaderingen. Bij een beroep op de medische exceptie met behulp van het eerste argument wordt meer gelet op de algemene taak van het strafrecht, terwijl bij het ontbreken van de materiele wederrechtelijkheid het handelen aan een specifieke delictsomschrijving wordt getoetst.

Ook bij het tweede argument wordt een beroep gedaan op het maatschappelijk belang. Maar dat wordt niet toereikend geacht. Daarbij wordt verondersteld dat een misdrijf twee kenmerken heeft: het is in strijd met zowel "de zedenwet" als met "het algemeen bellang". ${ }^{14}$ Daarvan uitgaande is een strafbaar feit:

"Elke onzedelijke handeling, waardoor het individu de algemeenen wil schendt, door ò een publiek- of een privaatrecht te krenken, of inbreuk te maken op de zedelijkheid, voor zooverre de Staat die laatste voor zijn bestaan noodig heeft". "145 Een consequentie van deze zienswijze is dat een medicus die op grond van een zedelijke plicht respectievelijk met een zedelijk doel handelt, dat inherent is aan de uitoefening van zijn beroep, niet strafbaar is. ${ }^{146}$ Witsen die met een beroep op het zedelijke doel de straffelloosheid van de vivisectie verdedigde, stelde dat de omstandigheid dat een wettelijk erkend beroep wordt uitgeoefend aan een handeling haar onrechtmatig karakter kan ontnemen. De reden daarvoor ligt volgens hem in het zedlelijke coel dat met de uitoefening van het beroep wordt nagestreefd. ${ }^{147}$

Tegen de zedelijkheid als algemeen criterium voor strafbaar gedrag bestonden all ten tijde van de totstandkoming van het WvSr bezwaren. Zo schreef Bijleveld in 1883:

"... dat, hoewel het goed is aan de zedeleer een adviserende stem toe te kennen, de meening onjuist moet geacht worden, dat de moraal den wetgever tot het strafbaar stellen van zekere handelingen zou dwingen.

Waar de moraal tot dezelfde resultaten voert als het criterium dat wij stelden "het belang der maatschappij" is zij overbodig; waar zij daarentegen andere eischen stelt dan het belang der maatschappij vordert, is de moraal onjuist en is het gevaarlijk haar als leidraad te gebruiken" ${ }^{\text {"1 }}{ }^{48}$

Volgens het derde argument heeft de medische exceptie haar grondslag in het gewoonterecht, dat in 1908 met het oog op de medicus omschreven werd als:

"regelen van doen of laten welke door bizondere personen bij hun doen of laten geregeld worden in acht genomen, ofschoon zij door geen wet zijn voorgeschreven ${ }^{\text {, }}$, 49

Tegen het gewoonterecht als grondslag voor de medische exceptie bestaan twee bedenkingen. De eerste bedenking houdt in dat het gewoonterecht niet als zodanig wordt erkend. In de woorden van Van Dam van Isselt:

"... war de wet strafbar stelt hem, die mishandelt - zonder uitzondering dus, een ieder die mishandelt - men toch op grond van het gewoonterecht geen uitzondering mag maken". ${ }^{150}$ "Reeds vroeger - ... - hebben wij er op gewezen, dat alléén de

144 Hirschl 1882, p. 58 .

145 Hirsch, 1882 , p. 55 . In origineel cursief...

146 Witsen, 1888, p. 31 .

147 Witsen, 1848, p. 31 .

148 Bijlevelld, 1883, p. 35.

149 Van Hugempoth tot Aerdi, in: De verantwoordelijkheid van den geneesheer, (1908), p. 45 .

150 Van Dam van Isselt, 1902 , p. 32. 
in de wet genoemde rechtsgronden de wederrechtelijkheid opheffen, en ook is reeds aangettoond - ... - dat de gewoonte in ons strafrecht onbekend is" ${ }^{151}$ "Immers, aangezlen de wet strafbaar stelt mishandeling, moord, doodslag, enz. verklaart zij deze handelingen eo ipso wederrechtelijk. Alleen wanneer de wetgever dat anders wil, wanneer hij zelf gebruik maakt van zijne bevoegdheid om uitzonderingen te maken, is de handeling niet wederrechtelijk ". . $^{\text {1.52 }}$

Als tweede bedenking tegen het gewoonterecht als grondslag voor de medische exceptie wordt aangevoerd dat medici niet allijd volgens dezelfde regels handelen.

"Wanneer de medicus zekere regels wel volgt, de andere weer niet, dan kan men

niet van gewoonte, laat staan van gewoonterecht spreken". ${ }^{153}$

We zien dat een deel van de bezwaren voortkomt uit bedenkingen tegen de erkenning van ongeschrewen strafuitsluitingsgronden in het algemeen. Die opvatting was onder straffechtjuristen in de eerste jaren na invoering van het WvSr de overheersende. Van Hugenpoth tot Aerdt bracht deze houding goed tot uitdrukking, waar hij schreef:

"Het is mij niet duidelijk kunnen worden hoe, op zich zelf door de wet strafbaar gequalificeerde feiten, straffelloos kunnen worden gepleegd uit hoofde van het beroep van de dader. Ieder is aan de strafwet onderworpen, tenzij de wet hem uitdrukkelijk uitslüt of bepallde handelingen te zijnen aanzien niet strafbaar stelt". ${ }^{154}$

De meeste juristen hadden er moeite mee om de medische exceptie op (regels uit) het ongeschreven recht te doen steunen. De reden daartoe is niet gelegen in de erkenning van de straffeloosheid voor operatieve ingrepen - dat deze straffeloos medisch moeten kunnen geschieden, werd niet betwist -, maar in de erkenning van het ongeschreven recht. Doch niet alleen stonden zij afwijzend tegenover ongeschreven rechtsgronden, ook kenden zij weinig gewicht toe aan de wetsgeschiedenis. Volgens J.W. Smidt kunnen de mededelingen van de Minister omtrent het geoorloofde van geneeskundige handelingen slechts beschouwd worden als een weergave van diens persoonlijke overtuiging. $\mathrm{Zij}$ kunnen wel in beperkte mate aanvullend zijn, maar nooit zelfstandig recht scheppen. ${ }^{\text {1ss }}$

Nog afwijzender formuleerde Simons:

Een "uitlegging van de Regering of van de volksvertegenwoordiging ieder voor zich zelf is niet bindend; eene uitlegging door de wetgever is niet anders dan de vaststelling eener nieuwe wettelijke regeling". ${ }^{156}$

De hoop van Minister Modderinan dat de wet geïnterpreteerd zal worden door rechtsgeleerden die het beginsel erkennen: niet strafbaar is de geneeskundige, die handelt naar de regelen zijner kunst, noemde J.W. Smidt een "ontoelaatbare eisch", daar deze in strijd is met de "wetenschappelijke regelen van uitlegkunde". ${ }^{157}$ Van Dam van Isselt verwees in verband met deze uitlatingen van Modderman nog naar art. $11 \mathrm{AB}$, dat de rechter verplicht volgens de wet recht te spreken, warbij hij nimmer de innerlijke waarde of billijkheid van de wet mag beoordelen. ${ }^{158}$

151 Vari Dann wan Isselt, 1902, p. 44.

152 Van Dam van Isselt, $1902, \mathrm{p}, 14$.

153 Van Hugenpolh tot Aerdt, in: De verantwoordelijkheid van den geneesheer, (1908), p. 45. Zie ook Van Dam van Isselti, 1902, p. 30-31.

154 Wan Hugenpoth tot Aerdit, in: De verantwoordelijkheid wan den geneesheer, (1908), p. 41.

155 J.W. Smidt, 1889 , p. $46-47$.

156. Simons, Ntvg 1905, l, p. 1315.

157 J.W. Snidt, 1889 , p. 46-47.

158 Van Dan van Isselt, 1902, p. 97. 
Maar deze afwijzende houding laat wel zien dat tegenstanders van een ongeschreven strafuitsluitingsgrond voor medisch handelen in de uitlatingen van de regering, bij monde van Modderman, wel een aamwijzing voor zulk een strafuitsluitingsgrond zagen.

\subsubsection{Het beroepsrecht}

Onder de juristen die van mening zijn dat de medische exceptie een wettelijke grondslag. vergt, zijn er enkelen die het niet nodig achten, dat deze grondslag in het WvSr zelf behoort te zijn opgenomen. Zo verdedigde Dorbeck de opvatting dat er buiten de in het WvSr opgenomen rechtvaardigingsgronden nog andere bestaan, die als zodanig niet uitdrukkelijk door de wetgever zijn erkend. Dergelijke rechtvaardigingsgronden vloeien volgens hem onder andere voort uit de wettelijk erkende beroepen. ${ }^{159}$ De grondsiag voor deze rechtvaardigingsgronden is gelegen in een wettelijk voorschrift, waaruit een bepaald recht kan worden afgeleid. Als een dergelijk specifiek recht in botsing komt met "een of ander algemeen verbod dan ontstaat daaruit de bevoegdheid te doen of na te laten datgene, waartoe dat wettelijk voorschrift machtigt" ${ }^{n}{ }^{160}$ Dat wettelijk voorschrift zien sommigen gelegen in de WUG.

"Lichamelijke mishandeling geheel volgens de regelen der medische wetenschap en ten behoeve van den patiënt door een medicus gepleegd, is niet wederrechtelijk; immers de uitoefening van zijn beroep, hetwelk van staatswege erkend wordt, rechtvaardigt zijn handeling; de Staat veroorlooft den medicus de heel-, genees- en verloskunde uit te oefenen; welnu, dan staat hij hem ipso jure toe die Jichamelijke mishandelingen te plegen, welke de geneeskunde met zich brengt. De medicus kan zich, voor den rechter gedaagd, beroepen op zijn beroepsrecht. Het feit, dat hij in de uitoefening van zijn betrekking was, maakt hem straffeloos" ${ }^{161}$

Van Hamel is wellicht de meest prominente voorstander van het beroepsrecht. Ook voor hem dient ledere rechtvaardigingsgrond direct of indirect op een wet te berusten en het beroepsrecht steunt volgens hem op de WUG. Hij beschouwde de bepalingen in de WUG, die de medische beroepsuitoefening regelen als lex specialis ten opzichte van de verbodsbepalingen in het WvSr. Tegenstanders hield hij voor dat zij ten onrechte het strafrecht als geîsoleerd van het overige recht zien. ${ }^{162}$

Maar zelfs juristen, die van mening waren, dat een rechtvaardigingsgrond niet per se in het WvSr behoeft te staan, zolang als hij in een andere wet is geformuleerd, vonden dat uit de WUG geen beroepsrecht kan worden afgeleid. De WUG staat volgens hen aan de medicus slechts toe de geneeskunde uit te oefenen. Zij verleent een bevoegdheid, maar yoorziet niet uitdrukkelijk in een uitzondering, zodat de medicus desondanks onderworpen blijft aan het WvSr. ${ }^{1.63} \mathrm{Zo}$ wees Simons de opvatting van de hand dat de straffe-

159 Dorbeck, 1893, p. 4.

160 Dorbeck, 1893 , p. 4.

161 Van Dam van. Issell, 1902, P. 12. Diens omschrijving wordt in iets algemenere bewoordingen door Van Hifugenpoth tot Aerdi ter omschrijwing van het beroepsrecht gebezigd: Wan Hugenpoth tot Aerdt, un: De: verantwoordelijkheid wan den geneesheer, $(1908), p_{n} 41$.

162 Van Hamel, 1907, p. 293. Ir dezelfde zin: Van Loon, 1910, p. 143-145; Witsen, 1888, p. 30, Dorbeck, 1893, p. 4. Waarschijnlijk ook: Ponpe, 1959, p. 111; Enschede, 1985, p. 19-38.

163 Van Dassi van Isselt, 1902, p. 14, p. 13 en p. 105; Nieuwenhuis, TwS 1917, p. 350. 
loosheid van de medicus voortvloeit uit art. 1 WUG, dat de medicus bevoegd verklaart tot uitoefening van de geneeskunst.

"Zeker mag de als zodanig toegelaten geneeskundige de geneeskunde in haar vollen omvang uitoefenen, doch daaruit volgt niet, dat hij daarbij niet zou gehouden zijn aan de voorschriften der strafwet. De WUG is een wet zoals ieder andere, maar men geeft aan die wet een strekking, die zij niet heeft, door in hare voorschriften omtrent de voorwaarden voor de beroepsuitoefening ook de bepaling te willen lezen; dat de geneeskundige, die aan de voorwaarde heeft voldaan, nu alles mag doen wat zijne wetenschap hem voorschrijft, ook dan wanneer daardoor de strafwet wordt overschreden. M.1. ligt de betekenis dezer wet vooral in hare negatieve zijde, in hare uitsluiting van onbevoegden ${ }^{\mathrm{B}}{ }^{164}$

De stelling van Modderman, dat niet strafbarar is de geneeskundige die handelt naar de erkende regelen zijner kunst, heeft wolgens Simons veel overeenkomst met die dlat de straffeloosheid haar reden vindt in art. 1 WUG. Een zodanige regel is in de Nederlandse strafwetgeving niet te vinden. En, voegde hij hieraan toe, zij kan "in ieder geval" voor de rechter niet bindend zijn, want "Elk beroep, ook dat van den geneeskundige, heeft de door de strafwet gestelde grenzen te eerbiedigen" ${ }^{165}$

\subsubsection{Een medische exceptie in het WwSr?}

Ondanks dat Simons een grondslag voor het beroepsrecht en a fortiori voor de medische exceptie ontkende, sprak hij zich in 1905 uit tegen het opnemen van een algemeen gestelde strafuitsluitingsgrond voor medici in het WvSr. Zijns inziens is het vraagstuk te ingewikkeld om thet met een algemeen gesteld wetswoorschrift op te lossen. ${ }^{166}$. Weliswaar heeft de geneeskundige er recht op "niet aan een strafvervolging te worden blootgesteld, wanneer hij naar eer en geweten doet, wat zijn kunst hem voorschrijft. De eerbiediging van dat recht is ook een algemeen maatschappelijk belang". Maar tegenover de rechten van de geneeskundige staan de rechten van de patiënt. De wetgever mag zich niet van zijn taak kwijten door alles afhankelijk te stellen van "den weinig vaststaanden beroepsregel". Tot nu toe is natar zijn mening in Nederland de hele problematiek onvoldoende onder ogen gezien. Wel hebben juristen zich hïerover uitgelaten, maar voor zover hem bekend geen geneeskundigen. En hij concludeerde: "De quaestie is, naar ik meen, nog niet "spruchreif" ". ${ }^{167}$ Daarom stelde hij voor een commissie van geneeskundigen en rechtsgeleerden hieromtrent onderzoek te laten doen.

Naar aanleiding hiervan werd in 1907 door de Nederlandsche Maatschappij tot bevordering der geneeskunst de Gemengde Commissie van 1909 ingesteld. Voorzitter was de gynaecoloog Treub en een van de leden was Slmons. Het rapport van deze commissie verscheen in 1909 . Eén van de voorstellen hield in thet opnemen in het WvSr van een nieuw artikel, luidende:

164 Simons, NTwG 1905, I, p. 1312-1313. Vgl. Leenen, 1991, p. 107-108. Leenen beeft een voorkeur voor de medische exceptie daar zijns inziens het medisch professionele handelen wiet op een wettelijke bevoegdheid berust.

165 Simons, NTYG 1905,1, p. 1313.

166 Simons, NTVG 1905, I, p. 1305-1306.

167 Simonis, NTVG 1905, L, p. 1906-1907. 
"Niet strafbar is de geneeskundige, die een feit begaat, dat naar redelijk inzicht

is geboden of toegellaten door de regelen zijner geneeskunst"

Evenals bij de andere voorstellen van de Gemengde Commissie, bleef de aandacht voor dit voorstel beperkt tot een enkele vermelding in de literatuur.

\subsubsection{De medische exceptie bij mishandeling en de Hoge Raad}

Hiervoor bleek dat de Hoge Raad de straffeloosheid van de medicus voor mishandeling in een interpretatie van de delictsomschrijving, met name in de subjectieve bestanddelen, zocht. Maar in het Euthanasie II-arrest ${ }^{169}$ ging hij om. Dit arrest betrof een arts die vanwege levensberoving op verzoek werd vervolgd en zich verweerde met een beroep op de medische exceptie. ${ }^{\| 70}$

In zijn pleitnotities verwees de cassatieadvocaat naar uitlatingen van Modderman tijdens de behandeling van de abortusbepalingen, die ter straffeloosheid van medische abortus had opgemerkt:

"Is het ooit bij iemand opgekomen om art. 309 Code Pénal van toepassing te achten op den chirurgijn die eene operatie verricht of op den Israëlitischen besnijder? Als een letterknecht de toepasselijkheid beweerd had op grond dat in dat artikel, geheel in 't algemeen, van "faire des blessures" ${ }^{171}$ sprake is, dan zou de jurist, gedachtig aan het 'scire leges, non est verba tenere sed vim ac potestatem' ${ }^{172}$ zelfs geen antwoord hebben noodig gekeurd" ${ }^{173}$.

Verder verwees de cassatieadvocaat naar de parlementaire behandeling van art. 251 bis Sr (abortus) in $1911^{174}$ en naar de twee Huizer veearts-arresten ${ }^{175}$. Uit de eerste verwijzing leidde hij af dat de wetgever de medische exceptie in het algemeen heeft erkend. En in de Huizer veearts-arresten las hij een erkenning van de medische exceptie door de Hoge Raad: : $^{76}$

Naar aanleiding hiervan overwoog de Hoge Raad, nadat hij eerst de medische exceptie ten aanzien van art. 293 Sr had verworpen ${ }^{177}$.

"Uit de geschetste geschiedenis ${ }^{178}$ en de aangehaalde jurisprudentie en literatuur is wel op te maken dat is aanvaard dat een arts, indien hij zou worden vervolgd wegens het toebrengen van pijn of (zwaar) lichamelijk letsel omdat zijn optreden binnen de letter van de desbetreffende strafbepalingen valt, zich met vrucht kan beroepen op zijn recht als medicus in het belang van zijn patiënt in het kader van een medische ingreep aldus te handelen".

168 Gemengde Commissie van 1909, NTvG $1909,1, \mathrm{p}, 77$.

169 HR 21 okt. 1986, NJ 1987, 607 m.nt. GEM.

170 De cossatieadvocaat bezigde de termen beroepsrecht en medische exceptie alls synoniemen.

171 Vrij vertaild: letsel weroorzaken.

172. Vrij vertakld: wees geen lenterknecht.

173 Smidt, $\mathrm{I}_{\text {, }} 1891$; P. 469.

174 HTK, 1910-1911, p. $1585-1590$.

175 HR 27 juni 1932 , NJ 1933, 60 m.nt. W.P. en FR 20 febr. 1933 , NJ 1933, 918 m.nt $T$.

176 De door de cassatiead vocaat besproken wetsgeschiedenis en jurisprudentite behoort systematisch en inhoudelijk thuis bij de bespreking van abortus en euthanasie en wordt aldaer nader besproken.

177 Zje daartoe: $\mathbb{H}$. IV B, onder 2.5.3.

178 De Hoge Radi refereert hier an het eerder door hem gebezigde woord "wetsgeschiedenis". 
Deze overweging is opmerkelijk, ondat de aangehaalde wetsgeschiedleris betrekking heeft op woorgestelde abortusbepalingen en de Huizer veearts-arresten op een strafbepaling uit de Veewet. Daarom was voor de hier aangehaalde overweging van de Hoge Raad: een gedachtensprong nodig van de betreffende wetsgeschiedenis en jurisprudentie naar de delictsomsishrijvingen van mishandeling.

\subsubsection{Samenvatting}

De medische exceptie werd - in verband met de delictsomschrijving van mishandeling - als strafuitsluitingsgrond voor medisch handelen in het algemeen niet erkend. Belangrijk voor deze houding was warschijnlijk een afwijzend standpunt ten opzichte van ongeschreven strafuitsluitingsgronden. Op den duur zien een aantal juristen het beroepsrecht als grondslag voor de straffeloosheid van medisch handelen in verband met mishandeling.

Nadat de Hoge Raad de straffelloosheid van de medicus voor mishandeling waarschijnlijk eerst in de bestanddelen van de delictsomschrijving zocht, heeft hij zich in 1986 woor de medische exceptie uitgesproken. Uit de overwegingen van de Hoge Raad in het Euthanasie II-arrest valt af te leiden dat hij de bevoegdheid van de medicus tot zijn beroepsuitoefening onvoldoende acht ter verklaring van de straffeloosheid voor operatieve ingrepen. Hij verwijst daartoe immers naar de wetsgeschiedenis en naar jurisprudentie.

\section{Conclusie}

In de wetsgeschiedenis zijn aanwijzingen te vinden die erop wijzen dat de wetgever een operatieve ingreep door een medicus als niet strafwaardig beschouwde, omdat de handeling nilet wederrechtelijk is. Zij was in zijn opwatting niet wederrechtelijk omdat met medisch handelen een geoorloofd, geobjectiveerd doel wordt nagestreefd. Dat wordt bevestigd door de wetsgeschiedenis yan de strafbepaling over dierenmishandeling.

Er is sprake van een objectief geoorloofd doel wanneer de handeling geschiedt in het belang van het betrokken individu (en in verband met de dierenmishandeling ten behoeve van een hoger belang dan het belang dat met de stratbaarstelling wordt beschermd). Een medische handeling in het belang van de patient is tevens een handeling die het belang van de samenleving dient, want deze heeft er baat bij dat haar individuen gezond zijn.

Tot de randvoorwarden voor de straffeloosheid van medisch handelen behoren, dat de handeling in de beroepsuitoefening moet zijn verricht, binnen de grenzen van het beroep, met inachtneming van de regelen der kunst en - in het algemeen - met toestemming van de patient.

Anders dan bij de dierenmishandeling werden de bepalingen omtrent mishandeling niet gewijzigd, noch werd nadrukkelijk erop aangedrongen deze te wijzigen. Vanuit de praktijk bestond hieraan ook geen behoefte. Om een theoretische grondslag voor de straffeloosheid van medisch handelen in verband met mishandeling te vinden, werden verschillende oplossingen aangedragen, die echter geen bevredigende verklaring konden geven, omdat zij te veel georienteerd waren op het wettelijk systeem en met datzelfde systeem in conflict kwamen. Deze benadering had te maken met het feit dat de erkenning van een ongeschreven rechtvaardigingsgrond in de beginperiode van het WvSr - en uit 
die tijd dateren de meeste geschriften over het onderwerp - niet of terughoudend plaats vond.

Het heeft tot 1986 geduurd voordat de Hoge Raad de medische exceptie als ongeschreven rechtvaardigingsgrond voor operatieve ingrepen van de medicus heeft erkend. Daarvoor heeft hij steun gevonden in de wetsgeschiedenis van de abortusbepalingen, de zedelijkheidswetgeving van 1911 en de Huizer veearts-arresten. Deze opvatting is eveneens de heersende in de huidige literatuur. 



\section{Abortus}

\section{Inleiding}

In de afgelopen honderd jaar zijn tien wetsvoorstellen ingediend om de abortusbepalingen van 1886 , de artt. $295-298 \mathrm{Sr}$, te wijzigen, aan te vullen of af te schaffen. Twee ervan haalden de eindstreep. In 1911 werd in het WvSr art. 251bis opgenomen, dat de strafbararheid voor abortieve gedragingen uitbreidde. In 1984 verviel dit artikel en werden de abortusbepalingen van de wetgever van 1886 vervangen door de Wet Afbreking Zwangerschap (WAZ) en een nieuw art. $296 \mathrm{Sr}^{1}{ }^{1}$ Aanleiding tot de wetsvoorstellen vormde de wens tot een effectievere strafrechtelijke bestrijding van criminele abortus te komen en de straffeloosheid van abortus door een medicus te waarborgen.

Dit hoofdstuk handelt over de wijze waarop getracht werd de straffeloosheid van de medicus vanwege abortus volgens de regelen der kunst, te bereiken. ${ }^{2}$

Abortus is een controversieel vraagstuk, dat met levensbeschouwelijke aspecten vervlochten is. Uit de bespreking van de wetsgeschiedenis, literatuur en jurisprudentie zal blijken dat met name daardoor de meningen over de gevallen waarbij straffeloos geaborteerd mag worden uiteenlopen.

In dit hoofdstuk worden de rechtsgronden die tot straffeloosheid van abortus door een medicus zouden kunnen leiden, niet afzonderlijk besproken. Met de invoering van de Wet Afbreking Zwangerschap (WAZ) zijn de artikelen 295-298 en 251 bis Sr vervallen. De discussie over de rechtsgronden ten aanzien van die bepalingen is daarmee in beginsel nog slechts van belang voor zover zij inzicht verschaft in achtergronden en motieven voor de spanning tussen het strafrecht en het handelen van de medicus en voor zover voorstellen worden gedaan om die spanning te verminderen. Ook is afgezien van een afzonderlijke bespreking van dergelijke rechtsgronden in verband met de WAZ. Na inwerkingtreding van die wet is over de strafrechtelijke aansprakelijkheid van de medicus in dat kader relatief weinig geschreven. Ook is de gepubliceerde jurisprudentie over dit onderwerp zeer schaars. Het verdient naar mijn mening daarom de voorkeur de huidige abortusregeling integraal te bespreken, waarbij de strafrechtrechtelijke aansprakelijkheid van de medicus centraal staat.

Een enikel woord over de terminologie. Met "abortus", "afdrijving" of "afbreking van zwangerschap" wordt hier een afbreking van de zwangerschap door een medicus bedoeld. Over de gevallen, meestal (medische) indicaties genoemd, op grond waarvan abortus niet strafbaar zou zijn, lopen de opvattingen zeer uiteen. Volgens het meest beperkte standpunt is abortus slechts toegelaten wanneer de zwangerschap het leven van de vrouw bedreigt. In de meest ruime opvatting is de wilsuiting van de vrouw toereikend. Tevens wordt hier, evenals bij de andere besproken gedragingen van de medicus, ervan uitgegaan

1 Wet wan 1 mei 1981 , houdende regelen met betrekking tot het aftokeken wan zwangerschap (Wet afbreking zwangerschap), Stb. 1981, ni. 257.

2 Zie voor andere benaderingen o.a. Ketting, 1978; De Bruijn, 1979; Roethof, 1982; Outshoorm, 1986. 
dat de gedraging van de medicus ook aan de owerige eisen voldoet, die aan een handelen lege artis worden gesteld. Een abortus lege artis wordt in medische kringen ook wel een abortus (arte) provocatus genoemd. Volgens de Nederlandse Gynaecologüsche Vereniging houdt de term "abortus arte provocatus" in:

"dat de vruchtafdrijwing wordt uitgewoerd volgens de regelen van het beroep (ars medica), hetgeen inhoudt, dat de ingreep technisch onder optimale omstandigheden en op verantwoorde wijze plaatsvindt en dat de indicatie ervoor niet strijdig is met de mening van te naam en faam goed bekende beofenaars van de verloskunde en gynaecologie - wat overigens niet behoeft te betekenen, dat er volledige overeenstemming van gevoelen bestaat tussen alle te naam en faam goed bekende beoefenaars van de verloskunde en gynaecologie". ${ }^{3}$

In de medische literatuur wordt nog onderscheiden tussen bijvoorbeeld abortus provocatus en abortus (p)arte praematurus. Bij abortus provocatus is de vrucht niet zelfstandig levensvatbaar, bij een abortus (p)arte praematurus is zij dat wel. ${ }^{4}$

De inmiddels verwallen artt. 251 bis en $295-298$ worden vanwege de leesbaarheid tot aan de bespreking van de WAZ zonder de aanduiding "oud" vermeld.

\section{De wetsgeschiedenis van de artt. $295-298 \mathrm{Sr}$}

\subsection{Inleiding}

Van den Wall Arnemann schreef in 1879 dat er weliswaar vrouwen zijn die uit andere dan geneeskundige redenen abortus willen en derden die vanwege financieel voordeel aborteren ${ }^{5}$, maar dat er ook gevallen zijn, waarin het de beroepsplicht van een arts is om te aborteren. Die verplichting achtte hij aanwezig als het leven van de wrouw door de zwangerschap wordt bedreigd. Als de medicus dan niet zou ingrijpen zouden zowell de vrouw als de vrucht overlijden. ${ }^{6}$ Door te aborteren kan de medicus tenminste het leven van de vrouw redden. Het betrof in zijn opvatting een niet strafwardige abortus. Naar zijn mening zou een medicus, die in een dergelijk geval nalaat te aborteren, zelfs voor doodslag kunnen worden vervolgd. ${ }^{7}$ Onder abortus die tot strafrechtelijke aansprakelijkheid diende te leiden, begreep Van den Wall Arnemann:

"Elke misdadige opwekking der bevalling, voordat die door den natuurlijken afloop der zwangerschap zelf volgt".

Daar hij abortus bij bedreiging van het leven van de vrouw als verplichting voor de medicus zag, hoopte hij, dat bij herziening van het ontwerp-WvSr een bepaling zou worden opgenomen die voorkomt dat de medicus an "lastige vervolgingen, die toch tot geen

3 Räppont van de Nederlandse Gynaccologische Vereniging MC 1969, p. 59.

4 Treub, TwS 1896, p. 1. Volgens Treub, TwS 1986, p. 1 en Nijhoff, NTVG 1905, I, p. 3, werd dat onderscheid door juristen veronachutand, warbij zij wermoedelijk, zolass Van dem Wall Arnentann, 1879, p. 9, ervan uitgingen, dat do aforeking van de zwangerschap met een medisch doel platsvindt.

5 Van den Wall Amemunn, 1879, p. 4.5.

6 Daar het gebruikelijk is wan het Jeven van een vrucht te spreken, is hier ervoor gzekozen on ook van het "overlijiten" van ween vacht te spieken.

7 Van der Wall Arnemanr, 1879, p.6.

8 Van den Wall Arnemann, 1879, p. 10. 
doel zouden leiden" wordt blootgesteld. "Volgens hem zou een dergelijke bepaling als volgt kunnen luiden:

"De geneesheer is gerechtigd, abortus te verwekken, daar waar hij het voor het leven

der vrouw of van het kind noodig acht". ${ }^{10}$

De zinsnede "of van het kind" was opgenomen, om te waarborgen dat de medicus straffeIoos een abortus arte praematurus, waarbij het kind levend wordt geboren, mag verrichten.

In het $\mathrm{NTvG}$, dat tot 1945 tewens het orgaan van de $\mathrm{NMG}$ was, was tussen 1880 en 1895 de strafrechtelijke aansprakelijkheid van de medicus voor abortus geen onderwerp van discussie. Maar het is de vraag of over abortus vór 1895 zoals De Bruijn schrijt, "in het algemeen milde opvattingen leefden" "I. De nuimte die bijvoorbeeld Van den Wall Arnemann in 1879 wilde toestaan, was zeer betrekkelijk: slechts in geval van levensgevaar van de vrouw of de vrucht. $^{12}$

Ook de wetgever van 1886 achtte, zoals hierna blijkt, abortus op deze indicatie geen strafbare handeling, maar hij zag ervan af daaromtrent een uitzonderingsbepaling in het WvSr op te nemen.

\subsection{De tekst wan de artikelen 295-298 Sr}

Na een uitvoerige discussie, waarbij met name werd ingegaan op de strafrechtelijke aansprakelijkheid van de medicus, kwamen de abortusbepalingen in 1886 als volgt te luiden.

Art. $295 \mathrm{Sr}$ :

De vrouw die opzettelijk de afdrijving of den dood van hare vrucht veroorzaakt of door een ander laat veroorzaken, wordt gestraft met gevangenisstraf van ten hoogste drie jaren.

Art. $296 \mathrm{Sr}$ :

Hij die opzettelijk de afdrijving of den dood der vrucht van eene vrouw zonder hare toestemming veroorzaakt, wordt gestraft met gevangenisstraf van ten hoogste twaalf jaren.

Indien het feit den dood van de vrourw ten gevolge heeft, wordi hij gestraft met gevangenisstraf van ten hoogste vijftien jaren.

Art. $297 \mathrm{Sr}:$

Hij die opzettelijk de afdrijving of den dood der vrucht wan eene vrouw met hare toestemming veroorzaakt, wordt gestraft met gewangenisstraf van ten hoogste vier jaren en zes maanden.

Indien het feit den dood van de vrouw ten gevolge heeft, wordt hij gestraft met gevangenisstraf van ten hoogste zes jaren.

Art. 298 Sr:

Indien een geneeskundige, vroedvrouw of artsenijbereider medeplichtig is aan het misdrijf in artikel 295 , of schuldig of medeplichtig aan een der misdrijven in de artikelen 296 en 297 omschreven, kunnen de in die artikelen bepaalde straffen met

9 Van den Wall Arnemann, 1879 , p. 36.

10 Varr den Wall Arnemanu, 1879, p. 9. In origineel cursiet.

11 De Bruijin, 1979, p. 40.

12 In dezelfde zin: J.W. Smidt, 1889 , p. 53 . Zie ook: H. III, onder 3. 
een derde worden verhoogd, en kan hij van de uitoefening van het beroep waarin

hij het misdrijf begaat worden ontzet.

Art. 295 Sr stelde derhalve strafbaar de vrouw die zelf de handeling bewerkstelligt of die de handeling door een ander laat begaan. Abortus zonder toestemming van de vrouw werd met een hogere straf bedreigd (art. $296 \mathrm{Sr}$ ) dan abortus met haar toestemming (art. 297 Sr).

\subsection{De totstandkoming van de artikelen $295-298 \mathrm{Sr}$}

De aanhef wan de artt. 320 en 321 O.R.O., de latere art. 296 en 297 Sr, luidde: "Hij die, behalve ingeval van levensgevaar woor de vrouw of de vruchit ${ }^{13}$, opzettellijk ..." Wanneer levensgevaar voor de vrouw of haar vrucht aanwezig was, moest vrijspraak volgen, omdat het bevrijdende, geobjectiveerde bestanddeel niet bewezen kon worden.

Over de strafbaarstelling van de wrouw in art. $295 \mathrm{Sr}$ merkte de MvT op:

"De vrucht heeft een eigen ontwikkeling, daarom is het afdrijven een misdrijf tegen de vrucht zelve en niet slechts tegen de zwangere vrouw. Wanneer men dit erkent, bestaat er geen grond, ook de vrouw die hare vrucht afdrijft, niet te straffen, terwijl men daarbij anders zoude hebben te denken aan straffelooze zelfverwonding" "* Volgens de MvT was de vrouw ten aanzien van de vrucht niet beschikkingsbevoegd. Zou daarover anders worden gedacht, dan zou het afdrijven of doden van de vrucht door de vrouw zelf, als "straffelooze zelfverwonding" worden beschouwd. ${ }^{15}$ Ook wanneer met toestemming van de vrouw werd geaborteerd of deze zelf de vrucht afdreef, bleef het misdrijf tegen de vrucht bestaan. Wel verschilde de strafbedreiging al naar gellang een derde met of zonder toestemming wan de vrouw aborteerde.

Het op deze wijze gesignaleerde belangenconflict tussen vrouw en vrucht was kennelijk voor de Raad van State in mindere mate aanwezig. Hij stelde voor de desbetreffende strafbepaling, art. 319 O.R.O., te schrappen of tenminste het strafmaximum te verlagen, waartoe hij aanvoerde:

"Het valt niet te ontkennen, dat, wat de vrouw zelve betreft, zoodanige strafbaarstelling vrij sterk in het private leven ingrijpt": 16

De regering handhaafde echter de strafbaarstelling onder verwijzing naar de $\mathrm{MvT}$, daaraan toevoegende dat er geen reden bestaat de vrouw straffeloos te verklaren.

Het advies wan de Raad van State, die opmerkte

"Het geval overigens, dat in de verloskundige praktijk het behoud der moeder somtijds den dood der vrucht noodzakeljjk maakt, behoort in het ontwerp alsnog te worden voorzien",

wolgde de regering wel op door de artt. 320 en 321 O.R.O. aan te vullen met de zinsnede: "behalve in geval van levensgevaar voor de vrouw of de vrucht". Het aldus geformuleerde bevrijdend bestanddeel was geobjectiveerd, ook al zouden de woorden in de MvT "zonder dat het doel er op gerigt was, om een voor de vrouw of de vrucht werkelijk dreigend

13 Cursief, J.W.

14 Smidi, II, 1891, p. 467.

15 Smidt, II, 1891, p. 467 .

16 Smidt, II, 1891 , p. 468. 
levensgevaar af te wenden" ${ }^{\text {"17 }}$, begrepen kunnen worden alsof dit bestanddeel onder het subjectieve schuldverband viel. De formulering van het voorgestelde bestanddeel wijst hier de weg naar de juiste interpretatie van de toelichting. Dat levert steun op voor het bij de bespreking van de wetsgeschiedenis van mishandeling verdedigde standpunt, dat de aldaar door de regering gebezigde woorden over doel en middel los van de inzichten van de handelende persoon en daarmee geobjectiveerd moeten worden begrepen. ${ }^{18}$

De Commissie van Rapporteurs vroeg zich af of in art. 319 O.R O. wel voldoende duidelijk tot uitdrukking was gebracht, dat de af te drijven vrucht leefde, daar het niet de bedoeling kon zijn het afdrijven van een dode vrucht onder de abortusbepalingen te laten vallen. ${ }^{19}$ Volgens de regering bleek dat uit de bepalingen zelf, waar immers werd gesproken van "afdrijving of dood .... veroorzaken". 20

Een tweede opmerking van de Commissie betrof het bevrijdend bestanddeel "behalve in geval wan levensgevaar voor de vrouw of de vrucht". De Commissie wilde dit bestanddeel cok in art. 319 O.R.O, dat de vrouw strafbarar stelde, opgenomen zien, om duidelijk te laten uitkomen, dat in de genoemde gevallen ook de vrourw niet strafbaar was.

De regering was het met de strekking van de laatste opmerking eens, maar koos voor een andere oplossing. $\mathrm{Zij}$ schrapte het bevrijdend bestanddeel in de artt. 320 en 321 O.R.O. Daartoe gaf zij als redenen op, dat de reserve "volstrekt overbodig" is en dat het opnemen van de reserve tot vragen en moeilijkheden zou leiden, die "nauwelijks te overzien" waren.

Modderman vond het bevrijdend bestanddeel overbodig, want:

"Is het ooit bij iemand opgekomen om art. 309 Code Pénal van toepassing te achten op den chirurgijn die eene operatie verricht of op den Israëlitischen besnijder ${ }^{21}$ ? Als een letterknecht de toepasselijkheid beweerd had op grond dat in dat artikel, geheel in 't algemeen, van 'faire des blessures' ${ }^{22}$ sprake is, dan zou de jurist, gedachtig aan het scire leges, non est verba tenere sed vim ac potestatem ${ }^{23}$ zelfs geen antwoord hebben noodig gekeurd". ${ }^{24}$

Hij vervolgde zijn betoog met:

"In 't algemeen is de genees-, heel- en verloskundige volkomen gedekt, zoo dikwerf hij handelt naar de regelen zijner kunst" ${ }^{\prime \prime}{ }^{25}$

De woorden "(i)n 't algemeen" kunnen zowel betekenen dat de medicus ten aanzien van verschillende handelingen gedekt is, wanneer hij lege artis handelt, als dat hij weliswaar in het algemeen gedekt is, maar bijzondere omstandigheden tot een uitzondering kunnen leiden. In de aan deze zinsnede voorafgaande passage sprak de regering over handelingen die - ondanks dat zij letterlijk aan de delictsomschrijvingen van mishandeling voldoen - niet als mishandeling zijn aan te merken. Maar dat gebeurde wel bij de bespreking van de strafrechtelijke aansprakelijkheid van de medicus voor abortus. Daaruit kan afgelejd

17 Sintidt, II, 1891, p. 467.

18 Zive H. II, onder 2.2 .

19 In dat gewal zou er wel sprake kumnen zijn van mishandelimg van de wrouw. Dawarbij kan nog onderscheiden worden, al naar gelang de wrouw toestemming tot de ingreep heeft gegeven.

20 Smidt, II, 1891, p. $468-469$.

$21 \mathrm{~KB} 20$ junit 1820, Stb. 1821 , no. 54 ; gewijzigd bỉ KB 28 maart 1868, Stb. 38.

22. Vrij vertaald: "letsel weroorzaken".

23 Vrij vertaald: 'wees geen Jetterknecht'.

24 Dit citait werd door de cassatieadwocal in het Euthanasie If-rarrest, HR 21 oft: 1986, NJ 1987, 607 nu.nt. GEM, antagehalald. Zie hiervoor iv.m. mishandeling: H. II, onder 3.5.5.

25 Simidi, II, 1891, p. 469. 
worden dat de woorden "(i)n "t algemeen" waarschijnlijk doelden op de strafrechtelijke aansprakelijkheid ten aanzien van verschillende delictsomschrijvingen en verder, dat de regering de niet-strafbaarheid noch ten aanzien van mishandeling, noch ten aanzien van abortus zocht in de betreffende delictsomschrifvingen, maar dat zij bepaalde gedragingen die aan de delictsomschrijvingen voldeden; desondanks niet strafwaardig achtte.

De medicus werd derhalve niet strafrechtelijk aansprakelijk geacht voor zover hij handelt naar "de regelen zijner kunst". Tot die regelen rekende de regering kennelijk niet de toestemming van de patient, want zij besteedde eerst aandacht aan de toestemming en vervolgens aan de regelen der kunst. Volgens de regering was toestemming van de vrouw niet altijd nodig, noch altijd voldoende. Toestemming zou bijwoorbeeld niet nodig zijn, als de patiênt bewusteloos is. Dat zij niet altijd voldoende is, bleek volgens de regering uit art $206 \mathrm{Sr}$, waarin het opzettelijk op verzoek ongeschikt maken voor de "krijgsdienst" strafbaar is gesteld. De chinurg die iemand "op zijn verzoek" een been afzet om te voorkomen dat degene in het leger moet, zou ondanks diens "toestemming", strafbaar zijn. ${ }^{26}$

Over de regelen der kunst merkte de regering in het algemeen op, dat voor beantwoording van de vraag of naar de regelen der kunst is gehandeld, uitgegaan dient te worden van het tijdstip waarop gehandeld wordt: Bovendien moet voor de beoordeling van het handelen een algemene maatstaf gehanteerd worden, volgens welke een medicus zo dient te handelen als de gemiddelde vakgenoot zou handelen.

Wanneer achteraf blijkt dat een operatie "niet noodig of wenschelijk" is geweest, dan is de medicus voldoende gedekt, als hij op het moment van het ingrijpen de handeling nodig of wenselijk kon achten. Of dat het geval was, kunnen zijn vakgenoten het beste beoordelen.

In de opvatting van de regering bestond tussen medici en juristen geen verschil in de waardering van de handelingen van de medicus. Wamneer tussen vrouw en vrucht een belangenconflict bestaat, weet de medicus wat hil moet doen.

"Uit niets hoegenaamd is gebleken dat hier te lande de wetgever met zijne door hare algemeenheid altijd gebrekkige formules moet tusschen beide treden, hetzij om de medici te beschermen tegen de juristen, hetzij om de maatschappij te beschermen tegen de medici ${ }^{\text {th }}{ }^{27}$

Voor het opwekken van vroegtijdige baring met een medisch doel was het bevrijdend bestanddeel reeds overbodig, omdat deze handeling, volgens de regering, niet onder het begrip "afdrijving" viel. De regering wees erop, dat de opwekking van vroegtijdige baring met medisch doel sinds tenminste 25 jaar een gebruikelijke operatie was ${ }^{28}$ en dat nog nooit was beweerd dat de medicus daarmee in strijd met zijn eed had gehandeld, hoewell tot 1879 in het eedsformulier de woorden "

26 Daar art. $206 \mathrm{Sr}$ van "verzoek" spreekt, beschouw de de regering kennelijk "toestemming" als de algemene term, waaronder ook verzok walt.

27 Snidt, I, 1891 , p. 469.

28 Vgl. Nijhoff, NTrG 1905, 1, p. 130-132 en De Jager, NTvG 1905, 1, p. 1524

29 Virij vertakld: 'het opwekken watn abortus is verboden'.

30 Simidi, II, 1891, p. $469-470$. 
In de MvT werd het als overbodig aangemerkt om in de delictsomschrijvingen naast "afdrijving" nog te vermelden "of de ontijdige geboorte der vruch", ondat de ontijdige geboorte onder "afdrijving" valt."

Vanwege deze uitlating van algemene strekking werd in de literatuur soms elke kunstmatige ontijdige geboorte als afdrijving beschoulwd. ${ }^{32}$ Daarbij werd echter onvoldoende aandacht geschonken aan het regeringsantwoord, volgens welk een ontijdige geboonte met medisch doel niet onder "afdrijving" viel Het regeringsantwoord dient als aanwulling op de MvT te worden beschouwd. ${ }^{33}$

Hieruit blijkt opnieuw dat volgens de regering een handeling die aan een delictsomschrijving beantwoordt, daarmede niet zondermeer strafwaardig behoeft te zijn.

Niet alleen achtte de regering thet door de commissie voorgestelde bevrijdend bestanddee overbodig, zij voorzag ook "tallooze" problemen indien het gehandhaafd bleef. Daarbij ging zij op drie punten nader in.

Volgens de artt. 320 en 321 O.R.O. was alleen afdrijving bij levensgevar voor vrouw en vrucht van de strafbaarheid uitgezonderd. Wanneer een medicus aan het begin van een zwangerschap met zekerheid voorziet dat de moeder geen levend kind ter wereld kan brengen en de vrucht derhalve "geheel noodeloos langzamerhand zou wegkwijnen" en wanneer hij dan tot afdrijving overgaat, dan zou hij strafbaar zijn, omdat op dat moment nog geen "llevensgevaar" bestaat. Dat zou niet te verdedigen zijn en daarom is hiervoor geen bevrijdend bestanddeel nodig ${ }^{34}$ De regering concludeerde:

"Wat onder dergelijke omstandigheden te doen is, kan de wetgever niet uitmaken;

hij late den medicus de vrije beoordeling". ${ }^{35}$

In de opvatting van de regering was abortus bij levensgevaar voor de vrouw of de vrucht niet strafbaar. Evenmin achtte zij abortus vanwege een te verwachten overlijden van de vrucht strafbaar. Voor de verwachting was kennelijk voldoende, dat de medicus op het moment van het ingrijpen kon oordelen, dat de vrucht zou komen te overlijden.

31 Smidt, II, 1891, p. 467.

32 Zne b.v. Treub en Tak, 1908, p. 115-116; Simons, II, 1923, p. 15; Van Hejinsbergen/Wan Balen Blanken, 1925, p. 34-45; HR 24 mei 1897, W 6978, Anders; Pompe, 1959, p. 112-113, Van Dam van Issell, 1902, P. 86-89: de wetgever heeft slechts het doden van een vrucht strafbaar willen stellen; , W. Smidt, 1889, P. 52: bij abortus parte praematuras ontbreekt bij de medicus opzel op de dood van de vracht en diarom gaat deze vrijuil.

In HR 12 april 1898, w 7113 , overwoog de Hoge Raad dat onder afdrijving in de abortusbupalingen ook begrepen was het afbreken wan een zwangerschap als de vrucht niet werd gedood. Uit deze uitsprak mag niet worden afgeleid dat - volgens de Hoge Raad - ook de aforijving met een mediscli doel onder de delictsonschrijving viel. De A-G had in zijn conchusie erop gewezen, dat in deze zaak met een misdadig doel wetrd gehandeld. Vgl. Pijls, Algemeen.Politieblad 1968, p. 254. Remmelink, NLR, aant. 2 op art. 295 (suppl. 14), noemt drie mogelijkheden die een ontijdige geboorte niet strafbaar kunnen doen zijn: alls de nuedicus uit moodzakelij|kheid handelt, als hij in overnacht handelt of omdat een "legtieme acte medical" het feit rechwaardigt.

$33 \mathrm{Vgl}$. Van Dam van Isselt, 1902, p. 89.

34 Hiertegen bracht Van Dam van Isselt, 1902, p. 98 in: "Welnu, als er geen levensgevaar is, dam mag de medicus ook niet aftrijven; begint de vrouw te kwijinen dan is er levensgevaar en staat het dus den nedicus wrij af the drijuen".

35 Smidt, II, 1891, p. 470. 
Voor de tweede reden verwees de regering naar de handelingen omtrent respectievelijk kinderdoodslag en kindermoord, artt. 290 en 291 Sr. Daarin zijn opgenomen de woorden "bij de geboorte". Zodra de geboorte (de baring) ${ }^{36}$ is aangevangen, is er geen sprake meer van een wrucht, maar wan een kind. Op het doden van een kind tijdens de geboorte zijn daarom niet de abortusbepalingen, maar de bepalingen omtrent doodslag en moord; de artt. 287 en $289 \mathrm{Sr}$, van toepassing. Wanneer nu in de abortusbepalingen het bevrijdend bestanddeel zou worden opgenomen, maar niet in de bepalingen omitrent doodslag en moord, dan zou de wetgever hebben beslist dat de verloskundige "tijdens de baring" niet het recht heeft om, "tot behoud van de moeder, het kind op te offeren". Maar ook dan dient hij, volgens de regering, straffeloos te blijven.

Handhaving van het bevijjdend bestanddeel zou bovendien tot problemen leiden voor het handelen van de medicus in verband met de delictsomschrijving van de zware mishandeling, art. $302 \mathrm{Sr}$. Wanneer bij abortus het bevrijdend bestanddeel onderdeel van de delictsomschrij ving is, terwijl de delictsomschrijving van zware mishandeling geen bevrijdend bestanddeel bevat, dan zou "voortaan het amputeeren bijv, van een been niet meer geoorloofd zijn. Het gemis van een been is ongetwijfeld zwaar lichamelijk letsel; ...; ergo".

Gezien deze redenen sprak de regering zich uit voor het achterwege laten van het bevrifidend bestanddeel.

"Beter echter schijnt het, haar (de reserve, J.W) overal weg te laten in 't vertrouwen dat de wet slechts zal worden geïnterpreteerd door rechtsgeleerden die, ook zonder wetsvoorschrift, het beginsel erkennen: 'niet strafbaar is de geneeskundige, handelende naar de erkende regelen zijner kunst"." ${ }^{37}$

Zonder nadere opmerkingen vanuit de Kamers werden vervolgens de abortusbepalingen aangenomen.

\subsection{Conclusie}

De regering achtte de medicus die volgens de regelen zijner kunst handelt in het algemeen niet strafbaar. Of naar de regelen der kunst is gehandeld, dienen de vakgenoten te beoordelen. De regering noemde, bij wijze van voorbeeld, enkele gedragingen van de medicus, die zij niet strafwaardig en daarmee niet strafbaar vond ${ }^{38}$, hoewel de ogenschijnlijk toepasselijke delictsomschrijvingen niet in een bevrijdend bestanddeel voorzagen en de regering voor de straffeloosheid evenmin naar een algemene wettelijke strafuitsluitingsgrond verwees.

Terwijl in het algemeen de kunstmatig opgewekte vroeggeboorte van een levensvatbare vnicht onder "afdrijving" valt, geldt dat niet als de ingreep met een medisch doel plaatsvindt.

36. Terwijl de artt. 290 en 291 Sr spreken van "geboorte", bezigde de regering het woord "baring". Vermoedelijk werden deze woorden als synomiemen opgevat. Volgens Treuben Tak, 1908, p, 60, woird in de verloskunde aan het begrip "gebootte" een beperktere inhoud toegekend dan aan "lbaring" Op p. 63 noemen zijde stelling, dat de wetgever in de artt. 290 en 291 Sr eigenlijk de "baring" bedoelde "rilet gewaagd".

37 Smidt, II; 1891 , p. 470.

38 Vgl. Mulder, in: Recht en Praktijk, 1979, p. 89: Met strafbaar wend bedoeld - zie Smijd, I, 1891, p. 64 -: strafbaar in de ogen van de wetgever. "Strafbaar" dient men te lezen als "strafwardig". 
De medicus mag bij een (toekomstige) levensbedreiging voor de vrouw of de vrucht (anticiperend) aborteren. De regering achtte evenmin strafbaar het door een medicus doden van een kind tijdens de geboorte ter redding van het leven van de moeder. Tevens bevestigde de regering bij de behandeling van de abortusbepalingen dat dezelfde reden die de straffeloosheid voor (zware) mishandeling meebrengt ook geldt ten aanzien van medische abortus.

De conclusie uit de wetsgeschiedenis van de antt. 254-oud en 300 e.v. Sr was dat de straffeloosheid van het handelen van de medicus zijn grondslag in het ongeschreven recht heeft. De wetsgeschiedenis van de abortusbepalingen bevestigt en versterkt dite conclusie.

Uit de wetsgeschiedenis van de gencemde bepalingen blikt, dat de regering niet alleen het medisch handelen van de respectieve delictsomschrijvingen uitgesloten achtte, maar evenzeer het tuchtrecht van opvoeders, de wetenschappelijke vivisectie en de besnijdenis. Hiermee werden de meest evidente handelingen genoemd, vermoedelijk zonder dat de regering deze opsomming als limitatief bedoelde.

Kennelijk was, volgens de regering wan 1881, voor de strafbaarheid van een gedraging nodig, dat deze aan een delictsomschrijving beantwoordt en tevens dat zij in strijd is met het (ongeschreven) recht.

De regering gaf er de voorkeur aan de straffeloosheid van deze gedragingen niet via de wet te regelen, daar een dergelijke regeling in haar ogen onvolkomen zou zijn en derhalve slechts tot problemen zou leiden.

\section{Opvattingen van juristen over de strafbaarheid van abortus}

Het standpunt dat abortus door een medicus niet strafbaar was, ontmoette kritick. Van Dam van Isselt vertolkte het gevoelen van vele juristen in de eerste jaren na de invoering van het WvSr toen hij de nadrik leggend op de tekst van de wet opmerkte:

"Ons Wetboek van Strafrecht stelt dit feit (abortus, J/W) zonder eenige uitzondering strafbaar; het moge eene grove fout zijn; het recht in ons Wetboek op dit punt neergelegd, moge in strijd zijn met ons rechtsgevoel, de rechter, die het geval, waarop we gedurig het $0 \circ g$ hebben, eenmaal te beoordeelen zal hebben, heeft slechts onze wet toe te passen en zich niet te verdiepen in hare al of niet juistheid" "39

Volgens J.W. Smidt viel "de medicus, die abortus naar de voorschriften zijner wetenschap provoceert, onder de artikelen over de afdrijving" stelsel en het verband van de wet schijnen geen andere uitleg toe te laten" dan dat ledereen en dus ook de medicus strafbaar is, zelfs was dat niet de bedoeling van de wetgever ${ }^{41}$. Wel werd ook door deze juristen erkend, dat abortus soms straffeloos behoorde te zijn; maar daarin diende een algemene wettelijke rechtvaardigingsgrond voor de medicus te voorzien. Daartoe stelde Smidt voor om tussen art. $42 \mathrm{Sr}$ en art. $43 \mathrm{Sr}$ een nieuw artikel te plaatsen, op grond waarvan

"de bevoegde geneeskundige, die overeenkomstig de erkende regelen zijner weten-

schap middelen aanwendt of eene kunstbewerking verricht"

in het algemeen niet strafbaar zou zijn. ${ }^{42}$

39 Van Dam van Isselt, 1902, p. 106-107, die dagtoe naar art 11 Wet AB verwijst.

40 J.W. Snuidt, 1889 , p. 58-59.

$41 \mathrm{~J} . W_{m}$ Smidit, 1889 , p. 46.

$42 \mathrm{~J} . \mathrm{W}_{\mathrm{m}}$ Smidt, 1889, p. 70. 


\section{Opvattingen van medici over de strafwaardigheid van abortus}

Een enigszins ander geluid was onder de medici te horen. In 1895 stelde de Afdeling Amsterdam aan het Hoofdbestiur van de NMG woor ervoor zorg te dragen dat abortus onder het WvSr nitet ongestraft zou blijven. ${ }^{43}$ Daartoe gaf de Afdeling drie redenen. De heersende toestand zou niet gunstig zijn voor "de warcligheid van onzen stand", abortus zou "hand over hand" toenemen en de medicus kreeg met patienten te maken. die tengevolge van een opgewekte abortus ziek waren geworden. In de Algemene Vergadering werd het voorstel verworpen, waartoe twee in elkaars werlengde liggende redenen werden gegeven: het betrof een zuiver juridische vraag, die bovendien niet voldoende medisch was voorbereid. ${ }^{44}$

De initiator van het voorstel, de gynaecoloog Nijhoff ${ }^{45}$, was van mening dat abortus uitsluitend in het belang van het leven van de vrouw mocht worden toegestaan. In andere gevallen behoorde abortus een misdrijf te zijn.

"Als het belang der maatschappelijke zedelijkheid beperking der vrijheid van handelen van den medicus elscht, ben ik worr mij gaarne bereid een deel mijner vrijhelld daaraan op te offeren, al walt het misschien hard." ${ }^{46}$

Daarentegen stelde de gynaecoloog Treub voor de abortusbepalingen te schrappen, hoewel zijn uilgangspunt, dat abortus veelvuldig plaatsvond zonder dat het tot een vervolging kwam, met dat van de Afdeling Amsterdam overeenstemde. Tevens merkte hij op dat de ingreep ook door medici werd verricht. In bijna elke stad

"(zijn) een of meer medici en yroedvrouwen (...), van wie bekend is dat zij abortus opwekken zonder anderen grond dan het verlangen der vrouw": 47

Vanwege de abortusbepalingen verkeende de medicus in rechtsonzekerheid, terwijl volgens Treub de abortus geïndiceerd kon zijn. Daarbij onderscheidde hij tussen een absolute en een relatieve indicatie. Abortus was absoluut geïndiceerd, wanneer de ingreep diende ter redding van het leven van de vrouw. Bij een relatieve indicatie worden de belangen van de vrouw tegen het doden van de vrucht afgewogen. Juist bij een relatieve indicatie worden hoge eisen aan de medische kennis en kunst gesteld ${ }^{43}$, terwijl vooral dan in het geheim en daarmee ten nadele van de volksgezondheid werd geaborteerd. ${ }^{49}$ Voor zover hem bekend, was het in Nederland welliswaar nog niet tot een veroordeling wegens afdrijving gekomen, "terwijl de bedoelde artikelen ongetwijfeld dikwijls worden overtreden" ${ }^{\text {"50, }}$, maar in het belang van de medicus en de wolksgezondheid was het nodig; dat de wetgever zijn wil duidelijk kenbaar makt.

"Wij moeten zekerheid hebben en die missen wij, zolang de wet aangaande dit punt geene uitdrukkelijke bepaling bevat" ${ }^{\text {ts }}$

43. NTVG 1895, I, pin 892 .

44. NVG 1895, I, p. 126.

45 Nifinoff, NTwG 1895, I, p. 1165.

46 Nifhof, NTWG $1895, I_{4}$ p. 1123.

47 Treub, TvS 1896, p. 24. Vgll. Pjnkhof, NTVG 1898, I, p. 720. In Trev'ben Tak, 1908, p. 100, wordt terughoudender opgenwerkt, dat "gelukkig sporadisch enkele geneesheeren van deze praktijken niet alkeerig schijnen".

48 Treub, TwS 1896, p. 3.

49 Treub, TVS 1896, p. 23-24. In dezelfde zin: Rutgers, NTVG 1895, $I_{1}$ p. 1201-1203.

50 Trenb, TwS 1896, p. 21-22,

51 Treub, TwS 1896, p, 9. 
De zekerheid zag hij niet in de toepassing van de ongeschreven rechtsregel. "Nietstrafbaar is de medicus, handelende naar de erkende regelen zijner kunst", immers "dan komt alles neer op de nergens in de wet geformuleerde vrijheid van handelen van den medicus, overeenkomstig de regelen zijner kunst" ${ }^{15}$ Ook de mededeling, dat "vele juristen beweren" dat abortus door een medicus als een "geval van noodtoestand" wordt beschouwd, kon hem niet geruststellen.

"Maar ik vraag ook nu, wie mij waarborgt, dat alle Nederlandsche rechters met

die wijde opvatting van art. 40 zullen instemmen?" ${ }^{* 3}$

Daarom stelde hij voor de artikelen 296,297 en 298 Sr te schrappen ${ }^{54}$ De voordelen daarvan zouden zijn, dat de bestaande bepalingen niet voortdurend werden overtreden zonder dat het tot een vervolging kwam en voorts dat abortus als gewone operatie en daarmee in overeenstemming met de regelen der kunst behandeld zou kunnen worden, hetgeen in het belang van de volksgezondheid zou zijn. ${ }^{55}$

\section{Straffeloosheid vanwege overmacht?}

Terwijl de overmachtsbepaling art. $40 \mathrm{Sr}$ vanuit de huidige invulling die aan de overmachtsvariant noodtoestand wordt gegeven betere mogelijkheden biedt om de strafbaarheid vanwege de toenmalige abortusbepalingen voor abortus door een medicus uit te sluiten, was dat in de eerste jaren na invoering van het WvSr minder vanzelfsprekend, zodat Treub terecht bedenkingen had tegen de toepassing van de "wijde opvatting van art. 40 ".

In de eerste plaats was omstreden of onder de overmachtsbepaling van art. $40 \mathrm{Sr}$ ook moodtoestand viel. Ten tweede stond ook bij acceptatie van overmacht in de zin van noodtoestand nog niet vast, of de nood van een vreemde handelen in strijd met de wet kan rechtvaardigen. In die tijd werd voor overmacht vaak geëist, dat een acute, onontkoombare drang tot handellen bestond. De nood van een vreemde kon een zodanige drang niet opleveren. Zo was Van Dam van Isselt van mening dat de medicus, die ter redding van het leven van de moeder aborteert, niet door overmacht daartoe is gedrongen.

"De medicus had even goed niet kunnen handelen. ... Voor ons recht, met ons wetboek in handen mag men derhalve niet aannemen, dat de medicus in het gestelde geval zich kan beroepen op noodtoestand". 56

Wordt voor noodtoestand geëist, dat het belang dat de dader wil beschemen van meer gewicht dient te zijn dan het bellang dat door het plegen van het feit wordt aangetast ${ }^{57}$, dan is het de vraiag, of noodtoestand ter rechtvaardiging van abortus kan dienen. ${ }^{58}$ Hierbij speelt de betekenis die aan de beschermwaardigheid van de vrucht wordt toegekend een doorslaggevende rol.

52 Treub, TrS 1896, p. 5 en 9.

53 Treub, TvS 1896, p. 9. Zie ook Nijhof, NTvG 1905 , Il, p. 1691 , die als bezwaar tegen ant 40 St noemt, dat medici dan "totaal afhankelijk van de opvatting van den rechter" zijn.

54 Treub, Tv' 1896, p. 9 en 23-24.

55 Treub, TwS 1896, p. 23-24. Vgl. Van Drooge, TvS 1900, p. 5 e.w.

56 Van Dam van Isselt, 1902, p. 101. In dezelfde zin: Simons, NTVG 1905, I, p. 1313-1314; Van Prang, 1885, p. 63.

57 Zie b.w. Van Bemmelem/Van Veetn, 1, 1989, p. 184.

$58 \mathrm{Vgl}$. Bromklorst, 1952 , p. 112-113. 
Wamneer noodtoestand aangenomen word, als van de dader redelijkerwijs niet gevergd kan worden anders te handelen dan hij doet en zijn keuze onder de gegeven omstandigheden begrijpelijk en aanvaardbaar is, dan kan noodtoestand tot straffelloosheid van abortus. door de medicus leiden. ${ }^{59}$

Van der Hoeven omschreef in 1905 noodtoestand, die hij 'telatieve overmacht' noemde, als:

"de kracht, macht, drang, die ons niet dadelijk, rechtstreeks, niet volstrekt noodzaakt, maar warvoor wij desniettemin bezwijken; de mogelijkheid om aan die kracht, dat geweld, die bedreiging weerstand te bieden, bestaat wel, maar van ons, gewone menschen, geen helden, geen engelen, is het weerstand bieden redelijkerwijze niet te vorderen": 60

Noodkostand kon volgens hem een uitkomst bieden bij allerlef conflicten:

"conflicten van plichten ${ }_{*}$ conflicten van belangen, conflicten van rechten, conflicten van plicht en recht enz." ${ }^{61}$

Op deze wijze kon art. $40 \mathrm{Sr}$ worden beschouwd als:

"het schild, dat de verloskundigen beschermt, wanneer zij uit plichtsbesef, in het belang van het leven of de gezondheid der zwangere vrouw handelingen plegen, die in de artikelen 296-299 Swb. als misdrijven zijn omschreven". ${ }^{62}$

Maar, zoals Van Hamel stellde, zelfs dan blijft onzeker "of de vrucht aan de moeder of de moeder aan de vrucht opgeofferd moet worden". ${ }^{63}$

\section{De abortusbepalingen in de novelle-Cort wan der Linden, 1900}

Vanaf 1900 ging de wetgever zich opnieuw bezig houden met de wettelijke regeling van abortus. Terwijl de regering in 1881 zo nadrukkelijk had verklaard dat een bevrijdend bestanddeel overbodig was en slechts tot problemen zou leiden, werd in de novelle-Cort van der Linden voorgesteld daarin wel te voorzien.

In de abortusbepalingen van de novelle-Cort van der Linden was geen materieel criterium opgenomen. Het bevrijdend bestanddeel koppelde de straffeloosheid aan de hoedanigheid van de handelende persoon. Voor straffelloosheid was nodig een handelen met genees-, heel- of verloskundige bevoegdheid. Tevens diende de handelling noodzakelijk te zijn. De medicus die opzettelijk met overschrijding van zijn bevoegdheid aborteert, verricht een niet noodzakelijke handeling. Dararvan was volgens de MvT van de novelle-Cort van der Linden sprake als de handeling niet nodig was voor "het leven of de gezondheid"

$59 \mathrm{Vgl}$. Bronkhorst, 1952 , p. 113-114 en p. 290 .

60 Van der Hoeven, Vrijheid wan bes]issing vow den Strafrechter volgens de Nederlandsche Wetgewing, rede op 10 april 1905, inn de vergadering van de Koninklijke Akademie van Wetenschuppen, afdeeling: taal en letterkunde. In NTVO 1905, I, p. 1598-1601 is het voor medici belangrijke gedeelte van deze rede weergegeven. Zie m. p. p. 1599 .

61 Van der Hoeven, NTwG 1905, I, p. 1599-1600.

62 Van der Hoeven, NTVG 1905, 1, p. 1600. In dezelfde zim: Noyon, 1904, aant, 6 op art 40 , Zie ook. Noyon-Langerneyjer, 1954 , aant. 4 en 16 op art. 40 en aant. 2 op art. 295 .

63 Van Hamel, 1927, p. 256. Vgl. Simons, NTvG 1905 , 1, p. 1313; Van Bemmelen/Van Hattum, 1,1953 , p. 371; Hazew whel-Suringa, 1964, p. 198. Van Hamel, 1927, p. 242-243, vatte overmacht als rechtvaardigingsgrond op in de zin die Van der Hoeven an de relatieve overmacht toekende. Vgl. Bronkhorst, 1952, p. 290. Maar vinwege de genoemde onzekerheid kon deze strafuitslutingsgond amn medici geen rechtszekerbeid verschafien. 
van de vrouw. De MvT bezigde daarmee een ruimer materieel criterium dan, na het advies van de RvS, door de regering in 1881 werd gehanteerd, die slechts van levensgevaar had gesproken.

Volgens het voorstel kwamen de artt. 295 tot 297 als volgt te luiden ${ }^{64}$ :

Art. 295:

"De wrouw die opzettelijk den dood van hare vrucht of de afdrijving van hare vrucht hetzij deze nog leeft, hetzij zij reeds dood is, veroorzaakt of wederrechtelijk door een ander laat veroorzaken, wordt gestraft met ..."

Art. 296:

"Hij die zonder genees", heel- of verloskundige bevoegdheid of met overschrijding van die bevoegdheid den dood der vrucht van eene vrouw of de afdrijving van hare vrucht, hetzij deze nog leeft, hetzij deze reeds dood is, zonder hare toestemming veroorzaakt, wordt gestraft met ..."

Voor art. 297 werden dezelfde wijzigingen als voor art. 296 voorgesteld.

Vanwege het ontbreken van een materieel criterium bleef het twistpunt bestaan, wanneer de medicus binnen zijn bevoegdheid en daarmee straffeloos bleef. ${ }^{65}$ Volgens Van Dam van Isselt waren "velen" van mening, dat de medicus zijn bevoegdheid overschrijdt, wanneer hij ter redding van het leven van de vrouw aborteert. ${ }^{66}$ In de door hem voorgestelde bepaling was wel een materieel criterium, namelijk levensgevaar voor de vrouw, verwerkt:

"Niet strafbaar is de geneeskundige, die vollgens de erkende regelen der geneeskunde opzettelijk den dood der vrucht van eene vrouw of de afdrijving van hare vrucht, hetzij deze nog leeft, hetzij deze reeds dood is, veroorzaakt, indien hij dit op redelijken grond voor het leven der vrouw noodzakelijk acht ${ }^{167}$.

Evena]s in het artikel van "Treub, werd in de novelle-Cort van der Linden tot herziening van thet WvSr, ten aanzien van abortus een dubbel doel vervolgd. ${ }^{68}$ Ten eerste moest abortus criminalis daadwerkelijk aangepakt kunmen worden. De bestaande bepalingen sorteerden vanwege de jurisprudentiële invulling, die daaraan gegeven werd, onvoldoende effect. De rechtspraak eiste, in overeenstemming met de wetsgeschiedenis ${ }^{69}$, het bewijs dat de afdrijving een levende vrucht betrof ${ }^{70}$ en dat het opzet op de afdrijving van een levende vrucht gericht moest zijn. ${ }^{71}$ Maar dat bewijs was bijna nooit te leveren, zodat de bepalingen nauwelijks werden toegepast.

Daarom werd in de novelle voorgesteld de woorden "de afdrijuing of den dood van hare vrucht veroorzaakt" te vervangen door "den dood van hare vrucht (resp. den dood der vrucht van eene vrouw) of de afdrijving van hare wucht, hetzij deze nog leeft, hetzij deze reeds dood is 't".

64 Cursief, $\mathrm{JW}$.

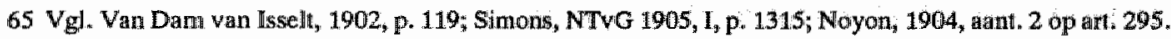

66 Van Dam van Isselt, 1902 , p. 119.

67 Van Dam van Isselt, 1902 , p. 123. In origineel cursief:

68 Handelingen der Staten-General, Bijli: 1900-1901, 1005.

69 Vgl Treub en Tak, 1908, p. 110.

70 Zie o.: HR 1 nov. 1897, W 7038 en HR 24 mei 1897, W 6978.

71 Zie 0.a. HR 11 matart 1907, W 8510 en HR 29 jull 1907, W 8580 . Uit de gedraging i. "m. het bewijs dat de vrucht letefde, kon worden afgelejd dat het opzet ook op hat leven was gericht. 
Minister Cort wan der Linden tilde er daarbij niet zwaar aan dat een afdrijuing vam een dode vrucht geen levensdelict is.

"Het formele bezwaar dat het misdrijf in zijn nieuwen vorm wellicht niet te rangschikken is onder de misdrijven tegen het leven gericht, heeft ... bij ondergeteekende niet overwogen." 72 .

In de tweede plaats wilde de Minister de straffeloosheid van abortus door een medicus wettelijk waarborgen door in de abortusbepalingen vast te leggen, dat niet strafbaar was de medicus die volgens de regelen zijner kunst aborteent.

De reden tot wijziging met het oog op abortus door de medicus strekte volgens de MvT

"t... ter waarborging van de wrije, onbelemmerde uitoefening van de verloskunde. De operatie, bestaande in vruchtafdrijving; heeft geheel het karakter van de in de bestaande artikelen omschreven strafbare feiten. Vele medici zullen daarom, uit vrees voor eene strafvervolging op grond van een dezer artikelen, nalaten die kunstbewerking toe te passen, ook daar waar zij noodig mocht zijn woor het leven of de gezondheid der vrouw.

De voorgestelde bijvoeging beoogt natuurlijk niet een vrijbrief te geven ook voor die gevallen, waar de handeling niet noodzakelijk mag worden geacht. Dit volgt uit de woorden 'opzettelijk met overschrijding van die bevoegdheid'.

In verband met deze wijziging is in art. 295 het woord 'wederrechtelijk' ingevoegd, dat door de beide volgende artikelen nader wordt bepaald, ...". 73

Het voorstel-Cort van der Linden werd in 1901 ingetrokken tengevolge van een wisseling van het kabinet ${ }^{74}$ en in 1904 opgevolgd door het hierna te bespreken voorstel-Loeff ${ }^{75}$, waarin opnieuw een poging werd gedaan om de abortusbepalingen te wijzigen.

\section{De abortusbepalingen in de novelle-Loeff, 1904}

De novelle-Loeff ${ }^{76}$ handhaafde de doelstelling van het voorstel-Cort van der Linden, om abortus strafrechtelijk effectief te kunnen aanpakken. Wel ontbrak de tweede doelstelling van de novelle-Cort van der Linden namelijk een rechtswarborg te verschaffen voor abortus op medische indicatie.

Voor de strafrechtelijke bestrijding van abortus werd art. 295 novelle-Cort van der Linden overgenomen. Dat bracht mee, dat zowel het afdrijven van een levende als van een dode vrucht onder de delictsomschrijving zou vallen. ${ }^{77}$ Als de vrouw abortus laat veroorzaken, dan was zij strafbaar, voor zover de ander wederrechtelijk heeft gehandeld. Maar doordat, anders dan in de novelle-Cort van der Linden in de artt. 296 en 297 van

72 Handelingen der Staten-Generaal, Bijl. $1900-1901,100.5$, p. 50.

73 Handelingen der Staten-Generaal, Bijl. $1900-1901,100.5$, p. 51 .

74 Handelingen der Staten-Generaal. Bijl. 1901-1902. Brief van de Minister van Justitie, J.A. Loeff van 20 sept. 1901.

75 Handelingen der Staten-Generaal, Bijl. 1904-1905, ars,80, $1 \mathrm{ntm} 3$.

76 Handelingen der Staten-General, Bijl. 1904-1905, nrs.80. $1 \mathrm{v/m} 3$.

77 Nijhof, NTVO 1905, I, p. 128, wees er op, dat een vrucht ook kan afsterven zonder een voorafgaande misdadige handeling. Het verwijderen wan die vrucht is dan een weldand voor de vrouw. 
de novelle-Loeff geen bevrijdend bestanddeel was verwerkt, had "wederrechtelijk in art. 295 van de novelle-Loeff een zelistandige functie en diende het slechts ter beperking van de strafbaarheid van de vrouw, zoals hieronder blijkt ${ }^{78}$

Bij een voor de aborterende arts welwillende lezing kan de indruk ontstaan dat Minister Loeff de medicus meer de vrije hand wilde laten dan Minister Cort van der Linden, of dat hij zelfs evenmin een bevrijdend bestanddeel noding achtte als de wetgever wan $1886 .{ }^{\text {9 }}$

Uit de tekst van de voorgestelde bepalingen in verband met de MvT en verscheidene uitlatingen van Minister Loeff blijkt echter dat in de novelle-Loeff het bevrijdend bestanddeel in de voorgestelde artt. 296 en 297 niet achterwege werd gelaten, omdat het overbodig werd geacht, maar om abortus door een medicus niet uitdrukkelijk van de strafbaarstelling uit te zonderen.

De MvT verschafte over de functie van het bestanddeel wederrechtelijk geen uitsluitsel. Het eerste gedeelte dat handelde over de vrucht, was gelijkluidend aan de MvT van de novelle-Cort wan der Linden. Tevens werd opgemerkt dat door de wijziging ten aanzien van de vrucht: "de strafbepaling toepasselijk (zal) zijn in elk geval van abortus provocatus", onmiddellijk gevolgd door:

"De ervaring, o.a. in groote ziekenhuizen en andere tot verpleging van kraamvrouwen bestemde inrichtingen opgedaan, brengt hoe langer hoe meer aan het licht, dat zoodanige gevallen veelvuldig voorkomen, terwijl bij voortduring advertentien in sommige nieuwsbladen aanbiedingen behelzen, die, hoewel niet rechtstreeks het plegen wan dien abortus aanbevelende, toch in menig geval er toe leiden, dat eene vrouw of een meisje dit middel op zich laat toepassen" ${ }^{80}$

Buiten het wetswoorstel om had Minister Loeff enkele malen de medicus in verband met abortus ter sprake gebracht. Op 28 januari 1904 zei hilj in de Eerste Kamer:

"Ik ben door een ingesteld onderzoek en ook ten gevolge van de gegevens, die mij van verschillende zijden, zonder dat ik er om vroeg, uit den lande zijn toegestroomd, tot de overtuiging gekomen, dat men hier te doen heeft met een zeer groot maatschappelijk kwaad, wartegen het beslist noodzakelijk is, maatregelen te nemen" 81

Deze uitspraak was mede aanleiding tot het aannemen van een motie in de Algemene Vergadering van de NMG, waarin eerst werd overwogen, "dat de kunstmatig opgewekte abortus een belangrijke chirurgische kunstbewerking is, die alleen door bevoegde hand en niet anders dan op een streng geneeskundige indicatie mag worden verricht" en vervolgens voldoening werd uittgesproken over de toezegging van de minister, om tegen criminele

78. Vgl. Simons, NTwG 1905, I, p. 1310, waarbij hij nog opmerkte dat de opneming vin het woord "wedter" rechtelijk" overbodig was, want: "Ik ken geenertei recht voor de vrouw om zich hare vinucht te laten afdrijwen".

79 In die zin: Treub, TVS 1904, p. 478-479, dhe is enige aannemelijke verklaring voor het achterwege laten wan het bewrijdend bestanddeel in de artt. 296 en 297-ontwerp kon bedenken dat de Minister blijkbaar van oordeel was, dat de abortusbepalingen "in geen enkel opzicht ingrijpen in het den bewoegden geneesheer werleende rechnt tot wolledige uitoefening, der verloskunde, daaronder begrepen het wolkomen wettige recht tot het verrichten van die operaties, welke de verloskundige regels voorschrijven ". Simons, NTwG 1905, Il, p: 1310: "Is wat de Minister MODDERMAN indertijd beweerde waar, het zal wavi blijwen ook nute verandering van het strafwetboek volgens de novelle LOEFF" "Anders: Burger, NTVG 1904, II, p. 1575; Nijhoff, NTVG 1905, I, p. 126-133.

80 Handellngen der Staten-Generaal. Bijl. 1904-1905, nr. 80.3, P. 33.

81 NTVG 1904, II, p. 369. 
abortus op te treden. ${ }^{82}$ Met het woord "streng" wilde de NMG onderstrepen dat niet buiten heit geneeskundig gebied gegaan zou worden." Hierover werd opgemerkt: "Moge de minister ook deze indicatie ter harte nemen" ${ }^{\text {".4 }}$

Maar na de indiening van het wetsvoorstel zei Minister Loeff in 1905 in de Tweede Kamer:

"Ik ben ten opzichte van deze gewichtige zaak van oordeel, dat ook de medicus bij toepassing van zijn wetenschap onderworpen is aan de wetten der zedelijkheid, en dat hif dus niet wettelijk mag gesteld worden buiten en boven de positieve wetsbepalingen, die mede moeten dienen om de zedelijkheid te handhaven ${ }^{11} .{ }^{85}$

Na wisseling van de regering werd de novelle-Loeff in 1905 ingetrokken.

\section{De opvattingen van medici over abortus}

Terwijl de woorgestelde wijzigingen van de abortusbepalingen in het voorstel-Cort van der Linden door medici positief werden ontvangen ${ }^{87}$, leidden de betreffende voorstellen in de novelle-Loeff tot felle afwijzende reacties onder medici ${ }^{88}$ en tot een versterkte roep om meer rechtszekerheid voor de op "uitsluitend medische indicatie" handelende medicus. ${ }^{\text {ma }}$

Volgens Nijhoff zouden de abortusbepalingen van de novelle-Loeff tot gevolg hebben, dat artsen veroordeeld kunnen worden, wanneer zij "bij de baring het levende kind perforeeren", " "op medische gronden" abortus opwekken", "de afgestorven vrucht uit den uterus verwijderen", "een kunstmatige vroeggeboorte opwekken", en misschien ook "de zieke (...) baarmoeder verwijderen" en "een buitenbatarmoederlijke zwangerschap opereeren", waraan hij de conclusie verbond, dat "bij een strenge toepassing daarvan bijna iedere verloskundige zijn loopbaan (zal) moeten eindigen in de gevangenis ${ }^{\text {t1. }}$. Hij wille dat risico

82 In masrt 1904 adwiscerde het Hoofdbestuur tot het verrichten van wen onderzoek naar de ornvang van "abortus crimunal is" en dan zal thet, "zan de hand van de bijeengegaarde bewijzen, gemakkelyjker vallen de Regeering te overtuigen dat krachtige matregelen tegen het misbruik inderdaad noodzakelijk zijn". NTWG 1904, I, p. 669

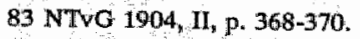

84 . mirger, NTVG 1904, II, p. 1148 .

85 MwJ (Loeff, $J_{i}$ W.) zitting TK 20 dec. 1905, Handelingen 1904-1905, p. 873. Zle hiertoe: Nijhof, NTvG $1905_{1}, 1$, p. $129-130$

86. Handelingen der Staten-Generam. Bjylagen 1905-1906, $\$ 8.1$.

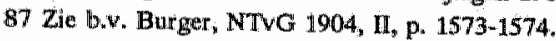

88 Burger, NTvG 1904, I, p. 1573-1575; Nijhoff, NTvG 1905, I, p. 126-133; m.n. p. 131-132. Op p. 1574 Schreef Burger: "Door wit het ONTWERP CORT VAN DER LINDEN al datgene weg te laten wat op den geoorloofden geneeskundigen abortus betrekking had, bindt de minister er de strijd aan met den geneeskundigen stand. Neen! wij willen ons niet het recht laten ontnemen, bij onze overwegingen om ment het heil onzer patiënten, gezondheid en leven eener wrouw awaarder the doen wegen dan het lieven van har ongeboren vrucht". Zie verder: Koch, NTVG 1905, I, p, $491-493$ en p. 628; Treub, NTvG 1905, II, p. 869-870.

89. Afdeling Amsterdam van de NMG, NTVG 1905, 1 , p. 867 , wamin ter toelichting wend verwezen naam: Nijhoff, NTVG 1905, I, p. 126-133. In de 56 A.V. van de NMG, ze NTVG 1905, I, p, 869-879, werd het gevijaigde voorstel van de Afdeling Ansterdam met 108 tegen 8 stemmen anngenomen. Het gewijzigde voorstel luidde - zie NTVG 1905, I, p. 879 -: "De Algemeene Vergadering draagt het Hoofdbestuur op tot de Regeering en de Volkswertegenwoordiging thet werzoek te richten, in werband met de voorgestelde

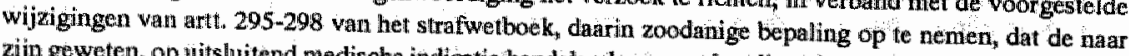
zijn geweten, op uitsluitend medische indicatie handelende, geneeskundige niet met de straf wet in botsing
kome". 
wel aanvaarden: "En wij mogen evenmin als ieder ander uit vrees voor straf ons laten weerhouden om datgene te doen, wat de kategorische imperatief van ons geweten ons beveelt: 90

Anderzijds konden vooral katholieke medici zich vinden in de abortusbepalingen van de novelle-Loeff en in die van het hierna te bespreken, in 1909 ingediende voorstel-Nelissen, dat leidde tot de zedelijkheidswetgeving van 1911. Deze medici wezen een rechtvaardigingsgrond ten aanzien van abortus door een medicus van de hand. Abortus was in hun ogen nooit te rechtvaardigen, wèl te verontschuldigen." Daarmee vertolkten zij het standpunt van de katholieke leer, volgens welke ook abortus door een medicus een ongeoorloofde daad is, zelfs wanneer deze geschiedt om het leven van de vrouw te redden. ${ }^{92}$

De afkeuring van abortus door de katholieke leer had geen betrekking op abortus als bijkomstig gevolg van een medische handeling, die met een ander doel werd verricht. ${ }^{93}$ De theoloog Vlaming stelde daarom, dat de veroordeling van abortus door de katholieke kerk "voor een zeer groot gedeelte slechts loos alarm is". ${ }^{\text {"9 }}$ "Want volgens hem waren in de katholieke leer alle operaties geoorloofd, die ten doel hebben het leven van de moeder te redden, voor zover zij "rechtstreeks niet aan haar vrucht maar aan haar eigen kranke organen worden ondernomen", waaronder operaties, die voor de vrucht indirect dodelijk zijn. ${ }^{95}$

Behalve het "kathollieke standpunt" bestonden onder medici in die jaren nog drie andere opvattingen over de geoorloofdheid van abortus. Ter illustratie van deze opvattingen wordt hier soms verwezen naar bronnen van vóór 1904, voor zover een arts voordien duidelijk bepaalde indicaties als geoorloofd of angeoorloofd had getypeerd en zich nadien nog slechts in algemene bewoordingen over de problematiek heeft uitgelaten. Vaak werd slechts gesproken van een "medische indicatie", van een "streng geneeskundige indicatie" of van "medische gronden", zonder dat blijkt, wat daaronder werd begrepen."

Volgens de een was abortus slechts toegestaan bij levensbedreiging voor de vrouw: ${ }^{97}$ Een tweede opvatting hield in dat abortus in het belang van het leven of de gezondheid van de vrouw geoorloofd was. ${ }^{98}$ In de derde opvatting konden ook sociale omstandigheden voldoende reden tot abortus opleveren. ${ }^{99}$ Volgens Treub waren er "bewijzen te

90 Nijhoff, NTWG 1905,1, p. 130-133.

91 Zie b.v. Struycken, NTvG 1905, II, p. 873 en Batenburg. NTVG 1905, II, p. 898-905, m.n. p. 899.

$92 \mathrm{Vgl}$, de theoloog Keuller, in: De verantwoordelijkheid varn den geneesheer, (1908), p. 4. Zie ook Treub, TwS 1902, p. 167-175. Het artikel werd voordien reeds gepubliceend in: Het levensrecht der ongebonen vrucht, 1901.

$93 \mathrm{Vgl}$. Keuller, in: De verantwoordelijkheid van den geneesheer, (1908), p. 5.

94 Vlaning, in: Het levensrecht der ongeboren vrucht, 1901, p. 93.

95 Vlaming, in: Het levensrecht der ongeboren vrucht, 1901, p. 88-94, m.n. p. 90. Sporken, MC 1967, p. 389, \#womt cen dergelijke bemadering "ethische acrobatie"

96 Zie b.V. NTVG 1904, II, p. 368-370. Kewchenus, NTVG 1898, 1, p. 826: Of er sprake is van een medische indicatie behoort te worden bepald door het geweten wan de medicus:

97 Pinkhot, NTVG 1898, 1, p. 529.

98 Oidman, in: De verantwoordelijkheid van den geneesheer, (1908), p. 20; Burger, NTVG 1904, I, p. 1574 en Nijhoff, NTvG $1905, \mathrm{M}$, p. 1691.

99 Treub, NTwG 1898,1, p. 745-755, m.n. p. 755. 
over, dat niet alleen bij wijze van uitzondering, sociale indicaties het medisch handelen bepalen ${ }^{\text {it }}$.

Maar ook sommige medici, die zich uitspraken voor een "strenge" medische indicatie, wezen wettelijke beperkingen af. Voor de wrijheid van handelen, zoals de arts meent, "dat zijn plicht hem gebiedt ... moet, ...., ieder medicus opkomen, ook hij, die meent dat zijn plicht niet gebiedt, wat een ander wel als zijn plicht beschouwt" ${ }^{\text {101 }}$

\section{Het standpunt van Simons}

Simons merkte in 1905 op dat het vraagstuk van de strafrechtelijke aansprakelijkheid van de medicus te ingewikkeld is om het met een algemeen gesteld wetsvoorschrift op te lossen. ${ }^{102}$ Weliswaar heeft de geneeskundige er recht op,

"niet aan cene strafvervolging te worden blootgesteld, wanneer hij naar eer en geweten doet, wat zijn kunst hem voorschrijft. De eerbiediging van dat recht is ook een algemeen maatschappelijk belang".

Mar tegenover de rechten van de medicus staan de rechten van de patient. De wetgever mag zich volgens hem, niet wan zijn taak kwijten door alles afhankelijk te stellen van "den weinig vaststaanden beroepsregel".

Als bezwaar tegen een algemene wettelijke rechtvaardigingsgrond voor abortus door een medicus; wees Simons op het belangenconflict tussen vrouw en vrucht:

Wat aan deze handeling har elgenardig karakter geeft, is dat zij niet, zooals een chirurgische operatie, uits/uitend betreft den patient zelf, maar aantast het recht van den ongeboren vrucht, een recht, zelfstandig staande naast dat van de persoon, voor wie de geneeskundige hulp werd ingeroepen, van de barende vrouw. Het hier bedoelde vraagstuk heeft derhalve zelfstandige beteekenis en vereischt bijzondere overwegingen". 103

Desondanks achtte hij te dien aanzien een rechtvaardigingsgrond gewenst. Inmiddels was immers gebleken dat de katholieke kerk abortus veroordeelde, zelfs als deze geschiedt om het leven van de vrouw te redden en zelfs als de vrucht zonder ingrijpen zou komen te overlijden. Bovendien had Minister Loeff verklaard het met deze leer eens te zijn. Daatom moest het niet uitgesloten worden geacht dat leden van het $\mathrm{OM}$, die deze opvatting deelden, tot vervolging van een medicus vanwege abortus provocatus over zouden gaan. ${ }^{104}$ Daar de wet niet in een witzondering voorzag kon in de zienswijze van Simons de rechter, ook al was hij een andere mening toegedaan, niet anders dan de medicus veroordelen. Het door Van Hamel verdedigde beroepsrecht kon hier de medicus niet helpen, omdat deze bij de uitoefening van zijn beroep niet in strijd met de strafwet mag komen.

Simons maakte terecht tussen dit beroepstrecht en het door Minister Modderman verdedigde recht van de medicus om straffeloos te handelen een verschil, hoewel hij erkende dat beide benaderingen veel overeenstemming vertoonden. Het recht dat Modderman

100 "Treub, NTVG 1898, I, p. 746-747 an in Verspreide opstellen, 1904, p.84-85; Aletta.H. Jacobs, NTwG 1898, I, p. 656-663; Burger, NTwG 1904, I, p. 15\%4.

101 Pinkhof, NTVG $1905, \Pi$; p. 874.

102 Simons, NTVG 1905,1, p. $1305-1306$

103 Simons, NTVG 1905, 1, p. 1306.

104 In gelijke zin m.b.t. het OM: Van Dam van Isselt, 1902, p. 115. 
bedoelde had volgens Simons zijn grondslag niet in art. 1 WUG, doch in het handelen lege artis. Maar de opvatting van Modderman was niet inde strafwet neergelegd, noch bond zij de rechter anderszins. Bovendien had zij bij abortus als nadeel dat daar niet vaststaat wat de regelen der kunst zijn. ${ }^{105}$ Met regelen der kunst bedoelde Simons hierbij materiêle criteria op grond waarvan abortus al dan niet geoorloofd is. ${ }^{106}$

Bovendien pleitte Simons voor en bijzondere rechtvaardigingsgrond met een materieel criterium, zoals dat bijvoorbeeld door Van Dam van Isselt was voorgesteld: "indien hij dit op redelijken grond ter redding van het leven der vrouw noodzakelijk acht". Maar anders dan Van Dam van Isselt; vond Simons het van belang, dat tevens aandacht werd geschonken aan de rol wan de toestemming tot deze ingreep. ${ }^{107}$

Daarentegen ontbrak een materieel criterium in de door Treub in 1904 voorgestelde algemene rechtvaardigingsgrond voor de medicus, waarmee aan de rechtsonzekerheid voor de medicus een eind moest worden gemaakt:

"Niet strafbaar is de genees-, heel-, of verloskundige, die een feit begaat, dat naar redelijk inzicht is geboden of toegelaten door de regelen zijner kunst". ${ }^{108}$

\section{De Gemengde Commissile van 1909}

Het artikel van Simons leidde in $1906^{109}$ tot het instellen van de Gemengde Commissie van 1909 door de NMG onder voorzitterschap van Treub en met als een van de leden Simons. In haar rapport stelde de Commissie voor als art. 42 a in het WvSr op te nemen:

"Niet strafbaar is de geneeskundige, die een feit begaat, dat naar redelijk inzicht

is geboden of toegellaten door de regelen zijner kunst". ${ }^{\text {t10 }}$

Behalve dat hierin evenmin als in de door Treub voorgestelde bepaling een materieel criterium was opgenomen, bezigde de Commissie ter verdediging van het wetsartikel ook diens argumenten. De geneeskundigen verkeerden onder de bestaande abortusregeling in rechtsonzekerheid ten aanzien van abortus provocatus. Die rechtsonzekerheid kon ertoe leiden dat een noodzakelijk geachte abortus achterwege werd gelaten.

Volgens de Gremengde Commissie had een bepaling als door haar voorgesteld als voordeel dat aan iedereen duidelijk zou zijn dat een medisch geïndiceerde abortus, die lege artis is uitgewoerd, geen misdrijf oplevert. Hetzelfde tesultaat zou weliswaar bereikt kunnen worden door, zoals in het voorstel-Cort van der Linden, een speciale strafuitsluitingsgrond voor abortieve handelingen in het WvSr op te nemen, maar in de ogen van de Commissie was een algemene strafuitsluitingsgrond "rationeler". Bovendien werd daarmee voorkomen dat de rechtspraak een chirurgische ingreep als mishandeling zou kwalificeren.

105 Simons, NTVG 1905, I, p. 1312-1313.

106 Een beroep op noodtoestand achte Simons evenmin mogelijk, omdat anders zowel een medicus die het leven van de vrow wedt, als degene die het leven van de vrucht redt, zjch daarop moeten kumen bercepen.

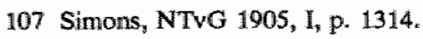

108. Treub, TVS 1904 , p. 480-481.

109 Zie NTVG 1906 , II, p. 528 en NTVG 1908, I, p. 148.

110 Genengde Commissie wan 1909, NTVG 1909, I, p. 77. 
De Gemengde Commissie achte het, ewenals Simons eerder, nodig om ter voorkoming van een mogelijk misbraik van de strafuitsluitingsgrond, een wettelijke regeling over de toestemming voor medische ingrepen te treffen. ${ }^{\text {II }}$

Eén lid van de Commissie, de katholieke arts Boekelman ${ }^{112}$, verzette zich in zijn minderheidsstandpunt tegen de voorgestelde strafuitsluitingsgrond. Naar zijn mening was een dergelijke bepaling in verband met abortus in strijd met de "hoofdeisen van het christendom". Met die bepaling werd, volgens hem, de deur open gezet tot het veelvuldig dooden van de vrucht volgens medische indicatie".

"Medische indicatie' is een zeer ruim, maar vooral subjectief begrip. Er zijn zo veel sociale omstandigheden (geld, eer, praktijk, enz.), die woor sommige geneesheren de grenzen der medische indicatie kunnen uitbreiden.. ${ }^{113}$

Nog afgezien wan de door Boekelman opgegeven redenen woor de grenzen van de medische indicatie bij abortus, staat vast dat over de inhoud van het begrip "medisch indicatie" in verband met abortus onder de medici verschillend werd gedacht, zoals hilerboven bleek.

\section{Abortus en de zedelijkheidswetgeving 1911}

\subsection{Inleiding}

Ondanks de strekking van de abortusbepalingen in de novelle-Loeff en de uitlatingen van Minister Loeff over de strafrechtelijke aansprakelijkheid van de medicus voor abortus bestond vermoedelijk onder medici in die tijd het vertrouwen dat de wetgever het abortus-vraagstuk op een voor hen aanvaardbare wijze zou oplossen. In elk geval wilden zij geen genoegen nemen met de bestaande regeling. Dat laatste had waarschijnlijk zijn oorzaak in de verschillende opvattingen onder juristen en politici over de strafbaarheid van abortus door een medicus. ${ }^{114}$ In 1908 wees Treub de toenmalige Minister van Justitie, Nelissen, op de "schromelijke gevallen van abortus" en op "de groote talrijkheid der gevallen". ${ }^{115}$ Het jaar daarop diende Minister Nelissen een wetsvoorstel ter bestrijding van de zedeloosheid in.. ${ }^{116}$

Tegen het einde van de beraadslagingen over het wetsvoorstel-Nelissen in de Tweede Kamer merkte de jurist Van Hamel, die in die tijd tevens lid van de Tweede Kamer was,
op:

"Ik beleef zeker op het oogenblik een van de gelukkigste oogenblikken die men in een loopbaan als de mijne beleven kan en ben daarvoor uiterst dankbaar". 117

111 Tie hiertoe nader: H. I, onder 3.3 .5 .

112 Zie HTK 1910-1911, p. 1586.

113 Boekelman, Nota der Minderheid, NTwG 1909, $I_{2}, p_{4} 82$.

114 Vgl. Treub, NTwG 1905, II, p. 869 en Nijhoff, NTVG 1905, I, p. 1074-1075.

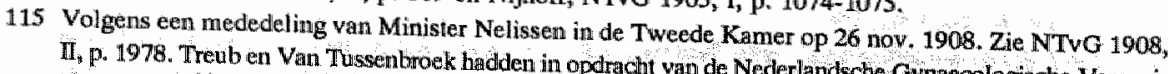
ging een onderoek verricht "Over der che in opdracht vam de Nederlandsche Gynaecologische Vereeni1908, I, P, 1149-1161.

116 Ontwerp van wet ter bestrijding van de zedeloosheid. Ingediend bij KB van 7 mei 1909. Hamdelingen
der Staten-Generaal. Bijl, 1908-1909, no. 293 .

117 HTK $1910-1911$, p. 1589. 
Deze uitlating van Van Hamel kwam voort uit zijn mening dat zowel Minister Regout als leden van de Tweede Kamer het met zijn opvatting over het beroepsrecht eens waren, mamelijk dat de medicus vanwege de wettelijke bevoegdheid tot de uitoefening van het medisch beroep gerechtigd was in dat kader handelingen te verrichten, die voor anderen strafbaar waren. ${ }^{\text {IL8 }}$ Een opvatting, die in de jaren zeventig en tachtig vooral door Enschedé in verband met euthanasie werd verdedigd. ${ }^{119}$ De Hoge Raad verwees voor de straffeloosheid van een operatieve ingreep in verband met "mishandeling" eveneens naar de geschiedenis van de zedelijkheidswetgeving 1911: ${ }^{120}$

Maar ook na het tot stand komen van de zedelijkheidswetgeving bleven, zoals we thans weten, de meningen over het beroepsrecht (en de medische exceptie) verdeeld, zodat hieronder de vraag centraal staat in welke zin de wetgever zich in 1911 over het beroepsrecht heeft uitgelaten. Uit de navolgende bespreking van de zedelijkheidswetgeving 1911 met betrekking tot abortus zal blijken dat in elk geval het beroepsrecht ten aanzien van abortus toen niet werd erkend, noch de wezenlijke strekking van een zodanig beroepsrecht, waarmee de totstandkoming en de uitkomst evenmin steun biedt voor de medische exceptie.

Van het bezigen van de term "medische exceptie" is in dit onderdeel afgezien, ondat de betrokkenen de term "beroepsrecht" bezigden en het wisselende gebruik van de term medische exceptie en beroepsrecht de leesbaarheid niet bevordert.

\subsection{Art. 451ter en het beroepsrecht van de medicus}

In het wetsvoorstel-Nelissen, dat tijdens de behandeling in de Kamers door Minister Regout werd verdedigd, kwamen twee bepalingen voor, waturmee de geneeskundige bij abortus te maken kon krijgen: de artt. 251 bis en 451 ter.

Art. 451ter luidde:

Hij die hetzij eenig middel tot voorkoming van zwangerschap, openlijk ten toon stelt, hetzij zoodanig middel of diensten ter voorkoming van zwangerschap openlijk of ongevraagd aanbiedt, of openlijk, of door verspreiding van eenig geschrift ongevraagd, als verkrijgbaar aanwijst, wordt gestraft met hechtenis van ten hoogste twee maanden of geldboete van ten hoogste tweehonderd gulden".2t

Volgens de tekst van deze bepaling was een geneeskundige, die met een medisch doel, maar ongevraagd, middelen of diensten ter yoorkoming van zwangerschap aanbood, strafbaar. Een minderheid in de Commissie van Rapporteurs vond het niet de taak van de wetgever om de medieus strafbaar te stellen;

"die in het belang van echtelieden, welke niet de noodige inkomsten hebben om een groot gezin te onderhouden en zelfbeheersing missen, of die zelfs in het belang

118 Zie ook: H. II, onder 3.5.3.

119 Fouwel Enschede van mening is, dat " Regout zich niet zo stellig heeft uitgelaten als Van Hamel hel wilde verstaan", ziet hij in de uitlatingen van Regout toch een erkening van bet beroepsurecht van de medicus. Vigl. Ensched., 1985 , p. 82-84, m.n. p. 84.

$120 \mathrm{HR} 21$ okt. 1986, NJ 1987, 607 mmt. GEM. Zhe hiertoe H. U, onder 3.5.5.

121. Dit is de tekst van art. 451 ter, zoals het artikel bij Wet van $20 \mathrm{Mei} 1911$, 5 tb. 130 werd vastgesteld. De verainderingen die bet artikel heeft ondergaan zijn niet van invloed op het hier gezegde. 
van de gezondheid der vrouw diensten ter voorkoming wan zwangerschap aanbiedt of als verkrijgbaar aanwijst, ..." 122

In de MVA ${ }^{123}$ merkte Minister Regout ter zake van art. 451ter op:

de "medicus, die aan behoeftige echtelieden een algemeen advies geeft to" geboortebeperking en zich, reeds uit overwegingen van kieschheid, daartoe beperkt, totdat hij zich heeft vergewist, of zijn nadere raad wordt gewenscht, valt buiten dit artikel, ... 124

De Minister zag hier de straffeloosheid van de medicus niet gellegen in het beroepsrecht, maar in de algemene strekking van het advies. Dit diende blijkbaar zo al gemeen te worden gehouden, dat er geen sprake was van een "ongevraagd" aanbieden. Verder sprak de Minister ten aanzien van de medicus van "advies" en niet van "aanbieden". Een advies is onbepaalder dan een aanbod en de woorden "algemeen advies" drukken nog nadrukkelijker de onbepaaldheld uit. Tot een straffeloos verstrekken van diensten of middelen mocht de medicus kennelijk pas overgaan, nadat "zijn nadere raad" werd gewenst. Maar op dat moment was de raad niet ongevraagd aangeboden.

De gedraging van de medicus terzake van art. 451 ter was derhalve volgens de Minister slechts straffeloos, als zij niet onder de delictsomschrijving viel. Daarvan was sprake als de medicus zich - ongevraagd - beperkte tot een algemeen gehouden advies.

Tijdens de parlementaire behandeling van art. 451ter kwam de medicus niet meer ter sprake. Dat gebeurde wel in verband met het voorgestelde art. 251 bis.

\subsection{Art. 251bis en het beroepsrecht van de medicus}

Artikel 251 bis Sr was bedoeld als aanvulling op de artt. 295-297 Sr, die in de praktijk, vanwege de door de Hoge Raad gestelde eisen, onvoldoende werkten. ${ }^{125}$ Art. 251 bis G.O. luidde ${ }^{126}$ :

"Hij die opzettelijk eene vrouw in behandeling neemt of eene behandeling doet ondergaan, te kennen gevende of de verwachting opwekkende dat daardoor zwangerschap kan worden verstoord, wordt gestraft met ...

Indien de schuldige uit winstbejag heeft gehandeld, van het plegen van het misdrijf een beroep of een gewoonte maakt, of geneeskundige, vroedvrouw of artsenijbereider is kunnen de straffen met een derde worden verhoogd.

Indien de schuldige het misdrijf in zijn beroep begaat; kan hij van de uitoefening van dat beroep worden ontzet".

Voor de plaatsing in de titel "Misdrijf tegen de zeden" gaf de MvT als reden op, dat de handeling zelf onzedelijk is en dat zij de onzedelijkheid in de hand werkt. ${ }^{27}$

122 Handelingen der Staten-Generaal. Bijl. 1909-1910, nr. 56.1 (VV), p. 8.

123 Handelingen der Stater General. Bijt, 1909-1910, nr. 56.2 (MvA).

124 Handelingen der Staten-General, Bijl. 1909-1910, nr. 56.2 (MvA), p. 21.

125 Handelingen der Staten-Generaal. Bijl, 1909-1910, nr. 293.3. (MvT), p. 6.

126 Dit was eveneens de definitieve tekst. Vgl. W 8893.

127 Handelingen der Staten-Genteraal. Bijl. 1909-190, ni. 293.3. (MvT), p. 6. In het W 8893 werd deze argumentatio niet overtuigend geacht: Wel is het verwekken van abortus in "verreweg de meeste gevallen" wen terecht strafbar gestelde handeling ${ }_{m}$ Voor een plaatsing van dit artikel buiten de titel "Misdrijven tegen het leven gericht" spreekt dat de afdrijwing van een dode vrucht geen misdrijf tegen het leven is. (Daarop wees ook de regering: zie Handelingen der Staten-Generaal. Bijl. 1909-1910, nr. 293.3. (MWT), P. 6. Zie ook Nijhof, NTwG 1905, 1, p. 131-132) Maar zij ss niet onzedelijk in de zin, waarin het woord in hat 
Volgens de MvT omvatte het "in behandeling nemen" drie handelingen, de toepassing van kunstmiddelen, het voorschrijven van inwendige middelen en het aan een " patiente" "th aanleren van een abortusmethode. Door het alternatieve bestanddeel een behandeling doet ondergaan" op te nemen, wilde de Minister het mogelijk maken de aborteur te straffen, die met helpers werkt.

In art. 251 bis O.R.O. werd niet gesproken van dat daardoor zwangerschap kan worden verstoord", maar van "dat daardoor eene miskraam kan worden opgewekt". ${ }^{28}$ Onder verwijzing naar het gewone spraakgebruik werd in de MvT opgemerkt, dat onder "miskraam" wordt verstaan "eene ontijdige kraam, zóó vroeg, dat de vrucht niet zelfstandig leven $\mathrm{kan}^{\prime \prime} .{ }^{29}$

In de Commissie van Rapporteurs werd als bezwaar tegen het woord "miskraam" aangevoerd dat de dader om straffeloos te blijven, slechts ervoor hoeft te zorgen, dat hij een levensvatbare vrucht afdrijft. Een ander bezwaar zag de Commissie daarin dat dan bewezen moest worden dat een niet-levensvatbare vrucht is afgedreven: ${ }^{130}$ Aan deze bezwaren kwam de redactie van art. 251bis G.O. tegemoet.

Volgens de MvA bood de gewijzigde redactie het voordeel dat "zij ook de gevallen omvat, dat de vrucht wel zelfstandig zou kunnen lleven". En tevens:

"Het springt overigens in het oog, dat de vraag; of die zwangerschap eene levende of doode vrucht betrof, ja zelfs of er wel eenige zwangerschap bestond, voor het onderhavige delict niets ter zake doet; de handeling is voltooid, zoodra de vrouw in behandeling is genomen en haar daarbij witzicht op zwangerschapsverstoring is gegeven; het gevolg der behandeling is voor dit delict onverschillig; blijkt a posterio$\mathrm{ri}$, dat eene levende vrucht is afgedreven of gedood, dan treedt de bepaling van art. 297 Wetboek van Strafrecht in werking", 131

De MvT maakte geen melding van de medicus die op medische gronden tot vruchtafdrijving overgaat. De Commissie van Rapporteurs stemde in met de bestrijding van abortus criminalis, maar verscheidene leden vonden de voorgestelde redactie van art. 251bis te nuim, omdat daardoor een medicus op twee wijzen strafbaar kon worden, zonder dat dat bedoeld kon zijn, namelijk:

1. de geneeskundige die een zwangere vrouw behandelt; waarbij als onbedoeld neveneffect een miskraam kan ontstaan en die dat aan de vrouw uit "nauwgezetheid" tevoren heeft meegedeeld ${ }^{132}$;

2. de geneeskundige "die naar de regelen zijner wetenschap en als naar redelijk inzicht geboden een abortieve handeling noodig acht, om het leven der wrouw te redden" ".

Terwijl in de novelle-Cort van der Linden naast het leven ook de gezondheid van de vrouw als materieel criterium was genoemd, werd hier slechts over het leven van de vrouw gesproken. "Ter voorkoming van de strafbaarheid van de medicus voor abortus

WVSr wordt gebruikt. In de door de Minister daaraan toegekende betekenis zouden bijwoorbeeld ook moord en diefstal onzedelijk zijnn.

128. Handelingen der Staten-Generaal, Bijl. 1909-1910, nx. 293.2.

129 Handelingen der Staten-Generaal. Bijl. 1909-1910, nr. 293.3. (MvT), p. 6.

130 Handelingen der Staten-Generaal. Bijl. 1909-1910. nir 56.1\% (VV), p. 11.

131 Handelingen der Staten-Generaal. Bijl. 1909-1910, nur. 56.2 (MvA), p. 25.

132 In dezelfde zin: W 8893 en Nijhoff, NTvG 1909 , I, p. 1925-1926.

133 Handelingen der Staten-Generaal. Bijl. 1909-1910, mr. 56.1. (VV), p. 11. 
bij levensgevaar woor de vrouw werd voorgesteld in het WwSr een uitzonderingsbepaling voor de médicus op te memen. Verder werd in overweging gegeven "ten einde misbruiken te keeren den geneesheer voor te schrijven in die omstandigheid hetzij vóór hetzij onmiddellijk na de behandeling hiervan kennis te geven aan de overheid". ${ }^{134}$

Bij mijn weten is dit de eerste keer in de geschiedenis van het WvSr dat ten aanzien van een handeling van de medicus en in verband met diens strafrechtelijke aansprakelijkheid voor abortus een procedureregel werd voorgesteld.

Andere leden beschouwden een wettelijke uitzondering voor de medicus als overbodig en niet wenselijk. $\mathrm{Zij}$ was overbodig, daar het $\mathrm{OM}$ in de hier bedoelde gevallen toch nooit tot vervolging overgaat. Zou men echter een uitzonderingsbepaling willen dan diende geen bijzondere, maar een algemene strafuitsluitingsgrond voor de medicus in het WvSr te worden opgenomen. ${ }^{135}$

Volgens Minister Regout was een bevrijdend bestanddeel in art. 251bis overbodig. Daartoe verwees hij naar de wetsgeschiedenis van de artt. 295-297 Sr in 1881. Evenals toentertijd Minister Modderman vond hij een wettelijke strafuitsluiting "volstrekt overbodig". Maar anders dan bij Modderman gebeurde dat bij hem "niet zozeer enkel op de juridische overweging, dat in het algemeen de geneeskundige volkomen gedekt is, zoo dikwerf hij handelt naar de regelen zijner kunst". Die reden vond hij onvoldoende, gezien de verdeeldheid van "gezaghebbende" juristen over de vraag of de "aldus optredende verloskundige door beroepsrecht, overmacht of noodtoestand straffeloos handelt" ${ }^{136}$

Regout achtte een wettelijke uitzondering "reeds hierom" overbodig, omdat noch onder de Code Pénal, noch onder de bestaande strafwet een medicus in Nederland voor een dergelijke handeling was gestraft, hoewel algemeen bekend was, dat "door den verloskundige de abortus nu en dan, de partus praematurus ${ }^{137}$ zeer dikwijls opzettelijk wordt opgewekt". Derhalve was een "regeling der positie van den medicus tegenover deze bepalingen der strafwet ... van zuiver theoretisch, niet van practisch belang". Bovendien zou een wettelijke uitzondering tot grote moeilijkheden leiden, zoals ook al in het Regeringsantwoord van 1881 betoogd werd. Hierna zei Minister Regout:

"Waarom zou er dan thans meer reden zijn dan in 1881, om hier de zoo netelige en in alle landen moeilijke vraag van de positie van den medicus tegenover de strafwet incidenteel te gaan regelen, terwijl indien er eenig praktisch belang bij die regeling bestond, er aanleiđing zou bestaan, het vraagstuk in zijn geheel, b.v. ook ten aanzien van kindermoord, dood door schuld, lichamelijk letsel enz. te regelen". ${ }^{138}$

Vanwege het vervolgingsbeleid van het $O M$ bestond zijns inziens ook geen urgentie om deze kwestie wettelijk te regelen.

Dit antwoord van de Minister was voor het Tweede Kamerlid Van Hamel aanleiding om samen met Goeman Borgesius een amendement in te dienen, waarin onder andere werd voorgesteld, aan art. 251 bis toe te voegen:

134 Frndellingen der Staten-Generaal. Bijl. 1909-1910, nr. 56.1. (VV), p. 11.

135 Handelingen der Staten-Generaal. Bijl. 1909-1910, nr. 56.1. (VV), p. 11.

136 Handelingen der Staten-General. Bijl. 1909-1910, nr. 56.2. (MvA), p. 26.

137 Zie H. III, onder 2.1 .

138 Handelingen der Staten-Generaal. Bijli 1909-1910, nr. 56.2. (MvA), p. 26. 
"Niet strafbaar is de geneeskundige, die handelt zooals naar redelijk inzicht is geboden of toegelaten door de regelen zijner geneeskunst ${ }^{\prime \prime}{ }^{139}$

In de toelichting wees Van Hamel op het onderscheid tussen abortus criminalis en abortus op medische indicatie. Het doel van thet amendement was de grens tussen beide in de wet vast te leggen, daar onder medici onrust bestond over hun strafbaarheid. Een abortus op medische indicatie voldeed - formeel gezien - immers aan de voorgestelde delictsomschrijving.

De in het amendement voorgestelde anvulling van art. 251 bis was inhoudelijk gelijk aan de door Van Hamel in zijn leerboek verdedigde. Er bestonden wel twee formele verschillen. Ten eerste zou het tot een formelle vastlegging van het beroepsrecht in het WvSr komen en ten tweede hield die vastlegging slechts verband met art. 251 bis.

Met de ondertekening van het amendement had Van Hamel een "wetenschappelijk offer" gebracht. Hij had immers altijd gesteld,

"dat het beroepsrecht van den medicus vaststat en het dus niet noodig is dit nog eens door een uitdrukkelijke bepaling in de Strafwet te erkennen".

Maar hij erkende dat de opvattingen van de rechtsgeleerden hierover uiteen liepen en zeer velen ontkenden dat "positiefrechtelijk een zoodamig beroepsrecht zou gelden". Die meningsverschillen gaven juist aanleiding tot onzekerheid onder medici.

De aanvulling bevatte twee alternatieve en open normen: handelen naar redelijk inzicht geboden en handelen toegelaten door de regelen van de geneeskunst. Over die regelen merkte Van Hamel op, dat zij bepaald worden door "medici van betekenis", die daartoe zullen worden geraadpleegd. Als bepaalde regelen in de medische praktijk naar het oordeel van die medici als "redelijk en vaststaand" worden erkend, "dan zal de geneeskundige die deze regelen volgde, naar de Strafwet niet aansprakelijk mogen zijn" : De regelen kunnen niet alles nauwkeurig omschrijven. Zij zullen "veel aan het degelijk oordeel van iedere medicus ... overlaten, maar stellig niet alles" 140

Vervolgens ging Van Hamel in op bezwaren die tegen het bepalen van de regelen van de geneeskunst door medici naar voren werden gebracht.

Abortus op medische indicatie werd door sommige medici vanwege hun "morele en kerkelijke" opvattingen veroordeeld. Dat bracht volgens hem echter niet mee, dat een wettelijke strafuitsluiting van de medicus bij abortus op medische-indicatie tevens een morele erkenning van de betreffende handeling inhoudt.

"Onze Strafwet heeft niets te maken met uitspraken over moraliteit naar godsdienstige of kerkelijke opvattingen. Men kan iets veroordeelen naar de zedenleer of ingevolge het kanonieke recht, maar dit behoeft daarom nog niet naar de Nederlandsche Strafwet te worden gestraft. ... Gij kunt dus ook den abortus medicalis veroordeellen, gij kunt wan uw medici verlangen dat zij het nooit zullen doen, omdat het strijden moet tegen hun moreel gevoel of strijdt tegen de voorschriften van de Kerk, maar de Nederlandsche Strafwet heeft daarmede niets te maken. $\mathrm{Zij}$ die den medischen abortus willen aanwenden, die het moreel niet ongeoorloofd vinden, die iniet door de voorschriften eener Kerk zijn gebonden, kunnen, omdat gij op die punten anders denkt, niet onder de Strafwet worden gebracht, indien zij een dergelijke handeling begaan. Het gaat hier alleen om de toepasselijkheid der Strafwet" : ${ }^{14}$

139 Handelingen der Staten-Generaat. Bjyl. 1909-1910, ni. 28.8.

140 HTK 1910-1911, p. 1586.

141. HTK 1910-1911, p. 1586. Vgl. W 8893. 
Volgens Van Hamel diende derhalve een verschil te worden gemaakt tussen de morele waardering en de strafwasardigheid van een handeling. Verder blijkt dat voor hem ook een - onder geneeskundigen - moreel omstreden handeling tot de beroepsuitoefening van de medicus kon behoren.

Art. 251 bis kon het gevaar meebrengen, dat een medicus die een medische handeling verricht, waarbij het alls neveneffect tot een miskraam kon komen en die de vrouw tevoren op dit gevaar wijsi, strafoaar zou zijn, terwijl de medicus, die deze informatie achterhoudt, vrijuit zou gaan.

Dat probleem zou zich niet voordoen bij erkenning van het beroepsrecht. Maar de woorden van Minister Regout gawen Van Hamel aanleiding tot twijfel of deze het beroepsrecht had erkend. Het leek Van Hamel waarschijnlijker dat de Minister de strafbaarheid van de medicus in een dergelijk geval vanwege toepassing van het opportuniteiltsbeginsel uitgesloten achite. Vanuit die zienswijze pleegt de medicus het misdrijf van art. 251 bis en blijft slechts een vervolging uit. Daarom verwierp hij "absoluut het beroep op het beginsel van de opportuniteit".

Verder was in de MwA aangevoend dat ook de rechter met de positie van de geneeskundige rekening kan houden. Dat: sprak Van Hamel tegen. Als men ervan uilgaat dat de medicus onder art. 251 bis valt en het $\mathrm{OM}$ de zaak aanhangig heeft gemaakt, dan kan de rechter niet anders dan veroordelen. ${ }^{142}$ Een opvatting die ook ten aanzien van de artt. 295-298 Sr vaker werd geutt. ${ }^{143}$

Van Wijnbergen, een oud-student van Van Hamel en woordvoerder van de regeringspartij, was het niet eens met het amendement. Hij wenste vast te houden aan het beroepsrecht, zoals dit door Van Hamel in zijn leerboek naar voren werd gebracht. ${ }^{144}$

Ook Minister Regout, eveneens een oud-student van Van Hamel ${ }^{1.45}$, voelde niet voor een uitzonderingsbepaling, zoals deze in het amendement was voorgesteld. Wel kon hij zich voorstellen, dat een algemene uitzonderingsbepaling voor medici in het WvSr terecht zou kunnen komen:

"Indien men werkelijk tot een regeling van de strafrechtelijke aansprakelijkheid van den geneesheer komen wil, dan behoort een artikel in den geest van het amendement toch een geheel andere plaats te winden, n.l. bij de algemene bepalingen van ons Wetboek van Strafrecht, in de buurt van art. 40, maar nilet er met het oog op én enkel geval in gebracht worden, terwijl al de andere gevallen over het hoofd worden gezien".

Maar: "Intussen is de materie naar mijn meening voor een definitieve wettelijke regeling nog niet rijp". Ter onderbouwing van dit standpunt verwees hij opnieuw naar de verschillende opvattingen die hierover onder rechtsgeleerden bestonden. Hij kon wel begrijpen dat de medici een algemene regeling wensten, maar bij het maken ervan zou zich het probleem voordoen

"als gij gaat spreken van 'medische indicatie', moeten wij weten wat dat is, hoever dat gaat. Welke zijn de beroepsrechten van de medici? Dat is op dit oogenblik een open vraag. Wij moeten weten wanneer er medische indicatie en wanneer abortus

142 HTK 1910-1911, p. 1587.

143 Zie b.v. H. III, onder 9.

144 HTK 1910-1911, p. 1588.

145 HTK $1910-1911$, p. $1588-1589$. 
criminalis is; wij moeten weten -... - of en in hoever tot de medische indicatie ook de sociale indicatie behoort

Hieruit blijkt dat de Minister bij een algemene strafuitsluitingsgrond niet met een open norm als "regelen der geneeskunst" genoegen wilde nemen, om de invulling van die regelen niet aan "gezaghebbende medici" over te laten. De Minister vervolgde zijn betoog met de enigszins kryptische opmerking:

"Ik ben het eens, niet met het Kamerlid van Hamel, (en dus niet met het door deze voorgestelde amendement, JW. ) maar met professor van Hamel: de toestand, zooals die bestaat, is zeer goed. Een goede leerling, die zich aan zijn leemeester houdt. Welnu, ik houd mij, althans wat de niet-urgentie eener wijziging betrefi ${ }^{146}$, aan mijn leermeester den professor van Hamel, ...".

Regout was het eens met de "toestand zooals die bestaat". Maar die toestand liet zijns inziens een definitieve algemene wettelijke regeling nog niet toe, omdat de materie er nog niet rijp voor was. Volgens Regout bestond er evenmin een noodzaak om thans tot een regeling te komen. Daarentegen beschouwde Van Hamell een wettelijke regeling dankzij het beroepsrecht als overbodig. Voor Regout was de uitdrukkelijke erkenning van het beroep op medische indicatie niet overbodig vanwege het beroepsrecht, maar

"gegeven de opvatting van het vervolgingsoffice in de sinds zooveel jaren gebleken praktijk".

En hij wees Van Hamel erop "meer gezag aan het werk wan dien hoogleraar toe te kennen" en

"zich aan diens boek, dat blijft, te houden. Want dat boek is goed gedocumenteerd, het zit wetenschappelijk in elkander en men kan er, althans ten aanzien van de practische conclusië ${ }^{147}$ in deze materle, gerust op bouwen". ${ }^{148}$

De strekking van dit betoog sluit aan bij het in de MvA aangevoerde. Zowel uit het alchaar opgemerkte als het in dit betoog gezegde, kan worden geconcludeerd, dat Regout niet als voorstander van het beroepsrecht kan worden beschouwd.

Van Hamel begon zijn antwoord met de reeds hierboven aangehaalde zin:

"Ik beleef zeker op het oogenblik een van de gelukkigste oogenblikken die men in een loopbaan als de mijne beleven kan en ben daarvoor uiterst dankbaar". ${ }^{149}$ Tegen de bedenking van de Minister, dat de regelen der geneeskunst niet vaststaan, voerde hiif aan; dat de medicus ter zake van "Kunstfehlet" straftechtelijk aansprakelijk gesteld kan worden. Of er sprake was van een "Kunstfehler" zou beoordeeld moeten worden naar de ongeschreven regelen der geneeskunst. Hij vergelleek dit met het geval dat een koetsier iemand overrijdt: Dan zou eveneens naar de regelen der koetsierkunst beoordeeld worden, of er bijvoorbeeld sprake was van culpa. Met dit voorbeeld hoopte Van Hamel te hebben aangetoond; dat

"'de regelen van de geneeskunst' dus wel vormen een begrip, dat bruikbaar is en in foro ook wordt gebruikt en moet worden gebruikt, evenals alle regelen van elke kunst",

Maar dit waren voor hem slechts opmerkingen over details. 
"Wat de hoofdzaak aangaat, heb ik mijn doel absoluut bereikt. Ik heb èn wan de Regeeringstafel, èn van een gezaghebbend rechtsgeleerde aarn de rechterzijde vernomen, dat ik in mijn boek gelijk heb gehad, dat het beroepsrecht van den medicus vaststaat als steunend op het geheel vian ons positieve recht. Om niets anders is het mij te doen geweest dan om die erkenning. Het is zeer zeker cen groote voldoening die ik smaak, dat ik, terwijl vele rechtsgeleerden mij altijd hebben toegevoegd. met dat beroepsrecht kunt gij niets worden, noodig is een uitdrukkelijke uitzondering in de Strafwet zelf, nu in deze Kamer en van den Minister èn van mijo oudleerlingen aan de rechterzijde de erkenning heb verkregen van mijn leer, die ik nu weer opvat en handhaaf: Ik blijf dus met de heeren bij mijn boek en wij trekken het amendement in $^{\text {th }}$. 150

\subsection{Een verschil van mening over de erkenning van het beroepsrecht}

Naar arileiding van de beraadslagingen in de Tweede Kamer merkte Treub ${ }^{151}$ op dat Van Hamel "zich in de luren had laten leggen". Volgens hem had Van Wijnbergen wel het beroepsrecht aanvaard, maar zeker is dat Regout dat niet had gedaan. Het resultaat was dat de situatie voor de medici niet was veranderd.

"De rechtsonzekerheid voor den geneesheer, die op medische gronden abortus opwekt, blijft bestaan en wij weten nu nog bovendien, dat de vraag of de officier van justitie al dan niet het beroepsrecht aanneemt, den doorslag in dezen geeft". ${ }^{152}$

Deze interpretatie van de opvatting van Regout werd door Van Hamel bestreden. ${ }^{153}$ Volgens hem had Regout het beroepsrecht van de medicus erkend. Wel had hij enige reserve betracht, maar die betrof niet het beroepsrecht als zodanig, doch de grenzen ervan in een concreet geval. Dergelijke "grensquaesties" kunnen zich echter bij elk beroep voordoen. Alle beroepen hebben immers hun "grensvragen". En afsluitend luidde zijn oordeel, dat het beroepsrecht zoals hij dit altijd heeft verdedigd door het Kamerdebat nieuwe steun heeft gekregen. Daaraan verbond Van Hamel de raad, dat medici zich geen zorgen hoeven te maken over het ontbreken van een "algemeen uitzonderingsartikel", "dat toch over de grenzen wan uw beroepsrecht geen uitsiuitsel geven zou" is4

Bij dit antwoord valt op, dat juist daar waar de meeste behoefte bestaat aan een beroepsrecht, namelijk bij "grensgevallen", het beroepsrecht, volgens Van Hamel geen oplossing kon bieden. In deze gevallen zijn het blijkbaar ook niet de medici die uitmaken of het geval al dan niet door het beroepsreeht wordt gedekt.

Bij vergelijking van de uitlatingen van Modderman in 1880 en van Regout en Wijnbergen in 1911, over abortus door een medicus, blijkt dat Modderman de terugtred van de wetgever ten aanzien van deze problematiek verdedigde, terwijl Regout de strafrechtelijke aansprakelijkheid niet wilde uitsluiten, zelfs niet als geaborteerd werd, omdat het leven van de vrouw door de zwangerschap werd bedreigd. Hij wenste een regeling, warin nauwkeurig werd omschreven, in welke gevallen de medicus mocht aborteren en sloot de mogelijkheid niet uit dat het ooit tot een zodanige regeling zou komen. Daarentegen

$150 \mathrm{HTK} 1910-1911$, p. 1590 .

151 Treub, NTVG 1911,1, p. $849-352$.

152 Treub, NTVG 1911,1, p. 851 .

153 Van Hamel, NTvG 1911, I. p. 986-989.

154 Van Hamel, NTwG 1911, I, p. 988-989. 
had Modderman juist erop gewezen, dat een dergelijke regeling slechts problemen in het leven zou roepen en bovendien overbodig was.

Evenalls Van Hamel was ook het Weekblad van het Recht van mening dat de Minuster het beroepsrecht had erkend. In overeenstemming met andere juristen in die tijd werd daaraan toegevoegd, dat daarmee echter de wetgever het beroepsrecht nog niet had erkend. De rechter was in die opvatting uitsluitend gebonden aan de tekst wan de wet. Daarom was het nog steeds noodzakelijk dat er een wettelijke uitzondering voor de medicus kwam. ${ }^{155}$ Volgens het Weekblad beriep Minister Regout zich "ook" op het opportuniteitsbeginsel. Maar met Van Hamel was het tijdschrift het eens, dat het opportuniteitsbeginsel niet gebruikt mocht worden om al te ruime uitdrukkingen in de wet goed te praten.

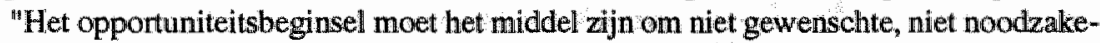
lijke toepassingen van eene strafbepaling te kunnen voorkomen, doch mag niet dienen om den wetgever de gelegenheid te bieden zich er bij de redactie van zijne strafbepalingen af te maken met een beroep op het beleid van het OM."

\subsection{De voorgestelde abortusbepaling in de Eerste Kamer}

Dat de interpretatie van de uitspraak van Regout ten aanzien van het beroepsrecht door zowel Van Hamel als het Weekblad niet juist is, werd bevestigd door het verdere verloop van de behandeling van het wetsontwerp. Uit de MwA op het Verslag der Commissie van Rapporteurs van de Eerste Kamer ${ }^{156}$ blijkt eens te meer, dat de Minister het beroepsrecht niet erkende. Omdat de passage voor zich zelf spreekt, geef ik thar zonder commentaar weer.

"Geheel andere beteekenis had de mededeeling van den ondergeteekende bij gelegenheid van het amendement van den heer VAN HAMEL in zake het artikel over den abortus provocatus; niet eene wetsuitlegging werd daarbij door den ondergeteekende gegeven, doch slechts een vaststaand feit geconstateerd, n.l. dat de practijk van zeer vele jaren had aangetoond, dat het vervolgingsoffice geen strafzaken pleegt aanhangig te maken, waarin beroep op de medische indicatie noodzakelijk zou worden. Hier betrof het dus slechts eene beschouwing over de toepassing van het opportuniteitsbeginsel, niet over de beteekenis der wet. Gedachtig aan zijn uitgangspunt, dat de strafwet niet regelend moet optreden waar de practijk de noodzakelijkheid dararvan niet had aangetoond, meende de ondergeteekende, dat hier geen reden kon bestaan om de wet eene beslissing te doen geven over de tot dusver louter theoretische twistvraag, in hoeverre de artit. 40 en 41 Wetboek van Strafrecht de strafbaarheid van den medicus in zoodanig geval opheffen. En ook over de vraag zelve koos de ondergetekende in dat debat geen partij, omdlat hij meende, dat het aanhangig wetsvoorstel daartoe geen aanleiding behoefde te geven en een theoretiseeren los van de wet tot bedenkelijke gevolgen leiden kan". ${ }^{157}$

Het Eerste Kamerlid Van den Biesen erkende, volgens zijn zeggem, het beroepsrecht. Maar bij een conflict tussen dit recht en bepalingen van het WvSr, dienden de strafrechtelijke bepalingen te worden nageleefd. Wanneer de medicus in strijd met een delictsomschrijving handelt, dan is hij strafbaar, "wil men hem dan niet vervolgen, dan is dat

156 De MVA is opgenomen irt het Eindwerslag der Conmissie van Rapporteurs. HEK 1910-1911, p. 506-517. 157 HEK 1910-1911, p. 510. 


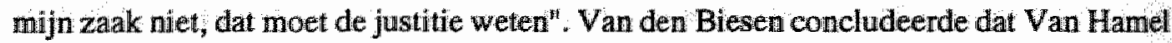
zich "verblijdde.... met een doode musch", toen hij meedeelde, hoe verheugd hij was over de bevestiging van zijn standpunt over het beroepsrecht. ${ }^{158}$ Moeilyk kan Van den Biesen op dit punt tegengesproken worden. In de beperkte strekking die Van Hamel in zijn reactie op het artikel van Treub aan het beroepsrecht toekende, kan zelis een erkenning van het door Van den Biesen ingenomen standpunt worden gelezen.

\subsection{Conclusie}

Het nieuwe art. 251 is $\mathrm{Sr}$ was bedoeld om abortus strafrechtelijk effectiever te kunnen aanpakken, dan met de bestaande abortusbepalingen mogelijk was.

De hoofddoelstelling van de zedelijkheidswetgeving was de bestrijding van de "zedeloosheid". Met de plaatsing van art. 251bis Sr in de titel "Misdrijven tegen de zeden", had de wetgever tol uitdrukking gebracht, dat abortus ook als een zedelijk vraagstuk werd gezien. Dat bracht mee, dat abortus door een medicus nilet uitsluitend aan de regelen der geneeskunst; maar tevens aan zedelijke normen getoetst kon worden.

Tijdens het wetgevingsproces werd veel aandacht besteed aan de strafrechtelijke aansprakelijkheid van de medicus. Daarbij erkende de wetgever het beroepsrecht van de medicus niet, althans niet ter zake van abortus.

Een bijzondere rechtvaardigingsgrond voor de medicus ter zake van abortus werd afgewezen. Tot opname van een algemene rechtvaardigingsgrond voor de medicus wilde de wetgever evenmin overgaan, daar deze te weinig inhoudelijk afgebakend kon worden. Een open norm, zoals "de regelen der geneeskunst", zou volgens Minister Regout aan de individuele medicus te veel vrijheid laten. Dat de medici ten aanzien van abortus één lijn trokken, stond voor hem, gezien de meningsverschillen onder medici over de regelen der geneeskunst, allerminst vast.

De Minister achtte ook geen noodzaak voor een wettelijke rechtvaardigingsgrond voor de medicus aanwezig. Met toepassing van het opportuniteitsbeginsel kon het OM voorkomen dat het tot onnodige vervolgingen kwam. En zelfs al zou dat een keer gebeuren, dan kon volgens hem de rechter alsnog tot straffeloosheid besluiten. Maar op welke grondslag de rechter deze beslissing diende te baseren, bleef onduidelijk. In de zienswijze van de regering van 1881 kon de rechter de gepleegde handeling niet-wederrechtelijk achten, maar dat was niet de zienswijze wan de regering in 1910.

Ten gevolge van de ruime redactie van art. 251 bis $\mathrm{Sr}$ was de rechtsonzekerheid voor de medici verder toegenomen.

\section{Beroepsrecht, medische exceptie en abortus}

De derde dnuk van het leerboek van Van Hamel, die in 1913 verscheen, verschilt ten aanzien van het onderdeel over het beroepsrecht nauwelijks van de tweede druk. Wel geeft Van Hamel expliciet te kennen dat onder abortus op medische indicatie niet abortus op sociale indicatie valt. "Sociale motieven, b.w. vruchtafdrijving om bij de bekrompen omstandigheden der ouders de geboorte van een kind meer te verhoeden, liggen hier 
buiten". Verder venwijst Van Hamel naar de beraadslagingen over art. $251 \mathrm{bis} \mathrm{Sr}$. Ook in het leerboek verdedigt hij dat zowel de Minister van Justitie als de woordwoerder Wan de regeringspartij, Van Wijnbergen, het beroepsrecht van de medicus in zijn zin erkent. ${ }^{160}$ De door Van Hamel gegeven interpretatie van de wetsgeschiedenis van art. 251 bis Sr was, zoals hij zelf erkende, uitzonderlijk. Velen, die voor 1911 voor de straffeloosheid van abortus door een medicus een uitdrukkelijke vrijstelling in de wet nodig achtten, waren van mening dat dit ook voor art. 25 tbis nodig was. ${ }^{161}$

In 1927 merkte Van Dijk in zijn bewerking van het leerboek van Van Hamel op: "Over het geheel verliest het in den tekst gestelle beroepsrecht van den medicus tot ingrijpen in aanhang; hoofdzaak der daarin verdedigde opvatting is intusschen de ontkenning van het wedernechtelijk karakter van dat: ingrijpen ${ }^{\text {: }}$ : 62

Daarmee stelde hij dat niet het beroepsrecht, maar de medische exceptie, of ruimer gezegd het ontbreken van de materielle wederrechtelijkheid steeds meer als rechtsgrond voor de straffeloosheid van de medicus werd gezien.

Zoals eerder opgemerkt, betreft de wezenlijke problematiek van de strafrechtelijke aansprakelijkheid van de medicus voor handelen lege artis niet de grondslag, maar de omvang van het beroepsrecht en daarmee ook die van de medische exceptie. Dat een medicus straffeloos bepaalde handelingen mag verrichten die voor anderen strafbaar zijn is onomstreden. Wie bepaalt echter welke gedragingen van de medicus daardoor van de strafbaarheid zijn uitgesloten?

Van Hamel noemde als voorwaarde voor het beroepsrecht, dat de medicus met inachtneming van de regelen der geneeskunst dient te handelen. Daarvan was volgens hem sprake, wanneer een medisch doel, een medische indicatie en een medisch rationele behandeling aanwezig zijn. ${ }^{163}$

Bij abortus is juist de vraag of met een medisch doel danwel op medische indicatie wordt ingegrepen. Modderman wilde het oordeel over de toelaatbaarheid van handelen van de medicus aan vakgenoten overlaten, maar uitgangspunt voor de toenmalige discussie over deze problematiek was, of in de abortusbepalingen als bevrijdend bestanddeel moest worden opgenomen, dat bij levensgevaar voor de vrouw of de vrucht was gehandeld. ${ }^{164}$ Het is twijfelachtig, of Modderman ten aanzien van abortus op andere gronden hetzelfde standpunt zou hebben ingenomen. Temeer, daar hij een praktische oplossing voorstond, waarbij de niet-strafbararheid van de gedraging in de samenleving (en daarmee ook onder medici) algemeen aanvaard was.

De geschiedenis van de verschillende voorstellen omtrent een wettelijke regeling van abortus en uitlatingen van medici over indicaties voor abortus, laat echter zien, dat hierover allerminst overeenstemming heerste. ${ }^{165}$

159 Van Hamel, 1913, p. 309.

160 Van Hamel, 1913 , p. 312.

161 Vgl. Van Hamel, 1913, p. 310 .

162 Van Dijk, in: Van Hamel, 1927, p. 258.

163 Van Hamel, 1927, p. 255. Zie ook Van Prag, 1885, p. 63-64, die abortus door een medicus "objectief rechtmatig" achtte, onder de voorwaarde dat de medicus de ingreep terecht noodzakelijk heeft geoordeeld. Vgl. De Kuijper, 1905, p. 112-113. Volgens Vos, 1947, p. 195, dient de oplossing " in deze richting" te worden gezocht.

164 Vgl. $\mathbb{H}$. III, onder 2.3.

165 Verderop zall blljken, tot welke moeilijkheden het ontbreken van die overeenstenming bij de aboriusdiscusssie in de jaren zestig en zeventig leidde. 
Abortus is niet uitsluitend een medisch vraagstuk, omdal deze gedraging niet slechts de zwangere vrouw, doch ook het leven van thaar vrucht betreft. De betekenis die toegekend wordt aan de beschermwatrdigheld van het leven van de vrucht is daardoor van invloed op de vraag wanneer er sprake is van geoorloofde of ongeoorloofde abourtus.

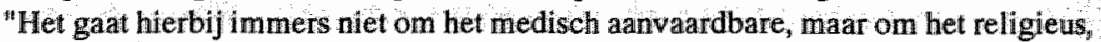
zedelijk cultureel aanwaardbare". ${ }^{16}$

Het beroepsrecht, noch de medische exceptie zijn naar hun aard geschilkt om de straffeloosheid van de medicus voor levensbeschouwelijk omistreden gedragingen te waarborgen. Het verdient daarom aanbeveling het geldingsbereik wan deze rechtsgrond te beperken tot aanvaarde handelingen van de medicus ${ }^{16}$ Vanwege zijn open karakter kan hij binnen dat kader de straffeloosheid van de medicus voor door deze verrichte gedragingen adequaat verklaren. Daartoe is hij meer geschikt dan andere rechtvaardigingsgronden, die immers bedoeld zijn voor uitzonderlijke en individuele gevallen. De aanvaarde gedragingen van de medicus zijn echter voor deze beroepsgroep structureel van aard.

Is een bepaald handelen van de medicus echter omstreden, en is daarmee sprake van een grensgeval van het handelen van de medicus, dan kan - desgewenst - langs twee andere wegen de straffeloosheid worden bereikt.

Ten eerste doordat de strafwetgever de betreffende strafbepalingen niet van toepassing verklaart op professioneel uitgevoerde handelingen van de medicus. Daarvoor kan worden aangevoerd, dat het strafrecht niet regulerend dient op te treden als de strafwaardigheid van een gedraging in de samenleving omstreden is. In die zin had zich Van Hamel tijdens de zedelijkheidswetgeving uitgelaten. ${ }^{169}$ Daartegen kan worden ingebracht, dat de beschermwaardigheid van het menselijk leven en ook dat van de vrucht een dermate belangrijk rechtsgoed is, dat de strafwetgever ook ten aanzien van de medicus in beginsel verbiedend dient op te treden.

Als aan het laatste argument de voorkeur wordt gegeven, dan biedt noodtoestand een goede mogelijkheid voor de straffeloosheid van een medicus. Dat is immers een rechtsgrond, die ondanks zijn rechtvaardigend karakter meer toegesneden is op uitzonderlijke situaties, dan het geval is bij het beroepsrecht en de medische exceptie. Bovendien kunnen op deze wijze zowel het $\mathrm{OM}$ als de rechterlijke macht inspelen op zich wijzigende opvattingen in de samenleving.

\section{Rechtspraak over art. 251 bis $\mathrm{Sr}^{170}$}

Uit de gepubliceerde rechtspraak over handelen in strijd met art. 251 bis Sr blijkt niet dat dit artikel an zijn doel beantwoordde om effectiever tegen (criminele) abortus te kunnen optreden, hoewel, zoals Noyon constateerde, art. 251 bis het "euvel in den wortel"

166 Hazewinkel-Suringa, $1964, \mathrm{p} .198 . \mathrm{Vgl}$ Leenen, $1991, \mathrm{p} .26$

167 Vgl Simons, $1,1927, p_{1} 280-281 ;$ Van Bemmelem/Van Hatrum, I, 1953, p. 370, Hazewinkel-Suringa,
$1964, \mathrm{p}, 195$.

168 Vgl. NLR, ant. 4 op Titel XIXA en Hazewinkel-Suringa/Remmelink, 1991, p. 348 .
169 Zie H. II, onder 11.3. 170 Zie ih. over art. 25 Ibis-oud Sr: Pijls, Algemeen Pollieblad 1968, p. 276-280 en de aantekeningen in
NLR op art. 251 bis (suppl.14). 
aantast en wel zodanig, dat ook "menige handeling strafbaar wordt gesteld al is verstoring van de zwangerschap niet het gevolg, zelfs al kan zij er het gevolg niet van zijn", ${ }^{777}$

Onder het in behandeling nemen van art. 251bis Sr viel ook het geven van raad en middelen tot een behandeling met het in dat artikel omschreven doel. ${ }^{172}$ Tevens was strafbaar een handeling die geen gevolg kon hebben en zelfs wanneer de 'dader' wist dat er geen gevolg van te verwachten was. Voldoende was dat hij het geloof opwekte, dat door zijn handeling zwangerschap werd verstoord, waarbij niet ter zake deed bij wie hij het geloof opwekte. Evenmin was vereist, dat de vrouw zwanger was, of dat de handeling met het doel de zwangerschap te verstoren geschiedde. Ook werd geen onderscheid gemaakt of hoop op of vrees voor abortus was opgewekt. Anderzijds behelsde art. 251bis Sr wel een lacune. Abortus zelf werd door het artikel niet getroffen:

"wordt die bewerkstelligd zonder dat daaromtrent eenige verwachting is opgewekt,

dan is zij straffeloos voor zoover zij niet onder artikel 296 en 297 valt"173, en daarmee onder de abortusbepalingen die in de toepassing grote bewijsmoeilijkheden opleverden. ${ }^{174}$

\section{Opvattingen over abortus}

\section{$14.1 \mathrm{Na} 1911$ tot de jaren vijftig}

Ondanks de voor de medici onbevredigende uitkomst van de zedelijkheidswetgeving 1911 en de verschillende opvattingen van juristen over een mogelijke erkenning van het beroepsrecht door de wetgever van 1911, begon de discussie over abortus zowel onder medici als onder juristen na 1911 tot in de jaren twintig weg te ebben. Wat hiervoor de redenen zijn, kan niet met zekerheid gezegd worden.

Vanwege de wetsgeschiedenis van art, 251 bis $\mathrm{Sr}$, waaraan in het NTVG relatief veel aandacht werd besteed, zou verwacht kunnen worden, dat dat artikel na inwerkingtreding op kritische reacties door medici zou blijven stuiten. Daarvan blijkt echter niet uit het NTvG. Tot de weinige uitlatingen over dit onderwerp in het NTvG, behoren die van Pinkhof, die in 1915 schreef:

"Terwijl in ons land zelfs het opwekken van abortus, al is het niet door de letter, dan toch door den geest der wet ongemoeid wordt gelaten, als daarmede een geneeskundige aanwijzing wordt vervuld, i...175,

en die in 1921 sprak van:

"de zoo bij uitstek practische bepalingen, die ons Wetboek van Strafrecht op dit punt bevat, en sedert de novelle van wijlen minister NELISSEN daarin opgenomen zijn". ${ }^{176}$

171 Noyon, 1926, aant. 1 op art. 251 bis.

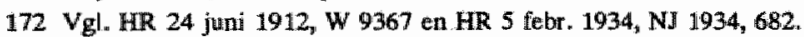

173 Noyon, 1926, aant. 1 op art. 251 bis. (In dat geval lijkt me owerigens voor toepassing van airt. $296 \mathrm{Sr}_{\text {i }}$ dat de toestemming van de vrouw eist, geen mogelijkheid te hebben bestaan.) Zie ook: Van Heijnsbergen en Van Balen Blanken, 1925, p. 38-42.

174 Zie o.a.: HR 27 april 1942, NS 1942, 593.

175 Pinkhof, NTVG 1915, $\mathrm{II}_{\text {, }}$ p. 526.

176 Pinkhof, NTwG 1921, II, p. 598. Maar in NTwG $1936, I_{*}$ p. 336 , merkte hij op, dat reeds in 1909 de AV met bijna algemene stemmen een motie heeft agagenomen, waarin wijziging van de bepaling van art. 251 bis werd gewenst. 
Net uit te sluten is derhalve dat onder medici de opvatting bestond, dat met de zedelijkheidswetgeving de straffeloosheid van abortus door een medicus was erkend, zodat het zwijgen van de medici hierin zijn verklaring heeft. Een andere verklaring is, dat ook de medici zich konden vinden in een verscherpte strafrechtelijke aansprakelijkheid. Een derde reden zou kunnen zijn, dat aan de versehillende argumenten niets meer was toe te voegen.

In 1917 hield de toenmalige voorzitter van de Sectie voor Verloskunde, Kouwer, een voordracht over abortus. "Daarin uitte hij kritiek op de materièle tijdsgeest, die volgens hem te hchtwardig aanleiding gaf tot abortus. ${ }^{78}$ Met betrekking tot abortus merkte hiil op, dat de invloed van de religie zwakker wordt en steeds meer verdedigd wordt, dat de vrouw het recht heeft om over de zwangerschap te beschikken. "De waarde der ongeboren vrucht wordt teruggebracht tot het kleinst denkbare minimum". Dit gedachtengoed had volgens hem eveneens onder medici opgeld gedaan. Daar kwam bij dat de regellen der kunst naar zijn mening minder vast zijn, dan buitenstaanders weleens geloven. ${ }^{179}$

"Alleen zoo is het te verklaren, dat het aantal medische indicaties tot afbreken der zwangerschap in de laatste twintig jaren zoo onheilspellend is toegenomen, en dat ook het gebied, waarop kwnstmatige sterilisatie der virouw op medische gronden verdedigbaar wordt geacht, zich al wijder en wijder heeft uitgebreid. De oude rem werkt niet meerl Men make zich dan ook niet wijs, dat men zich beperkt heeft tot de medische indicaties. Dat kon niet. Bij al onze handelingen als arts hebben wij als voorwerp van onze zorgen een mensch, die door zijn lichamelijke gesteldheid, door zijn karakter, door den maatschappelijken toestand, waarin hij verkeert, verschilt van lederen anderen mensch.

En zoo speelt in onze wijze van behandelen altijd en eeuwig ook de maatschappelijke toestand van onzen patiënt een rol van belang". ${ }^{180}$

In 1926 deelde de toenmalige Minister van Justitie, Donner, mede, dat hij een wijziging van art. 251 bis Sr, zoals die werd bepleit door Van Heijnsbergen en Van Balen Blanken, afwees. Deze stelden voor de strafrechtelijke aansprakelijkheid van de vrouw voor abortus af te schaffen, om zich zo van haar medewerking bij de vervolging van abortus te verzekeren. ${ }^{181}$ Donner had verschillende bezwaren tegen de straffellooshetd van de vrouw. Als eerste wees hij op godsdienstige en zedelijke bezwaren. Verder noemde hij als practische bedenkingen, dat ook dan de vrouw zelden zou meewerken en voor zover zij dat wel zou doen, bleef het bewijs nog moeilijk te leveren. Ten slotte bestempelde hij het denkbeeld, abortus door een medicus niet strafbaar te stellen als "volstrekt verwerpelij]k". ${ }^{132}$

Simons sprak zich in 1929 uit voor een uitzonderingsbepaling die straffeloosheid voor de medicus, die naar de regelen zijner kunst handelt, meebracht. Volgens hem zou een

177 Kouwer, NTwG 1917, 11; p. 1488-1493.

178 Eetrouwbare gegevens over de frekwentie van abortus al dan niel door ansen verricht, ontbreken tot in de junen zastig. Wel bestond de algemene indruk dat abortus veelvaldig voorkwam. Zie hiertoe: Valkhoff, 1934, p. $1-42$ en Kething, 1978, p. 135-136.

179 Kowwer, NTVG $1917, \mathrm{Ir}$, p. 1488-1490.

180 Konwer, NTVG 1917, II, p. 1491.

181 Vgl. Van Heignsbergen en Van Balen Blanken, 1925, p. 112-114,

182 Stantsbegrooting voor het dienstja ar 1926, MvA, Hfdst. IV, p. 20. 
medicus ook zonder medische indicatie straffeloos mogen aborteren, voor zover op verzoek van de vrouw wordt gehandeld. Maar hij erkende, dat een dergelijk voorstel bij de wetgever geen enkele kans maakte. ${ }^{183}$

In 1928 berhaalde Kouwer zijn kritiek op een te ruime toepassing van abortus door medici. Maar ondanks dat hij abortus in ethisch opzicht absoluut ongeoorloofd achite, voelde hij toen wel voor een beperking van de strafrechtelijke aansprakelijkheid van de arts. Daartoe stelde hij voor aan art. 251 bis Sr toe te voegen, dat een arts, die voor de rechter aannemelijk maakt, dat hij op gronden van geneeskundigen aard zich verplicht heeft gevoeld de zwangerschap af te breken, buiten vervolging wordt gesteld. Dat Kouwer een duidelijk onderscheid maakt tussen een zedelijk en een strafrechtelijk verbod, blijkt uit zijn opmerking: "geen afdrijving dan na ernstigen tweestrijd tusschen plicht en het in zedelijk opzicht volstrekte verbod ${ }^{\text {"n }}$. $^{84}$

In de jaren rond 1930 woedde onder de medici opnieuw een hevige discussie over abortus. Dat gebeurde in verband met de Rooms-Katholieke Ziekenfondsen, die eisten dat in overeenkomsten tussen R.K. Ziekenfondsen en de NMG een "moraalclausule" werd opgenomen, volgens welke een deelnemende arts ernstig rekening diende te houden met de R.K. moraal.

Volgens Pinkhof behoorde tot de eerbilediging van de R.K moraal onder andere, dat de medicus niet mocht overgaan tot rechtstreekse vruchtafdrijving van een levende, nog niet levensvatbare vrucht, ook niet met het doel om daardoor het leven van de moeder te redden. ${ }^{185}$ Van Lier wees erop, dat een medicus evenmin een vrouw in levensgevaar mocht adviseren om de zwangerschap af te breken, waarbij hij aantekende, dat naar zijn mening een arts, die opzettelijk een redmiddel verzwijgt, strafrechtelijk vervolgd zou moeten worden. ${ }^{1.86}$

De medici waren over de " moralclausule ${ }^{\text {tt }}$ onderling zeer verdeeld. Katholieke medici stemden er mee in, maar van niet-katholieke zijde werd scherpe kritiek geuit, vooral omdat de clausule als een beknotting van de persoonlijke vrijheid van de medicus werd beschouwd. ${ }^{187}$ Desondanks werden de yoorstellen van het Hoofdbestuur aangenomen, daar op deze wijze een splitsing van de NMG kon worden voorkomen. ${ }^{186}$ In de jaren daarna werd in het NTVG aan abortus nauwelijks aandacht besteed.

183 Zie Silmons, 1929, p. 216-217.

184. Kouwer, NTVG 1928, II, p. 5886-5892.

185 Pinkhof, NTvG 1928, I, p. 253 en Nijhoff, NTvG 1930, II, p. 4606. Ook was het, volgens Pinkhof, niet toe gestawn "pijnwerdowende" middelen te versinekken, die "tevens" tot doel hadden, on de dond te verhaasten en diaardoor pijnen te verkorien.

186 Virn Lier, NTVG $1930, \Pi, \mathrm{p} .6201$.

187 Zie voor negatieve en positieve reacties $0.2 ;$ NTVG $1928, \mathrm{l}, \mathrm{p} .142-144 ; \mathrm{p} .486-488$; NTwG $1930, \mathrm{I}, \mathrm{p}$. 1303; p. 1811; p. 2053; p. 2298-2299; p. 2603-2604; NTWG 1930, II, p. 3983-3985; p. 4601-4609; p. 4628-4634; p. 6015; p. 6199-6201; NTVG 1931, 1, p. 168-169. Ook Kowwer liet zich daarover krit isch uit; zie: NTVG 1931, II, p. 2009-2011.

188 Zie NTVG $1930, \mathrm{I}, \mathrm{p} .4628-4634$. 
In hoeverre voor het abortuswraagstuk in de jaren vijftig tot medio jaren zestig in medische kring belangstelling bestond, is vanwege het stilzwijgen dat in die tijd over abortus heerste, moeilifk vast te stellen.

"Er verschenen geen artikelen meer over het onderwerp; er vonden geen veroordelingen van artsen meer plaats en niemand had er kennelijk behoefte aan om het vraagstuk in het openbaar ter diskussie te stellen". 189

Onderzoeken naar abortus waren grotendeels gebaseerd op vooroorlogs materiaal en trokken nawwelijks de aandacht. De resultaten van twee soortgelijke onderzoeken uit 1954 en 1960 werden pas in 1967 gepubliceerd, dus nadat de openbare discussie over abortus op gang was gekomen. ${ }^{100}$

De houding van de medische stand ten aanzien van abortus was afwijzend. ${ }^{191}$ In het "Blauwe Boekje" van de KNMG werd abortus slechts behandeld in het hoofdstuk "De arts en de godsdienst" ${ }^{192}$ Er werd op gewezen dat de arts daarbij met de levensbeschouwing van zijn patiënten rekening dient te houden, maar in

"ons land waarborgen de medisch-ethisehe inzichten van de artsen gelukkig een grote mate van zekerheid, dat de medische indicatiestelling zelden in conflict zal komen met de religieuze opvatting van de patiënt, het zal voor de artsen daarom in het algemeen niet al te moelijk zijn" daarmee rekening te houden. ${ }^{193}$

In 1965 merkte de redactie wan het MC op:

"Nog steeds geldt algemeen de opvatting dat het verwijderen van een jonge graviditeit op andere dan de overigens zeer schaarse medische indicaties medisch-ethisch verwerpelijk en reeds uit dien hoofde ongeoorloofd is; daarnaast is er het uitdrukkelijke wettelijke verbod en de strafbaarheid bij overtreding daarvan" "194.

In 1966 gaf de redactie van het NTvG te kemnen, dat zij niet (veel) voelde voor legalisering van abortus op socialle indicatie. ${ }^{195}$ Muntendam achtte in hetzelfde jaar abortus slechts toelaatbaar in verband met het leven van de vrouw en eventueel nog vanwege de gezondheid van de vrouw in enge zin. Maar als abortus op sociale indicatie zou worden toegelaten, dan zou het hek van de dam zijn. ${ }^{196}$

\subsection{Vanaf het midden van de jaren zestig}

Vanaf het midden van de jaren zestig stond het abortusvraagstuk opnieuw in de belangstelling. Dat had volgens De Bruijn ${ }^{197}$ drie redenen. Anticonceptionele middelen werden geperfectioneerd en vonden ruimere toepassing. De medisch-technische ontwikkeling rond kunstmatige inseminatie, sterilisatie, eugenetiek, reanimatie en euthanasie leidde.

189 Ketting, 1978, p. 62. Zie ook Outshoorn, 1986 , p. 101 en 107.

190 Zle De Bruiju, 1979 , p. 166.

191 Vgl. Ketting, 1978, p. 64 en Outshoorn, 1986, p. 103.

$192 \mathrm{KNMG}, \mathrm{M}$ cisishe Ethiek en Gedragsleer, 1959; p. 259 e.v.

$193 \mathrm{KNMG}$, Medische Ethiek en Gedragsleer, 1959, p. 273.

194 Redictie MC, MC 1965, p; 909.

195 Redactie NTwG, NTwG 1966, $1, p_{n} 253-254$.

196 Muntendam, NTWG 1966, II, p. 1340-1341.

197 De Bruinn, 1979, p. 176-180. Zte ook Ontshoorn, 1986, p. 111 e.v. en Ketting, 1978, p. 65 e.v. 
tot een discussie over begin en einde van het menselijk leven. Ten derde stimuleerden de in het buitenland gevoerde discussies en wetswijzigingen over abortus de abortusdiscussie in Nederland ${ }^{199}$

In 1969 werd de "Stichting voor Medisch Verantwoorde Zwangerschapsafbreking"t, STI-

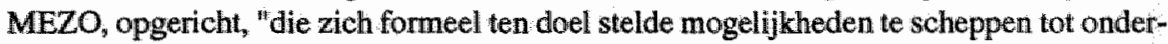
breking van zwangerschap binnen de grenzen van het recht en zonder winstoogmerk" . ${ }^{199}$ Een commissie die het Hoofdbestuur van de KNMG ter bestudering van het abortusvraagstuk in het leven had geroepen, bracht in hetzelfde jaar haar advies uit, ${ }^{200}$

In het begin van het advies merkte de commissie op, "dat welke normen ook zouden gelden voor geoorlloofde toepassing van abortus, er in elk geval grote behoefte bestaat aan de opstelling van z.g. procedureregels" ${ }^{201}$ Verderop gaf de commissie hiertoe enkele overwegingen. Zij was van mening dat de beslissing door één medicus genomen dient te worden. Bij de besluitvorming moeten wel tenminste twee andere artsen betrokken worden. De ingreep dient in een ziekenhuis te geschieden en mag slechts plaatsvinden als de patiënt toestemming heeft verleend. Bij een minderjarige patiënt dienen de ouders toestemming te geven. Verder spreekt de commissie zich uit voor een geanonimiseerde meldingsplicht. ${ }^{202}$

Volgens de commissie was naar de algemene rechtsopvatting de medicus niet strafbaar, die "handelend volgens de in medische kringen aanvaarde normen inzake de uitoefening van het medisch beroep" de abortieve ingreep verricht. Maar het probleem was juist, constateerde de commissie, dat onduidelijk is, wanneer een abortus binnen die norm valt. ${ }^{203}$ Aan de commissie was gebleken, dat onder artsen over de geoorloofdheid van abortus verschillend wordt gedacht. ${ }^{204}$ Een aantal artsen wilde abortus slechts toestaan indien het leven van de moeder "direct" werd bedreigd. ${ }^{205}$ Andere artsen achtten abortus geoorloofd bij bedreiging van de lichamelijke en/of de geestelijke gezondheid van de vrouw. ${ }^{206}$

De vele discussiebijdragen over abortus, die vanaf de tweede helft van de jaren zestig in Medisch Contact, dat sinds 1945 het officiêle orgaan van de KNMG is, en in het Nederlands Tijdschrift voor Geneeskunde werden afgedrukt, tonen de verscheidenheid van opvattingen die toen onder medici over deze kwestie leefde. ${ }^{207}$

198 Hiervan blijkt 0.a. uit: De Winter, 1966; NTvG 1964, I, p. 484-485; NTvG 1966, l, p. 253-254; NTyG 1965 , I, p. 672 ; NTVG 1965 , II, p. 1448.

199 Ketting, 1978, p. 87 e.v. Zie voor kritische reacties op deze oprichting: MC 1969, p. 1015 en MC 1970, p. 1286-1287.

200 Hoofdbestuur KNMG, MC 1969, p. 19-23.

201 Hoofdbestuur KNMG, MC 1969; p. 21.

202 Hoofdbestuur KNMG, MC 1969, p. 23.

203 Hoofdlsestur KNMG, MC 1969, p. 21.

204 Zie ook: Schuurmans Stekhoven, NJB 1970, pi 1007.

205 Hoofdbestur $\mathrm{KNMG}_{n} \mathrm{MC} 1969$, p. 22. Waarbiji de conmuissie opmerkt, dat zich dergelijke gevallen thans niel meer woordoen.

206 Hoofdbestuur KNMG, MC 1969, p. 22.

207 Zie voor een overzicht tot in 1968: Reitsma, MC 1968, p. 77-79, die constateerde dat de discussie gaat over indicaties op grond van "medisch-psychologische, sociale en existentielle problemen", waartussen geen scheiding mogelijk is: 
Volgens sommigen bestonden inmiddels ruimere opwattingen over het recht op zelfbeschikking, dientengevolge de vrouw over abortus moest kunnen beslissen. ${ }^{208}$ Daarom werd gepleit voor een wetswijziging, op grond waarvan abortus door een arts niet strafbaar behoorde te zijn. ${ }^{209}$

Anderen zagen het als taak van de medicus abortus terug te dringen. ${ }^{210}$ Daartoe werd aangevoerd, dat abortus ingaat tegen de diepste overtuiging ${ }^{211}$, dat de vrucht een contraindicatie tegen abortus is ${ }^{2 / 2}$ en dat het belangenconflict tussen vrouw en vrucht onderkend diende te worden ${ }^{213}$. Abortus is een noodoplossing in een noodsituatie: ${ }^{214}$

Voor artsen, die een tussenpositie innamen zou abortus altijd een dilemma blijven. ${ }^{215}$ Door hen werd abortus niet principieel afgewezen noch geoorloofd geacht. Deze artsen wensten bijvoorbeeld waarborgen voor de zorgvuldigheid van de ingreep. ${ }^{216}$.

Een in 1973 gepubliceerd onderzoek onder Nederlandse medici toonde aan dat bij de houding ten aanzien van abortus de belangrijkste factoren de godsdienstige overtuiging en de politieke voorkeur waren. Uit een in 1976 gepubliceerd onderzoek $^{217}$ kwam naar voren dat de gynaecologen het meest terughoudend tegenover abortus stonden. ${ }^{218}$ Van die houding blijkt ook uit het Rapport van de Nederlandse Gynaecologische Vereniging over abortus. ${ }^{219}$ Abortus werd alleen toelaatbaar geoordeeld bij zeer ernstige gevaren voor de vrouw of haar omgeving. ${ }^{220}$ Volgens het rapport speelt bij abortus een bellangenconflict en is abortus slechts toelaatbaar in een noodsituatie die niet anders kan worden verholpen. ${ }^{221}$ Tevens werd benadrukt dat een beslissing over abortus uitsluitend door de behandelende arts dient te worden genomen. De arts moet zijn beslissing voor zijn geweten als medicus kumnen verantwoorden, maar hij dient tevens in overeenstemming met de regels van zijn beroep te handelen. Vanwege een mogelijke strafvervolging werd het wan het grootste belang geacht, dat de arts een abortieve ingreep zo goed mogelijk documenteert. ${ }^{222}$

209 B.w. Schucking Kool, MC 1967, p. 933-934 en MC 1968, p. 241-244; Passier-Meijer, MC 1968, p. 352; Van Schowwen, NTVG 1969, I, p. 1861; Roest, MC 1970, p. 426-428; Pols, MC 1970, p. 977-981; A.J. Molenaar, NJB 1973, p. 384-385; Romijn, NJB 1973, p. 919.

209 O.a. Van Urk, MC 1968, p. 209-213, MC 1969, p. 383-384 en MC 1970, p. 425-426, Hallie, MC 1970, p. 199-200; Kroyver, MC 1970, p. 283-285. Van Urk, MC 1968, merkt op p. 213 op, dat het wanwege de uiteenlopende opwattingen niet goed mogelijk is indicaties in de wet op te nemen. Wel mogetijk is abortus door onbevoegde strafbaar te stellen en de arts van de stralbaarheid uit te zonderen. Volgens Hallie, MC $1970, p, 200$, is abortus een medische ingreep, tenzij contraindicaties anwwezig zijn.

210 Schulte, MC 1967, p. 989-990.

211 Tideman, MC 1967, p. 1201.

212 Ogilvie, $\mathrm{MC} 1967$, p. 1201-1202.

213 Sichulte, MC 1970, p. 781 782, die zich daarom tegen het voorstel Lamberts/Roethof wiltsprak. Zie ook Heering, MC 1969, p. 289-290; Van Doom, MC 1966, p. 21: abortus behoort slechts op strenge indicaties gelegaliseerd te worden.

214 Schulte, MC 1975, p. 231. Heering, MC 1969, p. 289-290.

215 Pu.F. Dupuis, MC 1970, p. 783-785. Op p. 785 noemt hij abortus een bijzondere medische ingreep.

216 Haspeis en Mante, MC 1971, p. 105-106.

217 Persoon en Sturmans, MC 1976, p. 649-655,

218 En de psychiaters het neest permissief. Vgl. ook Ketting, 1978, p. 65.

219 Rapport van de Nederlandse Gynaecologische Vereniging, MC 1969, p. 59-64

220 Rapport van de Nederlandse Gynaecologische Vereniging, MC 1969, p. 63, waarmee - volgenss Van Urk, MC 1969, p. 485 - de psycho-sociale indicatie werd erkend.

221 Rapport wan de Nederlandse Gynaecologische Vereniging, MC 1969, p. 59

222 Rapport wan de Nederlandse Gynaecologische Vereniging, MC 1969, p. 62-63. 
De Commissie van de Nederlandse Vereniging woor Psychiatrie en Neurologie sprak zich in haar rapport over abortus in $1970^{223}$ voor een "ja, tenzij-houding" wit en in verband daamee voor het afschaffen van de abortusbepalingen in het WvSr, althans voor zover deze de aansprakelijkheid van de medicus en de vrouw betroffen ${ }^{224}$ Daarentegen drong de Nederlandse Vereniging van Anthroposofische Artsen er op aan, dat de wetgever het recht op leven van de ongeborene beschermt. ${ }^{225}$

Ondanks de verschillende opvattingen werden in 1971 de door het Hoofdbestuur van de KNMG voorgestelde Richtlijnen voor abortus ${ }^{226}$ in de Algemene Vergadering aanvaard.

In deze Richtlijnen werd voor het begrip gezondheid de omschrijwing van de WHO gehanteerd, volgens welke

"Gezondheid (...) een toestand van volledig lichamelijk, geestellijk en sociaal welzijn

(is) en niet slechts afwezigheid van ziekte of zwakheid".

Abortus werd een uiterste oplossing genoemd, die hoge eisen stelt aan de zorgvuldigheid en de besluitvorming. Het besluit tot de ingreep dient door minimaal twee artsen te worden genomen, die desgewenst andere deskundigen kunnen inschakelen. De ingreep moet plaatsvinden in algemene ziekenhuizen of in inrichtingen, die aan bepaalde eisen moeten voldoen. Van elke ingreep behoort de arts een verslag te maken.

Daar volgens de KNMG de individuelle gevallen voor abortus te zeer verschillen; is het niet mogelijk in duidelijke indicaties te voorzien. Als reden werd opgegeven, dat indicaties geen steun kunnen bieden. Vanwege de persoonlijke interpretatie door de arts zijn er immers geen objectieve maatstaven. ${ }^{227}$ Daarom was het nodig de grootste zorgvuldigheid via zogenaamde procedureregels te bevorderen. Abortus werd echter slechts geoorloofd geacht, wanneer de zwangerschap ernstige consequenties heeft voor het leven of het welzijn van de vrouw. Ten aanzien van een registratie was het standpunt terughoudend. 228

In een door circa 200 artsen ondertekend rondschrijven werd sterk afwijzend op de Richtlijnen 1971 gereageerd. Abortus mag naar hun mening slechts bij "zeer hoge uitzondering" wonden verricht. Volgens het rondschrijwen is het door de WHO gehanteerde gezondheidsbegrip wel bruikbaar om de aandacht van de arts ook op andere dan somatische aspecten te vestigen. Dat begrip mag echter niet worden gebruikt om daarmee elke abortus te rechtvaardigen. De grens van het medisch handelen is gelegen in de door de World Medical Association in 1948 afgekondige norm van de absolute norm van het mensellik leven. Het rondschrijven sloot af met de dreiging, dat het Hoofdbestuur van de KNMG zijn

223 Commissie wan de Nederlandse Vereniging voor Psychiatrie en Neurologie, MC 1970, p. 143-154.

224 Commissie van de Nederlandse Vereniging voor Psychiatrie en Neurologie, MC 1970, p. 154. In dlezelfde zin, maar met een grotere nadruk op de wens van de mouw: Rapport van het Nederlands Gernootschap voor Medische Sexuologie over het abortusvrangstuk, MC 1970, p. 279-281. Kritisch m.b.t. het rapport van de eerstgenoemde commissie merkte Pannekoek, MC 1970, p. 283, op, dat het geweten vin de arts bij iedere beslissing een rol speel, dar anders een werkelijke gemeesikunde ondenkbaar is.

225 Nederlandse Vereniging van Anthroposofische Artser, MC 1970, p. 1285-1286.

$226 \mathrm{MC} 1971$, p. 1025-1027.

227 Hoofdbestuur KTMG, MC 1971, p. 1168. Zie ook: MC 1970, p. 1012-1014. In dezelfde zim: Van Urk, MC 1968, p. 209-213. Zie ook Kruyver, MC 1970, p. 273-285, die zich op p. 285 tegen een indicatiestelling in een weit witspreekt.

228 Zie over deze A.V. ook: MC 1972, p. 714-716. 
standpunt dient te herzien, daar anders vele opzeggingen voor het lidmaatschap van de KNMG het gevolg zullen zijn. ${ }^{22 *}$

Het Hoofdbestuur voerde in een reactie op dit rondschrijven aan dat de Richtlijnen van elke "levensbeschouwelike of maatschappelijke visie" ontdaan zijn, zodat iedere arts zich daarin kan vinden. De Richtlijnen behelzen geen "geoorloofde indicaties", aldos het Hoofdbestuur, omdat deze geen reëel houvast bieden. "Iedere arts pleegt daaraan een persoonlijke interpretatie te geven"

Een aantal artsen dat de Richtlijnen te liberaal vond, verenigde zich in het Nederlands Artsen Verbond (NAV), ten aanzien waarvan de Stuurgroep wan het Abortus Protest als voorloper kan worden beschouwd. ${ }^{231}$ De Stuurgroep benadrukte de absolute eerbied voor het menselijk leven en wees de Richtlijnen 1971 af. ${ }^{232}$ Ter eerbiediging van het recht op leven van de vrucht, werd eveneens in 1971 de Stichting voor het ongeboren kind opgericht.

In 1975 stelde het Hoofdbestuur voor de Richtlijnen uit 1971 te wijzigen. ${ }^{234}$ Er bestond bij het Hoofdbestuur twijfel, of de Richtlijnen uit 1971 in de praktijk op de juiste wijze werden toegepast, met name ten aanzien van de zorgvuldigheid van de besluitvorming en de uitvoering. Daarom wilde het Hoofdbestuur de Richtlijnen aanvullen met een regeling woor een regelmatige toetsing door een landelijk toetsingscollege. Zijn taak zou zijn het beoordelen van het functioneren van de artsen bij abortus en de beoordeling van de inrichtingen. Indien aan het college blijkt dat zijn nadere aanwijzingen niet of onvoldoende worden opgevolgd, dan dient dararan melding te worden gemaakt bij de Hoofdinspecteur voor de volksgezondheid, die de tuchtrechter kan inschakelen of aangifte kan doen bij het OM.

De Algemene Vergadering vond de Richtlijnen uit 1971 toereikend en wees derhalve het voorstel af ${ }^{235}$, waarna thet door het Hoofdbesturur werd ingetrokken. ${ }^{236}$

\section{Rechtspraak over abortus lege artis door een medicus}

Tot in de jaren veertig is ower abortus geen rechtspraak gepubliceerd, waaruit blijkt dat een medicus zich ter straffeloosheid op een bepaalde indicatie respectievelijk op een rechtvaardigingsgrond beroept. ${ }^{237}$ Vermoedelijk werden medici vanwege abortus ook naw elijks vervolgd. ${ }^{238}$ De rechtsonzekerheid die bij medici ten aanzien van abortus.

229 Hot rondschrijven over de richtlijuen inzake abortus provocatus, MC 1971, p. 1197-1198.

230 Hoofdbestiur KNMG, MC 1971, p. 1167-1168.

231 Vgl. Outshoom, 1986, p. 181 en p. 204-205 en Lindeboom, Tegen de stroom in - Tien jarar Neder lands Artsenverbond; woordracht van 26 nov, 1982. Zie voor het standpunt van de Stuurgroep inzake gbortus: MC 1971 , p. 1331-1333.

232 Nemens de Stuurgroep van het Atortus Protest; MC 1971, p. 1331-1333:

233 NTVG 1971, I, pi 83 an MC 1971, p. 104.

$234 \mathrm{MC} 1975$, p. $350 \times 352$.

235 MC 1975, p. 519-520.

236. Abortuswetgewing, MC 1976, p. 1071 e.w.

237 Zie biv: HR 25 juni 1923 , NJ 1923, 1296; HR 25 nov, 1929, NJ 1930, 141; Rb. Utrecht 19 febr. 1938 ,
NJ 1938; 333 .

238 Vgl. Van Dam van Isselt, 1902, p. 115; Simons, NTvG 1905, I, p. 1309-1310 en Van Heijnsbergen en Van Balen Blainken; 1925, $p, 71-72$. 
leefde, was daarom waarschijnlijk eerder weroorzaakt door de tekst van de betreffende bepalingen, het juridisch debat over hun aansprakelijkheid en uitlatingen van politici, dan door de juridische praktijk.

Na 1940 zijn over de aansprakelijkheid van de medicus voor abortus enkele uitspraken van lagere rechters verschenen, waarbij de vraag aan de orde was, in hoeverre het de medicus geoorloofd was de ingreep te verrichten. Daaruit blijkt allereerst dat het voor de straffeloosheil niet voldoende was, dat een medicus bevoegd was tot de beroepsuitoefening. Tevens kan daanuit worden opgemaakt dat het (uiteindelijk) niet de medici waren, die bepaalden op grond van welke indicatie abortus straffeloos mocht worden verricht, en bovendien dat de lagere rechtspraak het begrip medische indicatie steeds ruimer ging invullen.

De rechtbank Amsterdam van 5 febr. 1942, NJ 1942, 244, overwoog ter zake van art. 251 bis $\mathrm{Sr}$, dat "een zeer ernstige overspanningstoestand met direct suicidegevaar" een rechtvaardigende medische indicatie is, waarmee zij erkende dat in een geval waarin de zwangerschap voor de vrouw (indirect) levensbedreigend is, abortus gerechtvaardigd kan zijn. ${ }^{239}$

Enkele jaren later werd een medicus ter zake van overtreding van art. 251 bis Sr door de rechtbank Amsterdam van 20 jan. 1949, NJ 1949, 596, veroordeeld, waarbij de recht bank overwoog, dat abortus door een medicus slechts toelaatbaar is op geneeskundige gronden, dat de arts "wist; althans moest begrijpen, dat zowel naar Nederlands recht als maar hier te lande heersende begrippen omtrent bercepsplichten van geneeskundigen, verstoring van zwangerschap niet toelaatbaar is op maatschappelijke gronden, noch op andere gronden dan geneeskundige: te weten indien ter rechtstreekse beveiliging van de lichamelijke of geestelijke gezondheid ener zwangere vrouw, die ingreep volstrekt noodzakellijk is".

Daarmee erkende de rechtbank ook de psychische indicatie. Maar zij hield wel een slag om de arm. Dat blijkt uit het woord "rechtstreeks" en uit de zinsnede, dat de ingreep "volstrekt noodzakelijk" moet zijn. ${ }^{240}$

De van overtreding van art. $297 \mathrm{Sr}$ verdachte medicus stond voor de keuze "de zwangerschap af te breken ten einde te voorkomen, dat de ziekte van zijn vrouw (multiple sclerose, J.W.) in ernstige mate zou verergeren dan wel de zwangerschap te doen voortbestaan met als waarschijnlijk gevolg dat de moeder en mogelijk ook de vrucht te gronde zouden gaan". Omdat de verdachte in een noodtoestand verkeerde, toen hij voor deze keuze geplaatst de vrucht afdreef, stelde het hof Den Bosch hem in een bezwarschriftprocedure buiten vervolging. ${ }^{241}$

239 Volgens De Bruin, 1979, p. 167-168; Enschede, Cahier Van Hamel no. 6, 1970, p. 10, en Pijli ${ }_{\text {in }}$ Algenmeen Politieblad, 1968, p. 255 , heeff de rechtbank de psychiatrische indicatie erkend.

240 Volgens De Brujjn, 1979, p. 268, liet de rechtbank daamee bepaajde sociale elementen in de indicatiestelling toe. Frenkel las in de uitsprak geen erkenning van een sociale indicatie, NJB 1970, p. 1400; maar hiji vestigde wel de aandacht op de verwijzing door de rechtbank naar de beroepsplichton. Zle ook Frenkel, MC 1970 , p. 807 en Frenkel, MC 1971, p. 51.

241 Hof Den Bosch, 22 dec. 1953, NJ 1954, 161. 
Op 26 maart 1953, NJ 1953,377, werd een medicus vamwege overtreding van art. 251 bis Sr veroordeeld. De rechtbank Amsterdam overwoog toen, dat de wet van de arts niet vergt

"dat hij het leven zijner vrouwelijke patiënten in voorkomende gevallen kritiekloos opoffert aan het jonge leven, dat die vrouwen zouden kunnen voortbrengen, noch ook dat hij ernstige en blijvende benadelingen van hare lichamelijke of psychische gezondheid zoude moeten gedogen om dit doel te bereiken, doch die zeker niet toestat het hier in het geding zijnde - door de wet beschermde - belang op te offeren aan het geheel persoonlijk imzicht van een geneesheer in de levensdoeleinden van zijn patiënte en in de mogelijkheid en de wenselijkheid van het nastreven of bereiken daarvan, behorende de beoordeling van deze waarden immers geenszins tot de speclfieke medische taak".

Athankelijk van de inhoud die aan het begrip "sociale indicatie" wordt toegekend, namelijk of daaronder ook wordt begrepen de psychische gezondheid en - in het verlengde daarvan - de psycho-siociale gezondheid, kan verdedigd worden, dat in deze uitspraak al dan niet de sociale indicatie als rechtvaardigingsgrond werd erkend. Expliciet uitgesloten heeft de rechtbank slechts het handelen op "geheel persoonlijk inzicht" van de arts. ${ }^{242}$

In $\mathbb{R b}$. Amsterdam, 8 juli 1976, NJ 1977, 477, overwoog de rechtbank ter zake van art. 251 bis Sr, dat het handelen van een medicus gerechtvaardigd is, wanneer hij op medische indicatie aborteert. Tot die indicatie rekende de rechtbank ook de "sociale indicatie". Of een medische indicatie aanwezig is, staat in beginsel ter beoordeling van de arts en word bij een abortus door een medicus verondersteld.

Hiermee niet in strijd is de uitspraak van het Hof Arnhem, 19 okt. 1976, NJ 1977, 10, dat in het kader van een procedure ex art. $12 \mathrm{~Sv}$, de vervolging van een arts ter zake van art. 251 bis Sr beval. Het hof sloot niet uit, dat een psycho-sociale indicatie een rechtvaardiging voor abortus kan opleveren, maar was in deze zaak vanwege een combinatie van factoren van oordeel dat strafvervolging was aangewezen. Die factoren betroffen de leeftijd van het meisje (1.6 jaar) in verband met een door het meisje gefingeerde schriftelijke toestemming van de ouders tot de ingreep, de indicatiestelling (uitsluitend psycho-sociaal) en onvoldoende onderzoek voorafgaande aan de ingreep.

Uit deze uitspraak kan niet worden afgeleid, welke rol het hof aan de minderjarigheid van het meisje als zelfstandige factor heeft toegekend.

Volgens het Hof Den Haag, 9 aprill 1979, TvGR 1979/95, is abortus op medische indicatie, waaronder het ook abortus op sociale gronden begreep, niet strafbaar. ${ }^{243}$

242 Wel erkend: Frenkel, MC 1970, p. 807 en MC 1971, p. 51-52; NLR aant. 2 op Titel XXX. Niet erkend: Enschede, NJJ 1966, p. 1117 , Valkhof, Ten geleide, in De Winter, 1966, p. 8; Pijls Allgemeen Politieblad
1968 , p. 255.

243. In de uitspratak wan het Gerecht in eerste andeg Aruba van 14 maart $1980_{*}$ NJ 1981, 97, werd abortus op uitsluitend de wens van de vrouw ongeoorloof geacht, terwijl volgens de rechter van een psychische
(of een andere) indicatie niet was gebleken. 


\section{De opvatting vain Enschede}

In 1966 verscheen, op verzoek van de gynaecoloog Kloosterman" ${ }^{244}$, het artikel "Abortus op medische indicatie en strafrecht" wan Enschedé in zowel het NJB als in het NTvG. ${ }^{245}$ Daarin beantwordde hij de vraag, of "het nodig is, ter waarborging van de straffeloosheid van abortus op medische indicatie, in de wet een schriftelijke bepaling op te nemen", ontkennend. ${ }^{246}$ Ter staving van zijn standpunt verwees hij naar uitlatingen wan Modderman in 1880, van Regout in 1910 en naar het Huizer veeartsarrest van 1933. Hij kwam tot de slotsom:

"naar geldend recht pleegt de arts, die op medische indicatie een zwangerschap afbreekt, geen strafbaar feit; hij moge een delictsomschrijving hebben vervuld, maar; omdat hif deed wat wenselijk was, valt de wederrechtelijkheid ondanks het vervuld zijn van een delictsomschrijving weg". 247

Daaraan deed niet af dat het begrip "medische indicatie" van inhoud gewijzigd was.

"Het lijdt geen twijfel dat het begrip "medische indicatie" nu een andere en ruimere betekenis heeft dan bijvoorbeeld in de tachtiger jaren van de vorige eeuw, maar dat neemt niet weg dat het bimnen het juridische stelsel op overeenkomstige wijze kan functioneren", ${ }^{248}$

De rechtsgrond voor de straffeloosheid van de medicus was in de opvatting van Enschedé een ongeschreven rechtsgrond, te omschrijven als: de medicus die op medische indicatie aborteert, pleegt geen strafbaar feit, omdat hij doet wat rechtens wenselijk is en daardoor ontvalt de wederrechtelijkheid aan de gedraging. ${ }^{24}$

Ondanks dat Enschedé op deze wijze het ontbreken van de materiële wederrechtelijkheid als strafuitsluitingsgrond voor abortus op medische indicatie, maar wellicht ook de medische exceptie, had verdedigd, pleitte hij in 1970 voor een wijziging van de abontusbepalingen. ${ }^{250}$ Enschedé bestreed dat hij daarmee zijn eerder standpunt had gewijzigd: 251

Volgens Enschedé eiste de medische ethiek in 1970 voor abortus een medische indicatie. Het was best mogelijk dat de medische ethiek op den duur abortus zondermeer zou

$244 \mathrm{Vgl}$. Kloosterman, in: Ad personam, 1981, p. 155-160.

245 Enschedé, NIB 1966, p. 1109-1118. Hel artikel verscheen eveneens in het NTVG 1966, p. 1349.1353. Zie woor de doorwerking wan het artikel onder medici, b.v. MC 1969, p, $21-22$ en Nedertandse Verenuging woor Psychiatrie en Neurologie; MC 1970, pi 145. Zie voor kritiek op het standpunt van Enschede b; $w$. de jurist Kortmann, MC 1970, P. 1284-1285, die, uitgaande van cen bellangenconflict tussen vrourw en wruch bij abortus, stelt, dat niet elk "redelijk" belang van de vrouw abortus rechtwardigh, omdal ook het midde] redelijk dient te zijn. Dit betreft een normatieve kwestie, waarop niet alleen medici een antwoord moeten geven, marar vooral de wetgever.

246 Enschedé, NIB 1966, p. 1109.

247 Enschede, NJB 1966, p. 1114. In dezelfde zin: Pijls, Algemeen Politieblad, 1968, p. 255.

248 Enschede, NIB 1966, p. 1114.

249 Zie Enschedé, NJB 1966, P. 1113-1117, warmee hij voor de invulhing wan het onibreken van de materiële wederrechtelijkheid bij Langemeijer aanshoot. Zie Noyon-Langemeijer, 1954, arant. 1 op Indeiding. In dewellde zin: Frenkel, NJB 1970, p. 1399-1401; Frenkel, De Gids 1969, p. 283 e.v ; Frenkel, MC 1970, p. 805-813; Van Bermulen, I, 1975, p. 228; Van Bemmelen, ind, 1981, p. 22,

250 Enschede, NJB 1970, p. 718-720. Zie cok EnschedE, Cahier Van Hamel no. 6, 1970, p. 15 en NJB 1970, p. 1398 .

251. Enschede, NJB 1980, p. 719. In NJB 1978; p. 1002, schreef hij wel, dat anders dam ik woen (in 1966, J. W. Jacht - thet vraagstuk niet zonder hulp wan de wetgever" kan worden opgelost. Volgens $0 . a$, Leenen, 1988 , p. 133, was er wel sprake van een wijziging. 
toestaan, behoudens contraindicatie. De wet dient voor een dergelijke ontwikkeling van de medische ethiek de rümite te laten. Maar de "schijnbaar absolute abortusverboden in onze strafwet" werken remmend op de medische ethiek. Daarom pleitte Enschede voor een wetswijziging van de abortusbepalingen. Hij dacht daarbij aan een algemene strafbaarstelling voor abortus en aan een rechtvaardigingsgrond voor de medicus. De ingreep door een medicus is gerechtvaardigd als hij op verzoek van de vrouw plaatsvindt en wel met inachtneming wan enkele andere voorwaarden, die tezamen als behoorlijke beroepsuitoefening kunnen worden aangeduid.

\section{De Commissile Abortusvraagstuk}

In haar interimrapport in 1971 en daarmee na de indiening van het wetsvoorstel 10390 (Lamberts/Roethof) uitte de Commissie Abortusvraigstuk zich over het bestaande rechi in dezelfde geest als Enschedé in $1966 .^{252}$

"De wetgever heeft ... de "medische indicatie" - die in Minister Moddermans opvat-

ting aan de kring der medici ter beoordeling staat - als rechtvaardigingsgrond voor de abortus provocatus erkend" 253 .

Met "wetgever" bedoelde de Commissie zowel die van 1886 als die van 1911 . En, na deze vaststelling niet verwonderlijk, onderschreef zij expliciet de twee hierboven aangehaallde conclusies van Enschedé uit 1966, dat een medische ndicatie de wederrechtelijkheid wegneemt en dat het begrip "medische indicatie" bij abortus een ruimere invulling heef gekregen. ${ }^{254}$ Ook verwees de Commissie in dat verband instemmend naar de ruime omschrijving van het begrip "gezondheid" door de WHO in 1948.

Problematisch was in de Commissie de vraag of en op welke wiljze de wetgever hieraan tegemoet diende te komen. Enkele leden ${ }^{255}$ stelden voor de wet pas te wijzigen als de meningsworming was afgerond. Zij wilden de strafbaarheid van de vrouw zonder meer en in beginsel ook die van de arts vanwege verstoring van de zwangerschap laten vervallen. Het tuchtrecht was in hun ogen voldoende geschikt als repressief middel. Bovendien kon een arts onder omstandigheden vanwege mishandeling of dood door schuld worden vervolgd. Elke ingreep diende gemeld te worden bij de Inspectie voor de Volksgezondheid, die zonodig de zaak kon aanbrengen bij de tuchtrechter. Abortus door onbevoegden moest als misdrijf strafbaar blijven.

Andere leden ${ }^{256}$ waren het met de strekking van de beschreven opvatting eens, mat hadden bezwar tegen een aanvullende regeling met betrekking tot de besluitvormung. Voor hen was het vanzelfsprekend dat een arts zorgvuldig handelt.

De overige leden ${ }^{257}$ gaven als hun voorlopig oordeel te kennen, dat zij zich "om crimineelpolitieke redenen" konden vinden in het schrappen van de strafbaarstelling van

252 Commissie Abortusvratgstuk, Interimapport, HTK 1971, 11321. De voorzitter van de eommissie was

do gynatecoloog Klonsterman en cen wan de leden was de latere Minister van Justitie, Van Agt:

253 HTK 1971, 11321, D, 3.

254 HTK 1971, 11321, pi 3 en p; 11. De leden Van Agt, Diemer-Lindeboom, Overweel; Peters en Sporken

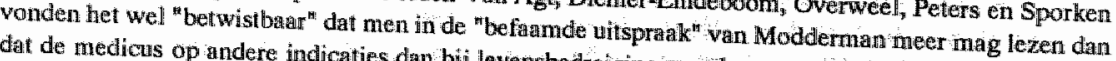
HTK $1971,11321, p_{1} 14$.

255 Koosterman, Veder-Smit en Severijmen-Cals, HTK 1971, 11321, p. 11-13

256 Sikkel, Querida, Rood-De Boer en Minkenhof, HTK 1971,11321, p. 13 .

257 Van Agt, Diemer-linindebom, Overweel, Peters en Sporken, HTK 1971, 11321, p. 13 . 
de vrouw, maar volgens hen moest de arts strafrechtelijk aansprakelijk blijven. Abortus rakte de beschermwaardigheid wan het ongeboren menselijk leven, en omdat deze kwestie de gehele samenleving aangaat, diende het strafrecht in een bescherming te voorzien.

\section{Straffeloosheid vanwege medische indicatie}

De Commissie Abortusvraggstuk achtte abortus op medische indicatie vanwege het ontbreken van de wederrechtelijkheid straffeloos. Zij trad daarmee in het voetspoor van Enschedé. Uit de wetsvoorstellen en enkele uitllatingen tijdens de parlementaire behandeling $\mathrm{kan}$ worden afgeleid dat vele politici deze mening deelden. ${ }^{258}$

Eveneens bestond er onder politici grote overeenstemming over, dat de wetgever van $1881 / 1911$ een zekere marge voor de invulling van de medische indicatie bif abortus had willen laten. Het lijdt geen twijfel dat

"het begrip 'medische indicatie' thans een andere en ruimere betekenis heeft dan in de tijd dat de bedoelde strafbepalingen tot stand kwamen; een ontwikkeling waarvoor de wetgever destijds ook welbewust ruimte heeft willen laten". ${ }^{259}$

Slechts een enkele keer werd de opvatting verdedigd, dat de wetgever van 1881/1911 uitsluitend abortus bij levensbedreiging voor de vrouw had willen toestaan. ${ }^{260}$

Over de actuele inhoud van het begrip "medische indicatie" bij abortus werd onder politici echter verschillend gedacht. Voor sommigen viel daaronder uitsluitend levensgevaar voor de vrouw of een ernstige bedreiging van de lichamelijke of psychische gezondheid van de vrouw. ${ }^{261}$ Volgens anderen was ook de sociale indicatie als een medische indicatie

258 Lamberts/Roethof, (PvdA), Kamerstukken 1969-1970, 10719, nr. 3 (MvT), p. 4. Veder-Smit/Geurtsen, (VVD), Kamerstukken 1974-1975, 13302, nr. 3(MVT), p. 10 en nr. 5 (MvA), p. 13. Van Schaik/Van Leeuwen, (KVP/ARP), Kamerstukken 1974-1974, 13253, nr. 3 (MvT), p. 17 i.v.m. p. 11-12, mar op p. 16 verwezen zij naar art, $40 \mathrm{Sm}$, en Gardeniers-Berendsen, KVP, die no het vertrek van Van Schaik mede-indienster van het woonstel 13909 werd. Zie ook Gardeniers-Berendsen HTK 16 sept. $1976,5.558$ en HTK 23 sept 1976 , p. 101. Albna/Verbrugh, (SGP/OPV), Kamerstukken 1978-1979, 15476, nr 5 (VV), P. 5 en Abma, HTK 27 now.1980, p. 1710-11. Tweede Regeringsvoorstel, Ginjar/De Ruiter, (VVD/CDA), Kamerstukken 1978-1979, 15475, nx. 3 (MVT), p. 9 en p. 14. Zie b.v, nog Dees (VVD), HTK 2 dec. 1980,1787 end Anconn (PwdA), HEK 28 april 1981, p. 788. In het eerste regeringswoorstel, het roorstel Stuyt/Wan Agt, Kamersiuken 1971-1972, 11390, bleef onduidelljk of de rechtsgrond woor de siraffeloosheid in het ongeschreven recht lag of dat abortus vanwege noodtoestand, art. $40 \mathrm{Sr}$, niet strafbaar werd geacht. De onduidelijkhehd werd weroorzalkt door de grote nadruk dall de indieners op het belangenconflict bij abortuis legden, terwijl een belangenconflict ook kenmerkend is woor noodroestand. Vg. Kamerstukken 1971-1972, 11390; n.. 3 (MNT); p. 9.

259 Ginjmar/De Ruitier, Kamerstukken 1978-1979, 15475, nr.3 (MvT), p. 14, met verwijzing naar Smidt II, p. 446. Zie verder: Abma/Verbrugh, Kamerstukken 1978-1979, 15475, in. 5 (VV), p. S en Abma (SOP) in de Tweede Kamer: de ruimate die "gelaten werd woor uitzondering op deze regel werd man de beoordelling valu de medicus overgelaten". HTK 27 nov. 1980, p. 1710-11. Dees (VVD), HTK 2 dec. 1980, p. 1787 en d'Ancona (PvdA), HEK 28 april 1981; p. 788.

260 Abma, HTK 16 dec. $1980, \mathrm{p}$ 2132; HTK 1978-1979, 15476 (Abme/Nerbrugh), nr. 3 (MvT), p. 7-8 i.v.m. p. 18.

261 Van Schailk/Van Leeuwen, Kamerstukken $1974-1975,13253$, nr. 3 (MvT), p. 13 en p. 17. Zite ook Outshoom, 1986 , p. 213 
aan te merken. ${ }^{262}$ Weer anderen meenden dat het begrip "medische indicatie" aan geen beperking was onderworpen en uilsluitend ter beoordeling van de medicus stond. ${ }^{263}$

Als rechtsgrond woor de straffeloosheid werd telkens de "medische indicatie" genoemd. Dat is in zoverre opmerkelijk omdat in dat verband werd venwezen narar de wetsgeschiedenis van de zedelijkheidswetgeving 1911. Maar toen werd in verband met de medicus uitsluitend de term "beroepsrecht" gebezigd. Doordat noch Enschedê, de Commissic Abortusvragastuk of de politici naar de WUG verwijzen ${ }^{254}$, lijkt het mij waarschijnlijk dat de geoorloofdheid van een abortieve ingreep niet afgeleid werd uit de bevoegdheid tot de beroepsuitoefening van de medicus. Zoals bij de bespreking van de opvatting van Enschedé is opgemerkt; kan "medische indicatie" hiler het beste als "medische exceptie" worden begrepen. Maar deze laatste term was toen nog niet gebruikelijk.

\section{De verschillende wetsvoorstellen inzake abortus}

\subsection{Inleiding}

Voorzover bekend waren alle politici die aan de abortusdiscussie deelnamen van mening dat abortus door een medicus in bepaalde gevallen straffeloos moest kunnen worden verricht. Overeenstemming bestond ook ten aanzien van de randwoorwaarden: de ingreep moet plaatsvinden door een bevoegde arts en op verzoek van de zwangere vrouw. De opvattingen divergeerden echter over de indicatie waaronder abortus straffeloos werd geacht.

In deze abortusdiscussie stonden de vragen centraal of abortus door een arts straffeloos mocht worden verricht en welke grenzen de arts daarbij in acht had te nemen. De diversiteit van opvattingen die hierover in de samenleving evenzeer als onder politici en artsen bestond, was voor sommige politici reden om te pleiten voor een nieuwe wettelijke regeling voor abortus, waarin met de pluriformiteit rekening werd gehouden. Voor anderen stond de wens voorop om daarmee de van overheidswege op den duur "oogluikend" toegestane abortuspraktijken terug te dringen.

Ook ten tijde van de behandeling van de wetsvoorstellen inzake abortus stelde het Openbaar Ministerie zich tegenover de toegenomen abortuspraktijken terughoudend op. In het najaar 1971 spraken de Procureurs-Generaal af dat alleen na overleg met het Staatstoezicht op de volksgezond heid tot vervolging zou worden overgegaan. ${ }^{265}$ Maar het Staatstoezicht beschouwde

"abortus provocatus, verricht door een medicus, als een medische handeling waarvoor de verantwoordelijkheid uiteraard geheel bij de medicus berust. ... De beoordeling

262 Veder-Smit/Geurtsen, Kamerstukken 1974-1975, 13302, nr. 3 (MvT); p. 11; Lamberts/Roethof, Kamerstukken $1969-1970,10719$, nr. 6 (MvA), p, s.

263 PSP, Kanrerstukken 1975-1975, 13909, nr $_{n} 4$ (VV), p 9 enin wezen ook Lamberts/Roethof, Kamerstukken $1969-1970,11719$, ar, 3 (MVT), p. 2.

264 Dat gebeurde wel door de RwS. Zie Kamersituklken 1978-1979, 15475, nrs. 1-4, bijl. 5, p. 96-97.

265 HTK 1971-1972. Aanhangsel, p. 1413, p. 1415, p. 1427, 24 aug. 1971; HTK 1972-1973. Aanhangsel, p. 1337; 5 okt. 1972; HTK 1973-1974, Aanhangsel, p. 2663; 5 maart 1974 . 
van abortus provocatus door de Inspectie van de Volksgezondheid is daardoor in principe niet anders dan bij welke andere medische handeling dan ook ${ }^{1266}$ Op kamervragen bevestigde Minister Van Agt de afspraak van de Procureurs-Generaal, maar tevens ontkende hij. dat er vervolgingsrichtlijnen inzake abortus bestonden. ${ }^{267}$

Naar anleiding van de bekende zaak-Bloemenhove ${ }^{268}$, warbij in verband met abortus het instrumentarium van deze abortuskliniek in beslag werd genomen, betreurde Van Agt het dat de overheid niet bij machte was "een wetgeving te handhaven die het afbreken van zwangerschap niet dan in uiterste nood toelaat, wanneer een zeer aanmerkelijk aantal van degenen die onder die wetgeving leven een daarvan sterk afwijkend ethisch oordeel over die ingreep heeft". Daarom pleitte hij voor een "ethisch revell in onze samenleving, voor een hernieuwde herbezinning op de unieke waarde van elk menselijk leven". ${ }^{269}$

In 1970 werd het eerste wetsvoorstel, een initiatiefontwerp van de PvdA-Kamerleden Lamberts en Roethof ingediend. ${ }^{270}$ Elf jaar later en na nog zes andere wetsvoorstellen inzake abortus ${ }^{271}$, werd het zevende voorstel, een regeringsvoorstel van de ministers Ginjaar (VVD) en De Ruiter(CDA) ${ }^{272}$ aangenomen, dat per 1 november 1984 in werking trad.

Volgens alle wetsvoorstellen kwamen in de plaats van de artt. 251bis en 295-298 een of meer nieuwe abortusbepalingen. Tevens werd in vijf van de zewen voorstellen ${ }^{273}$ een nieuw artikel voorgesteld, dat, afgezien van redactionele verschillen gelijk was aan het huidige art. $82 \mathrm{a} \mathrm{Sr}$ :

"Onder een ander, of een kind bij of kort na dle geboorte, van het leven beroven wordt begrepen: het doden van een vrucht die naar redelijkerwijs verwacht mag worden in staat is buiten het moederlichaam in leven te blijven".

Alle wetsvoorstellen beoogden een einde te maken aan de rechtsonzekerheid. In sommige werd wettelijk de ruimte geschapen voor de bestaande abortuspraktijken, terwijl andere wetswoorstellen de praktijk juist wilden terugdringen. Vanwege deze doelstellingen werd nadrukkelijker dan vroeger aandacht besteed aan inhoudelijke criteria, om met behulp daarvan legale van illegale abortus te kunnen afbakenen.

Daartoe werd ook ingegaan op het begrip gezondheid. Wanneer een medicus tot abortus gerechtigd is, indien de vrouw niet gezond is of haar gezondheid wordt bedreigd en voor de invulling van het begrip "gezondheid" de omschrijving van de WHO gebezigd wordt, dan kon ook bij abortus op sociale indicatie de besluitvorming als onderdeel van gewoon medisch handelen worden opgevat. De vrouw, die (terecht) om sociale redenen om abortus

266 Gedragslijn Staatstoezicht Volksgezondheid ten aanzien van abortusklimiekem, Nedertandse Staatscourant, 29 sept. 1972 , nr. 190.3.

267 HTK 1973-1974, Aanhangsel, p. 2363, 4 april 1974.

268 Zie hierover nader: De Bruijn, 1979, p. 210-215 en p. 220-222 en Outshoorn, 1986, p. $208-212$ en p. 221-225.

269 HTK 1975-1976, 13964, nr. 1, p. 5.

270 Kamerstukken 1969-1970, 10719.

271 In september 1980 werd nog een achtste wetsvoorstel, een tweede PvdA-/D'66iovoorstel (Roethof/Wes: sel-Tuinstra) bij de Tweede Kamer ingediend, dat echter niet in behandelling is gelkomen: HTK 1979-80, 16322. Aan dit voonstel lag het wetsvoorstell 13909 (Geur.tsen/Lambert/Roethol/Veder-Smit) ten grondslig. Zie nir. 3 (MvT), p. 14 en p. 17.

272. Kamerstukken $1978-1979,15475$.

273. Niet in de vocrstellen Lamberts/Roethof en Abma/Verbrugh. 
verzoekt, bevindt zich immers niet in een toestand van sociaal welzijin en is derhalve niet volledig gezond. ${ }^{274}$

Maar deze opvatting vond veel tegenstand. Bij abortus moest het begrip gezondheid "in zijn strikte betekenis" en dat wil zeggen, restrictief worden opgevat. ${ }^{275}$

Anderen waren van mening dat de begrippen gezondheid en ziekte als grondslag voor de medische indicatie bij abortus niet meer bruikbaar waren, vanwege de sterke wijzigingen die deze begrippen hadden ondergaan. ${ }^{276}$ Bij abortus ging het hoofdzakelijk om het begrip "leven" en dat begrip had zich ontwikkeld tot een vooral kwallitatief begrip, dat het beste in de tweeëenheid "leven en welzijn" tot uitdrukking werd gebracht."

De laatstgenoemde benadering vertoont in de ruimte die voor abortus werd gelaten overeenstemming met die van een ruime invulling van het begrip "gezondheid", maar verschilde daarvan in het uitgangspunt. Abortus was in deze benadering geen kwestie van gezondheid en ziekte, maar van leven en welzijn en - in juridische zin - van het recht op welzijn. Wanneer leven recht op welzijn impliceert, dan bepaalt - op individueel niveau - de persoon die het betreft, de grenzen van dat recht. Op deze wijze deed de zelfbeschikking van de vrouw en in het kielzog daarvan (opnieuw) het belangenconflict tussen vrouw en vrucht expliciet zijn intrede. Het vraagstuk van abortus betrof immers leven en welzijn van zowel de vrouw als de vrucht. De verst strekkende mogelijkheid om aan de daaruit voortvloeiende problematiek te ontkomen was om het belang van de vrouw en de vrucht te vereenzelvigen. Dat deed sleehts een enkeling. ${ }^{278}$

Hieronder worden de hoofdlijnen van de verschillende wetsvoorstellen inzake abortus beschreven. Het voorstel-Ginjaar/De Ruiter, dat heeft geleid tot de WAZ, wordt afzonderlijk besproken.

\subsection{Het wetswoorstel 10719 (Lamberts/Roethof) ${ }^{279}$}

Met het wetsvoorstel wilden de indieners Lamberts (PvdA) en Roethof (PvdA) de strafbaarheid van abortus voor de medicus opheffen. Daartoe stelden zij voor de artt 251 bis, 295-298 en 451 quater $S r$, te laten vervallen ${ }^{280}$ Deze bepalingen waren door de veranderde opvattingen over abortus steeds verder verwijderd geraakt van de praktijk.

Abortus moest ook mogelijk zijn op nadrukkelijke wens van de vrouw, want een medische indicatie kan "ten opzichte van alle geneeskwndige problemen en dus ook van abortus, zowel een lichamelijke, een geestelijke als een maatschappelijke indicatie zijn ${ }^{12}{ }^{281}$ Aan de verscheidenheid van opvattingen over de toelaatbaarheid van abortus

274 Leden CPN.fractie, Kumerstukken 1974-1975, 13302, nr. 5 (VV), p. 4 en d"Ancona, HEK 28 april 1981, p. $783-784$

275 Van Schaik/Van Leeuwen, Kamerstukken 1974-1975, 13253, nr. S (MvA), p. 14.

276 Veder-Smit/Geurtsen, Kamerstukken 1974-1975, 13302, ur. 3 (MvT), p. 11.

277 Veder-Smit/Geurisen, Kamerstukken 1974-1975, 13302, nr. 7 (MVA) , p. 3.

278 Glastra van Loon, HEK 1980-81, 28 aprill 1981, p. 807. Vgl. Ontshoom, 1986, p. 271-272.

279 HTK 1969-1970, 10719.

280 HTK $1969-1970,10719$, ne. 3 (MvT), p. 7

281 HTK 1969-1970, 10719, nr. 3 (MvT), p. 1. Op p. 6 ncemen zij dat kennelijk een "sociale indicatie". 
en de persoonlijke verantwoordelijkheid van de arts ${ }^{282}$, verbonden zij de consequentie dat de wetgever de

"vrijheid moet scheppen voor de beleving van de verantwoordelijkheid van de arts zoals hij die ziet. Dat betekent dat de arts bij het vraagstuk van abortus definitief uit de sfeer van het strafrecht moet worden gehaald" ${ }^{1283}$

Lamberts en Roethof beschouwden abortus door artsen, zowel wat de indicatie als wat de uitwoering betreft, als een medische handeling. Daarom wezen zij beperkende voorwaarden als overbodig en zelfs gevaarlijk af. $\mathrm{Zij}$ hadden de overtuiging,

"dat welke goedbedoelde wettelijke voorwaarden ook aan de arts bij de toepassing van abortus provocatus worden gesteld, deze geen beperkend effect hebben op het aantal gevallen, maar steeds zal leiden tot toenemende gevaren voor de volksgezondheid". ${ }^{284}$

Het tuchtrecht bood volgens hen voldoende mogelijkheden om tegen een medicus, die in strijd met de eisen van een behoorlijke beroepsuitoefening handelt, op te treden. ${ }^{28 s}$ Daarom behoefde slechts abortus door onbevoegden strafbaar gesteld te worden. Hiertoe stelden zij voor in de Titel "Misdrijven tegen de openbare orde" een nieuw art. 151 bis op te nemen, dat overeenkomsten vertoonde met art. 251 bis, maar waarin de medicus van de aansprakelijkheid werd uitgesloten. ${ }^{236}$

Een wetswijziging was volgens hen nodig; ondat zij niet het vertrouwen hadden dat langs de rechtsgrond "ontbreken van de materiële wederrechtelijkheid' hetzelfde resultaat voor de medicus bereikt kon worden. Daartoe gaven zij drie redenen. De jurisprudentie over de medische indicatie is beperkt. In de literatuur bestaan bezwaren tegen een uitbreiding van de rechtvaardigingsgronden, en hoewel het begrip "medische indicatie" een verruiming heeft ondergaan, staat njet vast of daaronder ook de sociale indicatie valt. ${ }^{287}$

Het wetsvoorstel, dat door zijn eenvoud en duidelijkheid uitblonk, werd door een aantal juristen positief ontvangen ${ }^{288}$, maar kon op te weinig steun in de volksvertegenwoordiging rekenen. ${ }^{289}$ Het werd op 6 mei 1976 ingetrokken. ${ }^{290}$ Lamberts en Roethof dienden toen; samen met Geurtsen en Veder-Smit, het wetsvoorstel 13909 , in. ${ }^{291}$

282 HTK 1971-1972, 10719, nr. 6 (MvA), p. 2.

283 HTK $1969-1970,10719$, nr. 3 (MvT), p. 5

284 HTK $1971-1972,10719$, nr. 6 (MvA), p. 3. Zie ook p. 7.

285 HTK 1969-1970, 10719, nr. 3 (MwT), p. 5-7.

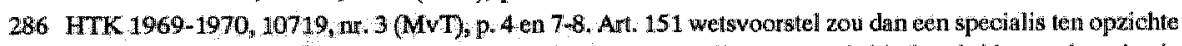
wan de in art $436 \mathrm{Sr}$ neergelegde generalis zingeworden. Zie woor cen kritisch geluid ower de redactie van het woorgestelde art. 151 bis: Wan Bemmelen, NJB 1970, p. 997 e.v. Zle hiertoe: HTK 1971-1972, 10719, nir.6 (MvA), p. 11. Schournans Stekhowen, NJB 1970, p. 1009, merkte over exen abortustepat ling in het WwSt in het aligemeen op: "Oe nog een apart strafwetturtikel nodig is tegen onverantwoordelijke knoevers, ..., betwijfel "ik".

287 HTK 1969-1970, 10719, nr. 3 (MvT), p. 2 .

288 Schuurmans Stekhoven, NJB 1970, p. 1009-1010; Van Bemmelen, NJB 1970, p. 997 e.v.; Bronkhorst, NJB 1972, p. 810 e. v; Davelaar Van Tongeren en Van de Pol, NJB 1979, p. 560 e.v.; Frenkel, NJB 1970, p. 1401. Zie voor cen positieve reactie wan en medicus b.v: Van Trommel, MC 1970, p. 1031-1032 en woor een negatieve: Schulte, MC 1970, p. 781-782.

289 Schuurmans Stekhoven, NJB 1970, p, 1009-10: "Het Lot wan het imitiatief-voorstel Lamberts-Roethof is noch een medische, noch een juridische, nurar een politieke kwestic, waarover ik verstandig doe in dit tijdschifift te awijgen":

290 HTK $1975-1976,10719$, nr. 10.

29.1. Zie H. III, 17.6 . 
Als tweede wetswoorstel inzake abortus volgde in 1972 het Regeringswoorstel 11890 , van de Ministers Stuyt (KVP) en Van Agt (KVP). In dit voorstell waren reeds alle belangrijke elementen van de latere Wet Afbreking Zwangerschap (WAZ) annwezig. ${ }^{293}$

Abortus betrof, volgens de indieners, het gebied tussen de innesteling van de vrucht en de zelfstandige levensvatbaarheid van de vrucht. ${ }^{294}$ In een nieuw art. 82 bis werd bepaald, dat onder "een ander van het leven beroven mede begrepen is het doden van een zelfstandig levensvatbaar geachte wrucht in het moederlicham.

Cit deze bepaling kan in verband met de nadruk die de indieners legden op de beschermwaardigheid van het leven van de vrucht worden afgeleid, dat het opwekken van een vroeggeboorte door de voorgestelde regeling niet bestreken werd. De (opklimmende) beschermw aardigheid van de vrucht brengt mee, dat met betrekking tot abortus een belangenconflict tussen de vrouw en de vrucht bestat. Daarom kan de beslissing niet alleen aan de vrouw toekomen. ${ }^{205}$ Vanwege de beschermwaardigheid behoort niet alleen abortus door een onbevoegde strafbaar te zijn, maar in sommige gevallen ook abortus door een medicus.

Naar hun mening was een wetswijziging nodig, omdat de bestaande wet niet meer in overeenstemming was met de gewijzigde opvattingen over dit vraagstuk. Maar de strafrechtelijke aansprakelijkheid moest gehandhaafd blijven, daar abortus het doden van menselijk leven betreft. Daarom mocht deze ingreep ook slechts plaatsvinden met inachtneming van wettelijke voorwaarden, tenzij de zwangerschap het leven van de vrouw bedreigt: $^{204}$

Dit uitgangspunt zou de strafrechter voor het probleem plaatsen te moeten beoordelen of een arts in een bepaald geval naar de regelen der kunst heeft gehandeld. Het raadplegen van deskundigen helpt hem niet verder, omdat deze over die regelen van mening verschillen. Daarom achtten Stuyt en Van Agt een regeling voor een zorgvuldige besluitvorming. nodig. Zij vonden het echter met het karakter van het WvSr in strijd, wanneer met betrekking tot een bepaald strafbaar handelen aan de eigenlijke strafbepaling de vaststelling van een aantal normen zou moeten voorafgaan. Derhalve stelden zij voor in een bijzondere wet, een 'Wet Afbreking Zwangerschap' ('WAZ") een vijj uitvoerige regeling van administratieve aard op te nemen. ${ }^{297}$

Volgens Stuyt en Van Agt kunnen geen concrete materiêle normen voor de ingreep worden gegeven. ${ }^{298}$ Dalarom moesten zij de normen ten aanzien van de samenstelling van het overlegteam en de besluitvorming in vage termen houden. ${ }^{299}$

Volgens art. 2 'WAZ' was abortus toegestaan, wanneer de zwangerschap het hichamelijke of geestelijke welzijn van de vrouw ernstig bedreigde en wanneer het belang van de vrouw zwaarder woog dan het belang van de vrucht, mede gelet op de duur van de zwangerschap. Over de normstelling in een concreet geval diende de medicus overleg te voeren

292 HTK $1971-1972,11890$.

293 Zie ook hun verwigzing natr het Regeerakkoord: HTK 1971-1972, 11890, nr. 3 (MvT), p. 6.

294 MTK 1971-1972, 11890, nr. 3 (MvT), p. 6.

295 HTK $1971-1972,11890$, nr. 3 (MvT) p. 9.

296 HTK $1971-1972,11890$, nr. 3 (MvT), p: 15.

297 HTK 1971-1972, 11890, wr. 3 (MVT), p. 9-10.

298 HTK 1971-1972, 11890, nr. 3 (MvT), P. 7.

299 HTK 1971-1972, 11890 , nr. 3 (MvT), p. 11. 
met de huisarts van de vrouw en met een of meer deskundigen. Naar aanleiding wan zijn eigen indicatiestelling en het overleg moest de medicus omtrent de ingreep beslissen (art. 4 WAZ). De ingreep zelf mocht slechts plaatsvinden in een algemeen of in een bepaald aangewezen ziekenhuis of in andere erkende inrichtingen. De medicus diende van elke ingreep aantekeningen te maken en deze aan de betreffende geneesheer-directeur te verstrekken. Wanneer de medicus geen aantekeningen bijhield of de ingreep niet in een van de genoemde plaatsen plaatsvond, maakte hij zich schuldig aan een overtreding.

Volgens het wetsvoorstel vervielen de artt. 25lbis, 295-298 Sr. Met betrekking tot art: 251 bis Sr merkten de indieners op, dat abortus thans vrijwel algemeen als misdrijf tegen de zeden wordt afgewezen. ${ }^{300}$ De strafbepalingen zouden in een nieuwe tittel XIXa: Afbreking van zwangerschap, komen te staan. In art. 296 werd strafbaar gesteld het aborteren door onbevoegden en in art. 297 lid 1 abortus door een geneeskundige. De omschrijving van de gedragingen in de artt. 296 en 297 lid 1 vertoonde overeenkomsten met die in art. 251 bis Sr, maar behelsde, zoals in de MvT te kennen werd gegeven, twee verschillen. Ten eerste behoefde voor de strafbaarheid niet de wetenschap of het vermoeden kenbaar gemaakt te zijn, dat door de behandeling de zwangerschap kon wordem afgebroken en ten tweede was vanwege dit artikel niet stratbaar een behandeling met volkomen ondeugdelijke middelen. ${ }^{301}$

In art. 297 lid 2 werden twee uitzonderingen op de strafbaarstelling van de medicus gegeven. Indien de behandeling van de medicus niet gericht was op het afbreken van zwangerschap viel de gedraging niet onder het eerste lid. ${ }^{302}$ Volgens de tweede uitzondering was de medicus niet strafbaar, wanneer hij met inachtneming van de wettelijke bepalingen omtrent het woorafgaand overleg in redelijklheid tot de behandeling had kunnen besiluiten.

Tot vervolging van de medicus ter zake van overtreding van art. 297 mocht pas worden owergegaan na een minder dan vier jaar tevoren gegewen waarschuwing door de Inspecteur. ${ }^{303}$ Art. 298 behelsde als strafverzwarende omstandigheden de dood van de wrow en het handelen zonder toestemming. Met betrekking tot de toestemming werd opgemerkt, dat ervan wordt uitgegaan dat toestemming altijd nodig is, tenzij de patiênt daartoe niet in staat is. ${ }^{304}$

In de regeringsverklaring van 28 mei 1973 werd meegedeeld, dat het regeringsvoorstel zou worden ingetrokken na indiening van een intiatiefvoorstel van christen-democratische zijde. Dientengevolge werd na indiening van het wetsvoorstel 13253 (Van Schaik/Van Leeuwen) op 23 januari 1975 het wetsvoorstel 11890 op 14 februari 1975 ingetrokken. $^{305}$

300 HTK 1971-1972, 11890, nr. 3 (MNT), p. 17.

301 HTK 1971-1972, 11890, nr. 3 (MvT), pr 18.

302. Zie ook: HTK 1971-1972, 11890, nr. 3 (Mv'T), p. 18.

303 HTK 1971-1972, 11890, nr. 3 (MvT), p. 16. Zie ook ant 14 van de voorgestelde WAZ.

304 HTK 1971-1972, 11890, nr. 3 (MvT), p. 18.

305 HTK 1974-1975, 11890, ar. 6. Zie voor een negatieve reactie uit medische kring over dit wetsvoorstel: Schuurmans Stelkhwven, MC 1972, p. 417-421 en MC 1972, p.770.771 en voor een instemmende reactie door een aintal districtsafgevaardigden wan de $\mathrm{KNMG}$, die het beleid van het hoofdlestuur inzake abortus in een brief aan de minister van Volksgezondheid en Milieuhygiene ter discussie stellen, Me 1972, p. 714-715; gevolgd door een reactie van de woorzitter van de $\mathrm{KNMG}_{4} \mathrm{MC} 1972$, p. 715-716. 
Het wetsvoorstel Van Schaik (KVP)/Van Leewwen (ARP) was in zijn uitgangspunten restrictiever dan het woorstel-Stuyt/Van Agt, maar het vertoonde in de uitwerking veel overeenkomsten daarmee. Hier wordt volstaan met een bespreking van die punten, die het voorstel van Schaik/Van Leeuwen van het voorstel-Stuyt/Van Agt onderscheidde.

Van Schalk en Van Leeuwen waren van mening dat de bestmande abortuswetgeving "in haar uitgangspunten" juist is. Daarmee bedoelden zij dat abortus slechts toelaatbaar zou moeten zijn, wanneer het leven wan de vrouw door de zwangerschap wordt bedreigd. Mar een wijziging van de abortusbepalingen was ook volgens hen onvermijdelijk geworden, omdat zij de jurisprudentie en het vervolgingsbeleid als niet meer toereikend beschouwden voor het doel de "beschermwaardigheid van menselijk leven in ontwikkeling niet alleen te formuleren, maar ook met de nodige waarborgen te omringen ${ }^{\text {nt }}{ }^{307}$ Die beschermwatdigheid was voor hen "het meest essentiële van de evangelische opdracht" ${ }^{\prime \prime}{ }^{308}$ Tewens erkenden zij echter dat over abortus in de samenleving ook anders wordt gedacht. Daarom kon niet met de door hen voorgestane norm "levensbedreiging voor de vrouw" worden volstaan. ${ }^{30 \%}$

Het wetsvoorstel voorzag, evenals het voorstel-Stuyt/Van Agt, in enkele strafbepalingen en in een bijzondere wettelijke regeling. In art. $2^{\text {' }}$ WAZ' was de norm omschreven. Abortus door een medicus is niet strafbaar, indien

"voortzetting van de zwangerschap voor de lichamelijke integriteit of geestelijke gezondheid van de vrouw een ernstige bedreiging meebrengt, en deze bedreiging slechts door afbreking van zwangerschap kan worden afgeweerd":

Deze norm lijkt strenger dan die in het voorstel-Stuyt/Van Agt. In het voorstel-Van Schaik/Van Leeuwen mocht abortus alleen plaatsvinden, wanneer slechts daardoor de genoemde bedreiging kon worden afgewend, in het voorstel-Stuyt/Van Agt waar het belang van de vrouw zwararcler woog dan het belang van de vrucht ${ }^{310}$ Maar terwijl de indieners uitdrukkelijk een "sociale indicatie" afwezen, achtten zij abortus wel toelaatbaar, als "onoverkomelijke moeilijkheden van sociale aard, die de geestelijke gezondheid ernstig bedreigen, niet door sociale voorzieningen kunnen worden opgeheven". ${ }^{311}$

De norm van art. 2 'WAZ' werd in art. 296 herhaald, waar zij de functie van een rechtvaardigingsgrond had. Bovendien eiste art. 296 nog, dat de medicus tot de behandeling loestemming van de vrouw moet hebben verkregen, "nadat zij in redelijke staat was gestield om tot een weloverwogen besluit te komen".

Ook in de rechtvaardigingsgrond van art. 296 zat enige rek. Zij begon met de woorden dat het eerste lid, waarin de strafbaarstelling van de medicus was geformuleerd, niet van toepassing is indien de medicus "redelijkerwijs tot het oordeell kon komen" dat voortzetting

306 HTK $1974-1975,13253$.

307 HTK 1974-1975, 13253, wr. 3 (MvT), p. 12 en nr. 5 (MVA), p. 9.

308 HTK 1974-1975, 13253, ni. 3 (MvT), p. 12.

309 HTK $1974-1975,13253$, nr. 3 (Mvi), p. 13.

$310 \mathrm{HTK}$ 1974-1975, 13253, nr. 3 (MvT) p. 15: "Het komt ons voor dat hier met sprake kan tijn wan een afweging van het belang wan de vroww tegen het belang van de vrucht, omdat narr ons oordeel tegenover het concrete belang van de vrouw het beginsel van de bescherming wan het leven stuat ${ }^{\text {* }}$.

311 HTK 1974-1975, 13253, m. 3 (MVT), p. 17. In HTK 1974-1975, 13302, nir. 7 (MVA), p. 3, wordt daarto: opgemerkt: "Het voorstel-Van Schaik-Van Leeuwen ..., wijst de sociale indicatie formeel af, maat erkent, dat sociale nood een rol kan spelen bij de bedreiging van de gezondheid". 
wan de zwangerschap een ernstige bedreiging van de lichamelijke of geestelijke gezondheid van de vrouw meebracht. ${ }^{312}$

Daarnaast was in art. 296 nog een andere rechtvaardigingsgrond opgenomen, op grond waarvan de medicus gerechtvaardigd was, indien hij "redelijkerwijze mocht aannemen, dat de vrouw niet zwanger was, danwel de behandeling niet was gericht op het afbreken van zwangerschap"

De in het voorstel-Stuyt/Van Agt geëiste voorwaarde voor vervolging van de medicus (een voorafgaande waarschuwing van de Inspecteur), was in het woorstel-Van Schaik/Van Leeuwen niet overgenomen. Ook betrof de strafbarstelling, anders dan in het voorstel Stuyt-Van Agt, maar in overeenstemming met art. 25 bis $\mathrm{Sr}$, gevallen waarin de vrouw niet zwanger was. Volgens de indieners konden daardoor bewijsmoellijkheden worden voorkomen. ${ }^{313}$

De abortusbepalingen waren toepasselijk vanaf de innesteling tot aan de zelfstandige levensvatbaarheid van de vrucht. Het opwekken van een vroeggeboorte werd niet als abortus beschouwd. ${ }^{314}$ Het in het moederlichaam doden wan een levensvatbare vrucht werd echter vanwege art. 82 bis aangemerkt als doodslag of moord. ${ }^{315}$

De noodzakelijk geachte waarborgen voor een gerechtvaardigde abortus waren te vinden in de normstelling en daarnaast vooral in een procedurele regeling voor de besluitvorming. Elke inrichting waar een abortieve ingreep mocht worden verricht, was verplicht een overleggroep in te stellen (artt. 3 jo 8 'WAZ'). Deze had tot taak bij te dragen tot een goede besluitvorming. De geneeskundige moest met minimal twee andere medici, waarvan er tenminste één lid van de overleggroep moest zijn, overleg plegen, om na te gaan, of aan de in art 2 opgenomen norm was voldaan. Als het verzoek van de vrouw te maken had met haar sociale omstandigheden, dan moest hij tevens met een "sociaal-deskundige" overleg plegen, art. 4'WAZ".

Art. $6^{\prime} \mathrm{WAZ}$ ' behelsde een beraad- en een beslistermijn. De medicus diende binnen drie weken nadat de vrouw zich tot hem had gewend en na overleg gevoerd te hebben, aan de vrouw zijn beslissing bekend te maken. Indien hij besloten had tot de ingreep over te gaan, dan moest hij de vrouw na minimaal zes dagen, nadat zij zich tot hem had gewend, in de gelegenheid stellen haar "uiteindelijke wil" kenbaar te maken. Voor de rechtvaardiging van de handeling eiste art. 296 dat de vrouw haar toestemming had gegeven. Daaronder werd verstaan de uiting van haar uiteindelijke wil. ${ }^{316}$

Het voorstel werd na behamdeling in de Tweede Kamer op 29 september 1976 , toen bleek dat het niet op een meerderheid kon rekenen, ingetrokken. ${ }^{317}$

\subsection{Het wetswoorstel 13302 (Veder-Smit/Geurtsen) $)^{318}$}

Het liberalle voorstel-Veder-Smit/Geurtsen uit 1975 vertoonde in zijn inhhoudelijke criteria vooral overeenkomsten met het voorstel-Lamberts/Roethof en in zijn procedurele regeling

312 HTK 1974-1975, 13253, ar. 5 (MvA), p. 5 .

313 HTK 1974-1975, 13253, nr. 3 (MvT), p. 25.

314 HTK $1974-1975,13253$, nr. 3 (MvT), p. 15 en art. 296bis.

31.5 HTK 1974-1975, 13253, nr. 3 (MvT), p. 17.

316 HTK 1974-1975, 13253, nr. 3 (MvT), p. 19 en nr. 5 (Mv:A), p. 23.

317 TK 29 sept. 1976, p. 215.

318 HTK 1974-1975, 13302. 
met de vootstellen Stuyt/Van Agt en Van Schaik/Van Leeuwen. Het stoelde volgens de indieners op vier beginselen: "vrijheid, verantwoordelijkheid, verdraagzaamheild en sociale gerechtigheid". 310

Zoals eerdere voorstellen betrof de regeling het aforeken van zwangersehap vanaf de innesteling tot aan de zelfstandige levensvatbaarheid van de vrucht. ${ }^{320}$

Centraal in het voorstel stond art. 2 ' WAZ', op grond waarvan de medicus dient te onderzoeken of de wrouw "in vrijheid en owereenkonstig haar verantwoordelijkheid jegens zich zelf en jegens de ongeboren wrucht tot haar besluit" is gekomen, hetgeen volgens de toelichting inhield dat "de wens van de vrouw, ..., moel worden gerespecteerd", tenzij er door de arts vast te stellen belemmeringen aanwezig waren. ${ }^{321}$ Van een normstelling hadden de indieners bewust afgezien, om aan de verschillende opvattingen over abortus recht te doen en voldoende ruimte te bieden voor zich wijzigende maatschappelijke omstandigheden. Bovendien waren naar hun mening criteria, zoals deze bijvoorbeeld gegeven werden in het voorstel-Van Schaik/Van Leeuwen, in verband met gewijzigde opvattingen over "gezondheid" en overde toelaatbaarheid van abortus in de praktijk "uiterst moeilijk hanteerbaar". ${ }^{322}$

De voorgestelde regeling van de strafrechtelijke aansprakelijkheid voor abortus vertoont overeenkomsten met die in het voorstel Stuyt/Van Agt. De arts diende strafrechtelijk ter verantwoording te kunnen worden geroepen, want de

"strafbaarstelling van de arts, ...., is ... het noodzakelijk uitvloeisel van de eigen verantwoordelijkheid; die de samenleving heeft met betrekking tot de rechtsbescherming van de ongeboren vrucht". ${ }^{323}$

Strafbaar was volgens de artt. 296 en 297 het geven van een behandeling, terwijl de onbevoegde of de medicus weet of redelijkerwijs kan vermoeden dat daardoor zwangerschap kan worden afgebroken. Voor de strafrechtelijke aiansprakelijkheid van de medicus was volgens art. 297 bovendien vereist dat diens behandeling gericht moest zijn op abortus en derhalve niet met een ander doel werd verricht. Tevens moest hij in strijd met het in art. 2 "WAZ" bepaalde handelen. Vervolging van de medicus kon vanwege dit artikel pas plaatsvinden na aangifte door de Adviescommissie. Deze commissie had een toezichthoudende en controlerende taak. De indieners spraken van een "Hintercollegiale toetsing" ten aanzien wan de plaatsen waar de ingreep verricht mocht worden en ten aanzien van de (besluiten tot) ingrepen. Zij verwachtten dat de commissie kon bijdragen aan het voorkomen van fouten. ${ }^{324}$ Daarvoor was ook de procedurele regeling bestemd, waarin eisen werden gesteld waaraan abortusklinieken dienden te voldoen. ${ }^{325}$

Het voorstel werd in verband met de indiening van het voorstel-Geurtsen/Lamberts/Roethof/Veder-Smit op 6 mei 1976 ingetrokken. ${ }^{326}$

319 HTK 1974m 1975, 13302, nr. 2 (MvT), p. 14 en HTK 1975-1976, 13302, nR. 7 (MvA), p. 8.

$320 \mathrm{Vgl}$. HTK 1974-1975, 13909, wr. 3 (MvT), p. 17 en p. 22 en art. 1 lid 3 "WAZ".

321 HTK 1974-1975, 13302, nr. 3 (MvT), p. 23.

322 HTK 197.4-1975, 13302, ar. 2 (MvT), p. 13 en HTK 1975-1976, 13302, nr. 7 (MvA) p. 11 .

323 HTK 1975-1976, 13302, nr. 7 (MvA), p. 17.

324 HTK $1974-1975,13302$, ne. 3 (MvT), p. 18.

325 HTK $1974-1975,13302$, in. 3 (MvT), p. 12.

326 HTK 1975-1976, 13302, wr. 10. 
Noch het voorstel van Lamberts/Roethof, noch dat van Veder-Smit/Geurtsen kon op een meerderheid in de Kamers rekenen. Daarom werden beide voorstellen ingetrokken en door het wetsvoorstel 13909 verwangen. ${ }^{328}$ Dit voorstel behelsde elementen van het voorstel-Lamberts/Roethof en van het voorstel-Veder-Smit/Geurtsen. ${ }^{329}$ De gemeenschappelijke hoofdpunten betroffen:

"a. het in de wet vastleggen van een aantal procedureregels,

b. het geven van registratievoorschriften, met name voor statistische en wetenschappelijke doeleinden,

c. het beëindigen van de strafrechtelijke aansprakelijkheid van de wrouw en van de behandelende arts, onder handhaving overigens van de tuchtrechtelijke aansprakelijklheid van deze laatste,

d. het instellen van een commissie met adviserende en toezichthoudende taak,

e. de samenstelling van die commissie" ${ }^{330}$

Op twee punten waarover de indieners geen overeenstemming hadden bereikt; lieten zij de beslissing over aan het oordeel van de Kamer. De punten betroffen de eisen, waaraan een inrichting moest voldoen en de vraag, of de leden van de toezichthoudende commissie in de abortushulpverlening werkzaam moeten zijn (geweest). ${ }^{331}$

In overeenstemming met het voorstel-Lamberts/Roethof werd afgezien van een strafrechtelijke aansprakelijkheid van de medicus. De indieners waren van mening, dat deze niet nodig was en in medische kringen ook miet in overeenstemming met een verantwoorde hulpverlening werd geacht. Bovendien zou een strafrechtelijke aansprakelijkheid tot "overvoorzichtigheid" onder medici kunnen leiden. ${ }^{332}$

Uit het voorstel-Veder-Smit/Geurtsen was art. 2 lid 1 'WAZ' overgenomen, volgens welke bepaling de arts diende te onderzoeken of de vrouw in vrijheid en overeenkomstig haar verantwoordelijkheid jegens zich zelf en jegens de ongeboren vrucht tot haar besluit is gekomen".

In art. 18 ' WAZ' was als overtreding strafbaar gesteld het verrichten van abortus in een niet-erkende inrichting en het niet-opvolgen van een richtlijn van de Adviescommissie. Bovendien kon de medicus door de tuchtrechter ter verantwoording worden geroepen.

Anders dan in het voorstel-Lamberts/Roethof, werd abortus door een onbevoegde in een nieuw art. 296 in een nieuwe titel XIX A strafbaar gesteld.

Dit wetsvoorstel werd door de Tweede Kamer met 83 tegen 58 stemmen angenomen ${ }^{333}$, maar door de Eerste Kamer met 41 tegen 34 stemmen verworpen. ${ }^{334}$ In de Eerste Kamer stemden van de twaalf VVD-leden acht tegen het voorstel. In de literatuur worden als verklaring hiervoor politieke motieven genoemd. Ook gaven uitlatingen van de toenmalige

327 HTK 1975-1976, 13909.

328 Vgl. HTK 1975-1976, 13909, nr. 3 (MvT), p. 11.

329 HTK $1975-1976,13909$, nr. 3 (MWT), p. 1.

330 HTK $1975-1976,13909$, nr. 3 (MvT), p. 12.

331 HTK 1975-1976, 13909, nr. 3 (MvT), p. 12-13.

332 HTK 1975-1976, 13909, nr. 3 (MvT), p. 15 en nr. 5 (MWA), p. 3 .

333 TK 29 sept. 1976, p. 214.

334 EK 14 dec. 1976 , p. 194 . 
Minister van Justitie, Van Agt, woeding aan de gedachte, dat hij het contraseign zoi. weigeren, wanneer dit voorstel zou worden goedgekeurd. ${ }^{33 s}$

\subsection{Het wetswoorstel $15476(\text { Abma/Verbrugh })^{33 \%}$}

Op dezelfde dag dat het tweede Regeringsvoorstel, het voorstel 15475 van de Ministens Ginjaar en De Ruiter, werd ingediend, dienden Abma (SGP) en Verbrugh (GPV) hum voorstel in. Daar het Regeringsvoorstel leidde tot de definitieve wet, wordt het verderop afzonderlijk besproken. ${ }^{337}$

Het woorstel-Abma/Nerbrugh vertoonde in zijn strekking nog de meeste overeenkomst met het woorstel-Van Schaik/Van Leeuwen en in zijn beknoptheid met het voorstel-Lamberts/Roethof. Het had ten doel de abortuspraktijken met behulp van het strafrecht terug te dringen. Dat blijkt reeds tuit de considerans, waarin wordt overwogen dat het noodzakelijk is "nieuwe regelen te stellen ter verbetering van de wettelijke bescherming van ongeboren menselijk leven". ${ }^{338}$

Het voorstel voorzag in een gewijzigd art. 2 Boek $1 \mathrm{BW}$ en in een vervanging van de artt. 295-297 Sr door vier nieuwe bepalingen. ${ }^{339}$ Volgens de voorgestelde bepalingem was de vrouw die abortus verricht of doet verrichten (art. 295 lid 1), en de derde die abortus verricht stralbaar (artt. 296 en 297). In deze artikelen werd echter niet van "abortus" gesproken of van "afbreken van zwangerschap", maar van een handeling "welke naar haar aard gericht is op het doden van de vrucht" de vrucht leefde, noch dat de vroww zwanger was. Voldoende was de veronderstelling dat er een vrucht was en dat de genoemde handeling opzettelijk werd verricht. ${ }^{340}$

Art. 297a verklaarde de artt. 296-297 niet van toepassing op de geneeskundige die

"1e. redelijkerwijs tot het oordeel heeft kunnen komen dat een verdere zwangerschap het leven van de moeder bedreigt en deze bedreiging slechts door afbreking van de zwangerschap kan worden afgewend; dan wel

$2 e$. de handelling verricht ter verwijdering van een kennelijk dode vrucht". In dat geval was de vrouw volgens het tweede lid van art. 295 evenmin strafbaar.

Onder bedreiging van het leven begrepen de indieners niet een neiging tot zelfmoord. Deze moest door andere geneeswijzen worden tegengegaan. ${ }^{341}$ Evenmin achtten zij abortus toelaatbaar, wanneer de zwangerschap was verwekt door verkrachting of incest. 32

Op 18 december 1980 werd het wetswoorstel Ginj|aar/De Ruiter met overgrote meerderheid door de Tweede Kamer aangenomen en het wetswoorstel Abma/Verbrugh verworpen. $^{343}$

335 Zie m.b.t. het contraseign: HTK 1975 1976, 13964, nr. 1 en nr. 2. Minister Van Agt deed zijn uitlatingen over het contraseign in verband met de zaak-Bloemenhove. Zie daartoe ook: $\mathbf{H}$. III, 19.1. Zie verder: De Bruijn, 1979, p. 222 en p. 227 en Outshoorn, 1986, p. 223 en p. 233-234.

336 HTK 1978-1979, 15476.

337 Zie H. III, onder 20.

338 HTK $1978-1979,15476$, nr. 2, p. 3.

339 HTK 1978-1979, 15476, n.. 3 (MvT), p. 13 en ur. 5 (MvA), p. 9.

340 Vgl. HTK 1978-1979, 15476, nr. 3 (MvT); p. 16.

341 HTK 1978-1979, 15476, nr. 3 (MvT), p. 18.

342 HTK 1978-1979, 15476, nr. 5 (MvA), p. 11.

343 TK 18 dec. $1980_{*}$ p. $2315=2318$. 
In de wetsvoorstellen Lamberts/Roethof en Ginjaar/Lamberts/Roethof/Veder-Smit werd voorgesteld de strafrechtelijke aansprakelijkheid voor abortus door een medicus te schrappen, om aan de verschillende opvattingen in de samenleving recht te doen. Het tuchtrecht bood volgens de indieners voldoende sanctiemogelijkheden tegen onzorgvuldig aborteren. Terwijl in het voorstel-Lamberts/Roethof hiermee werd volstaan, behelsde het wetsvoorstelGinjaar c.s., zoals de meeste andere hierboven besproken voorstellen, ook een procedureregeling in een bijzondere wet.

Met uitzondering van deze twee wetsvoorstellen, werd in elk wetsvoorstel ook abortus door een medicus in beginsel strafbaar geacht: Vanwege een bijzondere rechtvaardigingsgrond kon zijn handelen onder omstandigheden echter gerechtvaardigd zijn. In het voorstel-Stuyt/Van Agt hield de rechtvaardigingsgrond in, dat abortus door een medicus niet strafbaar was, wanneer de medicus in redelijkheid tot de beslissing kon komen dat de ingreep verricht moest worden. Volgens het voorstel-Veder-Smit/Geurtsen was abortus door een medicus vanwege het WvSr strafbaar, tenzij de handeling niet gericht was op thet afbreken van de zwangerschap of de vrouw weloverwogen tot haar beslissing tot de afbreking was gekomen, waarvan de medicus zich diende te overtuigen.

De wetsvoorstellen Van Schaik/Van Leeuwen en Abma/Verbrugh hadden tot doel de abortuspraktijk terug te dringen. Maar in het voorstel-Van Schaik/Van Leeuwen werd tevens erkend, dat met verschillende opvattingen in de samenleving over dit onderwerp rekening moest worden gehouden. Daartoe liet in hun voorstel de rechtvaardigingsgrond de nodige ruilmte. Deze hield in dat abortus door een medicus niet strafbaar is, indien de medicus redelijkerwijs tot het oordleel kon komen, dat de zwangerschap de lichamelijke integriteit of de geestelijke gezondheid van de vrouw ernstig bedreigde. Het meest beperkend was het voorstel-Abma/Nerbrugh, volgens hetwelk abortus slechts gerechtvaardigd was, wanneer het leven van de vrouw rechtstreeks door de zwangerschap werd bedreigd of wanneer het een dode vrucht betrof.

Sommige indieners hadden een voorkeur voor het opnemen van materiele normen in de wet. Maar slechts wanneer die normen zeer restrictief waren, konden zij voldoende duidelijkheid verschaffen. Materiele normen van een ruimere strekking vertoonden noodzakelijkerwijs een zekere vaagheid, zoals enkele indieners zelfs opmerkten.

Waarschijnlijk was dat de aanleiding om een grotere nadrulk te leggen op procedureregelingen. Daarmee koos de politiek voor dezelfde weg als de KNMG. Tegen een procedureregeling konden praktische maar geen principiële bezwaren bestaan. Een hoofdzakelijk procedureel opgezette regeling bood de kans om de meningsverschillen over de materiële normen en daarmee over de normatieve waardering van abortus opzij te zetten en de aandacht te concentreren op de meer technische punten omtrent de besluitworming en de uitvoering van de ingreep. Daarmee was een voorwaarde geschapen om tot een nieuwe abortusregeling in de Staten-Generaal te komen. 


\section{De Wet Afbreking Zwangersehap (WAZ)}

\subsection{Inleiding}

Tijdens de behandeling wan het regeringswoorstel Ginjaar/De Ruiter ${ }^{344}$ werd er in de Ifteratuur woor gepleit on van een nieuwe wettelijke regeling ten aanzien van abortus af te zien. Het voortdurende politieke touwtrekken ${ }^{345}$, het aantal wetsvoorstellen en de ingewikkeldheid, onduidelijkheid en tegenstrijdigheden van het regeringsvoorstel wezen uit, dat abortus (door een medicus) kennelijk niet goed geregeld kon worden, voor zover althans enerzijds de strafrechtellike aansprakelijkheid voor abortus door een medicus gehandhaafd blijft en anderzijds abortus door een medicus niet aan restrictieve materiële normen gebonden wordt.

Hülsman bracht als bezwaar tegen het voorstel Ginjaar/De Ruiter in, dat langs deze weg getracht werd een "moreel debat" te beslechten door in de (straf)wetgeving (impliciet) normen op te nemen ter bescherming van "waarden of belangen". Deze wijze van beslechting kon echter niet rekenen op een aanvaarding door de samenleving. Daarom stelde hij een tien jaar durend "moratorium" voor, in de hoop dat een toekomstige wetgever niet zou trachten zijn normen aan de samenleving op te leggen, of dat wanwege ontwikkelingen in de medische technologie geen abortusvraagstuk meer zou bestaan. ${ }^{346}$ Langemeijer sprak de hoop uit dat het voorstel zou worden verworpen, omdat het niet tegemoet kwam aan de voorstanders, noch aan de tegenstanders en omdat hij groot bezwaar had tegen de beraadtermijn van vijf dagen. Beter was het de bestaande toestand te laten voonduren. "Zij is óok slecht, maar zij geeft tenminste formeel satisfactie aan de principiêle tegenstanders en biedt praktisch uitkomst aan de overigen. En we zijn er eenmala aan gewend ${ }^{m} \cdot{ }^{347}$ Davelaar-Van Tongeren en Van den Pol gaven hun artikel over het voorstel de titel "Een krampachtig werkstuk" mee. ${ }^{348}$ En Soetenhorst-de Savornin Lohman beëindigde haar bijdrage "In droeve verwachting" ${ }^{\text {(1499 }}$ met de woorden van Modderman:

"Uit niets hoegenaamd is gebleken, dat hier te lande de wetgever met zijne door hare algemeenheid altijd gebrekkige formules moet tussen beiden treden, hetzij om de medici te beschermen tegen juristen, hetzij om de maatschappij te beschermen tegen de medicil" ${ }^{\text {iso }}$

344 HTK 1978-1979, 15475.

345 Zie hierower vooral: Outshoorn, 1986.

346 Huisman, DD 1979, p. 213-217.

347 Langemeijer, NJB 1981, p. 341.

348 Davelaar-Van Tongeren en Vari de Pol, NIB 1979, p. 560-571.

349 Soetenhorst-de Savormin Lohman, NJB 1979, p. 553-560.

350 Smidt, Ir, 1891, p. 469. 
In deze bespreking van de op 1 november 1984 in werking getreden Wet Afbreking Zwangerschap ${ }^{351}$ ligt het accent op de tot de medicus gerichte strafbepalingen in het WvSr en in de WAZ. ${ }^{352}$

Het wetsvoorstel voorzag in drie wettelijke regellingen: de eigenlijke Wet Afbreking Zwangerschap (WAZ), het Besluit Afbreking Zwangerschap (BAZ) en enkele bepalingen in het WuSr.

De WAZ geeft regels woor de besluitworming en de uitvoering van de ingreep, over de vergunningen en de eisen die aan de inrichtingen, waar abortus mag plaatsvinden, worden gesteld en over de registratie. Tevens behelst de WAZ in de artt. 15-18 strafbepalingen, die volgens art. 19 overtredingen zijn. ${ }^{353}$ In art. 56 lid 1 onder e Wet RO is bepaald, dat tot kennisneming van deze overtredingen in eerste aanleg de rechtbank bevoegd is. De MvT wijst in dat verband "op het bijzondere karakter van de in de Wet Afbreking $\mathrm{Zw}$ wangerschap vervatte strafbare feiten" ${ }^{354}$

Ten aanzien van het bepaalde in de artt. 4 lid 1,5 lid 1,6 lid 1 onder b en $c, 11$ lid 4 WAZ kunnen bij AMvB, met inachtneming van het in art. 13 bepaalde, nadere en aanvullende voorwaarden worden gesteld. Hierin voorziet het BAZ.

In het WvSr is aan de betekenistitel art. $82 \mathrm{a}$ Sr toegevoegd en is, achter de titel "Misdrijven tegen het leven", een nieuwe titel XIXA "Afbreking van zwangerschap" opgenomen, die één strafbepaling, een nieuw art. $296 \mathrm{~S}$, behelst.

Art. 296 lid $1 \mathrm{Sr}$ vertoont veel overeenkomsten met het vervallen art. 251 bis en is, evenals dit, ruim geformuleerd. Vanwege de doelstellingen van de wet, namelijk de rechtsbescherming van de vrucht en het recht van de vrouw op hulp bij ongewenste zwangerschap, wordt hier gepleit voor een enge interpretatie van art. 296 lid $1 \mathrm{Sr}$.

Voor de strafuitsluiting van abortus door een medicus dient een bijzondere strafuitsluitingsgrond, die geen materiële norm behelst, maar de strafuitsluiting afhankelijk stelt van een vergunning voor de inrichting, waar de ingreep wordt verricht.

Nadere voorwairden voor abortus zijn opgenomen in de WAZ en in het BAZ. Tussen die voorwaarden en art. $296 \mathrm{Sr}$ bestaat geen verband. Het niet-nakomen van sommige voorwaarden in de WAZ is als owertreding strafbaar gesteld.

In verband met de bewijsproblematiek en de afhankelijkheid van de afbakening van sommige in de nieuwe regeling gehanteerde begrippen van de stand van de medische wetenschap heeft de wetgever woor rume formuleringen gekozen. Daardoor is een aantal begrippen onvast.

Vanwege de bijzondere strafuitsluitingsgrond voor abortus door een medicus en in verband met bepaalde uitllatingen van de wetgever, kan niet langer worden verdedigd, dal de medicus zich bij abortus op de medische exceptle kan beroepen.

351 Wet van 1 mei 1981 , houdende regelen met betrekking tot het afbreken van zwangerschap (Wet afbre king zwangerschap), \$(t). 1981, nr. 257.

352 Zie woor algemene beschouwingen o.a.u Advies besluit albreking zwangersichap van de Emanicipatieraad, advies nr. 83/2, januari 1983; Singer-Delkker, in: Liber Amicorum Van Veen, 1985, p. 333-358; Leenen, 1988 , p. 137-142; Leenen; NJB 1985, p. 1357-1361; Snijders-Borst, NJB 1986, p. 187-189.

353 Zie HTK 1979-1980, 15475, nr.6 (MvA), p. 66.

354 HTK 1978-1979, 15475, ni. 3 (MVT)* p. 34 en HTK 1979-1980, 15475, nir.6 (MWA). 


\subsubsection{Inleiding}

Afbreking van zwangerschap, zoals abortus in art $296 \mathrm{Sr}$ en in de WAZ wordt aangeduid, kan plaatsvinden na de innesteling ${ }^{355}$ tot aan de zelfstandige levenswatbaarheid van de vrucht. ${ }^{356}$

Abortus wordt in de eerste vier leden van art. $296 \mathrm{Sr}$ strafbaar gesteld. Het vijfde lid geeft een rechtvaardigingsgrond woor de medicus. Art: 296 Sr luidt:

"1. Hij die een vrouw een behandeling geeft, terwijl hij weet of redelijkerwijs moet vermoeden dat daardoor zwangerschap kan worden afgebroken, wordt gestraft met gevangenisstraf van ten hoogste vier jaar en zes maanden of geldboete van de vierde categorie.

2. Indien het feit de dood van de vrouw ten gevolge heeft, wordt gevangenisstraf van ten hoogste zes jaren opgelegd of geldboete van de vierde categorie.

3. Indien het feit is begaan zonder toestemming van de vrouw, wordt gevangenisstraf van ten hoogste twaalf jaren opgelegd of geldboete van de vijfde categorie. ${ }^{358}$

4. Indien het feit is begaan zonder toestemming van de vrouw en tevens haar dood ten gevolge heeft, wordt gevangenisstraf van ten hoogste vijftien jaar opgelegd of geldboete van de vijfde categorie.

5 . Het in het eerste lid bedoelde feit is niet strafbaar, indien de behandeling is verricht door een geneeskundige in een ziekenhuis of kliniek waarin zodanige behandeling volgens de Wet afbreking zwangerschap mag worden verricht.".

\subsubsection{De strafbaarstelling}

Een "behandeling geven" in lid 1 omvat iedere handelling, waardoor de zwangerschap kan worden afgebroken. Waarschijnlijk valt daaronder ook reeds het geven van aanwijzingen woor een behandeling die de vrouw op zich zelf kan toepassen, zoals dat bij art. 251 bis-oud het geval was. ${ }^{359}$ Niet nodig is dat de behandeling met dat doel wordt gegewen. Voldoende is het weten of redelijkerwijs moeten vermoeden dat door de behandeling de zwangerschap kan worden afgebroken. ${ }^{360}$

Volgens Remmelink wijst het woordje " $\mathrm{kan}^{\text {"1 }}$ erop, dat woor de strafbaarheid volgens art. 296 lid 1 Sr niet wordt geeitst, dat de behandeling inderdaad tot abortus leidt. Evenmin acht hij het noodzakelijk dat de vrouw werkelijk zwanger is ${ }^{361 .}$

Toegegeven moet worden, dat de tekst van het eerste lid, evenals art. 251 bis-oud, de ruimte tot deze interpretatie laat. Daar staat tegenover dat de wetgever van 1981, anders

355 Dat kan wit HTK 1978-1979, 15475, nu. 3 (MvT), p. 24, voor art. 296 Sr worden affeleid en wordt voor de WAZ in art. 1 lid 2 WAZ, net zoveel woorden gezegd.

356 Zie HTK 1978-1979, 15475, nr. 3 (MwT), p. 16, p. 22 en p. 33.

357 25.000,

358 f 100.000 ,

359 Vgl. NLR, aant. 4 op ant 296. Zie ook NL.R aant. 5 op art. 251bis (suppl.12).

$360 \mathrm{Vgl.} \mathrm{NLLR}$, ant. 2 op art. 296.

361 NLR, ant. 2 op art. 296. 
dan die van 1911, met de nieuwe regeling de rechtsbescherming wan de ongeboren wrucht in verband met het recht van de vrouw op abortus wilde regelen, tenwijl hij abortus niet als onzedelijk gedrag kwalificeerde. ${ }^{362}$ De ruime, met art. 251 bis-oud veel overeenkomsten vertonende redactie van art. 296 lid 1 Sr dient naar mijn meming ter voorkoming van bewijsmoeilijkheden en niet om aan de nieuwe bepaling een zelfde actieradius toe te kennen als aan art. 251 bis-oud.

Het feit kan doleus of culpoos gepleegd worden. Hierop wijzen de bestanddelen "weet" en "redelijkerwijs moet vermoeden". ${ }^{363}$

Het bestanddeel "weet" duidt opzet aan. Daar onder opzet "willens en wetens" wordt verstaan, lijkt bij "weten" sprake te zijn van een onvolledige opzetaanduiding. Reeds in de opvatting van de wetgever van 1881 werd "weten" daar in een delictsomschrijving gebezigd, waar het voldoende werd geacht om opzet uit te drukken, zonder dat de wetgever hieraan een verschil in betekenis wilde verbinden ${ }^{364}$ De Hoge Raad is waarschijnlijk strenger. Hij lijkt bij "weten" zekerheidsbewustzijn te eisen, zodat kansopzet niet toereikend is voor het bewijs van het "weten". ${ }^{365}$ Doordat in art. 296 Sr het weten gekoppeld is aan de mogelijkheid dat door de behandeling de zwangerschap "kan" worden afgebroken, brengt de delictsomschrijving ondubbelzinnig mee dat ook kansopzet toereikend is.

Het schuldbestanddeel "redelijkerwijs moet vermoeden" trekt de aansprakelijkheid geheel in een normatief verband. Niet wat de medicus vermoedt, maar wat hij redelijkerwijs moet wermoeden, beslist ower de schuld. Het persoonlijke niet-vermoeden leidt niet tot zijn straffeloosheid, indien redelijkerwijs vermoed moet worden dat de handeling afbreking varı zwangerschap mee kan brengen. Bij een medicus wordt bovendien eerder dan bij een niet-medicus bewezen geacht dat het vermoeden aanwezig is, daar hij geacht wordt over meer kennis te beschikken dan de niet-medicus. Tevens wordt van de medicus geëist dat hij - vanwege zijn Garantenstellung - zorgvuldiger dan anderen te werk gaat.

\subsubsection{Strafverzwarende omstandigheden}

In de leden twee tot en met vier zijn als strafverzwarende omstandigheden opgenomen: het plegen van het feit zonder toestemming van de vrouw en de dood van de vrouw als geobjectiveerd gevolg.

Het eerste lid veronderstelt dat de vrouw toestemming heeft gegeven, want in de leden 3 en 4 wordt het feit zonder toestemming van de vrouw met een zwaardere straf bedreigd. De consequentie hiervan is dat de arts ook strafbaar is, wanneer hij in een toegelaten kliniek, maar zonder toestemming van de vrouw, de handeling verricht, want dan betreft zijn handelen niet de in lid 1 genoemde gedraging. ${ }^{366}$

$362 \mathrm{Vgl}$. HTK 1978-1979, 15475, nr. 1 (Considerans), p. 1: "met het oog op zowel de rechtsbescherming wan ongeboren menselijk lewen als op thet recht wan de vrouw op hulp bij ongewenste zwangerschap".

$363 \mathrm{~V}_{\mathrm{gl}} \mathrm{NL} \mathrm{N}_{\text {, }}$ aant. 5 op art. 296 .

364 Smidt, 1891, p. 83.

365 Zie b.v. HR 9 mei 1961, NJ 1962,83 mant. W.P. Vgl. Brouns, 1988, p. 230-232 en Hazewinkel-Suringa/Remmelink, 1991 , p. 195.

366 Vgl. NLR, alant. 4 op art. 296. Zje ook: HTK 1978-1979, 15475, mr. 3 (MVT), p. 33 en HTK 1979-1980, 15475, ni. 6 (MVA), p. 56; HEK 1980-1981, 15475, ni. 59d (Nadere MVA), p. 5. Zie onk Bijlage 6 (Nader Rapporti), p. 119: "Toestemming van de patiênt - wij hadden dit in het ontwerp vanzelfsprekend aangenomen - 
In het vijfde lid is een strafuitsluitingsgrond voor de medicus opgenomen. Onder "geneeskundige" in het vijfde lid wordt verstaan degene die vanwege art. 1 WUG bevoegd is tot het uitoefenen van de geneeskunde in haar volle omvang. Abortus door (tijdelijk) onbevoiegden is derhalve volgens de regeling altijd strafbaar.

Vanwege art. 296 lid 1 jo. lid 5 is niet strafbaar de medicus, die in een wolgens de WAZ aangewezen inrichting een vrouw met haar toestemming een behandeling geeft, terwijl hij weet of redelijkerwijs moet vermoeden dat daardoor de zwangerschap wordt afgebroken. Het door de medicus niet nakomen van (overige) in de WAZ, maar niet in art. 296 Sr gestelde eisen, leidt niet tot strafbaarheid vanwege handelen in strijd met art. 296 $\mathrm{Sr}^{36 \%}$ Volgens de MvA gaat het wetsvoorstel uit van

"de algemene norm dat abortus provocatus als misdrijf strafbaar is, tenzij de behandeling is verricht door een geneeskundige in een ziekenhuis of kliniek waarin zodanige behandeling volgens de Wet Afbreking Zwangerschap mag worden verricht (zie het nieuwe artikel 296 W.v.Sr.) Aan die algemene norm kan echter niet een individueel verzoek om abortus worden getoetst, voor zover de vrouw zich heeft gewend tot een geneeskundige als hier bedoeld" ${ }^{368}$

Verdedigd kan worden, zoals Meijers doet, dat in het vijfde lid geen rechtvaardigingsgrond maar eerder een vervolgingsütsluitingsgrond is neergelegd. Meijers verwijst hiervoor naar de aanhef van dat lid: "Het in het eerste lid bedoelde feit is niet strafbar ..." en naar de MvT, die zegt: "Afbreking van zwangerschap is alleen toegestaan in ziekenhuizen (...) en abortusklinieken, voor zover die inrichtingen voorzien zijn van een ... vergunning ...". ${ }^{369}$ Hieruit leidt hij af dat bij toepassing van dit lid de handeling "objectief bezilen, zonder enig defect" is en derhalve bij honorering door de rechter tot niet-ontvankelijkheid van de Officier van Justitie dient te leiden, waar nog bijkomt dat het Openbaar. Ministerie gemakkelijk kan nagaan of die volgens lid 5 vereiste vergunning is verleend. ${ }^{370}$

In art. 2 WAZ is, anders dan in art. 296 lid $1 \mathrm{Sr}$, de doelgerichtheid van de behandeling. aangegeven.

"Een behandeling, gericht op het afbreken van zwangerschap, mag slechts worden

verricht door een geneeskundige in een ziekenhuis of kliniek, waaraan door Onze

Minister vergunning tot het verrichten van dergelijke behandelingen is verleend". Daarmee bestrijkt art. 2 WAZ een beperkter gebled dan art. 296 lid $1 \mathrm{Sr}$. Een behandeling, die nilet gericht is op het afbreken van zwangerschap, behoeft volgens die bepaling niet in een toegelaten kliniek plats te vinden. ${ }^{371}$ Mar wanneer de ingreep elders wordt verricht, terwijl de medicus weet of redelijkerwijs moet vermoeden dat door de behan-

is in het algemeen nodig en zeker bij cen woor de patiënt delicate kwestie als een zwangerschapsafbreking.

367 Vgl. Minderheidsnota, in: Statscommissie Euthanasie, Deel 1,1985, p. 281 ; NLR, aant. 7 op art. 296 en Ha zewinkel-Suringa/Remmelink, 1991, p. 349. Anders: Davelaar-Van Tongeren en Van de Pol, NIB
1979, p. 567 en Leenen, 1988, p. 135 en 138.

368 HTK 1979-1980, 15475, nr. 6 (MvA), p. 8. Zie opk p. 55-57. Verder: TK 1978-1979, 15475, ms. 1-4, Bijlage 6 (Nader Rapport aan de Koningin), p. 108 en p. 117; ne. 3 (MvT), p. 21 en p. 33.

369 HTK $1978-1979,15475$, n. 3 (MvT), p. 10.

370 Meijers, in: Verantwoordelijk voor mensen, 1985, p. $121-128$.

371 Zie over de problenen die bij de afoukenimg wan "gerichl op het afbreken van zwangerschap" kunnen
spelen: Leenen, 1988, p 135 . 
deling de zwangerschap wordt afgebroken, valt de gedraging wel onder art. 296 lid 1 $\mathrm{Sr}^{372}$ Een beroep op art. $40 \mathrm{Sr}$ blijft dan naturijijk wel mogelijk. ${ }^{373}$

\subsubsection{Het afdrijven van een levensvatbare vrucht}

Vanaf het moment dat de geboorte begint, spreekt de wet niet meer van een vrucht, maar van een kind, artt. 290 en $291 \mathrm{Sr}$. Wie een kind opzettelijk doodt, maakt zich schuldig aan doodslag of moord, artt. 287 en $289 \mathrm{Sr}$, respectievelijk als de moeder de dader is en zij handelt bij of kort na de geboorte onder vrees voor de ontdekking van haar bevalling, aan kinderdoodslag of kindermoord, artt. 290 en 291 Sr.

De artt. 287-291 Sr zijn eveneens van toepassing als een levensvatbare vrucht wordt gedood. Dat blijkt uit art. 82a Sr. ${ }^{374}$ "Onder een ander, of een kind bij of kort na de geboorte, van het leven beroven" wordt, volgens die bepaling, begrepen het "doden van een vrucht die naar redelijkerwijs verwacht mag worden in staat is buiten het moederlichaam in leven te blijven". Zoals het woord "vrucht" aangeeft, betreft art. $82 \mathrm{a} \mathrm{Sr}$ een dodingshandeling voordat de geboorte begint, terwijl de zinsnede "naar redelijkerwijs verwacht mag worden in staat is buiten het moederlichaam in leven te blijven", de toepasselijkheid van de artt. 287-291 Sr beperkt tot een levenswatbare vrucht.

In de wet is voor de zelfstandige levensvatbaarheid geen tijdstip vastgelegd, omdat deze afhankelijk is van ontwikkelingen van de medische wetenschap. Daarom spreekt art. $82 \mathrm{a} \mathrm{Sr}$ van "redelijkerwijs verwacht mag worden". ${ }^{375}$ In de MvT wordt over dit criterium opgemerkt:

"Deze ... formulering is aldus gekozen, omdat het levensvatbaar zijn van een vrucht pas onomstotelijk kan worden vastgesteld, nadat deze levend ter wereld is gebracht en - mogelijk dankzij de geboden medische verzorging - in leven is gebleven. Waar het dus om gaat is dat het doden van een vrucht op zodanig tijdstip, dat zij naar ervaringsregels, gezien de stand van de medische wetenschap, een redelijke kans maakte - ter wereld grekomen - in leven te blijven, ..." ${ }^{376}$

Volgens de MvT moet "bij de huidige stand van de medische wetenschap" voor de levensvatbaarheid van een duur van de zwangerschap van 20 à 24 weken worden uitgegaan. Daarbij wordt de duur van 24 weken als "absolute grens" genoemd, zodat twijfel over de redelijke verwachting zich slechts op een eerder tijdstip "mag" voordoen. ${ }^{37}$ Maar:

"De marge van onnauwkeurigheid van deze schatting kan, indien gebruik is gemaakt van conventionele middelen, tot 4 weken bedragen. Alleen met zeer geavanceerde diagnostische hulpmiddelen is het mogelijk de genoemde marge van onnauwkeurigheid bij de vaststelling van de zwangerschapsduur te reduceren tot 2 weken.

Bij de besluitvorming aangaande zwangerschapsonderbreking betekent dit, dat een met conventionele middelen geschatte zwangerschapsduur van 20 weken de uiterste grens is waarbij nog abortus kan worden overwogen, aangezien daarboven

372. Vgl. Singer-Dekker, in: Liber Amicorum Van Veen, 1985, p. 344-348"

373. Vigl. HTK 1979-1980, 15475, wr. 6 (MvA), p. 57.

374. Zie ook Singer-Dekker, in: Liber Amicorum Van Veen, 1985, p. 348-349.

375 Vgl. HTK 1978-1979, 15475, nr. 3 (MvT), p. 32-33.

376 HTK 1978-1979, 15475, nr. 3 (MvT), p. 32-33, Zie ook: HTK 1979-1980, 15475, nr. 6 (MvA), p. 60 .

377 Zie ook art, 2 Wet op de Lijkbezorging: "De bepalingen dezer wei zijn njet van toepassing op een na een zwangerschapsduur van minder dan vier en twintig weken ter wereld gekomen menselijke vrucha". 
levensvatbaarheid niet is uit te islutten. Omdat het om een vitale grens gaat, zal in zulke gevallen immers de maximale extra-veiligheidsmarge van 4 weken moeten worden aangehouden". 378

Het opwekken van een vroeggeboorte valt - zoals hierboven reeds is opgemerkt - niet onder het afbreken van zwangerschap. Art. $296 \mathrm{Sr}$ is niet van toepassing, omdat dit artikel geld tot aan de zelfstandige levensvatbaarheid van de wrucht. ${ }^{379}$ Daar de vrucht niet is gedood, is evenmin art. $82 \mathrm{a}$ Sr van toepassing.

Als de vrucht door de ingreep (zwar) hichamelijk letsel oploopt, kunnen de strafbepalingen omtrent mishandeling en zwaar lichamelijk letsel door schuld niet worden toegepast, omdat die van een gelaedeerde mens uitgaan en een met art. 82 a Sr vergelijkbaar "koppelingsartikel" wer ontbreekt. In dat geval schijnt de enige mogelijkheid voor strafrechtelijke aans prakelijkheid te zijn, dat de vrouw bij de ingreep lichamelijk letsel of een benadeling van haar gezondheid onderwindt. ${ }^{380}$.

Hiermee heeft de wetgever van 1981 aan art. 296 Sr een beperktere werking toegekend dan de wetgever van 1881 aan de artikelen 295 e.w. en de wetgever van 1911 aan art. 25 Ibis-oud Sir.

Voor de toepassing van art. $82 \mathrm{a} \mathrm{Sr}$ is niet van belang hoe lang een bepalde vrucht vanaf de geboorte in leven blijft, aldus de Hoge Raad in HR 29 mei 1990, NJ 1991, 217 m.nt. Schalken. ${ }^{381}$

Deze zaak betrof een arts, die vanwege moord op een levensvatbare vrucht werd vervolgd. Volgens Remmelink was hierbij art. $82 \mathrm{a} \mathrm{Sr}$ "formeel" niet van toepassing, ondat "(uiteindelijk) een geboren mens" werd gedood. ${ }^{32}$ Art. 82a Sr spreekt immers van het doden van een "vrucht". In deze zaak vond de dodingshandeling jegens de vrucht (derhalve in het moederlichaam) plaats, terwijl het kind aan de gevolgen van de handeling kort na de geboorte overleed.

Voor de rechter kwam vast te staan, dat de arts bij het onderzoek tmet behulp van conventionele middelen de zwangerschap van het meisje op een duur van 19 a 20 weken had bepaald. Op het moment dat het meisje werd opgenomen, bedroeg de duur volgens die diagnose 20 à 21 weken. Tegen de assistent-arts die de ingreep verrichtte, noemde de $\operatorname{arts}^{383}$ een duur van 16 weken. Twee deskundigen verklaarden op de zitting dat de duur van de zwangerschap tussen 24 a 28 weken was gelegen. Het meisje kreeg een medicament toegediend, waardoor de vrucht zou komen te overlijden. Dat gebeurde niet en het kwam levend ter wereld, maar overleed ten gevolge van de behandeling enkele uren later:

De rechtbank verklaarde het telastegelegde feit bewezen, waarbij zij overwoog, dat de verdachte de 20 weken-grens kende en daarom een niader onderzoek had moeten verrichten. Bovendien had hij aan de assistent-arts een verkeerde voorstelling omtrent de duur van de zwangerschap gegeven. Door het nader onderzoek na te laten had hijj

378 TK 1978-1979, 15475, \#r. 3 (NvT), p. 33,

379 Vermosdalijk in dezelfde zin: Reminelink. Zie NLR, amt. 2 en 8 op art. 82 a.

$380 \mathrm{Zo}$ begrijp ik ook Remmelink: "Nu is het nog zo, dat alleen wanneer de vrouw zelf tegen haar will wordt getroffen, ook de foetus (indirect) strafrechtelijk tegen mishandeling wordt beschemd". NLR, aant, 9 op art. 82 a.

381 Zie voor het voorafgande arrest van het bof Hof Den Hagg 23 matart 1989, NJ 1989, 808.

382 NLR, ant. 3 en 8 op art. $82 \mathrm{a}$.

383 De arts die terechistond was de behandelende arts. Hij werd als functionele dader beschouwd. 
zich willens en wetens blootgesteld aan de aanmerkelijke kans dat de zwangersehapsduur meer dan 24 weken zou bedragen. Het hof voegde daaraan nog toe, dat de verdachte niet had getracht de duur met behulp van echoscople nader te bepalen, zoals hij volgens de door het hof gehoorde deskundigen had behoren te doen.

Volgens de Hoge Raad is van "een vrucht die naar redelijkerwijs verwacht mag worden in staat is buiten het moederlichaam in leven te blijven" sprake, "indien op het moment van de ten laste gelegde gedragingen redelijkerwijs mocht worden verwacht dat de vrucht in staat zou zijn bij een 'normale geboorte' op dat moment -zijnde mitsdien een fictieve situatie - buiten het moederlichaam in leven te blijven. Voor de vervulling van dit bestanddeel van de delictsomschrijving is niet van belang of de aan de medische wetenschap ontleende redelijke verwachting achteraf blijkt voor het onderhavige geval niet op te gaan".

Schalken acht in zijn noot, terecht, de formulering in de laatste zin onjuist, daar de redelijke verwachting aan de bestaande medische mogelijkheden juist wel mag worden ontleend. Wat de Hoge Raad kennelijk wilde zeggen, was, dat de verwachting gebaseerd moet zijn op zorgvuldig medisch onderzoek. En daarvan is in deze zaak geen sprake geweest. Daarom ontbrak een "redelijke" verwachting. ${ }^{384}$

Voor een redelijk vermoeden van levensvatbaarheid van de vrucht in de zin van art. $82 \mathrm{a} \mathrm{Sr}$ is derhalve niet van belang of een bepaalde vrucht achteraf niet levenswatbaar blijkt te zijn. Waar het om gaat is of de dader op het moment van de gedraging de redelijke verwachting kon en behoorde te hebben.

Wanneer een medicus een levensvatbare vrucht (in het moederlichaam) doodt, dan is op deze gedraging art. $82 \mathrm{a}$ Sr van toepassing. Dat betekent dat dan de bijzondere strafuitsluultingsgrond van art. 296 lid $5 \mathrm{Sr}$ niet kan worden ingeroepen. Daarom moet de reden voor de straffeloosheid in een algemene strafuitsluitingsgrond worden gezocht. In het bijzonder moet hierbij worden gedacht aan noodtoestand. ${ }^{385}$

\subsubsection{De overtijdsbehandeling:}

Met de levensvatbaarheid van de vrucht eindigt de alansprakelijkheid vanwege art. 296 lid $1 \mathrm{Sr}$. Als begintijdstip van die aansprakelijkheid werd hierboven de innesteling genoemd, die rond de dertiende dag na de conceptie plaatsvindt.

Van een overtijdsbehandeling wordt gesproken als de ingreep wordt verricht vanaf de conceptie totdat de vrouw maximaal zestien dagen over tijd is. ${ }^{387}$ Dat betekent dat deze behandeling in een bepaald geval voor of na de innesteling kan geschieden en afhankelijk daarvan zou zij dan al dan niet onder art. 296 lid $1 \mathrm{Sr}$ en onder de WAZ vallen.

384. Sichalken werwijst hilerbij naar HR 27 now. 1984, NJ 1985, 106 m.nit. ThWvV (Euthanasie I) en HR 21 okt. 1986, NJ 1987, 607 mint, GEM (Euthanasie II), warin de Hoge Raad heersende medisch-wetenschappelijke inzichten wel wan belang achtte. Maar bowendien was het juist de bedoeling wan de wetgever om. met behulp van medisch-wetenschappelijke methoden de dun wan de zwangerschap en daarmee de redelijkheid van de verwachting van art. 82 a Sr vast te stellen.

385 Vgl. HTK 1978-1979, 15475, nrs. 1-4, Bijlage 6 (Nader Rappori).

386. Vgl. NLR, aant. 4 op art. 296.

387 Wibaul ag, MC 1987, p. 683. 
Volgens de MvA wordt

de $\mathrm{z}, \mathrm{g}$. overtijdsbehandeling niet door het wetsontwerp bestreken, omdat bij die

behandeling niet met zekerheid vaststalat, dat de vrouw ook inderdaad zwanger

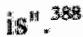

Na de inwerkingtreding van de WAZ stelde de Inspectie voor de Volksgezondheid zich op het standpunt dat bij owertijdsbehandeling de in art. 3 lid 1 WAZ gestelde wachttijd in acht moest worden genomen ${ }^{389}$

In 1987 verklaarde de Minister van WVC, dat de overtijdsbehandeling niet onder de WAZ valt: Onder een overtijdsbehandeling begreep hij een behandeling dile binnen 16 dagen na de conceptie plaatsvindt. ${ }^{390}$ In een antwoord op vragen van de vaste Commissie voor de volksgezondheid bevestigde Staatssecretaris Simons in 1990 dat standpunt. Tevens merkte hij echter op dat een overtijdsbehandeling inmiddels wel door art. 296 lid $1 \mathrm{Sr}$ wordt bestreken. Voorafgaande aan een dergelijke behandeling vindt immers een test plaats die een betrouwbarheidsgehalte van $95-99 \%$ heeft. Is de uitslag positief dan wordt tot overtijdsbehandeling besloten. Vanwege de praktijk en het hoge betrouwbaarheidsgehalte brengt een overtijdsbehandeling in beginsel strafrechtelijke aansprakelijkheid mee. Wanneer de arts deze behandeling in een inrichting met vergunning uitvoert, dan is hij vanwege art. 296 lid $5 \mathrm{Sr}$ niet strafbaar. ${ }^{391}$ Daar anderzijds de WAZ niet van toepassing is behoeft onder andere de wachttijd van art. 3 lid 1 WAZ niet in acht te worden genomen. Volgens de Staatssecretaris is het onwenselijk om de overtijdsbehandeling onder de WAZ te brengen, omdat de wachttijd zich niet verdraggt met de overtijdsbehandeling. ${ }^{322}$ HaasBerger (PvdA) wees er nog op dat een overtijdsbehandeling een "aanzienlijk minder belastende worm van zwangerschapsafbreking is ${ }^{1:}{ }^{393}$

Daarmee is gekozen woor een praktische benadering. Maar de gegeven uitleg brengt wel mee dat art. $296 \mathrm{Sr}$ en de WAZ met betrekking tot de overtijdsbehandeling niet sporen. Art. 296 lid $1 \mathrm{Sr}$ en art. 2 WAZ bieden weinig aanknopingspunten voor een dergelijk verschil. In het eerste lid van art. $296 \mathrm{Sr}$ wordt gesproken van "terwijl hij weet of redelijkerwijs moet vermoeden dat daardoor zwangerschap kan worden afgebroken" . Art. 2 WAZ spreekt van "gericht op het afbreken van zwangerschap".

\subsection{De aansprakelijkheid van de medicus vanwege de WAZ}

Art. 15 WAZ stelt strafbaar de medicus "die een behandeling, gericht op het afbreken van zwangerschap" verricht in een kliniek; "terwijl hij weet of redelijkerwijs moet vermoeden, dat de zwangerschap langer dan dertien weken heeft geduurd". Voor de bepaling. van de aansprakelijkheid wordt hier hetzelfde criterium als in art. $82 \mathrm{a}$ Sr gebezigd. Zou vanwege de onzekerheidsmarge de bij art. 82a Sr door de wetgever genoemde tijdsnimte ook hier gelden, dan zou bij een met conventionele middelen vastgestelde zwangerschaps-

388 HTK 1979-1980, 15475, nr. 6 MvA), p. 42 en p. 61. Zie ook: HEK 1980 -1981, 15475, nr. 59d (Nadere (W. A), p. 7 .

389 Zie: Wibaut e:a., MC 1987, p. 683.

390 HTK 1986-1987, 18386, nr. 25.

391 TK, 1990-1991, 18386, nr. 38, p. 2. Zie ook TK, 1990-1991, 18386, nr. 41, p. 3.

392 TK. 1990-1991, 18386, nar. 42, p. 14

393 Haas-Berger, TK 1990-199 1, 18386, n. 42, p, 6. 
duur van negen weken art. 15 WAZ van toepassing zijn. ${ }^{304}$ De medicus is niet strafbaar indien deze handeling wordt verricht in een inrichting waarvoor een bijzondere vergunning voor het afbreken van zwangerschappen van een langere duur dan dertien weken is afgegeven, art. 6 WAZ.

Art. 16 WAZ stelt twee feiten strafbaar. De medicus is volgens art. 16 lid 1 WAZ strafbaar, wanneer hij "een behandeling, gericht op het aforeken van zwangerschap," verricht vóór de zesde dag nadat de vrouw hem heeft bezocht en daarbij haar voornemen met hem heeft besproken (art. 3 lid 1 WAZ). Maar heeft hij de behandeling verricht ter afwending van een dreigend gevaar voor het leven of de gezondheid van de vrouw dan is het feit van het eerste lid, volgens het tweede lid niet strafbaar. ${ }^{395}$

Art. 3 WAZ bepaalt dat de 'behandelende' of "verwijzende" medicus binnen vijf (of bij dreigend gevaar voor het leven of de gezondheid van de vrouw, art. 16 lid 2 WAZ, binnen drie) dagen aan de vrouw meedeelt, of hij de aan hem gevraagde medewerking zal verlenen. Wordt de betreffende termijn overschreden, dan is de medicus krachtens het derde lid van art. 16 strafbaar.

Art. 11 lid 1 schrijft aan de medicus voor van elke behandeling, die gericht is op het afbreken van een zwangerschap, aantekeningen te maken, die onder andere betreffen: het aantal van dergelijke behandelingen, de duur van de zwangerschappen, bepaalde persoonsgegevens van de vrouw, en verschillende tijdstippen in verband met de behandeling. Yolgens het zesde lid dient de medicus de aantekeningen zo spoedig mogelijk na de behandeling te maken, deze ten minste vijf jaar te bewaren en op verzoek van de inspecteur aan deze beschikbaar te stellen. Handellen in strijd hiermee is volgens art. 18 lid 1 strafbaar.

In art: 5 WAZ wordt bepaald dat bij AMvB eisen worden gesteld aan de hulpverlening en de uitvoering van de ingreep. Die eisen, die in het Besluit Afbreking $\mathrm{Zwangerschap}$ te vimden zijn, strekken er, volgens het eerste lid toe, dat de "beslissing tat abortus met zorgvuldigheid wordt genomen en alleen dan uitgevoerd, indien de noodsituatie van de vrouw deze onontkoombaar maakt" ${ }^{396}$

Handelen in strijd met (één van) deze eisen, is voor de medicus niet zelfstandig strafbaar gesteld en valt, gezien de aard van de eisen (zie art. 5 lid 2 WAZ) evenmin onder een andere strafbepaling.

394 Zie ook Leeneri, 1988, p. 138, die het dan echter consequernt acht de termijn van art. 15 WAZ met vier weken te verlengen. Over onzekerheid onttent de 13 -weken-termijn wordt in de toetichting op het wetsvoorstel niet gesproken. In HEK 1980-1981, 15475, nr. 59d (Nadere MvA), p. 7, merken Ginjarar en De Ruìter zelfs op, dat bij overschrijding van de 13-weken-termijn nuet de in art. 3 lid 1 WAZ geéiste wachttijo

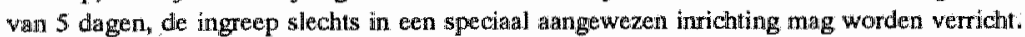

395 Op advies wan de RvS is deze bijzondere strafuits uitingsgrond toegevoegd. Zie HTK 1978-1979, 15475, nrs. 1-4, Bijlage 6 (Nader Rapporl), p. 106. Zie ook HTK 1979-1980, 15475, wr. 6 (MvA), p. 41-42.

396 Vgl. HTK 1979-1980, 15475, Mr. 6 (MVA), p. 6. 
Zowel in art. $296 \mathrm{Sr}$ als in de WAZ ontbreekt een materiele normstelling op grond waarvan abortus strafbaar of geoorloofd is. In art. 5 lid 1 WAZ wordt weliswaar bepaald dat de ingreep slechts mag worden uitgevoerd, "indien de noodsituatie van de vrouw deze onontkoombaar maakt". Maar, behalve dat overtreding van deze bepaling niet strafbaar is gestell, komt vollgens het tweede lid onder b het oordeel dat de noodsituatie "niet op andere wijze kan worden beëindigd" aan de vrouw toe. De taak van de medicus is het, volgens dezelfde bepaling, zich ervan te vergewissen, "dat de vrouw haar verzoek heeft gedaan en gehandhaafd in vrijwilligheid, na zorgvuldige overweging en in het besef van haar verantwoordelijkheid voor ongeboren leven en van de gevolgen voor haarzelf en de haren". ${ }^{397}$ In de MvT wordt met betrekking tot een normstelling opgemerkt:

"De wetgever is ... niet bij machte die (de grootst mogelijke, J.W.) zorgvuldigheid af te dwingen door een algemene normstelling te formuleren en deze zonodig in concrete gevallen via strafsancties te handhaven. De situaties van nood, ..., zijn zo uiteenlopend, dat een dergelijke algemene norm, indien zij al reële inhoud zou hebben, niet het beoogde effect zou hebben. ... De bescherming die de wet moet bieden aan ongeboren menselijk leven -...- hebben wij in het ontwerp willen bereiken door waarborgen te geven voor een procedure, die moet leiden tot een zorgvuldige besluitworming in concrete gevallen". ${ }^{398}$

\subsection{Geen medische exceptie bij abortus door een medicus}

Met de invoering van de WAZ is abortus door een medicus aan een uitwoerige regeling onderworpen, terwijl voor de strafuitsluiting krachtens het WvSr in een bijzondere strafuitsluitingsgrond is voorzien. Daaruit volgt naar mijn mening dat de regeling zelf een beroep op de medische exceptie niet toelaat. Bovendien heeft de wetgever hierover verklaard:

"Voor artsen zal, zoals voor iedere categorie beroepsbeoefenaren; gelden dat zij bij de uitoefening van hun beroep rekening moeten houden met eventuele beperkingen die de wet daaraan stelt",

en

"De arts die een zwangerschapsafbreking verricht in strijd met de bepalingen van het wetsontwerp is strafbaar; een beroep op de regels van zijn kunst waarnaar hij gehandeld zou hebben heft de strafbaarheid niet op, tenzij sprake is van een situatie van overmacht als bedoeld in artikel 40 W.v.Sr., of, bij overtreding van artikel 3 jo. artikel 16, eerste lid, indien de strafuitsluitingsgrond van het tweede lid van dat laatste artikel aanwezig is". ${ }^{399}$

In deze uitlatingen kan een ontkenning van de medische exceptie worden gelezen. Het wezen van deze exceptie is immers dat een gedraging van een medicus, die in strijd is met de strafwet de strafbaarheid wegneemt, althans voor zover de verbodsbepaling zich

397 Zie hiertoe: Leenen, $1988, \mathrm{p} .139-140$, die wan een niet professioneel en subjectief oordeel spreekt.

398 HTK 1978-1979, 15475, mr. 3 (MvT), p. 10. Zie ook de considerans, p. 1: "met het oog zowel op de reclutsbescherming van ongeboren memselijk leven als op het recht van de vrouw op holp bij angewerst
(curs. J.W.) zwangerschap".

399 HTK 1979 1980, 15475 , nr. 6 (MvA), p. 58. 
niet juist expliciet - mede - tot de medicus richt. De door Van Veen ${ }^{400}$ opgeworpen vraag, of de medische exceptie nog strafuitsluitend kan werken indien een arts buiten een aangewezen ziekenhuis of kliniek abortus toepast, moet daarom mijns inziens ontkennend worden beantwoord.

Uit de citaten blijkt tevens dat de indieners het verrichten van abortus als een gedraging beschouwden die onderdeel is van de beroepsuitoefening van de arts. Ook noemden zij abortus een medische verrichting. Daarbij merkten zij wel op, dat deze zich van andere medische verrichtingen onderscheidt doordat "de beschermwaardigheid van het ongeboren leven in het geding is". 401

\section{Samenvatting}

Vanaf de "uvoering van het Wetboek van Strafrecht in 1886 is een aantal keren getracht de abortusbepalingen te wijzigen, ${ }_{y}$ om zodoende de strafrechtelijke aansprakelijkheid uit te breiden en de straffeloosheid van de medicus voor abortus lege artis in de wet vast te leggen. Telkens bleek dat de meningen over de gevallen waarin de medicus mocht aborteren zeer uiteenliepen. Dat had zijn oorzaak in de verschillende benaderingen van het abortusvraagstuk en had tevens te maken met het feit, dat de medici zelf over de indicaties verdeeld waren en derhalve geen duidelijke indicaties konden aangeven.

Uit de wetsgeschiedenis van 1886 blijkt niet, dat de wetgever abortus als een zedelijk probleem beschouwde. Hij onderkende bij abortus een belangenconflict tussen vrouw en vnucht. Abortus werd door hem gezien als een handeling ter doding van de vrucht en werd daarom strafbaar gesteld. Hij vond wel dat abortus door een medicus geoorloofd kon zijn.

Voor de Wetgever behoefde de straffeloosheid van de medicus echter niet in het wetboek vastgelegd te worden. Daarbij ging hij van de veronderstelling uit, dat een medicus in beginsel niet strafwaardig handelt. Bovendien vreesde hij dat de wet in het omschrijven van de gevallen, waarin abortus straffeloos mocht worden verricht, te kort zou schieten. De straffelloosheid van de medicus had daarmee zijn grondslag in een geclausuleerde erkenning van het ontbreken van de wederrechtelijkheid van de gedraging.

Terwijl in de literatuur op velerlei wijze getracht werd de straffeloosheid van de medicus in verband met de delictsomschrijvingen van mishandeling te verklaren, werd de medicus ten aanzien van abortus meestal strafbaar geacht. Daartoe werd aangevoerd, dat de tekst van de abortusbepalingen geen strafuitsluitende mogelijkheid bood. Een enkele jurist achtte de medicus niet strafbaar vanwege de medische exceptie of omdat hij zich op noodtoestand kon beroepen. Hiertegen werd ingebracht, dat daarop de straffeloosheid niet gebaseerd kan worden, ondat deze gronden geen antwoord geven op de vraag of en zo ja, in welke gevallen, het belang van de vrouw of dat van de vrucht voorrang heeft.

Vanwege de verschillende en meestal afwijzende opvattingen van juristen over de straffeloosheid van abortus door een medicus, vroegen medici om het in de wet vastleggen wan hun straffeloosheid voor abortus. Daarnaast drongen zij aan op aanscherping van de abortusbepalingen om ongeoorloofde abortus beter te kunnen bestrijden. A.an deze beide doelen voldeden de abortusbepalingen in de novelle-Cort van der Linden. In de voorgestelde bepalingen was een bevrijdend bestanddeel voor de medicus opgenomen, wolgens welk een medicus die binnen de grenzen van zijn beroepsuitoefening aborteert, 
straffeloos zou zijn. Doordat het bevrijdend bestanddeel geen materiële criteria behelsde, was daarmee de medische exceptie in de delictsomschrijving verwerkt.

De novelle-Loeff en de zedelijkheidswetgeving van 1911 benaderden abortus vooral als zedelijk probleem. Daarmee was abortus door een medicus niet meer witsluitend een medische kwestie. Ook de medicus diende de door de overheid bepaalde grenzen van de zedelijkheid in acht te nemen. Doordat abortus als een zedelijk vraagstuk werd beschouwd, kon het werkingsbereik van de abortusbepalingen in 1911 worden uitgebreid. Niet van belang was of de gedraging het leven van de vrucht bedreigde, maar of zij een onzedelijk karakter had. De wetgever van 1911 erkende dat de medicus in sommige gevallen straffeloos moest kunnen aborteren, maar kon die gevallen niet nauwkeurig omschrijwen. Daarom zag hij ervan af de strafuitsluiting van de medicus wettelijk vast te leggen. Voor de straffeloosheid diende het Openbaar Ministerie door zijn vervolgingsbeleid te zorgen. Daarmee was de rechtsonzekerheid voor medici toegenomen, maar desondanks drongen zij niet opnieuw aan op beschermende bepalingen.

Vanaf het midden wan de jaren zestig stond het abortusvraagstuk opnieuw in de belangstelling. Met een beroep op de wetsgeschiedenis van 1881 en van 1911 en op het Huizer Veearts-arrest werd verdedigd, dat de medicus op medische indicatie straffeloos mag: handelen. Maar het begrip "medische indicatie" werd steeds ruimer ingevuld, hoewel ook reeds in het begin van deze eeuw zich sommige medici voor een ruime benadering uitspraken. Tevens werd voorgesteld om de abortusbepalingen zodanig te wijzigen dat abortus door een medicus van de strafrechtelijke aansprakelijkheid was uitgezonderd.

Maar de gevallen, waarin de medicus tot abortus mocht overgaan, konden noch de politici, noch de medici nauwkeurig omschrijven. Voor degenen die de wens van de vrouw uiteindelijk doorslaggevend achtten, was het niet nodig in een strafrechtelijke aansprakelijkheid van de medicus te voorzien. Werd meer de nadruk op het belangenconflict gelegd of abortus (mede) als zedelijk vraagstuk beschouwd, dan moest de strafrechtelijke aansprakelijkheid van de medicus in principe gehandhaafd blijven en via een strafuitsluitingsgrond aangegeven worden, wanneer de medicus vanwege abortus niet strafbaar was.

Vanwege sterk uiteenlopende opvattingen kon hierover geen overeenstemming worden bereikt. Uiteindelijk werd daarom een compromis bereikt, waarbij de medicus zich op een wettelijke strafuitsluitingsgrond kon beroepen. Die grond behelsde echter geen materiele criteria. Daarnaast werd in een procedureregeling voorzien, om een geoorloofde ingreep zorgvuldig te laten verlopen.

Daarmee heeft de wetgever de afbakening van strafbare en niet-strafbare abortus door een medicus opnieuw ter beslissing aan de medicus overgelaten. Waar deze slechts op hoeft te letten is dat hij met inachtneming van de procedurele regels werkt. Wel heeft de wetgewer ten aanzien van het begin- en het eindtijdstip voor het werkingsbereik van art. 296 lid $1 \mathrm{Sr}$ voor open formuleringen gekozen. Die tijdstippen kunnen derhalve veranderingen ondergaan en daarmee voor de medicus rechtsonzekerheid meebrengen. 


\section{Thanasie}

\section{Inleiding}

Dit hoofdstuk handelt over thanasie. Onder thanasie valt die gedraging van een arts die tot gevolg heeft dat de patiënt eerder overlijdt dan zonder die gedraging het geval zou zijn en waarbij dat overlijden geen gevolg is van een kunstfout of van een complicatie. In navolging van het verloop van de "euthanasiediscussie" is het zinvol om te onderscheiden tussen euthanasie, schijngestalten van euthanasie en levensbeëindiging.

Globaal kunnen deze thanatische gedragingen als volgt worden onderscheiden. Euthanasie is levensbeëindiging op verzoek. Levensbeëindiging zonder verzoek bij wilsonbekwame patiënten wordt aangeduid als "levensbeëindiging". De zogenaamde schijngestalten van euthanasie lijken op euthanasie respectievelijk op levensbeëindiging, maar worden, zoals werderop blijkt, daaronder niet begrepen daar zij als gewone medische gedragingen worden beschouwd.

Bij thanasie is altijd een arts betrokken, die de dodelijke gedraging verricht. Die gedraging kan bestaan uit een doen of uit een nalaten. In hoeverre aan de arts het overlijden van de patiënt strafrechtelijk kan worden toegerekend, wanneer hij nalaat (verder) te behandelen is één van de vragen waarop in dit hoofdstuk een antwoord wordt gegeven.

Ter wille van de leesbaarheid wordt hier in het algemeen volstaan met het noemen wan de gedraging, bijvoorbeeld staken (van een behandeling), zonder dat een verband wordt gelegd met het overlijden van de patient. Voor zover niet juist ter discussie staat of de patiënt ten gevolge van de gedraging is overleden, wordt daarvan in het navolgende telkens uitgegaan.

Tussen dodelijk handelen en niet-handelen van de arts bevindt zich een tussenvorm, namelijk hulp bij zelfdoding, waarin de arts de patient wel behulpzaam is bij diens overlijden, maar de eigenlijke dodelijke gedraging niet door de arts doch door de patiënt zelf wordt verricht.

Bij elk van deze gedragingen is een andere delictsomschrijving in het geding. Levensberoving op verzoek is in art. $293 \mathrm{Sr}$ strafbaar gesteld, hulp bij zelfmoord in art. $294 \mathrm{Sr}$ en het doden zonder verzoek in art. $287 \mathrm{Sr}$ (doodslag) en in art. $289 \mathrm{Sr}$ (moord).

De genoemde artikelen staan in Titel XIX van het WvSr onder de naam "Misdrijven tegen het leven gericht". Zoals in andere artikelen van deze titel wordt in art. $293 \mathrm{Sr}$ van levensberoving gesproken en in art. $294 \mathrm{Sr}$ van zelfmoord. Thans is het gebruikelijker in plaats daarvan de uitdrukkingen "doden op verzoek" en "hulp bij zelfdoding"t te bezigen. Deze terminologie wordt hier zo veel mogelijk gevolgd, behalve wanneer het binnen de context gangbaar is de oorspronkelijke uitdrukkingen te bezigen.

Hoewel derhalve formeel-juridisch een verschil bestaat tussen levensbeëindiging op verzoek en hulp bij zelfdoding, blijkt het verschil tussen euthanasie en hulp bij zelfdoding 
in de medische praktijk vaak klein en van toevallige omstandigheden af te hangen. Bovendien betreft het verschil de uitvoering en niet de woorafgaande beslissing van de arts. Voor de strafrechtelijke aansprakelijkheid wan de arts voor thanasie is een gedraging noodzakelijke voorwarde, maar voor de straffeloosheid is belangrijk of de arts, gezien de omstandigheden een op thanasie gerichte beslissing mocht nemen die een bepaalde gedraging tot gevolg heeft. ${ }^{2}$ Daarbij wordt onder hulp bij zelfdoding begrepen het opzettelijk behulpzaam zijn bij, en het opzettelijk middelen verschaffen tot de zelfdoding, maar niet het opzettelijk aanzetten tot zelfdoding dat eveneens in art. 294 Sr strafbatar is gesteld.

Doordat de euthanasiediscussie vooral gevallen betreft, waarin de arts de dodelijke gedraging verricht, neemt hulp bij zelfdoding ook in dit hoofdstuk slechts een ondergeschikte plaats in.

Doel van dit hoofdstuk is het na te gaan of en zo ja, onder welke omstandigheden een medicus een thanatische gedraging straffeloos mag verrichten en in hoeverre een wettelijke regeling ter bereiking van de straffeloosheid aangewezen is.

Het hoofdstuk bestaat uit drie gedeelten. In het eerste, algemene gedeelte wordt eerst de wetsgeschiedenis van de artt. 293 en 294 Sr beschreven en vervolgens het verloop van de vooral onder medici gevoerde discussie over thanasie in Nederland vanaf 1880 . Aan het eind van dit gedeelte worden de begrippen "euthanasie", "levensbeëindiging" en de zogenaamde "schijngestalten" ten opzichte van elkaar afgebakend.

Bij thanasie is de wilsuiting van de patiënt van groot belang voor de strafrechtelijke toetsing van de gedraging. Daarom worden euthanasie en levensbeêindiging afzonder lijk behandeld, waarbij telkens ook aandacht wordt besteed aan de zogenaamde schijngestalten.

In het tweede gedeelte wordt de euthanasie besproken; eerst recente voorstellen voor een wettelijke regeling van euthanasie en vervolgens verschillende mogellikheden voor de arts om straffeloos euthanasie te verrichten.

Het derde gedeelte betreft levensbeëindiging van patiënten die hun wil niet (meer) kenbaar kunnen maken en die ook niet eerder hun wil daaromtrent geuit hebben.

1 Vgl. Statalscommissie Euthanasie, Deel 1, 1985, p. 62-63 en Gezondheidsraad, 1982, Hfdst. 4; Feber, Preadvies Vereniging woor Gezondheidsrecht, 1989, p. 3, MWJ, EK 1982-1983, Aanhangsel, nr. 39. Zlie ook reeds: Smidt, III, 1891, p. 464. Van der Meer, in: Euthanasie, 1985, p. 74, geeft daarom de voorkeur aan de tern "auto-euthanasie in platis van suicide.

2 De Commissie Onderzoek Medische Praktjjk inzake Euthanasie, ook angeduid als Commissie Remimelink, bespreekt in harap raport "Medische Beslissingen rond thet levenseinde", 1991, euthanasie en hulp bij zelfdoding niet afzonderlijk. Als reden geeft zij op p. 5: "Voor de beschouwingen vam de commissie over de ard en de context van de medische beslissingen rond het levenseinde en ook anderszins is het versichil tussen beide ... niet relevant" Anders: Klijn, in: Euthanasie, 1985, p. 37-38, voor wie van belang is wie de "eerstverantwoordelijke" voor de levensbeëlndigung is. 


\section{De wetsgeschiedenis van de artt. 293 en $294 \mathrm{Sr}$}

\subsection{De totstandkoming van art $293 \mathrm{Sr}$, levensberoving op werzoek}

In de in Nederland tot 1886 geldende Code Pénal was de levensberoving op verzoek niet apart strafbaar gesteld. Zij viel onder de bepalingen over manslag en moord. ${ }^{3}$ Onder doodslag werd derhalve ook begrepen het doden op verzoek of met toestemming van de "verslagene", waarvan de zaak Jan Slotboom (HR 13 april 1852, W 1326) getuigt. In deze zaak had een boterkopersknecht op uitdrukkelijk en herhaaldelijk werzoek een wrouw met psychische problemen tegen betaling van het leven beroofd door haar de hals af te snijden. ${ }^{4}$

De wetgever van 1886 nam als art. $293 \mathrm{Sr}$ in de titel "Misdrijven tegen het leven" in het WvSr op:

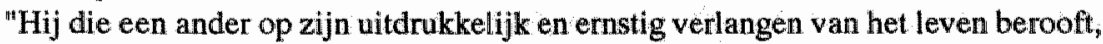
wordt gestraft met gevangenisstraf van ten hoogste twaalf jaren ${ }^{\text {t5 }}$.

De Raad van State (RvS) beschouwde de woorden "uitdrukkelijk en ernstig" als overbodig. De regering benadrukte dat voor het delict niet elk verlangen voldoende is, maar slechts een verlangen, dat "uitdrukkelijk kenbaar gemaakt en ernstig gemeend" is.

"Het verlangen moet meer zijn dan een ligt voorbijgaande indruk van het oogenblik,

misschilen door den moordenaar zelven kunstmatig opgewekt". ${ }^{6}$

Hieruit kan worden opgemaakt, dat het verlangen een zekere duurzaamheid moet bezitten en dat het niet door de dader mag zijn opgewekt.. Vermoedelijk is dat de reden dat in art. $293 \mathrm{Sr}$ niet, zoals in art, $206 \mathrm{Sr}$ (het ongeschikt maken voor de ${ }^{\text {t0 }}$ krijgsdienst ${ }^{11}$ ), wan "verzoek" wordt gesproken. Voor een uitdrukkelijk kenbaar gemaakt en ernstíg gemeend verlangen gelden strengere eisen dan voor een verzoek.

Het thier bedoelde verlangen mag niet door de dader "kunstmatig" zijn opgewekt. Dat hoeft niet te betekenen dat het "slachtoffer" het initiatief moet nemen. Wanneer op het moment dat de dader over levensbeëindiging begint te spreken er reeds een verlangen in de zin van art. $293 \mathrm{Sr}$ bij het "slachtoffer" bestaat, dan heeft de dader dat verlangen immers niet opgewekt.

Het verlangen kan verbaal of niet-verbaal kenbaar worden gemakt. Waar het op aankomt is dat dit "uitdrukkelijk" geschiedt. Dat wil zeggen, ondubbelzinnig en met de onmiskenbare bedoeling dat het "slachtoffer" gedood wil worden."

3 Vgl Bijleveld, 1883, p. 55 e.w., min. p. 65, NLR, aant. La op art. 293.

4 Zile voor vitwoerige beschrijving van deze zaaki Enthoven, 1988, p. 25446 .

5 Zo luidde ook art. 317 O.R.O. Zie: Smidt, II, 189 I, p. 463.

6 Sinidt, II, 1891 , p. 464.

7 Vgl. Baas, 1910 , p 132-134.

8 Voor Nysingh, 1898, p. 55 , is voldoende dat de will van de betrokkene op enigerlei wijze, wataronder een gebar, kenbar is gemaakt. Baas, 1910, p. 135, vind, in novolging wan Noyon, III, 1904 , atm. 1 op art. 293 Si, wezenljik de "onmiskembare bedoeling" zijn voorkeur gaat uit nat een mondelinge of schriftelijke uiting. Een gebaar acht hij echter niet principieel uitgesloten. Zie ook: NLL, ant. 12 op art. 293. Anders: Bijleveld, 1883, p. 73 , voor wie gebaren niet voldoen aan ce cis dat hel verlangen "uitdrukkelijk" dient te zijn. 
De regering bezigde soms ter asuduiding van het in art. 293 Sr bedoelde verlangen: de woorden "toestemming" en "verzoek". Zo werd in de MvT gesteld:

"De toestemming" kan de strafbaarheid van de levensberooving niet opheffen, maar

zij geeft aan het feit een geheel ander karakter"."10

Wanneer de woorden "toestemming" en "verzoek" in de betekenis worden gebruikt, die de wetgever bij het "uitdrukkelijk en ernstig verlangen" in art. $293 \mathrm{Sr}$ voor ogen stond, bestaat daar ook geen bezwaar tegen.

Het "geheel ander karakter" wijst de weg naar de techtsgrond van art. 293 Sr. Het delict blifft ondanks het verzoek een misdrijf tegen het leven, maar van een aanslag tegen de persoon kan niet meer worden gesproken.

"(D)e wet straft als het ware niet meer den aanval tegen het leven van een bepaald persoon, maar de schending van den eerbied aan het menschelijk leven in het algemeen verschuldigd - onverschillig uit welk motief de dader handelt"."

De regering riep met deze bepaling een ten opzichte van moord en doodslag strafverminderende specialis in het leven. ${ }^{12}$ Op het commentaar van de Commissies van beide Kamers die het strafmaximum van twaalf jaar in vergelijking met het voorgestelde strafmaximum van vier jaar voor de in art. 294 Sr geregelde hulp bij zelfdoding te hoog vonden, wees de regering ter rechtvaardiging van het door haar gestelde maximum op het in 1851 spelende en hierboven genoemde geval van Jan Slotboom die tegen betaling een vrouw "op haar verzoek slachtte", zoals de regering het uitdrukte. ${ }^{13}$

Daarmee werd het strafmaximum van art. $293 \mathrm{Sr}$ verdedigd met een beroep op een zaak, waarin op wrede wijze en tegen betaling aan het verzoek gevolg was gegeven.

\subsection{De totstandkoming van art. $294 \mathrm{Sr}$, hulp bij zelfmoord"}

"Naast de levensberooving op verzoek staat de hulp tot zelfmoord", aldus de MvT ${ }^{\mathrm{I4}}$ want zij "berust op gelijken grond, den eerbied voor het menselijk leven ook tegenover hen, die voor zichzelf daaraan te kort willen doen". ${ }^{15}$

Voor het bestaansrecht van de strafbaarstelling van hulp bij zelfmoord werwees de regering naar de zaak. Dettemeyer, die in 1858 te Amsterdam speelde. Toen moest de

9 Cursief, J.W.

$10 \mathrm{Smidt}$. II, 1891, p. 463. Zie ook: Smidt, II, 1891, p. 469, wam de regering in verband met art. 206 Sr in Gen aden van "verzoek en van "toestemming" spreekt. Vgl. ook de opmerking van de regering over het geval Jan Slotboom, hieronder. Zie verder: H. II, onder 23 .

11 MvT, Smidt $\Pi, 1891$, p. 463 . Bijleveld, 1883, p. 17, acht een betere reden, dat de dader gevaarlijk katn worden voor zijn medeburgers.

12. Vgl. MvT, Snidi, II, 1891, p. 448: "De hoofdvorm van opzetteli jke lewens berooving is doodsllag, waarwan de andere vornen slechts wijzigingen en schakeringen zjj", en p. 463 m.b.t. levensberoving op werzotk: "... is aanmerkelijk ligter te straffen dan de schuldige aan gewonen moord". Zie ook de conclusie van de A-G Remmelink vò̀ HR 27 nov. 1984, NJ 1985, 106 m.nt. "ThWvV.

13 MvA, Smidt, II, 1891, p. 464.

$14 \mathrm{Smijit}, \Pi_{,}, 1891$, p. 465.

15 Rapport aan den Koning, Smidt, II, 1891 , p. 465. 
rechter de verdachte vrijspreken, omdat medeplichtigheid aan zelfmoord niet strafbaar was. ${ }^{16}$ :

De hulp bij zell fmoord staat in art. 294 Sr omschreven:

Hij die opzettelijk een ander tot zelfmoord aanzet, hem daarbij behulpzaam is of hem de middelen verschaft, word, indien de zelfmoord volgt; gestraft met gevangemisstraf van ten hoogste drie jaren ".

Met "hulp bij zelfmoord" worden niet alle in art. $294 \mathrm{Sr}$ genoemde handelingen aangeduid. Want naast twee vormen van deze hulp, het behulpzaam zijn bij of de middelen verschaffen tot zelfmoord, is in dat artikel eveneens het aanzetten to zelfmoord strafbaar gesteld. In art. 318 O.R.O. was het "aanzetten tot zelfmoord" niet opgenomen.

Deze vorm van "hulp" werd in verband met het "Amerikaanse duel", op aandringen van de Commissie van de Tweede Kamer, in art. 294 Sr strafbaar gesteld. Dat duel houdt in, "dat de partijen overeenkomen te Loten, wie van beiden zich zelf van het leven zal berooven, terwijl ieder zich op zijn eerewoord verbindt om, indien het lot hem ongunstig mocht zijn, de verbintenis na te komen" ${ }^{17}$ Indien degene die het gunstige lot heeft getrokken bij de ander aandringt op de vervulling van zijn belofte en de andere daaraan gevolg geeft, dan is er sprake van het opzettelijk aanzetten tot zelfmoord. ${ }^{18}$ Terwijl het de bedoeling van de wetgever was om het aanzetten in art. $294 \mathrm{Sr}$ hiertoe te beperken, brengt de daartoe niet beperkte redactie van het artikel mee, dat elk aanzetten onder art. 294 Sr valt. ${ }^{19}$ Het aldus strafbaar gestelde aanzetten tot zelfmoord lijkt op uitlokking, maar zonder dat er een uitlokkingsmiddel aan te pas hoeft te komen. ${ }^{20}$.

De andere twee vormen doen denken aan medeplichtigheid. ${ }^{21}$ In art. $294 \mathrm{Sr}$ is echter, anders dan in art. $48 \mathrm{Sr}$, niet strafbaar gesteld het verschaffen van gelegenheid of inlichtingen tot, zodat hulp bij zelfdoding straffeloos kan geschieden, voor zover zij zich beperkt tot het verschaffen van gelegenheid of inlichtingen tot zelfdoding. ${ }^{22}$ Hieraan kan ook een van art. $48 \mathrm{Sr}$ afwijkende invulling van "behulpzaam zijn" in art. $294 \mathrm{Sr}$ niet afdoen, daar in art. $48 \mathrm{Sr}$ onderscheiden wordt tussen voorafgaande en gelijktijdige hulp en het "behulpzaam zijn" de gelijktijdige hulp betreft, terwijl het verschaffen van gelegenheid of inlichtingen aan de daad voorafgaat. ${ }^{23}$ De algemene deelnemingsvormen kunnen op de omschrijvingen in art. $294 \mathrm{Sr}$ niet van toepassing zijn, daar noch in dat artikel, noch elders de zelfmoord strafbaar is gesteld. Voor de zelfstandige strafbaarstelling "bij uitzondering $^{\text {"24 }}$ van in wezen accessoire deelnemingsvormen bezigde de MvT hetzelfde argument als voor de strafbaarstelling van levensberoving op verzoek, namelijk "schending van de aan het menschelijk leven verschuldigden eerbiedt". ${ }^{25}$

16 Ondat zelfmoord zelf niet strafloaar was. Zje verder over deze zatk: Enthoven, 1988, p. 47-51. Zie ook: W 2041, 2064, 2066, 2067.

17 Bags, 1910, p. 139. Vgl. Hirsch, 1882, p. 74-75.

18 Vgl. MvA, Smidt, III, 1891, p. 466.

$19 \mathrm{Vgl.} \mathrm{NLR}$, aant. 4 op art. 294.

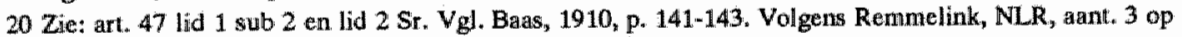
art. $294 \mathrm{Sr}$, kan het aanzetten zowel vö́r als na het besluit tot zelfmoord geschieden.

$21 \mathrm{Vgl.} \mathrm{art.} 48 \mathrm{Sr}$.

22 Vigl. Enschede, 1985, p. 59. Zie ook: Bass, 1910, p. 143-144.

23 Anders en wel rumer: NLR, arnt. 3 op art. $294 \mathrm{Sr}$.

24 MvT, Smidt, II, 1891, p. 465.

25 MvT, Smidt, II, 1891, P. 465. 
De Raad van State plaatste een vraagteken bij de rechtsgrond voor art. 294 Sr $^{26}$ De regering antwoordde dat dit feit een "delictum sui generis" was. ${ }^{27}$ Van het voorstel van de Raad dat de bedoelde hulp eventueel als overtreding gestraft zou kunnen wordem, wilde de regering net weten. Het betrof hier een feit, waarvan iedereen, ook zonder kenniss van de wet, het ongeoorloofde beseft. Waarmee de regering ter verdediging van de classificatie van de hulp bij zelfmoord terugviel op het argument dat zij ter verdeling van de strafbare feiten in misdriven (rechtsclelicten) en overtredingen (wetsdelücten) haniteerde. ${ }^{20}$

De hulp bil poging tot zelfmoord wilde de regering niet strafbar stellen.

"Als het biy poging blijft, behoort ook de derde straffeloos te wezen. Het tegendeel ware bij uitnemendheid onpractisch. Aan poging tot zelfmoord kleeft iets ridicuuls. Werd die poging door wervolging van den helper nuchtbaar, dan zou de hoofdpersoon allicht in de verzoeking komen het feit te herhalen".

\subsection{Conclusie}

In de artt. 293 en $294 \mathrm{Sr}$ heeft de wetgever van 1881 de levensberoving op verzoek en de hulp bij zelfmoord strafbaar gesteld. Onder "verzoek" moet daarbij worden verstaan het ondubbelzinnig kenbaar maken van de serieuze wil om door een ander gedood te worden. Deze wilsulting kan verbaal of non-verbaal geschieden.

Art. $294 \mathrm{Sr}$ kwam in het WWSr terecht om vooral het behulpzaam zijn bij en het middelen verschaffen tot zelfmoord strafbaar te stellen. Die gevallen zien op situaties, waarin degene die zich van het leven wil beroven de beslissing daartoe reeds heeft genomen.

De grondslag voor de strafbaarstelling van de genoemde gedragingen zag de wetgever in de schending van de eerbled aan het menselijk leven in het algemeen verschuldigd. De wil van het "slachtoffer" kan de strafbaarheid niet wegnemen. Bij levensberoving op verzoek brengt zij een strafvermindering ten opzichte van moord en doodslag mee. Met de strafbaarstelling van abortus met toestemming van de vrouw hebben de artt: 293 en $294 \mathrm{Sr}$ gemeen, dat één reden voor de strafbaarheid wegvalt, namelijk bij abortus het handelen jegens de zwangere vrouw zelf, respectievelijk bij de artt. 293 en $294 \mathrm{Sr}$ jegens degene die van het leven wordt beroofd of zich daarvan berooft. Daarmee heeft de wetgever van 1881 een zelfbeschikkingsrecht ten aanzien van het eigen sterven impliciet afgewezen."

Tijdens de totstandkoming van de artt. 293 en $294 \mathrm{Sr}$ werd niet over uitzonderingssituaties gesproken. Dat laat woor euthanasie respectievelijk hulp bij zelfdoding twee verklaringen toe. Doordat de medicus niet werd uitgezonderd, was het de bedoeling ook hem voor

26 Adwies RvS, Smidt, II, 1891, p. 465.

27 Rapport aru den Koning, Smidt, II, 1891, p. 465 .

28 Rapport am den Koning, Smidt, II, $1891, \mathrm{p}, 465$. In verband met de hierboven besproken zalk Dettemejer merkte het $W$ van 14 mant 1859 op: "Maar de zelfmoond heef in de hedendagse weitgevingen hala plaats niet meer in de rei der misdaden, die de menschen bebben te straffen. En sedert wanneer kan er medepligtigheid ziju dărir, waar geene misdand is?"

29 Zie: $\mathrm{H}_{\mathrm{I}} \mathrm{Il}$, onder 2.22.

30 Miva, Smidt, II, 1891 , p. 466.

31 Vgl. A-G Schalken, NJB 1984, p. 40 en Schalken, in: Euthanasie, 1985, p. 121. 
deze gedragingen principieel strafrechtelijk aansprakelijk te stellen. ${ }^{32}$ Een andere verklaing vloeit voort uit de wetsgeschiedenis van mishandeling en abortus. De medicus is niet strafbaar vanwege de artt. 293 en 294 Sr, wanneer hij met een medisch doel handelt; omdat dan de wederrechtelijkheid ontbreekt.

In verband met de abortusbepalingen heeft de wetgever echter opgemerkt dat voor een handelen met medisch doel toestemming geen noodzakelijk vereiste is. Daarvan uitgaande zou de medicus ook straffeloos in strijd met de artt. 287 en 289 Sr mogen handelen, voor zover hij dat met een medisch doel doet. Maar dat kan niet de bedoeling zijn geweest. Vermoedelijk kwam de wetgever van 1881 helemalal niet op de gedachte dat de in de artt. 293 en 294 Sr omschreven gedragingen met een medisch doel zouden kuninen worden gepleegd.

Niet onder de delictsomschrijving van art. 294 Sr valt het gelegenheid of inlichtingen verschaffen tot zelfdoding. Dat kan de medicus, maar ook leder andere derde, dan ook straffeloos doen.

\section{Gedachten over thanasie vanaf 1880}

\subsection{Inleiding}

Bij de totstandkoming wan de artt. 293 en 294 Sr werd noch over de medicus noch over euthanasie gesproken. Voor zover in de hedendaagse Nedlerlandse literatuur op de geschiedenis van thanasie wordt ingegaan, wordt die van het buitenland behandeld. ${ }^{33}$

Mijn literatuuronderzoek over thanasie in Nederland is voor de eerste tientallen jaren vanaf 1880 beperkt tot de strafrechtelijke literatuur en het NTvG. Het gaat er immers om vooral te achterhalen hoe onder strafrechtjuristen en medici over dit onderwerp werd gedacht.

Doordat het aantal hierna besproken bronnen tot in de jaren zestig gering is, kunnen aan de strekking van de uitlatingen slechts in zeer beperkte mate algemene gevolgtrekkingen worden verbonden. Uit de literatuur kan worden opgemaakt dat medici zich over de geoorloofdheid van thanasie vooral gedurende de eerste tientallen jaren zeer terughoudend uitlieten. Hieruit af te leiden dat thanatische gedragingen (zo goed als) niet werden verricht is dubieus. In 1987 stelde de toenmalige voorzitter van de KNMG, Derksen:

32 Vgi. Van Veen, NIB 1984 , p. 1068.

$33 \mathrm{Vgl}$ Meernam, 1991; Wan der Sluis, 1977; Lindeboom, 1978; Werkgroep Euthanasie wan het Katholiek Studiencentrum, 1983, Hfdst. III; Rutenfrans, Intermediair, 5 dec. 1986, p. 3-7 en p. 59-61.

Terwijl dwaruit zow kunnen worden afgeleid dat in Nederland geen belangstelling woor dill onderwerp bestond, oppert Meerman een andere nogelijkheid. Het is volgens hem miet wit te sluiten, dat het onderwerp onder andere termen dan "euthanasie" of in bepalde niet woor de hand liggende soorten literifuur te vinden is. Meerman, 1991, p. 107. Daartoe verwijst hij war cen brochure wan Grewe, Den Hag 1923, warin op de p. 56-57 een voorstel tot een wettelijke regeling voor euthanasie is opgenomen. (Die regeling is ook te vinden in hel eerder genoemde boek van de Katholieke Werkgroep op p. 47-51.) Zeer waiarschijiljk is deze mogelijkheid niet. In de door Meerman vermelde Nederlandse literatur tot 1939 komi en arantal keren de tterm "euthanasie" voor en ook in thet NTWG wordt de term vaker gebezigd. Meerman noemt 6 en vindplaats in het NTWG. 
"Euthanasie heeft altijd plaatsgevonden. Door maatschappelijke ontwikkelingen. mondiger patiënten, beter geinformeerde patiënten, grotere openheid, minder geheimzinnigheid, komt het vaker aan de oppervlakte ${ }^{\text {1: }}{ }^{34}$

\subsection{Gedachten over thanasie tot 1910}

In de juridische literatuur en in het NTvG ben ik tot 1910 over levensbeëindiging in verband met het lijden van een patient of omdat deze zich in de stervensfase bevond, uitlatingen van twee juristen ${ }^{35}$, viff mediei ${ }^{36}$ en twee theologen ${ }^{37}$ tegengekomen. Daarin werd euthanasie op twee witzonderingen na als een nauwelijks voorstelbare mogelijkheid of als een al dan niet wenselijke toekomstige mogelijkheid behandeld, maar niet als een in de toenmalige praktijk van de medicus spelende problematiek. Daarmee in overeenstemming is dat in de gepubliceerde jurisprudentie geen uitspraak ter zake van levensberoving op verzoek dan wel doodslag of moord ter vermindering van het lijden van een patiënt door een medicus is vermeld.

Uit de in de verschilllende uitlatingen beschreven toestand van de patiënt blijkt, dat daarin meestal diens lijden centraal staat. Telkens gaat het erom dat lijden, dat vaak als zeer ernstig wordt aangeduid, weg te nemen. Soms wordt aangegeven dat de ziekte ongeneeslijk is, in andere gevallen dat de patiënt $z i c h$ in de stervensfase bevindt.

De juristen geven aan dat de patiënt uittrukkelijk - één van hen spreekt tevens van "herhaaldelijk" - om levensberoving heeft verzocht. Bij hen bestaat een zeker begrip voor de handeling. De een is van mening dat de rechter onder het bestaande strafrecht verplicht is een "te zware" straf op te leggen, zodat slechts met behulp van gratieverlening soelaas te bereiken is. ${ }^{38}$ Maar " $(\mathrm{m})$ isschien zal het toekomstig strafrecht levensberooving op verzoek onder sommige omstandigheden straffeloos laten" ${ }^{139}$

De medici spreken nauwelijks over de strafrechtelijke aansprakelijkheid, maar vooral over de ethische toelaatbaarheid van de handeling. Voor één van hen is levensverkortende pijnbestrijding in de stervensfase zo vanzelfsprekend, dat hij in een ingezonden brief onder het kopje "Euthanasie" in de NTvG vraigt, welke middelen andere artsen ter verzachting van het lijden gebruiken." Zijn stuk begint met de zin: "De laatste zorg, die een patiènt van ons vereischt, is de zorg, het einde var zijn lijden zoo dragelijk mogelijk te maken, het ideaal der Ouden: exitus lethalis sine agone"." In het NTVG blijven reacties ulit.

Een andere medicus kan voor levensbeëindiging op herhaaldelijk verzoek van een patieñnt, die "verschrikkelijk" leed, begrip opbrengen, terwijl hij het anderzijds wenselijk

34. Derksen, in: Op sterven na dood, 1987, p. 41. Zie ook: Commissie Onderzoek Medische Praktijk inzalke Euthanasie, Onderzoek, 1991, p. 83. Op de stelling dat de "grote ophef die nw over euthanasie wordi gemaakt (...) misplatatst (is), evthanasie is er immens altijd geweest", autwoordi $59 \%$ van de respondenten bevestigend.

35 Bijleveld, Dorbeck.

36 Boekelman, Burger, Oidtman, Pinkhof, Rutgers.

37 Keuller, Vlaming.

38 Onder de destijds voor Nederland geldende Code Pénal.

39 Bijleveld, 1883 , p. 20 .

40 Rutgers, NTVG 1903, II, p. 52-53. Hij deelt mee zelf morfine te gebruiken.

41 Sterven zonder pign; wrij vertalld Rulgers, NTvG 1903, II, p. 51. 
acht; dat noch de wetgever, noch de religie hiervoor straffeloosheid zouden toestaan. Maar

"staats-en godsdienstige wetten (kunnen) niet elk dếtaill in de medische wetenschap (..) regelen. Hier en daar zal men stuiten op den mensch in den medicus, die op een gegeven oogenblik zich over alle wetten heenzet, en alleen handelt onder invloed van zijn menschelijk gevoel en geweten. Hij zal soms verkeerde wetten niet uitvoeren of gebreken in een wet voor een bepaald geval corrigeeren. Straffeloosheid mag hij echter voor dergelijke gevoelsdaden nooit eischen, de gevolgen zijner daad moet hij blijven dragen. Toch heeft ons Wetboek van Strafrecht een gelukkig beginsel, dat voor vele zaken als veiligheidsklep dienst kan doen, nl. het opportuniteitsbeginsel.

.... Of het geval, waarop ik doelde ook behoont tot die strafrechtelijke vorderingen welke voor het O.M. niet verplichtend zijn, kan ik niet beoordeelen" ${ }^{42}$

Voligens Dorbeck, die een vergelijkbaar geval beschrijt,, "wordt in zulk een geval noch tegen het rechtsbewustzijn van het volk, nòch tegen dat der juristen zwaar gezondigd, wanneer deze dader slechts met een geringe, ... straf wordt gestraft" ${ }^{4}$.

Voor de arts Pinkhof is euthanasie onder geen beding toelaatbaar. Reeds in 1898 had hij een verband gelegd tussen de toelaatbaarheid van abortus op niet streng medische indicatie en euthanasie.

"En als de medicus begint, al is het maar uit menschlievendheid; zijn kundigheden beschikbaar te stellen, niet tot behoud, maar tot vernietiging, dan is er, nog afgezien van het voorwendsel, dat hij aan belangzuchtigen en kwaadwilligen door zijn woorbeeld verschaft, geen einde aan de gevaarlijke dingen, die hij zou kunnen ondernemen.

Tot de geringste zaken zouden gaan behooren: het verwekken van abortus, het behulpzaam zijn bij kindermoord en het veroorzaken van gebreken om de militieplichten te ontgaan ${ }^{+4.4}$

Dit argument van het "hellend vlak"t wordt tien jaar later door de medicus Boekelman gebezigd om zich in zijn minderheidsstandpunt te verzetten tegen een door de meerderheid van de Gemengde Commissie voorgestelde algemene wettelijke strafuitsluitingsgrond woor een medicus.

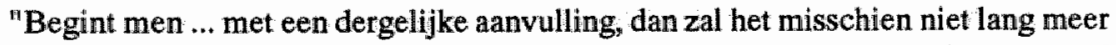
duren - er zijn reeds teekenen, die er op wijzen, - dat ook aanvulling zal gevraagd worden om straffeloos zieken, die uit hun lidden willen verlost worden, een zachten dood te bezorgen". 45

De theologen wezen stervenshulp zonder meer van de hand. ${ }^{46}$ Een van hen merkte tevens op dat eerder stervenshulp dan abortus aanvaardbaar was, want bij stervenshulp zou het levensrecht een "waardeloos recht ten behoeve van de rechts-subject zelf" zijn, terwijl bij abortus "ten behoeve van een derde" beschikt zou worden. ${ }^{47}$ Kennelijk ging hij ervan uilt dat stervenshulp op verzoek geschiedt.

42 Oidiman, in: De straftechtelijke verantwoordelijkheid van den geneesheer, Leiden $z_{. j}$. (1908), p. 18-19.

43 Dorbeck, 1893, p. $79-80$.

44 Pinkhof, NTwG $1898, I_{1}$, p. 527.

45 Boekelman, Nota der Minderheid, NTvG 1909, 1, p. 83 :

46. Keuller, in: De strafrechtelijke verantwoordelijkhoid van den gemeeslteer, Leiden Z.j. (1908), p. 2 en woor hulp bij zelfoloding, p. 8.

47 Vlaming, in: Het levensrecht der ongeboren vrucht, 1904, p. 101 en 104. 
Zowel deze theoloog, als de arts Burger, achtten het daadwerkelijk verlenen van enthanasie zeer onwaarschijillik. Burger sprak in dit verband in 1909 wan het "Principuis obsta", dat op deze onwaarschijulijke beschowwing (in het minderheidsstandpunt van Boekelman, J.W.) volgt, mogen ook zij zich gezegd rekenen, die zich bij hun geneeskundig handelen vóor alles willen laten leiden door het belang van de aan hun zorg toevertrouwde zieke"

\section{Gedachten over thanasie tussen 1910 en 1960}

Vanaf 1910 wordt het aantal personen dat zich over thanasie uitlaat nog kleiner dan voor die tijd. Wel treffen we in het NTVGeen aantal korte mededelingen over dit onderwerp aan. Die hebben vooral betrekking op buitenlandse ontwikkelingen op dit gebied. Deze mededelingen werschijnen in de rubriek "Beroepsbellangen", die opgezet was en enkele thentallen jaren werd verzorgd door de arts Pinkhof. ${ }^{50}$ In deze rubriek kwamen vooral medisch-ethische problemen ter sprake, zodat Pinkhof langere tijd het gezicht van de medische ethiek naar buiten toe bepaalde. ${ }^{51}$ Hieronder wordt aandacht besteed aan het, vooral van Pinkhof afkomstige commentaar bij de mededelingen in verband met thanasie: In hoeverre Pinkhof's opvattingen door andere medici werden gedeeld, kan bij het haast volledig ontbreken van commentaar van anderen moeilijk worden gezegd. Van Pinkhof is wel bekend dat hij een behoudend standpunt innam. ${ }^{\text {s2 }}$

Pinkhof is het eens met de opvatting van een Amerikaanse arts dat hij nooit een operatie aan een "monstrum" zou verrichten, om dit slechts enkele dagen langer te laten leven. "Dit was niet zo iets bijzonders, en ledere arts kan instemmen met zijn ongeneigdheid om een tutteloze operatie te verrichten" ${ }^{153}$

In dezelfde lijn is zijn commentaar in 1918 over een geval, waarin een Amerikaanse arts geweigerd had het leven van een kind van één dag te redden, omdat de arts van mening was; dat het kind een "idlioot" zou blijwen. Volgens Pinkhof is de beslissing terecht, als het oordeel van de arts op goede gronden steunt.

"Want, moge al ieder ingrijpen in de natuurlijke loop der dingen slechts geoorloofd

zijn ter vervulling van een geneeskundige indicatie - datarmede is niet gezegd, dat aan ledere geneeskundige indicatie moet; of zelfs mag worden voldaan ${ }^{\text {t1 }} .^{54}$

Als de patient zich in de stervensfase bevindt, dan mag de arts niet alleen de pijn bestrijden, het is zelfs zijn plicht, ook als daardoor "het toch verloren leven lets wordt verkort". Blijkbaar is Pinkhof van mening dat een medicus daarmee tevens contra legem handelt,

48 Vrij vertalld: weersta de begindellen.

49 Burger, NTwO 1909, I, p. 1480.

50 Zie: Wan Rijnbeek, NTvG 1929, I, p. 898-900.

S1 Tevens was Pinkhof, natast Van Eyk, tedacteur van het door de NMG uitgegever in 1915, 1921 en 1933 verschenen "Artsenboekje; dat als de voorloper van het zogenamde blauwe boek je (Medische Ethiek) beschouwd kam worden.

52. In NTWG 1919, I, p. 532, sehrijt Pinkhof: "Er is over geklaagd, misschien niet zonder grond, dat de woorlichting in deze rubriek een conservatief karakter draagt ... Het Tijdschrift stasit echter ten allen tijde open voor andere meentimgen, ...

53 Pinkhof, NTVG $1918,1, \mathrm{p}, 44$.

54 Pinkhof, NTvG 1918, I, p. 1018. 
want hij voegt eraan toe:" "gelijk bij iedere overtreding mag en moet de rechter met bijzondere omstandigheden rekening houden". 55

Terwijl Pinkhof levensverkortende pijnbestrijding in de stervensfase en het achterwege laten van medisch zinloos handelen geoorloofd acht, verzet hij zich ten sterkste tegen, wat hij noemt "actieve euthanasie". Daaronder verstaat hij het door een medicus rechtstreeks doden al dan niet op verzoek. ${ }^{56}$

Het onderscheid tussen levensverkortende pijnbestrijding en actieve euthanasie ligt voor hem in het doel waarmee wordt gehandeld. Is dat doel de bestrijding van pijn, dan is de handeling medisch-ethisch geoorloofd, ook is een nevengevolg de verkorting van het lewen. Handelt de arts met het doel het leven te verkorten, dan is er actieve euthanasie. Tot actieve euthanasie mag de medicus niet overgaan, ook niet wanneer de patiënt daarom verzoekt. Als "actieve euthanasie" beschouwt hij het geval dat door een arts een dodelijke hoeveel heid morfine aan een ongeneeslijke kankerpatiēnt die hevige pijnen lijjdt, gegeven wordt, met het doel diens dood enige weken te verhaasten, als de arts weet, dat de patiënt in elk opzicht bereid is te sterwen en naar de dood verlangt. ${ }^{57}$ Zo spreekt hij zich in 1921 uit tegen levensbeëindiging op verzoek bij "reddeloos verloren zieken of gewonden, die voortdurend hevig lijden, en wier leven nauwelijks meer waarde heeft voor anderen". .58

Een medicus mag niet ingrijpen in de fysieke toestand van zijn patiënten, behalve om de gezondheid te herstellen of het lijden te verzachten. ${ }^{59}$ Een arts heeft bijzondere plichten, die in - wat Pinkhof noemt - het "medisch geweten" verankerd dienen te zijn. Onder een medisch geweten verstaat hij het geweten als vermanende stem, die van een jeder hetzelfde eist, doch aan sammige mensen enkele bijzondere verplichtingen oplegt. "Het 'medisch geweten' is ... het bewustzijn van de bijzondere plichten, die aan artsen zijn opgelegd".

Levensbeëindiging op verzoek vanwege een lichamelijk lijden al dan niet in de stervensfase wijst hij af: Een dergelijk handelen beschouwt hij als - zo zouden we thans zeggen - in strijd met de normen van de medische ethiek. Tegen het rechtstreeks doden op verzoek vanwege een lichamelijk lijden buiten de stervensfase, brengt hij nog een ander bezwaar in. Dan zou de arts - desgevraagd - evengoed levensbeëindigend kunnen handelen vanwege psychische problemen, waarvoar men geen raad weet..$^{61}$

Het gevaar bij levensbeëindigend handelen zonder verzoek ziet hij daarin dat: "(w)ie zich eenmaal aanmatigt, te beoordelen of een leven het leven waard is, kan geen ander de vrijheid ontzeggen om deze vraag naar eigen inzicht te beantwoorden" "62

In dezelfde zin laat zich de arts Hulst uit. Hij hoopt, hoe men ook verder over dit "bij uitstek moeihijke vraagstuk" denkt, dat nergens ooit de gedachte ingang zal vinden,

55 Pinkhof, NTVG 1929, I, p. 2563. Zie ook: Pinkhof, NTWG 11925, II, p. 2329.

56 Pinkhof, NTVG 1921, I, p. 1897. Zie voor een eerder, in afkeurende toon gehouden mededeling over butitenlandse artsen die de geoorloofdheid van actieve euthanasie verdedigden: Pinkhof, NTVG 1904, I, p. $1479-1480$.

57 Pinkhof, NTvG $1922, \mathbb{1}, p .232$.

58 Pinkhof, NTVO 1921, 11, p. 1012.

59 Pinkhof, NTrG 1922,1, p. 235-236.

60. Punkhof, NTVG 1922, 1, p. 235:

61 Pinkhof, NTvG 1929,1, p. 2563.

62. Pinkhof, NTVG 1921, II, p. 1897-1898. 
dat een arts een patünt die aan een ongeneesijke en dodelijke ziekte lijdt en die viet meer in staat is zijn wil kenbaar te maken, straffeloos mag doden. ${ }^{63}$

In 1922 bericht Pinkhof over een Duitse jurist die wetsartikelen had ontworpen om geesteszieken te doden. Hij zegt daarover: het "weerzinwekkende van de "vernietiging van leven dat geen leven waard is' (Binding en Hoche) kan men niet beter aan de dag brengen dan door in wetsartikelen de practijk der theorie te laten zien ${ }^{\text {th }}{ }^{64}$

Over de stelling dat tegen degene die geen wil bezit, geen misdaad geschiedt, als men hem van het leven berooft, merkt hij later op: (m)en behoeft slechts te denken aan berooving of verkrachting van een idioot om het onzinnige van zulk een bewering in te zient. ${ }^{65}$

Pinkhof is in $1922^{66}$ van mening dat in de Jaatste tijd "herhaaldelijk" de opvatting niet meer gedeeld wordt dat "actieve euthanasie" niet is toegestaan. Hiervoor verwijst hij echter slechts nar een bespreking van boeken van Binding en Hoche in het NTvG. ${ }^{67}$

Ten aanzien van hel doden van ongeneeslijke zieken met toestemming van familieleden en indien mogelijk van de patiënt zelf en waarin het doden een verlossing voor de patiênt en zijn omgeving is, merkt hij op, dat vaak de zekerheid zal ontbreken of de ziekte ongeneeslijk is, of de patiênt met kennis van zaken naar de dood verlangt, en of de omgeving "aangenomen dat zij alleen door medelijden gedreven wordt", in staat mag worden geacht om over de draagwijdte van hun toestemming te oordelen. ${ }^{68}$

Een van de bezwaren tegen actieve levensbeëindiging ziet hij aldus in de onzekerheid van de indicatie. Met betrekking tot de sterilisatie merkt hij in 1933 op, "dat de stelling: 'geen geneeskundige handeling zonder geneeskundige indicatie', welke ik hier reeds in 1898 heb verdedigd, niet door allen beaamd wordt" ${ }^{69}$ Een probleem, dat zich ook bij abortus en de plastische chirurgie voordoet, is, wanneer er sprake is van een indicatie. Met het oog op het laatste formuleert hij als richtlijn, dat van een indicatie mag worden gesproken, wanneer een misvorming, die de chirurg ook in de niet-betalende praktijk nodig zou achten te verhelpen, in het algemeen ook in de betalende praktijk een indicatie oplevert. ${ }^{70}$

63 Hulst, NTVG 1923, II, p. 2753 .

64 Pinkhof, NTVG 1922, 11, p. 2970. Het geciteerde kan ook afkonistig zijin van de door Pinkhof weergegewen mening wan de Duitse jurist Ebermayer, maar in jeder geval is Pinkhof het darmee eens.

65 Pinkthof, NTVG 1925, I, p. 2329.

66 Pinkhof; NTVG $1922,1, p, 232-236$.

67 Dit betreft de bespreking van het boek wan $K$. Binding en A. Hoche, Die Freigabe der Vernichtung lewensun. werten Lebens, Ihr Masz und ihre Form, Leipzig 1920 en van thet boek van A. Hoche, Vom Sterben, Jena 1919, door Frets, NTVG 1921, II, p. 1330. Binding was een beroemde Duitse strafrechtjurist ent Hoche was psychigter. In die bespreking betreurt Frets enerzijds dat het boek wan Binding en Hoche in Firankin onder de titel: "A Mort les Incurables! A Mort (1Trformateur des alienistes, 1921, bldz-41) is veroordeeld. "Het is te betreuren, dat een ernstig werk op dergelijke luidruchtige wijze besproken is", anderzijds heef hij zelf ook bezwaren tegen dit boek. Volgens hem zov bet standpunt van de wuteurs onder zeer bijzondeire onstandigheden wit praktische overwegingen te verdedigen zjn, üt redelijke overwegingen is het dat miet. Daarnaast heeft hij nog een wetenschappelijk bezwar. Als men patiënten die man bepalde ziekten lijiden. zow doden, dan zou an hen geen onderzoek meer verricht kunnen worden ten bate van derden.

68 Pinkhof, NTVG 1931, III, p. 3977.

69 Pinkthof, NTVO 1933, III, p. 3402. Zie voor een reactie: Wibaut, NTVG 1933, II, p. 3809-3810. Zíe ook: Var Bemmelen, NTvG 1933, III, p. 3910.

70 Pinkhof, NTVG 1930 , II, p. 4581 . 
In 1936 formuleert Pinkhof nog eens kernachtig: "De bevordering der euthanasie is ons altijd toegestaan" ${ }^{71}$ In verband met zijn overige opmerkingen en het accent op "eu $u^{\text {"I }}$ is het waarschijnlijk; dat hij daarmee de levensverkortende pijnbestrijding in de stervensfase bedoelt. Hilerop wijst ook een uitlating van hem uit 1937.

"Euthanasie, wèl sterven, mogen wij slechts teweegbrengen als iemand inderdaad gaat sterven en dit zonder onze hulp een pijniging zal zijn. Maar zolang het levensvuur niet gaat uitdoven, moet de geneeskunst het behoeden". ${ }^{72}$

In 1936 voorspelt hij: "De dag zal wellicht komen, dat 't de arts vrijstaat, de zieke, die erom vraagt, pijnloos, zelfs aangenaam, te doden. Maar men moet niet om zulk "n dag vragen". ${ }^{73}$

De opvatting, dat levensverkortende pijnbestrijding in de stervensfase is toegestaan, treffen we, in de jaren vijftig, ook bij andere artsen aan. "Een zorgvuldig geformuleerd wijs woord ..." , noemt Van Loghem Sr de uitspraak van een Duitse arts: "De moraal verbiedt doden uit medelijden, ..., maar wel is het toegelaten met instemming van den zieke, met mate pijnstillende middelen te gebruiken, ook als zij de dood zouden verhaasten" ${ }^{74}$ In gelijke zin uit zich Sluyterman, die bovendien nog waarschuwt tegen een wet, waarin die gedraging (voor de arts) niet meer strafbaar gesteld wordt. Een dergelijke wet zou "uiterst gevaarlijke consequenties" kunnen hebben en daarom aanvaardt hij liever het risico in conflict met de wet te komen. ${ }^{75}$ In een reactie wordt opgemerkt, dat euthanasie een zo algemeen probleem betreft, dat het geen kwestie voor deskundigen is ${ }^{76}$ Maar levensverkortende pijnbestrijding in de stervensfase is kennelijk in de medische wereld geaccepteerd. De - ten aanzien van thanatische handelingen conservatieve - arts Schulte is van mening, dat hierbij geen sprake is van "euthanasie in de zin, die het woord bij meenigeen thans heeft gekregen" en dat die pijnbestrijding weinig of geen tegenspraak zal ondervinden. ${ }^{n}$

In de in 1959 verschenen derde druk van "Medische Ethiek en Gedragsleer" van de $\mathrm{KNMG}^{78}$ worden de tot nu toe beschreven standpunten bevestigd. Het doel van de arts mag nooit levensbeëindiging zijn. In tegendeel de arts heeft alles wat in zijn macht staat te doen om het leven te behouden, ook brengt dit "slechts vermeerdering van leed" mee. Wel mag hij het lijden van de patiënt verzachten, ook als daaraan "risico's" zijn verbonden. Weigert de patiënt een behandeling dan zou de arts hem proberen te "overreden" alsnog toestemming te geven. Blijft de patiënt bij zijn weigering dan dient de arts zich af te vragen, of de geestelijke vermogens van de patiênt diens weigering kunnen dragen. Als hij hierop bevestigend antwoordt, dan is de arts gehouden de weigering te eerbiedigen.

71 Pinkhof, NTwG 1936, 1, p. 89.

72 Pinkhof, NTwG 1937, II, p. 1487.

73 Pinkhof, NTWG 1936, I.I, p. 1147.

74 Van Loghem Sr, NTwG 1959, I, p. 114.

75 Sluyterman, MC 1950, p. 205.

76 Schlichting, MC 1950 , p. 321.

77 Schulte, MC 1950, p. 321.

$78 \mathrm{KNMG}, 1959$, p. 14-15. 
Het beginpunt van de actuele discussie over euthanasie ligt in de tweede helft van de jaren zestig. De vraag, wat daartoe aanleiding is geweest, is niet zo gemakkelijk te beantwoorden. Meestal wordt het standpunt ingenomen, dat de ontwikkelingen van de medische technologie het mogelijk hebben gemaakt het leven van een patiënt zover te verlengen, dat twijfel ontstaat over de zin van verdere behandeling. ${ }^{79}$ In zijn boek "Medische macht en ethiek" uit 1969, bespreekt Van den Berg deze problematiek. Daarbij plaatste hij tegenover elkalar, wat hij noemt, de "oude" en de "nieuwe" medische ethíek.

De oude medische ethiek hield in dat de arts verplicht is

"menselijk leven te behouden, te sparen en te verlengen, waar en wanneer dat slechts kan". "\$o

Deze ethiek past volgens hem bij de beperkte mogelijkheden die de arts ter beschikking stonden. Het weinige dat de arts kon doen, mocht en moest hij doen. ${ }^{81}$ De regel van de oude medische ethiek is de

"onbetwiste bescherming van menselijk leven. De regel, voor altijd woor elk medisch

handelen. Een heilige regel". ${ }^{2}$

De door Van den Berg gekozen bewoordingen doen denken aan de woorden uit de MvT op art. $293 \mathrm{Sr}$ : "De wet straft als het ware ... de schending van den eerbied aan het menschelijk leven in het algemeen verschuldigd - onverschillig uit welk motief de dader handelt ${ }^{\text {. }}{ }^{33}$

Inmiddels kan de arts menselijk leven rekken voorbij het redelijkerwijze aanvaardbare. Daarom is een nieuwe medische ethiek nodig, die kan worden omschreven alls:

"het is de arts geboden menselijk leven te behouden, te sparen en te verlengen, waar en wanneer dat zinvol is" ${ }^{84}$

Tot de lewensbeëindigende handelingen rekent Van den Berg zowel het staken van behandeling als het rechtstreeks levensbeëindigend handelen. Het woord "euthanasie" vermijdt hij consequent.

Niet uitgesloten is dat de tegenstelling tussen oude en nieuwe medische ethiek door Van den Berg enigszins gechargeerd is beschreven en er zijn enkele artsen die in deze nieuwe medische ethiek overeenkomsten zien met het gedachtengoed in Nazi-Duitsland. ${ }^{85}$

Toch staan ook behoudende medici niet altijd principieel afwijzend tegenover gedragingen die het leven van een patiênt verkorten. De gereformeerde medicus Lindeboom acht in 1960, zoals eerder Pinkhof, het staken van een behandeling bij stervenden legittiem, als de arts ervan overtuigd is dat de ingrepen "zinloos zijn of hoogstens een narar alle evidentie ten einde neigend leven slechts met enkele minuten of uren ${ }^{\mathrm{m}}$ verlengen. ${ }^{36}$

79 Voor Derksem, in: Op sterven na dood, $1987, \mathrm{p}$. 41, bracht de nedische technologie mee dat vaker dan vroeger orm euthanasie werd gevrand.

80 Van den Berg, 1970, p. 47. Vgl. Lindeboom, 1960, p. 118.

81 Van den Berg, 1970, p. $20-21$.

82 Van den Derg, 1970, p. 19.

83 Smidt; II, 1891, p. 463. Zie: H. IV A, onder 1.

84 Vent den Berg, 1970, p. 47. Vgl. Steendijk, MC 1959, p. 310 en Schreuder, in: Recent medisch ethisch denken $\mathrm{I}_{1}, 1968, \mathrm{p} .148-150$.

85 B.v. Sobulte, NTVG 1969, H, p. 1704.

86 Lindeboom, 1960 , p. 119; Kortbeek ${ }_{m}$ in: Recent medisch ethisch denken $I_{3} 1968$, p. 39 en Jongsma, in: Recent medisch ethisch denken 1,1968, p. 137. 
Over de vraag, of een medicus zich mag "onthouden van althans tijidelijk levensbehoudende of -rekkende maatregelen onder omstandigheden, waarin het leven zinloos geworden schijnt", is volgens Lindeboom, "de zedelijke oordeelsvorming nog gaande" 87 Over rechtstreeks levensbeëindigend handelen merkt hij op, dat een dergelijk handelen onder omstandigheden, door somnaige vooraanstaande (buitenlandse) medici wordt verdedigd en in de praktijk gebracht.

"Velen achten euthanasie een min of meer theoretische kwestie, die misschien in het buitenland in het hoofd van enige warhoofden rondspookt, maar een handeling betreft, die door ernstige medici toch zelden of nooit zal worden toegepast. De feiten liggen echter enigszins anders".

Ook de kathollieke kerk verbiedt pijnbestrijding met een levensverkortend nevengevolg niet langer. ${ }^{89}$

\section{Gedachten over thanasie vanaf de jaren zeventig}

In feite spitst zich de tegenstelling tussen de zogenaamde oude en nieuwe medische ethiek daarmee voornamelijk toe op de toelaatbaarheid van rechtstreeks levensbeëindigend handelen: Ten aanzien daarvan kunnen drie stromingen onder de medici onderscheiden worden, wier gedachtengoed in de standpunten van verschillende organisaties weerspiegeld wordt.

In 1972 wordt het Nederlandse Artsen Verbond (NAV) opgericht. Een aantal artsen dat zich niet kan vinden in het door (het Hoofdbestuur van) de KNMG ingenomen standpunt ten aanzien van abortus wordt er lid van. Het NAV presenteert zich als "pro life" -organisatie met als uiltgangspunt de "traditionele medische ethiek" ${ }^{110}{ }^{90} \mathrm{Zij}$ wijst rechtstreeks levensbeëindigend handelen en abortus, behalve op streng medische indicatie, strikt af. ${ }^{91}$

Enkele maanden later worden de Nederlandse Vereniging voor Vrijwillige Euthanasie (NVVE) en de Stichting voor Vrijwillige Euthanasie (SVE) opgericht, naar aanleiding van het vonnis van de rechtbank Leeuwarden van 21 febr. 1973 , NJ 1973, $183 .^{92}$

In deze zaak had de arts haar aan een ernstige ziekte lijdende moeder een dodelijke hoeveelheid morfine toegediend, nadat de moeder meerdere malen nadrukkelijk om levensbeëindiging had verzocht. De rechtbank veroordeelde de arts vanwege handelen in strijd met art. $293 \mathrm{Sr}$. Het beroep op overmacht werd verworpen met de overweging dat een minder vergaande weg openstond, namelijk levensverkontende pijnbestrijding en de arts derhalve daarwoor had behoren te kiezen.

87 Lindeboom, 1960 , p. 119 , hil zelf onthoudt zich wan een standpunt.

88. Lindeboom, 1960 , p. 127.

89) Paus Pius XII in 1956 en in 1958. Ontleend aan: Workgroep Euthamasie van het Katholiek Studkencentrum, 1983, p. 78. Zie ook: NTVG 1958, II, p. 2029 en NTWG 1962, I, p. 140.

90 Zie het interview met de vioe-voorzitter van de NAV, Van der Does de Willebois, in: Op sterven tha dood, 1987, p. 55-63.

91 Vgl. Lindeboom, Tegen de stroom in, Tien jaar Nederlands Artsenverbond, 1982. Zie ook: H. IL, onder 8.1. In dezelfde rin t.aw: actieve directe euthanasie: Oostvogel, in." Menswardig sterven, 1974, p. 189. Costwogel acht dit ongeoorloofd en overbodig, maar stagt nitet afwijzend tegenover pastsieve euthanasie. Zie ook: Van der Meer, in: Menswaardig sterven, 1974, p. 30 en Van Es, im: Menswaardig siterven, 1974, p. 68 in

92 Zie Indewey Gerlings-Humman, 1983, p. 11 e.v, en Enthoven, 1987, p. 18-19. 
De door de rechtbank gehoorde Inspecteur voor de Volksgezondheid in Friesland had verklaard, dat in "brede medische kring" de levensverkortende pijnbestrijding in de stervensfase wordt aanvaard, indien de patiênt ongeneeslijk ziek is, hel lijolen woor hem ("subjectief') ondraaglijk of ernstig is, hij om lewensbeëindiging heeft verzocht en door de behandelende arts of in overleg met deze wordt ingegrepen.

De rechtbank onderschreef al deze voorwaarden, met uibondering van de "stervensfases: Volgens de rechtbank kumnen zich ook buiten de stervensfase situaties voordoen, waarbi] levensverkortende pijnbestrijding geboden kan zijn. Daarmee had voor het eerst een rechtbank in Nederland de straffeloosheid van - wat toen werd genoemd - "indirecte euthanasie erkend.

Zoals al uit de naamgeving van de NVVE en de SVE blijkt, hechten zij grote waarde aan de vrijwilligheid van de levensbeëindiging. De standpunten van het NAV, de NVVE en de SVE veranderen in de loop der jaren niet wezenlijk. Het NAV blijft euthanasie afwijzen en de NVVE en de SVE zetten zich in voor het opheffen van de verbodsbepalingen van de artt. 293 en $294 \mathrm{Sr}$ ten aanzien van euthanasie door een arts, waarbij zij de vrijwilligheid van de patiënt blijven benadrukken. ${ }^{93}$

Wel treedt vermoedelijk in de loop van de tijd een verandering op in het denken over levensbeëindigend handelen bij de middengroep van de medici. Waarschijnlijk kan deze groep, die minder nadrukkelijk haar mening exponeerde dan uitgesproken voor- en tegenstanders van euthanasie, zich vinden in de door (het Hoofdbestuur van) de KNMG ingenomen standpunten. Maar dat euthanasie voor artsen een problematisch vraagstuk bleef, blijkt daaruit dat door het KNMG tot nu toe geen verbindende richtlijnen zijn uitgevardigd. Nog in 1987 merkte de toenmalige voorzitter van de KNMG op:

"Natuurlijk is er een standpunt van het hoofdbestuur van de KNMG. De KNMG is noch voor, noch tegen euthanasie. ...

We respecteren het dat er artsen zijn die om ethische of religieuze redenen euthanasie in alle omstandigheden afwijzen. ... Daarom laten we iedere arts in geweten vrij om in elke situatie te handelen zoals hij denkt te moeten handelen en hebben we de vraag 'voor/tegen euthanasie?' nooit in stemming gebracht in een ledenvergadering ${ }^{\text {t1 }}$. 94

Het KNMG wilde een voor zo veel mogelijk aangesloten artsen aanvalardbaar standpunt naar buiten brengen en dat betekende dat getracht werd een middenweg te kiezen. Daarom beschrijf ik de verschillende standpunten van (het Hoofdbestuur van) de KNMG inzake euthanasie ter illustratie van de verandering in het denken van medici over levensbeëindigend handelen op verzoek.

93 Zie b.v. Fretz (de toenmalige voorzitter van de NVVE), in: Op sterven na dood, 1987, p. 43-47 en Houben (bestiursild wan de NVVE), MC 1985, p. 1205. De SVE heef zich in 1985 opgeheven. Vanwege de ontwilkkeling van de rechtspratk over euthanasie ün de richting die de SVE woorstond, zag zij baar taak vervild. Volkskrant 6 april 1985 .

94. Derksen, in: Op sterven na dood, 1987 , p. $39-40$. 


\subsection{Het voorlopig standpunt inzake euthanasie van het Hoofdbestuur van de KNMG in $1973^{95}$}

In 1972 stelt het Hoofdbestuur van de KNMG een werkgroep in ter bestudering van het euthanasievraagstuk. Één jaar later, voordat de werkgroep haar werkzaamheden heeft afgerond, maakt het Hoofdbestuur zijn voorlopig standpunt over dit onderwerp bekend. Aanleiding daartoe zijn het hierboven genoemde vonnis van de Rb. Leeuwarden, 21 febr. 1973, NJ 1973, 183 en het verschijnen van het advies van de Gezondheidsraad inzake euthanasie. ${ }^{\%}$ Op het advies van de Gezondheidsraad en het vonnis van de Rb. Leeuwarden wordt door medici verdeeld gereageerd. Daarom ziet het Hoofdbestuur van de KNMG ervan af richtlijnen voor euthanasie op te stellen. Wel geeft het een voorlopig standpunt inzake het euthanasie-vraagstuk. Dat standpunt is een in hoofdlijnen met het advies van de Gezondheidsraad instemmend commentaar. Zo wordt onder andere aangesloten bij het begrippenstelsel van het advies.

In dit advies wordt euthanasie omschreven als

"een opzettelijk levensverkortend handelen of een opzettelijk nalaten van levens-

verlengend handelen bij een ongeneeslijke patiënt in diens belang". ${ }^{97}$

Volgens deze omschrijving kan euthanasie zowel door een doen als door een nalaten plaatsvinden. In beide gevallen is nodig dat de arts opzettelijk de gedraging verricht. In de medische wereld wordt in het algemeen met het woord "opzet" de bedoeling aangeduid. In die betekenis wordt "opzettelijk" ook in het advies van de Gezondheidsraad gebezigd en vermoedelijk ook in het voorlopig standpunt.

De thanatische gedraging mag slechts bij een patiënt geschieden die ongeneeslijk ziek is. Het Hoofdbestuur tekent hierbij aan dat euthanasie alleen overwogen mag worden als het stervensproces is ingetreden. Daaronder verstaat het dat de patiënt aan een ziekte lijdt "die onherroepelijk en binnen afzienbare tijd tot de dood leidt". Deze aanduiding kenmerkt zich evenals de omschrijving van de Gezondheidsraad door een zekere vaagheid. De Gezondheidsraad spreekt van "'een niet scherp te begrenzen periode kort vóór de dood waarin het duidelijk is dat de meeste vitale functies van het leven snel afnemen", en hij wijst erop dat het begrip niet nauwkeurig kan worden omschreven.

Het Hoofdbestuur is van mening dat euthanasie strafbaar dient te blijven, daar zij in het algemeen ongeoorloofd is. Uit de eis dat euthanasie slechts overwogen mag worden nadat het stervensproces is ingetreden, valt af te leiden dat het Hoofdbestuur wel ruimte will laten voor euthanasie in bijzondere omstandigheden. Daarbij onderscheidt het tussen enerzijds passieve en actieve euthanasie en anderzijds tussen vrijwillige en onvrijwillige euthanasie. Terwijl het Hoofdbestuur actieve euthanasie in beginsel niet toelaatbaar acht, laat het zich over passieve euthanasie minder duidelijk uit. Deze is in elk geval ongeoorloofd als zij "tegen de uitdrukkelijke wil van de patiënt" plaatsvindt.

Doordat niet geëist wordt dat slechts met toestemming van de patiënt gehandeld mag worden, mag de arts kennelijk (in bijzondere omstandigheden) tot passieve euthanasie overgaan, tenzij de patiënt dit weigert.

95 Hoofdbestuur KNMG, MC 1973, p. 587-588. Ook opgenomen in: MC 1984, p. 997-998 en in: KNMG, 1978, p. 38-41.

96 Gezondheidsraad, 1972.

97 Gezondheidsraad, 1972 , p. 10.

98 Zie H. IV C, onder 2.9. 
Dat het Hoofdbestuur wel gewicht toekent aan de weigering van de patient en tegelif kertijd uitdrukkelijke toestemming tot bepaalde verrichtingen van de arts niet als voorwaarde beschouwt, blijkt uit twee algemene standpurten, volgens welke "een patient. (...) het recht heeft om een behandeling te weigeren" en de arts verplicht is een behandeling te staken "indien de patiënt dat uitdrukkelijk vam hem verlangt"'. Eenzelfde benadering van de wilsuiting van de patiënt wordt door de Gezondheidsraad gehanteend, die ten: aanzien van het staken van een behandeling nog opmerkt, dat de weligering van de patiëmi de arts verplicht de behandeling te staken, maar daaraan toewoegt, dat het medisch-ethisch gezien de arts slechts is toegestaan een behandeling te staken als hij daartoe "bovendien een duidelijke medische indicatie aanwezig acht" ${ }^{99}$ In zoverre ademt het voorlopig standpunt (en het advies) nog de geest, van hetgeen Vanden Berg als oude medische ethiek heeft aangeduid, volgens welke de arts in beginsel levensreddend en levensverlengend dient op te treden.

Voor de mogelijke geoorloofdheid van actieve vrijwillige euthanasie acht het Hoofdbestuur nodig, dat de patiënt ongeneeslijk ziek is, zich in de stervensfase bevindt en hierom uitdrukkelijk verzoekt. In overeenstemming met eerdere uitlatingen van artsen merkt het Hoofdbestuur de levensverkortende pijnbestrijding in de stervensfase niet als euthanasie aan, daar de arts dan met de bedoeling handelt de pijn te bestrijden en nilet met de bedoeling het leven van de patiënt te verkorten. Verder is het Hoofdbestuur van mening dat "hulp bij zelfmoord", art. $294 \mathrm{Sr}$, niet thuis hoort bij het euthanasievraagstuk, maar zonder daarvoor redenen op te geven.

\subsection{De discussienota Euthanasie van de Werkgroep Euthanasie van de KNMG}

In 1975 verschijnt over euthanasie een discussienota van de door de KNMG in 1972 ingestelde Werkgroep Euthanasie. ${ }^{100}$ De nota dateert van 1973 en is na besprekingen met het Hoofdbestunr van de KNMG slechts tekstweel gewijzigd. Uitdrukkelijk wordt verklaard dat met de publikatie geen standpunt van het Hoofdbestuur tot uiting wordt gebracht.

De Werkgroep beveelt aan dat de KNMG geen officieel standpunt over euthanasie afkondigt, daar volgens haar over dit onderwerp zoveel meningen bestaan als er artsen zijn. ${ }^{101}$ Een speciale juridische regeling voor euthanasie acht de Werkgroep niet nodig, daar zij erop vertrouwt dat de strafwet voldoende ruimte laat voor de straffeloosheid van de arts. ${ }^{102}$

De nota begint met een beschrijving van de situatie waarin de medicus ten aanzien van leven en dood van zijn patiënten in verband met de medisch-technologische ontwikkelingen terecht kan komen. Die beschrijving doet sterk denken aan de onderbouwing van het hierboven ter sprake gebrachte pleidooi van Van den Berg voor een nieuwe medische ethiek, naar wiens "Medische macht en medische ethiek" ook verwezen wordt. ${ }^{103}$ 
De Werkgroep sluit voor de werkdefinitie van euthanasie aan bij de omschrijving, die de Gezondhe"dsraad en het Hoofdbestuur hebben gegeven. Aanduidingen als "ongeneeslijk $k^{\text {18 }}$ en "stervensfase" acht zij daarin echter niet op zijn plaats. Daarvoor geeft zij onder andere als reden, dat dan onbesproken zou blijven euthanasie, waarbij niet aan deze voorwaarden kan worden voldaan. Tevens is zij van mening dat in een definitie geen toelaatbaarheidseis thuis hoort. ${ }^{104}$

Euthanasie mag "in de regel" slechts worden overwogen, wanneer de arts ervan overtuigd is dat hem geen andere mogelijkheden meer ter beschikking staan. Van het grootste belang voor de toelaatbaarheid acht de Werkgroep dat de patiënt er uit zichzelf om vraagt. Kan de patiënt zijn wil niet (meer) kan uiten, dan komt het "beslissingsrecht van de patiennt" aan niemand anders toe.

Voordat de arts tot euthanasie overgaat, dient hij collegae te raadplegen, maar de behandellende arts is degene die uiteindelijk de beslissing neemt.

In de nota wordt onderscheiden tussen passieve en actieve euthanasie en ten aanzien van de patiënten, of deze zich al dan niet in de stervensfase bevinden.

Tot euthanasie rekent de Werkgroep niet de weigering van de patiënt tot een behandeling. In dat geval staakt de arts de behandeling immers niet met hef doel om de patiënt een goede dood te bezorgen, maar uit respect voor de rechten van de patient.

Daarentegen beschouwt de Werkgroep levensverkortende pijnbestrijding in de stervensfase als een wijze van passieve euthanasie. Geeft de medicus hierbij echter een te hoge dosis, dan valt de levensbeëindiging onder actieve euthanasie. Volgens de Werkgroep ligt het wezenlijke verschil daarin, dat bij een adequate pijnbestrijding het risico bestaat dat de dood verhaast wordt, terwijl dat bij een te hoge dosis zeker is.

In dit verband merkt de Werkgroep op, dat ook juridisch een verschil tussen beide handelswijzen bestaat. Het toedienen van een te hoge dosis is strafbaar, maar niet het toedienen van een adequate dosis. ${ }^{105}$

De Werkgroep acht passieve euthanasie ook bij patiēnten die zich niet in de stervensfase bevinden, niet principieel ongeoorloofd. Maar dan moet het leven well zinloos zijn, waaronder de Werkgroep verstaat "leven zonder intermenselijke communicatiemogelijkheden nu of in de toekomst". Daarbij wordt gedacht aan "ongeneeslijk mismaakt (onvolkomen) geboren kinderen", "ernstigsomatisch zieken, zoals totaal demente bejaarden en ernstig beschadigde mensen na een ongeval of ziekte ${ }^{\text {t. }}{ }^{10 *}$ Dan is er kennelijk sprake van een grenssituatie, die meebrengt dat er "soms beslissingen moeten worden genomen zonder dat de patiënt werd of kon worden gehoord". ${ }^{107}$. Hieruit bijkt dat de Werkgroep het nalaten van zinloos handelen toelaatbaar acht bij wilsonbekwame patiënten, die niet meer tot communicatie in staat zijn.

Actieve euthanasie is volgens de Werkgroep alleen toelaatbaar als de patient zich in de stervensfase bevindt en hij om euthanasie vraagt, waarbij het initiatief van hem uitgaat. De arts mag aan het verzoek slechts toegeven in gevallen waarin passieve euthanasie toelaatbaar is, maar deze niet tot een afdoende verlichting van het lijden leidt. Bevindt

104 Werlkgroep Enthanasie, MC 1975, p. 8.

105 Werkgroep Eutharasie, MC 1975, p. 9. Zie hiertoe: H. IV A, onder 3.3.

106 Werkgroep Euthanasie, MC 1975, p. 11.

Wierkgroep Euthanasie, MC 1975, p. 10. 
de patiênt zich niet in de stervensfase dan mag niet tot actieve vrijwillige euthanasie worden overgegaan. Volgens de Werkgroep "(zal) de arts zich in deze gevallen niet voor het doden (...) mogen lenen ${ }^{\text {th }}$.

Anders dan het Hoofdbestuur is de Werkgroep wan mening, dat suïcide tot euthanasie behoort te worden gerekend. De Werkgroep formuleen alls kernvrarg bij euthanasie: "Heef een mens het recht te beschikken over zijn eigen leven?" Naar de mening van de Werkgroep zou een arts nooit aan suicide mee mogen werken. Daarbij gaat zij erwan uit, dat degene die om hulp bij zelfdoding verzoekt, dat doet vanuit psychische problemen en het verzoek als onderdeel van de ziekte wordt beschouwd. ${ }^{109}$

\subsection{Het Standpunt van het Hoofdbestutr van de KNMG van 1984 inzake euthanasie}

Het standpunt wan het Hoofdbestuur van de KNMG van 1984 inzake euthanasie ${ }^{110}$ vertcont in zijn strekking veel overeenkomsten met het advies dat de Gezondheidsraad in 1982 over dit onderwerp uitbracht. ${ }^{11}$ Dat advies werd gevraagd in verband met het instellen van de Staatscommissie Euthanasie. ${ }^{112}$

Anders dan in het voorlopig standpunt uit 1973 en in de discussienota van de Werkgroep Euthanasie uit 1975 is "euthanasie" in het standpunt van 1984 beperkt tot levensbeeindigend handelen op verzoek. De zinsnede "in het belang van de patiēnt" is vervangen door "op diens uitdrukkelijk verzoek", zodat de omschrijving van euthanasie thans luidt: "handelen, dat beoogt het leven van een ander op diens uitdrukkelijk verzoek te beëindigen". ${ }^{113}$ Levensbeëindiging zonder verzoek wordt niet als euthanasie beschouwd.

Evenmin wil het Hoofdbestuur drie andere levensbeëindigende gedragingen onder "euthanasie" laten vallen. Het gaat daarbij om:

- het staken respectievelijk achterwege laten van een in medisch opzicht zinloze handeling, - levensverkortende pijnbestrijding in de stervensfase,

- het achterwege laten van (medische) handelingen op verzoek van de patiënt. ${ }^{114}$

Voor het staken respectievelijk achterwege laten van een in medisch opzicht zinloze handeling is toestemming van de patiënt niet vereist. De medicus bepaalt zelfstandig, al dan niet na consultatie van collega-artsen, of een handeling medisch gezien zinloos is. De medische zinloosheid is een objectief criterium en "mag niet worden verward met een oordeel over de zin van lemands leven". "1's Een arts mag slechts handelen voor zover zijn handelen medisch gezien zinvol is. Is dat niet het geval en handelt de arts desondanks, dan makt hij zich schuldig aan mishandeling. Maar als de patiënt van de arts verzoekt met de behandeling door te gaan, dan heeft de arts het recht daartoe.

108 Werkgroep Euthanasie, MC 1975, p. 12.

109 Werkgroep Einthanasie, MC 1975, p. 12.

110 Hoofdbestur $\mathrm{KNMG}_{2}$ MC 1984, p. 990-997.

111 Gezondheidsmad, 1982.

112 Zie:" H. IV B, onder 1.

113 Hoofdbestuur $\mathbb{K N M G}, \mathrm{MC} 1984$, p. $991-992$.

114 Hoofdbestium $\mathrm{KNMG}, \mathrm{MC} 1984$, p. 992.

115 Hoofdbestuur KNMG $\mathrm{MC}_{1984}$, p. 992. Hoewel, zolis het Hoofdbestur zegi, er grensgevallen zijn. 
Daarentegen is voor levensverkortende pijmbestrijding in de stervensfase, door het Hoofdbestuur thans "stervenshulp" genoemd, de toestemming van đe patiënt nodig. Daarvoor geeft het Hoofdbestuur twee redenen op. Voor elke behandeling is de toestemming van de patiënt vereist, maar in het bijzonder in dit geval omdat het neveneffect van de verlichting van het sterven een vervroeging van de dood is. Deze stervenshulp heeft als doel de verlichting van het geestelijk en lichamelijk lijden met als nevengevolg levensverkorting ${ }^{116}$ en werd daarom ook wel als "indirecte euthanasie" aangeduid. Het Hoofdbestuur bakent de verlichting van het lijden met als nevengewolg levensverkorting af met behulp van het begrip "stervenshulp". Levensverkortende bestrijding van het lijden buiten de stervensfase kan eventueell euthanasie zijn, mar geen "stervenshulp".

De derde gedraging die niet onder euthanasie valt, is het op verzoek van de patiênt achterwege laten van behandelingen. Daar slechts medisch gehandeld mag worden met toestemming ${ }^{117}$ van de patiënt, moet een medicus gevolg geven aan het verzoek van de patiënt om (medische) handelingen achterwege te laten, ook al heeft dit de dood van de patiënt tot gevolg. ${ }^{118}$

Terwijl het Hoofdbestuur deze verschillende gedragingen scherper van elkaar afbakent, laat het andere onderscheidingen vervallen. Het terminologische onderscheid tussen passieve en actieve euthanasie wordt niet langer gehandhaafd. ${ }^{119}$ Wat passieve euthanasie genoemd werd, is óf een op het verzoek van de patiënt achterwege laten van een behandeling, óf het niet (verder) behandelen, omdat de behandeling medisch zinloos wordt geacht. ${ }^{120}$

Het Hoofdbestuur wil evenmin langer een verschil maken tussen "euthanasie" en "hulp bij zelfdoding". Immers, "per slot van rekening gaat het bij beide methoden om hetzelfde, te weten de zelfbeschikking over een menswaardig levenseinde ${ }^{\prime \prime}$. Met de nadruk die het Hoofdbestuur hier op de zelfbeschikking legt; verdedigt het tevens het standpunt dat euthanasie buiten de stervensfase geoorloofd kan zijn.

De "kernvraag (is) niet of er al dan niet sprake is van een stervensfase, maar of er sprake is van een situatie, warin de patiënt vrijwillig en weloverwogen blijk geeft van zijn duurzaam verlangen naar de dood en de arts erkent dat de patiënt ondraaglijk lijdt en dit lijden - mede gelet op de stand van de wetenschap - als uitzichtloos moet worden aangemerkt" ${ }^{\text {th }}{ }^{121}$

Bowendien kan volgens het Hoofdbestuur het begrip "stervensfase" niet duidelijk worden afgebakend. Daarom is het opmerkelijk dat het Hoofdbestuur in verband met de levensverkortende pijnbestrijding wel van de stervensfase spreekt.

De enige die tot levensbeëindiging mag overgaan, is volgens het Hoofdbestuur de arts . "Er kan geen twijfel over bestaan dat euthanasie thuishoort in de arts-patiêntrelatie". Daarvoor geeft het Hoofdbestuur meerdere redenen. De handelingen die hierbij verricht worden, zijn nadrukkelijk aan een arts voorbehouden. Nog belangrijker is dat de arts

116 Hoofdbestuur $\mathrm{KNMG}_{\mathrm{y}} \mathrm{MC} 1984$, p. 992 .

117 In bijzondere omstandigheden met veronderstelde toestemming.

118 Hooldbesturur KNMG, MC 1984, p. 992.

119 Hoofdbesturur KNMG, MC 1984, pin 992 . Zie: H. IN Ais onder 3.4.

120 Hoofdbestuur KNMG, MC 1984, p. 992.

121 Hoofdbestuur $\mathrm{KNMG}, \mathrm{MC} 1984$, p. $992-993$. 
de enige is die op enkele vragen die voor een zorgwuldige besluitvorming essentieel zijn, een antwoord kan geven. Die vragen betreffen het ziektebeeld van de patiënt en de reele kansien op een verbetering van zijn toestand respectievelijk welk lijden hij waarschijnlijk nog tegemoet zal gaan. Bovendien is de arts tuchtrechtelijk aansprakelijk. ${ }^{122}$

Van een arts die levensbeëindigend handelen op principiele gronden afwijst, werwach het Hoofdbestunir đat hij eraan meewerkt dat de patiënt contact krijgt met een collega. ${ }^{\text {ws }}$

Met betrekking tot de zorgvuldigheidseisen merkt het Hoofidbestuur op, dat er sprake moet zijn van een weloverwogen en vrijwillig genomen verzoek, op grond van een duurzaam verlangen naar de dood in verband met een onaanvaardbaar, uitzichtloos lijden. Het enige begrip dat het Hoofdbestuur in verband met het lijden objectiveerbaar acht is de uitzichtloosheid van het lijden. Maar slechts in zoverre als door de arts kan worden nagegaan of er op korte termijn nieuwe mogelijkheden zijn in de bestaande situatie verandering te brengen. Als de patiënt zijn situatie niet op grond van strikt medische overwegingen uitzichtloos acht, dan heeft de arts minder mogelijkheden tot toetsing, maar is euthanasile niet uitgesloten. Daarbij acht het Hoofdbestuur de duurzaamheid van het lijden "strikt genomen" van ondergeschikt belang. Voor de arts is ten aanzien van het verzoek een belangrijke taak weggelegd. Naast de al genoemde mogelijkheid tot toetsing van de medische uitzichtloosheid van het lijden, behoort daar volgens het Hoofdbestuur ook toe dat hij er zorg voor draagt dat de patiënt goed wordt voorgelicht, zodat diens verzoek weloverwogen $1 \mathrm{~s}$." Verder dient de arts zich ervan te overtuigen, dat het verzoek vrijwillig tot stand is gekomen. ${ }^{124}$

Volgens het Hoofdbestuur zijn consultatie en toetsing onontbeerlijk, maar niet alle artsen doen dit momenteel: Daarom acht het Hoofdbestuur het de taak van de KNMG hier regelend op te treden: ${ }^{125}$

Daar levensbeëindigend ingrijpen aan de arts moet worden voorbehouden, heeft de medische professie, naar de mening van het Hoofdbestuur tot taak "een maatschappelijk aanvaardbare regeling van het euthanasievraagstuk te maken". Daarvan is sprake als de regeling aan de verschillende opvattingen in een pluriforme samenleving ruimte biedt. ${ }^{126}$

\subsection{De opwatting van Dessaur}

In 1985 lijkt de euthanasiediscussie in rustiger vaarwater terecht te komen. Het rapport van de Staatscommissie Euthanasie, dat hieronder besproken wordt; is op vele punten in overeenstemming met het standpunt van de $\mathrm{KNMG}$, en het in het rapport opgenomen voorstel lijkt ook politiek gezien kansrijk. ${ }^{127}$ Het schijnt alsof slechts enkelen zich nog verzetten tegen de wenselijkheid om euthanasie ook wettelijk toe te staan. ${ }^{128}$ Dan ver*

122 Hoofdhestuur KNMG, MC 1984, p. 993.

123 Hoofdbestur KNMG, MC 1984, p. 993.

124 Hoofdbestuur KNMG, MC 1984, p. 994-995.

125 Hoofdbestumir KNMG, MC 1984, p. 995-996.

126 Hoofdbestuur $\mathrm{KNMG}_{3} \mathrm{MC} 1984$, p. 997.

127 Daarvan getuigl ook de verderop besproken Proeve van de negering. Zie: H. IV B; onder 1 .

128 Zie voor een afwijzend reactie op het standpum van het Hoofdbestuur van de KNMG van 1984, het commentasar van de NAV, Vita Humanae, 1984, p. 165-168. Daarin wordt gewezen op de normen en watarden wan de medische ethiek, warmee de "oudle ethiek" wordit bedoeld. 
schijnt in de winter van 1985 het artikel "Euthanasie: de zelfmoord op zieken en bejaar. den" wan de Nijmeegse criminologe Dessaur. Dat artikel brengt een sneeuwbaleffect teweeg. ${ }^{120}$

Volgens Dessaur "blijkt het gif der nationaalsocialistische ideologie (...) diep in ons collectieve bewustzijn" te zijn doorgedrongen. ${ }^{130}$ Daarin ziet zij de reden dat het

(v)eertig jaar ná Hitler en zijn eugenetica (...) geenszins gemakkelijk (is) voor tegenstanders van (universele) abortus en (vanzelfsprekende) actieve euthanasie uit the leggen wat hun bezwaren zijn tegen de engeltjesmakers, of de do-gooders die met injectienaald en spuit maar al te gaarne hun medemensen uit het aardse lijden willen verlossen". ${ }^{131}$

Hoewel het artikel een filippica tegen het "abortus- en euthanasiedenken" is, met een voor het tijdschrift zeer ongebruikelijke toonzetting, waardoor wellicht mede de publieke belangstelling wordt gewekt, is het in zijn afwijzing van levensbeëindigend handelen niet absoluut. Wat Dessaur noemt "medische abortus provocatus", is ook in haar opvatting geoorlootd. Daaronder verstaat zij abortus na verkrachting of incest of in verband met de leeftijd. Maar abortus als een wijze van "anticonceptie" noemt zij het "prenataal uitroeien van mensen ${ }^{\text {th }}$. ${ }^{3.2}$

Ook acht zij "passieve euthanasie" "vanzelfsprekend toegestaan". Daaronder verstaat zij het stopzetten van een zinloze behandeling en het niet behandelen. Maar, in beide gewallen slechts dan alls op wens van de betrokkene nilet tot (verder) behandelen wordt overgegaan. ${ }^{133}$

Tegen actieve euthanasie voert Dessaur aan dat deze, ter bestrijding van pijn "onnodig en immoreel" is. Onnodig, want er zouden effectieve pijnbestrijdingsmiddelen bestaan ${ }^{134}$ en immoreel, want:

"Het nationaal-socialistische geestelijke erfgoed, verpakt in de rode vlag van het groepsheil of in het plastic yan het individuele hedonisme, kan tot niets anders leiden dan totale barbarij, totale angst van allen voor allen, totale vernietiging van wat eens onze beschaving was"

Het grootste effect dat het artikel van Dessaur teweeg brengt, is dat de invloed van tegenstanders op het verloop van de euthanasiediscussie groter gewicht krijgt. ${ }^{136}$ Tussen het KNMG-standpunt van 1984 en het artikel versehijnt het rapport van de Staatscommissie Euthanasie, waarin wetswijziging wordt voorgesteld, om straffeloosheid van euthanasie en levensbeeindiging van onherstelbaar comateuzen wettellijk te regelen. Dat rapport,

129 Degsaur, DD 1985, p. 913-918. Het artikel werd ook integraal afgedrukl in de NRC van 13 jan. 1986 en in het boek van Dessaur en Ruterterans, Amsterdam 1986.

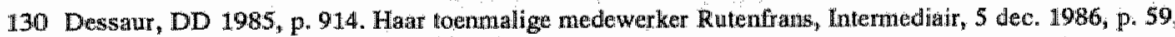
herformuleerde deze opmerking, zoals hij hett noemi "wat genuanceerder", als volgt: "het collectivisme dat zich manifesteen in het sociaal darwimisme, de eugenetica, het nationat-socialisme, mat ook in bel comnunisne, mamifesteert zich eveneens in de pleidooien voor het plegen endof legaliseren van euthanasic. ... In cleze visie worden morele warder beschoniwd als niel meer dan de vitdrukkingsvormen van instinctieve impulsen. Moralitteif zou kumen worden herleid tot wat nuttig is voor de soort".

131 Dessaur, DD 1985, p. 914.

132 Dessaur, DD 1985 , p. $915-916$.

133 Dessaur, DD $1985, \mathrm{p} .915$.

134 Dessaur, $\mathbb{D D} 1985$, p. 915.

135 Dessaur, DD 1985 , p. 917 .

136 lin DD 1986, p. 208-213, werzet Bins zich tegen een scherpe ondersche iding tussen actieve en passieve euthanasie en noemt zij abortus cen "principieel ... moeilijker probleem" dam euthanasie. Zij benadrulkt de vrije wil van het individu tot levensbeeindiging en van de vroww tot abortus. 
dat inhoudelijk hieronder aan bod komt, ontmoet weinig kritiek en het minderheidsstand. punt van twee leden van de commissie blift vrijwel ongehoord. Het lijkt er zelfs op dai een wetswijziging in de geest van het rapport politiek haalbaar is. Het artikel van Dessaut brengt darin verandering. Het vestigt de aandacht op argumenten die door tegenstanders van een permissief abortus- en euthanasiebeleid reeds langer worden gebezigd. Die argumenten worden ook door de NAV naar voren gebracht, maar dan in verband met de absolute eerbied voor het leven die de beroepsuitoefening van de medicus dient te bepalen.

Voor zover als waarschuwing naar historische verschijnselen wordt verwezen, betref dit verschijnselen in het buitenland, met name in het nationaal-socialistische Duitsland Dat de euthanasiediscussie in Nederland in wezen pas in de jaren zestig is begonnen en geen historische achtergrond kent; is een verschil dat deze discussie onderscheidt van die in een aantal andere landen. ${ }^{138}$

\section{3 "Euthanasie", "levensbeeindiging" en schijngestalten van euthanasie ${ }^{139}$}

\subsection{Inleiding}

Tot in de jaren tachtig werd het woord "euthanasie" voor verschillende gedragingen gebruikt die als gemeenschappelijk kenmerk hebben dat een derde het leven van een zieke in diens belang beëindigi. De derde moet meestal een arts zijn of tenminste onder toezicht van een arts het leven van de zieke beëindigen ${ }^{140}$, terwijl tussen de arts en de zieke een arts-patiënt-verhouding dient te bestaam.

Ter aanduiding van de verschillende wormen van euthanasie werden vaak bijvoeglijke naamwoorden gebezigd. Er werd van "vrijwillige" en "onvrijwillige", van "actieve" en "passieve" en van "directe" en "indirecte" euthanasie gesproken. Reeds in 1977 duidt Leenen enkele van deze vormen als "schijngestalten van euthanasie" aan. ${ }^{141}$ Daarmee bedoelt hij dat deze vormen wel op euthanasie lijken, maar daar niet onder vallen. De voorgestelde differentiatie heeft ingang gevonden in vele publikaties en in voorstellen tot wetgeving. ${ }^{142}$ Het begrip "schijngestalten" zelf wordt minder vaak gebruikt, maar het geeft in het kort de essentie weer en wordt daarom ook hier gehanteerd. Het voordeel

137 Zie o.a. Wan der Sluis, 1977; Lindeboom, 1978; Minderheidstota, in: Staatscommissie Euthanasie, Deel 1, 1985; Rutenffans, Internediair, 5 dec, $1986, \mathrm{p}, 3-7$ en $\mathrm{p} .59-61$

138 Zie ook de reactie van Van Wijmen, V(r)ijwertahl(d), 1988, nr. 6, p. 11 op een wit een Duits vertakild artikel van Dörner, Euthanasie gisteren - stervenshulp vandagg, V(r)ijvertaal(d), 1987, nrs. 3 en 4. Var Wijmen wigst daarbij op de nadruk die in Nederland wordi gelegd op hel verzoek van de patièn en clananee op de telfbeschilkking of autonomie van het individu.

139 Zie hiertoe in het algeneen: Leenen, 1988 , p. $287-303$.

140 Zie b.v. Gezondheidsraad, 1972, p. 10 en Wessel-Tuzustra, TK, 1983*1984, 18331, nr. 2. Na verschijnen van het rapport wan de Staatsconmissie Euthanasie wordt ook in het voorstel Wessel-Tuinstra uitsluntend de arts bevoegd verklaard de levensbeëindiging uit te woeren. Wessel-Tuinstra, TK, 1985-1986, 18331, nir. 10 .

141 Lexuen, in: Euthanasie, 1977, p. 100.

1,42 Zie 0,a Gezondheidsraad, 1982, p, 9-15; Standpunt Hoofidbestum KNMG, MC 1984, p. 992; Staatscom-

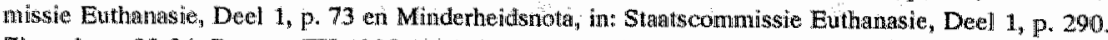
Zie ook: P. 23-24; Proeve, TK 1985-1986, 19359, ni, 2, Kabinetswoorstel, TK 1987-1988, 20383, ay. 2 en $\mathrm{H}$. IV B, onder 1.7 .16 . 
van deze differentiatie is dat de discussie zuiverder gevoerd kan worden en het gevaar van misverstanden kleiner wordt. ${ }^{143}$

Hieronder worden de verschillende "vormen van euthanasie" beschreven en wordt nagegaan in hoeverre deze als "schijngestalten van euthanasie" kunnen worden aangemerkt.

\section{2 "Vrijwillige" en "onvrijwillige euthanasie"}

In oudere omschrijvingen van euthanasie wordt vaak opgemerkt dat de levensbeëindiging "in het bellang" van de patiënt dient te zijn. Soms wordt er nog bij vermeld dat bij een patiënt die tot wilsuiting in staat is, niet tegen zijn wil, uitsluitend met zijn instemming of alleen op zijn verzoek, tot lewensbeëindiging mag worden overgegaan. ${ }^{144}$

Uitgaande van één van deze omschrijvingen en van het toestemmingsvereiste vervangt de toestemming echter niet de eis dat "in het belang van de patiënt" gehandeld dient te worden. Want anders zou met de toestemming reeds volledig het belang van het handeلen zijn aangetoond. De toestemming van de patiënt die tot een wilsuiting in staat is, werkt hierbij derhalve als een noodzakelijke, maar niet als een toereikende voorwaarde.

Bovendien wend verdedigd dat "in het belang" van de patiënt ook gehandeld kan worden bij patiênten die niet (meer) hun wil kunnen uiten en die evenmin eerder een verklaring over levensbeëindiging hebben afgelegd. Op deze wijze dekte de omschrijving zowel de vrijwillige als de onvrijwillige euthanasie. ${ }^{145}$

Nadien is het gebruikeli.jk geworden in de definitie van euthanasie de vrijwilligheid als constitutief element op te nemen en de zinsnede "in het belang van" achterwege te laten. De thans gangbare definitie luidt:

"het opzettelijk levensbeëindigend handelen door een ander dan de betrokkene, op diens verzoek". . $^{146}$

Uit de definitie blijkt niet van een onderscheidend kenmerk tussen "euthanasie" en "levensberoving respectievelijk levensbeëndiging op verzoek", dat "euthanasie" tot een niet-strafbare handeling maakt. De Staatscommissie geeft daartoe als reden op, dat in een definitie van euthanasie moet worden volstaan met "een samenvattende omschrijving van de kenmerken van een begrip" ${ }^{\prime}$. Voorwaarden en beperkingen behoren daarin niet thuis, omdat daarmee "een oordeel over de al dan niet toelaatbaarheid van euthanasie" tot uitdrukking wordt gebracht, zoals Leenen reeds in 1977 had opgemerkt. ${ }^{147}$

143 Vgl. Sutorius, TVGR 1985, p. 335.336 en Wan Wijmen, in: Euthanasie, recht en praktijk, 1985, p. 12; Hirsch Ballin, RR 1985 , p. 73.

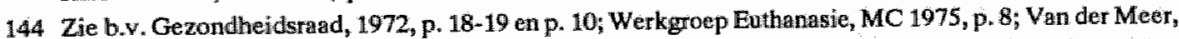
in: Euthanasie, 1985, p. 70-71. KJifn, in: Euthanasie, 1985, p. 38, wil in de definitie valn cuthanasie opgenomen zien, dat euthanasie "niet in het belang wain anderen" mag geschieden, om zo te woorkomen dat de pattient in het belang wan derden om euthanasie werzoekt.

145 Zie b.w. Gezondheidsraad, 1982, p. 28, die in dat werband de woorkeur geeft aan de woorden "kenbar gemaak" en "nier kenbaar gemalakt" in plaats wen "vrijwillig" en "onwrijwillig".

146 Staatscommissie Euthanasie, Deel 1, 1985, p. 26. Zo b.v. ook Hoofdbestun KNMG, MC 1984, p. $991-992$. KJjin, in: Euthanasie, 1985, p, 38-39, heeft een woorkeur om het "uitdrukkelijk en ermistig verzoek win de patient" niet a a de definitie op te nemen en alleen bij de voorwarden een rol te laten spelen. Daarvowr geeft hij als eerste reden op, dat de wernelding wan het verzoek de definitie cthisch geladen en darmee niet neutraal mak kt. Het belangrijhstie argument is woor hem echter dat er ook redenten kunnen zijn voor euthanasic bij wilsonbekwame patienten.

147 Leenen, in: Euthanasie, 1977, p. 80-81. Zie ook: Staatsconmissie Euthanasie, Deel 1, 1985, p. 26. 
Vanwege het vereiste "verzoek" is nodig dat het initiatief to euthanasie van de patient. uitgaat. Deze eis is enerzijds strenger dan die in art. $293 \mathrm{Sr}$, war van een "verlangen" wordi gesproken. ${ }^{148}$ Hierboven is verdedigd, dat voor dat "verlangen" niet nodig is dat de betrokkene het initiatief neemt. Anderzijds wijst het woord "verlangen" meer op. een duurzame innerlijke behoefte dan het woord "werzoek", dat eerder doet denken aian een rationeel genomen beslissing. In dat opzicht kan verdedigd worden dat "verzoek" bij euthanasie beter op zijn plaats is, want daar gaat het er immers juist om dat de patient goed gernformeerd over zijn toestand en zijn toekomstmogelijkheden een beslissing over zijn leven neem:

Een andere mogelijkheid was geweest om in plaats van "verzoek" voor "toestemming" te ktezen. Het woord "verzoek" vestigt er echter de aandacht op dat de patient in zijn wilsuiting niet door derden beinwloed mag worden en het sluit uit dat "veronderstelde toestemming" toereikend zou kunnen zijn. ${ }^{149}$ Met de fictie van de "veronderstelde toestemming" tot medische behandeling wordt gewerkt waar de patiënt zijn wil niet meer kenbaar kan maken en op dat moment niemand anders voor hem de beslissing op juridisch geldige wijze kan nemen. ${ }^{150}$ Daarbij wordt ervan uitgegaan dat de patiënt als hij tot wilsuiting in staat zou zljn geweest, ook voor de behandeling zou hebben gekozen.

Als veronderstelde toestemming bij euthanasie toelaatbear zou zijn, dan zouden bij wilsonbekwame patiënten derden aan hand van de situatie waarin de patiënt zich bevindt, tot levensbeeindiging kunnen beslissen. In hoeverre dat mogelijk is, is juist omstreden, zoals in het derde deel van dit hoofdstuk zal blijken.

In het woord "verzoek" ligt besloten dat de patiënt kiest voor euthanasie. Hoe zelfstandigen vrij kan een dergelijke wilsuiting van een ernstig zieke patiënt zijn? Er zou gesteld kunnen worden dat de ziekte de patiënt de vrijheid kan ontnemen om al dan niet voor euthanasie te kiezen. Volgens Leenen moet men

"ervoor waken aan wilsuitingen van patiënten niet bij voorbaat minder gewicht toe te kennen. ... In het normale maatschappelijke verkeer wordt iemands wilsuiting aanvaard, tenzil het tegendeel blijkt. Deze norm geldt ook voor patiënten". 15 .

Ook ten aanzien van patiẻnten die hun wil niet (meer) kenbaar kunnen maken, wordt wel eens voorgesteld onder bepaalde omstandigheden levensbeëindiging toelaatbaar te achten. Voor deze, in de oude terminologie, "onvrijwillige euthanasie" is het thans gebruikelijk om van "levensbeëindigend handelen" of "levensbeeindiging" te spreken. ${ }^{152}$

Daarmee is de vroegere terminologische tegenstelling tussen vrijwillige en onvrijwillige euthanasie vervangen door die tussen euthanasie en levensbeëindiging. Voor euthanasie zijn de artt. 293 en $294 \mathrm{Sr}$ van belang en voor lewensbeẽindiging de artt. 287 en 289 Sr.

148 Sutorius; in: Verantwoorde lewensbeëjndiging?, 1986, p. 42: noemt thet verschill tussen (een berhaaldelijk geuit) "verlangen" en een (uitdrukkelijk) "verzoek" essentieel.

149 Leenen, 1988, p. 278: "Veronderstelde toestenming is bij euthamasie niet mogelijk".

$150 \mathrm{Vgl}$. TK 1989-1990, 21561 (WGBO), nr. 3 (MvT), p. 48-49.

151 Leenen, 1988, p. 280-281. Zie ook: Werkgroep Euthanasie van het Katholiek Studiencentrum, 1983, p. 26.

152 Zie H. IV C, onder 1. 
Onder directe euthanasie wordt werstaan een thanatische gedraging, waarbij het door de medicus nagestreefde doel de levensbeëindiging van de patiënt is. Van indirecte actieve euthanasie is sprake als de medicus met het doel de pijn die de patient ondervindt, te bestrijden, middelen toedient die als nevengevolg het leven van de patiënt verkorten. ${ }^{153}$ Dit gevolg is onvermijdelijk, omdat de middelen dit "bijverschijnsel" hebben. De arts staat hier derhalve voor de keuze, of de pijn niet (adequaat) te bestrijden, of de pijn te bestrijden en de verkorting van het leven van de patiênt daarbij op de koop toe te nemen.

Levensverkontende pijnbestrijding met instemming van de patiënt voldoet aan de delictsomschrijwing van art. 293 Sr.

De stelling, dat levensverkortende pijnbestrijding (in de stervensfase) straffeloos mag geschieden, omdat het doel van de arts die pijnbestrijding en niet het vervroegde overlijden van de patiënt is, is onjuist. ${ }^{1.54}$ Het motief van het handelen, i.c. de pijnbestrijding, laat onverlet datt strafrechtelijk gezien (kans)opzet op het vervroegde overlijden aanwezig is. De arts die tot levensverkortende pijnbestrijding overgaat, weet dat een gevolg hiervan het overlijden van de patiënt is. Ook aanvaardt hij dit gevolg, want anders zou hij van zijn handelen hebben afgezien. ${ }^{155}$

Evenmin is de stelling houdbaar, dat bij levensverkortende pijnbestrijding de doodsoorzaak niet het toedienen van de middelen ter pijnbestrijding is, maar de in de patiënt aanwezige ziekte. ${ }^{156}$ Ook wanneer de levensverkortende werking van een pijnbestrijdend middel slechts als mogelijkheid wordt gezien ${ }^{157}$ is bij aanvaarding van die mogelijkheid sprake van kansopzet. Wanneer door toedoen van en met aanvaarding door een arts een patiênt eerder komt te overlijden, dan heeft de arts toch de dood bewerkstelligd. Zou daarvan niet worden uitgegaan, dan zou iedereen - zonder een levensdelict te plegen - aan een patiënt in de stervensfase een pijnbestrijdend middel mogen toedienen, ook al weet de toediener dat de mogelijkheid bestaat dat daardoor het leven wordt verkort.

Irmiddels wordt de levensverkortende pijnbestrijding als een schijngestalte van euthanasie opgevat en tot het normaal medisch handelen gerekend. ${ }^{158}$ Voorwaarde hiervoor is wel,

153 Zie oa. Marllet, in Recent medisch ethisch denken 1, 1968, p. 165; Schreuder, in: Recent medisch ethisch denken 1, 1968, p 166 en de Rang, in: Menswardigsterven, 1974, p. 265; Nederlands Gesprek Centrum,

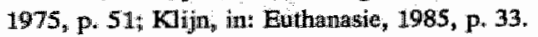

154 Dourdat Klinn, in: Euthanasie, 1985 , p. 36-40, de nadruk legt op het al dan niet beogen wan de dood, merki hij ten aamzien van de levenswerkortende pijnbestrijding op, dat de arts hierbij ook indirect niet de dood wan de patient beoegt. Hij is dan ook van mening dat bij levensverkortende pijnbestrijding sprake is wan een "matuurlijke doodsoorzatk". Nar zijn mening, p. 58, voldoet levensverkortende pijnbestrijding niet aran de delictsomschrijwing van de artt. 293 en 294 Sr. In dezelfoe zim: Van der Meer, in: Euthanasie, $1985, \mathrm{p}$ 74: levensverkortende pijnbestrijding is geen evthamasie, ondat het voomemen tot doden niet anwezig is.

$155 \mathrm{Vgl}$. Josephus Jitta $\mathrm{NJB}$ 1986, p. 46 .

$156 \mathrm{Vgl}$. o.a. Gezondheidsraad, 1975, p. 22 en Bijlage II, p. 4. Anders Van Veen, NJB 1984, p. 1069 en Einschedé, NJB 1985 , p. 801 .

$157 \mathrm{Vgl}$. Vaw Wijmen, in: Euthanasie, recht en praktijk, 1985, p. 13:

$158 \mathrm{Vgl}$. Klij, in: Euthanasie, 1985, p.39, volgens wie deze gedraging "in zekere zin bij witstek "euthanasie" genoemd zou mogen worden". Anders: Wessel-Tuinstral, TK, 1983-1984, 18331, nr, 3 (MvT), p. 11. 
zoals yoor elk medisch handelen, dat met toestemming van de patiënt is gehandeld ${ }^{\text {ts }}$ en het handelen aan de eisen van proportionaliteit en subsidiariteit voldoet. 160

Leenen stelt dat het "brengen van pijnbestrij ding als normaal medisch handelen onder voorwaardelijk opzet (...) de hele positie van het medisch handelen (zou) anatasten". De medicus verricht immers waker handelingen die een schadelijk neveneffect hebben. ${ }^{161}$ De vraag is echter, in hoeverre een schadelijk neveneffect dat in de sfeer van mishandeling ligt, gelijkgesteld mag worden met het (eerder) overlijden als neveneffect. Daarmee blijft de levensverkortende pijnbestrijding strafrechtelijk problematisch, voor zover deze niet langs wettelijke weg van de strafbaarheid wordt uitgezonderd. ${ }^{162}$

Daartegen wordt soms als bezwaar naar voren gebracht, dat deze schijngestalte niet goed te onderscheiden is van actieve euthanasie. Door levenswerkortende pijnbestrijding van de strafbaarheid uit te zonderen ${ }^{163}$ zou actieve euthanasie via deze weg aan strafrechtelijke toetsing kunnen worden ontitrokken. ${ }^{164}$

\section{4 "Passieve euthanasie"}

\subsubsection{Inleiding}

Van passieve euthanasie wordt gesproken, wanneer de arts van behandelen afziet en (mede) door zijn niets-doen de patiënt (eerder) overlijdt. Hierbinnen kan worden onderscheiden tussen het staken van een begonnen behandeling en het niet beginnen van een behandeling. Alhoewel het in de beleving waarschijnlijk moeilijker is een reeds begonnen behandeling

159 Anders: Commissie Onderzokk Medilsche Praktijk inzake Euthanasie, Rappont, 1991, p. 32-33. De Commissie is van mening dat het bewust levensbeëndigend handelen zonder uitdrukkelijk verzoek tot het normaal medisch handellen behoort. Zij geeft op p. 32 twee redenen op warron een verzoek niet vereist is. De patiên" kan zijn wil niet meer kenbaar maken. Bovendien is "de vragg naar thet uitdrukkelijk werzoek on levensbeeindiging bij intensivering van de pijn- of symptoombestrijding niet aan de orde". Op p. 33 merkt zij echter op, "dat de patiënt alt ijd kan besiluiten dat geen (of niet langer) middelen tot de pijm- of symptoombestrijding toegediend worden".

$160 \mathrm{Vgl}$. Statscommissie Euthanasie, Deel 1, 1985, p. 77-78 en Leenen, 1988, p. 301-302.

161 Leenen, 1988, p. 302. In: Enthanasie, 1977, p. 130, merkt hij op: "Art. 293 is niet van toepassing op indirecte euthanasie, ondat bet daarbij niet gaat on euthanasie, doch om pijnstilling", en op p. 113: "Primair doel en nevengevolg moeten niel worden verward, ook al liggen zij in Cen handeling besioten. Ook andere medische handelingen dan indirecte euthanasie kunnen nevengevolgen hebben, doch in die gevallen denkt men er ook niet over oni die handelingen naar bun gevolgen te definieren" .

162 Schalken, in: Euthemasie, 1985, p. 131, wijst erop dat bij levenswerkartende pijnbestrijding voorwarclelijk opzet aanwerig is. Matr het overlijden van de patiënt ten gevolge van de pijnbestrijding wordt door de arts als neveneffect ingecalculeerd. De ernst van het lijden en de medische prognose brengen zijns inziens mee, dat deze gedraging tot het gewone medisch handelen behoort.

163 Zie de negatieve begripsbepalingen in verschillende wetsvoorstetlen, die in hell volgende deel wan dit hoofdstuk worden besproken.

164 Zie: Nederlands Gesprek Centrum, 1975, p. 52; Josephus Jilta, NJB 1986, p. 46; Wessel-Tuinstra, TK 1983-1984, 18331, nur. 3 (MvT) p. 11 en TK 1984-1985, 18331, nr. 7 (MvA), p. 16; brief valn de voorzitter van de vergadering wan de procureurs-generalal, TK 1986-1987, 19359, nr. 8, p. 2. De artsen Rasker en Wan Hellenond, NJB 1984, p. 824: "Wie thans (na 1960, J.W.) snel opklimmende doses morfine geeft, uitskuitend voor langdurige pijnbestrijding, matkt als regel of exen kunstfout (want hij gebruikt een onnodige tiskante methode), of hij crmoufleert voor zichzelf en/of anderen dmt hij thet actieve doding bezig is en dat is hypocrisie". 
te staken dan een behandeling niet te beginnen ${ }^{165}$, is het onderscheid voor de strafrechtelijke aansprakelijkheid irrelevant, woor zover althans in beide situaties op de medicus een zorgplicht rust. ${ }^{165}$

Een tweede onderscheid betreft de redenen tot afzien van (verdere) behandeling. $D e$ reden kan gellegen zijn in een weigering, althans in het ontbreken van toestemming van de patient om (verder) behandeld te worden. De reden kan ook zijn, dat de arts van oordeell is dat een (verdere) behandeling zinloos is. Hieronder wordt eerst besproken het geval dat de patiënt geen toestemming tot behandelen verleent en daarna het geval dat de arts behandeling als medisch zinloos beschouwt.

\subsubsection{De patiënt verleent geen toestemming tot de behandeling}

Hierboven bleek dat de toestemming van de patiënt tot de behandeling in de hier behandelde periode altijd als een wezenlijke voorwaarde voor handelen van de medicus werd beschowwd, ook wanneer onder medici vermoedelijk de opvatting bestond dat met het aangaan van de behandelingsovereenkomst de patiënt toestemming geeft tot alle met de behandeling verband houdende verrichtingen. Deze opvatting had tot gevolg dat aan een weigering tot de behandeling groter gewicht werd toegekend dan aan het ontbreken van toestemming ${ }^{167}$ en dat voor de zogenaande passieve euthanasie werd geếist dat de patiënt de behandeling uitdrukkelijk had geweigerd, respectievelijk uitdrukkelijk de arts had verzocht van (verdere) behandeling af te zien.

In de laatste jaren heeft het toestemmingsvereiste meer aandacht gekregen ${ }^{168}$, zoals ook het wetsvoorstel Wet op de Geneeskundige Behandelingsovereenkomst (WGBO) aantoont. ${ }^{169}$ Zonder toestemming mag de arts niet handelen. Ontbreekt toestemming, dan kan het handelen tot strafbaarheid vanwege mishandeling leiden. ${ }^{170}$ Het vragen om medische hulp sluit niet in een toestemming tot elke behandeling, die de medicus in dat kader nodig oordeelt. Voor elke ingrijpende handeling, waartoe de medicus in

$165 \mathrm{Vgl}$. Marlet, in: Recent medisch ethisch denketn $1,1968, \mathrm{p} .173$ en Van der Meer, in: Menswardig sherven, 1974, p. 29; Van der Meer, in: Euthanasie; 1985, p. 81.

166 Vg. Minderheidsnota, in: Staatscommissie Euthanasie, Deel 1, 1985, p. 203-206, Van Wimen, in: Euthana* she, recht en praktijk, 1985, p. 15, Nieboer, 1991, p. 130: "De zorgplichten bijwen hier centrat stan". Zie over de zorgplichten, vooral in verband met oneigenlijke omissiedelicten: H. IV C, onder 4.4.8. Ook vanuil de ethiek word hierop gewezen. Khijn, int: Euthanasic, 1985 , p, 26 , tmerkt op: "Staken kan psychologisch als ingrijpender ervaten worden dan niet-beginmen, maar daarom is het nog geen actieve euthanasie of daaran analytisch gelijkwaardig. Het gat witeindelijk on een niet meer medisch intervenjêren en dus om nakaten, om welke reden dan ook".

167 Derksen, in: Op sterven tw dood, 1987, p. 41: de patient mag alijd wen bethandeling weigeren. Rang, in. Menswardig sterwen, 1974, p. 265: "als de arts niet kan behandelen ondat de patient weigert en $^{2}$ de dood daarvan het gewolg is, de arts daarvoor niet schuldig kan worder verklard".

168 Zie voor een terughoudende erkenning voordien, b.v. KNMG, 1959, p. $14-1.5$.

169 TK $1989-1990,21561$.

170 Zie b.w. Wan Agt, Katholiek Artsenblad, 1968, p. 378: de arts mag zonder toestemming van de patient de onafwendbar geworden dood niet vertragen. Gezondheidsraad, 1972, p. 22-23 en p. 25, Voorlopïg Standpunt Hoofdbestuur KNMG, MC 1973, p: 587 ex,; Werkgroep Exthanasie, MC 1975, p. 10. In uitzonderingssituaties mag toestemming verondersteld worden. Leenen, in: Euthanasie, 1977, p. 122. Zie ook: Commissie Onderzoek Medische Praktijk inzakke Euthanasie, Rappord, 1991, p* 14-15. 
het kader van een behandelingsovereenkomst wil overgaan, dient hij afzonderlijk toestemming te verkrijgen. ${ }^{171}$

Volgens de Staatscommissie kan de patiënt zowel mondeling als schriftelijk (verdere) behandeling weigeren en dient de medicus dit te eerbiedigen, "tenzij er duidelijke aanwijzingen" zijn dat de patiênt ten tijde van de wilsuiting zijn wil niet (goed) kon bepalen. ${ }^{\text {in }}$ In hun minderheidsnota zijn Klijn en Nieboer van mening dat een schriftelijke verklaring een arts nooit een absolute verplichting oplegt en slechts als één van de factoren bij de verdere besluitvorming beschouwd mag worden. ${ }^{173}$

De toestemming respectievelijk de weigering omvat slechts dat gedeelte van de behandeling waarop zij betrekking heeft. Geeft de patiënt tot een bepaalde behandeling geen toestemming, dan is de medicus niet gerechtigd ander handelen achterwege te laten, voor zover daardoor aan de patiẻnt (ernstige) schade zou kunnen worden toegebracht. ${ }^{174}$

De nadruk die op de toestemming van de patiënt tot handelen van de medicus is komen te liggen, is in overeenstemming met art. $11 \mathrm{GW}$ dat bepaalt:

"Ieder heeft, behoudens bij of krachtens de wet te stellen beperkingen, recht op onaantastbaarheid van zijn lichaam ${ }^{\text {"1 }}$. ${ }^{175}$

Deze norm bepaalt dat derden zich van inbreuken op de lichamelijke integriteit dienen te onthouden, tenzij het betreffende individu van de uitoefening van zijn recht afziet. Uit art. $11 \mathrm{GW}$ vloeit tevens voort, dat voor euthanasie altijd een overeenstemmende wilsuiting wan de patiënt is vereist en dat het nalaten van een behandeling, vanwege weigering van de patiënt om toestemming tot de behandeling te verlenen, de medicus van zijn verplichting tot handelen ontslaat en zelfs het recht daartoe ontmeemt. Ten aanzien van de gebruikelijke medische handelingen kan veronderstelde toestemming wel toereikend zijn: 176

Verleent de patiënt geen toestemming tot de behandeling, weigert hij deze of trekt hij de toestemming in, en geeft de arts daaraan gevolg, dan heeft dat met euthanasie

$171 \mathrm{Vgl}$ art. 1653d lid 1, TK 1989-1990, 21561 (WGBO), nr. 2: "Voor verrichtingen tar uitoefening wain aen behandelingsovereenkomst is telkens de toestenuming van de patiènt vereist" "In de MvT zijn de afzonderlijke toestemmingen beperkt tot imgrijpende verrichtingen.

172 Vgl. Leenen, 1988, p. 283 een verklaring van weigeren is rechtsgeldig en moel door de arts worden opgevolgd. Op p. 201 wijst hij op het werschil met een exthanasieverklaring. Aan deze laatste kan da

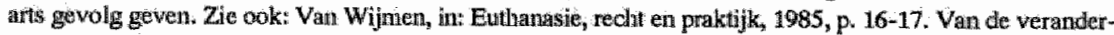
de zienswijze op de zogenande passieve enthanasie getuigen ook eerdere ufitlangingen wan Leenen. It: Euthanasie, 1977 , p. 106 , makte hüj een versehil tussen passieve euthanasie en het staken van een zirloze: midische handeling. Daar buj passieve euthanasie de bedoelling van de arts levenswerkorting van de patient. is en de woortzetting van de behandeling niet medisch zinloos behoeft te zijn, is ben werzolk van de patiènt nodig;

173 Minderheidsnota, in Statscommissie Euthanasie, Deel 1, 1985, p. 290-291. Iri vergelijkbare zin livet MwI Korthals Altes, TK 1983-1984, Handel ingen n. 487, zich vit. Wanneer een persoon in omstandigheden is komen te verkeren dall hij zijn will net kenbaar kan maken, dan kan een arts uitgaan wan de stilzwijgende instenming met het verlenen wan medische hulp, tenzij them wit feiten of omstandigheden het tegendeel is gebleken. Een euthanasieverklaring kan hierbij slechts een beperkte betekenis hebben. Een arts dive vanwege en evthanasieverklaring niet behandeli, makt zich surabar.

174 Ziie b.Y. Leenen, in: Euthanaste, 1977, p. 122; Gevers, TwGR 1985, p. 329 en Van Wijmen, in: Euthanasie, recht en praktijk, 1985, p. 14. Zije ook: TK 1989-1990, 21561 (WGBO), nr. 3 (MvT), p. 14.

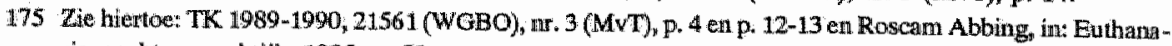
sile, recht en praktijk, 1985 , p. 50 .

176 Leenen, 1988 , p. 303 . 
nilets te maken. ${ }^{17}$ De arts beëindigt dan immers niet het leven van de patiênt, noch helpt hij daarbij. De weigering van de patiênt brengt juist mee, dat op de arts geen zorgplicht rust. Daarom is het overlijden van de patient tengevolge van zijn weigering tot behandeling een schijngestalte van euthanasie.

\subsubsection{Medisch zinloos handelen}

Onder passieve euthanasie werd ook begrepen het afzien wan medisch zinloos handelen. ${ }^{178}$ Leenen noemt als kenmerken voor medisch zinloos handelen:

"Bij medisch zinloos handelen is er geen medische indicatie, noch een concreet behandelingsdoel terwijl doorgaan met het handelen vaak niet in overeenstemming zal zijn met de regelen der kunst. Medisch zinloos handelen is in deze gedachtengang wederrechtelijk" ${ }^{* 179}$

Daar waar handelen medisch zinloos is, kan voor de arts ook geen juridische plicht tot handeten bestaan. Wanneer een behandeling als medisch zinloos wordt aangemerkt, ontbreekt de zorgplicht ten aanzien van die behandeling, want tot zinloos handelen kan niemand gehouden zijn. Ook bestaat geen causaal verband tussen het nalaten en thet overlijden. ${ }^{180}$ Daarom is ook het nalaten van medisch zinloos handelen een schijngestalte van euthanasie. ${ }^{181}$

Voor het nalaten van medisch zinloos handelen is de toestemming van de pat iènt niet nodig. Spreekt de patiënt zich voor doorbehandelen uit en geeft de medicus daaraan gevolg, dan zou zelfs sprake kunnen zijn van mïshandeling, daar toestemming op zichzelf aan mishandeling nog niet het wederrechtelijke karakter ontneemt. ${ }^{182}$

De Staatscommissie besteedt in dit verband kort aandacht aan twee bijzondere situaties. In de ene vraagt de patient, ondanks dat het handelen medisch zinloos is, om voortzetting van de behandeling. De andere betreft de vraag in hoeverre de medicus ondanks zijn oordeel dat het handelen zinloos is, tot verder handelen gerechtigd is

Ten aanzien van de tweede vraag merkt de Staatscommissie op, dat "in het algemeen ... patiënten niet mogen worden onderworpen aan zinloze medische behandeling". Wanneer desondanks tot handelen wordt overgegaan, dan zou het handelen het lijden of het stervensproces kunnen verlengen. Daarom is de medicus niet gerechtigd tot handelen.

Ondanks dat (verder) behandelen medisch zinloos is, krin het voor de patiënt een zin hebben. Bijvoorbeeld omdat hij afscheid will nemen van bepaalde mensen. Wanneer de

$177 \mathrm{Vgl}$. Roscam Abbüng, in: Euthrinasie, recht en praktijk, 1985, p. 51-\$2; Leenen, 1988, p. 303. Enschedé, 1985, p. 94: "indien mu de pattënt weet, dat zija besluit de (verdere) behandeling af te wijzen dood met zich brengen $\mathrm{kan}$ - en het medisch advies zal hem daarontrent niet in het ongewisse laten - dan is de dood het gevolg wan een besluit van de patiemt en niet wan de arts die hier rechtems geen vrijheid van handelen heeft". Anders - vanuit etlhisch perspectief - K Jijn, in: Euthanasie, 1985, p. 28, volgens wie niet in te zien is, warnom hel achterwe ge laten van cen behamdeling na weigering van de patient geen pessieve euthanasie zou kunnen zijn. De patiênt kan immers met de weigering zijn dood beogen.

178 Zie b.w. Michels, in: Menwwaardig sterven, 1974, p. 217-218.

179 Leenen, 1988, p. 289. Vgl. b.w. Van der Meer, in: Euthanasie, 1985, p. 82.

180 Vgl. Klin, in: Euthanasie, 1985, p. 24 .

181 Vgl. Langemeijer, MC 1960, p. 188-191; Von Agt; Katholiek Arisenblad 1968, p 378; Rang, in: Menswardig sterven, 1974 , p. 264 Leenem, in: Euthanasie, 1977 , p. 102-105; Van Veen onder HR 15 dec. 1987, NJ 1988, 811; Commissie Onderzoek Medische Praktik inzake Euthanasie, Rapport, 1991, p. 16, 29, 32-33; Schalken, in: Euthanasie, 1985, p. 121.

182 In diezelfde zin: Van Wijmen, in: Euthanssie, recht en praktijk, 1985, p. 14. 
pattent dan om (verdere) behandeling vraagt, bevindt de medicus zich in een conflictsituatie. Medisch gezien is (verdere) behandeling zinloos, maar voor de patient is deze nog zinvol. De Statscommissie is van mening dat de medicus dan gehouden is binnen een redelijke termijn de patiënt (verder) te behandelen. De grens ligt daar waar de toestand van de patient te zeer verslechtert.

Zoals reeds bij het niet (verder) behandelen op verzoek van de patiënt opgemerkt, brengt het oordeel dat (vercter) behandelen medisch zinloos is, niet mee dat ook de normalle verzorging van de patiënt mag worden gestaakt. "Tot het overlijden dienen aan de patiënt normale zorg en pijnstilling te worden gegeven". ${ }^{84}$ Dat ligt voor de hand, want de normale zorg en pijnstilling behoeft niet medisch zinloos te zijn, wanneer een bepaalde behandeling dat wel is:

De omstreden vraag wanneer handelen medisch zinloos is, raakt het wezen van deze schijngestalte evenmin als die wanneer bij euthanasie van een verzoek sprake is. Deze vraag betreft de kwestie of "medisch zinloos" uitsluitend een oordeell over de strikte medische zinloosheid mag en kan inhouden, of (mede) een waardering van de kwaliteit van het verdere leven van de patiênt. Deze problematiek komt in het derde gedeelte van dit hoofdstuk uitgebreider aan de orde.

\subsection{Een vierde schïjngestalte?}

In verscheidene voorstellen ${ }^{\mathrm{t} s}$, werd van euthanasie uitgezonderd:

"het niet behandelen van een bijkomende ziekte of aandoening bij een patiënt die naar heersend medisch inzicht onomkeerbaar het bewustzijn heeft verloren"'.

Ook al zou het niet behandelen van die ziekte of aandoening in het algemeen tot de dood van de patiënt leiden, is de Staatscommissie van mening dat deze gedraging wan de strafbaarheid dient te worden uitgezonderd, omdat "Het behandelen van de bijkomende ziekte of aandoening (...) ... in de gegeven omstandigheden - onomkeerbaar coma - tot een onnodig rekken van de situatie (leidt) ${ }^{n+}{ }^{186}$ In dat geval is de behandeling medisch gezien zinloos en daarom is de medicus gerechtigd stil te blijven zitten. ${ }^{187}$

In de voorstellen tot wetgeving is deze "schijngestalte", behalve in de Proeve ${ }^{188}$, terecht niet terug te vinden. Want er zijn te dien aanzien twee mogelijkheden. Of de behandeling is medisch zinloos en daarin voorziet reeds een andere schijngestalte, of zij is niet medisch zinloos. Is de behandeling niet medisch zinloos en heeft de patient de behandeling niet geweigerd, dan wordt verondersteld dat de (tijdelijk) wilsonbekwame

183. Staatscommissie Euthanasie, Deel 1, 1985, p. 75. Zie ook: Leenen, in: Euthanasie, 1977, p. 103-104, en Leonen, 4988, p." 290.

184 Stantscommissie Euthanasie, Deel 1,1985, p. 76 .

185 Staatscommissie Euthanasie, Deel 1, 1985, p. 43; Minderheidsnota, in: Staatscommissie Euthanasie, Deel I. 1985, p. 297; Proeve, TK 1985-1986, 19359, nr. 2.

136. Staaiscommissie Euthanasie, Deel 1,1985, p. 76.

187 Staa iscommissie Euthanasie, Deel 1, 1985, p. 77. Klijn en Nieboer, Munderheidsnota, in: Staatscommissie Euthanasie, Deel 1, 1985, p. 293, maken in de toelichting op deze schijngestalte een onderscheid tussen thet niet beginmen en het staken van een behandeling. $\mathrm{Zjj}$ kunnen zich vinden in de wettelijke vastlegging wan deze schijngestalte ten aanzien van het niet beginnen van de behandeling, omdat zij het nalaten dan

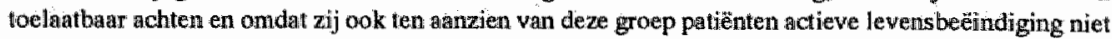
willen toestatan.

188 Proeve, TK 1985-1986, 19359, nr. 2. 
patient toestemming heeft verleend. De enige reden om van de behandeling af te zien, is dan blijkbaar gelegen in de comateuze toestand van de patiènt. In de oude terminologie houdt het afzien van handelen in dat geval onvrijwillige euthanasie in. In de recentere terminologie is het de vraag of het hier bedoelde nalaten onder "levensbeeindiging" valt. ${ }^{189}$ Dat wordt in het derde gedeelte van dit hoofdstuk besproken.

\section{Conclusie}

De wetsgeschiedenis van de artt. 293 en 294 Sr biedt geen aanknopingspunten woor het standpunt dat de medicus vanwege zijn beroep trandelingen die aan de delictsomschrijvingen van deze bepalingen beantwoorden, straffeloos mag verrichten.

Uit de schaarse mededelingen van medici over thanatische gedragingen gedurende de eerste helft wan deze eeuw ontstaat de indruk dat levensverkortende pijnbestrijding in de stervensfase en het afzien van medisch zinloos handelen als normaal medisch handelen werd beschouwd. Actieve euthanasie, ook op verzoek, werd door medici tot in de jaren zestig afgewezen.

Daarna ontstaan drie stromingen onder artsen. Een ervan houdt vast aan de beoordeling van thanasie conform uitlatingen van medici uit de eerdere perioden. Andere artsen spreken zich uit voor de toelaatbaarheid van levensbeëindiging op verzoek onder bepaalde voorwaarden. In die richting tenderen ook de standpunten van (het Hoofdbestuur van) de KNMG.

Van de jaren tachtig wordt gedifferentieerd tussen euthanasie, levensbeëindiging en schijngestalten. Het kenmerkende verschil tussen euthanasie en levensbeëindiging ligt daarin, dat voor euthanasie een daartoe strekkende wilsuiting nodig is en levensbeëindiging thanatische gedragingen bij wilsonbekwame patiënten betreft. Schijngestalten worden die handelingen genoemd die op euthanasie (en levensbeëindiging) lijken, maar niet daaronder vallen. Als schijngestalten zijn inmiddels op grote schaal erkend: het nallen van (verder) handelen op verzoek van de patiënt, het nalaten van medisch zinloos handelen en levensverkortende pijnbestrijding.

Voor de strafrechtelijke aansprakelijkheid zijn de eerste twee schijngestalten niet relevant. In beide gevallen rust op de medicus geen plicht om te behandelen. Vanwege de ontbrekende zorgplicht kan hij met betrekking tot deze gedragingen niet als normadressatat van de artt. 287 e.v. Sr worden aangemerkt. Dat ligt anders bij de derde schijngestalte, de levensverkortende pijnbestrijding. In strafrechtelijke zin vertoont deze gedraging overeenstemming met euthanasie voor zover zij met toestemming geschiedt; en met levensbeeindiging voor zover de toestemming ontbreekt.

De vraag, in hoeverre de medicus voor levensverkortende pijnbestrijding, euthanasie en levensbeeindiging strafrechtelijk aansprakelijk is, wordt in de twee volgende delen besproken. 


\section{B EUTHANASIE}

\section{Voorstellen tot wetgeving}

\subsection{Inleiding}

In dit gedeelte worden verschillende voorstellen tot wetgeving op het gebied van de euthanasie besproken. Daarbij zijn met name van belang de grondslag, de doelstelling en de structumur wan de voorgestelde regeling. Voor zover een voorstel in de loop van de tijd werd gewijzigd, ligt het accent op de laatste variant.

De bespreking van de voorstellen geschiedt chronologisch. Daamaast worden de voorgestelde regeling van het initiatiefvoorstel Wessel-Tuinstra, het advies van de Staatscommissie Euthanasic en de Proeve, onderling vergeleken.

Deze voorstellen hebben een overeenkomstige structuur. Zij voorzien in een wijziging en aanvulling van de artt. 293 en 294 Sr en in een bijzondere strafuitsluitingsgrond die ertoe leidt dat onder bepaalde omstandigheden handelen in strijd met de artt. 293 en 294 Sr niet strafbaar is. Daarbij moeten bepaalde zorgvuldigheidseisen en administratieve verplichtingen in acht worden genomen:

Aan het slot van de bespreking van de voorstellen wordt aandacht besteed aan het rapport van de Commissie Onderzoek Medische Praktijk inzake Euthanasie, dat in het najatr 1991 is verschenen en aan thet standpunt van thet kabinet inzake medische beslissingen rond het levenseinde, dat op 8 november 1991 aan de Tweede Kameris aangeboden.

\subsection{Voorgeschiedenis}

Naar aanleiding van een verzoek van het Tweede Kamerlid Tilanus (CHU) aan de Staatssecretaris van Sociale Zaken en Gezondheid een commissie in te stellen ter bestudering van het vraagstuk van medische macht en medische ethiek ${ }^{190}$, verzoekt de Staatssecretaris in 1970 de Gezondheidsraad om advies "inzake de moderne ontwikkelingen op het gebied van de medische ethiek". ${ }^{191}$ Als gevolg hiervan verschijnt in 1972 het eerste interimadvies van de Commissie Medische Ethiek van de Gezondheidsraad, het "Advies inzake Euthamasie" ${ }^{192}$ Dat advies wordt in 1975 opgevolgd door een interimadvies over "euthanasile bij pasgeborenen"."103

In de motie-Dees uit $1978^{194}$ wordt de regering uitgenodigd "te bevorderen dat een in te stellen staatscommissie advies zal worden gevraagd over toekomstig overheidsbeleid inzake euthanasie". Als redenen worden genoend dat de maatschappelijke discussie over euthanasie "nog volop in beweging" is en een "nadere bezinning over de rol van de overheid wenselijk is".

190 HTK, $1969-1970_{3} 3$ febt. 1970, p. 9954.

19:1 Gezondheidsraad, 1972 , p. $3-4$.

192 Gezondheidsrand, 1972.

193 Gezondheidsraad, 1975 .

194 TK, $1978-1979,15300$ Hfdlst. XVII, nr. 26. Naast Dees (VVD), was een van de indieners mw. Wescel-Tuinstita $\left(D^{*} 66\right)$. 
In 1978 verzoekt de Staatssecretaris de Gezondheidsraad in dat verband om nader adviles. ${ }^{195}$ Aanleiding daartoe was de motie-Dees en de Recommendation nr. 779 van de Raad van Europa inzake de rechten van zieken en stervenden. ${ }^{19}$ Centraal in het verzoek staat de behoefte aan materiaal voor een in te stellen staatscommissie. Daarnaast wondt onder andere voorgesteld het begrippenkader opnieuw te bezien.

Op 25 maart 1982 wondt het advies van de Gezondheidsraad aan de regering aangeboden ${ }^{197}$ en op 19 oktober 1982 wordt de Staatscommissie Euthanasie geïnstalleerd.

\subsection{Het initiatiefivoorstel}

In 1984, het jaar waarin de standpuntbepaling van het Hoofdbestuur van de KNMG over euthanasie verschijnt, dient het D'66. Tweede Kamerlid Wessel-Tuinstra een wetsvoorste】 inzake euthanasie in ${ }^{108}$, dat vanaf juni 1986 door haar partijgenoot Kohnstamm wordt verdedigd. ${ }^{199}$ Het initiatiefvoorstel beperkt zich tot levensbeëindigende gedragingen op verzoek. Voor wetgevend werk ten aanzien van irreversibel comateuze patienten acht de indienster de tijd nog niet rijp. ${ }^{200}$ Het voorstel van de Staatscommissie te dien aanzien noemit zij "niet goed doordacht"201, doch zij sluit een regeling daaromtrent voor de toekomst niet uit. ${ }^{202}$

Het voorstel houdt in de artt. 293 en $294 \mathrm{Sr}$ met een bijzondere rechtvaardigingsgrond uit te breiden en met enkele bepalingen waarin zorgvuldigheidseisen en administratieve verplichtingen zijn opgenomen. In de MvT wordt gewezen op de toegenomen mondigheid van de burger en de voortgeschreden medische technologie, die meebrengen dat verzoeken om levensbeëindiging worden gedaan. ${ }^{203}$ Omtrent euthanasile bestaat echter, aldus de indienster, grote rechtsonzekerheid en rechtsongelijkheid voor de hulpverleners en de hulpzoekenden. De rechtsonzekerheid wordt door de jurisprudentie niet weggenomen. Bovendien kan een jurisprudentiêle weg tot grote verschillen in mogelijkheden voor de hulpverlening leiden. Tegen een oplossing via het vervolgingsbeleid bestaan dezelfde bezwaren. ${ }^{204}$ Vanwege de rechtsonzekerheid kon met het indienen van het wetsvoorstel niet gewacht worden op het rapport van de Staatscommissie. ${ }^{205}$

De taak van de overheid ten aanzien van euthanasie wordt in de MvT als volgt omschreven:

195 Brief van 9 okt. 1979.

196 Recomnendation $779(1976)$ on the tights of sick of dying Parliamentary assembly of the Council of Europe, twenty-seventh session. De tekst wan deze anbeweling is opgenomen in: Statscommissie Euthanasile, Deell 1 , 1985, p. $131-133$.

197 Gezondheidsraad, 1982.

$198 \mathrm{TK}, 1983-1984,18331$.

199 Vanwege het vertrek van nw. Wessel-Tunnstra uit de Twete Kamer. "TK, 1985-1986, 18331, ni. 42.

200 TK, 1983-1984, 18331, nu. 3 (MvT), p. 4 en TK, 1984-1986, 18331, nr 7 (MvA), p. 12 .

201 TK, 1985-1986, 18331, ar, 9 (Nota n.a.v. hell eindverslag), p. 34 en p. 53.

202 TK, 1984-1985, 18331 B (Opmerkingen n.a.v. het advies van de RvS), p. 3 en TK, 1985-1986, 18331, ni. 9 (Notm n.a.v. het eindwers lag), p. 18 .

203 TK, 1983-1984, 18331, nr, 3 (MWT), P. 5. N,a.v. een amendenent van Haas-Berger (PvdA), TK, 1985-1986, 18331, nr. 29, wordt deze beweegreden ook in de considerans van het nader C.V, (TK, 1985-1986, 18331 , nir, 38, p. 1) opgenomen.

204 TK, 1983-1984, 18331, nr. 3 (MvT), p. 2.

205 TK, 1983-1984, $18331, \mathrm{nr}, 3$ (MvT), p. 4. 
"Zij dient, uitgaande van de algemeen geaccepteerde norm van de beschermwardigheid van het leven, ruimte te scheppen voor ieders individuele beslissing de grenzen wan die bescherming voor zijn eigen leven te bepalen, met inachtneming van haar specifieke verantwoordelijkheid ten aanzien van de versterking in de rechtspositie van de zwakken in de samenleving en de kwaliteit van de hulpverlening ${ }^{\mathrm{ft}}$. In een pluriforme samenleving moet derhalve ruimte zijn voor verschillende opvatingen over euthanasie. 2 .

De uiltgangspunten van het wetsvoorstel zijn: de beschermwaardigheid van het leven, de humanisering wan het sterven, de erkenning wan het zelfbeschikkingsrecht onder bepaalde omstandigheden, een zorgvuldige hulpverlening en de controleerbaarheid van levensbeeindigend handelen. ${ }^{208}$

\subsection{Het eindrapport van de Staatscommissie Euthanasie}

In augustus 1985 biedt de Staatscommissie Euthanasie haar eindrapport aan de regering aan. ${ }^{209}$ De commissie had tot taak "advies uit te brengen omtrent het toekomstige overheidsbeleid inzake euthanasie en het verlenen van hulp bij zelfdoding, in het bijzonder ten aanzien van wetgeving en wetstoepassing"' ${ }^{210}$ De uit 15 leden bestaande Staatscommissie is multidisciplinair samengesteld. Haar voorzitter is de jurist Jeukens.

Het rapport bestaat uit een meerderheids- en een minderheidsstandpunt. De minderheidsnota is afkomstig van de ethicus Klijn en de jurist-psychiater Nieboer. De structuur van het voorstel van de meerderheid, verder het advies genaamd, lijkt op die van het initiatiefvoorstel, maar het is ruimer van opzet. Voorzien is in een zogenaamde negatieve bepaling, waarin gedragingen zijn omschreven die niet als levensbeëindïging worden beschouwd, maar die tot het normale medisch handelen behoren. Ook wordt actieve levensbeëindiging van irreversibel comateuze patiënten onder bepaalde omstandigheden gerechtvaardigd geacht. ${ }^{211}$

Het advies heeft op een aantal punten navolging gevonden in het gewijzigde wetsvoorstel Wessel-Tuinstra en in de Proeve. Daarentegen zijn in de minderheidsnota argumenten van tegenstanders van een wettelijke regeling van euthanasie te vinden. In het bijzonder is deze nota daarnaast van belang in verband met het na de Proeve verschenen "kabinetsvoorstel".

Het advies is op de praktijk gericht. Zonder dat het advies veel aandacht besteedt aan de grondslagen, bespreekt het de daarin voorgestelde regeling zelf op zijn technische merites. Daarentegen richi zich de minderheidsnota in het bijzonder op mogelijke grondslagen en uitgangspunten ten aanzien van levensbeëindiging op verzoek.

In het advies gat de aandacht vooral uit naar waarborgen, die ten doel hebben de wilsvrijheid van de patiënt te garanderen en de voor de gerechtvaardigde levensbeëindiging vereiste noodsituatie te kunnen afbakenen en bepalen. Daartoe zijn een aantal zorgvul-

$206 \mathrm{TKK}, 1983-1984,18331, \mathrm{nr} .3$ (MwT), p. 13.

207 Wessel-"Tuinstra, TK, 1983-1984, 18331, nr. 3 (MvT), p. 3.

$208 \mathrm{TK}, 1983-1984,16331$, nr. 3 (MvT), p. 11.

209 Statscommissie Euthanasie, Deel 1-3, 1985.

210 Art. 1. instellingsbesluit wan 18 okt. 1982.

211 Zie hiertoe nader: $\mathrm{H}$. IV $\mathrm{C}_{3}$ onder 3. 
digheidseisen geformuleerd, waarvan verwacht wordt dat deze "de rechtszekerheid en rechtsgelijkheid ten goede komen" en "een duidelijk richtsnoer" voor de rechter zijn. ${ }^{22}$

Het advies steunt op het zelfbeschikkingsrecht van de mens ten aanzien van zijn leven en dood. Weliswar wordt erkend dat dat recht de mens niet altijd de vrijheid geeft te beschikken over het tijdstip van zijn dood, maar wel als hij in een bepalde situatie, door de Staatscommissie aangeduid als "witzichtloze noodsituatie", verkeert.

Het recht van de mens het tijdstip van zijn dood te mogen bepalen en daartoe de hulp van derden in te roepen wordt in de minderheidsnota juist bestreden, met de argumenten dat een dergelijk recht nooit aan de mens toekomt, dat de "waardigheid van de mens" daardoor in hell gedrang zou komen en dat een wetswijziging in de zin van het advies een "historische vergissing" zou zijn."

In de minderheidsnota wordt onverkort aan de strafbaarstelling van levensbeëindiging op verzoek vastgehouden. De redactie van art. 293 minderheidsnota is gelijk aan die van art. 293. lid 1 advies, maar de maximumstraf wordt niet - zoals in het advies voorgesteld - van twaalf jaren tot vier jaren en zes maanden, doch tot zes jaren teruggebracht. Hiermee wordt tot uitdrukking gebracht, dat de minderheid levensbeëindiging op verzoek als een ernstiger delict beschouwt dan de Staatscommissie. ${ }^{214}$ Tevens wordt strafbaar gesteld het opzettelijk onjuist of onvolledig doen van opgaven ter zake van overlijden. Evenals in het advies wordt in de minderheidsnota een negatieve bepaling voorgesteld, die op één negatieve omschrijving na ${ }_{y}$ identiek is aan die van het advies. ${ }^{21,5}$

Klijn en Nieboer zijn van mening dat de Nederlandse wetgever niet tot enige vorm van rechtvaardiging van (hulp bij) actieve directe levensbeêindiging mag overgaan. ${ }^{216}$ Een wetswijziging zoals in het advies voorgesteld zou een gevaarlijke grensoverschrijding betekenen ${ }^{217}$ en neerkomen op een "voortgaande devaluatie van innerlijke waarde van het leven". ${ }^{218}$

"De 'innerlijke waardigheid van de mens' is een werkelijkheid die er is zolang een mens leeft en die door geen enkele toestand van het leven teniet kan worden gedaan" ${ }^{\text {"1 }} 219$

In de minderheidsnota wordt opgemerkt dat euthanasie vooral een ethisch vraagstuk is . ${ }^{220}$ Daarom liggen de bezwaren tegen de toelaatbaarheid van euthanasie met name op ethisch gebied.

De patiënt die om levensbeëindiging verzoekt, heeft daarmee ook te kennen gegeven dat hij het hem resterende leven zinloos acht. Klijn en Nieboer zijn wan mening dat de arts altijd mede over de zinloosheid oordeelt, door al dan niet aan het verzoek te voldoen. Daar komt bij dat in het advies van de Staatscommissie de arts geacht wordt zich zelfstandig een oordeel over de noodsituatie van de patiënt te vormen. ${ }^{221}$

212 Staatscommissie Euthanasie, Deel 1, 1985, p. 64.

213 Minderheidsnota, im: Staatscommissic Euthanasie, Deel 1, 1985, p. 195-200.

214 Minderheidsnota, in: Staatscommissie Euthanasie, Deel 1, 1985, p. 282-283.

215 Zie hiertoe mader: $H_{n}$ IV $A_{3}$ onder 1.7.16.

216 Minderheidsnota, in: Staatscommissie Euthanasie, Deel 1, 1985, p. 195.

217 Minderheidlsnata, in: Staatscommissie Euthanasie, Deell 1,1985, p. 197.

218 Minderheidsmata, in: Stantscommissie Euthanasic, Deel 1, 1985; p. 195.

219 Minderheidsnota, in: Stratscommissie Euthamasie, Doel 1, 1985, p. 196.

220 Minderheidsnota, in: Staatscommissie Euthanasie, Deel 1, 1985, $p, 196$.

221 Minderheidsnota in: Stalatscommissie Euthanasie, Deel 1, 1985, p. 249. 
Marr zelfs wamneer de arts niet daartoe genoodzaakt zou zijn en derhalve slechts de patiënt zijn leven zinloos zou achiten, dan nog spreken Klijn en Nieboer zich tegen wettelijke straffeloosheid van euthanasie uit.

"Voor ons bestaat de inverliesbare waarde van het leven in de 'dignity' van de menselijke persoon en daarom kan naar ons oordeel levensbeëindiging op grond van de wil en/of de toestand van de betrokkene zelf nooit subjectief gerechtvaardigd zifjn ${ }^{\text {*n }} 222$

Daarmee wijzen Klijn en Nieboer derhalve ook het zelfbeschikkingsrecht van de mens ten aanzien van het tijdstip van zijn dood af.

De " $(. .$.$) waardigheld van de mens (maakt) het ontoelaatbaar dat derden een oordleel$ van de betrokkene over de zinloosheid van het resterende leven op grond van zijm eigen vrijheid aanvaarden". 203

Euthanasie ontkent "de waardigheid van de menselijke persoon". Het ethisch beginsel de wardigheld van de mens te eerbiedigen heeft, volgens hen, ook zijn weg gevonden in internationale verdragen, zodat een wettelijke rechtvaardigingsgrond voor euthanasie zowel in strijd zou zijn met de ethiek als met de betreffende verdragen. ${ }^{24}$

Elders heeft Klijn opgemerkt: "de ontplooiing van de mens hangt af van de uitoefening van de mensenrechten en deze gaan weer terug op zijn waardigheid". Voor hem gaat de waardigheid vooraf aan een vrije en volle ontplooiling. ${ }^{225}$

Voor Scheltens is het de vrijheid van de mens die aan diens waardigheid voorafgaat.

"Vrijheid is echter niet zonder meer met keuzevrijheid te vereenzelvigen en kan ook niet aan de menselijke waardigheid worden tegengesteld. Men zou eerder moeten erkennen dat de echte vrijheld van de mens zijn waardigheid uitmaakt en de wortel is wan alle rechten en plichten. Moet het criterium van de verplichting niet worden gevonden in wat Kant noemt de autonomie van de vrijheid, in de vrijheid zelfs als redelijk vermogen (in tegenstelling tot de willekeur) eerder dan in de het onderwerpen van de vrijheid aan de erkenning an de menselijke waardigheid? Is het niet in de reclelijkheid en de universaliteit van de vrije wil dat de ethische normen worden ontdekt? Het gaat dan om een vrijheid die alle consequenties van haar beslissing in de behandeling betrekt en dus uiteraard ook rekening houdt met verder verwijderde sociale repercussies. Het standpunt door Klijn verdedigd, wordt daarmee niet afgewezen of ondermijnd. De nadruk valt echter meer op de vraag of wij ons met een principiële goedkeuring van de euthanasie niet op een hellend vlak begeven waardoon wij onvermijdelijk dreigen te vergelijden naar toestanden die onmenselijk zijn en daarom niet voor een universele toestemming - en dus evenmin voor een ethisch verantwoorde instemming - vatbaar zijn". ${ }^{236}$

Wetswijziging in de zin van het voorstel van de Staatscommissie is volgens Klijn en Nieboer zowel in strijd met medische codes ${ }^{227}$, als met het internationale recht, waaron-

222 Minderheidsnota, in: Staatscommisste Euthanasie, Deel 1,1985, p. 261. Zie ook: p. 250.

223. Minderheidsnota, in: Statscommissie Euthanasie, Deel 1, 1985, p. 251.

224 Minderlleidsnota, in: Stabtscommisste Euthanasic, Deel 1, 1985, p. 243-249. Genoemd worden onder meer de Universele Verklaring voor de Rechten van de Mens, de preambule van het VN-Verdrag Ill over de burgerlijke en poltieke rechten, 1966 , en de preambule van het WN-Verdrag III over de economische; sociale en culturele rechten, 1966 .

225 Klijn, in: Euthanasie, 1985, p. 47.

226 Schelleins, RR 1986, p. 179-180. Ook volgens Leenen, TVGR 1985, p. 308, kount de menselijke waardigheid juist tot uiting in zajn vrigheid.

227 Minderheidsnotia, in: Staatscommissie Euthanasie, Deel 1, 1985, p. 235-240. 
der het recht van de Europese Gemeenschap" 228 "Geen enkell land ter wereld" kent een zodanige wettelijke rechtvaardigingsgrond ${ }^{229}$, en op een uitzondering na, is de jurispnudentiele ontwikkeling in geen ander land in die mate toegevend als de Nederlandse. ${ }^{230}$ Inwoering van een rechtwaardigingsgrond voor euthanasie zou derthalve betekenen dat Nederland in een international isolement terecht zou komen.

In hoeverre de menselijke waardigheid door euthanasie wordt ontkend, hangt naar mijn mening af van de invulling die aan dit normatieve begrip ${ }^{231}$ wordt gegeven. Het recht waarin en waardoor de waardigheid van de mens juridisch wordt bepaald, is bedoeld voor intersubjectieve situaties. De vastlegging van een dergelijk beginsel houdt mijns inziens een gebods- respectievelijk een verbodsnorm voor derden in, maar is geen juridische norm voor de betrokkene zelf. ${ }^{232}$

Bovendien biedt het advies volgens Klijn en Nieboer te weinig duidelijkheid en rechtsbescherming. Dat wordt volgens hen veroorzaakt door gebruik van de open term "uitzichtloze noodsituatie" ${ }^{133}$, die zij als "enige materiële voorwaarde voor de straffeloosheid" beschouwen, terwijl de verder in het advies omschreven eisen omtrent de voorlichting aan de patiënt en de consultatie in hun ogen alleen procedureel van aard zijn: ${ }^{234}$

\subsection{De Proeve}

De regering kondigt in december 1985 een proeve van een wetsvoorstel aan ${ }^{235}$, die op 20 januari 1986 bij de Tweede Kamer wordt ingediend. De Proeve behelst tevens het standpunt van het kabinet ten aanzien van het rapport van de Staatscommissie. ${ }^{236}$

Het wetsvoorstel bestaat uit vijf artikelen. Hoewel het stoelt op het voorstel van de Staatscommissie Euthanasie, zijn er enkele belangrijke verschillen. Als strafuitsluitingsgrond voor euthanasie wordt een bijzondere schulduitshitingsgrond voorgesteld. De strafbepaling ten aanzien van levensbeëindiging uit "medelijden" is niet overgenomen, omdat het omstandigheden betreft; waarmee de rechter bij de strafoplegging rekening kan houden. Evenmin is voorzien in een strafuitsluitingsgrond ten aanzien van de levensbeëindiging van irreversibel comateuze patiënten. Het kabinet acht het verzoek zo wezenlijk dat daarvan ook niet bij comateuze patiënten kan worden afgeweken. Bovendien werpt het de vraag op, of een dergelijke rechtvaardigingsgrond niet in strijd zou zijin met art. 2 EVRM. ${ }^{237}$

Ook wordt afgezien wan het in deze regeling strafbaar stellen van het niet voldoen aan de verplichtingen tot het doen van opgaven terzake van het overlijden (art. 293 ter Staatscommissie). Het kabinet is van mening dat deze materie beter in de Wet op de

228 Minderheidsnota, in: Staatseommissie Euthanesie, Deel 1, 1985, p.207-209, p.233-234, p.264-281.

229. Minderheidsnota, in: Staatscommissic Euthanasie , Deel 1,1985, p. 197 en p. 209-233.

230 Minderheidsnota, in: Statscommissie Euthanasie, Deel 1, 1985, p. 197, Klijn en Nieboer verwijzen daurbij naar "én enkel omstreden Japans arrest in 1963".

231 Vgl. Minderheidsnota, in: Stantscomnissie Euthanasie, Deel 1, 1985, p. 247" "heeft als beginsel eien düdelijk normatief karakter".

232 Wgl. Wessel-Tuinstra, TK, 1984-1985, $18331 \mathrm{~B}, \mathrm{p} .1-2$ : art. 2 EWRM heeff werticale en horizontale werking.

233 Minderheidsnota, in: Statitsommissie Euthanasie, Deel 1,1985 , p. 284-285.

234 Minderheidsnota, in: Staatscommissie Euthanasie, Deel $1,1985, p_{i} 287$.

235 TK, 1985-1986, 19359, nr. 1.

236 TK, 1985-1986, 19359, nr. 2 (Brien), p. 2 .

237 TK, 1985-1986, 19359, nr, 2 (MvT), p. 13. Zie hiertoe nader: H. TV C, onder 1.6. 
lijkbezorging kan worden geregeld ${ }^{238}$ en wordt in deze opvatting gesteund door de $\mathrm{RWS}^{239}$

In de MvT wordt erop gewezen, dat door de voortschrijdende ontwikkeling van de medische technologie het vraagstuk van de euthanasie nieuwe dimensies heeft gekregen. ${ }^{240}$

De regering voert zowel argumenten voor als tegen nadere wetgeving op het gebied wan de euthanasie aan. $\mathrm{Zij}$ constateert dat er bij alle betrokkenen behoefte aan rechtszeker heid bestaat. ${ }^{24 l}$ Daartoe zijn algemeen geldende duidelijk omschreven criteria nodig. waarin de rechtspraak niet kan voorzien. Bovendien mist zij de duurzaamheid, het gezag. en de volledigheid van een wettelijke regeling. ${ }^{2.2}$ Daar komt bij dat enkele gevallen, die ook aan de rechter zijn voorgelegd, onrust hebben gewekt. ${ }^{243}$

Tegen wetgeving op dit terrein wordt aangevoerd, dat de rechtspraak niet voldoende is uitgekristalliseerd. Tot nu toe heeft de Hoge Raad zich slechts eenmaal over dit onderwerpuitgelaten. ${ }^{244}$ Daar het scheppen van ruimte in de wet tot een toekomstige grensverlegging kan leilden, is grote terughoudendheid geboden ${ }^{245}$ Verder is het de vraag of alle aspecten (levensbeschouwelijke, ethische en juridische) wel voldoende zijn afgewogen, want na het rapport van de Staatscommissie is de juridische discussie "in alle hevigheid" ontbrand. ${ }^{246}$ Het kabinet is van mening dat de nadelen, die aan wetgeving verbonden zijn, uiteindelijk zwaarder lijken te wegen dan de voordelen, maar stelt voor deze afweging uitelindelijk tezamen met de volksvertegenwoordiging te maken. Mocht wetgeving op dit terrein gewenst zijn, dan zou dat aan de hand van de "Proeve van een voorstel van wet met toelichting" kunnen geschieden. ${ }^{247}$

In de Tweede Kamer lijkt zich een meerderheid voor het initiatiefvoorstel af te tekenen. Nadat echter de regering heeft gedreigd het contraseign te weigeren, wanneer dat wetsvoorstel zou worden aangenomen ${ }^{248}$, komt het op 12 maart 1986 in de Tweede Kamer wel tot een behandeling van het voorstel, maar niet tot stemming. Besloten wordt om eerst advies bij de RvS over de Proeve en - voor de tweede keer - het initiatiefvoorstel in te winnen. ${ }^{249}$

238 TK, 1985-1986, 19359, nr. 2 (MVT), p. 16.

239 TK, 1985-1986, 18331, nar. 43, C en D (RvS), p. 8. 240 TK, $1985-1986,19359$, nr. 2 (MWT) op de Proeve, p. 14, In die zin ook de RvS, TK, 1985-1986, 18331,
nr. 43, C en D, p. 3.

241 TK, 1985-1986, 19359, ni. 2 (Brien, p. 1 en mr. 2 (MVT), p. 6r.7.

242 TK, 1985-1986, 19359, ne. 2 (MvT), p. 6.

243 Vermoedelijk wordt hiermee vooral gedoeld op de Terp-zakk (Hof Den Haag, 12 nov. 1986, NJ 1987, 609 m.nt. GEM, TVGR 1987/11), Zie hiertoe: H. IV C onder 3.

244 HIR 27 now, 1984, NJ 1985, 106 m.nit. ThWvV.

245 TK, 1985-1986, 19359, nr. 2, p. 1.

246 TK, 1985-1986, 19359, nr. 2, p. 2. Zie hiettoe: H. IV A, onder 2.9.

247 TK, 1985-1986, 19359, nr. 2 (Brie), p. 2.

248 Zhe: HTK, 1985-1986, 12 maart 1986, p. 4018 e.w.

249 HTK, 1985- 1986 , 12 maart 1986, p. 4049 . 
In art 2 EVRM wordt aan de nationale wetgever de taak opgedragen langs wettelijke weg het menselijk leven te beschermen. "Everyone's right of life shall be protected by

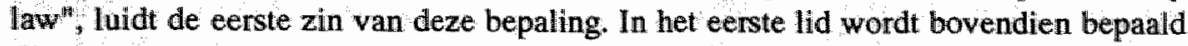
dat opzettelijke levensbeëindiging niet is toegestaan, tenzij deze geschiedt ter tenuitvoerlegging van de doodstraf. In het tweede lid worden drie gedragingen genoemd, die geen conflict met het in lid 2 opgenomen verbod opleveren.

Volgens art. 3 EVRM mag niemand onderworpen worden aan folteringen, onmenselijke of vernederende behandelingen of bestraffingen. Voor het medisch handelen is vooral van belang het in deze bepaling neergelegde verbod op onmenselijke en vernederende behandelingen. De woorden "onmenselijk" en "vernederend" zijn normatief van aard. Het onmenselijke of vernederende van een behandeling wordt bepaald door gedachten die hieromtrent in een samenleving op een bepaald moment leven en door de omstandigheden van het geval. ${ }^{250}$

Een adequate medische behandeling valt niet onder art. 3 EVRM.Ook wanneer de patient geen toestemming tot de behandeling heeft gegeven, brengt dit niet zonder meer mee dat reeds daardoor een medische behandeling het karakter van een onmenselijke of vernederende handeling in de zin van art. 3 EVRM krijgt. Tot de omstandigheden van het geval behoort ook het al dan niet verlenen van toestemming. Een behandeling die zonder toestemming van de patiënt wordt verricht kan daardoor wel eerder een onmenselijk of vernederend karakter krijgen, dan een behandeling met toestemming. ${ }^{251}$

Voor de interpretatie van art. 2 EVRM in verband met een wettelijke regeling van euthanasie is van belang of het recht op leven onvervreemdbaar is en welke verhouding tussen de arth 2 en 3 EVRM bestaat. Tot nu toe ontbreken hierover uitspraken van het Europees Hof en van de Europese Commissie.

Algemeen wordt erkend dat art. 2 EVRM een wettelijke regeling van euthanasie niet uitsluit. De verschillen in opvatting betreffen de wijze waarop en de voorwaarden waaronder euthanasie straffeloos mag worden gesteld.

In het advies van de Staatscommissie en in het initiatiefvoorstel wordt verdedigd, dat euthanasie onder bepaalde voorwaanden gerechtvaardigd kan zijn. De Staatscommissie merkt daarbij op, dat het in strijd met art. 2 EVRM zou zijn als met behulp wan een inhoudelijk nieuwe rechtvaardigingsgrond de straffeloosheid bereikt zou worden. Zij beschouwt de door haar voorgestelde bijzondere rechtvaardigingsgrond als verbijzondering van de rechtvaardigende noodtoestand voor euthanasie, zoals deze door de Hoge Raad 27 nov. 1984, NJ 1985, 106 m.nt. ThWvV, op euthanasie van toepassing werd geacht. Naar de menïng van de Staatscommissie is art. 2 EVRM niet van invloed op bestaande strafbaarstellingen en strafuitsluitingsgronden.

Een wettelijke regeling mag echter niet zo ver gaan dat levensbeëindiging op verzoek zonder meer toelaatbaar zou zijn, daar als doel van de regeling de bescherming van het leven voorop moet staan. $^{252}$

250 Vgl. Van Dijk en Van Hoof, 1990, p. 256 en Kastelein, MC 1990, p. 50.

251 Vgl. Van Dijk en Van Hoof, 1990, p. 255.

252 Staatscommissie Euthanasie, Deel 1, 1985, p. 36-39. 
Met uitzondering van de minderheldsnota, wordt in de toelichting op de overige voorstellen eenzelfde redenering gevolgd. ${ }^{253}$

Naar de mening van de indienster van het initiatiefroorstel betreft de toelaatbaarheid van een wettelijke regeling van euthanasie de afweging tussen de in art. 2 en art. 3 EVRM beschermde belangen. In die gedachte geldt het door art. 2. EVRM beschermde belang (het recht op leven) niet absoluut en kan het door het in art. 3 EVRM beschermde belang (bescherming van de persoonlijke integriteit) beperkt worden. De belangenafweging is een tak van de nationale wetgever, die daarbij binnen de randwoonwaarden van het EVRM moet blijven. Het hoofddoel van de regeling moet de bescherming van het menselijk leven zijn. De uitkomst van de afweging tussen de belangen van de artt. 2 en 3 EVRM kan meebrengen, dat straffeloosheid van euthanasie via een rechtvaardigingsgrond wordt bereikt. ${ }^{254}$

In hoeverre de nationale wetgever een terechte afweging heeft gemaakt, is ter toetsing aan het Europees Hof. Daar de afweging moreel van aard is, kan het Hof slechts toetsen of er sprake is van willekeur. De uitzonderingen in art. 2 EVRM zijn weliswaar limitatief bedoeld, maar betreffen slechts handelen door toedoen van de overheid, terwijl euthanasie de verhouding tussen burgers onderling aangaat. ${ }^{255}$

In de minderheidsnota wordt voorgesteld straffeloosheid voor euthanasie met behulp van een schulduitsluitingsgrond te bereiken; daardoor wordt het feit immers niet gerechtvaardigd. Het kabinetsvoorstel voorziet in een bijzondere schulduitsluitingsgrond inzake euthanasie. Volgens de MvA op dat voorstel geldt art. 2 EVRM niet onbeperkt en sluit de bepaling een wettellijke regeling van euthanasie niet uit, voor zover deze een beperkte strekking heeft. ${ }^{256}$

Klijn en Nieboer zijn van mening dat de inhoud van art. 2 EVRM normatief van aard is en dat daarmee grenzen worden gesteld aan de invoering van strafuitsluitingsgronden. ${ }^{257}$ Volgens hen zou het in strijd zijn met art. 2 EVRM als de wetgever actieve directe levensbeëindiging vanwege het verzoek en/of vanwege de situatie van

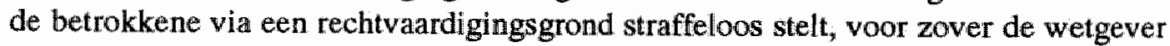
dan niet regelt dat in dezelfde gevallen langs andere weg deze levensbeëindiging wordt tegengegaan. ${ }^{258}$

Volgens De Blois, wiens standpunt bij dat van Klijn en Nieboer aansluit, mag tussen de belangen die door de art: 2 en 3 EVRM worden beschermd geen afweging worden

$253 \mathrm{Vgl}$.TK, 1983-1984, 18331, A (RvS), p. 1-2, TK, 1985-1986, 18331 (Wessel-Tuinstra), ni. 9 (Nota n.2." het eindverslag), p. 38 e:W: TK, $1985-1986,18331$, 1u, 43 , C en D (RvS), p. 4: een euthanasie-regeling dient - zeker op dit monent - beper kt te blijven tot leverusbeçindiging op vierzoek. TK, 1985-1986, 18331, nr. 43, C en D, Bijlage (MvT op gexijzigde Proeve), p. 12: een wettelijke regeling ontrent euthanasie moet zorgwildig worden afgewogen tegen art. 2 EVRM, mar het EVRM sluit zeker niet bij voorbat cen wettelijke regeling uit. TK, 1987-1988, 20383 (kabinetsvoorstel), ar. 3 (MvT), p. 10: art. 2 EVRM is voor euthanasie van groor belang. Zoals reeds in de Proeve werd gezegd, sluit het EVRM een regeling van wathanasile niet wit.

254 Vgl. Alkema, 1978, p. 47-49 en Vam Dijk en Van Hoof, 1990, p. 245.

255 TK, 1985-1986, 18331, wr. 9 (Nota n.a.v. het eindverslag), p. $40-43$.

$256 \mathrm{TK}, 1987-1988,20383$, nt. 6 (MvA), p. 43.

257 Minderheidsnota, in: Statscommissie Euthanasie, Deel 1, 1985, p. 271.

258 Minderheidsnota, in: Statscommissie Euthanasie, Deel 1, 1985, p. 265. 
gemaakt: ${ }^{259}$ Zelfs als men een belangenafweging tussen de beide artikelen zou kunnen verdedigen, dan nog zou een wettelijke regeling van euthanasie niet mogelijk zijn, daar het door art. 2 EVRM beschermde recht onvervreemdbaar is en daarmee het belang dat art. 2 EVRM beschermt van een hogere orde is dan het recht op persoonlijke integriteit. ${ }^{260}$ Daarbij lijkt van belang dat De Blois spreekt van "legaliseren van euthanasie". Naar mijn mening behoeft een wettelijke regeling van euthanasie, waarin euthanasie onder uitzonderlijke omstandigheden niet strafbaar wordt geacht, niet als een "legaliseren van. euthanasie" te worden beschouwd; temeer niet wanneer men daarbij binnen het bestaande recht blijft, zoals dit ondermeer door de rechtspraak wordt geïnterpreteerd wordt gebleven.

Voor Alkema daarentegen is het recht op leven niet absoluut of onvervreemdbaar. Een beperking van dat recht als gevolg van een belangenafweging tussen art. 2 en art. 3 EVRM acht hij toelaatbaar. Een euthanasie-regeling is volgens hem, in verband met art. 3 EVRM beschouwd, in principe niet onverenigbaar met art. 2 EVRM. Bij de belangenafweging tussen art. 2 en art. 3 EVRM hebben de staten grote beleidsvrijheid. ${ }^{261}$

Van Dijk en Van Hoof stellen eveneens dat een euthanasieregeling niet per se in strijd is met art. 2 EVRM, daar de waarde van het menselijk leven tegen andere rechten van de betrokkene, met name die van art. 3 EVRM, mag worden afgewogen Of de wens van de betrokkene beslissend is, hangt af van de vraag, of het recht op leven al dan niet als onvervreemdbaar moet worden beschouwd. ${ }^{262}$

Schalken, voor wie het recht op leven onvervreemdbaar is, acht een belangenafweging tussen de in de artt. 2 en 3 EVRM beschermde belangen wel mogelijk en soms nodig. Dientengevolge heeft de patiënt het recht de behandeling te weigeren: Maar daaruit volgt niet dat hij ook van het recht op leven afstand kan doen. ${ }^{263}$

In de Memorie van Toelichting op de gewijzigde Proeve wordt opgemerkt, dat het wellicht aanbeveling verdient de mogelijkheid van euthanasie-wetgeving in internationaal verband, bijvoorbeeld in de Raad van Europa, te bespreken. ${ }^{264}$

In een latere brief van de Minister van WVC wordt meegedeeld, dat de "plaatsvervangers van de ministers geen - nadere - discussie aan het onderwerp hebben willen wijden" ${ }^{\prime \prime}$. Volgens de deskundigencommissie ad hoc inzake de ontwikkeling in de biomedische wetenschap (CAHBI) wordt een studie betreffende euthanasie

"moch passend, noch opportumn geacht. Als redenen daarvoor worden aangevoerd de voorzienbare problemen met artikel 2 van het Europees Verdrag tot bescherming van de rechten van de mens en de fundamentele vrijheden, alsmede de onstandigheid dat euthanasie in de ogen van de regeringen van de lidstaten van de Raad van Europa een strafbaar feit behoont te blijven" ${ }^{26.5}$

In het algemeen wordt mijns inziens terecht een afweging tussen de in de artt 2 en 3 EVRM beschermde belangen toelaatbaar geacht. Vanwege uitzonderlijke omstandigheden in verband met het werzoek van de betrokkene aan een mensonterende situatie een einde

259 De Blois, 1989, p. 260.

260 De Bliois, 1989, p. 262-263. Hij merkt tevens op, dat het verbod in art.6 BUPO ninder duidelijk is.

261 Alkema, $1978, \mathrm{p}$. $47-49$.

262 Van Dijk en Van Hoof, 1990, P. 245 .

263 A.G Schalkeri, NJB 1984, p. 44.

264. TK, 1985-1986, 19359, nr. 2 (MvT), p. 7-8. In ar. 2 (Brief), p. 2.

$265 \mathrm{TK}, 1988-1989,20383$, nr. 8 (Brief wh de Minister wan WVC, Btinlkman, van 8 dec. 1988). 
te maken, laten het naar mijn mening toe een wettelijke regeling te maken, waarbij het recht op leven niet ten nadele van het betrokken individu werkt. Het recht op leven mag niet tot een plicht tot leven worden in die mate, dat het leven onmenselijk of vernederend in de zin van art. 3 EVRM wordt.

\subsection{Onderlinge vergelijking van het (gewijzigd) initiatiefvoorstel, het advies en de Proeve}

\subsubsection{De strafbepalling van levensbeëindiging op verzoek}

In de drie voorstellen wordt art. $293 \mathrm{Sr}$ vervangen door art. 293 lid 1. De voorgestelde bepaling verschilt op vier punten van de huidige. De bestanddelen "opzettelijk" en "diens" zijn uitdrukkelijk vermeld. In plaats van "beroofd" wordt gesproken van "beëindigd". Deze drie veranderingen leiden niet tot een wijziging van de strekking van de bepaling. De Staatscommissie geeft als reden voor de keuze van de term "beëindiging", dat hij neutraler aandoet ${ }^{260}$ dan het woord "beroven" en dat het woord "beëindigen" in de euthanasiediscussie geaccepteerd is.

De vierde wijziging betreft het strafmaximum. Dat is van twaalf jaar naar vier jaar en zes maanden, respectievelijk in thet initiatiefvoorstel naar vier jaar, gevangemisstraf teruggebracht. De Staatseommissie verwijst voor de redictie naar het anders, volgens haar, te grote verschil met het strafmaximum van art. $294 \mathrm{Sr}^{267}$ Vanuit die gedachte had echter evengoed een werhoging van het strafmaximum van art. 294 verdedigd kunnen worden. ${ }^{268}$ Een reden van de Staatscommissie om niet tot een lagere maximumstraf te komen, was de mogelijkheid een verdachte voorlopig te kunnen hechten. ${ }^{269}$

\subsubsection{De constructie van de bijzondere rechtvaardigingsgrond}

In het advies en in het initiatiefvoorstel wordt levensbeeindiging op verzoek niet strafbaar geacht, indien de beëindiging van het leven geschiedt door een geneeskundige en aan bepaalde voorwaarden is voldaan. De Staatscommissie noemt daarbij als beperking dat gehandeld wordt "in het kader van zorgvuldig medisch handelen ten aanzien van een patient die in een uitzichtloze noodsituatie verkeert", terwijl het initiatiefvoorstel spreekt van handelen "in het kader van zorgvuldige hulpverlening aan iemand, die zich in een uitzichtloze noodsituatie bevindt". Het desbetreffende kader wordt met behulp wan zorgvuldigheidseisen nader bepaald.

De Stalscommissie verwijst voor de door haar gehanteerde constructie van "zorgvuldig medisch handelen" naar art. 280 lid $2 \mathrm{Sr}$, waar gesproken wordt van: "Het voorgaande

266 De Statancommissie spreekt van "neutraler van aand is". Staatscommissie Euthanasie, Deel 1, 1985, p. 50 .

267 Staatscommissie Euthanasie, Deel 1, 1985, p. 50. Bovendien verwijst zij naar een opmerking wan de Conmissies van beide Kmmers bij de totstandkoning van art. 293 Sr. Zie: Smidt, II, 1891, p. 464 en H. IV $A$, onder 1.1 .

268 Strijards, TvGR 1988 p. 145, is van mening dat de verlaging van het strafmaximum losstaat van de euthanasiekwestie en dat de wetgever daarmee kennelijk de in art. $293 \mathrm{Sr}$ verboden gedraging minder wederrechtelijk acht.

269 Statscommissie Euthanasie, Deel 1, 1985, p. 50. 
is niet van toepassing op hem ... die handelt in het kader van zorgvuldige hulpverlening aan de minderjarige". Tevens verwijst zij naar art. 5 lid 1 WAZ. Vanwege die bepaling kunnem bij AMvB nadere eisen voor de hulpverlening en besluitvorming worden gesteld. ${ }^{270}$ Maar anders dan in de door de Staatscommissie voorgestelde regeling maakt de eis van zorgvuldig medisch handelen geen onderdeel uit van de in art. 296 lid $5 \mathrm{Sr}$ opgenomen rechtvaardigingsgrond voor abortus.

In het initiatiefvoorstel was bepaald dat de levensbeëindiging "in het kader van zorgvuldige hulpverlening" plaatsvindt. ${ }^{271}$ In verband daarmee werd degene die om levensbeèindiging werzoekt als "hulpvrager" aangeduid. Als reden voor deze terminologie gaf Wessel-Tuinstra $o p$, dat "het onderhavige wetsvoorstel het medisch-technisch gebeuren voor de kwaliteit van de hulpverlening wel uitermate belangrijk acht, maar het sterven toch meer als een algemeen menselijk gebeuren ziet". Met name verwees zij daarbij naar de consultatie-eis ${ }^{272}$, waar van een "deskundige" werd gesproken, omdlat de consultatie niet alleen medische aspecten zou betreffen. ${ }^{273}$

In het gewijzigd initiatiefvoorstel is voor de uitvoering aansluiting gezocht bij het advies. De term "deskundige" is vervangen door "geneeskundige" en de uitvoering is voorbehouden aan een arts. ${ }^{274}$ Gezien de centrale rol die de arts daarmee in het initiatiefvoorstel heeft verkregen ${ }^{275}$, lijkt de handhaving van de term "hulpverlening" in plaats van "medisch handelen" nog slechts terminologisch van aard. ${ }^{276}$

Daar in de rechtvaardigingsgrond naar het feit van art. 293 lid 1 wordt verwezen, dient de patiënt een "uitdrukkelijk en ernstig verlangen" naar levensbeëindiging kenbaar te maken. De Staatscommissie merkt in verband met de rechtvaardigingsgrond op, dat het vanzelfsprekend is dat het verlangen "duurzaam" moet zijn en niet "in een opwelling of in een depressieve toestand van voorbijgaande aard" gedaan moet zijn. ${ }^{277}$

Voor zover een eenmalig verzoek niet een uitdrukkelijk en ernstig verlangen kenbaar kan maken, moet in verband met de eis van de duurzaamheid van het verzoek in bijzondere gevallen op andere strafuitsluitingsgronden worden teruggevallen.

De Raad van State is van mening dat de rechtszekerheid voor hulpverleners met het initiatiefvoorstel niet wordt gediend, omdat de bijzondere rechtvaardigingsgrond opsporings-en vervolgingsactiviteiten niet uitsluit en ook een art. 12 Sv-procedure mogelijk

270 Stantscommissie Euthanasie, Deel 1, 1985, p. 61-62.

271 Voor de formulering van de rechtwaardigingsgrond word nar art. 280 Sr verwezen. TK, 1983-1984, 18331, nr. 3 (MvT), p. 15.

272 TK, 1985-1986, 18331, nr. 9 (Nota n.a.v. het eindwersliag), p. 2*

273 TK, 1985-1986, 18331, nr. 9 (Nota n.a.v. het eindverslag), p. 2 en p. 7-8.

274 Met de wijziging wordt gevolg gegeven aan een amendement van Haas-Berger (PvdA); TK, 1985 1986, 18331, nr. 21. In de Nota n.a.v. het eindverslag, TK, 1985-1986, nr, 9, p. 6-7, werd opgemerkt dat de rechtwaardigingsgrond van het tweede lid in verband met art. 50 Sr niet ten aanzien van betrokken denden zou gelden, wanneer daarin slechts de arts als vitvoerder was aangeduid. Later - zie: TK, 1985-1986, 18331, nr. 13 (Lijst van antwoorden) - wordl deze foutieve opvaning gecorrigeterd.

275 Zie ook: TK, 1985-1986, 18331, nr. 9 (Nota n.a. wet eindversiag), p. 5-6, waar die tol benadrukt wordt.

276 Van Veen, NJB 1984, p. 1069, acht de term "hulpverlening" te ruim, omdat slechts de arts wordt bedoeld endat de arts een speciale soort hulp verleent.

277 Stratscommissie Euthanasie, Deel 1,1985 , p. 51 . 
blijft. ${ }^{278}$ Wessel-Tuinstra voert daartegen aan dat de rechtszekerheid niet gelegen is in de mogelijkheid tot vervolging, maar in de bestaande onduidelijkheid of euthanasie al dan niet teen strafbaar feit is. Oorzaak van deze onduidelijkheid is derhalve in haar visie het ontbreken van wettelijke criteria. ${ }^{279}$ Daar komt bij dat het de vraag is of een wetsvoorstel inzake euthanasie alleen of vooral de rechtszekerheid van de hulpverleners moet dienen.

Als gevolg van een amendement van Haas-Berger (PvdA) ${ }^{280}$ is in het initiatiefvoorstel een bijzondere vervolgingsuitsluitingsgrond opgenomen voor het geval de rechtwaardigingsgrond van het tweede lid niet van toepassing is en de verpleegkundige "in opdracht van en onder verantwoordelijkheid van" een arts heeft gehandeld, terwijl hij te goeder trouw meende dat het feit niet strafbaar was. Daarmee is ten aanzien van de assisterende verpleegkundige een vervolgingsuitshitingsgrond gecreêrd, terwijl ten aanzien van de arts een rechtvaardigingsgrond geldt. De vervolgingsultsluitingsgrond is materieel een schulduitsluitingsgrond. Zonder deze bepaling zou onder de geschetste omstandigheden de verpleegkundige een, naar mijn mening succesvol, beroep op AVAS kunnen doen, wanner tot vervolging zou worden overgegaan.

\subsubsection{De constructie van de bijzondere schulduitsluitingsgrond in de Proeve}

In het tweede lid van art. 293 Proeve is een bijzondere strafuitsluitingsgrond opgenomen. Het kabinet koos voor een schulduitsluitingsgrond, om hiermee het uitzonderlijk karakter van de gedraging te benadrukken en de kans op een toekomstige grenswerlegging te verminderen. ${ }^{281}$ Daar de beslissing van de arts en de uitvoering "onlosmakelijk" met elkaar verbonden zijn, mag de uitvoering slechts door een arts geschieden. ${ }^{262}$ Voor hem is dan ook de schulduitsluitingsgrond bedoeld.

Het kabinet houdt er wel rekening mee dat anderen dan de arts bij de uitvoering betrokken kunnen zijn. Daarom is aan het eind van deze bepaling de zin opgenomen: "Alsdan zijn evenmin strafbaar andere deelnemers aan het feit ${ }^{\mathrm{t}}{ }^{283} \mathrm{De}$ als schulduitsluitingsgrond bedoelde strafuitsluitingsgrond is als een rechtvaardigingsgrond geformuleerd. ${ }^{284}$ Daaruit leidt Van Veen af, dat de toevoeging over de deelnemers overbodig is. ${ }^{285}$ Volgens de RvS is de toevoeging onnodig, omdat de gewone deelnemingsbepalingen toereikend zijn. ${ }^{286}$ Voldoet de arts echter niet aan bepaalde voonwaarden en zorgvuldigheidseisen,

278 TK, 1983-1984, 18331, A (RvS), p: 2.

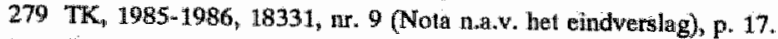

280 TK, $1985-1986$, nr. 31.

$281 \mathrm{TK}, 1985-1986,19359, \mathrm{nr} .2$ (MvT), p; 84.

$282 \mathrm{TK}, 1985-1986,19359$, nr. 3 (Brief Min. v. WVC), p. 4. Van Veen, DD 1986, p. 880-881, acint het nivet uitgesloten, dat de Proeve andere daders dan artsen niet wilde uitsluiten van een beroep op overmacht. On dat beter te laten witkomen stelt hij voor in de aanhef van art. 293 lid 2 de woorden "Wiet strafbaar is de geneeskundige die ..." te vervangen door "Indien een geneeskundige het in art. 293 hid 1 strafbar gesteldie feit pleegt is hij niel sirafbaar indien w. .

283 TK, $1985-1986,19359$, nr. 2 (Mw $)_{j}$ p. 14.

284 Vgl. Van Alphen c.s., NJE 1986; p. 312-313:

$285 \mathrm{Vgl}$. Vin Ween, DD 1986, p. 883-884.

286 TK, 1985-1986, 18331, ne. 43, C en D (RvS), p, 8-9. 
dan rest de te goeder trouw handelende verpleegkundigen niets anders dan een beroep te doen op AYAS. .87 $^{\text {A. }}$

\subsubsection{Uitwoering door een arts}

In de drie voorstellen wordt het uitsluitend aan geneeskundigen toegestaan tot levensbeëindiging op verzoek over te gaan. De Staatscommissie geef daarvoor de volgende redenen. De medicus heeft de deskundigheid die voor een zorgvuldige besluitvorming is vereist. Hij is in staat tot een verantwoorde diagnose en prognose. Bovendien is hij direct betrokken bij de patiënt en is er meestal al een behandelingsrelatie van enige duur aan het verzoek en de mogelijke levensbeëindiging voorafgegaan. ${ }^{238}$ Tevens is uitsluitend hij bevoegd tot het voorschrijven van medicamenten. ${ }^{289}$ Doordat hij ook tuchtrechtelijk ter verantwoording kan worden geroepen, bestaat er een versterkte controlemogelijkheid. Bovendien behoort hij tot een gekwalificeerde en duidelijk onderscheiden groep hulpverleners. ${ }^{290}$

Dat de medicus bij uitsiuiting bevoegd wordt geacht, betekent niet dat hij - ook wanneer aan de eisen is voldaan - verplicht is aan het verzoek van de patiënt te voldoen. Hij kan de uitvoering weigeren, maar dient dan volgens de voorstellen ervoor te zorgen, dat de patient met andere geneeskundigen in contact komt. ${ }^{291}$

De Staatscommissie heeft hieromtrent geen bepaling voorgesteld. Zij achtte dat kennelijk niet nodig. ${ }^{292}$ In het initiatiefvoorstel en in de Proeve is dat wel gebeurd. Voldoet de medicus niet aan het verzoek dan dient hij wel "desgevraagd" inlichtingen over de toestand van de patiënt aan andere geneeskundigen te verstrekken. De voorgestelde bepaling is gelijk aan die in art. 20 lid 1 en lid 3 WAZ voor abortus. ${ }^{293}$

Daar aan het niet-naleven van het aldus bepaalde geen strafrechtelijke consequenties worden verbonden, lijkt het artikel slechts een gedragscode te behelzen en behoort het zeker niet thuis in het WvSr. ${ }^{294}$

\subsubsection{De situatie van de patiënt}

Levensbeëindiging op verzoek is volgens de Staatscommissie slechts dan gerechtvaardigd, wanneer de pattënt in een "uitzichtloze noodsituatie" verkeert. Daaronder verstaat zij

257 Zie hiertoe Van Veen, DD 1986, p. 884, die hierbij onderscheidt of "Alsdan" al dan nie! wordt begrepen alls "Alleen dan".

288 Striatscommissie Euthanasie, Deel 1, 1985, p. 60.

289 Sir

290 Staatscommissie Euthamasie, Deel 1, 1985, p. 61. Vgl m. b.t. tot deze overwegingen: Floofdbestuur KNMG, MC 198.t, p. 7-8 en Gewers, TVGR 1985, p. 331.

291 Staatscommissile Euthanasie, Deel 1, 1985, p. 61.

$292 \mathrm{Vgl}$ Statatscommissie Euthansisie, Deel 1, 1985, p. 61.

293 'TK, 198S 1986, 19359, nr. 2 (MvT), p. 15. Zie hiertwe HIVB, onder 2.3. Volgens, Gevers, TvGR 1988, p. 363, mag van een gewetensbezwaarde arts niet werwacht worden dat hij an de patielunt informatie werstrekt over instanties die hem well willen helpen. Maar wanneer eenmal de behandeling door cen andere arts is overgenomein, moet ook de gewetensbezwaarde arts inllichtingen verstrekken. Zou hij immers weigeren informatic te verstrekken, dan wou bij een goede halp kunnen belemweren of onmiogelikk maken.

294. V.l. m.b.t. de Proeve; Van Veen, DD 1986, p. $888-889$. 
"dat de nood warin de betrokkene verkeert zodanig is dat levensbeëindiging onontkoombaar is". ${ }^{295}$ De Staatscommissie is van mening dat het begrip "noodsituatie" zich niet voor nadere afbakening leent en verwijst hiertoe naar de MvT op de WAZ ${ }^{296}$ Wel merkt zij op dat zowrel een lichamelijk als een geestelijk lijden de noodsituatie kan veroorzaken. Vier leden wijzen een geestelijke uitzichtloze noodsituatie aff. ${ }^{297}$

Daar de Staatscommissie het standpunt inneemt, dat ook vóór de stervensfase een patiënt in een uitzichtloze noodsituatie kan komen te verkeren, ziet zij ervan af de stervensfase als criterium in de regeling op te nemen, maar de vier hiervoren genoemde leden willen euthanasie slechts als een vorm van stervensbegeleiding toestaan en daarom aan lid 2 toegevoegd zien: "... en wiens overlijden onafwendbaar aanstaande is" ${ }^{\prime 2}$

Evenmin wordt geêist dat de patiënt ongeneeslijk zlek is. Volgens de Staatscommissie behoeft een ongeneeslijke ziekte niet mee te brengen, dat zich een uitzichtloze noodsituatie yoordoet. ${ }^{209}$ De conclusie is well juist, maar de redengeving schiet mijns inziens te kort. Het criterium "ongeneeslijke ziekte" zou immers ến van de minimumeisen voor euthanasie kunnen zijn. Vanuit een meer "principieel standpunt (kan) worden opgemerkt, dat de stervensfase wél het criterium van de ongeneeslijkheid van het lijden impliceert, maar niet perse dat van de ondraaglijkheid". ${ }^{300}$

In verband met de afwijzing van de stervensfase als criterium merkt de Staatscommissie op:

"Centraal staat immers de vraag of het lijden vam de patiënt uitzichtloos is omdat daarin, gelet ook op de stand van de wetenschap, een verergering, althans geen verbetering kan worden verwacht" 301

Voor het uitdrukkelijk niet opnemen van de duurzaamheid van het lijden als criterium, hanteert de Staatscommissie daarentegen als argument, dat de "duurzaamheid van het lijden (...) ... al gegeven (is) met de voorwaarde dat de patiënt in een uitzichtloze noodsituatie verkeent" ${ }^{102}$

In het oorspronkelijk initiatiefvoorstel werd geëist dat de hulpvrager zich in de stervensfase bevindt of ondraaglijk lijdt danwel het lichamelijk of geestelijk lijden als ondraaglijk ervaart. In het nader gewijzigd initiatiefvoorstel wordt, evenals in het advies, gesproken van een "uitzichtloze noodsituatie".

Tot de wijziging is besloten naar aanlleiding van opmerkingen vanuit verschillende fracties die de gebezigde terminologie onduidelijk vonden. ${ }^{303}$ Ook de KNMG hanteert

295 Stat tscommistie Euthanasie, Deell 1, 1985, p. 56.

296 Staatsconmissic Euthenasie, Deel 1, 1985, p. 56-57. Zie HTK 1978-1979, 15475, nr. 3 (MvT), p. 10 t.v. Zie ook H. II, onder 20.5 .

297 Van Gerstel, Jeukens, De Lange en Mout. Startscommissie Euthanasie, Devel 1, 1985, p. 59.

298 Statscommissio Euthanasie, Deel 1 , 1985, p. 58-59.

299 Stantscommissie Euthanasie, Deel 1, 1985, p. 59.

300 Gezondheidsrata, $1982, \mathrm{p} .28$. In het initiatiefvoorstel, TK, 1985-1986, 18331, nr. 9 (Nota r.a.v. het eindverslag), p. 35, wordt opgemerkt, dat ongeneestijkheid niet goed is vast te stellen en dat nensen ondraglijk kumen lijden zonder ongeneeslijk ziek te zijn.

301 Statscommissie Euthrnasie, Deel 1, 1985, p. 58 .

302 Sttaatscommisste Euthanasie, Deel 1, 1985, p. 59. Zie ook p. 51.

303 Gevers, TVGR 1985, p. 331, acht ide term "uitzichtloze noodsituatie" even onbepald als de oorspronikelijk gehanteerde termen. De woorkeur van Sutorius, TwGR 1985, p. 338, gaat uit naar de door de Hoge Raad in het eerste euthanasie-arrest, FR 27 nov, 1984, NJ 1985, 106 m.nt. ThWvV geformuleerde critteria. Houben, MC $1985, p$, 1205, acht de term "hitzichtloze noodsituatie" wel cen verbetering, magr hil zag daar nog liefst aan toegevoegd "vanuit medisch oogpunt bezhen". Vroom-Kastelein, Metamedina 1986, 
het begrip "stervensfase" niet langer, omdat het niet duidelijk te omschrijven is en zich situaties kunnen voordoen, waarin ook buiten de stervensfase euthanasie mogelijk moet zijn. 304

In plaats van een nadere uitwerking van thet begrip noodsituatie, wordt een aantal voorschriften geformuleerd, die de zorgvuldigheid van de besluitvorming moet waarborgen $^{305}$, zodat zich ook hier de vergelijking met de WAZ opdringt.

In de omschrijving vam de situatie waarin een verzoek tot levensbeëindiging gehonoreerd mag worden en in die van het besluitvormingsproces, vertoont het voorstel van de Staatscommissie veel overeenstemming met de regeling van abortus in de WAZ. Evenmin als het daar lukte duidelijk te maken, waardoor de eigen verantwoordelijkheid van de patiënt en van de medicus zich kenmerkt, slaagt het advies daarin. ${ }^{306}$

De strafuitsluitingsgrond in de Proeve verschilt niet alleen naar zijin aard, maar ook naar zijn inhoud wan die in de twee andere voorstellen. Er is, volgens het kabinet, gestreefd naar geobjectiveerde normen. Het criterium van de Staatscommissie en van het initiatiefvoorstel, de "uitzichtloze noodsituatie", acht het onvoldoende. ${ }^{307}$ In de Proeve is gekozen voor een combinatie van drie factoren. Er moet sprake zijn van een concrete doodsverwachting, van een ondraaglijk lijden en tevens moet verdere geneeskundige behandeling geen enkel redelijk doel voor de patiënt meer kunnen dienen. ${ }^{308}$ Het kabinet acht de omschrijving "concrete doodsverwachting" yoor "iedere ervaren arts" voldoende duide$11 \mathrm{ik} .{ }^{3009}$

De RvS vindt de door het kabinet genoemde combinatie van drie factoren weliswaar restrictiever dan het begrip "witzichtloze noodsituatie", maar naar zijn mening biedt zij evenmin voldoende houvast. ${ }^{310}$

De niet strafbare levensbeeindiging dient volgens de Proeve te geschieden "in het kader van stervensbegeleiding", waarbij de levensbeêindiging moet voortvloeien uit het zorgvuldig medisch handelen van de geneeskundige. Het kabinet is van mening dat het niet mogelijk is een nauwkeuriger criterium dan "stervensbegeleiding" in een wettelijke regeling op te nemen. Wellicht omdat daardoor de objectivering van de normen onvoldoende waargemaakt wordt, voegt het hieraan toe, dat ook de consultatie-eis ter objectivering van zowel de voorzienbaarheid van het overlijden als van het ondraaglijk karakter van het $\|$ ijden dient. ${ }^{311}$.

p. 92 , ziet juist een woordeel in de onbepalldheid: het begrip biedt voldoende ruinte voor toekomstige ontwikkelingen.

304 TK, 1985-1986, 18331, n. 9 (Nota n.a.w. het eindverslag), p. 4-5 en p. 52.

305 Staatscommissie Euthanasie, Deel 1, 1985, p. 57.

$306 \mathrm{Vgl}$. Manderheidsnota, in: Staatscommissie Euthanasie, Deel 1, 1985, p. 283-287: het criterium uitzictitloze roodsituatie is te rwim en te onbepald.

307 TK, 1985-1986, 19359, n. 2 (MvT), p. 14.

308 TK, 1985-1986, 19359, nr. 3 (Brief Min. v. WVC), p. 3.

309 TK, 1985-1986, 19359, nr. 3 (Brief Min. v. WVC), p. 5.

310 TK, 1985-1986, 18331, nr. 43, C en D, (RvS), p. 4-5. Vgl. Van Alphen c.s., NJB 1986, p. 312.

311 TK, 1985-1986, 19359, nr. 2 (MvT), p. 10. 
Het criterium dat een verdere geneeskundige behandeling geen enkel redelifk doel voor de patiênt meer kan dienen, hijkt weel op medisch zinloos handelen: ${ }^{312}$ In dat geval mag de medicus zelfstandig van de zinloze behandeling afzien. ${ }^{33}$

\subsubsection{De relatie tot de zorgwuldigheidseisen}

In de voorstellen wordt uitgewerkt, wat onder zorgvuldig medisch handelen respectievelijk zorgvuldige hulpverlening wordt verstaan. In het advies betreft dit minimumeisen, zoals blijkt uit "houdt in ieder geval in". In de Proeve zijn de zorgvuldigheidseisen limitatief bedoeld, hetgeen kan worden opgemaakt uit de formulering is slechts aanwezig indien". Als reden woor deze limitatie geeft de MvT op, dat de door de Staatscommissie gebezigde formulering niet goed is voor de rechtszekerheid van de arts. ${ }^{314}$ In het initiatiefvoorstel wordt voorgesteld te spreken van "voor zorgvuldige hulpverlening is vereist", zodat ook daar de zorgvuldigheidseisen woor de strafrechtelijke aansprakelijkheid limitatief zijn bedoeld.

\subsubsection{Het verzoek als zorgvuldigheidseis}

Een van de zorgvuldigheidseisen in het initiatiefvoorstel houdt in, dat "de hulpvrager zijn verzoek tot levensbeëindiging vrijwillig en weloverwogen gedaan en zelf kenbaar gemaakt heeft". De Raad van State achtte deze eis terecht overbodig, daar hij reeds in het "uitdrukkelijke en ernstige verlangen" gelezen kan worden..$^{315}$

De indienster reageert hierop door te verwijzen naar het vonnis van de rechtbank Rotterdam van 1 dec. 1981 , NJ 1982, 63, waarin de rechtbank de term "uitdrukkelijk en ernstig verlangen" voor de hulpverlening (bij zelfdoding) heeft uitgewerkt, en door te wijzen op de mogelijkheid hierdoor de interactie tussen arts en patiênt "inzichtelijk en toetsbaar" te maken. ${ }^{316}$

De desbetreffende overweging van de rechtbank luidt, dat "de persoon een goed besef heeft van de situatie, waarin hij verkeert, alsmede van de alternatieve mogelijkheden, in staat is een en ander tegen elkaar af te wegen en dat ook heeft gedlaan". Deze uitwerking is in de voorgestelde zinsnede slechts rudimentair aanwezig.

Volgens het initiatiefvoorstel is vereist, dat de geneeskundige zich ervan heeft overtuigd, dat het verzoek van de hulpvrager op de bedoelde wijze is gedaan. Die eis is ook opgenomen in het advies en in de Proeve.

Vanwege de onzekerheidsmarge kan niet meer worden geëist dan dat de overtuiging is verkregen. Dat dient mijns inziens te worden verstaan als:" "redelijkerwijs de overtuiging

312 Vgl. Sutorius, in: Verantwoorde Jevensbeedndiging?, $1986, \mathrm{p} .50$; Alsof het voortzetten van een medisch zinloze behandeling niet reeds op zichzelf onjuist zou zijn, nog afgezien van de wraag of de patient zijin toustemming daaraan zou kumen onthouden"

313 Vgl. Vroon-Kastelein, Metantedica 1986, p. 91.

314 TK, 1985-1986, 19359, nr. 2 (MvT), p. 14. Anders Van Veen, DD 1986, p. 885, die de formulering in de Proeve stringenter acht. Volgens hem brengt het woord "slecht" anders dan "houdt in ieder geval in" ${ }^{\prime}$ mee dat woor cen beroep op de exceptie alle eisen moeten zign nageleefd.

315 TK, 1983-1984, 18331, A, (RVS), p. 3.

316 TK, $1984-1985,18331$, B, p. 5 . 
kon krijgen". Daarom verdient het aanbeveling on deze zinsinede in plaats van de voorgestelde op te nemen.

In thet advies en in de Proeve wordt als additionele woorwaarde gesteld, dat de medicus ook de overtuiging moet hebben gekregen, dat de patiênt zijn verzoek "in vrijwilligheid" heeft "gehandhaafd". 317

Met de handhavingseis wordt kennelijk bedoeld de durzaamheid van het verzoek. te benadrukken. In zoverre voegt dit weinig toe aan hetgeen verstaan moet worden onder het "uitdrukkelijk en ernstig verlangen". Maar het woord "gehandhaafd" impliceert tevens dat de patiënt meerdere malen het verzoek moet doen. Daartoe moet hij dan wel in staat zijn.

\subsubsection{De voorlichtingseis}

Volgens de drie voorstellen is de arts gehouden de patiënt omtrent zijn situatie voor te lichten. Deze eis wordt in het initiatiefvoorstel en in de Proeve nog aangevuld met de voorwaarde dat de voorlichting zich dient uit te strekken over "behandelingen die kunnen strekken tot het verlichten van zijn lijden".

De voorlichtingseis is, naar aanleiding van een amendement, in het nader gewijzigd initiatiefvoorstel opgenomen. In de toellichting op het amendement wordt gesteld, dat daarmee nagestreefd wordt dat de patiënt "een zo juist mogelijk inzicht heeft in de situatie waarin hij verkeert". ${ }^{318}$ Volgens het advies is de voorlichting bedoeld om de patient met behulp van "duidelijke informatie" "inzicht in zijn medische situatie en de proginose ter zake" te verschaffen:

De gebezigde term "voorlichting" (aan de patiënt) onvat meer dan alleen het verschaffen van informatie, die voor een geldige toestemming tot een behandeling wordt vereist. ${ }^{320}$ Reeds taalkundig houdt de term daarnaast ook in iemands gedrag in gunstige zin beînvloeden. In die zin wordt bijwoorbeeld van "patiêntenvoorlichting" gesproken? ${ }^{321}$

Daar uit de scharse toelichting afgelleid kan worden, dat deze term in de voorstellen is bedoeld als synoniem aan "informatie", verdient het aanbeveling in de betreffende bepalingen van "informatie" of, zoals in het wetsvoorstel op de geneeskundige behandelingsovereenkomst ${ }^{322}$, van "inlichtingen" te spreken. Maar het is de vraag, of een dergelijke bepaling gehandhaafd moet blijven, want een medicus is in het algemeen gehouden tot het verstrekken van de nodige informatie aan de patient, zodat deze in staat wordt gesteld op grond van de beschikbare informatie een weloverwogen beslissing te nemen.

317 Staatscommissie Euthanasie, Deel 1, 1985, p. 64. Zie ook: p. 57.

318 Amendement van Dees (VVD), TKK, 1985-1986, 18333, nr. 23.

319 Stratscommissie Euthanasie, Deell 1, 1985, p. 64.

320 Zie: Van Wijmen, in: Patièntenwoorlichting, 1988, p. 28.

321 Zie: Damoiseaux, in: Patiëntenvoorlichting, $1988, \mathrm{p} .4$.

322 TK, $1988-1990,21561$, nr. 2, p. $2-3$ en nr. 3 (MvT), p. 4 en p. 30 
Het subjectieve van de uitzichtloze noodsituatie blijkt uit de eis in het voorstel van de Staatscommissie dat de medicus tezamen met de patiênt tot de "overtuiging" moet zijn gekomen, dat er geen andere oplossingen dan levensbeëindiging zijn.

"(E)en beslissing tot levensbeëindiging in het concrete geval (is) het resuiltaat (...) van een beshitvormings proces tussen verzoeker en geneeskundige, warbij ledere betrokkene een efigen verantwoordelijkheid heeft ${ }^{\text {H: }}$.323

De patiënt beoordeelt of in de noodsituatie levensbeëindiging de enige aanvaardbare oplossing is of dat hij eventuele alternatieven als een werkelijke oplossing aanmerkt: De geneeskundige is gehouden tot een eigen beoordeling van de noodsituatie van de patuént. Hij dient te beoordelen of de beslissing tot levensbeëindiging verantwoord is en te bepalen of nog andere oplossingen voorhanden zijn. De beoordeling van de beslissing van de patientit zal moeten geschieden op grond van "de omstandigheden van het concrete geval ${ }^{\text {H. }}$. Het is de patiênt die de noodsittuatie kenbaar maakt, terwijl de geneeskundige deze beoordeelt en wel met inachtneming van de in art. 293 geformuleerde zorgvuldigheidseisen.

Voor de rechtwaardiging wan euthanasie moet onderscheiden worden tussen de besluitvorming en de situatie waarin de patiênt zich bevindt. De situatie wordt aangeduid als een uitzichtloze noodsituatie. Enerzijds stelt de Staatscommissie dat de patiënt bepaalt wanneer een noodsituatie uitzichtloos is. Dat is het geval, wanneer hij eventuele alternatieven niet meer als een "werkelijke oplossing" aanmerkt voor de noodsituatie waarin hij verkeert. ${ }^{324}$ Anderzijds staat in de toelichting, dat het lijden van de patiënt uitzichtloos is, wanneer, "gelet ook op de stand van de wetenschap, een verergering, althans geen verbetering kan worden verwacht": ${ }^{225}$ De medicus bepaalt of tenminste een verbetering van de noodsituatie kan worden verwacht. Wanneer hij daarvan niet overtuigd is en de patiênt over zijn situatie heeft ingelicht en deze vervolgens om levensbeëindliging verzoekt, dan mag de medicus aan het verzoek voldoen.

Terwijl ook in de toelichtingen op het initiatiefvoorstel en - maar minder expliciet - in de Proeve de eigen verantwoordelijkheden van de patiënt en de arts worden benadrukt ${ }^{326}$, is in de desbetreffende wetsvoorstellen niet de eis van een gezamenlijke besluitvorming opgenomen, zoals dat in art. 293 lid 1 onder $c$ van het advies wel is geschied. Volgens die bepaling is vereist dat "de geneeskundige tot het oordeel is gekomen dat levensbeêindiging op grond van zijn bevindingen verantwoord is, omdat hij met de patiënt tot de overtuiging is gekomen dat er woor de noodsituatie waarin deze zilch bevindt geen andere oplossingen zijn"."

323. Stratscommissie Euthanasie, Deel 1, 1985, p. 58. Zie ook: p. 66.

324 Staatscommissic Euthanasie, Deel 1,1985, p. 57.

325 Staatscomnissie Euthanasic , Deel 1,1985, p. 58.

326 TIK, 1984-1985, 18331, nr. 7 (MvA), p. 25: "het (js) en misverstand (w.) te menen dat het zelfbeschikkingsecht wan de patient het beschikkingsrecht van de arts wordi. Dat is in strijd met het wezen van het zelfbeschilkkingsrecht". Zie ooki p. 20. Dat betekent niet, dat de arts verplicht is aan het verzoek wan de patient te voldoen. TK, 1985-1986, 18331, nr. 9 (Nota n.a.v. het eindverslag), p. 46: "Er zijn twee beslismomenten het verzoek van de betrokkene en zijn beleving wan de noodsitwatie en helt besluit van de arts on daar al dan miet op in te gaan. In art. 293 lid $3 \mathrm{c}$ staat dit nadrukkelijk". Zie tevens: TK, 1985im 1986, 1833», nr. 43, C en D, Bijlage (gewijzigde Proeve), p. 17. 
Het lijkt inderdaad beter om af te zien van de eis van gezamenlijke besluitvorming. Wat deze eis in de praktijk inhoudt, is onduidelijk. Tevens kan de patient zich, nadat hij het verzoek heeft gedaan, in een toestand bevinden, die het niet mogelijk maakt om aan de eis van gezamenlijke beshitvorming te voldoen.

\subsubsection{De consultatie-eis}

Volgens de drie voorstellen is consultatie verplicht. De Staatscommissie geeft als reden voor deze eis, dat het on "zeer verstrekkende beslissingen" gaat, "waarbij ook veelal voor de geneeskundige emotionele overwegingen een rol spelen". De consultatie dient entoe de besluitvorming een objectiever karakter te verlenen. Bovendien zit in het inschakelen wan een tweede geneeskundige een controle-element. Dat element wenst de Staatscommissie kennelijk ook, want zij stelt voor de te consulteren geneeskundigen te laten aanwijzen door de Minister van WVC. ${ }^{32 \pi}$

De Staatscommissie merkt op, dat de behandelende arts niet gebonden is aan het oordeel van de geconsulteerde medicus ${ }^{328}$. Maar een behandelend arts die tegen het uitdrukkelijke oordeel van de geconsulteerde medicus tot levensbeeindiging overgaat, zal strafrechtelijk in een zwakkere positie verkeren.

In het initiatiefvoorstel wordt van de te consulteren arts geëist, dat deze "onafhankelijk" is en tot de behandelende arts "niet in enig samenwonings- of familieverband" staat. ${ }^{329}$ In de Proeve houdt deze eis in dat een door de Minister van WVC aangewezen arts is te consulteren en tevens dat deze "niet in enig samenwerkings- of familieverband" tot de behandelende arts stat. ${ }^{3130}$ De nadere voorwaarden lijken me aan de vereiste "onafhankelijkheid" weinig toe te voegen ${ }^{331}$ Van Veen merkt terecht op, dat het veel belangrijker is om aan te geven dat de geraadpleegde arts niet tot de patiënt in een dergelijk verband staat. ${ }^{332}$

De consultatie van een tweede arts wordt als een essentieel onderdeel van de regelingen beschouwd. ${ }^{333}$ Het hieraan niet voldoen brengt daarom zowel in de Proeve als in het initiatiefvoorstel aansprakelijkheid voor het hoofddelict mee. ${ }^{334}$ Voor de deelnemers betekent dit dat voor hen evenmin de strafuitsluitingsgrond van het tweede lid geldt.

In het advies is het niet nakomen van de consultatie-eis afzonderlijk en kennelijk als misdrijf strafbaar gesteld en bedreigd met een gevangenisstraf van ten hoogste drie jaren of een geldboete van de vierde categorie.

327 Statitsoommissie Euthanasie, Deel 1, 1985, p. 67.

328 Stalatsconmissie Euthanasie, Deel 1, 1985, p. 68 .

329 De latste voorwarde is in owereenstemming met een anuendenent van Dees (VVD), TK, 1985-1986, 18331, nir., 24:4.

330 Beide cursief, J.W.

331. In die zin ook het initiatiefwoorste: TK, $1985-1986,18331$, nt. 9 (Notit nav. het eindverslag), p. 8.

332 Van Veen, DD 1986, p. 886.

333 TK, 1985-1986, 19359, nr. 2 (MvT) op de Proeve, p. 15.

334 TK, 1985 -1986, 19359, nr. 2 (MVT) op de Proeve, p. 16. 


\subsubsection{De euthanasieverklaring}

Een euthanasieverklaring kan een tweeledige functie hebben. $\mathrm{Zij}$ kan als aanvulling op een mondeling werzoek om euthanasie dienen en daarmee bijdragen aan het verschaffen van zekerheild dat het verzoek van de patient weloverwogen en duurzaam is. De andere functie van een dergelijke verklaring is dat zij in de plats treedt van een mondeling verzoek wanneer de patiënt niet meer in staat is zijn wil te uiten. In die situatie kunnen naast een euthanasieverklaring nog andere schriftelijke verklaringen een rol spelen.

In de euthanastediscussie is de aanduiding van de verschillende soorten verklaringen onvast. De Statscommissie onderscheidt wanwege inhoudelijke verschillen drie vormen van verklatingen. De eerste is de "euthanasieverklaring". In die verklaring geeft de betrokkene te kennen dat hij onder bepaalde omstandigheden zijn leven op een bepaalde wijze beëindigd wil zien. De "non-reanimatieverklaring" bevat een weigering van medische behandeling voor situaties, waarin de patient in een bewusteloze staat verkeert en grote kans op zware en blijvende hersenbeschadiging bestaat. Ten derde kan de betrokkene in een verklaring tot uitdrukking brengen, dat hij onder geen beding wil dat de arts zijn leven beëindigt. ${ }^{335}$

Leenen onderseheidt verklaringen van weigering van medische behandeling - waartoe hij ook de non-reanimatieverklaring rekent - en euthanasieverklaringen. De eerste soort verklaring legt aan de arts de plicht op de verklaring op te volgen. Een euthanasieverklaring schept evenmin als een mondeling verzoek een plicht woor de arts om tot euthanasie over te gaan. ${ }^{336}$ Hij kan bijvoorbeeld vanwege gewetensbezwaren daarvan afzien. ${ }^{337}$

Volgens Sutorius en Jansen werd het zogenaamde "levenstestament" door de Nederland se Vereniging voor Vrijwillige Euthanasie in 1973 in Nederland geintroduceerd. Onder dat begrip viel vanat het begin zowel de eigenlijke euthanasieverklaring als een verklaring omtrent weigering van medische behandeling. Daarvan onderscheiden zij de "non-reamimatieverklaring"

In de MvT op het voorstel-WGBO wordt in één adem gesproken over een " "levenstestament' en een "non-reanimatieverklaring". Daarmee wordt in beide gevallen een schriftelijke verklaring bedoeld, "die ertoe strekt dat onder omstandigheden behandeling achterwege blijft ${ }^{\mathrm{m}}$. Aan een dergelijke verklaring is de arts gebonden, tenzij hij van een door de patiënt aangewezen vertegenwoordiger toestemming heeft gekregen tot voortzetting van de behandeling. ${ }^{39}$

Ten aanzien van de werking van een euthanasieverklaring zijn drie mogelijkheden denkbaar. Er wordt geen enkele waarde aan toegekend, er wordt een beperkte waarde aan toegekend of deze wordt gelijkgesteld met een mondeling werzoek.

De Staatscommissie stelt een euthanasieverklaring gelijk aan een mondeling verzoek. Weliswaar spreekt zij in verband met de schriftelijke verklaring van een "aanwijzing", maar daamee bedoelt $z i j$ dat de euthanasteverklaring een aanwijzing is voor het verlangen

335 Stalatsconmissie Euthanasie, Deell 1, 1985, p. 52 .

336 Vgl. Stantscommissie Euthanasie, Deel 1, 1985, p. SS.

337 Leenen, 1988, p. 283. Vgl. Kastelein, MC 1991, p. 653. Zie m.b.t. het Lattste punt: Leenen, 1991, pu 45. Vgl. ook art. 20 lid 1 WAZ.

338 Sutorius en Jansen, AA 1991, p. 990-991.

339 TK, 1989-1990, 21361, nu. 3 (MvT), p 13. 
van de patiënt om euthanasie in een daartoe aanleiding gevende situatie. ${ }^{340}$ Voor de nuime werking die de Staatscommissie aan een euthanasieverklaring toekent, valt; zoals de commissie ook overtuigend aantoont ${ }^{341}$, wel iets te zeggen, voor zover althans bij euthanasie het verzoek van de betrokkene "centraal" staat. ${ }^{342}$

Zonder euthanasieverklaring zou de geneeskundige moeten uitgaan van de veronderstelde will van de patiènt, dat hij behandeld will worden. De zodanig veronderstelde toestemming is een aanwijzing op grond van algemene ervaringsregelen. Bij een euthanasieverklaring staat tegenover deze veronderstelling een wilsuiting van de patiënt, weliswaar afgelegd op een eerder tijdstip, maar die verklaring is de enige kenbron van hetgeen de patiênt will. Door geen aandacht aan die verklaring te schenken, zou een derde de duidelijke wilsuiting op grond van veronderstellingen kunnen passeren. De bezwarem, die tegen een euthanasieverklaring worden geuit ${ }^{343}$, stuiten naar mijn mening hiertegen. Daarom lijkt mij verdedigbaar dat ook een oudere euthanasieverklaring als relevante wilsuiting geldt, zolang het tegendeel niet blijkt. ${ }^{344}$

Wanneer de patiënt niet in staat is zijn wil kenbaar te maken, dan moet de geneeskundige zelfstandig tot het oordeel komen of levensbeëindiging verantwoord is. Daarvan is sprake als hij ervan overtuigd is dat er voor de noodsituatie van de patient geen andere oplossingen zijn. ${ }^{345}$ Daar de patiënt over de actuele situatie niet gehoord kan worden, acht de Staatscommissie consultatie nog meer op haar plaats dan bij een patiënt die daartoe nog wel in staat is. ${ }^{346}$

In het oorspronkelijk initiatiefvoonstel was geen bepaling opgenomen over een euthanasieverklaring. Dat is in het gewijzigde initiatiefvoorstel wel het geval. Daarmee is volgens de MvA vastgelegd wat de indienster ook in het oorspronkelijk woorstel mogelijk achtte ${ }^{347}$ Het in lid 4 bepaalde verschaft daarover de nodige duidelijkheid. ${ }^{348}$ De zorgvuldigheidseisen die aan het gevolg geven van een euthanasieverklaring worden gesteld zijin identiek aan die van het nakomen van een verzoek ${ }^{349}$ Alleen is in het nader gewij-

340 Staatscommissie Euthanasie, Deel 1, 1985, p. 55 en p. 70.

341 Staatscommissie Euthanasie, Deel $1,1985, p_{n} 53-54$

342 Staatscommissie Euthanasie, Deel 1,1985, p. 53 en p. 26.

343 En die de Statscommissie noemt. Zie: Statscommissie Euthanasie, Deel 1, 1985, p. 53.

344 Leenen, 1988, p. 284: "Het is een algemeen beginsel dat een verklaring de wil vain degene die hear heef opgesteld, weergeeft tenzij het tegendeel word aangetoond. Het risico dat hij tent tijde wan het gotueet worden van de verklaring wellicht anders zou wensen; heeft de betrokkene, aldus de Stantscommisaie Euthanasie, bewust genomen, ondall hij een ander risico wilde uitsiluiten, namelijk dat hij ander woor hem alet aanwardbare onstandigheden zou moeten voortleven ${ }^{\mathrm{F}}$. In dezelfde zim" Van Wijmen, 1990 p. 54 en Kastelein, MC 1991, p. 654. Vermoedelijk anders. Schalken, in: Euthanasie, 1985, p. 134. Van der Meer, in: Eutharusie, 1985 , p. 75 , acht een euthanasieverklaring bij een wilsbekwame patient van geringe warde, omdal in de praktijk blijkt, dat patienten in de acute situatie daarvan alstand doen of er niet naar verwijzen. Hij sluit nül til dat wen euthwnasieverklaring vooral bij later wilsbekwa me patienten een zekere warde kan hebbet.

345 Minderheidsnota, in: Statscoummissie Euthanaste, Deel 1, 1985, p. 289. Het begrip "noodsitwatie" krijgt hier een meer objectieve betekewis van "mensonwarardige toestand".

346 Sta atscomnissie Euthanasie, Deel 1, 1985, p. 71 .

347 TK, 1984-1985, nr. 7 (MvA), p. 22-23.

348 Met lid 4 is gevolg gegeven alan een amendement wan Dees, TK, 1985-1986, 18331, nr. 27. Evenals ü dat amendement wordt ook in lid 4 niet van een "lalpwrager", magr wan een "patient" gesproken. Damarnee is in het initiatiefvoorstel de anduiding van de persoon die om levensbeendiging wraagt niet consistent. Zje ook: H. IV B, ander 1.7.2.

349 Zie: TK, 1985-1986, 18331, nr. 9 (Nota n.a.v. het eindwerslag), p. 4, 58 en 67. 
zigde initiatiefvoorstel nog opgenomen, dat in de euthanasieverklaring de situatie wordt aangeduid als een wan ondraaglijk lijden.

In lid 8 van art. 293. Proeve wordt bepaald dat op een euthanasieverklaring "mag acht worden geslagen", mits de medicus tot de overtuiging is gekomen, dat deze is afgelegd na zorgvuldige overweging en in vrijwilligheid. Daarmee kan zowell in de Proeve alls in het advies en in het initiatiefvoorstel een euthanasieverklaring bij een patiënt die zijn wil niet meer kan uiten, in de plaats van een mondeling verzoek komen. ${ }^{350}$

De euthantasieverklaring kan volgens de Proeve alleen bettekenis hebben, wanneer daarin aangegeven wordt; bij welk ondraaglijk lijden levensbeëindiging verzocht wordt. ${ }^{351}$

Evenals bij een mondeling verzoek dient de arts bij een euthanasieverklaring de overtuiging te krijgen dat de patiênt in vrijwilligheid en na zorgvuldige overweging tot zijn wilsuiting is gekomen. Tot de overtuiging kan bijdragen dat hij met naaststaanden van de patiënt overlegt: ${ }^{352}$ Dat levert natuurlijk slechts dan een zinvol resultalat op, wanneer de patiënt over het opstellen van de euthanasieverklaring met de genoemde personen, onder wie de huisarts niet onbelangrijk is ${ }^{353}$, heeft gesproken. Ter voorkoming van onduidelijkheid en interpretatieproblemen bestaat hiertoe wel aanleiding. Bovendien is het wenselijk dat een getuige de euthanasieverklaring mede ondertekent en dat de betrokkene een vertegenwoordiger aanwijst die namens hem aan het besluitvormingsproces kan deelnemen ${ }^{354}$ De bewijsfunctie van een euthanasieverklaring kan tevens versterkt worden, door deze bij notariële akte op te maken. ${ }^{355}$

Problematisch bij een euthanasieverklaring is wooral de aanduiding van de omstandigheden waaronder euthanasie gevraagd wordt. De patiënt dient te trachten deze omstandigheden zo nauwkeurig mogelijk te omschrijven. Daarbij zal een zekere vaagheid onvermijdelijk zijn. ${ }^{356}$ Om interpretatieproblemen zoveel mogelijk te voorkomen is het wenselijk dat de patiënt met zijn huisarts en met naasten hierover uitvoerig spreekt.

Naast de genoemde punten dient een euthanasieverklaring vanzelfsprekend de personalia van de betrokkene en, indien de betrokkene een vertegenwoordiger heeft aangew ezen en met de huisarts gesprekken over de verklaring heeft gevoerd, ook de personalia vam hen te vermelden,

In een civiel vonnis van de rechtbank $\mathrm{Zwolle}^{\$ 57}$ had de arts geen gevolg gegeven aan een non-reanimatieverklaring van een patiënte die een poging to zelfdoding had gedaan. De eiseres stelde dat de arts daarom jegens haar aansprakellijk was uit onrechtmatige daad, althans onbehoorlijke zaakwaarneming. De rechtbank was het daarmee niet eens. Volgens de rechtbank had de arts onvoldoende tijd ter beschikking gehad om zilch van

350 Van Veen, DD 1986, P.887, noent de eis dai een eerdere vierklaring schriftelijk dient te zajn "én van de schaduwkanten wan de will tot regelen. ... Ha papier gat boven de wherkelijkheid".

$351 \mathrm{TK}, 11985-1986,19359$, nr. 2 (MvT), p. 15.

352 Zue ook: Staatscommissie Euthanasie, Deel 1, 1985, p. 55 en p. 70.

$353 \mathrm{Vgl}$. Kastelein, MC 1991, p. 654.

354 Vgl. Van Wijmen, 1990 , p. 53 en Sutorius en Jiansen, AA 1991, p. 992.

$355 \mathrm{Vgl}$. Statsconmissie Euthanasie, Deel 1,1985, p. 55.

356 Vgl. Sutorius en Jansen, AA 1991, p. 992.

$357 \mathrm{Rb}$. Zwolle 13 dec. 1989, TVGR 1990/63. 
de weloverwogenheid van het besluit tot zelfdoding te vergewissen, terwijl bovendien de non-reanimatieverklaring niet de benodigde informatie verschafte. Ondermeer ontbrak daarin haar eigen naam en de naam en het adres van de executeur-testamentair.

Tot nu toe heeft - voor zover mij bekend - de strafrechter zich nog niet uitgelaten over euthanasie op schriftelijk verzoek. Het lijkt me niet in strijd met de verderop te bespreken strafrechtelijke jurispnidentie, als de strafrechter de medicus gerechtvaardigd acht, wanneer deze onder bepaalde omstandigheden op schriftelijk verzoek van een ten tijde van de euthanasie wilsonbekwame patiënt de handeling verricht.

\subsubsection{Minderjarigen}

In het oorspronkelijke initiatiefvoorstel en in het advies is geen bepaling opgenomen ten aanzien van minderjarige patiënten. Volgens de Staatscommissie mogen derden niet over levensbeëindiging van minderjarigen beschikken. ${ }^{358}$ De wettellike vertegenwoordigers van het kind dienen wel gehoord te wonden, maar hun stem is niet doorslaggevend. ${ }^{359}$

Heeft de minderjarige inzicht in zijn situatie en is hij zich bewust van de gevolgen van zijn verzoek, dan mag aan een verzoek van hem tot levensbeëindiging niet voorbijgegaan worden. ${ }^{360}$ De Staatscommissie ziet af van het stellen van een leeftijdsgrens.

"Niet de leeftijd van het kind is van doorslaggevende betekenis, maar de mate waarin hij inzicht heeft in zijn ziekteproces en in de draagwijdte van zijn verzoek om levensbeeindiging". ${ }^{361}$

De Statscommissie acht het wenselijk, dat een minderjarige die een verzoek om levensbeëindiging doet een vertrouwenspersoon krijgt toegewezen, die de belangen wan het kind behartigt, maar die heeft evenmin als een wettelijke vertegenwoordiger een beslissende stem. ${ }^{362}$

Met betrekking tot euthanasieverklaringen sluit de Staatscommissie zich aan bij de in art. 4.3.2.1. Nieuw B.W. voorgestelde leeftijdsgrens van 16 jaar tem aanzien van het maken van uiterste willsbeschikkingen. ${ }^{363}$

In het nader gewijzigd initiatiefvoorstel is, ten gevolge van een daartoe strekkend amendement van Dees (VVD) ${ }^{364}$, een bepaling omtrent minderjarigen opgenomen. Deze houdt in; dat de wettelijke vertegenwoordigers steeds bij de besluitworming worden betrokken en dat zij een vetorecht hebben. In het amendement Haas-Berger (PvdA) ${ }^{365}$ wordt wel de raadpleging van de wettelijke vertegenwoordiger voorgestell, maar aan hen geen vetorecht toegekend. Een met het nader gewijzigd initiatiefvoorstel te dien aanzien overeenkomstige regeling is opgenomen in de Proeve.

358 Staatsconmissie Euthanasie, Deel 1, 1985, m.11. p. 91.

359 Staatsconmissie Euthanasie, Deel 1,1985 , p. 95.

360 Staatscommissie Euthanasie, Deel 1, 1985, p. 94 .

361 Staatscomnissie Euthanasie, Deel 1, 1985, p. 94. Vgl. Leener, 1991, 28, 281-282.

362 Staatscommissie Euthanasie, Deel 1, 1985, p. $97-98$.

363 Stagtscommissie Euthanasje, Deel 1, 1985 , p. 94.

364. TK, 1985-1986, 18331, nr. 26.

365 TK, 1985-1986, 18331, nr. 30. 
De RwS kiest voor een gedifferentieerde benadlering. Hij stelt voor een verschil te maken tussen minderjarigen ouder dan 16 jaar en minderjarigen tussen 12 en 16 jaar. Bij minderjarigen ouder dan 16 jaar zou het "oordeel des onderscheids" meer van belang kunnen zijn dan bij minderjarigen tussen de 12 en 16 jaar. Bij minderjarigen van de laatste categorie, bij wie dit oordeel niet aanwezig is, zou aan de wettelijke vertegenwoordiger een wetorecht kunnen worden toegekend. Maar hiervoor acht de RvS nadere bestudering nodig. ${ }^{366}$

In het voorstel-WGBO is voor het aangaan van een behandelingsovereenkomst ten aanzlen van minderjarigen voor een dergelijke benadering gekozen. Is de minderjarige jonger dan $12 \mathrm{jaar}$ dan is toestemming van de wettelijke vertegenwoordiger vereist. Bij een minderjarige tussen de 12 en de 16 jaar is naast de toestemming van de minderjarige in beginsel ook die van de wettel ijke vertegenwoordiger nodig (art. 1653d lid 2). Een minderjarige van 16 jaar en ouder kan zelfstandig een behandelingsovereenkomst aangaan en toestemming verlenen tot het verrichten van daarmee verband houdende handelingen (art. 1653 a lid 1)

\subsubsection{Verslaglegging}

In het initiatiefvoorstel, maar niet in het advies wordt bepaald, dat de arts een journaal dient bij te houden. Tevens wordt bepaald wat daarin tenminste moet worden vastgelegd en dat het journaal desgewenst aan de OvJ ter beschikking moet worden gesteld. In het nader gewijzigd initiatiefvoorstel wordt bovendien geeist dat de arts het journal gedurende tenminste vijf jaar dient te bewaren ${ }^{368}$ en dat in het journaal vermeld moet worden, wanneer aan een verpleegkundige opdracht wordt gegeven bij de levensbeëindiging te helpen.

Ook in de Proeve is het bijhouden, gedurende vijf jaar bewaren en op verzoek aan de OvJ ter inzage afgeven van een journaal verplicht gesteld. Eerst was voorgesteld het journaal ter inzage aan de geneeskundig inspecteur af te laten geven. Met het oog op een beter toezicht door het $\mathrm{OM}$ is de bepaling gewijzigd. ${ }^{369}$ Volgens het zesde lid moeten in beginsel de naaste familieleden worden geraadpleegd. Gebeurt dat niet dan dienen de redenen in het journal te worden vermeld.

Het niet voldoen aan de journaal-verplichtingen leidde in het oorspronkelijk initiatiefvoorstel tot aansprakelijkheid vanwege het hoofddelict. Hiertegen maakte de RuS bezwaar. Tevens merkte hij op dat dit voorschrift van administratiefrechtelijke aard niet thuis hoort in het WvSr. ${ }^{370}$ In het nader gewijzigd initiatiefvoorstell wordt het niet aan deze verplichtingen voldoen in het WvSr zelfstandig strafbar gesteld en bedreigd met een gevangenisstraf van ten hoogste een jaar of een geldboete van de derde categorie.

$366 \mathrm{TK}, 1985-1986,18331$, nr. $43, \mathrm{C}$ en D (RvS), p. 7.

367 Zie cok: TK, 1989-1990, 21561, nr. 3 (MvT), p. 19-20.

368 Naar aanleiding van een amendement van Dees (VVD), TK, 1985-1986, 18331, nr. 28.

369 TK, 1985-1986, 19359, nr. 2 (MvT), p. 16-17. Volgens de RvS; TK; 1986-1986, 18331, nr. 43, C en D (RvS) p. 8.9 , verdient de oorspronkelijke regelling aanbeveling.

370 TK, 1983-1984, 18331, A (RvS), p. 2. 
Het niet-nakomen van de journal-verplichting is cok in de Proeve zelfstandig strafbaar gesteld. Overtreding wordt hier bedreigd met een geldboete van de derde categorie.

Daar voorgesteld wordt deze bepalingen, die op art. 18 lid 1 WAZ lijken ${ }^{371}$, in het Tweede Boek van het WvSr, met de titel "Misdrijven", op te nemen, zijn de bepalingen als misdrijven aan te merken. Voor de betreffende bepaling in het initiatiefvoorstel is dat gezien de gevangenisstraf kennelijk ook de bedoeling. Onduidelijk is echter, of voor de strafbaarheid is vereist dat culpoos of doleus wordt gehandeld. ${ }^{372}$ In de Proeve kan uit de gestelde straf worden afgeleid dat de betreffende bepaling als overtreding is bedoeld. Het past echter niet in de systematiek van het Wetboek van Strafrecht om een overtreding in het boek met de titel "Misdrijuen" op te nemen.

\subsubsection{De verklaring van overlijden}

Het advies voorziet in een strafbepaling over het opzettelijk onjuist invullen van opgaven in verband met de levensbeëindiging, voor zover het handelen niet reeds door art. 228 $\mathrm{Sr}$ (het opzettelijk afgeven van een valse geneeskundige verklaring) bestreken wordt. ${ }^{379}$

In de MvT op de Proeve wordt hieromtrent opgemerkt, dat een dergelijke strafbepaling eerder thuishoort in de Wet op de lijkbezorging (WLB). ${ }^{374}$

Vanwege de (nieuwe) Wet op de lijkbezorging ${ }^{375}$ mag degene die de lijkschouwing verricht (de behandelende arts of de gemeentelijk lijkschouwer) slechts dan een verklaring. van overlijden afgeven, "indien hij overtuigd is dat de dood is ingetreden ten gevolge van een natuurlijke doodsoorzaak" (art. 7 WLB). Is de behandelende geneeskundige van mening niet tot afgifte van een verklaring van natuurlijk overlijden te kunnen overgalan, dan dient hij dit onverwijld aan de gemeentelijk lijkschouwer mee te delen.

In de artt. 228 en $229 \mathrm{Sr}$ is strafbaar gesteld het opzettelijk afgeven, het valselijk opmaken of vervalsen en het gebruik van een valselijk opgemaakte of vervalste overlijdensverklaring. Vanwege art. 10 WLB moet de gemeentelijk lijkschouwer die meent niet tot afgifte van een verklaring van natuurlijk overlijden te kumnen overgaan, onverwijld verslag uitbrengen aan de OvJ en onverwijld de ambtenaar van de burgenlijke stand waarschuwen.

Enschedé heeft verdedigd dat na euthanasie een overlijdensverklaring mag worden afgegeven, alls de arts ervan overtuigd is dat zijn euthanaserend handelen in overeenstemming is met de medische ethiek. ${ }^{376}$ In die opvatting zou onder de in art. 7 WLB genoende covertuiging de subjectieve opvatting van de arts begrepen zijn, zodat er voor een rechterlijke toetsing nauwelijks ruimte blijft.

$371 \mathrm{TK}, 1985-1986,19359$, nr. 2 (MwT), p. 16.

$372 \mathrm{Vgli}$. Van Veen, DD 1986, p. 887 .

373 Zie mib.t. toli de overlijdenswerklaring uitvoerig: Siatsconmissie Euthanasie, Deel 1, 1985, p. 79.86.

374 TK, 1985-1986, 19359, nr. 2 (MvT), p. 16. In TK, 1985-1986, 18331, nir 9 (Nota nal v. het eindverslag), p. 15 en p. 63 verklaarde Wessel-Tuinstra dat cen zelfstandige stratbaarstelling van het niet naar waarheid invullen van de overlijdensverklaring naast de bestaande artt. 228 en $229 \mathrm{sr}$ (het valselijk opmaken of wervalsen wan een geneeskundige werklaring) overboding is.

375 De nieuwe Wet op de lijkbezorging (WLB), de Wet van 7 maan 1991, houdende nieuwe bepalingen inzake de lijkbezorging, Stb. 1991, 130, wijkt m. b.t. het hier opgenerkte niet af wan de vervangen wet. Zje hiertove cok: Leenen, 1988, p. 342-345.

376 Enschede, 1985 , p. 10. 
In de verschillende standpunten wan het Hoofdbestum van de KNMG wordt het afgeven van een overlijdensverklaring in geval van euthanasie als onjüst beschouwd. Wel is er begrip voor die handelwijze in verband met de justitielle consequenties die het niet-afgeven met zich meebrengt. ${ }^{377}$ Onomstreden lijkt het afgeven van een overlijdensverklaring. als zich én van de drie schijngestalten heeft voorgedaan. ${ }^{378}$

In HR 15 dec. 1987, NJ 1988,811 m.nt. C, heeft de Hoge Raad overwogen dat de arts "dile de delictsinhoud van art. 293 Sr vervult, (...) de dood van de patiënt (veroorzaakt). Alsdan kan niet gezegd worden dat de dood is ingetreden ten gevolge van een natuurlijke oorzaak als bedoeld in ant. 29 p lid 2 Wet op de lijkbezorging". In de wetsgeschiedenis van deze, inmiddels oude wet zijn voor het tegendeel geen aanwijzingen te vinden. Ook het oordeel van de rechter dat de arts in noodtoestand heeft gehandeld en evenmin de omstandigheid dat de patiënt vanwege zijn ziekte "onafwendbaar" zou overlijjden, kunnen daraan iets af doen.

In de nota nar aanleiding van het eindverslag op de nieuwe WLB merkte de regering op: "Als er sprake is van levensbeeindiging op verzoek, is er sprake van een niet-natuurlijke dood als bedoeld in artikel 7 van de wet ...". 379

Volgens de gelijkluidende bepalingen in het nader gewijzigd initiatiefvoorstel en in de gewijzigde Proeve is de arts verplicht, om bij een niet-natuurlijke doodsoorzaak in de zin van de artt. 293 en 294 , een verklaring van overlijden ${ }^{380}$ onverwijld aan de gemeentelijke lijkschouwer te zenden. Deze doet de verklaring aan de OvJ toekomen, die naar aanleiding daarvan beslist of hij het journaal will inzien en tot vervolging wil overgaan, dan wel of hij een verklaring van geen bezwaar afgeeft. ${ }^{381}$ Daarmee is, volgens de MvT op de gewijzigde Proeve, de voorkeur gegeven aan "een eenvoudige maar niet minder doeltreffende regeling". 382

Het niet voldoen aian deze bepaling wordt met dezelfde straffen bedreigd als het niet-nakomen van de journaal-verplichtingen. Ook ten aanzien van de journaal-verplichting: is derhalve onduidelijk of de strafbepaling een misdrijf of een overtreding is. ${ }^{383}$

\subsubsection{Hulp bij zelfododing}

De Statscommissie houdt in wezen vast aan de huidige strafbaarstelling van hulp bij zelfdoding. Behalve dat het woord "zelfmoord" door het thans meer gebruikelijke woord "zelfdoding" is vervangen, is het voorgestelde art. 294 identiek aan het huidige art. 294 $\mathrm{Sr}^{384}$

377 Zie: H. IV A, onder 2.6, $2.7 \mathrm{en} \mathrm{2.8.} \mathrm{Vgl.} \mathrm{Commissie} \mathrm{Onderzoek} \mathrm{Medische} \mathrm{Praktijk} \mathrm{inzake} \mathrm{Euthanasie,}$ Rapport, 1991, p. 25-27.

378 Vgl. o.a. Corstens onder HR 15 dec. 1987, NJ 1988, 811.

379 TK, 1986-1987, 19448, ni: 5 (Nota n.l.v. het eindwerslag), p. 2.

380 Dat is derhalve geen verklaring van overlijden in de zin van de Wet op de lijkbezorging (het zogenaande overlijdensbriefje), die immers slechts bij een natuurlijke doodsoorzalk mag, worden afgegeven. Bij een niet-naturlijke doodsoorzalk mag volgens die wet, geen overlijdensbriefje worden afgegeven.

381 TK, 1985-1986, 18331, nr. 9 (Nota n.a.v. het eindverslag), p. 9 en mr. 13 (Lijst van antwoorden), p. 6.

382 TK, 1985-1986, 18331, nr. 43, C en D, p. 16.

383 Zie: H. IV B, onder 1.7.13.

384 Het in de Minderheidsnota voorgestelde art. $294 \mathrm{Sr}$ heeft dezelfde redactie. 
Lid 3 van art. 293 Staatscommissie verklaart ten aanzien van het verschaffen van middelen tot zelfdoding en het daarbij behulpzaam zijn, lid 2 van overeenkomstige toepassing.

3. Voor de toepassing van het tweede lid worden onder het beeindigen van het leven mede verstaan het in het kader wan zorgvuldig medisch handelen verschaffen van middelen tot zelfdoding en het daarbij behulpzaam zijn."

Ten gevolge van lid 3 jo. lid 2 zal het verschaffen van middelen tot en het behulpzaam zijn bij zelfdoding van een patiënt die zich nitet in een uitzichtloze noodsituatie bevindt onder art. $294 \mathrm{Sr}$ vallen.

In het advies van de Gezondheidsraad uit 1982 wordt voorgesteld dat voor levensbeëindiging door de medicus slechts zou mogen worden gekozen, wanneer de patiēnt zelf niet in staat is de handeling te volbrengen. ${ }^{386}$ De Staatscommissie wil dit onderscheid niet maken, ondat beide vormen van hulpverlening gericht zijn op levensbeèindiging, omdat thet in wezen geen verschil maakt wie de eigenlijke handeling verricht en omdat in een concreet geval een bepalde vorm van levensbeëindiging de meest aangewezene kan zijn, los van de vraag of de patiënt de handeling kan verrichten. ${ }^{387}$

Het voordeel van de eis dat levensbeëindiging door de patiënt dient te geschieden als deze daartoe in staat is, is wel dat hij op deze wijze duidelijk met zijn eigen beslissing geconfronteerd wordt en tot het laatste moment daarop terug kan komen. ${ }^{38 s}$

Afgezien van kleinere wijzigingen is lid 3 Proeve, waarin de strafuitsluitingsgrond van het tweede lid op hulp bij zelfdoding, met uitzondering van het aanzetten tot, van toepassing wordt verklaard, gelijk aan art. 293 lid 3 Staatscommissie.

Van Veen wijst erop dat de gekozen constructie kan meebrengen dat de dader vrijuit gaat, wanneer de OvJ in de onjuiste veronderstelling verkeert dat levensbeëindiging op verzoek heeft plaats gevonden en een daarop afgestemde dagvaarding uitbrengt, terwijl op de zitting blijkt dat strafbare hulp bij zelfdoding is verleend. Vanwege art. 55 lid 2 Sr moet hulp bij zelfdoding dan als specialis van levensbeetindiging op verzoek worden aangemerkt, maar daar in de dagvaarding niet alle bestanddelen zijn verwerkt kan geen veroordeling volgen. ${ }^{389}$ Dit gevolg wordt voorkomen in de constructie van het initiatiefvoorstel. Daarin is de strafuitsluitingsgrond voor de strafbare hulp in het voorgestelde art. 294 zelf verwerkt.

Art. 294 van het initiatiefvoorstel bestaat uit drie leden. In het eerste lid wordt het aanzetten tot zelfdoding strafbaar gesteld, in het tweede lid het behulpzam zijn of daartoe middelen verschaffen ${ }^{393}$ Het anzetten tot zelfdoding wordt met een straf van twaalf jaren bedreigd en het in lid 2 genoemde feit met een straf van vier jaren. Het aanzetten

385 Staatscommissie Euthanasie, Deell 1,1985 ; p. 78 .

386 Gezondheidsraad, 1982 , p. 16-17. In dezelfde zin o.a. Elders, in: Euthanasie, recht en praiktijk, 1985, p. $42-43$.

387 Staatscommissie Euthanasic, Deell 1, 1985, p. 63 . Vgl. Leenen, 1988, p. 337.

388. Vgl. Van der Meer, in: Euthanasie, 1985, p. 74. Van Binsbergen, DD 1974, p. 462, verbaascle zich erover dat voorstanders van exthanasie de levensbeëndiging door een ander willen laten doen.

389 Van Veen, DD 1986 , p. 884885.

390 Van Veen, NJB 1984, p. 1070 , spreekt wich teget deze constructie wit. Een constructie als die van art. 134 bis Sit (mislukte uitlokking) lijkt hem hier mogelijk. In DD 1986, p. 880, stelt hijj dat geen behoefte bestatil aan strafloarstelling van hulp bij poging tot zelfdoding. 
tot zelfdoding wordt daarmee duldelijk als ernstiger delict beschouwd. ${ }^{391}$ Door de maximumstraf van vier jaren ter zake wan het feit in lid 2 blijft inverzekeringstelling. mogelijk. ${ }^{392}$

De RvS is wan mening dat het onderscheid tussen "aanzetten tot" en de andere twee vormen van "hulp" geen rekening houdt met de praktijk en de doctrine. Voor de doctrine. verwijst hij naar het commentalar op het WvSr, wolgens welk zowel voor als na het besluit tot zelfdoding kan worden aangezet. ${ }^{393}$ Wessel-Tuinstra stelt hier tegenover dat sprake is van aanzetten, indien niet aannemelijk is dat het besluit reeds is genomen. Tevens wijst zij op de gewijzigde inhoud van "aanzetten" in het voorstel, waardoor de doctrine in casu aan betekenis heeft verloren. ${ }^{394}$

Naar mijn mening is het voor de in het initiatiefvoorstel voorgestelde strafiverhoging niet nodig om aan "aanzetten een andere inhoud toe te kennen. Ook ten aanzien van "aanzetten" in het huidige art. $294 \mathrm{Sr}$ valt te verdedigen dat deze gedraging een ander karakter heeft dan de andere twee vormen. Ik meen dat de passage in het losbladig commentaar aldus kan worden verstaan, dat een besluit tot zelfdoding aan het aanzetten vooraf kan gaan. "Aanzetten" houdt dan in bij de ander aandringen op verwezenlijking van dat besluit. Dat lijkt me ook in overeenstemming met de reden die in $1881 / 1886$ ten grondslag. lag aan het opnemen van deze variant in art. $294 \mathrm{Sr}^{395}$

Terecht wordt in het initiatiefvoorstel bij het strafmaximum voor hulp bij zelfdoding een verschil gemaakt tussen enerzijds het aanzetten tot zelfooding en anderzijds het behul pzaam zijn bij en het daartoe verschaffen van middelen. ${ }^{396}$ Bij het aanzetten speelt de "helper" een centrale rol. Hij is in wezen een uitlokker, zij het dan formeel-juridisch. van een niet-strafbare handeling.

Hoewel anders dan in het advies van de Staatscommissie de rechtvaardigingsgrond voor de hulp bij zelfdoding in art. 294 is opgenomen, wordt ook in de MvT van het initiatiefvoonstel gewezen op de vloelende overgang tussen levensbe ëindiging op verzoek en hulp bij een dergelijke levensbeëindiging. ${ }^{397}$

Voor het gerechtvaardigde behulpzaam zijn bij of verschaffen van middelen tot zelfdoding, worden in lid 3 de leden drie, zes en zeven van art. 293 van overeenkomstige toepassing verklaard. Dees (VVD) stelde voor deze rechtwaardigingsgrond van het initiatiefvoorstel in art. 293 onder te brengen. ${ }^{398}$ Vanuit wetssystematisch gezichtspunt lijkt dat minder aangewezen, zeker nadat in het nader gewijzigd initiatiefvoorstel nog slechts enkele van de zorgvuldigheidseisen van het derde lid van art. 293 voor de rechtvaardiging van lulp bij zelfdoding (lid 2) van toepassing worden verklaard. ${ }^{399}$ Bovendien zou dan - zoals hierboven besproken - bij de dagvaarding de specialis-generalis-problematiek kunnen spelen.

391 Zje m.b.t het verschil in strafmata TK, 1983-1984, 18331, nr. 3 (MvT), p. 20. Zie ook: TK, 1984-1985, 18331, mr. 7 (MvA), p. 18.

392 TK, 1983-1984, 18331, nr. 3 (NVT), P. 14.

393 TK, 1983-1984, 18331, A (RvS), p. 3 .

394. Wiessel-Tuirustra, TK, 1984-1985, 18331, B, p. 5-6.

395 zie: H. IV A, onder 2. Vgl. NLR, want. 4 op art. 294.

396 Vl. Michiels-Wan Kessenich-Hoogeridam, in: Euthanasie, recht en praktijk, 1985, p. 24-25.

397 TK, $1983-1984,38331$, nr. 3 (MvT), p. 13.

$398 \mathrm{TK}, 1985-1986,18331$, wr. 22.

399 Vgl. Josephus Jitta, NJB 1986, p. 45. Zie ook: Van Veen, DD 1986, p. 884-885. 
In art. 293 quater merkt de Staatscommissie vier gedragingen niet als levensberoving respectievelijk levensbeëindiging aan. Het betreft de weigering van de patiênt zich te laten behandelen, de levenswerkortende pijnbestrijding (al dan niet in de stervensfase), het afzien van medisch zinloos handelen en het niet behandelen van een bijkomende ziekte of aandoening van een irreversibel comateuze patient. ${ }^{400}$

Het in de negatieve bepaling van de Staatscommissie niet behandelen van een bijkomende ziekte bij een irreversibel comateuze patiënt is op zo veel kritiek gestoten, dat deze gedraging nog slechts in de Proeve is te vinden.

Evenals in het advies, maar anders dan in het initiatiefvoorstell, is in de Proeve een negatieve bepaling, art. 293 quater, opgenomen, waarin "schijngestalten van euthanasie" van de strafbaarstelling worden uitgezonderd. Met deze bepaling, aldus de MvT, wordt onzekerheid weggenomen. ${ }^{401}$ Het ongewenste gevolg van het achterwege laten van deze bepaling zou zijn, dat alle hier omschreven gedragingen in beginsel onder het nieuwe art. 293 zouden worden gebracht. ${ }^{402}$

Dat lijkt me niet juist bij het afzien van een medisch zinloze behandeling en van het niet behandelen van een bijkomende ziekte of aandoening bij een irreversibel comateuze paẗ̈̈̈nt, daar in beide gevallen geen verzoek is vereist.. Bovendien gaat de regering er dan kennelijk vanuit dat handelen dat aan een schijngestalte voldoet thans onder de bestaande levensdelicten valt. Dat geldt echter niet voor thet nalaten van medisch zinloos handelen en voor het niet (verder) behandelen van een patiënt die weigert toestemming tot de behandeling te geven of die een gegeven toestemming intrekt. ${ }^{403}$

Behalve ten aamzien van het afzien van medisch zinloos handelen, zijn de in de Proeve genoemde schijngestalten identiek aan die van de Staatscommissie. De Proeve spreekt niet, zoals de Staatscommissie Euthanasie, van een behandeling, die "naar heersend medisch inzicht zinlloos is", maar van "waarin een zodanige behandeling naar heersend medisch inzicht geen voor de patiënt redelijk doel meer dient". Daarmee wordt aansluiting gezocht bij het betreffende voorstel in de minderheidsnota. ${ }^{404}$ Daar is de afwezigheid van een redelijk doel echter ến van meerdere, cumulatief bedoelde, criteria: "waarin deze behandeling naar heersend medisch inzicht geen ander effect meer heeft dan het tijdelijk uitstellen van een dood, die onafwendbaar aanstaande is dan wel na meer dan één ingreep onvermijdelijk zal volgen, en dit uitstel geen voor de patiënt redelijk doel meer dient".

Terwijl de Proeve met de gekozen formulering een nadere beperking wil geven, heeft zij in feite het criterium ruimer dan in het advies gesteld. Vanwege de gekozen formulering in de Proeve ("redelijk doel") wordt aan de arts ruimte gegeven om over de waarde van het toekomstig leven van de patiënt te oordelen.

400 Zie hiertoe H. IV A, onder 3 .

401. TK, 1985-1986, 19359, nr. 2(MwT), p. 16.

402 TK, 1985-1986, 19359, nr. $2(\mathrm{MWT})$, p. 16.

403 Zie hiertoe: H. IV A, ander 3.

404 TK, 1985-1986, 19359, ar. 2 (MwT), p. 16. 
In het initiatiefvoorstel is geen negatieve bepaling opgenomen. Ook na herhaald aandringen $^{405}$ wordt daartoe niet overgegaan. De indienster heeft daartegen zowel formele als inhoudelijke bezwaren. Volgens haar hoort een megatieve bepaling "eigenlijk" niet thuis in het WvSr. Bovendien wil zij voorkomen dat op deze wijze de euthanasieregeling wordt ontdoken. In haar voorstelling zou een negatieve bepaling een "alibi-functie" kunmen vervullen om aan dle strafbaarstelling van levensbeëindiging op verzoek te ontkomen. $Z_{i j}$ is van mening dat het gevolg van de weigering van de patiënt om toestemming toit behandeling te werlenen in een wet op de patiëntenrechten thuishoort en acht het overbodig het afzien van medisch zinloos handelen in het WvSr op te nemen.

Ten aanzien van levensverkortende pijnbestrijding merkt zij op dat hiermee in werkeIijkheid slechts de dood wordt beoogd. Immers, zo werpt zij alls retorische vraag op: "wordt die ook toegepast bij patienten die zich niet in het voorportaal van de dood bevinden?"407 Daarom wil zij op de zogenaamde levenswerkortende pijnbestrijding de bepalingen van euthanasie toegepast zien.

Het niet behandelen van een bijkomende ziekte of aandoening van een irreversibel comateuze patient past volgens haar niet in het kader van het initiatiefvoorstel, dat slechts euthanasie betreft. Bovendien betreft het hier een situatie waarin het handelen medisch zinloos is, euthanatisch gehandeld wordt of een levensdelict wordt gepleegd. ${ }^{408}$

Enschede heeft in een bespreking van het advies van de Staatscommissie betoogd, dat een negatieve bepaling overbodig is en problemen schept. $\mathrm{Zij}$ is overbodig omdat de daarin omschreven gedragingen onder het thanatisch handelen van de medicus vallen en dat handelen binnen de grenzen van de medische standaard straffeloos mag geschieden, ook als dat niet met zoveel woorden wettelijk is bepaald.

De strafuitsluitingsgrond waarop hij hierbij het oog heeft is de medische exceptie. Dat deze exceptie ook voor deze gedragingen van toepassing is, leidt hij af uit het door hem gestelde feit, dat artsen deze gedragingen altijd hebben verricht zonder dat iemand van mening was dat de arts zich daardoor strafbaar heeft gemaakt. Een negatieve bepaling getuigt volgens hem van een te legalistische opvatting van het recht. Ook acht hij een negatieve bepaling problematisch, ondat zij onvoldoende flexibel is. ${ }^{409}$

Doordat Enschedé van de premisse uitgaat dat euthanasie ook onder de huidige wetgeving dankzij de medische exceptie straffeloos mag geschieden, is het niet verwonderlijk dat hij ook de in de negatieve bepaling van de Staatscommissie genoemde gedragingen vanwege de medische exceptie als niet strafbaar beschouwt.

Over de werking van de medische exceptie ten aanzien van euthanasie bestaat echter verschil van mening, zoals al blijkt uit de verschillende voorstellen inzake euthanasie. Na publikatie van het artikel van Enschede heeft de Hoge Raad overwogen dat de medische exceptie ten aanzien van euthanasie niet geldt. ${ }^{410}$

405 Zie o.a. amendement van het lid Dees (VVD), TK, 1985-1986, 18331, nr. 25; subamendement van fhet lid Haas-Berger (PvdA), TK, 1985-1986, 28331, nr. 32; subamendement van het lid Leerling; TK. $1985-1986,18331, \mathrm{nr}, 35$.

406 Wessel-Tuinstra, TK, 1985-1986, 18331, nr. 9 (Nota wa.v. het eindverslag), p. 37.

407 TK, $1984-1985,18331$, nr. 7 (MvA), p. 29. Zie ook: H. IV A, onder 3.3.

408 TK, 1985-1986, 18331, nr. 13 (Lijst van amtwoorden), p. 3-4.

409 Enschedé, NJB $1986, p, 37-42$.

410 HR 21 okt. 1986, NJ 1987, 607 m.nt GEM. Zie verder* H. IV B, onder 2.4.3. 
Voor Enschede zijn het de medici die bepalen welke gedragingen tot het medusch handelen behoren, voor zover zij daarmee niet in strijd komen met de apenbare orde of de goede zeden. In de inleiding werd opgemerkt, dat Leenen twee categorieän medisch handelen onderscheidt. Medisch handelen dat op grond wan materiële medisch-professionele normen geschiedt en medisch handellen op grond van maatschappelijke en juridische normen en regelingen. In het laatste geval worden de normen en regelingen door andere normatieve systemen dan het medisch-ethisch systeem bepaald. Als voorbeelden van deze categorie noemt hij onder andere abortus, euthanasie en de rechten van de patiënt. Slechts ten aanzien van de medisch-professionele handelingen kent hij de medische exceptie een strafuitsluitende rol toe..$^{41}$

Wie bepaalt of een zeker handelen van de medicus medisch-professioneel dan wel maatschappelijk genormeerd wordt, blijft bij Leenen onduidelijk. Het lijkt erop dat die gedragingen van de medicus ten aanzien van welke in de samenleving verschil van mening bestaat over de vraag of deze gedragingen aan de medicus geoorloofd zijn, aan de maatschappelijke normering en regeling onderworpen zijn. Daarbij kan een negatieve bepaling voor duidelijkheild zorgen.

\subsection{Het kabinetsvoorstel}

In zijn advies van 11 juli 1986 adviseert de RvS tegelijk over de Proeve en het gewijzigd initiatiefvoorstel. ${ }^{4.12}$ Aangezien hij reeds eerder advies over het initiatiefvoorstel heef uitgebracht ${ }^{43}$, richt hij zich voornamelijk op de Proeve. Daarbij gaat hij op de bepalingen zelf zeer beknopt in. Het is hem voorall te doen over de structuur van het voorstel en de vraag, of een dergelijk voorstel tot wetgeving dient te leiden.

De RvS constateert dat er behoefte bestaat aan meer rechtszekerheid ten aanzien van euthanasie. ${ }^{414}$ Tevens is gebleken dat veelal de juistheid van een negatieve bepaling wordt erkend. Bovendien bestaat grote overeenstemming over de zorgvuldigheidseisen. Wel heeft hij bedenkingen tegen een bijzondere wettelijke strafuitsluitingsgrond voor levensbeëindiging op verzoek. Hij is van mening dat een "zeer diepgaand verschil van opvatting" in de Nederlandse samenleving bestaat over de vraag of tot euthanasiewetgeving moet worden overgegaan en war de grens moet worden getrokken. ${ }^{415}$ De normen "vitzichtloze noodsituatie" en, zij het in mindere mate, "concrete doodsverwachting" acht hij onwoldoende duidelijk. Ook heeft de Hoge Raad zich tot nu toe slechts én keer over deze problematiek uitgelaten en bestaat in vergelijkbare rechtsstelsels geen dergelijke regeling.

Daarom adviseert de RvS tot een beperkte regeling, van welke hij bovendien verwacht dat deze wellicht een uitgebreidere wetgeving overbodig maakt. ${ }^{416}$ Die beperkte regeling zou er volgens de Raad als volgt kunnen uitzien.

In het WvSr wordt een negatieve bepaling opgenomen en in een bijzondere wet worden de zorgvuldigheidseisen en administratieve verplichtingen vastgelegd. Via een koppelings-

411 Leenen, 1991, p. 25-26.

412. TK, 1985-1986, 18331, nr, 43, C en D, (RvS).

413 TK, $1983-1984,18331, A$.

414 TK, $1985-1986,18331$, nr. 43, C en D (RvS), p. 3.

415 TK, 1985-1986, 18331, ar. 43, C en D (RvS), p. 4.

416 TK, 1985-1986, 18331, ir. 43, C en D (RvS), p. 5 . 
bepaling in het WvSr wordt een relatie gelegd tussen de strafrechtelijke aansprakelijkheid in het WvSr en de desbetreffende bepalingen in de bijzondere wet. ${ }^{417}$

Als mogelijke strafuitslutingsgrond voor euthanasie dient de overmachtsbepaling. art. $40 \mathrm{Sr}$. Volgens de Raad brengt het woldoen aan alle verplichtingen in de bijzondere wet niet noodzakelijkerwijs mee, dat een beroep op overmacht slaagt. Evenmin betekent het niet nalleven van(een van) deze verplichtingen dat een beroep op overmacht geen succes heeft: ${ }^{418}$

Het advies van de Raad van State is voor het kabinet aanleiding om na te gaan of een beperkte wetgeving in de door de RwS voorgestelde zin mogelijk is. Daartoe worden aan de Grezondheidsraad advies en aan de vergadering van de Procureurs-Generaal eem oordeel gevraagd. ${ }^{410}$

Ofschoon zowel de Gezondheidsraad ${ }^{420}$ als de vergadering van de Procureurs-Generaal $^{421}$ zich nogal kritisch over het in de adviesaanvraag omschreven voorstel uitlaten, houdt het kabinet in zijn "kabinetsvoorstel ${ }^{1022}$ vast aan de principiële opzet. Maar anders dan de RvS adviseerde, wordt in het WvSr volstaan met een redactionelle wijziging van art. 293 Sr en een verlaging van de maximumstraf naar vier jaren en zes maanden, komt behalve de bepaling over de zorgvuldigheidseisen, art. $6 \mathrm{~b}$, ook de negatieve bepaling in een bijzondere wet, art. 6a van de WUG, te staan en wordt de koppeling tussen het WvSr en de zorgvuldigheidseisen niet in het WvSr gelegd, maar in de WUG, waar in de aanhef van art. $6 \mathrm{~b}$ wordt gesproken van: "Met behoud van zijn verantwoordelijkheid volgens de strafwet ....".

Met het opnemen van de negatieve bepaling in de WUG wil het kabinet tegemoet komen aan de kritiek van de vergadering van Procureurs-Generaal, die een negatieve bepaling in het WvSr vanuit een wetssystematisch oogpunt een onwenselijk geachte fictie noemde. $^{423}$

Deze vergadering vroeg zich ook af of het hanteren van een negatieve bepaling niet mee zou brengen dat bepaalde vormen van actieve euthanasie aan de strafrechtelijke toetsing zouden kunnen worden onttrokken. ${ }^{424}$ Tevens werd opgemerkt dat er in verband met de rechtshandhaving geen behoefte aan een negatieve bepaling bestaat, terwijl de voorgestelde tekst geen ruimte laat voor nieuwe ontwikkelingen en inzichten. Daarom stelde de vergadering voor te volstaan met een uiteenzetting over de negatieve omschrijvingen in de MvT. ${ }^{225}$ Het kabinet acht het wit een oogpunt van rechtszekerheid echter onvoldoende. ${ }^{426}$

$417 \mathrm{TK}, 1985-1986,18331,1 \mathrm{r}, 43, \mathrm{C}$ en D (RvS), p. 5-6.

418 TK, 1985-1986, 18331, nr. 43, C en D (RWS), P, 6. Zie m.b.t. hel advies wan de RvS: KIijn, NJB 1987, p. $333-235$.

419 TK, 1986-1987, 19359, nr. 4 (Brief van MwJ en Minister van WVC), 16 jen. 1987.

420 Gezondhe idsraad, 1987.

$421 \mathrm{TK}, 1986-1987,19359$, nr. 8.

422 TK, 1987-1988, 20383 .

423 TK, 1986-1987, 19359, nr. 8, p. 2. Vgl. Van Veen, NJB 1984, p. 1069 en DD 1986, p. 885.

424 Vgl. H. IV B, onder 1.7.16.

425 TK, 1986-1987, 19359, nr. 8, p. 2 .

426 TK, 1987-1988, 20383, nr. 3 (MVT), p. 3. Zo ook, maar dan t.a.v. art. 293quater wan de Staatscommissie: Gevers, TVGR 1985, p. 329-330. 
In de negatieve bepaling is het niet-behandelen van een bijkomende ziekte of aandoening bij een irreversibel comateuze patiënt niet overgenomen. Het kabinet heeft zich de kritiek van de RvS $^{427}$ op dit onderdeel eigen gemaakt. ${ }^{428}$

Na bezwaar van de Gezondheidsraad tegen het zinsdeel "nadat de geneeskundige de overtuiging heeft gekregen dat de patiënt het verzoek daartoe heef gedaan en gehandhaafd in vrijwilligheid en na zorgvuldige afweging", volstaat het kabinet de weigering tot een behandeling in de negatieve bepaling te omschrijven als "op uitdnikkelijk en ernstig verlangen $^{n !}$. De Gezondheidsraad vond de oorspronkelijke formulering geen recht doen aan het toestemmingsvereiste. Dat vereiste houdt immers niet in, dat de patiënt uitdrukkelijk moet verklaren niet behandeld te willen worden, maar dat hij niet zonder (terecht veronderstelde) toestemming behandeld mag worden. ${ }^{429}$

Dat met de formulering "op uitdrukkelijk en ernstig verlangen" aan het bezwaar voldoende is tegemoet gekomen, zoals het kabinet stel ${ }^{430}$, moet betwijfeld worden, omdat volgens de voorgestelde bepaling nog steeds een actieve houding van de patiënt wordt geëist, terwijl bij het ontbreken van (terecht veronderstelde) toestemming de medicus geen recht tot behandelen heeft.

De tweede negatieve omschrijving betreft het nalaten van behandelingen, waarin de behandeling "naar heersend medisch inzicht zinloos is". Hiermee heeft het kabinet terecht de in de Proeve gebezigde formulering ("redelijke doel") ) $^{431}$ laten vallen en de in het advies van de Staatscommissie gebezigde zinsnede overgenomen.

De derde negatieve omschrijving betreft levensverkortende pijnbestrijding. Anders dlan in het advies van de Staatscommissie is hier de pijnbestrijding niet alleen het rechtstreekse doel, maar kan het ook een bijkomend doel zijn ("dan wel mede gericht op"). Deze toevoeging is opgenomen naar aanleiding van een opmerking van de $\mathrm{KNMG}$, dat vele medische handelingen, bijvoorbeeld operaties, het onbedoelde neveneffect kunnen hebben dat de patiënt overlijdt; een risico dat de arts welbewust neemt. ${ }^{432}$

Zonder deze toevoeging zou mijns inziens de arts in het in het voorbeeld genoemde geval een beroep op de medische exceptie kunnen doen. Het gaat daarbij immers om gew oon medisch handelen en voor zover de behandeling aan de eisen van proportionaliteit en subsidiariteit voldoet is deze als rechtmatig te beschouwen. Vanwege de toevoeging wordt de grens tussen levensverkortende pijnbestrijding en levensbeëindiging vager; want een arts zal bij levensbeẻindiging vaak mede beogen dat het lijden van de patiënt wordt werlicht.

In art. $6 b$ staan de zorgvuldigheidseisen vermeld. Het eerste lid luidt:

427 TK, 1985-1986, 18331, 1ur. 43, C en D (RvS), p.5-6. Zie ook het subanendenent van Habsi-Berger, TK, $1985-1986,18331, \mathrm{n} .35$.

428 TK, 1987-1988, 20383, nr. 3 (MvT), p. 12. Voor de RvS: TK, 1985-1986, 18331, nr. 43, Cen D (RvS), p. 5-6. Zie ook: H. IV $A$, onder 3.5.

429 Gezondhe idsraad, 1987, p. 14-15. Zie ook het wetsyoorstel WOBO.

430 TK, 1987-1988, 20383, nr. 3 (MVT), p. 11-12.

431 Zie: H. IV B, onder 1.7.16.

432 TK, 1987-1988, 20383, nr. 3 (MwT), p. 12-13. 
"Met behoud van zijn werantwoordelijkheid volgens de strafwet dient de geneeskundige die ingaat op het uitdrukkelijk en ernstig verlangen van een patiënt tot levensbeeindiging, daarbij de vereisten voor zorgvuldig medisch handelen in acht te nemen". En in de aanhef van lid 2 staat:

"Als vereisten woor zorgvuldig medisch handelen, bedoeld in het eerste lid; kumnen worden beschouwd:".

Met het woord "kunnen" heeft het kabinet de limitatieve eis van de Proeve door een open formulering verwangen, waarbij zelfs geen minimumeisen meer worden gesteld.

De zorguuldigheidseisen houden in dat de arts aan de patiënt informatie dient te verstrekken en dat op wens van de patiẽnt de naaste omgeving in de besluitworming wordt betrokken. Ook dient de arts, evenals in het advies, maar anders dan in het initiatiefvoorstel en in de Proeve, tezamen met de patiënt en, voor zover geraadpleegd met de naaste omgeving, tot de overtuiging te komen, dat de patiënt zijn verzoek vrijwillig en na zorgvaldige overweging heeft genomen en gehandhafd. De vierde zorgvuldigheidseis betreft de euthanasieverklaring bij patiënten die hun will niet meer kunnen uiten. De geldigheidsduur van deze verklaring wordt op vijf jaar gesteld. ${ }^{433}$ Als vijfde eis is de consultatie opgenomen.

Daarnaast is vastgehouden aan de journaalverplichting. Maar het kabinet heeft het woord "journaal" van de Proeve door "schriftelijk verslag" vervangen en anders dan in de Proeve is de gemeentelijke lijkschouwer degene an wie het verslag ter beschikking moet worden gesteld, die het op verzoek van de OvJ aan deze ter inzage afgeeft.

Zowel in het voorstel van de Staatscommissie als in het initiatiefvoorstel kan aan een verzoek van een minderjarige om levensbeëindiging worden voldaan mits deze over het "oordleel des onderscheids" beschikt, ook als een wettelijke vertegenwoondiger zich daartegen uitspreekt. In de brief aan de Gezondheidsraad stelt het kabinet, in navolging van de RvS $^{434}$, voor een verschil te maken tussen minderjarigen beneden en boven de zestien jaar. Beneden de zestien jaar heeft elke wettelijke vertegenwoordiger een vetorecht.

De Gezondheidsraad voelt meer voor de in het advies van de Staatscommissie gekozen benadering, op grond waarvan niet de leeftijd van de minderjarige bepalend is, maar diens vermogen al dan niet zelfstandig tot een verzoek te kunnen komen. ${ }^{435}$ In het voorstel van het kabinet wordt te dien aanzien echter weer bij de Proeve aangesloten, waarmee het kabinet in het voorstel een restrictiever standpunt inneemt dan in de brief aan de Gezondheidsraad. Het vetorecht van de wettelijke vertegenwoordiger geldt ten aanzien van elke minderjarige, ongeacht zijn leeftijd. Het kabinet ziet geen aanleiding om daarvan af te wijken.

Op 27 april 1989 vergadert de Tweede Kamer over het kabinetsvoorstel en over het initiatiefvoorstel. Nadien wordt het kabinet demissionair en ziet de Tweede Kamer van

433 Voor een tifdlimiet b.v. ook Vroom-Kastelein, Metamedica 1986, p. 94.

434 TK, 1985-1986, 18331, ar, 43, C en D (RvS), p. 7, die echter nog eens tot grondige overdenking van deze problematiek had geadviseerd. Van Veen, DD 1986, p. 888, voelt er voor om bij weigering van de wettelijkie vertegenwoordiger de rechter te laten beslissen.

435 Gezondheidsraad, 1987, p. 22-24. Zie: H. IV B, onder 1.7.12, voor het standpunt van de Staatscommissie Euthanasie.

436 TK, 1987-1988, 20383, ar. 3 (MvT), p. 16. 
verdere behandeling af. In het vervolgens tot stand gekomen regeerakkoord wordt vastgesteld dat er geen werkelijk inzicht in de aard en de omvang wan de euthanasiepraktijk bestaat. Daarom wordt voorgesteld een commissie hiemaar onderzoek te laten verrichten: $^{437}$

\subsection{Het rapport wan de Commissie Onderzoek Medische Praktijk inzake Euthanasie}

Op 18 januari 1990 wordi de Commissie Onderzoek Medische Praktijk inzake Euthanasie ingesteld, naar haar voorzitter ook wel de Commissie-Remmelink genoemd. Volgens art. 2 van de Instellingsbeschikking is het de taak van de Commissie een "rapport wit te brengen over de stand van zaken met betrekking tot de praktijk van het handelen of nalaten door een arts dat leidt tot het levenseinde van een patiënt, al dan niet op diens uitdrukkelijk verzoek".

Hieruit blijkt dat de Commissie niet alleen over euthanasie, maar ook over andere thanatische gedragingen zou rapporteren. Dat dient te geschieden op basis van een onderzoek naar de thanasie-praktijk. Het desbetreffende onderzoek wordt verricht door het Instituut Maatschappelijke Gezondheidszorg onder leiding van de hoogleraar Maatschappelijke Gezondheidszorg Van der Maas.

Één van de taken van de Commissie is de uitkomsten van het onderzoek te beoordelen. In art. 8 van de Instellingsbeschikking wordt erop gewezen dat zij daarbij ook aandacht dient te schenken aan de grenzen van de zorgplicht van artsen, aan de levensverkortende pijnbestrijding en aan het nalaten van een medische behandeling. Het behoort niet tot de taak van de Commissie de wenselijkheid van nieuwe wetgeving te beoordelen.

Ter bereiking van een grote medewerking van artsen wordt nadrukkelijk vermeld dat het onderzoek anoniem zou plaats vinden. Bovendien wordt met ingang van 2 november 1990 een landelijke meldingsprocedure voor euthanasie en hulp bij zelfdoding ingevoerd. ${ }^{438}$ De onderzoekers van de Commissie-Remmelink merken hierover op:

"Daarnaast had de KNMG als voorwaarde voor haar steun aan dit onderzoek gesteld, dat er een instructie zou komen omtrent de meldingsprocedure en het politie-optreden bij euthanasie. De toezegging dat deze richtlijn tot stand zou komen heeft waarschijn-

lijk mede bijgedragen aan de bereidheid tot medewerking van de beroepsgroep" ${ }^{439}$ Volgens de door de vergadering van de Procureurs-Generall opgestelde brief an de hoofdofficieren van justitie is de politie gehouden bij de melding van euthanasile of van een niet-natuurlijke dood zeer disicreet het onderzoek te verrichten. ${ }^{440}$ Deze meldingsprocedure houdt echter geen inhoudelijke wijziging in van het "bestaande vervolgingsbe-

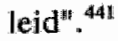

437 TK, 1989-1990, 21132, nr. 8, p. 47. Griffiths, NJB 1987, p. 682-683, noemt als punt van kritiek op de euthanasiediscussie, dat de deelnemers nawwelijks belangstelling tonen voor feiten. Schalken, DD 1986, p. 665, acht nader ondercoek naar ondermeer de effectiviteil van normering van belang, alvorens tot euthomasie-wetgewing wordt overgegaan.

438 Commissie Onderzoek Medilsche Praktijk inzake Euthanasie, Rapport, 1991, p. 65.

439 Commissie Onderzoek Medische Praktijk inzake Euthanasie, Onderzoek, 1991, p. 12.

440 Commissie Onderzoek Medische Praktijk inzake Euthanasie, Rapport, 1991, p. 65-66.

441 Commissie Onderzoek Medische Pralktijk invake Euthanasic, Rapport, 1991, p. 67. 
De Commissie en de onderzoekers hebben als werkdefinitie de door de Staatscommissie Euthanasie gegeven definitie van euthanasie overgenomen. Daar het onderzoek echter een breder terrein omvat is gekozen voor de term: "medische beslissingen rond het levenseinde". Hieronder verstaat de Commissie:

"alle situaties ... warin artsen beslissingen nemen die (mede) tot doel hebben het lijden te beëindigen door het levenseinde van de patiënt te bespoedigen of waarin ten minste rekening moet worden gehouden met de warschijnlijkheid van bespoediging van het levenseinde".

Als medische besllissingen rond het levenseinde worden derhalve niet aangemerkt "dodelijke complicaties van medisch handelen en medische fouten" ${ }^{442}$

Uit het onderzoek blijkt dat in Nederland jaarlijks circa 130,000 mensen overlijden. In alle gevallen waarin de arts een medische beslissing rond het levenseinde kan nemen $(87.000)_{\text {; }}$ doet hij dat ook in meer dan de helft van de gevallen $(49.000)$.

In de vragen aan artsen wordt vaak gesproken van handelen of nalaten dat tot doe! heeft of mede tot doel heeft het levenseinde te bespoedigen. De aandacht gaat daarbij uit naar de intentie warmee de arts handelt.

Naar de intentie worden drie categorieèn onderscheiden:

- handelen met het uitdrukkelijke doel het levenseinde te bespoedigen,

- handelen mede met het doel het levenseinde te bespoedigen,

- handelen, rekening houdend met de waarschijnlijkheid dat daardoor het levenseinde zal worden bespoedigd.

In het verslag van het onderzoek wordt opgemerkt, dat de intentie van de arts een van de moeilijkste begrippen in dit onderzoek was. ${ }^{43}$ Intentioneel handelen is een restrictiever begrip dan het begrip opzettelijk handelen in zijn strafrechtelijke betekenils. Dat betekent dat een handeling die volgens de artsen geen euthanasie, hulp bij zelfdoding of actieve levensbeëindiging is, omdat bij hen de intentie tot de dood van de patient ontbrak wel onder een van de toepasselijke delictsomschrijvingen kan vallen.

Terwijl het volgens het onderzoek slechts in 2.300 gevallen tot euthanasie en in 400 gevallen tot hulp bij zelfidoding komt; worden de meeste beslissingen in verband met de zogenaamde schijngestalten van euthanasie genomen. Daarvan maakt het staken of niet beginnen van een behandeling, op verzoek van de patiënt slechts een klein gedeelte wit ( 5.800$)$. Verreweg de meeste gevallen betreffen - en dan wel gelijkelijk verdeeld het nalaten van medisch zinloos handelen en de levensverkortende pijnbestrijding (telkens $22.500)$.

Actieve levensbeëindiging zonder verzoek geschiedt rond 1.000 keer per jaar. In het verslag van het onderzoek wordt opgemerkt dat het hierbij gevallen betreft, waarbij de arts met het "uitdrukkelijke doel het levenseinde te bespoedigen" heeft gehandeld. ${ }^{44 d}$ Tevens geeft het onderzoeksteam aan, dat het ten gevolge van de zeer uiteenlopende interpretatie van deze vragen en door het ontbreken valn een vraag naar de intentie van de arts bij dit handelen, niet mogelijk is om op grond van de interviewgegevens tot een

442 Commissie Onderzoek Medische Praktijk inzake Euthanasie, Rapport, 1991, p. 11.

443 Commisste Onderzok Medische Fraktijk inzake Euthanasie, Onderzoek, 1991, p. 14.

444 Conmisste Onderzoek Medische Fraktijk inzake Euthanesie, Onderzoek, 1991, p. 155. 
betrouwbare schatting te komen over het aantal gevallen van levensbeëndigend handelen zonder uitdrukkelijk verzoek van de patiënt. ${ }^{445}$

De Commissie-Remmelink noemt de actieve levensbeëindiging zonder verzoek een vorm van stervenshulp omdat het in vrijwel alle gevallen patienten in een terminale fase betrof: De rechtvaardiging voor het levensbeëindigend handelen is volgens de Commissie daarin gellegen dat het lijden van de patiênt ondraaglijk is geworden en dat volgens strikte medische maatstaven het leven van de patiënt als opgegeven moet worden beschouwd. ${ }^{446}$

De vraag is echter en dat geldt behalve voor de actieve levensbeëindiging zonder verzoek ook voor het nalaten van medisch zinloos handelen, of de responderende medici en de Commissie dezelfde maatstaven hebben gehanteerd. Terwijl de Commissie spreekt van "strikte medisch matstaven" wordt in de introductie op meerdere vragen aan de artsen ook een verband gelegd met de kwaliteit van het leven. Bijvoorbeeld: "..., of indien de toestand van de patiënt evident onleefbaar is". ${ }^{447}$ In de introductie op de vragen over het staken en het niet instellen wan een behandeling zonder uitdrukkelijk verzoek van de patiënt wordt gesproken van een "aanmerkelijke levensverlenging" die "als niet gewenst of als niet zinvol wordt gezien" ${ }^{14} .48$

Zeker even belangrijk is dat een behandeling die naar objectieve medische maatstaven medisch zinloos is nog geen rechtvaardiging verschaft om het leven van een patiënt actief te beëindigen.

In $30 \%$ van de gevallen van levensverkortende pijnbestrijding was het beëindigen van het leven mede doel van de arts. In $6 \%$ van de gevallen was dat zelfs het uitdrukkelijke doel van de arts. In deze $36 \%$ gevallen had de patiënt ooit iets kenbaar gemaakt over levensbeëindiging en in tweederde van deze $36 \%$ was er sprake van een uitdrukkelijk verzoek. 49

Voor levenswerkortende pijmbestrijding is - zoals voor elke ingri.jpende behandeling afzonderlijke toestemming van de patiënt vereist. Terwijl volgens de artsen de patiënt in $63 \%$ van de gevallen volledig in staat was de situatie te overzien en op adequate wijze een beslissing over de pijnbestrijding te nemen, werd de behandeling slechts in $39 \%$ van de gevallen met de patiênt besproken ${ }^{450}$ In $27 \%$ van de overige gevallen was dit wel mogelijk en in de resterende $34 \%$ van de gevallen beschouwden de artsen de patiënt als "niet (geheel) wilsbekwaam". 451

De Commissie geeft voor het ontbreken wan toestemming bij de levensverkortende pijnbestrijding twee verklaringen. Een deel van de patiënten was niet meer in staat zijn wil kenbaar te maken. Bij een ander deell van de patiënten was bij levensverkortende pijnbestrijding een witdrukkelijk verzoek niet an de orde. ${ }^{452}$ Verderop merkt de Commis-

445 Commissie Onderzok Medische Praktijk inzake Euthamasie, Onderzoek, 1991, p. 45 en p. 53. Leenen; TVGR 1991, p. 462-463, is terecht wan mening dat de resultaten van het onderzoek over de actieve levensbeeindiging nacler onderzoek op dit gebied vereisen.

446 Commissie Onderzoek Medische Praktijk inzake Euthanasie, Rapport, 1991, p. 15.

447 Conmissie Onderzoek Medische Praktijk inzake Euttimasie, Onderzoek, $1991, \mathrm{p} .45$.

448 Commissie Onderzoek Medische Praktijk inzake Evthanasie, Onderzoek, 1991, p. 68. Onder een ammerkelijke levenswerllenging versta de Commissie cen tijdsdurar van meer dan ecti maand.

449 Commissie Onderzoelk Medische Praktijk inzake Euthanasie; Onderzoek, $1991, \mathrm{p} .58$.

450 Commissie Onderzoelk Medische Praktijk inzake Euthanasie, Onderizoek, 1991, 19.61.

451 Commissie Onderzoek Medische Praktijk inzake Euthanasie, Rapport, 1991, p. 61-62.

452 Commissie Onderzoek Medische Praktijk inzake Euthanasie, Rapport, 1991, p. 32. 
she op dat de patiënt kan besluiten dat van het toedienen van middelen tot pijn- of symptoombestrijding wordt afgezilen: ${ }^{453}$

De Commissie is van mening dat artsen zich bij levensverkortende pijnbestrijding op rechtvaardigende noodtoestand kunnen beroepen. ${ }^{454}$ Doordat de Commissie beklemtoont dat voor de straffeloosheid van levensverkortende pijnbestrijding een strafuitshuitingsgrond nodig is, heeft zij tevens te kennen gegeven dat zij het overlijden van de patiènt tengewolge yan die handeling niet als natuurlijke dood beschouwt, zodat geen overlijw densverklaring mag worden afgegeven:

Belangrijk is het overleg met de patiênt over de te volgen behandeling en handellwijze. Een wilsbekwame patiënt kan slechts rechtsgeldig toestemming verlenen of weigeren, wanneer hij toereikend is ingelicht over het object van zijn beslissing. In dat verband is het opmerkelijk, dat de inlichtingeneis, die een van de zorgvuldigheidseisen is, slechts door $11 \%$ van de ondervragde artsen is genoemd. ${ }^{45 \%}$ Niet uit te sluiten is echter dat medici de inlichtingeneis in de weloverwogenheid van het verzoek hebben ingelezen.

$20 \%$ van de artsen geeft als reden op om over een medische beslissing rond het levenseilnde niet met de willsbekwame patiënt te overleggen, daar dat duidelijk het beste voor de patiënt was en $6 \%$ dat hem overleg meer schade dan goed zou hebben gedaan. ${ }^{4 * 6}$

In een aantal gevallen werd de patient door de arts niet in staat geacht tot een wilsbepaling omtrent de levensbeëindigende gedraging. De onderzoekers merken op dat over de criteria voor willsonbekwaamheid voor dergelijke besluiten nog weinig consensus bestaat. ${ }^{457}$

Al met al ils uit het onderzoek niet goed op te maken of op de instemming van de patiënt in die mate wordt gelet als mogelijk is. Voor zover de wetgever (eu)thanasie wil regelen, ligt hier woor hem een taak.

Verder blijkt, dat medici in verreweg de meeste gevallen (70\%) ten onrechte meedelen dat de patiënt een natuurlijke dood is gestorven. Voor het onjuist invullen van de overlijdensverklaring worden als redenen vooral opgegeven, dat de nabestaanden door een justitieel onderzoek te veel worden belast, het gevaar voor strafrechtelijke vervolging, en de juridische "rompslomp" in het algemeen. Deze redenen worden eveneens genoemd als bezwaar tegen een strafrechtelijke afdoening van euthanasie.

In alle gevallen van Jevenswerkortende pijnbestrijding werd een overlijdensverklaring afgegeven. In verreweg de meeste gevallen (meer dan 90\%) omdat naar de mening van de arts een naturlijke dood had plaatsgehad. ${ }^{458}$

$22 \%$ van de artsen is onder geen enkele voorwaarde bereid euthanasie als zodanig te melden bij politie, lijkschouwer of justitie. Van de artsen die zich voor een toetsing uitspreken, zijn $30 \%$ van mening dat de toetsing door het OM dient plaats te vinden,

453. Conumissie Ondlerzoek Medische Praktijk inzake Euthanasie, Rapport, 1991, p. 33.

454 Conmissie Onderzoek Medusche Praktijk inzake Euthanasie, Rapport, 1991, p. 32-33.

455 Commissie Onderzoek Medische Praktijk inzake Euthanasie, Onderzoek, 1991, p. 110.

456 Commissie Onderzoek Medische Praktijk inzake Euthanasie, Onderzoek, 1991, p. 110.

457 Commissie Onderzoek Medische Praktijk inzake Euthanasie, Onderzoek, 1991, p. 16.

458 Commissie Onderzoek Medische Praktijk inzake Euthanasie, Onderzoek, 1991, p. 60 . 
3\% spreken zich voor de gemeentelijke lijkschouwer uit en 37\% woor de geneeskundig inspecteur. 459

Volgens de huidige strafrechtelijke situatie is euthanasie strafbaar, tenzij in noodtoestand is gehandeld. Voor handhaving van de huidige situatie spreken zich $8 \%$ van de artsen uit. $66 \%$ heeft een voorkeur voor het initiatiefvoorstel, volgens welk euthanasie gerechtvaardigd kan zijn. $12 \%$ van de artsen voelt voor de benadering die in het kabinetsvoorstel is gekozen en kan zich derhalve vinden in een schulduitsluitingsgrond voor euthanasie. ${ }^{40}$

De Commissie is van mening dat de voor euthanasie vereiste zorgwuldigheidseisen ook zouden moeten gelden voor andere thanatische gedragingen. Zeer groot belang hecht zij daarbij aan de consultatie en het schriftelijk verslag. ${ }^{461}$ In het algemeen worden de bekende zorgvuldigheidseisen redelijk nageleefd. Bij de twee in verband met de toetsbaarheid belangrijkste, namelijk het consult en wooral de journaalverplichting, schort het daar nogall aan.

Met name beveelt de Commissie-Remmelink aan de meldingprocedure te bestendigen en uit te breiden tot actief levensbeëindigend handelen zonder verzoek en meer aandacht te schenken aan het verplichtend karakter van het consult en van het journaal.

\subsection{Het kabinetsstandpunt inzake medische beslissingen rond het levenseinde}

Als taak wan de overheid bij medische beslissingen rond het levenseinde ziet het kabinet in zijn standpunt van 8 november 1991

"dat zij verantwoordelijkheid aanvaardt voor een effectieve beseherming van het menselijk leven, ook in zijn kwetsbare slotfase. Daarnaast dient de overheid zich rekenschap te geven van de wens van patiënten om waardig te sterven en ondraaglijk lijden te bekorten en deze wens serieus te nemen."

In de concept-nota van toelichting wordt opgemerkt, dat de in het standpunt voorgestelde regelling een vastlegging is van de sinds 1 november 1990 geldende meldingsprocedure voor gevallen van euthanasie en hulp bij zelfdoding. Via deze procedure kan elk gemeld geval door het $\mathrm{OM}$ getoetst worden aan de geldende wettelijke norm en aan de uitleg die daaraan in de jurisprudentie wordt gegeven. Volgens het kabinet bevordert de meldingsprocedure dat de vereisten voor zorgvuldig medisch handelen "daadwerkelijk $k^{\text {" }}$ in acht worden genomen.

Anders dan de Commissie-Remmelink beschouwt het kabinet de actieve levensbeeindiging niet als normaal medisch handelen. Het merkt op dat deze gedraging in de jurisprudentie in het algemeen niet aanvaard is en acht het daarom gewenst dat de rechter zich hierover nader kan uitspreken. "In elk geval dient de toetsbaarheid van zodanig handelen ten volle verzekerd te blijven". Daarom heeft de meldingprocedure ook hierop betrekking.

Uit het onderzoek blijkt dat artsen terughoudend zijin om euthanasie te melden. $24 \%$ geeft op dat zij euthanasie wil melden indien de melding niet leidt tot vervolging en

459 Commissie Medische Praktijk inzake Euthanasie, Onderzoek, 1991, p. 81.

460 Commissie Onderzoek Medische Praktijk inzake Euthanasie, Onderzoek, 1991, p. 85.

461 Commissie Onderzoek Medische Praktijk inzake Euthanasie, Rapport, 1991, p. 34. 
$22 \%$ geeft aan dat zij onder geen enkele voorwarde euthanasie wil melden. Slechts $20 \%$ is bereid euthanasie te melden indien een gewijzigde procedure voor het melden wordt gevolgd. Naar hun bereidheid om gevallen van actieve levensbeeindiging te melden werd niet gevraagd.

Volgens de in het kabinetsstandpunt woorgestelde procedure dient de ants de gemeentelijke lijkschouwer te informeren, indien hil geen verklaring van natuurlijk overlijden afgeeft. Bovendien moet hij in geval van euthanasie of actieve levensbeëindiging zonder verzoek een ingevulde vragenlijst aan de lijkschouwer opsturen. De lijkschouwer beoordeelt of is voldaan aan de zorgvuldigheidseisen. Dat oordeel maakt hij bekend aan de OwI. Deze toetst aan de wettelijke normen en aan de uitleg die daarvan in de jurisprudentie wordt gegeven. Indien de OWJ twijfels heeft over de ware toedracht dient hij contact op te nemen met de regionaal inspecteur van het Staatstoezicht op de Volksgezondheid. Het laatste zal via richtlijnen gestalte krijgen.

De mellingsprocedure wordt gekoppeld aan de Wet op de Lijkbezorging. Art. 7 WLB luidt:

"1. Hij die de schouwing heeft verricht geeft een verklaring van overlijden af, indien hij overtuigd is, dat de dood is ingetreden ten gevolge van een natuurlijke oorzaak. 2. Indien de behandelende geneeskundige meent niet tot afgifte van een verklaring van overlijden te kunnen overgaan, deelt hij dit onverwijld mede aan de gemeentelijke lijkschouwer..."

en art. 10 WLB:

"Indien de gemeentelijke lijkschowwer meent niet tot afgifte van een verklaring van overlijden te kunnen overgaan, brengt hij onverwijld verslag uit aan de officier van justitie door invulling van een door Onze Minister van Justitie vastgesteld formulier en waarschuwt hij bovendien onverwijld de ambtenaar van de burgerlijke stand." Het kabinet stelt voor art. 10 WLB in die zin te wijzigen dat het daarin genoemde formulier niet door Onze Minister van Justitie, mair bij algemene maatregel van bestuur wordt vastgesteld.

In dit formulier dient de gemeentelijke lijkschouwer ondermeer te verklaren dat de behandelende arts van de overledene hem heeft meegedeeld dat de dood is ingetreden ten gevolge van de uitvoering van euthanasie of het verlenen van hulp bij zelfdoding of het actief medisch ingrijpen ter bekorting van het leven zonder uitdrukkelijk verzoek. Dit formulier is derhalve bedoeld voor gevallen waarbij de medicus rechtstreeks levensbeelindigend heeft gehandeld of daarbij heeft geholpen. Het is niet bedoeld voor gevallen waarin de behandeling werd nagelaten, omdat deze als medisch zinloos werd beschouwd of omdat de patiênt toestemming tot behandeling heeft geweigerd of een gegeven toestemming heeft ingetrokken. Daarvoor spreekt dat in deze gevallen het overlijden gevolg is van een naturlijke doodsoorzaak. Daartegen spreekt dat daarmee deze gedragingen aan toetsing onttrokken zijn. Bovendien kan ook in deze gevallen van een medische beslissing inzake het levenseinde worden gesproken.

Evenmin geldt deze meldingsprocedure voor gevallen van levensverkortende pijnbestrijding. Maar in dat geval is er wel sprake van een niet-natuurlijk overlijden, zoals ondermeer de Commissie-Remmelink heeft opgemerkt.

In het formulier verklaart de gemeentelijk lijkschouwer eveneens dat hij van de behandelnd arts heeft ontvangen "een door laatstgenoemde beredeneerd en volledig ingevulde lijst met aandachtspunten, bedoeld in de Bijlage, die een onderdeel vormt van dit besluit". 
De genoemde lijst moet door de behandelend arts worden ingevuld in geval van euthanasie, hullp bij zelfdoding of levensbeëindiging zonder verzoek.

De lijst van aandachtspunten omvat vijf rubrieken. Er worden vragen gesteld over de ziektegeschiedenis, over het vrijwillig verzoek tot levensbeêindiging, over het actief ingrijpen ter bekorting van het leven zonder uitdrukkelijk verzoek, over de consultatie van een collega-arts en over de toepassing van de levensbeëindiging.

Het kabinet benadrukt het belang van de toetsbaarheid van levensbeëindigend medisch handelen:

"De toetsbaarheid van het levensbeëindigend medisch handelen (moet) onverkort verzekerd (...$)$ blijven. Omwille van de effectieve bescherming van het menselijk leven past het, die toetsing zo nodig in het uiterste geval in een strafrechtelijk kader te doen plaatsvinden".

\subsection{Samenuatting}

De voorstellen tot wijziging van de artt. 293 en 294 Sr behelzen een erkenning van schijngestalten van euthanasie en dragen daardoor bij tot een betere afbakening van verschillende vormen van thanasie ten opzichte van elkaar. De schijngestalten worden beschouwd als normaal medisch handelen. Alleen het initiatiefvoorstel maakt op dit punt voorbehouden.

Alle voorstellen leggen veel nadruk op procedurele en zorgvuldigheidseisen, terwijl de materiele norm weinig houvast biedt:

In het advies van de Staatscommissie Euthanasie, het initiatiefvoorstel en de Proeve wordt voorgesteld onder bepaalde voorwaarden euthanasie en hulp bij zelfdoding door een arts van straf uit te sluiten. Dat willen de Staatscommissie Euthanasie en het initiatiefwoorstel met behulp van een rechtvaardigingsgrond en de Proeve met een zogenaamde schulduitsluitingsgrond bereiken.

Een wettelijke regeling waarbij onder bepaalde voorwaarden euthanasie vanwege een bijzondere rechtvaardigingsgrond of eem bijzondere schulduitsluitingsgrond straffeloos mag geschieden, is vermoedelijk niet in strijd met art. 2 EVRM. Alleen in de minderheidsnota van de Staatscommissie wordt verdedigd dat een euthanasieregeling daarmee in strijd is als de straffeloosheid op een bijzondere rechtvaardigingsgrond berust.

Volgens de Staatscommissie en het unitiatiefvoorstel moet de patiênt in een uitzichtloze noodsituatie verkeren, die door een lichamelijk of geestelijk lijden veroorzaakt kan zijn. De Proeve stelt de eis dat de patiênt in de stervensfase verkeert en verdere medische behandelling geen enkel redelijk doel voor de patiënt meer dient. Daardoor worden euthanasie en hulp bij zelfdoding in wezen slechts toelatatbaar geacht, wanneer medisch handelen zinloos is geworden.

Slechts op verzoek mag tot de desbetreffende gedragingen worden overgegaan. Het verzoek is alleen dan rechtsgeldig, als de patiënt op grond van toereikende informatie beslist. In verband daarmee wordt aan de arts de eis gesteld, dat hij de patiënt behoorlijk voorlicht:

Het initiatiefvoorstel en de Staatscommissie Euthanasie kennen a an een euthanasieverklaring in principe evenveel gewicht toe als aan een mondelinge wilsuiting, voor zover de patiënt daartoe niet meer in staat is. De Proeve is ook op dit punt terughoudender. 
De Staatscommissie laat de beslissingsbevoegdheid van minderjarigen afhangen van hun oordeelswermogen. Het initiatiefvoorstel en de Proeve spreken zich voor een vetorecht van de wettelijke vertegenwoordiger uit.

Volgens de Staatscommissie en het kabinetsvoorstel moet het besluit tot euthanasie en hulp bij zelfdoding door de patiënt en de arts gezamenlijk worden genomen. De eis van gezamenlijke besluitvorming doet denken aan de WAZ. Het initiatiefvoorstell en de Proeve zien het besluit van de patient en dat van de arts meer als twee afzonderlijke gegevens.

Alle drie de voorstellen stellen consultatie en het bijhouden van een journaal verplicht. Het belang van deze eisen blijkt daaruit dat niet-nakoming een zelfstandig misdrijf of een overtreding van het hoofddelict oplevert:

Euthanasie en hilp bij zelfdoding mogen slechts door een arts worden verricht. De gedragingen zijn in een medisch kader geplaatst, dat voor de vereiste zorgvuldigheid dient te zorgen. De arts is volgens de Proeve en het initiatiefvoorstel tot verslaglegging gehouden en tot het zenden van een verklaring van overlijden in de zin van deze regelingen aan de Gemeentelijke lijkschouwer.

Volgens alle drie de voorstellen gelden ten aanzien van hulp bij zelfdoding in het algemeen dezelfde voorwaarden als voor euthanasie. Het initiatiefvoorstel wil ten aanzien van de strafbarrstelling een verschil maken tussen het behulpzaam zijn en het middelen verschaffen enerzijds en het aanzetten tot zelfdoding anderzijds.

Anders dan de regeling voor de afbreking van de zwangerschap zal, op één uitzondering na, de volledige regeling voor (hulp bij) levensbeëindiging op verzoek in het WvSr worden opgenomen. Dat leidt soms tot problemen ten aanzien van met de thanasie verband houdende, maar zelfstandig strafbaar gestelde strafbare feiten, zoals de journaalverplichting en het opzenden van de verklaring van overlijden, omdat het karakter van de betreffende strafbepalingen onduidelijk is. Bovendien verdraagt een uitgewerkte regeling voor een specifieke beroepsgroep zich niet met het karakter van het WvSr. Dat blijkt onder andere uit de zojuist genoemde problematiek en uit het opnemen van behoorlijkheidseisen in de regeling.

Het kabinetswoorstel wijkt qua structuur af van de andere voorstellen. Volgens dat voorstel wordt in het WvSr volstaan met een wijziging van de artt. 293 en $294 \mathrm{Sr}$, terwij] procedurele en zorgvuldigheidseisen in de WUG zullen komen. Terwijl meestal de straffeloosheid bereikt zal worden via een bijzondere rechtvaardigingsgrond en de Proeve in een bijzondere schulduitshuitingsgrond voorziet, is in het kabinetsvoorstel geen strafuitsluitingsgrond opgenomen. De overmachtsbepaling, ant. $40 \mathrm{Sr}_{n}$ wordt in dat voorstel toereikend geacht om straffeloosheid te bereiken. In de andere voorstellen zijn de zorgvuldigheidseisen in beginsel dwingende voorwaarden voor effectuering van de bijzondere strafuitsluitingsgrond. In het kabinetsvoorstel zijn deze als vingerwijzingen bedoeld.

Uit het rappont van de Commissie Remmelink kan worden opgemaakt dat het aantal euthanasie-gevallen in Nederland relatief kleim is. Daarentegen geschiedt het afzien van medisch zinloos handelen en levensverkortende pijnbestrijding relatief vaak. Dat werpt de vraag op, of niet vooral ten aanzien van deze thanatische gedragingen een wettelijke regeling nodig is. Een summiere omschrijving in een negatieve bepaling kan hier legitimerend en grensverleggend werken. Dat geldt met name voor de levensverkortende pijnbestrijding. Daarom zou de straffeloosheid van het afzien van medisch zinloos handelen en van de levensverkortende pijnbestrijding aan bepaalde voorwaarden moeten worden gebonden, voor zover althans aan een negatieve bepaling wordt vastgehouden. Het is 
echter wel de vraag of een wettelijke regeling enerzijds voldoende nawwkeurig kan zijn en anderzijds voor dergelijke problemen de noodzakelijke nuimte kan laten.

Het aantal gevallen van actieve levensbeëindiging, maar tevens de onzekertheid over de betrouwbaarheid van dit aantal en de onduidelijkheid ower de criteria op grond warvan deze handeling geoorloofd zou kunnen zijn, pleiten voor nader onderzoek. Dat is eveneens wenselijk in verband met de levensverkortende pijnbestrijding en het nalaten van medisch zinloos handelen, omdat het onderzoek hierover onvoldoende duidelijkheid verschaft.

Het kabinetsstandpunt onthoudt zich van een keuze omtrent het wel of niet mogen nemen van een medische beslissing rond het levenseinde. Het verwijst daartoe naar de in de jurisprudentie ontwikkelde criteria. Voor zover deze ontbreken vertrouwt het op toekomstige rechtspraak. Verwacht moet echter worden dat de meeste gevallen de rechter niet zullen bereiken.

De belangrijkste rol in de meldingsprocedure wordt toebedeeld aan het Openbaar Ministerie. In wezen wordt levensbeëindligend handelen daarmee onderworpen aan een sepotbeleid.

\section{Strafuitsluiting bij euthanasie}

\subsection{Inleiding}

In het hierna volgende wordt onderzocht in hoeverre euthanasie door een arts, onder de bestaande wetgeving tot strafrechtelijke aansprakelijkheid leidt en op welke wijze straffeloosheid kan worden bereikt.

Op de mogelijkheden die de voorgestelde regelingen voor strafuitsluiting bieden; wordt hier verder niet ingegaan. Dat is minder zinvol, zolang het onduidelijk is of het überhaupt tot wetswijziging komt. Wanneer het tot een regeling komt, zoals in het kabinetsstandpunt voorgesteld, dan is strafuitsluiting mogelijk vanwege noodtoestand. Op deze rechtvaardigingsgrond wordt in verband met euthanasie hieronder ingegaan.

Voor de uitsluiting van de strafrechtelijike aansprakelijkheid onder de bestaande wetgeving is de gepubliceerde jurisprudentie, die vanaf 1973 in redelijke mate voorhanden is, de voomaamste bron. Vòr die tijd is deze beperkt tot een uitspraak van de Rb. Amsterdam in $1908^{462}$, gevolgd door en uitspratak van dezelfide rechtbank in $1909^{463}$, een arrest van de Hoge Raad in $1944^{464}$ en een vonnis van de rechtbank Utrecht in $1952^{465}$. Slechts de laatste uitspraak heeft rechtstreeks betrekking op euthanasie.

Begonnen wordt met een onderzoek nar de mogelijkheden die een taalkundige interpretatie van de delictsomschrijwing biedt. Vervolgens worden verschillende variaties van het ontbreken van de materiële wederrechtelijkheid besproken. De medische exceptie, die als verbijzondering van het ontbreken van de materięle wederrechtelijkheid kan worden beschouwd, komt daarna ter sprake. Hoewel het onderzoek gericht is op de mogelijke rechtvaardiging van de betreffende feiten, worden na de noodtoestand enkele aspecten van de psychische overmacht besproken. In de juridische praktijk is de grens tussen deze varianten van overmacht vloeiend. 
Vooral in de lagere rechtspraak zijn voorwaarden voot gerechtvaandigde euthanasie geformuleerd. Deze worden systematisch behandeld. Daama wordt nagegaan welke warde de Hoge Raad aan dergelijke voorwaarden toekent. Tenslotte wordt aandacht besteed aan het vervolgingsbeleid inzake euthanasie.

\subsection{De gedraging voldoet niet aan de bewoordingen wan de delictsomschrijving}

\subsubsection{Inleiding}

Pleegt een aris die een ondraaglijk lijdende patiënt op diens uitdrukkelijk en ernstig verzoek doodt de in art. $293 \mathrm{Sr}$ omschreven "levensberoving op verzoek"? Als we naar de tekst van art. $293 \mathrm{Sr}$ kijken, dan heeft de arts aan alle bestanddelen voldaan. Mar is de tekst zo cenduidig of laat hij verschillende interpretaties toe? Is de delictsomschrijving van art. $293 \mathrm{Sr}$ wel voor deze gevallen bedoeld? De delictsomschrijving van art. $293 \mathrm{Sr}$ biedt verschillende mogelijkheden voor een kwalificatieverweer door een arts.

Hij kan stellen:

1. dat zijn handelen niet beantwoordt aan de bewoordingen van de delictsomschrijving,

2. dat de wetgever euthanasie door een arts niet daaronder wilde laten vallen, zonder dat met zoveell woorden uit de delictsomschrijwing zelf te laten blijken,

3. dat euthanasie wel aan de delictsomschrijving beantwoordt en aan de bedoeling die de wetgever met de strafbaarstelling vervolgde, maar dat euthanasie door de samenleving wiet (langer) als strafwaardige gedraging wordt beschouwd.

Dit zijn drie mogelijkheden om te stellen dat ontslag van alle rechtsvervolging moet volgen, omdat het bewezenverklaarde feil niet te kwalificeren en daarmee niet stratbaar is. Maar wat in wezen een kwalificatieverweer is, leidt bij de gebruikelijke wijze van ten laste leggen tot ontkenning van het telastegelegde. De telastelegging leunt immers in het algemeen dicht tegen de delictsomschrijving aan, omdat bestanddelen van een delictsomschrijving in de telastelegging zo veel mogelijk letterlijk worden verwerkt. Als een andere intepretatie van een woord dat zowel in de delictsomschrijving als in de telastelegging wordt gebezigd, tot een beperktere uitleg leidt, dan kan dat meebrengen dat de telastelegging niet bewezen kan worden en vrijspraak moet volgen.

In dit onderdeel staat de taalkundige interpretatie van de delictsomschrijving centraal. Het is weliswaar niet goed mogelijk daarbij geheel voorbij te gaan aan de twee andere, genoemde vormen van kwalificatieverweren. Daartoe bestaan er te veel onderlinge overlappingen ${ }^{467}$ Beroepen op de bedoeling van de wetgever en op een gewijzigde maatschappelijke opvatting horen echter systematisch eerder thuis bij de bespreking van het ontbreken van de materiële wederrechtelijkheid en worden derhalve daar besproken.

\subsection{2 "Van het leven beroven"}

In art. $293 \mathrm{Sr}$ biedt thet bestanddeel "van het leven beroven" ruimte voor een talkundige interpretatie. Art. $293 \mathrm{Sr}$ stelt strafbarar een ander op diens verzoek van het leven beroven.

466 Dat is slechts mogelijk als een begrip in de delictsomschrijving niet een uitsluitend kwallicatieve bete kenis heeft.

467 Vgl. Van Veen, RR 1980 p. 14. 
Het woord "beroven" klinkt negatief en agressief. Wie jemand van jets beroof, neemt wan degene in het algemeen iets weg, wat deze niet wil prijsgeven en waartegen hij zich wellicht verzet. In euthanasiezaken is langs meerdere wegen gepoogd om aankmopend bij de negatieve notie van het woord "beroven" tot een vrijspraak te komen.

In de zaak die leidde tot het Euthanasie 1-arrest ${ }^{469}$, werd door de verdediging voor de rechtbank Alkmaar" 470 aangevoerd, dat de handeling van de huisarts niet als "van het leven beroven" kan worden aangemerkt, aangezien bij hem een voor levensbeëindiging noodzakelijk "actief en opzettelijk" element ontbrak. Kennelijk werd daarmee bedoeld dat voor levensberoving in de zin van art. $293 \mathrm{Sr}$ is vereist dat het doden op een agressieve wijze geschiedt en het opzet gericht is op deze wijze van handelen, respectievelijk dat met boos opzet moet worden gehandeld. Daarentegen had de arts welbewust juilst ean zachte dood teweeg gebracht.

De rechtbank verwierp het verweer met de overwegingen dat "van het leven beroven" in art. $293 \mathrm{Sr}$ synoniem is aan "doden" of "doen sterven" en dat de wetgever van 1881 een actieve en opzettelijke handelling in de betekenis die de verdediging daaraan heeft gegeven, niet noodzakelijk achtte. Elke opzettelijke dodingshandeling komt voor art. $293 \mathrm{Sr}$ in aanmerking.

Voor het hof Amsterdam ${ }^{471}$ werd het verweer herhaald met de toevoeging dat bovendien is vereist "een handelen dat min of meer geschiedt tegen de zin van de "behandelde"

Zoals het verweer in de NJ is weergegeven, is het reeds op het eerste gezicht tegenstrijdig met het bestanddeel "op diens uitdrukkelijk en emstig verlangen". De tegenstrijdigheid wordt niet weggenomen in een artikel van de raadsman in deze zaak, waarin hij opmerkt:

"Een taalkundige uitleg van het begrip levensberoving veronderstell iets opzettelijks of wederrechtelijks, dat ontbreekt bij levensverkorting op eigen verzoek waarbij immers de hand van de arts de manus ministra is van zijn patiênt. Levensberoving geschiedt niet alleen tegen de zin van de beroofde, maar bovendien gat van de berover zelf iets actiefs, opzettelijks en wederrechtelijiks uit" ${ }^{172}$

Het lijkt mij waarschijnlijk dat met het verweer getracht werd tot uitdrukking te brengen dat voor levensberoving nodig is dat de dodingshandeling indinist tegen het respect voor het leven van een ander of, anders gezegd dat de dodingshandeling niet tegen het belang van de ander gericht mag zijn.

Het hof volstond ter verwerping van het verweer met de constatering dat wan het leven beroven in art. $293 \mathrm{Sr}$ niets anders betekent dan het leven benemen en het derhalve niet ter zake doet op wellke wijze of met welke intentie gehandeld wordt.

468 Zie ook: Van Binsbergen, DD 1974, p. 464-465.

469 HR 27 nov. 1984, NJ 1985, 106 m.nt. ThWvV.

470 Rb. Alkmaar 10 mel 1983, NJ 1983, 407.

471 Hor Amsterdan 17 nov. 1983, NJ 1984, 43.

472 Sutorius, NJB 1984, p. S5-56. Volgens de A-G Schalken, NJB 1984, p. 41, hield het betoog van de raadsman woor de rechubank Alkmaar in, dat bij de arts de eerbied woor het menselijk leven miet heeft ontbroken. Door de patient een zachte dood op verzoek te bezorgen, heeft hij juist de door de wetgever bedoelde eerbied getoond. Dat zow de rechtbank niet weerlegd hebben met de door hat aangebaalde zinzmede uit de MVT. M.i. wordi hiermee de strekking van het verweer miskend, zoalls ook uilt de aangehaalde prissage en cle behandeling in volgende instanties blijkt. 
Voor de Hoge Raad ${ }^{43}$ in het Euthanasie I-arrest werd een derde benadering gekozen. In de toellichting op het verweer werd aangevoerd dat onder "van het leven beroven in art. $293 \mathrm{Sr}$ niet valt "een door een ants in het kader van zorgvuldig medisch handelen op grond van duurzaam lijden toegepaste levensbeëindiging". Met andere woorden: euthanasie lege artis door een arts is van de delictsomschrijving van art. 293 Sr uitgezonderd.

De cassatieadvocaat heeft hier de aandacht gevestigd op de interpretatie van de delicts:omschrijwing. Zoals hierna blijkt, kan met dezelfde inhoud ook een beroep op het ontbreken wan de materielle wederrechtelijkheid en de medische exceptie worden gedaan. Er besitaan, behalve langs de weg van de taalkundige interpretatie, twee mogelijkheden om een dergelijk verweer te voeren.

Geopperd kan worden dat de woorden in een delictsomschrijving beperkt geînterpreteerd dienen te worden om aan de bedoeling van de wetgever recht te doen. In de toelichting op het cassatiemiddel werd gesteld ${ }^{47}$ dat art. 293 Sr vooral ziet op de "impulsieve doodslager", waarmee aangeknoopt werd bij de negatieve notie van het woord "beroven". De arts die lege artis het leven op verzoek beëindigt kan niet als een impulsieve doodslager worden aangemerkt en daarom is de delictsomschrijving niet voor euthanasie door een arts geschreven.

Ook kan aangevoerd worden dat - verkort gezegd - de wetgever weliswaar euthanasie door een arts niet van art. $293 \mathrm{Sr}$ wilde uitzonderen, maar dat inmiddels de opvattingen in de samenleving hierover dusdanig zijn gewijzigd, dat aan die opvattingen gevolg dient te worden gegeven en niet aan de "verouderde" bedoeling van de wetgever. Voor art: $293 \mathrm{Sr}$ is daarbij van belang het recht op zelfbeschikking, door de cassatieadvocaat een "cruciaal onderdeel" van het eerste middel genoemd. ${ }^{475}$

De A-G Remmelink achtte het middel ongegrond. Hij was van mening dat indien de wetgever euthanasie lege artis door een arts van de delictsomschrijving wilde uitzonderen, hij daarvan, evenals bij abortus en mishandeling, melding zou hebben gemaakt. Hoewel hij in het algemeen niet uitsloot dat een gewijzigde maatschappelijke opvatting tot een van de bedoeling van de wetgever afwijkende interpretatie kan leiden, achtte hij ten aanzien van euthanasie de algemene opvatting onvoldoende uitgekristalliseerd. Bovendien bestreed hij de toelaatbaarheid van de bedoelde interpretatie, daar deze zijns inziens niet slechts tot een restrictie leidt maar contra legem gericht is.

De Hoge Raad verwierp in het voetspoor van de $\mathrm{A}-\mathrm{G}$ beide benaderingen. Hij bevestigde dat "beroven" in art. 293 Sr als synoniem aan "benemen" dient te worden begrepen. Daraan voorafgaand overwoog hij:

"Noch de wetsgeschiedenis - ....-, noch een gewijzigde maatschappelijke opvatting leveren grond op voor de juistheid van de primair in het middel verdedigde stelling, dat art. $293 \mathrm{Sr}$ beperkt moet worden uitgelegd in die zin, dat onder degene die cen ander op diens verzoek "van het leven berooft' niet kan worden begrepen de arts die in het kader van zorgvuldig medisch handelen het leven van een ander op diens verzoek beëindigt op grond van duurzaam lijden".

Van Veen haakt in zijn noot aan bij de wetsgeschiedenis en herinnert in verband hiermee aan de betekenis van de term "beroven" in andere delictsomschrijvingen:

473 HR 27 now. 1984, NJ 1985, 106 an.nt. ThWvV.

474 Plettnota, p. 32 (niet gepubliceerd).

475 Pleithotid, p. 36. 
Het woord beroven klinkt wel geladen met boze bedoelingen, maar men mag gezlen de wetsgeschiedenis niet op die klank afgaan. Ook elders wordt in het WvSr van vrijheidsberoving gesproken, waar duidelijk is dat niet meer dan vrijheidsbeneming wordt bedoeld. Zie bijv. art. 282 Sr waarin het opzettelijk wederrechtelijk van de vrijheid beroven strafbaar wordt gesteld. Kennelijk zit het "opzettelijk wederrechtelijk niet ingebakken in het woord beroven: Vrijheidsberoving is niet meer dan vrijheidsbeneming".

\subsection{3 "Van het leven benemen"}

De delictsomschrijving van art. $293 \mathrm{Sr}$ dient derhalve gelezen te worden als "... van het leven beneemt" . Deze formulering wordt ook gebezigd in de voorstellen tot wijziging van art. $293 \mathrm{Sr}$. Is het woord "benemen" in deze context zo eenduidig dat het niet geclausuleerd kan worden geïnterpreteerd?

De rechtbank Alkmaar, het hof Amsterdam, de Hoge Raad, de A-G Remmelink en de annotator Van Veen, vonden van wel. De rechterlijke instanties achtten dat kennelijk zo voor de hand liggend dat zij volstonden met een verwijzing naar het woord "benemen" als synoniem voor "beroven" in art. $293 \mathrm{Sr}$.

De A-G Remmelink merkte hierbij op, dat het zijn voorkeur heeft om voor de interpretatie van een delictsomschrijwing vast te houden aan de bewoordingen van de delictsomschrijving en de bedoeling van de wetgever. ${ }^{476}$

De vaststelling dat "beroven" in art. $293 \mathrm{Sr}$ niets anders betekent dan "benemen", is niet zonder meer toereikend om aan te tonen dat euthanasie lege artis door een arts onder de delictsomschrijving valt. Hoewel zich vooral normatief geladen begrippen voor een "creatieve interpretatie" lenen, kan ook een meer feitelijk begrip in het strafrecht. een van het alledaagse spraakgebruik afwijkende betekenis toegekend krijgen. Dat leidt bij extensieve interpretatie tot een uitbreiding van de betekenis en bij restrictieve interpretatie tot een beperking van de betekenis. Daarvan getuigen een aantal arresten over de grondslagproblematiek, Meer en Vaart-situaties en Dakdekker-verweren. ${ }^{477}$ In enkele van die arresten week de Hoge Raad ook meermalen af van de bedoeling van de wetgever, onder verwijzing naar veranderde opwattingen en inzichten. ${ }^{478}$ 't Hart merkt hierbij op:

"Is een tekst eenmaal tot stand gekomen, dan heeft hij een eigen zelfstandig leven dat niet steeds vanuit het verleden moet worden ingevuld, maar geactualiseerd kan worden naar de zich steeds vernieuwende contekst waarin de tekst een functie moet vervullen" ${ }^{40}$ :

Volgens ondermeer Schalken biedt art. $293 \mathrm{Sr}$ weinig ruimte voor een interpretatie die tot straffeloosheid van euthanasie leidt. Het verzoek, dat voorwaarde is voor de geoor-

476 Zie, in dezelfde zin, mu.b. "beroven" in art. 293 St: Van Veen ander HR 27 nov. 1984, NJ 1985, 106 m.nt. ThWwV; Van Veen, RR 1980, p. 6; Kelk, AA 1985, p. 337 en Schalken, in: Euthanasie, 1985, p. 124.

$477 \mathrm{Vgl}$. "t Hart onder HR 11 mei $1982, \mathrm{NJJ} 1982,583$.

478 Zie b.v. HR 18 juni 1985 , NJ $1986,183$.

479. "i Hart onder HR $11 \mathrm{okt}$. 1983, NJ 1984, 111. Zie b.v. ook "1 Hart onder HR 10 april 1984, NJ 1984 , 612. 
loofdheid van euthanasie, is juist bestandeel van de delictsomschrijving: "Bij een dergelijke duidelijkheid kan alleen de wetgever zijn bedoeling wijzigen" "*

Door te stellen dat het handelen van een arts die lege artis tot levensbeëindiging op verzoek overgaat niet onder de delictsomschrijwing valt, werd inhoudelijk gezien, tevens impliciet een beroep gedaan op de medische exceptie en het ontbreken van de materiêle wederrechtelijkheid. De aangehaalde overweging van de Hoge Raad geeft weing aanleiding om te veronderstellen dat hij welwillender staat tegenover beroepen op deze uitsluitingsgronden die verderop worden besproken.

\subsection{Ontbreken van de materiële wederrechtelijkheid}

\subsubsection{Inleiding}

Een beroep op het ontbreken wan de materiële wederrechtelijkheid kan de gedaante van een kwalificatieverweer aannemen of die van een exceptief verweer. ${ }^{481}$

Het ontbreken van de materiele wederrechtelijkheid als kwalificatieverweer betreft de interpretatie van de (strekking van de) delictsomschrijving. Dat brengt mee dat dit verweer de "creatieve interpretatie" overlapt.

Voor de bespreking van het ontbreken van de materiële wederrechtelijkheid bij euthanasie nemen het Euthanasie I-arrest ${ }^{482}$ en de daaraan voorafgaande rechterlijke uitspraken van de rechtbank Alkmaar en het hof Amsterdam ${ }^{483}$ een voorname plaats in.

\subsubsection{Betere naleving van de strekking van de wet}

In de meest gebruikelijke vorm komt het beroep op het ontbreken van de materiele wederrechtelijkheid erop neer dat met overtreding van de strafbepaling volgens haar bewoordingen het door de wetgever met de normstelling nagestreefde belang beter wordt nageleefd dan door het verbod letterlijk na te leven. In die opvatting bestaat een spanning tussen de tekst van de delictsomschrijving (het formele element) en de daaraan ten grondslag liggende norm (het materiêle element).

Bij euthanasile kan dit verweer geen succes hebben, want dat zou betekenen, dat het (onder bepalalde omsitandigheden) doden van lemand op diens verzoek juist datgene is wat de wetgever met de strafbarstelling van levensberoving op verzoek nastreefde.

De van hulp bij zelfdoding verdachte, die geen medicus was, berilep zich voor de rechtbank Utrecht ${ }^{484}$ op het ontbreken van de materiêle wederrechtelijkheid, daartoe wijzende op het ondraaglijk lijden van zijn echtgenote en aanvoerende dat hij juist eerbied voor haar lijden (en derhalve in wezen eerbied woor het menselijk leven) heeft getoond door haar bij de zelfmoord te helpen. Dit verweer komt neer op de stelling*

480 Schalken; wn: Euhanasie, 1985, p. 123-124.

481 Zie voor deze benadering: Var Veen, RR 1980, p. 1-22. Zie ook: Van Veen, DD 1975, p. 189-207 en p. 274-290. Zie cok: Vernunt, DD 1984, p. 109-120 en 712-724.

482. HR 27 now. 1984, NJ 1985, 106 nu.nt. "ThWwV.

483 Rb. Alknwar 10 mei 1983, NJ 1983, 407 en Hof Amsterdam 17 nov. 1983, NJ 1984, 43.

484 Rb. Utrecht 21 dec: 1982 , NJ 1983, 264. 
"A beëindigt het leven van $B$ uit eerbied voor diens leven, dus hij kan niet geacht worden hem in de zin van art. $293 \mathrm{Sr}$ te hebben gedood, in tegendeel hij heeft nu juist datgene gedaan wat de wetgever will". 485

De rechtbank venwierp het verweer met de overweging dat de rechter de innerlijke waarde van de wet niet mag beoordelen, daarmee impliciet naar art. 11 Wet AB verwijzend."

2.3.3 De materiële wederrechtelijkheid ontbreekt vanwege de rechtsontwikkeling

Met betrekking tot euthanasie kan een beroep op het ontbreken van de materiele wederrechtelijkheid inhouden dat de wettelijke norm van art. $293 \mathrm{Sr}$ thans onvoldoende steun in de samenleving ondervindt, of nog een stap verder, dat een meerderheid in de samenleving uitgaat van een met die norm contrariërende norm. ${ }^{487}$ Ten aanzien van euthanasie zou aan art. $293 \mathrm{Sr}$ een verouderde norm ten grondslag liggen. Of in de woorden van de rechtbank Alkmaar ${ }^{488}$ : "ook al levert die hulpverlening in formele zin een overtreding van art. 293 of art. 294 Sr op, de materiële wederrechtelijkheid kan ontbreken, indien en voor zover dat handelen rechtens niet als onwenselijk kan worden aangemerkt".

Dat roept de vraag op, wanneer een dergelijk handelen "rechtens niet als onwenselijk kan worden aangemerkt".

\section{De maatschappelijke aanvaarding van het zelfbeschikkingsrecht ${ }^{499}$}

De rechtbank Alkmaar ${ }^{490}$ anderbouwde het rechtens niet onwenselijke handelen met een verwijzing naar de maatschappelijke aanvaarding van het zelfbeschikkingsrecht ter zake van de beëindiging van het eigen leven. Van die aanvaarding ging ook de rechtbank Rotterdam ${ }^{491}$. uit, om zo eveneens het zelfbeschikkingsrecht te accentueren: "dat de beslissing van degene, die zijn leven wil beëindigen, viteindielijk gerespecteerd dient te worden".

Voor het hof Leeuwarden ${ }^{402}$ werd door de verdediging aangevoerd, dat gehandeld was overeenkomstig de eisen die in enkele rechterlijke uitspraken aan het geoorloofd toepassen van euthanasie worden gesteld: Het hof Leeuwarden verwierp het verweer op een wijze die overeenkomst vertoont met de hieronder te bespreken verwerping door het hof Amsterdam ${ }^{193}$. Het hof Leeuwarden overwoog:

"(I)n aanmerking genomen, dat het vraagstuk van de euthanasie thans in studie is bij een bij KB van 8 okt. 1982 ingestelde Staatscommissie, naar "s Hols oordeel. thans nog niet kan worden gesproken van een reeds voldoende witgekristalliseerde

485 Aldus de A-G Remmelink in zijn conclusie wö̀r HR 27 nov. 1984, NJ 1985, 106 m.nt. ThWwV.

486 In dezelfde zin: Rb. Groningen 1 maart 1984, NJ 1984, 450.

487 Onder een contrariënende norm verstat Remmelink een (ongeschrewen) norm nit de positieve rechtsorde die alls rechlwardigingsgrond werkl. Zie: Hazewinkel-Suringa/Remmelink, 1991 , p. 329

$488 \mathrm{Rb}$. Alkmaar 10 mei 1983, NJ 1983, 407.

489 Op het zelfbeschikkingsrecht wordt hier slechts als juridisch argiment in verband metl het ontbreken van de materiele wederrechtelijkheid ingegaan.

$490 \mathrm{Rb}$. Alkmaar 10 mei 1983 , NJ $1983,407$.

49 1. Rb. Rotterdam 1 dec 1981, NJ 1982, 63.

492 Hof Leeuwarden 11 okl. 1984, NJ 1985, 241.

493 Hof Amsterdan 17 nov. 1983, NJ 1984, 43. 
algemene opvatting, op grond waarvan euthanasie in actieve, directe vorm, zoals door verdachte toegepast - met terzijdestelling wan art. $293 \mathrm{Sr}$ - als algemeen maatschappelijk aanvaardbaar kan worden beschouwd, ook niet wanneer deze ín genoemde vorm wordt toegepast overeenkomstig de normen, die verdachte aan enkele rechterlijke uitspraken meent te kunnen ontlenen".

De omvang en de invloed van de maatschappelijke aamvaarding van het zelfbeschikdingsrecht

Op welk moment kan gesproken worden van een "voldoende uitgekristalliseerde algemene opvatting"? Met andere woorden: hoe groot behoort de maatschappelijke aanvaarding van het zelfbeschikkingsrecht te zijn om de materiële wederrechtelijkheid te laten ontbreken? De rechtbank Alkmaar en de rechtbank Rotterdam" ${ }^{494}$ spraken van "steeds bredere kring(en $)^{\text {n. }}$. De rechtbank Rotterdam erkende dat recht niet onverkort, maar beperkte het tof "uitzonderlijke" gevallen, zodat zij als het ware de aldus ingevulde materiële wederrechtelijkheid aan de noodtoestand koppelde. ${ }^{495}$

Het hof Amsterdam ${ }^{496}$ erkende weliswaar een wijziging in de maatschappelijk opvattingen ten gunste van euthanasie, maar oordeelde dat er te dezen nog geen sprake was van een "voldoende uitgekristalliseerde algemene opvatting". Dat leidde het hof af uit het feit dlat het vanwege de aan euthanasie verbonden "evidente gevaren" gecompliceerde vraagstuk ten tijde van de behandeling van de zaak in studie was bij de Staatscommissie Euthanasie. ${ }^{497}$

De A-G Remmelink ${ }^{498}$ merkte ten aanzien van art. 293 Sr op dat "in ons rechtsleven .... zo'n strafbepaling als element functioneren moet" ". Dat brengt volgens hem mee, dat voor de aanvaardbaarheid van een "interveniërende of contrariërende norm" ten aanzien van art. 293 Sr meer nodig is, dan een "zich in meerderheid al of niet ergeren aan blootheden e.d. waarvan in de norm van art. $240 \mathrm{Sr}$ sprake is. ${ }^{499}$ Bij dat "meer" denkt hij aan opvattingen van "gezaghebbende schrijvers" en aan "gewoonte, rechtspraak, algemeen aanvaarde beginselen, tuchtrechtspraak, parlementaire meerderheid, administratiefrechtelijke praktijk enz.".

Het bezwaar dat Van Veen ${ }^{500}$ tegen de maatschappelijke aanvaardbaarheid naar woren brengt, heeft een ruimere strekking. Hij voelt er kennelijk niet voor, dat een contrariërende norm die op maatschappelijke aanvaarding steunt, een wetsbepaling buiten spel zet. Daar het woord "beroven" in art. $293 \mathrm{Sr}$ begrepen moet worden als "benemen", "valt euthanasie onder de delictsomschrijving van art. $293 \mathrm{Sr}$. Daaruit vloeit voort, dat de argumenten om niet te straffen ontleend moeten worden aan de uitzonderlijke omstandigheden, waaronder een levensberoving op verzoek heeft plaatsgevonden".

494 Rb. Alkmatr 10 meil 1983, NJ 1983, 407, en de RB. Rotterdam l dec. 1981, NJ 1982, 63.

495 Vermoedelijk daaron theeft zij het beroep op het O.M.W. en op noodioestand tezamen besproken.

496 Hof Amsterdam 17 nov. 1983, NJ 1984; 43.

497 Stuatscommissie Euthanasie, bij $\mathrm{KB}$ van 8 okt. 1982 ingesteld.

498 A.G Remmelink vöor HR 27 nov. 1984, NJ 1985, 106 m.nt. ThWvV.

499 Bij de interpretatie van de aanstotelijkheid van de eerbaarheid, waarvan art. $240 \mathrm{sr}$ spreekt, heeft de Hoge Raad de norm beperkt gelezen, vanwwege gewijzigde maatschappelijke opvattingen, steunend op een belangrijke meeraterheid in de Nederlandse bevolking. Vgl. A-G Remmelük vò̀r HR 27 nov. 1984, NJ 1985,
$106 \mathrm{m.nt}$. ThWVV.

500 Onder HR 27 nov. 1984, NJ 1985, 106. 
Schaffmeister en Heijder hebben voorgesteld dat de rechter zich reeds bij de wraag of een gedraging aan een delictsomschrijving beantwoordt, dient af te vragen of de gedraging wederrechtelijk is. ${ }^{501}$ De wederrechtelijkheid wordt derhalve door hen als een impliciet bestanddeel beschouwd. Zij noemen dit de concretisering van de wederrechtelijkheid.

In de Euthanasie I-zaak ${ }^{502}$ werd door de verdediging aangeknoopt bij de benadering van Schaffineister en Heijder en tevens - materieel daarmee verband houdend - bij het ontbreken van de materiële wederrechtelijkheid. In de toelichting op het eerste cassatiemiddel $^{503}$ werd gewezen op de norm die ten grondslag ligt aan art. $293 \mathrm{Sr}$ : de eerbied voor het leven. Volgens de cassatieadvocaat houdt die norm tevens eerbied woor het sterven in, daar het stervensproces een deel van het leven is. Bij euthanasie handelt een arts uit eerbied voor het sterven. Volgens deze creatieve interpretatie van de delictsomschrijving van art. $293 \mathrm{Sr}$ werd met de litigeuze gedraging aan de bedoelingen van de wetgever juist recht gedaan.

Het hof Amsterdam zou volgens het middel ten onrechte hebben nagelaten de afweging tie maken op, wat Schaffmeister en Heijder het eerste niveau noemen, het niveau van het strafrecht. De verdediging was van mening dat de in de delictsomschrijying van art. 293 Sr geïmpliceerde norm, namelijk de eerbied voor het leven in het algemeen, in casu niet was geschonden.

Evenmin had het hof, aldus het middel, een afweging op het tweede niveau, de normen van andere rechtsgebieden, gemaakt. Die afweging had moeten inhouden "of de regeling van de geschonden norm en haar interpretatie in het strafrecht als ook in het gezondlheidsrecht, waaronder i.c. in bijzonder het medisch tuchtrecht wordt begrepen, zich al dan niet verzetten tegen aanvaarding" van het beroep op het ontbreken van de materiële wederrechtelijkheid.

Reeds bij de bespreking van de "concretisering van de wederrechtelijkheid" van Schaffmeister en Heijder in het eerste hoofdstuk blijkt dat Remmelink slechts in zeer uitzonderlijke omstandigheden voor hun benadering voelt. Maar daarvan is volgens hem, zo merkt hij als A-G op, bij euthanasie geen sprake, daar door euthanasie het door de norm beschermde belang of rechtsgoed juist wel wordt geschonden. ${ }^{504}$ Daarom acht hij een arts die lege artis euthanasie toepast in beginsel aansprakelijk:

${ }^{\text {" }}$ Met de wetgever acht ik het volkomen aanvaardbaar, dat ook een arts die een ander op zijn verzoek op vakkundige wijze doodt; de juridische schijn tegen zich krijgt een levensdelict te hebben begaan, zij het dan de mildere variant van art. 293 St. Over eventuele rechtvaardiging of schulduitsluiting kan daarna gesproken worden"

501 Schafmeister en Heijder, an: Bij deze stand van zaken (Melai-bundel), 1983, p. 441-474, Zie woor cerv benadering die daamee een alantal owereenkomsten vertoont: Van Eikeria-Homnes, in: Strafrectht ir perspecthet, 1980, p. $161-178$.

S02 HR 27 now. 1984, NJ 1985, 106 m nt. ThWwW.

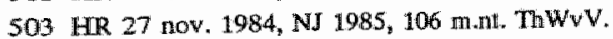

504. Vgl. Hazewnikel-Suringa/Remnelink, 1991, p. 341. Zie ook: A-G Schalken, NJB 1984, p. 40-41 an Schalken, in: Eutbanasie, 1985, p. 124.

505 A-G Remmelink wò̀ HR 27 now. 1984, NJ 1985, 106 m.nt. ThWvW. 
In zijn zienswijze was het hof niet verplicht, nadat het had vastgesteld dat de gedraging. aan de delictsomschrijwing beantwoordde, ook nog expliciet vast te stellen, dat het doow art. 293 Sr beschermde belang door het gedrag van de arts geschonden was. Met de wervulling van de delictsomschrijving is in beginsel de strafbaarheid gegeven.

"Het Hof mocht er van uitgaan, dat de vervulling van de bestanddelen wan art. 293 door het gedrag van rekwirant impliceerde schending van het door de wetgewer beschermde belang, dat mensen, ook op eigen verzoek, niet worden gedood, ongeacht de motieven, waaruit de dader handelt. Zulks impliceert, dat ook het doden, juist uit eerbied voor het leven van de betrokken mens, niet geacht kan worden te corresponderen met het doel dat de wetgever voor ogen stond (en staat) ${ }^{\text {tt }}$.

$\mathrm{Nu}$ het hof terecht had overwogen, dat de wederrechtelijkheid niet ontbrak, was niet wain belang of de gestelde norm als impliciet bestanddeel van de delictsomschrijving moest worden opgevat danwel als element moest worden beschouwd.

Tegen de overwegingen van het hof Amsterdam waarmee het hof het beroep op het ontbreken van de materiële wederrechtelijkheid verwierp, werd in cassatie ${ }^{506}$ aangevoend, dat het hof uitsluitend de maatschappelijke aanvaardbaarheid van bellang heeft geacht, terwijl rekening moet worden gehouden met de maatschappelijke aanvaardbaarheid in verband met enkele andere omstandigheden. Vanwege deze combinatie moet voor de maatschappelijke aanvaardbaarheid een "belangrijke meerderheid van de Nederlandse bevolking voldoende .... worden geacht".

Voor de andere omstandigheden werd door de verdediging gewezen op twee nomen, die tegenover de norm van art. 293 Sr staan. De norm van art. $293 \mathrm{Sr}$ is de eerbied voor het menselijk leven in het algemeen. De twee normen die - in combinatie met de maatschappelijke aanvaarding - een overtreding van de norm van art. 293 Sr rechtvaardigen, zijn volgens de verdediging: de eerbiediging van het zelfbeschikkingsrecht enerzijds en de hulp aan de mens in nood, het behoeden van diens waandigheid en het verlichten of beëindigen van zijn ondraaglijk lijden anderzijds.

In de verwerping van het verweer was het hof Amsterdam niet expliciet op deze normen ingegaan. Ter beoordeling van het desbetreffende middel haalde de Hoge Raad eerst de zinsneden uit het proces-verbaal van de zitting van het hof aan, waarin het betoog van de raadsman met betrekking tot deze normen was opgenomen. Vervolgens overwoog de Hoge Raad dat het hof terecht tot uitdrukking heeft willen brengen, dat de opvatting dat de verdachte

"onder de gegeven omstandigheden gerechtigd was te voldoen aan de ... vermelde wee normen - zijnde a. eerbiediging van het zelfbeschikkingsrecht en b. hulpverlening aan de mens in nood, het behoeden van diens waardigheid en het verlichten of beëindigen van zijn ondraaglijk lijclen - niet kan worden beschowwd als een maatschappelijk zó algemeen als juist aanvaarde opvatting, dat op grond daarvan euthanasie, toegepast op een wijze en onder omstandigheden als te dezen is geschied, reeds op zich zelf rechtens toelaatbaar zou zijn en mitsdien van een strafbaar handelen als in art. $293 \mathrm{Sr}$ omschreven geen sprake zou kunnen zijn".

Uit deze overweging blijkt, dat de Hoge Raad niet uitsloot dat met de aangevoerde normen: rekening wordt gehouden. De rechtskracht van de genoemde normen is echter afhankelijk van de mate van de maatschappelijke aanvaarding. De Hoge Raad is het met het hof 
Amsterdam eens dat die aanvaarding niet een zo breed draagvlak heeft dat zij de delictsomschrijving van art. $293 \mathrm{Sr}$ in het hier bedoelde geval terzijde kan stellen.

Het hof Amsterdam had bovendien nog de vraag opgeworpen of de rechter vanwege gewijzigde maatschappelijke opvattingen het door art. $293 \mathrm{Sr}$ beschermde belang en het door de verdachte nagestreefde bellang tegen elkagr mag afwegen. Naar deze passage verwees de Hoge Raad niet, althans niet expliciet. Daarom kan op grond van het Euthanasie I-arrest niet met zekerheid worden gezegd, dat de Hoge Raad deze belangenafweging door de rechter niet toelaatbaar acht. ${ }^{507}$ Maar in het Euthanasie II-arrest ${ }^{508}$ werpt hij - in verband met de medische exceptie - de vraag zelf op, nadat hij heeft overwogen dat van een maatschappelijke aanvaarding van de medische exceptie in brede kring niet blijkt:

"nog daargelaten of de rechter, indien dat wel zo zou zijn, de vrijheid zou hebben aan die door de wetgever niet erkende uitzondering strafuitsluitende werking toe te kennen".

De aangehaalde overweging van de Hoge Raad laat zien dat deze terughoudend is ten aanzien van de kansen wan een beroep op het ontbreken van de materiële wederrechtelijkheid, zelfs als de genoemde opvatting voldoende zou zijn uitgekristalliseerd. Van die terughoudendheid getuigt ook de overweging van het hof Amsterdam ${ }^{509}$ waarim het hof de vraag had opgeworpen, of het de rechter well vrijstaat een belangenafweging te maken tussen enerzijds de belangen die aan de naleving van art. $293 \mathrm{Sr}$ zijn verbonden en de belangen die met een overtreding van die bepaling worden nagestreefd. ${ }^{510}$

Het probleem bij deze inkleding van de materiële wederrechtelijkheid is dat de rechter de door de delictsomschrijving beschermde norm niet beperkter interpreteert, maar haar vanwege een andere norm uitschakelt, hetgeen in wezen neerkomt op een onverbindendverkllaring van art. 293 Sr. Daarmee begeeft de rechter zich in feite op het terrein van de wetgever. Zo komt de scheiding van de rechtsprekende en de wetgevende macht in gevaar en komt de rechter in strijd met het in art. 11 Wet $A B$ bepaalde:

"De regter moet volgens de wet spreken; hij mag in geen geval de innerlijke waarde of billijkheid der wet beoordelen".

Het hof Amsterdam sprak daarom in dat verband van een "terzijdestelling van art. 293 $\mathrm{Sr}^{\prime \prime}$. De A-G Remmelink, volgens, wie in beginsel euthanasie onder het werkingsbereik wan art. $293 \mathrm{Sr}$ valt, was vam mening:

"Wil men anders, dan zall de wetgever moeten spreken Het betreft dan een staatsrechtelijk vraagstuk, dat niet door de strafrechter opgelost kan worden" ${ }^{\text {if11. }}$.

In de overweging van de Hoge Raad zit ook de afwijzing van de stelling dat eerbied voor het leven in art. 293 Sr eerbied voor het sterven inhoudt, opgesloten. De Hoge Raad kon mijns inziens moellijk anders beslissen. Eerbied voor het leven impliceert weliswaar ook eerbied voor het sterven als onderdeel van het leven, maar dat eerbied voor het leven

507 Vgl. Nieboer, 1991, p. 261 en Schalken, in: Euthanasie, 1985, p. 138. Volgens Sehalken kent de Hoge Raad vermoedelijlk onvoldoende gewicht toe aan gewijzigde malischappeljjke inzichten, om an cen strafbarr feil het wederrechtelijk karakter in algemene zin te ontnemen.

so8 HIR 21 okt. 1986, NJ 1987, 607 m.nt. GEM.

509 Hof Ansterdam 17 nov. 1983, NI 1984, 43.

510 Zonder trouwens - evenals als de Hoge Raad hiervoot - een antwoord daarop te gever.

511 A-G Remmelink vờr HR 27 nov. 1984, NJ 1985, 106 m.nt. ThWwV. Vgl. A-G Schalken, NJB 1984, p. 49. 
het recht op doden impliceert, is een interpretatie wan het recht die de grenzen van het aanvaardbare overschrijdt.

Wanneer de rechter zou erkennen dat art. $293 \mathrm{Sr}$ vanwege gewijzigde maatschappelijke opvattingen op euthanasie door een arts niet van toepassing is, dan zou hij de bepaling te extensief interpreteren. Maatschappelijke opvattingen mogen er niet toe leiden dat de wet contra legem wordt geinterpreteerd. ${ }^{512}$

In de literatuur bestaat verschil van mening over de vraag of er een recht op zelfbeschik king ten aanzien wan het eigen sterven bestaat. Door sommigen, in het bijzonder door Leenen, wordt dit recht afgeleid uit grondrechten en mensenrechten. ${ }^{513}$ Tegen deze opvatting brengt Schalken in, dat "het Nederlandse recht ook ten aanzien van persoonlijke belangen beperkingen inhoudt op het recht op zelfbeschikking ten aanzien van die belangen". ${ }^{514}$ Ten tweede wijst hij op de bescherming van het menselijk leven als grondslag van de rechtssitaat:

"deze bescherming berust niet daarop dat mensen meestal niet wensen te sterven, maar op de intrinsieke waarde van het menselijk leven. Het is daarom dat er een gemeenschapsbelang bij het in beginsel niet ter dispositie-staan van het sterven is" .515

Daarentegen voelt Kelk wel voor een erkenning van het zelfbeschikkingsrecht ten aanzien van het elgen sterven. Hij acht daarvoor niet nodig dat een zogenaamde uitgekristalliseerde algemene opvatting bestaat. In een pluriforme maatschappij als de Nederlandse dient rekening te worden gehouden met verschillende opvattingen. Volgens hem had de Hoge Raad op grond daarvan in het Euthanasie 1-arrest de materiële wederrechtelijkheid afwezig kunnen achten. ${ }^{516}$

Maar ook in latere rechtspraak is het zelfbeschikkingsrecht in verband met euthanasie niet erkend. Inmiddels zijn daarvoor wel meer argumenten dan ten tijde van dit arrest. Immers, zowel maatschappelijk als in verscheidene wetsvoorstellen is aanvaard dat een patiënt niet zonder zijn toestemming medisch behandeld mag worden, zelfs wanneer het niet-behandelen tot gevolg heeft dat de patiënt overlijdt. ${ }^{517}$ Door de erkenning van dit recht wordt het verschil met euthanasie zeer klein. Centraal staat dan niet langer de vraag of de betrokkene over het tijdstip van zijn eigen sterven mag beslissen, maar de vraag in hoeverre derden aan de uitoefening van dat recht mogen meewerken.

De grond voor de strafbaarstelling van de in de artt. 293 en 294 Sr omschreven gedragingen was de schending van de eerbied aan het menselijk leven in het algemeen verschuldigd. Zowel degene die het verzoek doet of tot zelfododing overgat als de derde die de levensbeëindiging pleegt of daarbij behulpzaam is, schendt die eerbied. Puur praktische

512 Vgl. Van Eikenna-Homnes, in: Strafrecht in perspectief, 1980, p. 175 en Van Veen, RR 1980 , p. 6.

513 Leenen, $1988, p .30$. Terwijl Leenen het zelltueschikkingsrecht als één van de pijlers van he gezondligeidsrecht beschouwt, is Sluyters, 1985 , p. 19 en 23, wan oordect dat een zodanig recht in het Nederiands irecht niet bestawl. Naar zijn mening kan beter van het beginsel wan zelfbeschikking worden gesproken; dem beginsel dat bij specifieke onderwerpen dienst kan doen. Dit beginsel wordt ook wel als "autonomie-
beginsel" aangedwid.

514 A-G Schalken, NJB 1984, p. 43. Vgl. Strijards, 1987, p. 69-70: zelfs als thans een "ideẻel zelfbeschikkingsrecht" aanvatard zou zijn, dan is het niet de tak van de wetstoepasser, maar die van de wetgever om daaraan recht vardigendk werking toe te kennen.

515 A-G Schalken, NJB 1984, p. 44.

$516 \mathrm{Kelk}$, AA 1985, p. 338, Zie oolk: Kelk, in: Grenzen aan de zotg, 1990, p. 149-169.

$\$ 17$ Zie: H. IV A, onder 3.4.2. 
redenen sloten degene op wiens verzoek wordt gehandeld en de zelfdoder vat de strathatstelling uit.

Het aldus toegekende recht zou beperkt opgevat kunnen worden in die zut dat leder mens het recht heeft zijn natuurlijke dood te sterven. Maar wanneer bijvoorbeeld wanand een poging tot zelfdoding doet en vervolgens medische behandeling weigent en diestenge volge overlijdt, kan moeilijk van een naturlijke dood worden gesproken.

Als de (maatschappelijke) erkenning van het zelfbeschikkingsrecht ter zake van de eigen levensbeëundiging tot terzijdestelling van art. 293 (en art. 294) Sr zou kunnen leiden, dan zou iedereen levensbeëindigende hulp mogen verlenen. Behalve het juridische argument dat hiermee het recht contra legem geïnterpreteerd zou worden, is dit ook falehlik niet aanvaardbaar. Voor zover derhalve in de desbetreffende rechterlijke overwegingen een erkenning van het zelfbeschikkingsrecht ten aanzien van de eigen dood kaw worlen gelezen, dient dat recht geclausuleerd te worden begrepen. Niet elke wijze van levensilewindiging op verzoek wordt geoorloofd geacht, maar slechts de niet "gewelddadige" respectievelijk niet "gruwelijke ${ }^{\text {t1519. }}$. Met anderen woorden: er dient sprake te zijn wan een hulpverlening die tot een "zachte" dood leidt. Daarbij heeft niet alleen de betrokkene zelf belang, maar ook zijn naaste omgeving. ${ }^{520}$ Voor een zachte dood is de hwip van derden vaak "noodzakelijk" s21, die ter bereiking van dit doel wel zongvuldig te werk behoren te gaan.

Als het recht op een zachte dood wordt erkend en als daartoe vaak de hulp van derden nodig is, dan kunnen alleen die derden een succesvol beroep doen op het ontbreken van de materiële wederrechtelijkheid, die bij dit handelen tot een zorgvuldige hwpvertening. in staat zijn. Daarom wordt in de rechtspraak meestal uitsluitend de arts daartoe geschint geacht. Een enkele keer wordt de kring van personen niet tot artsen beperkt. Zo 11jkt de rechtbank Rotterdam ${ }^{522}$ ter zake van art. 294 Sr genoegen te willen nemen met derden die over "middellen tot een zachte dood" beschikken. Maar daar ging het om behulpzarm: zijn bij zelfoloding.

Verdedigd kan ook worden dat het accent niet op het zelfbeschikkingsrecht Higt, matar op de noodsituatie, waarin de patiënt zich bevindt en dat het aan een derde rechtens slechts geoorloofd is aan deze noodsituatie een einde te maken, wanneer - natast andere hie niet relevante voorwaarden - de patiënt dat ondubbelzinnig kenbaar heeft gemaakt.

Deze benadering biedt het voordeel dat met behulp van de invulling van het begrip noodsituatie ten aanzien van derden beperkingen inzake de levensbeëindiging kunnen worden gesteld. Daarentegen heeft het benadrukken van het zelfbeschikkingsrecht als voordeel dat de noodsituatie niet het overheersend criterium voor de beslissing wordt, waardoor uiteindelijk de wil van de patiênt niet meer relevant zou zijn.

Zo lang de toelaatbaarheid van euthanasie mede afhankelijk wordt gesteld van een noodsituatie van de patiënt, bestaat voor strafuitsluiting geen behoefte aan het ontbreken van de materiële wederrechtelijkheid, omdat hetzelfde resultaat met de geschreven strafuitsluitingsgrond noodtoestand kan worden bereikt. En daarbij is de waarborg groter dat de rechter het recht niet te vrijelijk interpreteert. ${ }^{523}$

518 Rb. Alkmatar 10 mei 1983 , NJ 1983,407 .

519 Rb. Rotterdam 1 deci 1981 , NI 1982, 63, ad art. $294 \mathrm{Sr}$.

520 Rb. Rotterdam 1 dec. 1981, NJ 1982, 63 .

521 Rb. Alkmaar 10 mei 1983, NJ 1983, 407; Rb. Rotherdam 1 dec. 1981, NJ 1982, 63.

522 Rb. Rotterdarn 1 dec. 1981 , NJ 1982, 63.

$523 \mathrm{Vgl}$. Gezondheidsraad, 1982, p. 93-95. 


\subsubsection{Inleiding}

In verband met abortus door een arts heeft Enschedé vooral het ontbreken van de materielle wederrechtelijkheid verdedigd en stond de medische exceptie als verbijzondering van deze rechtsgrond nog meer op de achtergrond. Voor de straffeloosheid van euthanasie door een arts beriep hij zich expliciet op de medische exceptie. ${ }^{524} \mathrm{Hij}$ werd hierin bijgevallen door Langemeijer en Van Veen. ${ }^{525}$ Maar het is de vraag of de medische exceptie ook ten aianzlen van euthanasie geldt.

In het eerste hoofdstuk wordt tegen het einde van de bespreking van de Huizer veeartsarresten opgemerkt dat zelfs wanneer wordt aangenomen dat de Hoge Raad in die anresten de medische exceptie heeft erkend, daruit niet volgt dat deze exceptie ook ten aanzien van euthanasie geldt:

Art. 293 Sr is in feitelijke bewoordingen gesteld. Dat brengt mee, dat de delictsomschrijving zelfs nauwelijks ruimte biedt woor een taalkundige interpretatie van de bestanddelen. De vraag is dan of via het door de delictsomschrijving beschermde belang strafuitsluiting kan worden bereikt. De eerste aanwijzing voor de straffeloosheid van het handelen van de Huizer veearts leverde diens veeartsenijkundige bevoegdheid op, krachtens welke "de genees - en heelkundige zorg voor het vee wettelijk is geregeld". Maar is bij euthanasie door een medicus wel sprake van een, daarmee vergelijkbare, genees- en heelkundige zorg? Daarover wordt binnen de medische kring verschillend gedacht. ${ }^{526}$ De volgende vraag is of in het recht aanwijzingen zijn te vinden op grond waarvan een uitzondering op de delictsomschrijving van art. $293 \mathrm{Sr}$ mogelijk is.

\subsubsection{De wetgever heeft de medische exceptie ten aanzien van euthanasie niet erkend}

Naar mijn mening heeft de wetgever van 1886 de medische respectievelijk veterinaire exceptie terzake van (dieren)mishandeling en abortus erkend, maar dan als variant van het ontbreken van de materiële wederrechtelijkheid als kwalificatieverweer. In verband met de artt. 293 en 294 Sr heeft hij zich daarover niet uitgelaten.

Enschede stelt dat uit de opmerkingen van Modderman bij de behandeling van abortus en mishandeling valt af te leiden, dat de wetgever van 1881 in algemene zin de medische exceptie van de medicus heeft erkend. ${ }^{527}$

Hoewel ik met Enschedế van mening ben dat de medische exceptie, zoals deze door Modderman ter sprake werd gebracht, een strekking heeft die verder reikt dan de delictsomschrijvingen waarbij zij naar woren kwam, mag daaruit niet worden afgeleid, dat deze exceptie ook van toepassing is op de in de artt. 293 en $294 \mathrm{Sr}$ omschreven gedragingen. $^{523}$

Daartegen spreekt immers, dat de wetgever met art. $293 \mathrm{Sr}$ een strafbepaling in het leven heeft geroepen, waarmee door middel van strafvermindering met verzoeken van

524 Enschede, 1985.

525 Langemeijer, Buschedé en Vă Veen, NJB 1987, p. 50-51 en NRC van 14 jan. 1986.

526 Zie: H. IV A, onder 2.

527 Enschede, 1985 , p. 84 .

528 Zie daartoe: Enschede, 1985, b.v. p. 34. 
de betrokkene rekening wordt gehouden. Daartegen spreekt ook, dat de Commissie de Wal in dit verband heeft gesproken over het doden op verzoek van "lijders met verschrikkelijke kwalen" ${ }^{* 529}$ Dit voorbeeld bezigde de Commissie echter als argument voor de aparte strafbaarstelling van levensbeëindiging op verzoek.

De bedoeling die de wetgever met de delictsomschrijvingen van de artt. 293 en 294 Sr nastreefde, is duidelijk: de bescherming van de eerbied voor het leven in het algemeen. Als normadressaat geldt iedere derde die op die bescherming een inbreuk kan maken.

Daar komt bij dat tijdens de behandeling van de zedelijkheidswetgeving van 1911 de medische exceptie ook niet terzake van abortus werd erkend. Gedurende de abortusdiscussie van de jaren zestig en zeventig werd weliswaar de medische exceptie voor abortus erkend, maar dan wel geclausuleerd: de abortus behoorde (strikt) medisch geîndiceerd te zijn. Daaronder werd verstaan, dat het leven of de lichamelijke (en/of de psychosomatische) gezondheid van de vrouw door de zwangerschap ernstig werden bedreigd. Juist vanwege deze geclausuleerde aanvaarding van de medische exceptie voor abortus, was voor de verruiming van de criteria voor abortus een nieuwe abortuswetgeving nodig.

\subsubsection{De medische exceptie in de jurisprudentie over euthanasie}

De rechtbank Groningen ${ }^{530}$ vatte het ter ondersteuning van het beroep op het ontbreken van de materiële wederrechtelijkheid aangevoerde op als een beroep op de medische exceptie. Daaronder begreep zij:

"dat een handelen of nalaten, waardoor de bestanddelen van enig strafbaar feit vervuld worden niettemin niet strafbaar is, wanneer deze gedraging geboden is op grond van medische noodzaak, dan wel uit het oogpunt van medische hulpverlening dringend wenselijk is, indien en voorzover als de gedraging bestaat in een medische ingreep of het nalaten daarvan, waarbij alle door de medisehe wetenschap en praktijk vereiste zorgvuldigheid in acht is genomen". 531

Toegesneden op de delictsomschrijving van art. $293 \mathrm{Sr}$ en in verband met euthanasie kan de medische exceptie als volgt worden aangeduid: de delictsomschrijving van art. $293 \mathrm{Sr}$ is niet geschreven voor "een door een arts in het kader van zorgvuldig medisch handelen op grond van duurzaam lijden toegepaste levensbeëindiging". Deze formulering werd in de Euthanasie I-zaak gebruikt, om te stellen dat een dergelijke handeling niet onder de term. "van het leven beroven" valt. ${ }^{532}$

Volgens de Hoge Raad" komt de medische exceptie bij art. 293 Sr "dogmatisch" erop neer, "dat de strafbepaling van art. $293 \mathrm{Sr}$ voor haar als arts in de uitoefening van haar beroep naar de regelen der kunst handelende niet is geschreven". Die opvatting vindt, volgens de Hoge Raad, geen steun in het recht. ${ }^{534}$

529 Staatscommissie voor de zamenstelling van een Wetboek van Strafregt (Commissie de Wal), Notulen IV, p. 155, (ed. Nieboer cs.).

$530 \mathrm{Rb}$. Gronimgen 1 maart 1984 , NJ 1984, 450 .

531. I.c. verwierp de rechtbank het verweer, omdat niet woldaan was an de door haar geformulecrde voorwarde, dat de door de verdachte arts geraadpleegde personen door deze niet in stant waren gesteld zich zelfstandigg een oordeel te vormen omtrent de conditie van de patiênt.

532 Zie: $\mathrm{H}$. IV $\mathbf{B}$, onder 2.2 .2 .

533 HR 21 okt 1986, NJ 1987, 607 wint. GEM.

534 In dezelfde zin Rb. Haarlem 4 aprill 1986, NJ 1987, 287. 
"9.3. Immers, de wetsgeschiedenis noch een gewijzigde maatschappelijke opvatting levert grond op voor de juistheid van de namens de verdachte verdedigde opvatting. dat art. $293 \mathrm{Sr}$ niet is geschreven woor de arts die in het kader van zorgvuldig medisch handellen het leven van een ander op diens uitdrukkelijk en ernstig verlangen beeindigt". 535

Tevens blijkt onvoldoende dat de maatschappelijke opvattingen in brede kring ten gunste wan euthanasie zijn gewijzigd.

"Nergens echter valt uit het bij pleidooi dienaangaande betoogde de gevolgtrekking te maken dat in brede kring als juist is aarvaard dat die medische exceptie ook tot gelding zou kunnen komen in gevallen van opzettelijke actieve levensberoving als waarop in art. $293 \mathrm{Sr}$ is gedoeld, nog daargelaten of de rechter, indien dat wel zo zou zijn, de vrijheid zou hebben aan die door de wetgever niet erkende uitzondering strafuitsluitende werking toe te kennen" .

De Hoge Raad liet de door hem zelf opgeworpen vraag onbeantwoord. Maar door haar te stellen, gaf hij te kennen er niet voor te voelen vanwege maatschappelijke opvattingen de medische exceptie ter zake van euthanasie te erkennen. ${ }^{536}$

In het Euthanasie II-arrest ${ }^{57}$ nam hij de volgende stap en wees hij de medische exceptie ten aanzien van levensbeëindiging op verzoek af. Volgens de Hoge Raad kan uit de wetsgeschiedenis niet worden afgeleid

"dat art. $293 \mathrm{Sr}$ niet is geschreven voor de arts die in het kader van zorgvuldig medisch handelen het lleven van een ander op diens uitdrukkelijk en ernstig verlangen beëindigt. Terecht heeft het hof dan ook overwogen dat uit de wetsgeschiedenis en ook anderszins niet blijkt dat de wetgever ten aanzien van het bepaalde in art. $293 \mathrm{Sr}$ voor een geval als het onderhavige, waarin een arts door het toedienen van een injectie een patiënt het leven beneemt onder omstandigheden als zich te dezen hebben voorgedaan, een uitzondering van meer algemene aard heeft willen maken ${ }^{\text {". }}$. Of zoals hij het in het tweede Huizer veearts-arrest met betrekking tot de interpretatievrijheid van de rechter nog stringenter formuleerde:

"dat de strafwet zich well in de deliktsomschrijving van zoodanige bewoordingen kan bedienen, dat voor dergelijke; buiten den tekst der wet zellve liggende beschouwingen, geen ruimte wordt gelaten".

Van die ruimte blijkt - anders dan ten aanzien van de Veewet - niet uit of in verband met het WvSr.

Daarmee heeft de Hoge Raad bepaald dat euthanasie door een arts (in beginsel) onder de delictsomschrijving wan art. $293 \mathrm{Sr}$ valt; ook zou euthanasie (onder omstandigheden) als medisch handelen kunnen worden aangemerkt. Daanuit volgt dat voor de straffeloosheid niet reeds voldoende is - zoals ook al bleek uit de Huizer veearts-arresten - dat conform de regels van het medisch beroep wordt gehandeld.

535 In de bij pleidooi gegeven toelichting op het niddel werd uitvoerig verwezen nar wetsgeschiedenis en jurisprudentie. Daaruit is, nara de mening van de Hoge Raad, wel op te maken dat een arts die "in het belang van zijn patièn in het kader wan een medische ingreep" de patient "pijn of (zwaar) lichannelijk letsel" toebrengt, zich met sucoes op de medische exceptie ter zake van mishandeling kan beroepen. Zje: H. II, onder 3.5.5.

536. Vgl. hof Amsterdan 17 nov. 1983, NJ 1984, 43.

537 HR 21 okt. 1986, NJ 1987, 607 munt. GEM. 


\subsubsection{Samenwatting}

Opeén uitzondering na werd in de rechtspraak de medische exceptie ter zake van euthanasie afgewezen. Vermoedelijk zal ook een gewijzigde maatschappelijke opvatting niet tot een erkenning leiden. De strafrechter is immers in zoverre gebonden aan de delictsomschrijvingen en de bedoelingen van de wetgever, dat hij niet in strijd daarmee de wet mag interpreteren. Well mogelijk is een extensieve of een restrictieve interpretatie. Maar die kan bij art. $293 \mathrm{Sr}$ geen straffeloosheid meebrengen.

Tot nu toe mochten noch de genoemde invullingen van het ontbreken van de materielle wederrechtelijkheid, noch de verschillende aangevoerde interpretaties van het begrip "van het leven beroven" en evenmin de medische exceptie ter zake van art. $293 \mathrm{Sr}$ baten. Aangezien daarbij telkens het nagestreefde belang in strijd is met het door de delictsomschrijving beschermde belang, ziet het er niet naar uit, dat hierin verandering zal komen.

De besproken jurisprudentie heeft betrekking op art. $293 \mathrm{Sr}$. Daar art. $294 \mathrm{Sr}$ hetzelfde belang dient als art. $293 \mathrm{Sr}$, is niet te verwachten dat een van de genoemde verweren bij hulp bij zelfdoding meer succes heeft.

\section{Noodroestand}

\subsubsection{Inleiding}

Voor een succesvol beroep op noodtoestand moet sprake zijn van conflicterende belangen, waarbij het met de wet strijdige bellang een objectieve meerwaarde dient te bezitten ten opzichte van het door de wet beschermde belang. Voor euthanasie kan bij mogelijke meerwaardige belangen gedacht worden aan het belang bij een zachte dood en aan het belang op een waardige wijze te sterven.

Verder is voor noodtoestand vereist dat zich geen culpa in causa voordoet en moet aan het subsidiariteits-en proportionaliteitsbeginsel zijn voldaan. ${ }^{538}$

\subsubsection{Culpa in causa}

Als een persoon zichzelf in de noodsituatie heeft begeven, is er sprake van "culpa in causa" en kan een beroep op noodtoestand reeds daarom niet meer baten.

Enkele euthanasiezaken getuigen hiervan. Voor de rechtbank Den $\mathrm{Haag}^{539}$ voerde de verdediging aan, dat de van moord verdachte arts objectief medisch gezien permanent in een latente noodsituatie verkeerde, van waanuit op een gegeven moment een acute noodsituatie ontstond. De rechtbank overwoog dat de mogelijke latente noodsituatie aan de verdachte te wijten was, omdat hij in het verzorgingstehuis De Terp te lang de touwtjes in handen had gehouden. Evenmin was er volgens de rechter sprake van een acute noodsituatie, want de verdachte werd ervan verdacht coma-patienten te hebben gedood en bij coma-patienten bestaat geen (merkbaar) lijden. ${ }^{540}$

538 Vgl. Haxewinkel-Suringa/Remmelink, 1991 , p. $281-282$ en Bronkhorst, 1952 ; p. 201.

539 Rb. Den Haag 6 aug. 1985, NJ 1985, 708.

540 De Rb. Haarlem 4 april 1986, NJ 1987, 287, verwees - ter zake van het doden wan een comateuze pahent. - in cen overweging ten owervloede natar culpa in caussia. 
Het hof Leeuwarden ${ }^{341}$ verwierp zowel het beroep op noodtoestand als op psychische overmacht met de overweging dat de arts, die tevens vriendin van de patiënte was, zichzelf in de situatie had gebracht en wel doordat zij uitdrukkelijk aan de patiënte had toegezegd desnoods levensbeeindigende hulp te verlenen en doordat zij, toen het door de patiente ingenomen middel ontoereikend werkte, haar een dodelijke dosis morfine had toegediend. Maar die overweging vond geen genade voor de Hoge Raad. In het Euthanasie 1 -arrest ${ }^{542}$ overwoog de Hoge Raad:

"10.3. ... Het is immers niet begrijpelijk dat een toezegging en voorbereiding als in het onderhavige geval is gedaan, wordt opgevat als een zich door eigen schuld brengen in een overmachtssituatie, aangezien een dergelijke toezegging en voorbereiding pas kunnen volgen op een daaraan voorafgegaan besluit tot het inwilligen van de wens wan een patiënt een einde aan diens levens te maken.

10.4. Het hof had derhalve ervan rekenschap behoren te geven of de verdachte, toen zij evenbedoeld besluit nam en vervolgens daaraan uitvoering gaf, handelde in noodtoestand of psychische overmacht" .

De Hoge Raad maakte derhalve een onderscheid tussen het besluit tot stervenshulp enerzijds en de uitvoering, waaronder hij begreep de toezegging, het aan de patiënte ter beschikking stellen van een middel tot zelfdoding en het toedienen van de morfine anderzijds.

De annotator Mulder voelt meer voor de door de A-G Remmelink gegeven interpretatie van het arrest van het hof. Dientengevolge had de verdachte als vriendin en niet als arts gehandeld en in die hoedanigheid was havar besluit tot medewerking onjuist, waardoor zij zich door de toezegging in een "ongeoorloofde zaak" begaf. Daarom had zij de toezegging niet mogen doen en was er sprake van culpa in causa.

Mijns inzlens blijkt uit het arrest van het hof niet voldoende duidelijk of de verdachte als vriendin of als arts had gehandeld. In de door de Hoge Raad aangehaalde strafmotivering overwoog het hof wel dat het "niet aan twijfel onderhevig is, dat verdachte in alle oprechtheid meende als medicus ${ }^{543}$ niet anders te mogen handelen ...".

Het Euthanasie II-arrest leidde tot een uitspraak van het hof Arnhem van 27 febr. 1987, TVGR 1987/35 54 , dat de arts/vriendin tot dezelfde straf veroordeelde als het hof Leetwarden. Het hof Arnhem verwierp thet beroep op noodtoestand, omdat de arts/vriendin geen collega-arts had geconsulteerd. Dat is op zichzelf geen voldoende grond ter verwerping van het verweer, want ook zonder consultatie kan in noodtoestand worden gehandeld, zoals de Hoge Raad in HR 3 mei 1988, NJ 1989, 391 m.nt. GEM overwoog. Maar het hof had ter verwerping ook de verklaring van de verdachte aangehaald, waarin deze onder meer had meegedeeld:

"- dat toen zij besloot gevolg te geven aan die verzoeken, de zilekte van mevr. R.-S. niet terminaal was en ook niet kort tevoren een min of meer ernstige wending ten kwade had genomen; ...".

Uit deze feitelijke vaststelling leidde de Hoge Raad af, dat het hof impliciet had geoordeeld:

541. Hof Leetwwarden 11 oktt. 1984, NJ 1985, 241.

542 HR 21 okt. 1986, NJ 1987, 607 m.nt. GEM.

543 Cursieft, J.W.

544 Vò̀ HR 3 mei 1988 , NJ 1989, 391 mut. GEM, wees de A-G erop dat de datum vari de nitspraak 27 februari moet zijta niet, zoals het arrest zelf vermeldt, 28 februari. 
alat, zo op de verdachte ten opzichte van mevr. R.-V. al onderling strijdige plichten drukten, aan het hof niet aannemelijk is geworden dat zij in die situatie een gerechtvaardigde keuze heeft gedaan. Deze grond draagt de verwerping van het beroep op noodtoestand zelfstandig".

Volgens de annotator Mulder kan hieruit worden afgeleid, dat bij een niet-terminale ziekte in beginsel niet tot euthanasie mag worden overgegaan. Deze gevolgtrekking volgt mijns inziems niet noodzakelijk uit het arrest, want het hof had immers als alternatief voor de stervensfase een "min of meer ernstige wending te kwadle" genoemd.

\subsubsection{Proportionaliteit en subsidiariteit}

Het proportionaliteitsbeginsel houdt bij noodtoestand in dat het belang dat met overtreding van de wet gepaard gaat objectief gezien van groter gewicht is dan het belang dat met de naleving van de wet is gemoeid. Volgens het subsidiariteitsbeginsel dient het met de wet strijdige belang op de minst ingrijpende wijze te worden nagestreefd. ${ }^{\text {s.s }}$

De rechtbank Rotterdam ${ }^{546}$ noemde ter zake van art. $29.4 \mathrm{Sr}$, en de rechtbank Groningen $^{547}$ ter zake van art. $293 \mathrm{Sr}$, de twee tegenstrijdige belangen het belang van de persoon en zijn omgeving bij een zachte dood versus het belang dat de wetgever met de strafbaarstelling van de artt. 293 en $294 \mathrm{Sr}$ beoogde te beschermen. Terwijl de rechtbank Rotterdam het belang bij een zachte dood onder bepaalde voorwaarden als rechtvaardigend beschouwde, concludeerde de rechtbank Groningen dat het belang bij een zachte dood niet als objectief meerwaardig kan worden aangemerkt. De Hoge Raad schaarde zich in dit opzicht aande zijde van de rechtbank Rotterdam. ${ }^{548}$ Daarmee is in de jurisprudentie erkend, dat thanatisch handelen een belang kan zijn van een hogere waarde dan het met de levensdelicten te beschermen belang.

Als het ondraaglijk lijden van de patiënt via levensverkortende pijnbestrijding verholpen kan worden, dan behoort die weg bewandeld te worden in plaats van euthanasie. Als de arts de keuze heeft tussen een pijnstillend middel met en zonder levenswerkortende bijwerking, dan moet hij voor het tweede middel kiezen. Wanneer de keuze van de arts anders uitvalt; dan handelt hij in strijd met de subsidiariteitseis.

Omdat de arts niet voor de weg van de opklimmende doses had gekozen, maar woor het toedienen van een dodelijke doses ineens, verwierp de rechtbank Leeuwarden ${ }^{549}$ zowel het beroep op psychische overmacht als op overmacht in de zin van noodtoestand $^{550_{\text {: }}}$

"O. dat het beroep op overmacht in de zin wan (psychische) noodtoestand niet opgat, nu verdachte naar eigen woorden wan haar en haar raadsman geen hierboven aangege-

5.45 Vgil. Hazewinkel-Suringa/Remmelink, 1991 , p. 290 en Schalken, in: Euthanasie, 1985, p; 126.

546 Rb. Rotterdam 1 dec. 1981, NJ 198:, 63.

547 Rb. Groningen 1 maart 1984, NI $1984,450$.

548 HR 27 now. 1984, NJ 1985, $106 \mathrm{~m} . n t$. ThWvV en HR 21 okt. 1986, NJ 1987, 607 mint. GEM. In dezelfde zin b.w. Rb. Den Hage 21 juni: 1985, NJ 1985, 709.

$549 \mathrm{Rb}$. Leenwarden 21 febr. $1973, \mathrm{NJ} 1973,183$.

550 De werweren richtten zich op het ontbreken van de materiële wederachtelijkheid en op het handelen in de zin van (psychische) overmacht. De rechtbank verwierp bet beroep op beide vormen van owermacht en - maar zonder dit vitdrukkelijk aan te gewen - het bercep op thet ontbreken wan de materiële wederrechtelinkheid. 
ven weg van verzachting met het bewust levensverkorting op de koop toenemen, ten anzien wan haar moeder heeft ingeslagen noch zelfs heeft geprobeerd in te slaan, in plaats van het bewezenverklaarde ineens toedienen van de letale dosis, hoewel objectief genomen een zodanige weg blijkens de omschreven verklaring van de getuige-deskundige openstat en subjectief bezien openstond voor verdachte, die volgens eigen verklaring jarenlang praktizerende medica is met belangstelling op het door als euthanasie in ruime zin angeduide gebied en die over de verkrijgbaarheid voor haar van de psychofarmaka alleen heeft verklaard, dat die in een huisartsapotheek niet aanwezig zijn, waaraan echter niet afdoet dat die middelen voor praktizerende artsen op redelijke termijn elders verkrijgbaar plegen te zijn en waar voorzoweel nodig bijkomt, dat volgens de getuige-deskundige geneeskundig inspecteur voor de volksgezondheid in Friesland die weg door haar, medisch-ethisch bezien, geprobeerd had moeten worden".

De rechtbank Leeuwarden overwoog dat er objectief bezien een andere - minder vergaande - weg openstond. Daarom kon het beroep op noodtoestand niet slagen. Bovendien stond ook subjectief bezien, dat wil zeggen gezien de persoon van de verdachte een andere weg open. Daarom kon evenmin het beroep op psychische overmacht succes hebben.

De rechtbank Utrecht ${ }^{552}$ verwierp in dezelfde zin het beroep op noodtoestand ter zake van hulp bij zelfmoord. Het was niet aannemelijk geworden dat de mogelijkheden voor een medische behandeling wan de pijn waren uitgeput. ${ }^{553}$

Het hof Amsterdam ${ }^{554}$ had in de Euthanasie I-zaak zijn twijfels dat de verdachte redelijkerwijze geen andere keuze had dan aan het verzoek te voldoen, maar twijfels sluiten niet uit, dat de verdachte inderdaad geen andere keuze had. Daarom had de rechter, volgens de Hoge Raad in het Euthanasie I-arrest ${ }^{555}$ die twijfels behoren weg te nemen.

In hetzelfde arrest omschreef de Hoge Raad noodtoestand (bij euthanasie) als conflict van plichten en belangen, waarbij het de vraag was of de arts:

"de plichten en belangen welke in casu tegenover ellkaar stonden zorgvuldig - ...

- tegen elkaar heeft afgewogen en daarbij een keuze heeft gemaakt welke - objectief beschouwd en gelet op de zich te dezen voordoende bijzondere omstandigheden - gerechtvaardigd was". 556

Voor de zorgvuldigheid van de belangenafweging gaf de Hoge Raad twee bijzondere matstaven waarmee bij euthanasie door een arts rekening dient te worden gehouden. De belangenafweging dient "volgens normen van medische ethiek." en "met de kennis van zaken waarover hij (de arts, J.W. ) wit hoofde van zijn beroep als medicus geacht moet worden te beschikken" plaats te vinden.

551 Vanwege de "volkomen zuiverheid wan har tnotieven" werd de arts tot een gevangenisstraf van eếtn week voorwatardelijk veroordeeld.

552. Rb. Utrecht 21 dec. $1982, \mathrm{NJ} 1983,264$.

553 Bij de Rb. Haarlen 4 april 1986, NJ 1987, 287, stond de verdachte terecht ter zake van moord omdat hij een patient die zich in coma bewond, had gedood. De rechtbank Utrecht verwierp het beroep op noodtoestand eveneens met de overweging dat niet ammemelijk was geworden dat de verdachte ten tijde van het toedienen van de dodelijke injecties geen andere keuze had. En bet woegde er nog ten overvloede ara toe, dat de verdachte zive zelf in de situatie had gebracht (culpa in causa).

554 Hol Amsterdam 17 nov. 1983, NJ 1984, 43.

S55 HR 27 nov, 1984, NJ 1985, 106 mnt. ThWvV.

556 Bijua letterlijk herhatt de Rb: Den Haag 21 juni 1985 , NJ 1985, 709, deze alinea om de verdachte vanwege noodtoestand wan alle rechtsverwolging te ontslaan. 
Of de keuze gerechtvaardigd was is "afhankelijk van diverse factoren, welke van geval ot geval kunnen verschillen", waarmee een nadere invulling afhankelijk wordt gemaakt van omstandigheden van het concrete geval. Vervolgens geeft de Hoge Raad aan op welke vragen in deze zaak bijwoorbeeld een antwoord had moeten worden verkregen. De rechter had nader behoren te onderzoeken:

"of naar verantwoord medisch inzicht, getoetst aan in de medische ethiek geldende normen, te dezen sprake was van een noodtoestand". 557

In het Euthanasie II-arrest ${ }^{58}$ gebruikte de Hoge Raad een ietwat andere formulering dan in het Euthanasie I-arrest. Het is bij uitstek de taak van de rechter te onderzoeken:

"of naar wetenschappelijk verantwoord medisch inzicht en naar in de medische ethiek

geldende normen, zich een situatie voordeed welke als noodtoestand aangemerkt mocht worden ${ }^{\prime \prime}$.

IK beschouw de tweede formulering als een accentuering van de eerste. Het woord "wetenschappelijk" wijst erop dat het verantwoord medisch inzicht een objectief karakter behoort te hebben. Ten tweede plaatst de Hoge Raad het medisch inzicht naast de medisch-ethische normen, terwijl hij in het Euthanasie I-arrest het medisch inzicht aan deze normen getoetst wil zien. Het verdient de voorkeur medisch inzicht en medisch-ethische normen naast elkaar te plaatsen. Bij medisch inzicht gaat het om medisch-wetenschappelijke kennis en bij medisch-ethische normen om gewetensafwegingen en gedragsregels.

Het handelen volgens normen van de medische ethilek en met de kennis van zaken waarover een medicus geacht moet worden te beschikken, kan worden gezien als maatstaf die de medische exceptie kenmerkt. Daarom is Van Veen ${ }^{559}$ van mening dat bij euthanasie "in een noodtoestand de medische exceptie wordt aanvaard". En hij vervolgt:

"Wordt in zo"n toestand door de arts gehandeld naar de regels van zijn beroep dan doet zich een strafuitsluitingsgrond voor. Door aan de noodtoestand vast te houden, wordt geen uitspraak gedaan over euthanasie in het algemeen. Binnen de noodtoestand wordt de bijzondere positie van de arts erkend.

De vraag of van een noodtoestand kan worden gesproken, wordt uiteraard ook zelf sterk beinvloed door wat medisch inzicht leert over de toestand van de verzoeker. Binnen de noodtoestand is er voor de arts een ruimte, die er niet is voor degenen, die geen arts zijn". ${ }^{600}$

"Geldende" medisch-ethische normen zijn normen die door de meerderheid van de medici gedragen worden. Het hof Den Haag $^{561}$ dat met de Euthanasie I-zaak na de verwijzing door de Hoge Raad te maken kreeg, overwoog op dit punt:

"dat, nu een aanmerkelijk aantal medici in Nederland actieve levensbeëindiging medisch-ethisch geoorloofd achten, doch andere medici zulks als medisch-ethisch ongeoorloofd beschouwen; derhalve kan ter zake nilet van een algemeen aranvaarde

557 Nieboer, 1991, p. 53: In thet eerste euthanasie-arrest koos de Hoge Raad voor noodioestand. Niet volstaan werd dus met de bewoegdheid van de arts om te doden maar hij moest hiertoe (mexdisch) verplicht zijun, anders kon de plicht die voortvloeit wit art. 293 Sr kennelijk niel overruled worden door een rechtward"gingsgrond. Juist ondat zo een verpllichting ideologisch erg omstreden is krijgt deze beslissing een zwawe levensbeschouwelijke lading. Maar de wetgever haakte hierop maar al te graag in (w.v. 20383).

558 HR 21 okt. 1986, NJ 1987, 607 m.nt. GEM.

559 Onder HR 27 nov. 1984, NJ 1985, 106.

560 Vgl. Bergkamp, MC 1985, p. $91-93$ en Van Till-d"Aulnis de Bourouill, MC 1985, p. 560.

561 Hof Den Haag; 10 juni 1985 en 11 sept. 1986, NJ 1987 , 608 m.nt. GEM. 
norm van medische ethiek worden gesproken. Daarom is het niet aan de rechter on op dit stuk een keuze te maken"

Het hof motweert de annemelijkheid van de noodtoestand als volgt:

"Verdachte heeft op grond van zijn kennis en inzicht als medicus en van zijn ervaring als huisarts van mevr. B., na een volgens normen van medische ethiek zorgvuldige afweging van de plichten en belangen die tegenover elkaar stonden, een keuze gemaakt die, gelet op de omstandigheden van het geval, naar redelijk medisch inzicht als gerechtvaardigd moet worden beschouwd".

Doordat het hof Den Haag de keuze achterwege heeft gelaten, heeft het in feite de beoordeling van de geoorloofdheid van actieve levensbeêindiging door medici aan de medici zelf overgelaten.

Dat is ook de kritiek die Schalken op het Euthanasie I-arrest heeft:

"Het medisch-ethisch inzicht lijkt voortaan bepalend bij de beantwoording van de vraag, in welke bijzondere gevallen het beëindigen van het leven objectief van een hogere waarde is dan de bescherming van het leven of de eerbied daarvoor". ${ }^{562}$

\subsubsection{Samenvatting}

De Hoge Raad heeft de medische exceptie van de medicus ter zake van euthanasie niet erkend. Wel heeft hij de rechtvaardigingsgrond noodtoestand onder bepaalde omstandigheden op euthanasie door een medicus van toepassing geacht.

Voor noodtoestand is een noodsituatie vereist. Het moet niet aan de medicus te verwijten zijn dat hij in de noodsituatie is terecht gekomen. De noodsituatie begint bij euthanasie ten tijdle van het verzoek van de patiênt en niet pas op het moment dat de "stervenshulp" begint. De noodsituatie moet - gezien de aard van deze rechtvaardigingsgrond - een uilzonderlijk karakter hebben. Vanwege het bijzondere karakter van de noodsituatie is daarbij door de Hoge Raad een in noodtoestand handelen voorbehouden aan een arts. Niet omdat hij zich dan kan beroepen op de medische exceptie, maar omdat de rechter moet beoordelen "of naar wetenschappelijk inzicht en naar in de medische ethiek geldende normen", derhalve of ook medisch-objectief gezien, sprake was van een situatie, die als noodtoestand mocht worden aangemerkt. ${ }^{563}$

Als bezwar tegen noodtoestand als weg om straffeloosheid voor de medicus te bereiken, $\mathrm{kan}$ aangevoerd worden, dat euthanasie-situaties voor de medicus geen uitzonderlijk karakter hebben. ${ }^{564}$ Afgezien van de vragg, of deze situatie niet ook voor de medicus

562 Schalket, in: Euthanasie, 1985, p. 128. Dear merkt hij tevens op" "Voor de uitkomsk var die belangenafureging is door de Hoge Rarad in gevallen van euthanasie hett objectief medisch inzicht thans doorslaggevend geacht. Daarmee is de rechivatardigende noodtoestand aanzienlijk opgerekt en normatief gecollectüeverd naar thet model van de beroepsgroep van medici. Vanuit dogmatisch oogpunt is dir opmerkelijk, omdat tot nu toe deze rechtvaardigingsigrond sterk op de dader was geindwidualkeerd: ..." . Van Binstergen, DD 1974, p. 464, heeft reeds op de door de Hoge Raad gekozen mogelijkheid gewezen en in dat werlband opgemerkt, dat het oordeel van de medicus "ongetwijfeld het grootste gewicht in de schaal zal werpen". Vgll. ook: Politof en Koopmans, 1991, p. 181-182.

563 HR 21 okt. 1986, NJ 1987, 607 m.nt. GEM; r.o. 10.5.

564 In die zin: Sutorius, in: 100 jaar Wetboek van Strafrecht, 1986 , p. 418 en Enschedé, 1985, p. 66. 
exceptioneel is ${ }^{565}$, moet in een samenleving het doden van mensen steeds als uitzonderlijk worden beschouwd. In de Titel "Misdrijven tegen het leven gericht" is dat strafrechtelijk tot uitdrukking gebracht.

Voordelen van de straffeloosheid van euthanasie via noodtoestand zijn, dat -ondanks het normerende karakter van de jurisprudentie van de Hoge Raad - het uitzonderlijke van de gedraging beklemtoond wordt en - daarmee verband houdend - dat elke zaak die woor de rechter komt, op haar merites kan worden getoetst. Bowendien blijft de rechter eerder binnen de door art. 11 Wet AB getrokken grens wan zijn bevoegdheid dan bij het ontbreken van de materiële wederrechtelijkheid het geval zou zijn. ${ }^{566}$ Wil men verder gaan, dan dient de wetgever te spreken.

\subsection{Psychische overmacht, gewetensdrang en gewetensbezwaren}

\subsubsection{Inleiding}

Bij overmacht gaat het altijd om een overweldigende invloed van exceptionele omstandigheden, warmee iemand onverwacht geconfronteerd wordt. ${ }^{567}$ Zowel bij psychische overmacht als bij noodtoestand voldoet het handelen aan de delictsomschrijving. Bij noodtoestand is het handelen gerechtvaardigd, maar bij psychische overmacht niet. Daar is de vraag of het foutieve handelen aan de dader kan worden verweten. Zo was de rechtbank Leeuwarden ${ }^{568}$ van oordeel dat de arts - subjectief bezien - wel een keuze had kunnen maken, omdat zij in plaats van het toedienen van een letale dosis ineens de weg van de levensverkortende pijnbestrijding had kunnen en moeten kiezen. Daarmee heeft de arts in strija met de beginselen van proportionaliteit en subsidiariteit gehandeld. ${ }^{569}$ Maar de exceptionele omstandigheden kunnen zo sterk op een dader inwerken dat hij geen reële keuze meer kan maken.

Hoewel voor overmacht in het algemeen geldt dat de confrontatie met exceptionele omstand"̈gheden onverwacht geschiedt, is het overrompelende effect van die omstandigheden voor psychische overmacht belangrijker dan voor noodtoestand. Want de plotselinge confrontatie maakt het aannemelijker dat de dader tot zijn foutief handelen werd gedrongen.

Van personen in een bepallde hoedanigheid wordt verwacht, dat zij in hun beroepswitoefening beter dan anderen opgewassen zljn tegen acute noodsituaties. Die personen hebben, zo wordt gezegd, een "Garantenstellung". Hiertoe behoort de arts.

565 Uit het rapport van de Commissie Onderzoek Medische Praktijk inzake Euthanasie, 1991, kan worden afgeleid, dat thanasie-situaties voor medici geen exceptioneel karakter hebben. Wel is hel antal euthandsiemgevallen relatief klein.

566 Vgl. Bronkhorst, 1952, p. 130 en p. 299.

567 Vgl. Van Bemmelem/Van Veen, 1 , 1989, p. 179 en 183. Schalken, in: Euthanasie, 1985, p. 133: "Die eis van "acutheid" is in de jurisprudentie weliswar verzacht, matar als voorwatirde blijft gelden dat de subjectief emotionele druk de objectief verkeerde keuze onontkoomberar moet hebben gemaakt".

$568 \mathrm{Rb}$. Leeuwardlen 21 febr. 1973, NJ 1973, 183.

569 Vgl Schalken, in: Euthanasie, 1985, p. 133. 
Ter zake van een verdachte die geen medicus was en die ten aanzien van zijn echtgenote: hulp bij zelfdoding had verlleend, verwierp de rechtbank Utrecht ${ }^{570}$ het beroep op psychische overmacht met de owerweging dat de "verdachte zichzelf in de situatie van psychische overmacht heeft gebracht door zijn echtgenote - en zichzelf - niet (tijdig) van professionele hulp, .... te voorzien".

Eveneens ten aanzien van een verdachte die geen arts was, en die zijn echigenote op haar verzoek had gedood, stelde de rechtbank Almelo ${ }^{574}$ vast dat de verdachte de beslissing tot levensbeëindiging had genomen, zonder dat hij zich tot een arts had gewend. Door die beslissing, die voor hem een actieve rol bij de levensbeëindiging meebracht, had hij zichzelf in een overmachtssituatie gebracht.

\subsection{3 "Garantenstellung"}

In hoeverre iemand door gebeurtenissen overweldigd tot bepaalde handelingen wordt gebracht, hangt af van de gesteldheid van de persoon. De een is daarvoor ontvankelijker dan de ander. Het strafrecht gaat in het algemeen uit van een fictieve "doorsnee-burger". Maar er zijn uitzonderingen naar beide kanten. Van sommige personen wordt verwacht dat zij zich ten opzichte van bepaalde gebeurtenissen beter in de hand weten te houden dan de "doorsnee-burger". Bepaalde personen hebben, zo wordt gezegd, een "Garantenstellung" .572 Tot die personen behoort de arts in zijn beroepsuitoefening. Een arts wordt met veel lijden geconfronteerd. Daarom wordt van hem verwacht dat hij daartegen beter opgewassen is dan liemand anders. De "Garantenstellung" brengt mee dat een beroep van een arts op psychische overmacht weinig kans van slagen heeft.

Dat blijkt ook uit de euthanasiezaken, waarbüj de verdediging aanvoerde dat de arts zich door de omstandigheden (het lijden en het verzoek van de patiênt) in een dwwangpositie geplaatst zag, van waaruit hij geen andere mogelijkheid meer had dan aan het leven van de patiënt een einde te maken.

Een beroep op psychische overmacht kan volgens de rechtbank Groningen ${ }^{573}$ "in beginsel alleen slagen wanneer het dilemma, waarin de verdachte verkeerde op haar zo $\mathrm{n}$ overweldigende indruk maakte; dat zij de onjuistheid van de door haar gekozen gedragslijn niet heeft ingezien". Volgens de rechtbank was dat in dit geval niet aannemelijk gewordem,

"waarbij de rechtbank in aanmerking neemt, dat van de verdachte als arts gevergd mag worden, dat zij ook onder door haar als belastend ervaren omstandigheden in staat blijft haar gedragslijn op zodanige wijze te bepalen, dat zij daarvoor de volle verantwoordelijkheid kan dragen".

Ondanks dat de verdachte in HR 3 mei 1988, NJ 1989, 391 m.nt. GEM, als arts en als vriendin had gehandeld kon aldus de Hoge Raad het hof het beroep op psychische overmacht verwerpen, omdat de verdachte "arts is en ten tijde van het bewezenverklaarde feit het beroep van psychiater uitoefende". 
De Garantenstellung brengt derhalve bij euthanasie door een arts mee, dat hij zich niet met succes op psychische overmacht kan beroepen ${ }^{574}$ In de woorden van de $\mathrm{A}-\mathrm{G}$ Meiljers $^{575}$ :

"Juist van een arts mag worden verwacht niet alleen dat hij, zoals Van Veen in zijn noot onder HR NJ 1985, 106 (sub 5) zegt,

'tegen moeilijke situaties, voortvloeiend uit ernstige ziekte en aanstaande dood, is opgewassen",

maar ook dat hij, gesteld voor beslissingen in die moeilijke situaties, zijn persoonlijke gevoelens zal laten overstemmen door het professionele karakter van de relatie tot een zieke."

Terwijl voor de arts vooral de "Garantenstellung" in de weg staat bij het honoreren van een beroep op psychische overmacht, is dat bij een niet-arts culpa in causa, doordat deze onvoldoende actief is geweest in het zoeken naar professionele hulpverlening.

\subsubsection{Gewetensdrang en gewetensbezwaren}

Essentieel voor overmacht is, dat een invloed van buitenaf op de mens inwerkt. Dat lijkt uit te sluiten dat een beroep op het geweten opgevat kan worden als een beroep op psychische overmacht. Hierbij is het evenwel zinvol om te onderscheiden tussen gewetensbezwaren en gewetensdrang.

Bij gewetensdrang erkent de verdachte onjuist gehandeld te hebben, maar stelt hij tevens, dat zijn geweten hem geen keuze liet. De Hoge Raad heeft gewetensdrang onder psychische overmacht gerangschikt. ${ }^{576}$ En mijns inziens terecht, want exceptionele omstandigheden die iemand overrompelen, kunnen zodanig op zijn geweten inwerken, dat het geweten hem tot een bepaald handellen dwingt. ${ }^{57}$

Daarentegen verdient het geen aanbeveling gewetensbezwaren als beroep op overmacht op te vatten. Bij gewetensbezwaren stelt de verdachte dat hij de stem van zijn geweten heeft gevolgd en dat de daaruit voortkomende gedraging de juiste was. Gewetensbezwaarden zijn overtuigingsdaders. Zij zijn ervan overtuigd dat hun met de wet strijdige gedraging. de juiste is ${ }^{578}$ Een gewetensbezwaarde heeft een keuzemogelijkheid. Daarom lijkt een beroep op gewetensbezwaren naar zijn strekking op een beroep op een rechtvaardigingsgrond. Alleen wordt deze in de hedendaagse rechtspraak van de Hoge Raad niet erkend. Gebruikelijk is het een beroep op gewetensbezwaren te verwerpen met de motivering, dat de wetgever in sommige gevallen met gewetensbezwaren rekening heeft gehouden, zodat ervan moet worden uitgegaan, dat hij in de gevallen, waarin hij daarover heeft gezwegen, niet wilde dat gewetensbezwaren tot straffeloosheid zouden kunnen leiden. ${ }^{579}$

574 Vgl. Muilder onder HR 3 mei 19.88, NJ 1989, 391.

575 Vòòr HR 3 mei 1988 , NJ 1989, 391.

576 HR 16 jan. 1968, NJ 1969, 2 m.nt. Bronkborst.

577 Anders Strijards, 1987, p. 120: Het Nederlandse strafiecht erkent in beginsel gewetensorift alls zelfstandigge schulduitsluitingsgrond en soms - ten onfechte - als grond van overmacht.

578 Vgl. Schallken, in: Euthanasie ${ }_{\mu}$ 1985, p. 146; Politoff en Koopmans, 1991, p. 179: bij gewetensbezwaretn heeft de verdachte de innerlijke overtuiging dat de door de rechtsorde wereiste gedraging zedelijk ongeoorllowe is.

579 Vgl. Van Bemmeten/Van Veen, I, 1989, p. 191 en Hazewinkel-Suringm/Remmellink, 1991, p. 288-289; Strijards, 1987, p. 121; Vermeulen, 1989, p. 272. Zie cok: HR 26 juni 1916, NJ 1916, 703. 
Naast deze formele reden bestaat er mujis inziens een nog belangrijker grond om een beroep op gewetensbezwaren niet te honoreren. Als de keuze zijn oorzaak heeft in een gewetensconflict tussen enerzijds de stem van het geweten en anderzijds de normstelling en een verdachte voent aan dat hij de stem van zijn geweten moest volgen, dan is deze keuze bij aanvaarding van het verweer door de rechter niet meer te toetsen, want dan bepallen de subjectieve gevoelens van de werdachte diens keuze. ${ }^{580}$

In euthanasie-zaken is verscheidene keren een beroep op gewetensbezwaren en op gewetensdrang gedaan en niet altijd zijn deze beroepen in een concreet geval goed van elkaar te onderscheiden. ${ }^{581}$

Voor de rechtbank Utrecht ${ }^{582}$ voerde de huisarts aan dat hij "niet kon, noch mocht weigeren gehoor te geven aan de stem van zijn geweten", waaraan de raadsman toevoegde, dat het geweten "als norm en alls buitenwettelijke strafuitsluitingsgrond" geaccepteerd dient te worden. De rechibank vatte het verweer op als een beroep op gewetensbezwaren, waartoe vooral vanwege de toevoeging door de raadsman aanleiding bestond en verwierp het beroep met de gebruikelijke motivering, dat "de wetgever in gewetensconflicten geen grond theeft gevonden voor uitsluiting van de strafbaarheid ingevolge" art. 293 Sr. $^{\text {s.3 }}$

Ter zake van hulp bij zelfdoding door een niet-arts begreep de rechtbank Utrecht ${ }^{584}$ het door de raadsman aangevoerde, namelijk dat de verdachte geen weerstand heef kunnen bieden aan een gewetensdrang, als een beroep op psychische overmacht en verwierp zilj het verweer vanwege culpa in causa, omdat de verdachte niet (tijdig) professionele hulp had gezocht.

In de Euthanasie 1-zaak beriep de arts zich op overmacht, daartoe stellende, dat "hij zich onder de gegeven omstandigheden als behandelend arts van M.B., geconfronteerd met het lijden van zijn patiënte; in een dwangpositie bevond en tot geen andere beslissing zegt te hebben kunnen komen dan haar verzoek tot beëindiging van haar leven in te willigen". Terwijl het door het hof Amsterdam aldus weergegeven verweer kennelijk een beroep op psychische overmacht is, die elementen van gewetensdrang bevat, verwierp het hof het verweer met een motivering die eerder past bij een beroep op gewetensbezwaren dan bij psychische overmacht.

Het "(is) onvoldoende aanmemelijk (...) geworden, dat de opvattingen van verdachte die aan zijn handelen ten grondslag lagen hem dermate dwingend noopten tot het plegen van het bewezenverklaarde feit, dat het voor hem onmogelijk was daarvan af te zien".

Het hof voerde ter ondersteuning aan dat

"weliswaar annemelijk is geworden dat M.B. zelf haar lichamelijk lijden en, haar - ... - geestelijk lijden als ondragelijk ervoer, maar niet voldoende aamnemelijk is geworden, dat het lijden op het moment dat verdachte haar leven beëindigde - ...

580 Vgl. Van Benmelen/Van Veen, I, 1989, p. 190.

581 Vgl. Holland, 1989, p. 268: het is niet goed mogelijk scherp te onderscheident tussen een van buitten konsende en een van binnen komende drang:

$582 \mathrm{Rb}$. Utrecht 11 mam 1952 , NI $1952,275$.

583 Schalken, in: Euthanasie, $1985, \mathrm{p} .46$, wijgst erop dat de rechtbank het verweer ook als een beroep op gewetensdrang en datamee als eem wom van psychische overnacht had kunnen opvatten, omdat het cen door het lijden veroorzalakte en dus een wan buiten komende gewetensdrang betrof.

584 Rb. Utrecht 21 dec. 1982 , NJ 1983,264 : 
- ook als zo ondragelijk moest worden beschouwd dat werdachte redelijkerwijs geen

andere keuze had dan haar dat lijden door euthanasie te besparen; ...".

De twijfel die het hof hieromtrent uitte, betreft het punt of de verdachte "redelijkerwijs geen andere keuze had". Als reeds hieromtrent twijfels bestaan, dan kunnen, zo begrijp ik de overweging van het hof, gewetensbezwaren en/of gewetensdrang niet zo dwingend zijn geweest als de verdachte stelde. ${ }^{585}$ De Hoge Raad vatte het verweer op als cen bercep op gewetensdrang en achtte de verwerping voldoende gemotiveerd. ${ }^{\text {s\$6 }}$

De rechtbank Rotterdam ${ }^{587}$ verwierp het beroep op "gewetensdwang ${ }^{11}$ met de overweging dat uit het onderzoek niet aannemelijk was geworden, "dat het geweten van verdachte har dwong te handelen op de onzorguldige wijze zoals hierwoor omschreven".

\subsubsection{Conclusie}

Een beroep op psychische overmacht kan voor een arts in euthanasiegevallen geen soelaas bieden, vanwege de hoge eisen die aan hem in zijn beroepsuitoefening worden gesteld. Bovendien kleven aan psychische overmacht, zoals aan alle schulduitsluitingsgronden, voor gevallen als euthanasie twee nadelen. Ten eerste werkt psychische overmacht te persoonsafhankelijk, terwijl er - onder de medici als beroepsgroep - behoefte bestaat aan meer rechtszekerheid. Ten tweede zou in eenzelfde zaak de arts straffeloos kunnen zijn, terwijl ten aanzien van zijn mogelijke helpers (bijvoorbeeld een andere arts of een verpleegkundige) psychische overmacht niet aannemelijk is geworden, want hoe en in welke mate omstandigheden van buitenaf op iemands psyche inwerken, hangt af van de persoon en van de wijze waarop de persoon met de omstandigheden wordt geconfronteerd.

\subsection{Voorwaarden voor euthanasie}

\subsubsection{Inleiding}

Hierboven werden mogelijke uitsluitingsgronden voor de strafrechtelijke aansprakelijkheid van de medicus bij euthanasie besproken. Daartoe werd veelvuldig gebruik gemaakt van de beschikbare jurisprudentie. Voorall in de lagere rechtspraak werden in verband met diverse uütsluitingsgronden, met name noodtoestand, voorwatarden geformuleerd, waaraan moet zijn voldaan voor een succesvol beroep.

Dezelfde feiten en omstandigheden kunnen, in beginsel, bij verschillende uitsluitingsgronden en ten aanzien van euthanasie, schijngestalten van euthanasie en hulp bij zelfdoding, aangevoerd worden. Dat maakt het mogelijk, de voorwaarden los van de onderscheiden uitsluitingsgronden te bespreken.

Meteen in het eerste euthanasievonnis uit 1973, waarin niet uitgesloten werd geacht, dat een medicus straffeloos tot levensverkortende pijnbestrijding zou kunnen overgaan,

585 Anders; het derde cassatiemididel, waarin wordt gesteld dat de motivering van het hof tegenstrijdig is. HR 27 nov. 1984, NI 1985, 106 m.nt. ThWwV.

586 Evenals de A-G Remmelink.

587 Rb. Rotterdam 1 dec. $1981, \mathrm{NJ} 1982,63$. 
verbond de rechtbank Leewwarden ${ }^{58 \%}$ aan deze wijze van hulpverlening algemeen geformuleerde voorwaarden. Het is opmerkelijk dat de rechtbank zoveel aandacht besteedde aan voorwaarden voor straffeloze levensberoving op verzoek, nu zij in de zaak zelve tot een veroordeling kwam. De rechtbank had immers kunnen volstaan met de gemotweerde overweging dat in plaats van "directe" euthanasie een andere, minder ingrijpende weg, de weg van de zogenaamde pijnbestrijdende levenswerkorting, ingeslagen had kunnen en derhalve had moeten worden.

Hetzelfde verschijnsel doet zich acht jaar later voor wanneer de rechtbank Rotterdarn ${ }^{580}$ te maken krijgt met een geval van hulp bij zelfdoding, art. $294 \mathrm{Sr}$, door een niet-arts. In het concrete geval oordeelde de rechtbank dat de verdachte hoogst onzorgvuildig heeft gehandeld en daarom achite zij een gevangenisstraf op haar plaats. ${ }^{590}$ Maar daarnaast formuleerde ook zij algemene voorwaarden die tot straffeloze bulpverlening bij hulp bij zelfdoding zouden leiden.

Volgens Van Veen ${ }^{\text {sit }}$ zijn aan het formuleren van algemene voorwaarden door de rechter nadelen verbonden.

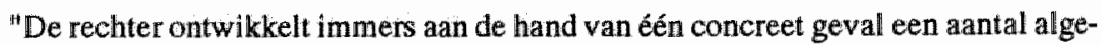
mene normen, zonder te kunnen overzien of hij naar aanleiding van een ander geval tot precies dezelfde regels zou komen. Dat komt ook in andere dan euthanasie-zaken wel voor, zie HR 15 juli 1983, NJ 1984, 63 ${ }^{592}$, met dezelfde risico's. Bovendien, als het om de medische exceptie gaat dreigt de rechter min of meer uit de losse hand een complex van regels in zijn vonnis neer te leggen, waarover binnen de medische professie nog onvoldoende consensus bestaat. Vergelijkt men de sedert 1973 gevelde vonnissen dan ziet men telkens verschillen in de normen, waaraan de rechter heeft getoetst" ${ }^{\prime 93}$

Of en zo ja, in hoeverre, de in de lagere rechtspraak geformuleerde normen onderling verschillen wordt hieronder onderzocht. Daarvoor is het zinvol om een onderscheid te maken tussen de voorwaarden aan de kant van de patiënt en voorwaarden bij de hulpverlening zelf. Hiervan uitgaande worden reeds twee voorwaarden verondersteld: degene die de handeling ondergaat is patiënt en een derde verleent hulp.

588 Rb. Leewwarden 21 febr. 1973, NJ 1973, 183.

$589 \mathrm{Rb}$. Rotterdan 1 dec $1981, \mathrm{NJ} 1982,63$.

590 Die echler, gezien de persoon van de verdachte, woorwaardelijk wordt opgellegd.

591 Onder HR 27 now. 1984, NJ 1985, 106.

$\$ 92$ In het arrest HR 15 juli 1983, NJ 1984, 63 m.nt. GEM, beriep de terzake van overtreding van art.. 25 WVW verdachte zich ondermeer op afwezigheid van alle schuld, daartoe aanvoenende dat de onstandigheden wan de situatie hern noopren op een bepalde wijze te handelen. De rechtbank verwierp het verweer en noende in dal verband drie alternatieve handelswijzen.

593 Ook volgens Van Wijmen, in: Euthanasie, recht en praktijk, 1985, p. 17-19, zijn in de lagere rechtsprank steeds "verschillende criteria en voorwaarden" gehanteerd. 


\section{De sitervensfase}

In afwijking van de verklaring van de getuige-deskundige achtte de rechtbank Leeuwarden $^{594}$ het (voor levensverkortende pijnbestrijding) niet nodig, dat de betrokkene zich in de stervensfase bevindt of deze zich althans heeft aangekondigd, daar

"het de Rb. uit algemene wetenschappelijke ervaring bekend is, dat zich in vele gevallen ongeneeslijke ziekten of laesies door ongeval, gepaard aan een zeer ernstig lichamelijk en of geestelijk lijden, voordoen bij overigens vitale mensen, die in die toestand lange jaren in leven blijven en dat de Rb. niet van oordeel is, dat aan zodanige lijders de door de getuige-deskundige bovenomschreven verzachting zou moeten worden onthouden, vaak langdurig onthouden nog wel".

Hiermee werd meteen in het begin van de euthanasiediscussie door een rechter de stervensfase als noodzakelijke voorwaarde losgelaten ${ }^{595}$ Vermoedelijk eist de Hoge Raad deze evenmin. Uit HR 3 mei 1988, NJ 1989, 391 m.nt. GEM kan wel worden afgeleid dat hij de stervensfase als een belangrijke aanwijzing voor de noodsituatie ziet.

\section{Het lijden}

De betrokkene, die meestal als "patiënt" wordt aangeduid, moest volgens de rechtbank Leeuwarden ${ }^{596}$ door ziekte of ongeval "ongeneeslijk" zijn of medisch als ongeneeslijk worden aangemerkt. De rechtbank Rotterdam ${ }^{597}$ sprak in plaats van "ongeneeslijk", wan een "duurzaam lijden" : Die formulering werd eveneens door de rechtbank Alkmaar ${ }^{\text {s9s }}$ gebezigd, die er nog aan toevoegt dat de hulpverlener dient te beoordelen of het lijden duurzaam is. De rechtbank Groningen ${ }^{599}$ gebruikte in plaats van de term "duurzaam" de uitdrukking "irreversibele conditie"t.

Het lijden kan volgens de rechtbank Leeuwarden ${ }^{600}$ zowel lichamelijk als geestelijk zijn, of zoals de rechtbank Rotterdam ${ }^{601}$ formuleerde: "lichamelijk of psychisch". De rechtbank Alkmaar ${ }^{602}$ sprak zonder meer van "lijden", terwijl de rechtbank Gronin$\operatorname{gen}^{603}$ het lijden aanduidde als "lichamelijk en/of psychisch".

Niet voldoende is dat de patiënt ongeneeslijk ziek is. Daarnaast is volgens de rechtbank Leeuwarden ${ }^{604}$ vereist, dat het lijden ondraaglijk of althans ernstig is en wel "subjectief" voor de patiënt. Ook de rechtbank Rotterdam ${ }^{605}$ ging uit van een subjectieve belevingseis

594 Rb. Leeuwarden 21 febr. 1973, NJ 1973, 183.

595 Cok niet: Rb. Rolterdarn 1 dec. 1981, NJ 1982, 63; Rb. Alkmatr 10 mei 1983, NJ 1983, 407; Rb. Groningen 1 maart 1984, NJ 1984, 450.

$596 \mathrm{Rb}$. Leewwarden $21 \mathrm{febr} .1973$, NJ 1973, 183.

597 Rb. Rotterdam 1 dec. 1981, NJ 1982, 63.

598 Rb. Alkmaar 10 mei 1983, NJ 1983, 407.

$599 \mathrm{Rb}$. Groningen 1 maart 1984, NJ 1984, 450 .

600 Rb. Leeuwarden 21 febr. 1973, NJ 1973, 183.

601 Rb. Rotterdam 1 dec. 1981, NJ 1982, 63.

602 Rb. Alkmaar 10 mei 1983; NJ 1983,407.

603 Rb. Groningen 1 maart 1984, NJ 1984, 450 .

604 Rb. Leewwrarden 21 febr. 1973, NJ 1973, 183.

605 Rb. Rotterdam I dec. 1981, NJ 1982, 63. 
van het lijden, dat "ondraaglijk" dient te zijn. De rechtbank. Alkmaar ${ }^{606}$ volstond met een "duurzaam lijden". De rechtbank Groningen" sprak van een lijden, dat door de betrokkene "duurzaam als ondragelijk" wordt ervaren.

In de overweging van het hof Amhem ${ }^{608}$ komt het onderscheid tussen de medische beoordeling van het lijden en de subjectieve beoordeling door de patiênt goed tot uitdrukking. Volgens het hof:

"(heeft) de verdachte als behandellend geneesheer (...) kunnen oordelen dat bij mevr.

D. ... sprake was van een duurzam, ernstig en uitzichtloos lijden, welk lijden door

mevr. D. zelf als zinloos en ondragglijk werd ervaren", waarbij met "uitzichtloos" vermoedelijk werd bedoeld "medisch gezien uitzichtloos".

\section{Het verzoek}

In de Terp-zaak interpreteerde de rechtbank Den Haag ${ }^{609}$ het "uitdrukkelijk en ernstig verlangen" in art. $293 \mathrm{Sr}$ als volgt:

"Art. 293 Sr spreekt van iemand op zijn "uitdrukkelijk en ernstig verlangen" van het leven beroven. Dit impliceert, dat de uitingen van dat verlangen ondubbelzinnig, dus niet voor tweeërlei uitleg vatbaar moeten zijn en tevens dat er zodanig verband bestaat tussen die uitingen en de levensbeëindigende daad, dat die uitingen de daad bepaald hebben"

De patient moet, volgens de rechtbank Leeuwarden ${ }^{610}$ te kennen hebben gegeven het leven te willen beëindigen, in elk geval uit zijn lijden verlost te willen worden. Van een "te kennen heeft gegeven" kan ook sprake zijn als de patiënt niet meer verbaal kan communiceren. ${ }^{611}$ Die kennisgeving moet inhouden dat de patient het leven wil beëindigen, althans dat hij "uit zijn lijden verlost wil worden". De tweede kennisgeving is vager dan de eerste en lijkt niet noodzakelijk een verlangen naar levensbeëindiging in te houden. Toch valt zij te verdedigen, mits de arts de patiênt heeft voorgelicht over het bijkomend gevolg van de pijnbestrijding, als er derhalve sprake van "informed consent" is.

In verband met andere omstandigheden kan zelfs de herhaalde uiting "Help me toch", als kenbaarmaking van een uitdrukkelijk en ernstig verlangen worden beschouwd ${ }^{612}$

Juist op dit onderdeel was de door de rechtbank Rotterdam ${ }^{613}$ genoemde voorwaarde scherper gesteld. Het verlangen naar de dood moet duurzaam zijn en het besluit tot levensbeëindiging moet vrijwillig zijn genomen. Deze rechtbank gaf in feite ook een nadere omschrijving van "informed consent". $\mathrm{Zij}$ stelt immers als voorwaarde dat:

"de persoon een goed besef heeft van de situatie, waarin hij verkeert, alsmede van de alternatieve mogelijkheden, in staat is een en ander tegen elkaar af te wegen en dat ook heeft gedaan".

$606 \mathrm{Rb}^{2}$. Alkmasr 10 mei 1983, NJ 1983, 407.

$607 \mathrm{Rb}$. Groningen 1 manrt 1984, NJ 1984, 450.

608 In: HR 23 juni 1987, NJ 1988, 157 m.nt. ThWWV.

609 Rb. Den Haag 6 aug. $1985, \mathrm{NJ} 1985,708$.

$610 \mathrm{Rb}$. Leeuwarden 21 febr. $1973, \mathrm{NJ} 1973,183$.

611 Vgl. H. IV A, onder 1.1.

612 HIR 23 juni 1987, NJ 1988, 157 m.ant. ThWvW.

613 Rb. Rotterdan 1 dec. $1981, \mathrm{NJ} 1982,63$. 
De rechtbank Alkmaar ${ }^{614}$ zei het wat meer summier. Het besluit tot levensbeèndiging moet weloverwogen zijn en op grond van een duurzaam lijden genomen. Maar ook dat betekent dat er sprake moet zijn van "informed consent". De hulpverlener moet de duurzambeid van het lijden beoordelen en waarschijnlijk ook, maar op dit punt is de rechtbank Alkmaar onduidelijk, de welovenwogenheid van het besluit tot levensbeeindiging.

Volgens de rechtbank Groningen ${ }^{615}$ behoort het uitdrukkelijk en ernstig verlangen naar levensbeëindiging duurzaam" te worden ervaren. Het lijkt me waarschijnlijk dat dit een eis is die aan de buitenwereld, met name de hulpvertener wondt gesteld. Hij behoort het verlangen als duurzaam te ervaren. Het verlangen dient gestoeld te zijn "op inzicht van de betrokkene in de eigen situatie". De rechtbank Groningen vervolgde: "en op afweging van alternatieve mogelijkheden van hulpverlening". Zeer waarschijnlijk dient in haar ogen die afweging (mede) door de betrokkene te geschieden.

Juist bij psychiatrische patiënten kunnen zich moeilijkheden voordoen bij thet toetsen van de eisen die aan een verzoek om euthanasie of hulp bij zelfdoding worden gesteld.

In een bezwaarschriftprocedure ${ }^{616}$ oordeelt het hof Den Haag het bezwaar ondermeer ongegrond, orndat het zich op grond van de beschikbare informatie niet in staat acht vast te stellen of de patiënte haar wens tot levensbeëindiging heeft geuit "in volle vrijheid en in volle bewustzijn". De Hoge Raad besteedt aan deze overweging geen aandacht. Volgens hem draagt de overweging van het hof dat niet uitgesloten moet worden geacht dat er een kans op verbetering of genezing bestond de beslissing van het hof zelfstandig."

\subsubsection{Voonwaarden aan de kant van de hulpverlener}

\section{De hoedanigheid wan de hulpverlener}

Degene die ingrijpt moet volgens de rechtbank Leeuwarden ${ }^{618}$ in beginsel een arts zijn en wel de behandelende arts of een medisch specialist. Is de handelende persoon niet de behandelende ants of een medisch specialist; dan moet in overleg met een van beide genoemde artsen worden ingegrepen.

Het geval voor de rechtbank Rotterdam ${ }^{619}$ betrof hulp bij zelfdoding, art. $294 \mathrm{Sr}$. Wellicht dat daarom de rechibank volstond met te eisen: "bil de beslissing om hulp te

614. Rb. Alkmaar 10 mei 1983 , NJ 1983, 407 .

615 Rb. Groningen 1 maart 1984, NJ 1984, 450 .

$616 \mathrm{HR} 28$ mei 1991 , NJ 1991, 789 mant. 'tH.

617 Opmerkelijk is, zoals, "t Hart in zijn woot onder de beschikking schrijf, dat de Hoge Raad geen andacht heeft besteed aan de overweging van het hof, dat de beslwitworming onder andere onzorguldig heef: platsgewonden, ondat de arts heeft nagelaten een onaliankelijke collega te randplegen. Hierin kan een bewestiging wordet gelezen over bet geen in $\mathrm{H}$. IV B, onder 2.7 .5 , wordt opgemerk. Anders dain de Hoge: Raad bekfemtcont het Centraal Medisch Tuchtcollege in zijn beslissing van 29 maart 1990, TwGR 1990/77, de noodzaak van consultatie om na te gaan, af een psychiatrisch patient tot een vrije wilsworming in staal was. In casu werden twee psychiaters in de inrichting geraadpleegd. Dat ach het CMT onvoldownde. Vanwege de interactie tussen psychiater en patiënt dient tenninste een psychiater buiten de inrichting bij de besluitvoming te worden betrokken. Tevens denen de geraadpleegde psychiaters hun meningen sichriftelijk te geven.

618 Rb. Leevwarden 21 febr. $1973, \mathrm{NJ} 1973$, 183.

619 Rb. Rotterdana 1 dec. 1981, NJ 1982,63, 
verlenen is altijd een arts betrokken, die het te gebruiken middel zal voorschrijven". Het erbij betrekken van een arts achtte zij noodzakelijk, "zowel om onzorgvuldige beslissingen te vermijden als om de beslissing achteraf te kumnen toetsen" ${ }^{\text {"t. }}$ Blijkbaar vond de rechtbank Rotterdam het niet nodig dat het behulpzaam zijn bij de zelfdoding door een arts geschiedi.

De rechtbank Alkmaar ${ }^{620}$ stelde ter zake van euthanasie niet expliciet de eis dat de hulpverlener een arts dient te zijn. Maar het moet wel om iemand gaan, die de duurzaamheid van het lijden van de betrokkene kan beoordelen. Daartoe is echter bij uitstek een geneeskundige in staat, zodat waarsehijnlijk ook de rechtbank Alkmaar bij een hulpverlener aan een geneeskundige dacht.

Volgens de rechtbank Groningen ${ }^{621}$ moet de ingreep door een arts plaatsvinden. Die arts kan de behandelende arts zijn of een andere arts. In het laatste geval dient de arts overleg te hebben gepleegd met de behandelende arts.

Met betrekking tot de strafmaat overwoog de rechtbank Utrecht ${ }^{622}$ ten aanzien van een niet-arts die tot levensbeëindiging op verzoek door wurging was overgegaan:

"Verder heeft tot het oordeel van de rechtbank bijgedragen dat verdachte tot de levensberoving op verzoek is overgegaan, ondanks de wetenschap dat de dader van dat strafbare feit bij de huidige stand van de rechtspraak in beginsel slechts straffeloos zal zijin zo éen en ander een zogenaamde 'zachte dood' betreft, die onder nog niet vast omschreven voorwaarden, maar in ieder geval door een (medisch) deskundige - ... - is voltrokken".

De rechtbank Almelo ${ }^{623}$ verwierp de beroepen op psychische overmacht en AVAS, omdat de niet-arts, niet althans in onvoldoende mate geprobeerd heeft professionele hulp te krijgen.

\section{De beslissing ten aanzien van de hulpverlening}

Volgens de rechtbank Rotterdam ${ }^{624}$ mag de beslissing tot hulp bij zellfodling "niet door één persoon" worden genomen. Deze voorw aarde stelde de rechtbank, evenals de andere voorwaarden inzake de hulpverlening, "zowel om onzorgvuldige beslissingen te vermijden als om de beslissing achteraf te kunnen toetsen".

Bij de rechtbanken Leeuwarden en Alkmaar ${ }^{625}$ treffen we deze eis niet aan. Wel betrok de rechtbank Alkmaar bij haar oordeel dat het handelen van de verdachte aan de eisen van de allergrootste zorgvuldigheid beantwoordde, dat overleg en beraad heeft plaatsgevonden met een andere arts.

Tot de ingreep behoort de arts, volgens de rechtbank Groningen ${ }^{626}$ "rinstemming te hebben van "minstens één andere arts of psychiater". De instemming behoort gegrond te zijn op "eigen oordeelsvorming door de geraadpleegde aangaande de conditie van de
patiënt".

620 Rb. Alkmaar 10 mei 19:33, NJ 1983, 407.

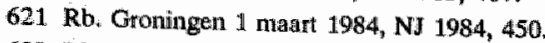

622 Rb. Utrecht 5 juli 1985, TvGR 1986/22.

623 Rb. Almelo 26 sept. 1989, TVGR 1990/5.

624 Rb. Rotterdam 1 dec. 1981, NJ 1982,63 .

$625 \mathrm{Rb}$. Leeuwarden 21 febr. 1973, NJ 1973, 183 en Rb. Alkmaar 10 mei 1983, NJ 1983, 407.

626. Rb. Groningen 1 maart 1984, NJ $1984,450$. 
De huip bij zelfdoding mag, volgens de rechtbank Rotterdam ${ }^{627}$ slechts verleend worden als zowel bij de beslissing om hulp te verlenen als bij de hulp zelf "de grootst mogelijke zorgwuldigheid in acht" wordt genomen. De rechtbank vult dit begrip niet nader in, maar volstaat met het geven van woorbeelden. Wanneer de betrokkene in de stervensfase verkeert, dan acht de rechtbank Rotterdam het voor de zorgvuldigheid nodig, dat door de arts collegiaal overleg wordt gepleegd. Ook buiten de stervensfase komt het de zorgvuldigheid ten goede als een andere deskundige wordt geraadpleegd. Bij die deskundige dacht de rechtbank Rotterdam aan een "psychiater, psycholoog of sociaal werker". Het raadplegen van deze deskundigen buiten de stervensfase houdt waarschijnlijk nauw verband met hulp bij zelfdoding. ${ }^{628}$ De rechtbank wil vermoedelijk hiermee zeker stellen dat er inderdaad geen andere weg meer openstaat dan levensbeëindiging en dat het verzoek tot levensbeëindiging niet in wezen een verzoek om andere hulpverlening is.

Ook de rechtbank Alkmaar"629 sprak van de "eisen van de allergrootste zorgvuldigheid", zonder de eisen in het algemeen nader in te vullen. Wel betrok zij bij haar overweging ten aanzien van het concrete geval het feit dat de verdachte overleg heeft gepleegd met een andere arts en met familieleden.

De rechtbank Groningen ${ }^{130}$ formuleerde het minder nadrukkelijk: "terwijl ook overigens aan de te stellen eisen van zorgvuldigheid bij de uitwoering van de ingreep is voldaan".

\section{Proportionaliteits- en subsidiariteitsbeginsel}

In de door de rechtbank Rotterdam ${ }^{631}$ gestelde voorwaarde, dat "er geen redelijke andere oplossing is om verbetering in de situatie te brengen", liggen het proportionaliteits- en het subsidiariteitsbeginsel opgesloten. Er behoort voor de minst ingrijpende weg te worden gekozen.

Dat beginsel keert terug bij de rechtbank Groningen ${ }^{632}$ waar zij overweegt, "terwijl een andere - voor betrokkene redelijkerwijs aanvaardbare - oplossing dan levensbeëindiging ontbreekt" ".

Waarschijnlijk is de reden dat deze beginselen niet altijd onder de voorwaarden zijn opgenomen te wijten aan het feit, dat een rechtvaardigingsgrond slechts kan slagen als conform die beginselen gehandeld is, zodat de rechter bij een beroep op een rechtvaardigingsgrond "automatisch" mede aan deze beginselen toetst.

627 Rb. Rotterdam 1 dec. 1981 , NJ 1982, 63.

628 Bevündt de betrokkene zich in de stervensfase, dan dient collegialal overleg door de arts plaats te vinden. Is de stervensfase nog niet aangebroken, is hij gehouden met een deskundige uit een andere discipline te owerleggen.

629 Rb. Alkmiar 10 me 1983 , NJ 1983, 407.

$630 \mathrm{Rb}$. Groningen 1 maart 1984, NJ 1984, 450 .

631 Rb. Rotierdam 1 dec. 1981 , NJ $1982,63$.

632 Rb. Groningen 1 maart 1984 , NJ 1984, 450 .

633 Zile hiertoe: H. IV B, onder 2.5 .3$. 
De rechtbank Rotterdlam ${ }^{634}$ stelt de eis dat "door de dood geen onnodig lleed aan anderen wordt toegebracht". Deze voorwaarde klinkt ook door in de vaststelling van de rechtbank Alkmaar ${ }^{635}$ dat de beslissing om levensbeërndigende hulp "in samenspraak met de naaste familieleden van M.B. welke familieleden haar wens tot vrijwillige levensbeëindiging respecteerden en ondersteunden", was genomen.

De door de rechtbanken Rotterdam en Alkmaar toegekende rol wan de (naaste) omgeving is terecht niet door andere rechters genoemd en ook niet in de wetsvoorstellen teng te vinden. Want zij opent de mogelijkheid dat aan derden vamwege hen moverende redenen een mede-beslissingsbevoegdheid wordt toegekend, die tot gevolg zou kunnen hebben dat het lijden van de patiẽnt langer duurt dan in diens belang is.

\section{Samenvatting}

Het antwoord op de vraag of de in de lagere rechtspraak genoemde voorwaarden verschillen hangt af van thet abstractieniveau waarop het wordt gegeven. Wanneer slechts gelet wordt op de telkens genoemde voorwaarden en de wijze waarop deze zijn geformuleerd, dan kan gesteld worden dat de voorwaarden nogal uiteenlopen. Wanneer daarentegen de aandacht uitgaat naar de gemeenschappelijke kenmerken dan kunnen enkele minimumvoorwaarden worden geformuleerd.

Minimaal is voor straffeloosheid vereist, dat de patiênt om levensbeëindiging heef verzocht, dat hij ernstig lijdt en zijn lijden duurzaam en uitzichtloos is. In beginsel dient een arts de handeling te verrichten, nadat hij collegiaal overleg heeft gepleegd. Van groot belang wordt geacht dat de arts zeer zorgvuldig te werk gaat. Deze voorwaarden zijn in overeenstemming met die in de verschillende voorstellen inzake een wettelijke regeling van euthanasie.

In de rechtspraak ontbreekt wel een voorwaarde waarop in de voorstellen nogal nadruk wordt gellegd, namelijk de verplichting voor de arts om schriftelijk verslag te doen.

\subsubsection{Voomwarden en de Hoge Raad}

Het hof Amsterdam had in de Euthanasie I-zaak vastgesteld, dat de arts besloot om aan de wens van de betrokkene tegemoet te komen "omdat zij naar zijn oordeel (hetgeen de HR leest als "naar zijn vakkundig oordeel als medicus", J.W.) elke dag dat zij nog leefde als een zware taak ervoer waaronder zij op ondragelijke wijze leed". Het oordeel van de medicus hield in dat er sprake was van een noodtoestand. Deze term werd hier feitelijk gebruikt en niet strafrechtelijk. Het hof had twijfels of het lijden wel zó ondraaglijk was dat de verdachte redelijkerwijze geen andere keuze had dan levensbeëindigend
te handelen.

Volgens de Hoge Raad dient dan nader te worden onderzocht "of naar verantwoord medisch inzicht, getoetst aan in de medische ethiek geldende normen, te dezen sprake was van een noodtoestand als door de verdachte gesteld" ${ }^{1 *}$, want pas dan kan van een naar

634 Rb. Rotterdam 1 dec. 1981 , NJ 1982, 63.

$635 \mathrm{Rb}$. Alkmaar 10 mei 1983, NJ 1983, 407 . 
objectief medisch inzicht handelen in noodtoestand gesproken worden. Dat hij nuet veel voelt voor het formuleren van nadere algemeen geldende voorwarden, blijkt uit zijn overweging, dat de vraag

of naar verantwoord medisch inzicht, getoetst aan in de medische ethiek geldende normen, te dezen sprake was van een noodtoestand ... afhankelijk is van diverse factoren, welke van geval tot geval kunnen verschillen".

Behalve de reeds door het hof vastgestelde omstandigheden, dat de betrokkene zeer sterk leed door de gestage achteruitgang van haar gezondheid, dat zij kort voor haar dood opnieuw een belangrijke lichamelijke inzinking kreeg, dat zij daarna weer helder van geest was, dat zij zowel lichamelijk als geestelijk zeer ernstig onder de inzinking leed, dat zij opnieuw met klem op euthanasie aandrong, had het hof - om de genoemde twijfel weg te nemen - "onder meer van belang kunnen achten":

"1. of, en zo ja in hoeverre, naar vakkundig medisch inzicht een steeds verdergaande ontluistering van de persoon van M.B. en/of een nog verdere verergering van haar toch reeds als ondraaglijk ervaren lijden moest worden gevreesd,

2. of, mede in verband met de mogelijkheid van nieuwe ernstige inzinkingen, viel te voorzien dat zij - ... (anders dan op de dag van haar overlijden, J.W.) - weldra niet meer in staat zou zijn op een waardige wijze te sterven, en

3. of, en zo ja in hoeverre, nog mogelijkheden bestonden tot verzachting van haar lijden". ${ }^{\text {636 }}$

In deze zaak had de verdachte arts zijn assistent-arts en de zoon van de betrokkene geraadpleegd, die met de euthanasie hadden ingestemd. Volgens het hof Amsterdam konden beiden niet "als voldoende objectief en als te dezen voldoende onafhankelijk ... worden beschouwd". Dat laat echter, volgens de Hoge Raad, onverlet, "dat de door de verdachte toegepaste euthanasie naar objectief mediseh inzicht als een in noodtoestand verricht handelen gerechtvaardigd was te achten". In een later arrest ${ }^{637}$ ging de Hoge Raad nog een stap verder door te overwegen dat het niet raadplegen van een andere deskundige miet uitsluit dat objectief gezien in een noodtoestand is gehandeld. ${ }^{638}$

Terwijl de Hoge Raad in het Euthanasie I-arrest het "verantwoord medisch inzicht" aan de "in de medische ethiek geldende normen" getoetst wil zien, plaats hij nadien het medisch inzicht en de medisch-ethische normen maast elkaar. De meest pregnante formulering gaf hij in HR 3 mei 1988, NJ 1989, 391 mnt. GEM, maar de strekking van die formulering is gelijk aan die in het Euthanasie 1 -arrest ${ }^{639}$.

"6.1. In gevallen als het onderhavige; warin de verdachte aanvoert te hebben gehandeld in noodtoestand, dat wil zeggen dat hij, staande voor de noodzaak te kiezen uit onderling strijdige plichten, de zwaarstwegende daarvan is nagekomen, dient de rechter - zijnde dit bij uitstek des rechters taak - te onderzoeken of naar wetenschappelijk verantwoord medisch inzicht en naar in de medische ethiek geldende normen zich inderdaad een situatie heeft voorgedaan welke als noodtoestand mag worden aangemerkt, en of de keuze daarin van de verdachte als gerechtvaardigd mag worden geoordeeld. ${ }^{1640}$

636. In HR 21 okt. 1986, NJ 1987, $607 \mathrm{~m}$.nt. GEM, wiet de HR af van thet noemen van voorbeclden.

637 HR 23 juni 1987, NJ 1988, 157 mat. ThWvV.

638 In dezelfde zim: HR 3 mei 1988, NJ 1989, 391 m.nt. GEM.

639 HR 21 okt. 1986, NJ 1987, 607 m.nt: GEM.

640 HR 3 mei 1988 , NJ 1989,391 m.nt. GEM. 


\subsubsection{Voorwaarden woorwaardelijk?}

Volgens de Hoge Raad kan euthanasie door een arts in een situatie van noodtoestand gerechtvaardigd zijn als volgens wetenschappelijk verantwoord medisch inzicht en naar in de medische ethiek geldende normen is gehandeld.

De strafuitsluitingsgrond overmacht is door de wetgever bewust open geformuleend, zodat rimte kon worden gelaten aan jurisprudentiele ontwikkelingen. ${ }^{641}$ Ook de Hoge Raad wil bij euthanasie door een medicus voldoende ruimte aan de feitenrechter laten om rekening te kunnen houden met de omstandigheden van het concrete geval.

Is de consequentie van deze benadering dat door de lagere rechtspraak geformuleerde voorwaarden, die ingang hebben gevonden in hel vervolgingsbeleid van het $\mathrm{OM}^{\mathrm{s}+2}$, alls algemene voorwaarden van generlei waarde zijn?

Zo algemeen kan dat niet gezegd worden. Ten eerste moet zich een noodsituatie woordoen, die een medicus tot handelen "dwingt" of tot het maken van een keuze (die op haar beurt weer tot handelen leidt). Daarmee verband houdend moet onderscheiden worden tussen de voorwaarden aan de kant van de betrokkene en de voorwaarden voor hulpverlening. De voorwaarden aan de kant van de betrokkene blijven overeind.

Deze voorwaarden typeren immers de noodsituatie van de patient, de noodsituatie waarmee de medicus geconfronteerd wordt en die hem plaatst voor de keuze uit tegenstrijdige belangen: het belang van de patient om aan het ondraaglijke lijden een einde te maken en het belang dat met naleving van de wet is gemoeid. De keuze voor het belang wan de patiënt dient objectief gerechtvaardigd te zijn. Juist voor de objectieve rechtvaardiging is handelen volgens wetenschappelijk verantwoord medisch inzicht en volgens normen van de medische ethiek nodig.

Ondanks het niet-naleven van bepaalde zorgvuldigheidseisen kan er sprake zijn van zorgvuldige hulpverlening, zolang de zorgvuldigheid binnen de patiënt-arts-relatie in acht wordt genomen. Voor de objectieve rechtvaardiging is niet nodig, dat de handelende medicus bijvoorbeeld een andere deskundige raadpleegt, dat hij een dagboek bijhoudt, dat hij gesprekken voent met familieleden. Als hiervan blijkt dan kan het de medicus wel helpen, want het maakt een beroep op noodtoestand eerder aannemelijk.

Niet uitgesloten moet worden geacht, dat de onzorgvuldigheid jegens derden in strijd kan komen met normen van de medische ethiek, zodat de medische tuchtrechter tot een ondermijning in het vertrouwen van de medische stand zou kunnen concluderen, maar die onzorgvuldigheid betreft in het kader van de hier besproken hulpwerlening slechts een randverschijnsel. Zodra de patiënt zich in een hierboven omschreven noodsituatie bewindt en de arts jegens hem zorgvuldig te werk is gegaan, kan een bercep op noodtoestand slagen. Niet-zorgvuldig handelen jegens derden moge medisch-ethisch laakbaar $z i j n$, maar is strafrechtelijk niet relevant. ${ }^{643}$

\subsection{De vervolging van euthanasie}

Het strafrechtelijk apparaat treedt pas in werking wanneer het vermoeden bestaat dat een strafbar feit is gepleegd. Dat vermoeden is bij levensdelicten door artsen moeilijk

641 Bronkhorsi, 1952, p. 14 en p. 114.

642 Zit hiertoe: H. IV B, onder 2.8 .

643 Zie: Enschede, 1985, p. 114, noor 30 . 
te verkrijgen. Het is immers de arts die door het invullen van de overlijdensverklaring te kennen geeft, dat een patiënt een natuurlijke dood is gestorven. De gemeentelijke lijkschouwer, de geneeskundige inspectie en het Openbaar Ministerie worden eerst actief wanneer omtrent de juistheid van die verklaring twijfel rijst of wanneer de arts geen overlijdensverklaring afgeeft. Vooral artsen die niet in teamverband werken, hebben derhalve in het algemeen de mogelijkheid de ware toedracht van het overlijden van een patiënt verborgen te houden. ${ }^{1.44}$

Wanneer een strafbaar feit aan justitie bekend wordt, maar het bewijs niet is "rond te krijgen", dan zal het OM tot een bewijssepot komen. Wanneer voldoende bewijsmateriaal voorhanden is, staat het OM voor de keuze of het tot (verdere) vervolging zal overgaan danwel de zak zal seponeren. Een sepot is mogelijk vanwege gronden aan het algemeen belang ontleend, artt. 167 lid 2 en 242 lid 2 Sv.

Het OM kan soms een zaak transigeren of voorwardelijk seponeren. Maar transactie is vanwege art. 74 Sr slechts mogelijk ten aanzien van delicten met een maximale gevangenisstraf van zes jaar. Daarom kan wel in geval van hulp bij zelfdoding getransigeerd worden, maar niet levensberoving op verzoek. ${ }^{645}$

Het strafvorderingsbeleid van het $O M$ kan vastgelegd worden in vervolgingsrichtlijnen, die al dan niet extern worden bekend gemaakt. In het algemeen komen voor vervolgingsrichtlijnen geen delicten in aanmerking waarbij het toebrengen van letsel of dood van een mens bestanddeel van de delictsomschrijving is. ${ }^{646}$ Op grond daarvan is een vervolgingsrichtlijn ten aanzien van handelen in strijd met de artt. 293 en 294 Sr niet goed denkbaar.

Het bijzondere bij euthanasie door een ants is, dat de verantwoordelijke OvJ over de vervolging niet zelfstandig beslist. Elk geval van euthanasie (en van hulp bij zelfdoding) door een arts ${ }^{647}$ dat ter kennis van justitie komt, wordt in de vergadering van de Procureurs-Generaal besproken. Deze vergadering komt regelmatig onder leiding van de secretaris-generaal van het Ministerie van Justitie bijeen, in een enkel geval zit de Minister van Justitie zelf voor. 648

In 1982 is afgesproken, dat "ten behoeve van eenheid van besluitvorming" in deze vergadering elk thanasie-geval besproken wordt. Ter toetsing dienen in de jurisprudentie ontwikkelde criteria. ${ }^{649}$

Zeker tot aan het Alkmaarse euthanasie-arrest waren daarbij vooral van belang de door de rechtbanken Leeuwarden in 1973 en Rotterdam in 1981 genoemde voorwar.

644. Vgl. Feber, Preadvies Vereniging woor Gezondheidsrecht, 1989, p. 12 en Commissie Onderzoek Medische Praktijk inzake Euthanasie, 1991, p. 26.

645 Vanwege de lagere maximale gevangenisstraffen volgens de woorstellen tot wetswijziging van de art. 293 en $294 \mathrm{Sr}$, zov transactie ook voor levensberoving op verzoek in anmerking komen.

646. Vgl. Feber, Preadvies Vereniging woor Gezondheidsrecht, 1989, p. 2.

647 Vgl. EK 1982-1983, Aanhangsel nr. 39.

648 Schalken, in: Euthanasie, 1985, p. 115.

649 TK 1981-1982, Aanhangsel mr. 88,; Regeringswerklaring, TK 24 nov. 1982, p. 740; TK 1982-1983, Aanhangsel nr. 940 ; 
den. ${ }^{650}$ Die voorwaarden zijn ook terug te vinden in de standpuntbepaling van de $\mathrm{KNMG}$ ten aanzien van euthanasie. ${ }^{651}$

Ik deel niet de kritiek dat het OM ten onrechte nallaat vervolgingsrichtlijnen voor euthanasie bekend te maken. Er is mijns inziens sprake van een, in de woorden van Feber, "duidelijk en consequemt beleid" ${ }^{6.52}$ Voordat het rapport van de Staatscommissite verscheen, heeft de Minister wan Justitie expliciet naar de voonwarden van de genoemde rechtbanken verwezen. In verband met de lopende werkzaamheden van de Staatscommissie betrachtte de Minister wel enige terughoudendheid in zijn antwoorden, maar die betrof met inachtneming van de woorwaarden, de strafwaardigheid van euthanasie. ${ }^{653}$

Ook los van de werkzaamheden van de Staatscommissie kon de Minister moeiljk meer duidelijkheid verschaffen. In dat stadium van het euthanasie-debat moest elke zaak, in verband met de genoemde voorwaarden, op haar eigen merites worden beoordeeld. Daarom kwam het juist tot de bijzondere wijze van besluitworming.

In hoeverre de "euthanasie" -jurisprudentie van de Hoge Raad tot een herbezinning op de voorwaarden heeft geleid, is mij niet bekend. Feber noemt het Euthanasie I-arrest een "belangrijk sleutelarrest woor het $\mathrm{OM}$-belleid", maar tevens blijkt uit zijn preadvies dat de eerdere voorwaarden nog steeds gelden. ${ }^{6.54}$ Dat lijkt mij ook niet in strijd met de betekenis van het Euthanasie I- en het Euthanasie II-arrest. De Hoge Raad heeft ermee volstaan de medische exceptie binnen de noodtoestand te erkennen. Dat betekent dat de criteria die in de lagere rechtspraak zijn ontwikkeld, binnen het door de Hoge Raad gestelde kader nog steeds dienst kunnen doen. Wanneer de arts aan de Leeuwardense en Rotterdamse voorwaarden voldoet, dan kan hij erop vertrouwen, dat hij vrijuit gaat.

Oak thans is er nog iets te zeggen voor een terughoudende opstelling van het $O M$ ten aanzien van het bekendmaken van euthanasie-richtlijnen. ${ }^{655} \mathrm{De}$ in de verschillende voorstellen tot wetswijziging van de artt. 293 en $294 \mathrm{Sr}$ voorgestelde voorwaarden wijken op sommige punten af van de in de jurisprudentie ontwikkelde. Zolang een wettelijke regeling van euthanasie tot politieke conflicten leidt verdient het aanbeveling dat het OM niet op de wetgever vooruitloopt. Dat klemt temeer nu de Hoge Raad heeft beslist, dat vervolgingsrichtlijnen, zeker wanneer zij bekend zijn gemaakt, als recht in de zin van art. 99 Wet RO worden beschouwd ${ }^{656}$ Gevolg hiervan is, dat het OM onder omstandigheden gehouden is te motiverem, waarom het van een richtlijn afwijkt. ${ }^{657}$

650 MEK 1982-1983, Arnhangsel nr. 39. Zie ook: TK 1981-1982, Aamhangsel nr. 873, watrin de Minister van Justitie verklaande dat de opvattingen vain de Rb. Rotterdam 1 dec. 1981, NJ 1982, 63 (een gevall van hulp bij zelfdodingl) en van thet OM over de strafwardigheid van het handelen "nagenoeg volledig"
overeenstemden.

651 Zie: H. IV A, onder 2.8. Vgl. Feber, Preadvies Vereniging voor Gezondheidsrecht, 1989, p. 17.

652 Feber, Preadvies Vereniging voor Gezondheidsrecht, 1989, p. 17. Zie ook: Josephus Jitta, in: Euthanasite: russen wet en geweten, 1986, p* 13:-135.

653 EK 1982-1983, Aanhangsel ar. 39 en EK 1983-1984, Aanhangsel nr. 7.

654 Feber, Preadvies Vereniging voor Gezondheidsrecht, 1989, p. 13 en p. 17-19.

655. Vgl. Schalken, in: Euthamasie, 1985, p. 165: OM an inspectie kunnen zich uitshuitend tot voorlichting in algemene zin beperken. Anders: Feber, Preadvites Vereniging voor Giezondheidsrecht, 1989, p. 23.

656 HR 19 juni 1990, NJ 1991, 119 m.nt. ThWvV en MS. Zie hierover: Corstens, DD 1991, P. 1-6.

657 Zie in dit verband: HR 5 maart 1991, NJ 1991, 694 m.nt. C. In de noot merkt Corstens op, dat in de richtlijnen steeds de mogelijkheid wordt opengehouden in concrete gevallen van de richtlijn af te wijken. 


\section{Conclusie}

De wetgever van 1886 heef de medische exceptie voor euthanasie en hulp bij zelfdoding niet erkend en de wetgever van 1911 heeft de medische exceptie in elk geval ter zake van abortus niet erkend.

Voor zover euthanasie door een arts gerechtvaardigd kan zijn, moet de oplossing derhalve langs andere wegen worden bereikt. Daarbij kan gedacht worden aan andere strafuitsluitingsgronden en aan wetswijziging.

De delictsomschrijving van art. $293 \mathrm{Sr}$ biedt geen ruimte voor een taalkundige interpretatie op grond waarvan euthanasie niet aan de delictsomschrijving voldoet.

Straffeloosheid kan evenmin worden bereikt via het ontbreken van de materiële wederrechtellikheid. Tegen een nime invulling van deze rechtsgrond pleit dat de rechter zich dan op het terrein van de wetgever begeeft. Wanneer het ontbreken van de materiële wederrechtelijkheid beperkt wordt opgevat in die zin dat met het overtreden van de wet het door de wet beschermde belang beter wordt nageleefd dan wanneer conform de wet wordt gehandeld, dan heeft deze rechtsgrond eerder bestaansrechi. In euthanasie-gevalien kan hij echter geen dienst doen, want dat het door art. 293 Sr beschermde belang, de eerbied voor het menselijk leven in het algemeen, beter nagestreefd wordt door aan dat leven een einde te maken, druist in tegen de bedoeling van de wetgever van 1886 en tegen de logica.

De Hoge Raad heeft de medische exceptie ter zake van euthanasie uitdrukkelijk van de hand gewezen. Daartoe heeft hij terecht aangevoerd dat de wetgever van 1886 de medische exceptie in verband met art. $293 \mathrm{Sr}$ niet heeft erkend. Bowendien voelt de Hoge Raad er waarschijnlijk niet voor met een beroep op gewijzigde maatschappelijke opvattingen euthanasie van het werkingsbereik van art. 293 Sr uit te zonderen. Bij een dermate normatief geladen ondenwerp als euthanasie is dat ook wel wenselijk. Waar de verschillende levensbeschouwelijke opvattingen over de geoorloofdheid van euthanasie zo zeer tegenover elkaar staan verdient het aanbeveling dat de wetgever hierover een beslissing neemt.

Zolang een wetswijziging voor euthanasie achtenwege blijft, biedt de rechtvaardigingsgrond noodtoestand goede mogelijkheden voor de straffeloosheid van de medicus. Voor noodtoestand bij euthanasie pleit dat daarmee recht wordt gedaan aan het uitzonderlijk karakter van het rechtsgoed dat in het geding is.

Voor euthanasie is vereist een uitzichtloze noodsituatie en een verzoek van de patient om levensbeëindiging. Eerst moet komen vast te staan dat medisch gezien de noodsituatie uitzichtloos is. Daarvan is sprake alls het medisch handelen de situatie van de patiënt niet verbeteren kan, maar wel nog enige tijd in stand kan houden. Bovendien dient de patiënt de situatie, waarin hij zich bevindt als uitzichtloos en ondraaglijk te ervaren en zulks kenbaar te maken. Reeds het verzoek om euthanasie geeft aan dat hij zijn situatie als uitzichtloos en ondraaglijk beschouwt. Het fysieke en/of geestelijke lijden maakt de noodsituatie voor de patiënt uitzichtloos en ondraaglijk. Dat lijden kan (mede) bestaan doordat de patiënt een ontluisterend aftakelingsproces meemaakt, dat ertoe kan leiden dat hij zich niet meer in staat acht op een waardige wijze te sterven.

De Hoge Raad ziet af van het formuleren van algemene voorwaarden voor de toelaatbaarheid van euthanasie via de noodtoestand. Hij volstaat ermee het lijden en het recht op waardige wijze te sterven te beklemtonen. Ook indien niet aan alle in de lagere rechtspraak geformuleerde voonwaarden van de hulpverlening is voldaan, kan er sprake zijn van een gerechtvaardigd handelen in een noodsituatie. 
De benadering van de Hoge Raad biedt flexibiliteit om op verschillende omstandigheden die tot euthanasile kunnen leiden, in te spelen. In de wijze waarop noodtoestand op euthanasie-situaties wordt toegepast, heeft de medische exceptie wel een belangrijke rol gekregen. Zij dient zowel als waarborg voor de zorgvuldigheid bij euthanasie in een noodsituatie als ter vaststelling van die noodsituatie. Aan deze constructie zit echter ook een nadeel vast. Doordat de Hoge Raad de medische exceptie in de noodtoestand heeft verwerkt, bestaat het gevaar dat de rechter op het kompas van de medici gaat varen en dat daarmee van een zelfstandige strafrechtelijke toetsing weinig terechtkomt.

Het verdient geen aanbeveling de straffeloosheid van euthanasie via het vervolgingsbeleid te waarborgen. Deze weg kan wel tijdelijk begaan worden. Maar het vervolgingsbeleid als instrument te bezigen in plaats van wetgeving draagt niet bij tot rechtszekerheid en verzwakt de normerende werking die van een strafbepaling kan uitgaan.

Het verloop van de diverse pogingen om tot een wijziging van de artt. 293 en 294 Sr te komen, doet denken aan de wijze waarop in de jaren zeventig getracht werd een nievwe abortuswetgeving tot stand te brengen.

In de voorstellen tot wijziging van de artt. 293 en $294 \mathrm{Sr}$ wordt veelal aangesloten bij eerder in de lagere rechtspraak ontwikkelde, meer specifieke voorwaarden. Vanwege het besef dat deze onvoldoende geëigend zijn als wettelijke waarborgen te dienen, zijn daarnaast procedurele eisen gesteld. Dientengevolge vertonen de voorstellen veel overeenkomst met de regeling van de WAZ.

De tegenstellingen van de voorstellen openbaren zich vooral in de wijze waarop getracht wordt de straffelloosheid te bereiken, namelijk via een rechtvaardigingsgrond dan wel met behulp van een schulduitsluitingsgrond.

Evenals in de meeste andere voorstellen is ook in het kabinetsvoorstel een negatieve bepaling opgenomen, op grond waarvan bepaalde thanatische gedragingen van euthanasie worden uitgezonderd en evenmin strafbaar zijn. Terwijl het kabinetsvoorstel aan de medici formeel-juridisch niet de door hen geeiste rechtszekerheid verschaft, zal het dat in de praktijk wel doen. De in dat voorstel opgenomen, maar niet noodzakelijk bevrijdende voorwaarden kunnen voor meer duidelijkheid zorgen en kunnen de rechter een handvat bieden. De vraag is echter, of de wetgever zich niet duidelijker over de geoorloofdheid van euthanasie moet uitspreken, dan in het kabinetsvoorstel wordt gedaan.

Ten aanzien van twee in de negatieve bepaling vermelde schijngestalten, namelijk het afzien van medisch zinloos handelen en de levensverkortende pijnbestrijding, is echter wel wenselijk dat ook voor deze gedragingen voorwaarden worden vastgelegd. De noodzaak daarvan blijkt uit het rapport van de Commissie Onderzoek Medische Praktijk inzake Euthanasie. Deze schijngestalten betreffen evenals euthanasie gedragingen waarbij het leven in het geding is. Het aantal gevallen overstijgt de euthanasie-gevallen veellvoudig. Voor het afzien van medisch zinloos handelen is een overeenkomstige wilsuiting van de patiẻnt niet relevant en het onderzoek naar de praktijk van de levensverkortende pujnbestrijding wijst uit dat de toestemming van de patiênt tot die behandeling niet altijd aanwezig is.

Naar aanleiding van het onderzoek voor en het rapport van de Commissie Onderzoek Medische Praktijk inzake Euthanasie heeft het kabinet besloten thanatisch handelen met behulp van een meldingsprocedure te regelen. Die procedure zou gekoppeld worden aan de Wet op de lijkbezorging. Aan het kabinetsstandpunt kleeft een aantal bezwaren. De belangrijkste zijn dat niet in een wet komt vast te liggen onder welke omstandigheden euthanasie gerechtvaardigd kan zijn en dat het kabinet door levensbeëindiging onder 
de meldingsprocedure te brengen, impliciet de straffeloosheid van deze gedraging heeft erkend. Het kabinet heeft daarbij wel nagelaten aan te geven onder welke omstandigheden levensbeëindiging straffeloos zou mogen worden verricht. Voor verdere opmerkingen over het kabinetsstandpunt wordt naar de slotbeschouwing verwezen.

\section{LEVENSBEËINDIGING}

\section{Inleiding}

Ofschoon bij wilsonbekwamen een verzoek tot levensbeëindiging ontbreekt, heeft in de euthanasiediscussie altijd de vraag een rol gespeeld, of een arts onder bepaalde omstandigheden straffeloos het leven van een wilsonbekwame mag beëindigen. Die vraag staat in dit onderdeel centraal.

Onder euthanasie wordt verstaan levensbeëindiging op verzoek. De eis tot aanwezigheid wam een verzok brengt mee dat bij patiënten die hun will niet (meer) kumen uiten euthanasie niet mogelijk is. Het gaat dus om levensbeëindiging zonder verzoek. In de medische ethiek is het inmiddels gebruikelijk om levensbeëindiging zonder verzoek als "levensbeëindigend handelen $n^{\text {t" }}$ aan te duiden. In dit boek wordt in plaats dararvan zoveel mogelijk van "levensbeëindiging" gesproken, om te benadrukken dat levensbeëindiging zowel door een doen als door een nalaten kan plaatsvinden.

Met "wilsonbekwame patiênten" of "wilsonbekwamen" worden hier patiënten aangeduid die hun wil niet kunnen uiten en derhalve niet in staat zijn een rechtens relevant verzoek tot levensbeëindiging te doen. Het onvermogen om de wil te kunnen bepalen kan tijdelijk of blijwend zijn. Een wilsonbekwame die eerder zijn wil kon uiten, kan in die periode van zijn leven een levenstestament hebben opgesteld. Wanneer daaraan geen enkele waarde wordt toegekend, dan verschilt zijn situatie niet van die van andere wilsonbekwamen. Naarmate aan het levenstestament meer betekenis wordt toegekend, wordt het verschil met levensbeëindiging groter en met euthanasie kleiner. De rol van een levenstestament is reeds in verband met euthanasie ter sprake gekomen. Daar werd ook aandacht besteed aan andere minderjarige patiënten dan pasgeborenen.

In dit onderdeel wordt uitgegaan van de veronderstelling dat de patiënt wilsonbekwarm is. Tot de wilsonbekwamen kunnen gerekend worden pasgeboren, comateuze en ernstig geestelijk gehandicapte patiënten.

Bij levensbeeindiging van wilsonbekwame patiënten moet onderscheiden worden tussen enerzijds het niet aanvangen te behandelen en het niet verder behandelen en anderzijus het actief doden. Want dat de medicus niet werplicht is (verder) te behandelen en wellicht zelfs gehouden is om af te zien van (verdere) behandeling, betekent niet dat hem is toegestalan het leven van de wilsonbekwame patiënt actief te beëindigen. Het niet (verder) behandelen met als gevolg dat de patiënt op een eerder tijdstip komt te overlijden dan bij (verder) behandelen het geval zou zijn, wordt hier als passieve levensbeëindiging aangeduid. Daar het verschil tussen actieve en passieve levensbeezindiging minder scherp is dan de woorden doen vermoeden, verdient het aanbeveling om actieve levensbeëindiging te omschrijven als door de medicus bewerkstelligde levensbeèndiging anders dan door niet (verder) te behandelen. Deze actieve levensbeëindiging geschiedt, althans zou moeten 
geschieden, met behulp van "euthanatica'.658 De kwestie van de actieve levensbeëindiging komit pas aan de orde wanneer de arts het behandelen heeft nagelaten danwel heef gestaakt, althans daartoe heeft kunnen besluiten.

Evenals ten aanzien van euthanasie wordt ook met betrekking tot levensbeeindiging van pasgeborenen en comateuze patienten gesteld, dat de problematiek in zijn huidige dimensie door de ontwikkeling wan de medische technologie (na 1945) is ontstaan ${ }^{659}$, terwijl de publieke discussie daarover in de jaren zeventig is begonnen. ${ }^{660}$ Die technologie heeft het mogelijk gemaakt langer dan vroeger met de behandeling van mensen door te gaan. Daardoor kummen mensen in bepaalde situaties terechtkomen en verblijven, die tot de vraag leiden of het wenselijk is met de behandeling door te gaan.

Deze vraag is in de neonatologie en bij comateuze patiènten belangrijker dan de vraag of met de behandeling dient te worden begonnen. Op dat moment is de prognose vaak onzeker. Dankzij de medische technologie kan bij een onzekere prognose meestal met de behandeling worden begonnen, hetgeen vanwege het veelal positief effect ook gebeurt. Een behandeling krijgt daardoor het karakter van een proefbehandeling, totdat een prognose met meer zekerheid kan worden gesteld. ${ }^{661}$ Die prognose kan gunstig of ongunstig voor de patiënt zijn. Bij een ongunstige prognose staat de arts voor de vraag, of met behandelen dient te worden doorgegaan, danwel het behandelen gestopt mag worden of tot actieve lewensbeèindiging mag worden overgegaan. ${ }^{62}$

Uitgangspunt voor levensbeeindiging is dat behandelen zinloos is. Daarom is het wan belang of een handeling al dan niet als behandeling wordt aangemerkt. Met "behandelen" wordt bedoeld "medisch handelen" ". Niet de hoedanigheid van de handelende persoon, maar de aard van de handeling bepaalt of deze als medisch handelen wordt aangemerkt. In die zin kan bijvoorbeeld een verpleegkundige medische handelingen verrichten.

De opbouw van de bespreking van dit vraagstuk is zoveel mogelijk gelijk aan die van de eerder besproken gedragingen. Begonnen wordt met een beschrijving van de medisch-ethische benaderingen van deze kwestie. Daarna worden voorstellen tot wetswijziging besproken, voor zover daarin aandacht aan levensbeëindiging wordt besteed. Over de vraag naar de strafrechtelijke aansprakelijkheid van de medicus voor levensbeëindiging van wilsonbekwamen is inmiddels enige jurisprudentie gepubliceerd, die in verband met de bespreking van strafuitsluitingsgronden aan de orde komt.

658 Onder "euthanatica" worden verstaan "famaca warvan het gebruik aangewezten is, indien men een "goedc docd" will bewerkstelligen ${ }^{*}$. CAL, 1991, p. 4.

659 Gezondheidsragd, 1975, p. 1; Van Zeben, in: Euthanasie, 1977, p. 169-170; Versius, MC 1989, p. 606; CAL, 1990 , p. 4-5; CAL, 1991 , p. 8-9.

660 Voor de pasgeborenen zie: Musschenga, 1987 , p. 48.

664. CAL, 1990, p. 5-6.

662 CAL, 1991, p. 7-9. 


\section{Recente medisch-ethische benaderingen van "levensbeëindiging"}

\subsection{Inleiding}

Toen de huidige euthanasiediscussie aan het eind wan de jaren zestig begon, werd in de discussie meteen de levensbeëindiging van wilsonbekwamen betrokken. De toentertijd gangbare omschrijvingen van euthanasie, waarin meestal niet over het verzoek werd gesproken, maar over handelen in het belang van de patiënt, laten zien dat levensbeëindiging op verzoek en zonder verzoek niet duidelijk van elkaar werden gescheiden. De differentiatie begon pas rond het begin van de jaren tachtig op grote schaal plaats te vinden. Voor zover mogelijk wordt voor de beschrijwing van de standpunten de thans gebruikelijke terminologie aangehouden.

De wijze waarop vanuit de medische ethiek over levensbeẻindiging wordt gedacht, wordt hoofdzakelijk geillustreerd aan de hand van enkele rapporten. De voor deze rapporten verantwoordelijke commissies zijn meestal multidisciplinair samengesteld.

In thet Eerste Interimrapport over euthanasie uit 1972 van de Gezondheidsraad ${ }^{663}$ werd zijdelings ingegaan op levensbeëindiging van wilsonbekwamen. De geringe aandacht die deze problematiek in dat rapport kreeg, was voor de Gezondheidsraad aanleiding om in 1975 een Tweede Interimrapport uit te brengen, deze keer toegespitst op levensbeeindiging van pasgeborenen. ${ }^{664}$

In november 1989 verscheen een rapport van de Nederlandse Vereniging voor Kindergeneeskunde (NVK) met de titel "Doen of laten?"66.5. Het rapport werd op verzoek van de Sectie Perinatologie ${ }^{666}$ van de NVK opgesteld door een werkgroep van de Sectie $\mathrm{e}^{667}$. De sinds september 1986 bestaande werkgroep (hier aangeduid als "werkgroep Doen of laten" of als "werkgroep"), wordt gevormd door zes artsen. ${ }^{668}$ Zij heeft onder andere tot doel binnen de Sectie een discussie in gang te zetten over het "al of niet beginmen met en het staken van levensverlengende maatregelen alsook betreffende het overgaan tot levensbeêindiging bil pasgeborenen in verband met een slechte prognose" ${ }^{160}$.

De Commissie Aanvaardbaarheid Levensbeëindigend Handelen (CAL), die multidisciplinair is samengesteld ${ }^{670}$, werd door het Hoofdbestuur van de KNMG op 3 september 1985 ingesteld. Zij kreeg tot taak een standpuntbepaling van het Hoofdbestuur ten aanzien van levensbeëindiging bij wilsonbekwamen voor te bereiden. De CAL heeft besloten eerst over enkele categorieën wilsonbekwamen afzonderlijke deelnota's uit te brengen en daxarma een eindrapport. In 1988 verscheen de als discussiestuk bedoelde eerste deeinota wan de CAL. Deze betreft levensbeëindiging van pasgeborenen. De discussienota werd

663 Gezondheidsraad, 1972.

664 Gezondheidsraad, 1975.

665 Voorafgegaan door een interimrapport in 1988.

666 Perinatologie: de geboorte betreftend, rond de geboorte.

667 De werkgroep "Ethische aspecten van de neonatologie".

668 Jansen. Kollée, De Leeuw, Sauer, Versluys (voorzitter) en Wierenga:

669 Doen of laten, 1989, p. 7.

670 Tot haar leden behoren twee ethici, een chirurg, een internist, een neuroloog, wwee psychiaters, een kinderarts, een huisarts, een geriater, de secretaris-generaal van de $\mathrm{KNM} G$, zetleen arts, en de secretaris-jurist wan de $\mathrm{KNMG}_{\text {; }}$ een rapporteur, en - later toegewoegd - een kinderarts/neonatoloog. 
in 1990 gevolgd door een interim-rapport over hetzel fde onderwerp. ${ }^{671}$ Tussen de CALnota en de werkgroep bestonden contacten, die vermoedelijk tot een in hoofdlijnen owereenstemmende benadering van het onderwerp hebben bijgedragen. ${ }^{672}$

In 1991 bracht de CAL een tweede discussienota uit, nu ten aanzien van levensbeëindiging van comateuze patiënten ${ }^{673}$ Evenals bij het interimrapport over levensbeëlndiging bij zwart-defecte pasgeborenen maakt de CAL ook hier het uitdrukkelijk voorbehoud dat deze nota slechts haar voorlopig standpunt weergeeft.

De genoemde rapporten worden hier zoveel mogelijk tezamen besproken, waarbij telkens de nadruk op de laatste versie ligt.

\subsection{Medisch zinloos handelen bij zwaar-defecte pasgeborenen}

In het eerste deel van dit hoofdstuk bleek dat een medicus niet gehouden is en zelfs niet gerechtigd is tot medisch zinloos handelen. Het nalaten van medisch zinloos handelen wordt als schijngestalte van euthanasie gezien. Levensbeëindiging bij wilsonbekwame patiënten betreft derhalve niet het nalaten van medisch zinloos handelen. ${ }^{674}$ Daar de legitimatie voor levensbeëindiging slechts in de toestand en de toekomstige mogelijkheden van de patiëmt kan worden gevonden, is de afbakening tussen levensbeëindiging en nalaten van medisch zinloos handelen van belang. Dat is vermoedelijk de reden dat medisch zinlloos handelen in verband met levensbeëindiging veel meer ter sprake wordt gebracht dan bij euthanasie: Aldus biedt de bespreking van levensbeëindiging de mogelijkheid het begrip medisch zinloos handelen nader te bepalen.

Met betrekking tot medisch zinloos handelen bestaat er geen verschil tussen wilsonbekwame en wilsbekwame patiënten. Dat de medicus hierbij geen rekening behoeft te houden met de wens van een wilsbekwame patiënt, neemt niet weg, dat hij om niet-medische redenen met de behandeling op wens van de patiënt langer kan doorgaan dan de prognose rechtvaardigt, om zodoende bijvoorbeeld de patiënt gelegenheid te bieden van zijn naasten afscheid te nemen. Bij wilsonbekwame patiënten kunnen de naasten de wens uiten om met de behandeling door te gaan. Voor zover zij daartoe een valide reden kunnen aanvoeren en vooral voor zover het enige tijd doorbehandelen niet tot een langere lijdensweg van de patiënt leidt, mag de medicus aan die wens gehoor geven.

Volgens de rapporten is handelen medisch zinloos als de patiënt geen overlevingskans heeft en het resterende leven waarschijnlijk met een ernstig en niet op te heffen lijden

671 Cormmissie Aanvardbarheid Levensbeëindigend Handelen, Levensbeêindigend handelen bij wils-onbekwame patienten, Interim-rapport, Utrecht 1990. Zhe voor de eerdere discussiemota: Deell I: Zwaar-defecte pasgeborenen, MC 1988, 697-704.

672 Zo ook Versluys, MC 1989, $p_{4} 606$ en in: Beslissen over leven \& dood, 1989, p. 37. Van Berkestijn, in: Beslisisen over lewen dood, 1989, p. 33.

673 Commissie Aanvaardbatarheid Levensbeëindigend Handelen, Levensbecindigend handelen bij willsonbekwame patiénten, discussienota. KNMG, Deel H: Langdurig comateuze patiênten, Utrecht 1991.

674 Ten onrechte, zo wordt gezegd door Smelt, (anesthesioloog), Bakter (chirurg), Van Bruggen (kinderants), Jochemsen (directeur Prof. Dr. G.A. Lindeboom Instituut, Ede); MC 1989, p. 18, heeft de CAL niet duidelijik gesteld dat bet niet beginnen en het staken van medisch zinloos handelen schijngestalten zijn van euthanasia en a fortior wan levensbeeindigend handelen bij pasgeborenten. Zie ook: Boom, MC 1989, P. 1301: Katholieke Vereniging woor Ziekenimichtingen, MC 1989, p. 20 . 
gepaard gaat. ${ }^{675}$ De werkgroep Doen of laten noemt dit handelen een "kansloos medisch handelen". Medisch handelen is kansloos, als naar "heersend medisch inzicht overleven niet mogelijk is" ${ }^{n}{ }^{676}$ De CAL spreekt van de daaraan ten grondslag liggende prognose als van de "geen reële overlevingskans"-prognose. Deze prognose geldt als "objectieve" reden voor levensbeëindiging van een pasgeborene. ${ }^{677}$ Behalve ten aanzien van de (sterk) immaturen ${ }^{678}$, bestaat onder de neonatologen over de "geen reële overlevingskans" -prognose een grote mate van overeenstemming. ${ }^{679}$

De CAL geeft er de voorkeur aan de overlevingskans als "reële kans" boven "goede kans" op te vatten, daar bij geneeskundige prognoses zo goed alls nooit volledige zekerheid mogelijk is. Een reële kans is aanwezig als er gegronde medische redenen zijn voor de verwachting dat de pasgeborene niet zal overleven. Daaromtrent mag geen gerede twijfel bestaan. Deze progmose "dient te worden gebaseerd op persoonlijke ervaring en intuitie, maar in principe tevens ... te corresponderen met de beschikbare statistische gegevens dienaangaande"t ${ }^{680}$ Hieruit blijkt dat de CAL aan de statistische gegevens een ondergeschikte rol voor de besluitvorming toekent.

Hoe meer zekerheid voor de reële overlevingskans-prognose gewenst wordt ${ }_{\text {, }}$ des te eerder komt de medicus in conflict met de regel "in dubio abstine". ${ }^{681}$ De CAL spreekt in dit verband van een "dilemma". Is de vereiste zekerheid er niet dan kan de medicus echter wel voorwaardelijk met de behandeling beginnen. Zodra voldoende zekerheid omtrent de kwade kans is verkregen, dient hij alsnog de behandeling te staken en desnoods het leven actief te beëindigen. ${ }^{62}$

De CAL geeft twee voorbeelden van medisch zinloze handelingen bij pasgeborenen. Zo mag bij een pasgeborene met een levensbedreigende, maar niet curabele aangeboren afwijking in het algemeen niet tot palliatieve ${ }^{683}$ operatie worden overgegaan. Evenmin acht zij het toegestarn apparatuur ter ondersteuning van de vitale functies te gebruiken, indien niet tevens verwacht mag worden, dat deze functies zich uiteindelijk zullen herstellen of in ieder geval verbeteren en zonder dat op andere gebieden ernstige schade wordt veroorzalakt. ${ }^{684}$

Als de prognose luidt dat (verder) levensverlengend behandelen medisch zinloos is en derhalve de prognose op medische criteria gebaseerd is, dan verdient het aanbeveling dat de behandelende arts hierover een collega-arts raadpleegt. Het besluit tot abstineren of staken kan weliswaar door de arts zelfstandig genomen worden, maar vanwege de ingrijpendheid van het besluit en een latere mogelijkheid tot toetsing is overleg met een andere onafhankelijke arts wenselijk.

675 Gezondheidsraad, 1975, P. 26; CAL, MC 1988, p. 699.

676. Doen of laten, $1989, \mathrm{p}, 11$.

677 CAL, $1990, \mathrm{p} .7$.

678 Volgens Van Alphen cs , MC 1988, p. 1389, is het criterium "geen overlevingskans"' nisuwelijks objectiveerbatar woor b. $*$. de groep immahren. "Immaturen" zijn pasgeborenen met een zwangerschapsduur van 24 tot 26 weken. Zic." CAL, 1991, p. 4.

679 CAL, 1990, p. 7-8 en p. 14.

680 CAL, MC 1988, p. 700.

681 In dubio abstine: Geen behandeling word gestart als niet bij woorbaat 20 goed als zeker is dal het lijden wan de patient kan worden opgeheven of tenminste worden verlicht.

$682 \mathrm{CAl}, \mathrm{MC} 1988$, p. 700 r.k. en Doen of laten, 1989 , p. 26-28, min. p. 28.

683 Palliatief: verzachtend, zonder de zilekte zelf tot genezing te brengen.

684 CAL, MC 1988, p. 699. 
Hoewel niet nodig is dat de ouders omtrent de beslissing over de medische zinloosheid van de behandeling worden gehoord, verdient het wel aanbeveling hen bij de besluitvorming te betrekken. ${ }^{685}$ De mogelijkheid bestaat immers met de behandeling niet te beginnen, deze te staken of het leven wan het kind actief te beëindigen en bij een keuze voor éen van deze mogelijkheden dient zoveel mogelijk met de mening van de ouders rekening te worden gehouden.

Alle drie rapporten ower levensbeëindiging bij zwaar-defecte pasgeborenen spreken zich ervoor uit om ook in dat geval zo veel mogelijk aan de wens van de ouders tegemoet te komen. Slechts als dat tot een onaanvaardbare verlenging of verergering van het lijden van het kind zou leiden, dient de arts daarvan af te zien. ${ }^{686}$ Blijven de ouders echter vasthouden aan hun wens om door te gaan met de behandeling, dan is de arts gerechtigd de door hem medisch zinloos geachte behandeling niet uit te voeren. Of overdracht van de behandeling een uitkomst biedt ${ }^{\text {6*77 }}$ moet betwijfeld worden, daar in dit geval te verwachten is dat andere artsen tot dezelfde beslissing zullen komen.

Daar de beschreven situatie betrekking heeft op medisch zinloos handelen zijn het de medici die op grond van medische criteria beslissen of het handelen al dan miet zinvol is.

Het bovenstaande geld voor zower de prognose met grote zekerheid gesteld kan worden. In twijfelgevallen krijgt niet de stem van de ouders meer gewicht, maar is de arts gehouden een second opinion in te winnen.

\subsection{Ethisch zinloos handelen bij zwaar-defecte pasgeborenen}

Een patiënt mag niet tegen zijn will worden behandeld, zelfs als het niet-behandelen de dood ten gevolge heeft. Het overlijden van de patiënt vanwege zijn weigering is een schijngestalte van euthanasie. In de aanvaarding van deze schijngestalte ligt de erkenning van de autonomie van de patiënt ten aanzien van zijn eigen lichaam en zijn eigen dood besloten. Het rechtstreekse gevolg van de weigering is dat een arts een behandeling niet mag beginnen en een begonnen behandeling moet staken.

Hierboven bleek dat het nalaten van medisch zinloos handelen niet als levensbeëindiging wordt aangemerkt. Onder levensbeëindiging door nallaten (verder) te behandelen valt daarom niet het gevolg geven aan een overeenkomstige willsuiting van de patient, noch het nalaten te behandelen op grond van de vaststelling dat behandelen medisch zinloos is.

Volgens de rapporten is de aanleiding en rechtvaardiging wan levensbeëindiging door nalaten gelegen in het te geringe levensperspectief van de patiënt. ${ }^{600}$ Onder een "te

$685 \mathrm{CAL}, \mathrm{MC} 1988$, p. 701 r.k. en Doen of liaten, 1989, p. 45.

686 Gezondheidsraad, 1975, p. 16 e.w (mpliciet); Doen of laten, 1989; p. 44 en CAL, MC 1988, p. 701 r.k.

687 Zo de CAL, MC 1988, p. 702.

688 Doen of laten, $1989, \mathrm{p} .45$.

$689 \mathrm{CAL}, \mathrm{MC} 1988$, p. $702 \mathrm{rk}$.

690 Doen of laten, 1989 , p. 13. De werkgroep koos voor de omschrjjing "een zeer slechte prognose wat betref de latere gezondheid, gelet op de geringe kans op een leefbaar leven" on daarmee aan te sluiten. bij de euthanasie-discussie voor wolwassenen. Zjj zou anders de woorkeur geven aan de term "te gering levensperspectief" 
gering levensperspectief ${ }^{\text {t }}$ verstaat de werkgroep Doen of laten een naar ethische maatstaven zinloos medisch handelen, "wanneer de prognose wat betreft de latere gezondheid zeer slecht is, gelet op de geringe kans op een leefbaar leven". ${ }^{\text {pl }}$. De CAL spreekt in dat geval van een "geen leefbaar leven" ${ }^{\text {"prognose }}{ }^{692}$ Een naar ethische maatstaven zinloos geacht medisch handelen word hier verkort als "ethisch zinloos handelen" aangeduid. In dat geval voldoet het toekomstige leven van de patiënt niet aan bepaalde niet strikt medische criteria.

Levensbeëindiging door niet (verder) te behandelen mag slechts geschieden naar aanleiding van een "onleefbaar leven" -prognose. Die prognose betreft een inschatting en waardering van waarschijnlijke toekomstige levensomstandigheden van de wilsonbekwame. De prognose dat behandelen ethisch zinloos is, wordt in sterke mate subjectief bepaald. ${ }^{693}$ Ook voor de vaststelling dat (verder) levensverlengend handelen ethisch zinloos wordt geacht is het nodig de kans op ernstige defecten aan de hand van medische gegevens te bepalem. ${ }^{694}$ In verband daarmee is hier van belang de insehatting van hetgeen genoemd wordt "witzichtloos lijden", "uitzichtloze situatie", "te gering levensperspectief", "onleefbaar leven" en "t onvoldoende kwaliteit van leven ${ }^{116}{ }^{698}$ De begrippen worden als synoniemen gebruikt.

Wanneer objectief komt vast te staan dat de pasgeborene met zeer ernstige defecten zall moeten leven, dan wordt daaraan "subjectief" de prognose verbonden dat hij uitzicht heeft op een onleefbaar leven. Als objectief feit gelden bijvoorbeeld zeer ernstige hersenbeschadigingen $^{696}$, die communicatiemogelijkheden uitsluiten. Het laatste leidt tot de subjectieve prognose "onleefbaar leven" ${ }^{\text {" }}$ "

Om het subjectieve element in deze prognose zoveel mogelijk te beperken, adviseren de CAL en de werkgroep het te verwachten levensperspectief en daarmee het begrip "onleefbaar" (nader) te preciseren. De werkgroep denkt daarbij aan een lijst van aandachtspunten voor de inschatting van de kans op ernstige handicaps. ${ }^{698}$ De CAL stelt voor dat door de neonatologen een "algemeen aanvaard referentiekader" wordt ontwikkeld ${ }^{699}$, waarbij te verwachten handicaps in kaart worden gebracht. ${ }^{700}$ Eerst dient de prognose gesteld te worden, die een inschatting van ernstige handicaps bevat. Vervolgens moeten de prognostische gegevens naar "functionele termen" worden vertaald.

Voor de lijst van aandachtspunten respectievelijk voor het referentiekader denken de werkgmoep en de CAL aan vijf criteria in combinatie met elkaar. ${ }^{701}$ Deze zijn de

691 Doen of laten, 1989, p. 11 en p. 13 .

$692 \mathrm{CAL}, \mathrm{MC} 1988$, p. 698.

693 Vgl. Kuitert, 1989, p. 51 .

694 Zie Doen of laten, 1989, p. 16.

695 Doen of laten, 1989, p. 16, en op p. 13: De beoordeling van hetgeen als " Jeefbar leven" wordt beschouwd is nict (uitsluitend) medisch van aard. De "kwalite wa van leven" speelt voor de beoordeling een belangrijke ral.

696 CAll, 1990 , p. 7.

$697 \mathrm{CAL}, 1990, \mathrm{p}$. 8.

698 Doen of laten, 1989, p. 16-17.

699 CAL, 1990 , p. 15.

$700 \mathrm{Vg}$. De Lange, in: Grenzen aan de zorg, 1990, p. 183-184.

701. Doen of laten, 1989 , p. 16-17. 
mogelijkheid tot communicatie, de mate van zelfredzaamheid ${ }^{202}$, de afhankelijkheid van het medisch circuit, de mate van lijden en de verwachte levensdurur ${ }^{703}$ Tensllotte moet het levensperspectief van het kind in verband met zijn draagkracht en met die van het gezin worden afgewogen. ${ }^{704}$ De communicatie met de buitenwereld, ook genoend de mogelijkheid tot toekomstig intermenselijk contact, is het enige criterium dat de Gezondheldsraad in dit verband noemt. ${ }^{\text {70s }}$

Hoewel de CAL en de werkgroep aangeven dat een beoordeling van de kwaliteit wam leven door een derde een subjectief karakter heeft en ondanks hantering van de genoemide criteria blijft houden ${ }^{\text {Tos }}$, pogen beiden een zekere objectivering van de inschatting vam die kwaliteit te bereiken. Zij denken daarbij aan consensusbevordering.

In hoeverre een handicap als ondraaglijk is te beschouwen, hangt volgens de werkgroep Doen of laten af van de concrete situatie. Daarvoor kan geen objectieve maatstaf worden gegeven. Z $0^{*}$ n maatstaf zou slechis een schijn van objectiviteit opwekken ${ }^{707}$ Of de grens wan het draglijike in een bepaald geval is bereikt, dienen de artsen en de ouders open te bespreken, waarbij de criteria dienst kumnen doen als aandachtspunten. ${ }^{708}$

Terwijl de werkgroep daarmee wil volstaan, stelt de CAL voor aan de criteria grenswariden toe te kennen. ${ }^{709}$ De grenswaarden zijn bedoeld als maatstaf voor de beoordeling van de kwaliteit van het toekomstig leven. ${ }^{7 t o}$ Als die waarden worden overschreden zou de beslissing tot levensbeëindiging genomen mogen worden. ${ }^{71}$

Terwijl de neonatologen het referentiekader dienen te ontwikkelen, is volgens de CAL het bepalen van de grenswaarden niet alleen een taak van de beroepsgroep. ${ }^{712}$ Daar ondanks het referentiekader en de grenswaarden de oordeelsvorming een subjectief karakter blifft behouden, dient in een concreet geval aan de arts voor toepassing van de algemene maatstaf voldoende ruimte te worden gelaten ${ }^{713}$ Het doel van de algemene maatstaf is dan ook 'slechts' om tot een "evenwichtiger oordeel" te komen. ${ }^{714}$

702 De door de CAL genoemde mogelijkheid tot zelfstandigheid en tot oniplooiing is in het rapport van de werkgroep Doen of laten sarmengevat onder de noemer "zelfredzaamheid".

$703 \mathrm{CAL}, \mathrm{MC} 1988$, p. 701 l.k. en Doen of laten, 1989, p. 18.

704 Doen of laten, 1989, p. 18.

705 Gezondheidsraad, 1975 , p. 21 .

706 CAit, MC 1988, p. $700-701$ en Doen of laten, 1989 , p. 18.

707 Doen of Iaten, $1989, \mathrm{p}, 18$.

708 Doen of laten, 1989, p. 18.19,

709 In de discussienota uit 1988, MC 1988, p. 701 1.k., sprak de CAL van een "scoretabel".

$710 \mathrm{CAll}, 1990$, p. 16 .

711 Volgens Van Alphen cs, MC 1988, p. 1389-1390, laat de leefbaarheid zich getalsmatig nauwelijks bepalen, terwijl de criterin amper houvasi biedea, zodat de samenleving daaraan geen normen kan ontlenen voor het mens-zijn. Versluys, MC 1989, p.607, spreekt i.v.m. de sconetabel van "quasi-objectiviteit". Een ander bezwar noemen de Katholieke Vereniging voor Ziekeninrichtingen, MC 1989, p. 21 en Croughs, MC 1989, p. 649: met het stelien van grenswarden door de "samenleving als geheel" word de weg vrijgemaakt on ook t.a.v" andere wilsonbekwamen dan zwar-defecte pasgeborenen grenswaarden te stellen. Volgens Smelt e.t, MC 1989, p. 17.18, kan daardoor het handelen te zeer afhankelijk worden van heersende ideologieển.

$712 \mathrm{CAL}, 1990, \mathrm{p}, 16 . \mathrm{Vgl}$. Gezontheidsraad, 1975, p. 16: Daar de beslissing van de arts mede op ethische gronden wordt getroffien, dient zij mede te baseren "op de aan hem kenbaar gemaakte opvattingen en owertwigingen die leven in de gemeenschap". Zie ook: Gezondheidsrand, 1972, p. 7-8 en Van Berkestrjin, in: Beslissen over leven dood, 1989, p. 35.

$713 \mathrm{CAL}, 1990, \mathrm{p} .16$.

$714 \mathrm{CAL}, 1990$, p. 16-17. 
De bevoegdheid tot het oordelen over en het werken met deze criteria ontleent de arts volgens de CAL en de werkgroep aan zijn hoedanigheid. Slechts een medicus die niet alleen "medisch technicus" is, maar zich ook afvraagt of een behandeling een patient meer kwaad dan goed doet, is een goede arts. ${ }^{715}$

\subsection{Medisch en ethisch zinloos handelen bij irreversibel comateuze patiënten}

Patiënten die zich in een irreversibel coma bevinden, kunnen zeer lang in leven worden gehouden. Hoewel bij een langere duur van het coma de kans om weer bij bewustzijn te komen afneemt, is dat niet uitgesloten. Daarom geeft de CAL de voorkeur aan de term "langdurig" in plaats van "irreversibel". In de praktijk wordt onderscheiden tussen een "langdurig coma" en een "aanhoudend vegeterende toestand" ${ }^{716}$ Bij een vegeterende toestand lijkt het erop alsof de patiènt (soms) bij bewustzijn is, omdat hij spontaan zijn ogen opent. Maar in beide gevallen zijn er geen aanwijzingen dat hij psychisch functiomeent. ${ }^{717}$ Aangezien coma en vegeterende toestand in wezen overeenkomstige wormen van bewustzijnsverlies zijn, spreekt de CAL doorgaans van coma, waaronder de vegeterende toestand is begrepen ${ }^{718}$; een gebnik dat hier wordt gevolgd. Een patiënt die uit een langdurig coma bij bewustzijn komt, leidt een "ernstig lichamelijk en geestelijk gehandicapt bestaan" en kan de "dagelijkse levensverrichtingen" niet zonder hulp van anderen verrichten, zodat hij volledig afhankelijk is. ${ }^{70}$

Ten aanzien van zowel de patiênten die niet meer bij bewustzijn komen als de patiënten bij wie dat wel het geval is, is het daarom de vraag, of

"het ondanks hun slechte prognose blijven behandelen van deze patiënten nog wel

in overeenstemming kan worden geacht met de primaire doelstellingen van de genees-

kunde, in casu behoud van leven en opheffen van lijden" " 220

Voor de beslissing bij comateuze patiënten heeft de CAL geen referentiekader voorgesteld. Uitgangspunt daarbij is dat een patiënt die zich in een langdurig coma bevindt, niet behoeft te worden doorbehandeld. Factoren die bepalen of een coma langdurig is, zijn de oorzaak van het coma, de leeftijd van de patiënt en de duur van het coma.

De CAL gaat ervan uit, dat comateuze patiënten (kunnen) lijden ${ }^{721}$ en dat verreweg de meeste comateuze patiënten (circa $85 \%$ ) na een bepaalde tijd in een langdurig coma verblijven, terwijl het kleine aantal dat weer bij bewustzijn komt, ernstig lichamelijk en geestelijk gehandicapt is. Dat heeft twee consecquenties.

715 Doen of laten, 1989, Bijlage 2, p. 5; CAL, MC 1988, p. 699 r.k. en p. 700 l.k. Volgens Roscam Abbing, TVGR 1988, P. 473-47.4, heeft de CAL met de antroductie van de tem "onleefbaar leven" hel ganglore onderscheid tussen medisch zinloos en medisch zinvol losgelaten en een onduidelijk begrip geïntroduceerd. De CAL gaat er a an voorbij dat het recht op leven onverveemdbaar is en de vragg of men leven wil handhaven een eigen keuze is.

716 Een "manhoudend wegeterende toestand" wordt ook wel genoemd een "persistent vegetative state" (PVS). CAL, 1991, p. 7.

$717 \mathrm{CAL}, 1991$, p. 7.

718 CAL, 1991, p. 5 en p. 7.

719 CAL, 1991, p. 7-9.

$720 \mathrm{CAL}, 1991, \mathrm{p}, 9$.

721 Anders: Michels, in: Handlwek Gezondheidsethick, 1988, p. 363; Hylkema, MC 1985, p. 1185 1190; De $\mathbb{L a n g e ,}$ im: Grenzen aan de zorg, 1990, p. 188. 
Volgens de CAL zou na een bepaalde tijd - athankelijk van de oorzaak van het coma met de behandeling, waartoe zij ook sondevoeding rekent ${ }^{722}$, gestopt mogen worden. Zij denkt daarbij aan een periode van ongeveer één maand voor niet-traumapatiënten en ongeveer zes maanden voor traumapatiënten. ${ }^{723}$ Met het woord "ongeveer" geeft de CAL aan dat voor de bepaling van de termijn in een bepaald geval rekening dient te worden gehouden met de bijzonderheden van dat geval.

Ten tweede blijkt in deze opvatting ten aanzien van het overgrote deel van de patiënten behandelen medisch zinloos te zijn en ten aanzien van een kleine groep ethisch zinloos. Daarmee is juist bij langdurig comateuze patiënten de grens tussen medisch zinloos handelen en ethisch zinloos handelen niet goed te trekken. ${ }^{24}$

Het verblijven in een comateuze toestand beschouwt de CAL niet als overleven. De comateuze patiênt heeft "waarschijnlijk geen bewustzijn en is volledig afhankelijk". De CAL spreekt van een "beperkt biologisch leven". Zij beschouwt het behandelen van de in coma verblijvende patiënten als "een bejegening die in strijd is met de menselijke waardigheid". ${ }^{725}$ Daarom heeft volgens haar een comateuze patiënt in een langdurig coma geen reële overlevingskans en is medisch handelen bij die patiënt medisch zinloos. Daarbij is van belang dat volgens de CAL ervan uitgegaan dient te worden dat een comateuze patiënt lijdt; hetgeen echter niet zeker is. Zeer waarschijnlijk ontbreekt bij comateuze patiënten enig bewustzijn. Daaruit zou kunnen worden afgeleid dat deze patiënten niet lijden ${ }^{726}$ Maar omdat dat niet met zekerheid gezegd kan worden, heeft het de voorkeur van de CAL om er rekening mee te houden dat de patiënt wel kan lijden. ${ }^{727}$

Het is omstreden of een toestand van langdurig coma op zichzelf medisch handelen als medisch zinloos kwalificeert. Terwijl bijvoorbeeld de arts Minderhoud het leven in een toestand van een langdurig coma als "zinloos" typeert ${ }^{28}$, merkt de ethicus Musschenga op dat deze toestand niet als "zinloos" kan worden aangemerkt, daar een langdurig comateuze patiënt tenminste nog in leven blijft.

Musschenga onderscheidt twee benaderingen van kwaliteit van leven. In de ene wordt kwaliteit van leven positief ingevuld en nagegaan in hoeverre de patiënt normal kan functioneren en zijn leven als een welzijn kan worden begrepen. Criteria als "communicatiemogelijkheid" en "wilsvorming" hebben in het algemeen op deze invulling betrekking. De andere benadering leent zich zijns inziens voor het bepalen van de grenzen aan levensverlengend handelen. Hierbij wordt kwaliteit van leven als "minimaal mens-zijn" begrepen. ${ }^{729}$ Daartoe bezigt hij dezelfde criteria, maar in negatieve zin; niet van belang is in welke mate zij aanwezig zijn, maar dat zij niet meer aanwezig zijn. Desondanks berust naar zijn mening het uiteindelijke argument voor levensbeëindiging van irreversibel

$722 \mathrm{Vgl}$. Minderhoud; in: Beslissen over leven \& dood, 1989, p. 71 en Michels, in: Handboek Gezondheidsthiek, $1988, p_{i}, 362,2$ ie verder: H. IV C, onder 4.3.

$723 \mathrm{CAL}_{3}, 1991, \mathrm{p}, 26$.

724 In deze zin: Croughs, MC 1989, p. 648-649. Anders: Katholieke Vereniging voor Ziekeninrichtingen, MC 1989, p. 21

$725 \mathrm{CAL}_{0}, 1991, \mathrm{p}, 25$

$726 \mathrm{CAL}_{3}, 1991$, p. $20-21$

$727 \mathrm{CAL}, 1991, \mathrm{p}, 21-22$. Volgens Musschenga, $1987, \mathrm{p}_{n} 169-170, \mathrm{kan}$ levensbeeindiging slechts dan in belang wan de patient zojm, als deze ooit zoveel bewustzijn heeft dat hij aan zijn beperking zal lijden.

728 Minderhoud, in. Beslissen over leven \& dood, 1989, p. 71. In dezelfde zin: De Lange, in: Gremzen aan de zorg, 1990, p, 187.

729 Musschenga, 1987, p. 59. 
comateuze patiènten "op een vooroordeel over de waarde van mensellik leven", namelijk: Menselijk leven dat de vermogens tot bewustzijn, zelfbewustzijn en communicatie mist, is slechts in biologische zin menselijk leven. Biologisch leven dat miet meer de voonwande is voor de realisering van menselijke warden, heeft geen waarde meer" " 730 Volgens Musschenga blijven langdurig comateuze patiënten onder elke grens van kwaliteit van leven, hoe deze ook wordt omschreven. Daarom beoordeelt hij de vraag naar de inhoud van de criteria van kwaliteit van leven als "niet zo urgent" ${ }^{731}$ Het bestaan van een mens beneden de grens van mens-zijn verschaft echter nog geen legitimatie om levensverlengend handelen na te laten. Ook in dat geval wordt op grond van een moreel vooroordeel over de waarde van menselijk leven een beslissing genomen. ${ }^{732}$

In 1989 had de CAL opgemerkt dat de term "medisch handelen" aan herziening toe is ${ }^{733}$ In 1991 zegt zij daarover het volgende. Een medische handeling is zinloos als zij "geen positief effect" heeft. Wat onder "positief effect" wordt verstaan, hangt af van de gestelde doelen. Medisch handelen kent twee doelen: het behouden van leven en het verbeteren of tenminste behouden van de kwalliteit van leven. ${ }^{734}$ Door het (te verwachten) wegvallen van de kwaliteilt van leven kan de legitimatie voor het behouden van leven wegvallen. ${ }^{73}$ ledere medische handeling betreft beide doelen en daarom kan moeilijk een scheidslijn worden getrokken tussen een handeling die "medisch gesproken zinloos" is en een handeling die "op grond van een kwalitatieve of niet-medische beoordeling zinloos zou zijn". 36

Volgens de CAL kennen artsen en juristen verschillende inhouden toe aan "medisch zinloos handelen". Voor artsen is handelen medisch zinloos, zowel vanwege "strikt medisch-objectieve criteria" ("geen reële overlevingskans" -prognose) als vanwege "maatschappelijke aspecten" ("onleefbaar leven"-prognose), terwijl juristen maatschappelijke aspecten niet daaronder begrijpen. Ten dienste van de toetsbaarheid en controleerbaarheid van levensbeëindiging acht de CAL het "van groot belang dat het ... verschil van interpretatie op korte termijn wordt beslecht". ${ }^{737}$ ?

\subsection{Morele rechtvaardiging man nalaten van ethisch zinloos handelen bij zwaar-defecte pasgeborenen}

Voor een antwoord op de vraag of de arts de behandeling mag staken (of deze niet beginnen) wanneer deze ethisch zinloos is, is het zinvol om na te gaan, waaraan hij het morele recht zou kunnen ontlenen om een wilsonbekwame patiènt wel te behandelen. Daarbij wordt onderscheiden tussen een gunstige en een ongunstige prognose. Is de prognose gunstig dan voldoet de arts met het handelen aan eén van de centrale doelen van de geneeskunde, namelijk het leven te behouden.

730 Musschenga, 1987, p. 163. Hij uit darir ook kritiek op het standpunt van Kuitert en van de Staatscommissie, die wel van medisch zinloos bandelen spieken.

731 Musschenga, $1987, \mathrm{p} .48$.

732 Musschenga, 1987, p. 179 .

733 CAL, MC 1988, p. 697 .

$734 \mathrm{CAL}, 1991, p * 23$

735 CAL 1991, p. 24.

$736 \mathrm{CAL}, 1991$, p. 24.

737 CAL, 1991, p. 44-45. 
Een ander central doel van de geneeskunde is het voorkomen of althans verzachten van lijden. De doelen het leven te behouden en lijden weg te nemen kunnen met elkaar in botsing komen. Het nastreven van andere geneeskundige doelen kan een bepaalde mate van lijden rechtvaardigen. Zelfs een zo belangrijk doel als het behoud van leven rechtvaardigt echter niet elk lijden. Daarom mag bij het ontbreken van andere mogelijkheden pijn worden bestreden met middelen die het neveneffect hebben dat zij het leven verkorten.

Hoe onzekerder de prognose is, des te "zwakker" is de daarop gebaseerde beslissing. Bij een grote mate van onzekerheid omtrent het positieve effect van een behandeling kan de arts beslissen te behandelen ("in dubio fac"), maar ook om niet te behandelen ("in dubio abstine $\mathrm{e}^{\text {) }}$. De beslissing tot een van beide gedragingen stoelt dan op niet-medische factoren.

De Gezondheidsraad kiest in dat geval woor het behandelen vanwege het doell van de behandeling; het behoud van leven en vanwege de eerbied die de mens verschuldigd is aan thet leven.

"Een arts dient zich van euthanasie (euthanasie en levensbeëindiging, J.W.) te onthou-

den in alle gevallen waarin hij, na grondig overleg, op diagnostische of op ethische gronden blijft twijfelen aan de toelaatbaarheid daarvan ${ }^{17}$. ${ }^{73}$

Dat betekent dat voor uitzonderingen op dit uitgangspunt "zwaarwegende argumenten" aangevoerd dienen te worden. ${ }^{739}$ De Gezondheidsraad is van mening dat jegens het menselijk leven geen absolute eerbied verschuldigd is, maar "de grootst mogelijke eerbied" ${ }^{140}$ Vanuit deze benadering acht hij levensbeëindiging niet principieel uitgesloten. Zodoende erkent de Gezondheidsraad dat de arts niet onder alle omstandigheden gehouden is door te behandelen. ${ }^{71}$

Het is ook mogelijk te zeggen dat onder bepaalde omstandigheden juist eerbied voor het leven wordt getoond door niet te behandelen. Bij een dergelijke redenering worden de uitzonderingen op het behoud van het leven in de eerbied voor het leven verwerkt en daarmee minder goed zichtbaar. In dit verband wordt aan de stelling herinnerd, dat de arts juist eerbied voor het leven toont door een patiënt, die zich in een uitzichtloze noodsituatie bevindt, op diens uitdrukkelijk werzoek het leven te benemen. Strafrechtelijk gezien kan deze redenering geen hout snijden om aan te tonen, dat de gedraging niet onder de delictsomschrijving van art. $293 \mathrm{St}$ valt. Het voordeel van de benadering van de Gezondheidsraad is, dat de uitzonderingen tegenover de eerbied voor het leven worden geplatst en dat daarmee het uitzonderlijke karakter wordt benadrukt.

In de CAL-nota en in het rapport van de werkgroep zijn noch algemene uitgangspunten noch algemene morele kaders opgenomen, maar wel ethische normen voor het medisch handelen, gebaseerd op hetgeen beiden beschouwen als een feitelijke consensus binnen de beroepsgroep of maatschappij. De werkgroep Doen of laten en de CAL gaan in het algemeen uit van "in dubio abstine", maar maken een verschil al naar gelang het gaat om het beginnen van een behandeling danwel om het doorbehandelen. Bij een zwaar-defec-

738 Gexondheidstaid, 1975 , p. 20 .

739 Gezondheldstaid, 1975, p. 19-20. Zie ook: Bijlage 1, p. 5.

740 Gezondheidsraad, 1975, p. 15. Dat leidt zij ook af, wit de verklaring van de WMA uit 1948, waar gesproken wordt van "utmost respect". Zie ook: p. 8.

741 Gezondheidsraad, 1975, p. 16. Zie ook: Bijlage 2, p. 7 en 9. 
te pasgeborene en een comateuze patiënt forceert de toestand van de patiënt op korte termijn een beslissing over het al dan niet beginnen met behandelen, terwijl op dat moment de prognose vaak onzeker is. Voor die situatie verdedigen zij het beginnen van de behandeling. Die keuze biedt de mogelijkheid, om op een later tijdstip tot een prognose te komen, die meer zekerheid verschaft.

Met behandelen wordt alleen niet begonnen als de prognose voldoende zekerheid verschaft ower het niet-positieve effect van de behandeling. Daardoor speelt de kwestie van levensbeë̈indiging bij zwaar-defecte pasgeborenen en comateuzze patienten in het algemeen pas tijdens een behandeling.

Volgens de $\mathrm{CAL}$ is de verruiming van de behandelingsmogelijkheden in de neonatologie voor de meeste zieke pasgeborenen positief, maar enkele overlijden desondanks of blijven met ernstige tot zeer ernstige gebreken in leven, waar vroeger de dood onontkoombaar was. ${ }^{742}$ Vanwege de in het algemeen positieve effecten acht de CAL hierbij ten aanzien van het beginnen met behandelen een uitzondering op de regel "in dubio abstine" gerechtvaardigd. ${ }^{733}$ De CAL vraagt zich af, in hoeverre het behandelen van de groep pasgeboremen die thans een langere levensduur kunnen hebben, in overeenstemming is met een van de primaire doelen van de geneeskunde, te weten opheffing c.q. verlichting van lijden. Luidt het antwoord ontkennend, dan doet zich de "gewetensvraag" voor, "of het in die gevallen dan niet humaner is, om deze zwaar-defecte pasgeborenen als keuze van het minst kwade alsnog te laten overlijden". ${ }^{74}$

Terwijl de werkgroep Doen of laten enerzijds van mening is dat bij twijfel omtrent de prognose in een concreet geval met optimaal levensverlengend handelen doorgegaan dient te worden ${ }^{745}$, merkt zij anderzijds op, dat er zowell voldoende argumenten voor het stoppen als voor het voortzetten van een behandeling dienen te zijn. ${ }^{746} \mathrm{Zij} \mathrm{legt}$ daarmee nadruk op het feit dat verder behandelen niet vanzelfsprekend is, maar evenals het niet (verder) behandelen gemotiveerd dient te zijn. ${ }^{747}$

De CAL is van mening dat levensverlenging niet als zinvol medisch handelen kan worden beschouwd, wanneer daardoor langdurig ernstig lijden zou worden veroorzaakt of in stand gehouden. Dat zou immers in strijd zijn met het doel van de geneeskunde om lijden op te heffen, althans te verlichten. Als met een behandeling niet het gewenste zinvolle doel kan worden bereikt, dan dient derhalve de behandeling gestaakt te kunnen worden. ${ }^{748}$

742 CAL, 1990, p. 5.

743 CAL, 1990, p. 13-14. Zie ook: Bijlage 3,p. XV.

7.44 CAL, 1990, p. 5.

745 Doen of laten, 1989, p. 20. In dezelfde zin inpliciet ook de CAL, MC 1988, p. 699.

746 Een voldoende argument acht de werkgroep bijwoorbeeld als statistisch vaststaat dat de "overgrote meenderheid van kinderen in een bepaalde klinische situatie ernstig gehandicapt zal xijn" of als de "kans op cen minder ernstig handicap of zelfs de (geringe) kans op een wrjjwel ongestoorde ontwikkeling niet met een $100 \%$-ige zekerheid is uit te sluiten".. Daarbij is wel van belang dat de weging van de informatie van arts tot arts kan verschillen en dat de ouders mogelijk een andere afweging maken. (Doen of laten, 1989, p. 17. Dit is in overeenstemming met: HR 28 april 1989, NJ 1990, 46 n.nt. GEM. Zie: H. IV C, 4.4.8.) Indien de ouders weloverwogen verzoeken om toch door te gaan wordt daaraan in het algemeen gehoor gegeven, totdat de stervensfase ingat of een mensonwraardige situatie ontstaat.

$747 \mathrm{Vgl}$. Dupuis, in Bijlage II van de werkgroep Doen of laten, 1989. Zie ook: Dupuis, in: Beslissen over leven \& dond, 1989, p. 14; Mollenaar, Gill, Dupuis, NTvG 1988, p. 1916; Molenaar, NTwG 1988, p. 1924-1926.

748 CAL, 1990, p. 10-11. Zie ook: Bijlage 3, p. XIIr. 
Hieruit bilikt dat het behoud van het leven en het voorkomen van lijden met elkaar in strijd kunnen zijn. En dan is de vraag, wanneer de medicus in een individueel geval woorrang mag toekennen aan de opheffing van het lijden door te kiezen voor levensbeëindiging. Daarbij spelen niet alleen "de aard, ernst en duur van het lijden" een rol, maar ook omstandigheden, zoals "de draagkracht en levensovertuiging van de ouders" ${ }^{\text {"Th }}$

\subsection{Morele rechtwaardiging wan malaten van medisch/ethisch zinloas handelen bij irrever-} sibel comateuze patienten

Levensverlenging en levensbeëindiging zijn beide moreel relevante gedragingen. De afweging over de morele aanvaardbaarheid van levenswerlengend handelen gaat vooraf aan die van levensbeëindigend handelen. ${ }^{750} \mathrm{De} \mathrm{CAL}^{751}$ is van mening dat de morele argumentatie over levensbeëindiging bij zwaar-clefecte pasgeborenen niet onverkort wan toepassing is bij langdurig comateuze patiënten.

Daar een zorgvuldige diagnose en prognose bij een comatteuze patiênt (evenals bij] een pasgeborene) pas na enige tijd kan worden gesteld, wordt eerder behandeld (in dubio fac") dan niet behandeld ("in dublo abstine"). Deze uitzondering op de medische grondregel 'in dubio abstine' acht de CAL gerechtvaardigd vanwege de positieve uitkomsten voor "vele" patiènten. Dat betreft comateuze patiënten die zich niet in een langdurig coma bevinden.

Een comateuze patiënt wordt behandeld, "niet om de patiënt in coma te houden maar met het oog op de kans dat de betrokkene weer bij bewustzijn komt". Naarmate de kanis kleiner wordt, neemt de legitimatie voor het doorbehandelen af, want ook levensverlengend handelen behoort gelegitimeerd te zijn.

Wanneer de patient langer in coma blijft wordt de prognose ongunstiger en wordt het steeds duidelijker dat de patiënt nog slechts in leven is als tesultaat van voortdurend medisch handelen. Daardoor is de arts medeverantwoondelijk voor de situatie waarin de patiënt zich bevindt respectievelijk zich zal gaan bevinden. Dan is het (behoud van) leven van de patiënt nog wel relevant, maar "niet een voldoende argument om door te

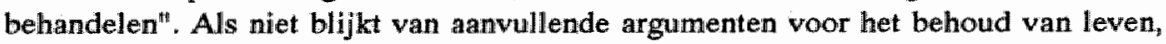
dan vervalt "iedere legitimatie om te blijven (be)handelen".

Voor de circa $85 \%$ langdurig comateuze patiënten die in coma blijven, bestaan volgens de Commissie geen argumenten om de situatie te laten voortduren, terwijl er wel een argument tegen pleit. "Het in deze situatie doorgaan met behandelen -...- is een bejegening die in strijd is met de menselijke waardigheid". Het handelen kan dan immers in strijd zijn "met hetgeen de persoon in kwestie zelf gewild zou hebben" en het kan voorkomen dat een stervensproces tot een einde komt.

De enige reden om door te behandelen is de minimale kans dat de patient weer bij bewistzijn komt, waarbij uitgegaan wordt van de veronderstelling dat de patiënt dat ook wenst. De patiënt die bij bewustzijn komt, heeft ernstige bewustzijnstoornissen, zodat die wens "echter lang niet evident" is. Er kan ook gesteld worden dat niet duidelijk is dat de patiënt de behandeling niet wenst en dat daarom wordt behandeld. Deze patiënten 
blijwen bovendien "vrijwel altijd ermstig lichamelijk en geestelijk gehandicapt" . Met name de geestelijke veranderingen scheppen een zeer belastende situatie voor de patiënt en voor diens naaste familie.

Daar niet uit te sluiten is dat een comateuze patiënt weer bij bewustzijn komt kan worden verdedigd, dat behandeld moet worden totdat de patiënt zijn wil kan uiten. Op het moment dat de prognose voldoende zekerheid verschaft dat de patiënt in coma verblijt of slechts emstig gehandicapt weer bij bewustzijn komt, ontvalt de legitimatie voor doorbehandelen. Vanwege zijn "medeverantwoordelijkheid voor de ontstane situatie" mag dan van de medicus gevraagd worden de behandeling te staken "en de gevolgen daarvan waar nodig te verzachten".

"Slechts op de voorwaarde dat een eenmaal (zonder wilsbeschikking van de patiënt) ingestelde behandeling ook kan worden gestaakt, kan worden bereikt dat niet de medische techniek, maar de medisch-ethische normen die van oudsher hun waarde hebben bewezen, i.c. 'in dubio abstine"752 en "primum non nocere ${ }^{353}$, het gezicht van de geneeskunde blijven bepalen en het belang van de individuele patiënt ('salus aegroti suprema lex" ${ }^{754}$ ) gewaarborgd kan blijven". ${ }^{755}$

\subsection{Besluitvorming bij zwaar-defecte pasgeborenen}

In de fase van de besluitvorming dient een onderscheid te worden gemaakt tussen de meningsvorming en het nemen van het besluit van de bij de besluitvorming betrokkenen. Van belang is wie bij de besluitvorming betrokken zijn en wat jeders aandeel in de besluitvorming is.

In alle rapporten wordt erkend dat uiteindelijk de behandelende arts de beslissing over het al dan niet behandelen neemt. ${ }^{756}$ Daaraan vooraf gaat een besluitvormingsproces, waarbij wel meerdere personen in zekere mate betrokken dienen te worden. Dat zijn, naast de behandelende arts, de naasten van de patient, het team en de verpleegkundigen. ${ }^{757}$ De rol van de andere betrokkenen kan zijn de arts meer duidelijkheid te verschaffen omtrent de prognose of subjectieve factoren voor de beslissing aan te dragen. Aan het team en de bij de behandeling betrokken verpleegkundigen komit geen doorslaggevende stem in het besluitvormingsproces toe. Wel is van belang dat de behandelende arts hen hoort. ${ }^{758}$

Wanneer de prognose is gesteld en de meningen van de betrokkenen bekend zijn, is de vraag welke beslissing genomen moet worden. Vooral bij de "onleefbaar leven" -prognose kan het geweten van de arts een rol spelen. ${ }^{759}$ In dat geval is het "onontbeerlijk" dat de arts een onafhankelijke collega raadpleegt met als doel:

752 Vrij vertaald: bij twijfel afzien.

753 Vrij vertaald: het eerste beginsel is geen schade te berokkenen an de gezondheid van de patienth.

754 Vrij wertaald: de gezondheid van de patient is de hoogste wet:

755 CAL, 1991, p. 27.

756 CAL, MC 1988, p. 702 r.k. en Doen of later, 1989, p. 41 .

757 Doen of laten, $1989, \mathrm{p} .38$ e... en $\mathrm{CAL}, 1990, \mathrm{p} .20$, en minder nadrukkelijk Gezondheidsrand, 1975 , P.19.

758 Doen of laten, 1989 , p. $24-25$

759 CAL, 1990, p. 20-21. 
"het eigen oordeel te zuiveren van eventuele overwegingen die niet primailr het belang van het patientje dienen alsmede het krijgen van een onathankelijk advies over de vraag of de mening van de ouders in het onderhavige geval dient te prevaleren" ${ }^{760}$ Daarenboven wordt het vooral in twijfelgevallen nuttig geacht een onafhankelijke medicus voor een second opinion te raadplegen. ${ }^{761}$ Maar de behandelende arts blijft verantwoondelijk voor de beslissing. ${ }^{762}$

Bij zwaar-defecte pasgeborenen zijn de meest belangrijke andere betrokkenen de ouders. ${ }^{763}$ In het adwies van de Gezondheidsraad uit 1975 nemen de ouders zowel woor wat hun belang bij levensbeëindiging betreft als voor hun rol in de besluitvorming een minder prominente plaats in dan in de interimrapporten van de werkgroep Doen of latem en de CAL.

Verschillen ouders en arts van mening, dan is de arts volgens de Gezondheidsraad gehouden eerst te streven naar overeenstemming. Daartoe verdient het aanbeveling dat hij collega's raadpleegt. ${ }^{764}$ De meeste ouders ${ }^{765}$ willen het advies van de arts "volledig" opvolgen, zodat het kennelijk zelden tot een verschil van opvattingen komt. ${ }^{766}$ Die uitspraak staat op gespannen voet met die van de juridische werkgroep, die opmerkt dat men bij overeenstemming van de wens van de ouders en de beslissing van de arts, er in het algemeen van uit mag gaan, dat het belang van het kind de doorslag heeft gegeven. ${ }^{767}$

Zowel de CAL als de werkgroep Doen of laten zijn van mening dat de wensen van de ouders in het beslluitvormingsproces zo veel mogelijk gerespecteerd dienen te worden, waarbij evenwel de belangen van het kind primair zijn. De CAL acht het in 1989 niet per se vereist dat de gesprekken tussen ouders en arts (steeds) door de behandelende arts worden gevoerd, daar het vooral om het expliciteren van de mening van de ouders gaat. $^{768}$ In 1990 is zij van mening, dat het aanbeveling verdient als voor het peilen van de mening van de ouders de gesprekken "(m)ede om praktische redenen" door een andere deskundige dan de behandelende arts worden gevoerd. ${ }^{769}$

Het standpunt van de ouders omtrent de (verdere) behandeling van de pasgeborene is niet opgenomen in het voorgestellde referentiekader. Dat betreft ook slechts de "persoonli.jke meningsvorming van de behandelend arts" mening van de ouders wel degelijk van belang. ${ }^{770}$ Voor het gewicht dat aan de mening

760 CAL, 1990, p. 21.

761 Zie voor team, verpleegkundigen en ondhankelijke firts: Gezondheidsraad, 1975, p. 19 en p. 26; CAL, MC 1988, p. 702 r.k. en p. 703 l.k.; Doen of laten, 1989, p. 38 e.v.

762 CAL, 1990, p. 21.

763 Anders: Volgens J. en P. Mol, MC 1988, p. 1536 behoort dit tot hun zorgplicht. Maar, zoals Roscam Abbing, NTwG 1988, p. 1543, schrijft: "Ouders kunmen aan hun zorgplicht geen beslissingsbevoegdheild inzake lewen of dood van bun kind onllenen".

764 Gezondheidsraad, 1975 , Bijlage $I_{3}$ p. 7 .

765 Onder ouders begrijpt de Gezondheidsrand aok andere wettelijke vertegenwoordigers voorzover deze dezelfde wettelijke bevoegdheden hebben. Gezondheidsraia, $1975, p_{*} 8$.

766 Gezondheidsraad, 1975 , p. 11.

767 Zie: Gezondheidsraad, 1975, Bijlage I, p. 6.

$768 \mathrm{CAL}, \mathrm{MC} 1988$, p. $702 \mathrm{l} . \mathrm{k}$.

769 CAL, 1990, p. 19.

770 CAL, 1990, p. 17. 
van de ouders dient te worden toegekend, moet worden onderscheiden tussen de "geen reele overlevingskans" -prognose en de "onleefbaar leven" -prognose. Vanwege de grotere mate van objectiviteit die aan de "geen reelle overlevingskans"-prognose is verbonden, weegt de mening van de ouders vooral bij de "onleefbaar leven"-prognose. Want wanneer de ouders zich bij een "geen reële overlevingskans" prognose tegen levensbeëindiging (op een bepaald tijdstip) uitspreken, dan zou een daaraan gevolg geven tot meer uitzichtloos lijjden voor de pasgeborene kunnen leiden. ${ }^{71}$

Terwijl de prognose dat (verder) levensverlengend handelen medisch zinloos is, een uitslujtend of althans overwegend medische beslissing is en derhalve slechts door een arts kan worden gedaan, kunnen zowel de arts als de ouders relevante uitspraken doen over de ethische zin van (verder) levensverlengend handelen. Daarbij wordit in de rapporten van de CAL en de werkgroep Doen of laten gestreefd naar objectivering van respectievelijk consensus omtrent de leefbaarheidscriteria, maar wordt tevens opgemerkt dat de kwalificatie ethisch zinloos handelen voor een groot deel subjectief is.

Die kwalificatie berust zowel op medische criteria als op waardeoordelen. Dat betekent dat de arts zijn mening vormt op grond van zijn medisch inzicht en aan de hand van kwaliteit van leven-criteria. Primair dient hij daarbij zijn beslissing te baseren op de te werwachten lichamelijke en/of geestelijke gebreken. Als door de gemeenschap grenswaarden ten aanzien van de leefbaarheidscriteria vastgesteld zijn, dan behoort de arts deze in zijn beslissing te betrekken. Maar die grenswaarden kunnen nooit een absoluut karakter hebben, zodat er altijd sprake is van een "grijs gebied". Ten aanzien van dit gebied moet de beslissing in overleg tussen arts en ouders tot stand komen. ${ }^{77}$

Daar de grenswaarden bij de "onleefbaar leven"-prognose geen absoluut karakter hebben, weegt hierbij de mening van de ouders zwaarder. De ouders zijn immers vooral degenen die - naast de pasgeborene zelf - de gevolgen van de beslissing moeten dragen. Daarbij is hun draagkracht van belang, maar ook hier is deze niet doorslaggevend, want eerst dient de prognose gesteld te worden; de mening van de ouders is als aanvulling daarop te beschouwen. Maar waar de prognose een marge voor twijfel laat "(dient) aan de mening van de ouders in principe een zeer zwaarwegende betekenis (...) te worden toegekend ${ }^{H}{ }^{773}$ Dat klemt, volgens de CAL, nog meer, wanneer eerst doorbehandeld is om het overlijden te voorkomen en in het bijzonder, wanneer de ouders daartoe geen toestemming hebben verleend. ${ }^{77}$

Een inschatting van het levensperspectief komt mede tot stand uit de verwachting en houding van de ouders over het toekomstig leven van het kind. Bovendien moet een verder leven van het kind ook voor hen draaglijk zijn, hoewel de belangen van het kind voorop staan. ${ }^{775}$ In hoeverre dat het geval zal zijn; is voornamelijk een subjectieve beslissing, maar wel naar aanleiding van een geconstateerd ernstig defect van de pasgeborene.

771 CAL, 1990, p. 17-18.

772 CAL, MC 1988, p. 702 l.k.

773 CAL, 1990 ; p. 18.

$774 \mathrm{CAL}_{0}, 1990$, p. 18.

775 Croughs, MC 1989, p. 649. 
Uiteindelijk moet de behandelende arts echter zijn eigen verantwoordelijkheid nemen $^{776}$ en dat kan bij een verschil van mening tussen arts en ouders betekenen, dat gezocht moet worden naar een andere arts die bereid is conform de opvatting van de ouders te handelen.

\section{De ouders spreken zich voor een ethisch zinloze behandeling wit}

De Gezondheidsraad, de CAL en de werkgroep Doen of laten blijken niet alleen een grotere rol aan de inbreng van de ouders te willen toekennen ten aanzien van de vraag of een behandeling ethisch zinloos geacht moet worden, maar tevens wanneer de ouders, in afwijking van de arts, wensen door te gaan met levensverlengend handelen.

Als cle ouders levenswerlengende maatregelen wensen en de arts daarvoor niet voelt, dan mag de arts, volgens de juridische werkgroep ${ }^{777}$ en de werkgroep Doen of laten, de behandeling niet nalaten, doch dient hij de behandeling aan een andere arts over te dragen, die zich wel in de mening van de ouders kan vinden. Als reden geeft de juridische werkgroep op, dat de ouders in dit geval de veronderstelde wil van het kind, dat zijn recht op leven en rechtsbescherming wil handhaven, vertolken: ${ }^{78}$

Als naast de behandelend arts zich andere artsen woor levensbeeindiging uitspreken, terwijl de ouders daartegen zijn, dan mag volgens de juridische werkgroep ervan worden uitgegaan, dat de ouders niet (meer) de veronderstelde wil van het kind vertolken. ${ }^{779}$

\section{De ouders spreken zich tegen een ethisch zinloze behandeling uit}

De ouders hebben in beginsel het recht een behandeling van hun kind te weigeren. Als de arts niet aannemelijk acht dat de ouders het belang van het kind laten prevaleren, dan behoeft hij hun wens niet op te volgen. ${ }^{780}$ Naar de mening van de juridische werkgroep dient hij dan zelfs aangifte te doen om de ouders tijdelijk uit de ouderlijke macht te laten ontzetten. ${ }^{781}$

Als de ouders behandelen ethisch zinloos achten en de arts hun mening niet deelt, dan geeft de wens van de ouders in beginsel de doorslag, zo merkt de werkgroep Doen of laten op. ${ }^{782}$ Maar zij vermeldt er tevens bij dat hierover onder de Nederlandse kinderchirurgen "allerminst een communis opinio" bestaat. De werkgroep illustreert dit aan hand van een voorbeeld, dat grote gelijkenis vertoont met het verderop te bespreken geval dat tot HR 28 april 1989, NJ 1990, 46 (baby Ross) leidde.

Daarbij gaat het om de vraag of een goed corrigeerbare bijzondere afwijking verholpen moet worden, als deze gepaard gat met andere afwijkingen van algemene aard. Zo doet

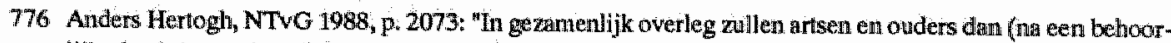
lijke besluitworming, J.W. ) een besluat moeten memen".

777 Gezondheidsraad, 1975 , Bjjlage I, p. 9.

778 Zo ook Doen of Haten, 1989, p. 24-25.

779 Grzondheidsraad 1975 , Bijlage I, p. 9.

780 Gezondheidsrat, $1975, \mathrm{p} .29$ en Doen of laten, $1989, \mathrm{p} .35$.

781 Gezondheidsraed, 1975, p. 33 en Bijlage I, p. 7.8. De CAL bespreekt deze sihwatie niet, maar slechts die warin de ouders met levenswerltengend handelen verder willen gaan, terwijl de arts deze nier wenst te beginnen of wenst deze te staken.

782. Doen of laten, $1989, \mathrm{p}, 32$. 
zich bij pasgeborenen met het syndroom van Down vaker een afsluiting van de twaalfvingerige dam voor. Het syndroom van Down is onvoldoende reden om tot levensbeèindiging te beslissen en de darmafsluiting kan in vele gevallen worden hersteld. Volgens de werkgroep komt het regelmatig voor dat ouders bij een dergelijke combinatie van afwijkingen toestemming weigeren de darmafsluiting te verhelpen. Hoe dient ulltgaande van dit voorbeeld gehandeld te worden?

Volgens de werkgroep bestaan hierover onder de Nederlandse kinderchirurgen twee opvattingen. De ene houdt in dat het leven van de pasgeborene niet mag afhangen van de toestemming van derden, ook al zijn dit de ouders. ${ }^{783}$ Het kind dient tegen de ouders beschermd te worden en daarom moet - desnoods via de Raad voor de Kinderbescherming - alles in het werk gesteld worden om de ingreep uit te voeren. ${ }^{784}$

Andere kinderchirurgen, aldus de werkgroep Doen of laten, zijn van mening dat de wens van de ouders gerespecteerd behoort te worden, voorzover de ouders ervan overtuigd zijn dat een operatieve correctie hun kind en hun gezin niet ten goede komt. Al twijfelt de arts over de juistheid van deze keuze en zells zou hij voor zijn eigen kind anders kiezen, "dan nog hebben wij hier te maken met een grenssituatie waarin veel weldenkende burgers in onze pluriforme samenleving van een operatie zouden willen afziem. Door in zulk een twijfelachtige situatie een therapie door te drijven die de ouders niet wensen, gaat de arts zijn boekje te buiten". ${ }^{\text {7BS }}$

Een ruime meerderheid van de werkgroep heeft een voorkeur voor het tweede standpunt. Zij constateert bovendien een toenemende neiging bij zowel ouders als artsen ${ }^{786}$ om in dergelijke situaties van een operatie af te zien. ${ }^{787}$

\section{De mening van de ouders bij actieve levensbeëindiging}

De mening van de ouders treedt ook meer op de voorgrond als de vraag aan de orde is of - na abstineren of na staken van de levenswerlengende behandeling - tot actieve levensbeëindiging zal worden overgegaan. Volgens de werkgroep Doen of laten hebben de ouders een vetorecht wanneer door de ants (en het team) besloten is tot opzettelijke levensbeëindiging. In de terminologie van de werkgroep mag derhalve de arts een medisch zinloze handeling wel zelfstandig staken, maar niet vervolgens tegen de wil van de ouders het leven van de pasgeborene opzettelijk beëindigen. ${ }^{785}$ De werkgroep Doen of laten acht ouderlijke toestemming tot beoogde levensbeëindiging een "absoluut moreel vereiste" . Ontbreekt die toestemming dan dient voor het staken van de levensvertengende behande-

783 Vgll. Boon, MC 1989, p. 1300-1301. Zie ook Musschenga, 1987, p. 171: ouders hebben moreel gezien niet het recht behandelingen te weigeren in die gevallen warin een kind daarbij duidelijk gebat zow zijn, b.w. het mongooltje met een obstructie van de twaallfingerige darm. Als het behandeld wordt, bliff bet in leven. Zijn mentale retardatic is geen grond voor het achterwege laten van een operatieve ingreep.

78.4 Eveneens voor een beaderningsindicatie bij een te vroeg geboren mongooltje: Doen of laten, 1989 . P. 32.

785 In die zin ook Musschenga, 1987, p. 173 en Kuitert, 1981, p. 119-120. Beidan zijn van mening, dai de belangen war ouders slechts een rol mogen spelen als het resultal van de behandeling van een pasgeborene onduidelijk en onzeker is. Het is echter niet aan de owders orm over de warde van bet leven van het kind te beslissen en op grond daarvan een op zichzelf zinvolle behandeling af le wijzen.

786 Vgl. m.b.t. artsen: Dupuis; in: Beslissen over leven dood, 1989, p. 15 .

787 Dwen of laten, 1989, p. 32 .

788 Doem of latien, 1989, p. $44-45$. 
ling gekozen te worden, terwijl met andere medische handelingen en met de verzorging doorgegaan moet worden. Op dezelfde wijze moet worden gehandeld als de arts beoogde levensbeëindiging ongeoorloofd acht of slechts gecorloofd acht als het lijden van het kind vanwege het afzien van actieve levensbeëindiging verergerd wordt. ${ }^{789}$

Spreken de ouders zich voor actieve levensbeëindiging uit en is de arts daartoe niet bereid, dan dient de arts de behandeling aan een andere arts over te dragen, die in overeenstemming met de wens van de ouders wel tot actieve levensbeëindiging wil overgaan. ${ }^{\text {. }}$

\subsection{Besluitworming bij itreversibel comateuze patiènten}

Voor de prognose van een comateuze patiënt zijn van belang de oorzaak van het coma, de leeftijd van de patiënt en de duur van het coma. ${ }^{791}$ De prognose dient te worden bepaald door "enerzijds de kans om nog bij bewustzijn te komen dan wel in coma te blijven, anderzijds de toestand waarin de patiënt zal zijn nadat deze bij bewustzijn is gekomen". ${ }^{72} \mathrm{Bij}$ "gerede twijfel" omtrent de individuele prognose, dient de arts overlleg te plegen met de andere leden van het team, de betrokken verpleegkundigen en de naaste familie. Hun meningen kunnen voor de te nemen beslissing van "wezenlijke betekenis" zijn. ${ }^{793}$

De belangrijkste zorgvuldigheidseis voor de besluitvorming betreft de wil van de patiënt. Met betrekking tot de wilsonbekwaamheid verschillen irreversibel comateuze patiënten van pasgeborenen doordat een comateuze patiënt zijn wil "niet meer" kan uiten. ${ }^{794} \mathrm{Bij}$ een comateuze patiënt kan een eerdere wilsuiting blijken uit een codicil en/of uit hetgeen naaststaanden omtrent de wil van de patiënt kunnen vertellen. Is een codicil van niet ouder dan circa vijf jaar voorhanden, dan moet daaraan voorrang worden toegekend boven de "persoonlijke opvattingen van de behandelende arts of andere betrokkenen". ${ }^{795}$ "Als de familie zich tegen de naleving van het codicil van de patiënt mocht verzetten, dan dient de wil van de patiënt de doorslag te geven ${ }^{10}{ }^{796}$ Als geen codicil aanwezig is, kan de arts slechts afgaan op hetgeen familieleden omtrent de wil van de patiënt verklaren. Omdat deze wellicht moeilijk zuiver te achterhalen is, verdient het aanbeveling de verpleegkundigen vanwege hun contact met de familieleden te horen. ${ }^{797}$

Vooral bij twijfelgevallen dient aan de mening van de naaste familie in principe evenveel gewicht toegekend te worden als bij de besluitvorming omtrent zwaar-defecte pasgeborenen. ${ }^{798}$ Dat betekent echter niet dat de arts tot medisch zinloze handelingen kan worden verplicht of tot handelingen die hij voor zichzelf niet kan verantwoorden. ${ }^{799}$ De beslissing wordt genomen door de behandelende arts, nadat de prognose is gesteld en de meningen van alle betrokkenen zijn geïnventariseerd. De CAL vindt overleg met

789 Doen of $\operatorname{laten}_{\text {" }} 1989$, p. 22.

790 Kennelijk ook in die zin: CAL, MC 1988 , p. 701 r.k. en p. 702 l.k.

791 CAL, 1991, p. 9-15 en p. 47-48.

$792 \mathrm{CAL}, 1991, \mathrm{p} .37$.

793 CAL, 1991; p. 37.

$794 \mathrm{CAL}, 1991$, p. 5.

$795 \mathrm{CAL}_{2} 1991$, p. 38.

$796 \mathrm{CAL}_{1} 1991$, p. 29.

797 CAL, 1991, p. 39.

798 CAL, 1991, p. 39-40.

799 CAL, 1991, p. 40. 
de verpleegkundigen evenzeer nodig als met de andere betrokken artsen. Maar hen kont, evenmin als de overige teamleden een beslissende stem toe. Met name wanneer de prognose onzeker is en de meningen van de arts en de waste familie uit de pas lopen, acht de CAL het nodig, dat de arts "zijn mening toetst aan die van een ervaren, onafhankelijke collega"t. Dat dient bij voorkeur een arts te zijn die niet tot het team behoort. Doel van deze toetsing is het verschaffen van meer duidelijkheid aan de arts, die wel voor de witeindelijke beslissing verantwoordelijk blijt. ${ }^{300}$

\subsection{Vormen van levensbeëindiging}

Hieronder worden door de medici gemaakte verschillen van vormen van levensbeëindiging bij pasgeborenen en bij comateuze patiënten besproken. Daaruit zal blijken dat de benaderingen van medici en van strafrechtjuristen hierover uiteenlopen. Aangezien het mogelijk is deze kwestie ten aanzien van pasgeborenen en comateuze patiënten gezamenlijk te behandelen, is daaraan de voorkeur gegeven.

De problematiek van het niet (verder) behandelen doet zich slechts voor bij een "onlleefbaar leven ${ }^{17}$-prognose. Daarentegen kan actieve levensbeëindiging aan de orde zijn zowel wanneer behandelen medisch zinloos is als wanneer dat handelen ethisch zinloos is. Wanneer behandelen medisch zinloos is, dan is de medicus gehouden van behandeling af te zien. De prognose medisch zinloos geeft echter geen legitimatie om tot actieve levensbeëindiging over te gaan.

In de hier besproken rapporten wordt een onderscheid gemaakt tussen drie vormen van levensbeëindiging:

- niet beginnen met een levensverlengende behandeling;

- staken of stoppen van een reeds begonnen behandeling,

- actieve levensbeẻindiging. ${ }^{801}$

Als gesproken wordt over levensbeëindiging, dan wordt in het algemeen bedoeld levensbeëindiging door nalaten (verder) te behandelen. In alle rapporten wordt een nadrukkelijk moreel verschil gemaakt tussen levensbeëindiging door dit nalaten en actieve levensbeëindiging.

Actieve levensbeeindiging is het meest controversieel ${ }^{802}$, ook binnen de commissies zelf. Voor zover deze toelaatbaar wordt geacht, betreft dat gevallen, waarin nalaten te

800 CAL, 1991, p. 40-42,

801 CAL, MC 1988, p. 698. De werkgroep Doen of laten spreekt wan "primair afzien, "staken" en "'opzettelijke lewensbeeindiging. Onder "primair affien" werstaat zij hetzelfde als de CAL onder abstineren. (Medici gebruikem thet begrip ook in iets andere betekenis. Zo spreekt J.H. Mulder, MC 1988, p. 1418, wan alustinenthe als de behamdeling wordt gestaakt en volstaan wordt met "basale elementen" van zorg. Hij vermeld dakarbij dat men er dan "meestal" van abstinentie spreekt.) De term "staken" wordt overeenkomstig gebruilkt Met "opzettelijke levensbeëindiging" bedoelt de werkgroep "beoogde levensbeëindiging". Niet de arard van de gedraging, marar de intentie van de arts bepaalt daarbij of de levensbeeindiging oprettebijk geschiedt. Doen of laten, 1989, p. 11-12.

802 Deze wordit ontoelatbarar geacht door 0.a.: Van Alphen e.a., MC 1988, p. 1389-1390; Leenen, MC 1988, p. 1050 en Roscam Abbing en Leenen, MC 1988, p. 1265; Dupuis, in: Handboek Gezondhe idsethiek, 1988, p. 369: omdal deze "mastschappelijk ontarwaandbaar" is. Eerder afwijzend, maar als "niet-onschuldige nowdbeslissing" begrijpelijk: Sporken, in: Handboek Cezondheidsethiek, 1988, p. 350. Zie van dezeltide schrijwer: MC 1988, p. 1238-1240 en MC 1988, p. 1554; en Boon, MC 1989, p. 1300 . De Katholieke Vereniging voor Ziekeninrichtingen, MC 1989, p. 21-22, wijst tevens op het gevaar van het hiellend wlak. 
behandelen geoorloofd wordt geacht. Tevens dienen bijzondere omstandigheden aanwezig te zijn, die tot deze worm wan levensbeeindiging nopen. ${ }^{803}$ Die omstandigheden zijn per gewal zo verschillend dat hierwoor geen algemene criteria gegeven kunnen worden. Een andere reden om voor actieve levensbeëindiging van regels af te zien, is te voorkomeni dat het uitzonderlijk karakter van de handeling verloren gaat.

De Gezondheidsraad verstaat onder "levensbeëindiging" bij zwaar defecte pasgeborenen:

"een opzettelijk levensbeëindigend of levensverkortend handelen of een opzettelijk nalaten van levenswerlengend handelen bij deze kinderen in hun belang"

In deze omschrijving speelt alleen het belang van de betrokkene een rol. De vaststelling dat de levensbeëindiging in het belang van de pasgeborene is, kan mede op ethische gronden getroffen worden. ${ }^{805}$

In het rapport van de Gezondheidsraad wordt het verschil tussen actieve en niet-actieve levensbeeindiging benadrukt. De Gezondheidsraad onderscheidt tussen het staken van een behandeling, levensverkortende pijnbestrijding en het toedienen van dodelijke middelen. Het staken van een behandeling, waar deze nog wel mogelijk is en het toedienen van dodelijke middelen, zijn vormen van levensbeëindiging. Bij de levensverkortende pijnbestrijding onderscheidt de Raad de pijnbestrijding met de bedoeling het lijden te verlichten respectievelijk met de bedoeling het leven te beëindigen. Handelt de medicus met de bedoeling de pijn te bestrijden, dan acht de Gezondheidsraad dit geen vorm van levensbeëindiging. ${ }^{806}$

In de ethische werkgroep van de Gezondheidsraad zijn de verschillen tussen actieve en passieve levensbeëindiging nader uitgewerkt, waarbij erkend wordt dat in beide gevallen de levensbeëindiging opzettelijk geschiedt. ${ }^{807}$

Bij passieve levensbeëindiging luiden de vragen: hoever de plicht tot handellen strekt en of het behandelen nog zinvol is. Bij actieve levensbeeindiging is de vraag of iemands: leven het nog voor hem en woor anderen waard is geleefd te worden. ${ }^{808}$

Naar de mening van de ethische werkgroep markeent de geboorte slechts een gradueel verschil van mens-zijn. Voor actieve levensbeëindiging van zwaar defecte pasgeborenen maakt zij een vergelijking met abortus vanwege een zwaar genetisch defect. Indien abortus dan geoorloofd wordt geacht, is het volgens haar niet goed mogelijk on principieel bezwaar te maken tegen actieve levensbeëindiging bij zwaar defecte pasgeborenen. Wie principiële bezwaren heeft tegen actieve Jevensbeëindiging kan niet in casu abortus toelaatbaar achten, voor zover in beide gevallen het belang van het kind respectievelijk de wrucht als motief wordt angevoerd. ${ }^{800}$

803. Vgl. Kuitert, 1989, p. 128 en Musschenga, 1987, p. 174 .

804. Gezondheidsraad, 1975, p. 9 en p. 25. De Gezondheidsraad bezigde toen nog de term "euthanasie" voor zowel whanasie als levens beeindiging. De ethici van de Gezondheidsrata, 1975, Bijlage Il, werkgroep ethici van de Gezondheidsragd, $\mathrm{p}_{4} 8$, hebben moeite met de term "belang", die volgens her, op het voordeel of hel mut duidi dat wemand kan genieten. Een mens is eerder een drager van belangen dan dat diens leven zelf een "belang" is. Daaron zouden zij er de voorkeur aan geven het leven in dit werband alls cen "goed" te. tien.

805 Gezondheidsraad, 1975 , p. 17 .

806 Gezondheidsrat, 1975, p. 22. Vgl. CAL, 1990, p. 4.

807 Gezondheidsraad, 1975, Bijlage II, p. 1-2.

808 Gezondheidsran, 1975, Bijlage I, p. 1-2.

809 Gezondheidsrad, 1975, Bijlage II, p. 34 . 
Volgens de ethische werkgrop wordt inmiddels in de Nederlandse samenleving eerder geoondeeld, dat levensbehoud onder omstandigheden inhumaan kan $z$ ijn. Bovendien wordit soms actileve levensbeëindiging uit respect voor het leven verdedigd. ${ }^{810}$

De ethische werkgroep acht het niet (verder) behandelen van zwaar-defecte pasgeborenen zonder overlevingskans of zonder communicatiemogelijkheden moreel te rechtvaardigen. Ten aanzien van de eerste categorie omdat een uitstellen van de dood tot ondraaglijke pijn leidt en met betrekking tot de tweede categorie, omdat er geen hoop is op enigerlei menselijke communicatie. ${ }^{811}$

De vraag of actieve levensbeëindiging bij deze categorieën toelaatbaar zou kunnen zijn, beantwoordt de ethische werkgroep ontkennend vanwege een strijd met het "ontzag voor het menselijk leven" ${ }^{112}$ De werkgroep ziet een ethisch verschil tussen actieve en passieve levensbeëindiging, dat uiteindelijk berust op de overtuiging dat onze maatstawen ontoereikend zijn ter bepaling van de waarde van memselijk leven. ${ }^{\$ 13}$ Maar zij kan zich voorstellen dat in uitzonderlijk moeilijke situaties tot actieve levensbeëindiging wordt overgegaam. Zij acht zich evenwel niet in staat om daarvoor regels te geven. Dat is volgens haar ook onjuist, want het gaat om "een stellig niet on-schuldige noodbeslissing":

Volgens de werkgroep Doen of laten handelt een medicus opzettelijk levensbeëindigend als hij daarmee de dood van zijn patiēnt beoogt. Beëindigt de medicus actief het leven van de pasgeborene dan handelt hij volgens de werkgroep altijd met opzet, want hij beoogt steeds de dood van het kind. De medicus kan ook een behandelen staken met het oogmerk dat het kind overlijdt. Naast deze twee vormen van wat de werkgroep noemt "opzettelijke levensbeëindiging" bespreekt zij twee vormen van levensbeẽindiging, die volgens haar niet opzettelijk geschieden. Ten eerste het staken van een behandeling zonder oogmerk op het overlijden en ten tweede het afzien van levensverlengend behandelen zonder dit oogmerk. In deze gevallen wacht de medicus af wat er met het kind gaat gebeuren en omdat hij zonder oogmerk op het overlijden de behandeling staakt of daarvan afziet, geschiedt de levensbeeindiging volgens de werkgroep niet opzettelijk ${ }^{815}$

Is geen verzoek gedaan, dan spreekt de CAL, van "levensbeeindigend handelen ", waaronder zij in 1988 verstaat

"handelingen van artsen die het overlijden van een wils-onbekwame patiènt beogen. Hieronder valt dus niet het medisch handelen dat weliswaar het overlijden van de patiênt tot gevolg heeft, maar waarbij dat overlijden door de arts niet werd beoogd"

Vormen van beoogde levensbeeindiging in dit verband kunnen volgens de CAL afzien van behandelen, staken van behandelen en actieve levensbeëindiging zijn. De medicus ziet echter van de behandeling af of staakt deze vanuit de ovenweging dat de pasgeborene

810 Gezondheidsraad, 1975, Bjlage II, p. 5-6.

811 Gezondheidsraad, 1975, Blijlage II, p. 7.

812 Gezondheidsraad, 1975, Bijlage $\mathrm{n}$, p. 8.

813 Gezondheidsraad, 1975 , Bijlage $\mathrm{n}$, p. 9.

814 Gezondtherdsraad, 1975 , Bijlage $\Pi_{1}, \mathrm{p} .10$.

815 Doen of laten, 1989, p. 11-12, Zje ook: Postmes, MC 1988, p. 806; Smelt e, , MC 1989, p. 17-18; Croughs, MC 1989, p. 648; die tevens bezwaar maken tegen de term "levensbeêndiging ", omdar daardoor het wezenlijke verschil russen nalaten en handelen niet meer zichtbaar zou zijn. Versiuys, MC 1989 , p. 606 , acht het verschil in de praktijk "wakk papierdun".

816 CAL, MC 1988, p, 697 \%.K. 
geen overlevingskans heeft (medisch zinloos) danwel geen leefbaar leven tegemoet gaat. (ethisch zinloos). Heeft de pasgeborene geen overlevingskans dan is behandelen medisch zinloos en is niet-behandelen geen vorm van levensbeëindiging.

In 1990 omschrijft zij "levensbeëindigend handelen" als:

"alle handelingen van artsen, die het overlijden van een wilsonbekwame patiênt beogen, ongeacht of deze het toedienen van euthanatica, pijnbestrijding, het niet aanvangen of staken van de behandeling dan wel enigerlei tussenvorm daarvan betref: fen" ${ }^{11}$. ${ }^{217}$

De CAL onderscheidt globaal twee wijzen van levensbeëindiging: niet (verder) behandelen. en actieve lewensbeëindiging. Wanneer zij over de toelaatbaarheid van levensbeëindiging in het algemeen spreekt, dan bedoelt zij slechts levensbeeindiging door niet (verder) behandelen. De reden daarvoor is niet dat de CAL een moreel verschil maakt tussen deze beide wijzen wan levensbeëindiging, maar tussen handelen met en zonder intentie tot levensbeëindiging. ${ }^{818}$ Wanneer gehandeld wordt met de intentie het leven te beëindigen, is er sprake van "levensbeëindigend handelen".

Tot actieve levensbeêindiging mag pas worden overgegaan, als passieve levensbeëindiging niet het beoogde resultaat oplevert. Wanneer de arts reeds voordat hij de behandeling staakt, verwacht dat het staken niet tot levensbeëindiging leidt, dan verdient het volgens de CAL de voorkeur, dat hij meteen actieve levensbeëindiging toepast. De rechtvaardiging voor actieve levensbeëindiging ziet de $\mathrm{CAL}$ in het voorkomen van onnodig lijden door medisch handelen. ${ }^{19}$ Dat betekent dat voor de toelaatbaarheid van actieve levensbeëindiging aan de proportionalliteitseis dient te zijn voldaan.

Vanwege de onzuiverheid van de begrippen 'actief' en 'passief' en omdat in beide gevallen de arts de dood van de patiënt "bewerkstelligt" ${ }^{1820}$, onderscheidt de CAL in 1991 tussen levensbeëindiging door niet (verder) behandelen en actieve levensbeëindiging, waaronder verstaan wordt levensbeëindiging met behulp van 'euthanatica'.

In de tweede discussienota omschrijft de CAL levensbeeindigend handelen als "handelingen van artsen, die het overlijden van een wilsonbekwame patiënt bewerkstelligen" .21 In het interimrapport levensbeëindigend handelen bij zwaar-defecte pasgeborenen spreekt zij daarentegen van "beogen" in plaats van "bewerkstelligen". ${ }^{822}$

Alleen wanneer 'euthanatica' toegediend worden en darmee het leven actief wordt beeindigd, is "direct" levensbeëindiging beoogd ${ }^{823}$, respectievelijk sprake van "levensbeeindiging in engere $\mathrm{zin}^{\mathrm{n} 824}$.

In deze benadering is het niet (verder) behandelen geen beoogde levensbeeindiging, dat wil zeggen dat de "beweegredenen" dan niet "per definitie" gericht zijn op levensbeèin-

817 CAL, 1990, p. 4

818 Zie: CAL, 1990, Bijllage 3, p. XIII.

819 CAL, 1990, p. 12.

820 De Werkgroep ad hoo van het Prof. Dr. G.A. Lindeboon Instituut, MC 1991, p. 1481, wijst er op, dat "bewerkstelligen" synoniem is aan "weroorzaken". Zij is van mening dat het onjuist is een oorzakelijk verband te leggen tussen afkien of staken van medisch zinloos handelen en de dood van de patientut.

821 CAL, $1991, \mathrm{p} .3$ :

822 CAL, $1990, \mathrm{p}, 4$.

$823 \mathrm{CAL}_{3}, 1991, \mathrm{p}_{\text {. }}$.

$824 \mathrm{CAL}_{2}, 1991$, p. 32 . 
diging. Dat neemt echter niet weg dat de medicus ook dan voor het overlijden verantwoordelijk is, omdat het overlijden uit de gedraging voortvloeit. ${ }^{25}$

Voor de morele beoordeling van de gedragingen is de intentie van de arts van eminent belang. Maar zij vormt tevens een lastig obstakel. De CAL beschrijft twee benaderingen van de bij de arts levende intentie. Daarbij gaat zij uit van de gedraging. Actieve levensbeeindiging acht zij pas geoorloofd, als er voldoende reden tot passieve levensbeêindiging bestaat en als daartoe besloten is. Vanuit deze dwingende volgorde kan actieve levensbeeindiging worden beschouwd als het gevolg van (de beslissing tot) het staken van de behandeling of als een "verdergaande stap". $\$ 26$

In de eerste benadering legitimeert (de beslissing tot) het staken van de behandeling de actieve levensbeëindiging. In de tweede benadering wordt tussen passieve en actieve levensbeëindiging een scherpe grens getrokken. Terwijl het staken van de behandeling aanvaardbaar kan zijn, wordt het "expliciet beogen" van de dood van de comateuze patiênt (in het kader van actieve levensbeëindiging) "onaanvaardbaar" genoemd. Maar actieve levensbeëindiging is evenmin uitgesloten. De CAL schrijt hierover dat in deze benadering verwacht mag worden "dat het stervensproces, ingezet door het staken van de behandeling, adequaat wordt begeleid" ${ }^{\prime 27}$, waartoe kennelijk ook actieve levensbeëindiging kan behoren.

De aandacht voor de intenties heeft te maken met het verschil tussen de beide gedragingen: passieve en actieve levensbeëindiging en met het gegeven dat actieve levensbeëindiging slechts dan geoorloofd wordt geacht, als zij op (de beslissing tot) niet (verder) behandelen volgt. Zoals de beslissingen (en de gedragingen) elkaar kunnen opvolgen, kunnen ook de intenties elkaar opvolgen. De intentie bij niet (verder) behandelen is dan te voorkomen dat medisch zinloos wordt gehandeld. Door het staken van de behandeling komt de patiēnt in de stervensfase terecht. De stervensfase wordt in deze benadering als een nieuw en zelfstandig gegeven beschouwd. Nu kan de medicus de intentie hebben het stervensproces "te verlichten en te begelleiden". Gevolg van het handelen met deze intentie kan zijn dat de patiënt overlijdt. Daar de verschillende stappen vanaf de beslissing tot het staken tot aan de dood van de patiënt als op zich zelf staande gebeurtenissen worden beschouwd, had de medicus nooit de intentie op de dood van de patiënt. ${ }^{828}$ Het verloop van de gedragungen brengt noodzakelijkerwijs de dood van de patiënt mede, maar zonder dat de intentie van de arts daarop was gericht.

In de andere benadering wordt uitgegaan wan een algemene intentie om het overlijden van de patiënt te bewerkstelligen. Elke stap die de medicus zet, neemt hij vanuit deze intentie.

De CAL erkent dat de onderscheiden vormen van levensbeëindiging soms verschillend worden beoordeeld, doordat men een moreel verschil ziet tussen doen of nalaten en 
daarmee tussen het staken wan een behandeling en actieve levensbeëindiging. ${ }^{829}$ Slechts de actileve levensbeëindiging wordt dan als "ongeoorloofde daad" aangemerkt: ${ }^{830}$

Maar, zoals de CAL opmerkt, omdat ook het staken als een doen kan worden begrepen, is er geen scherp verschil tussen staken en actieve levensbeëindiging, noch verschilt de verantwoordelijikheid van de arts voor "de gevolgen van zijn beslissing voor de toestand van de patiënt" ${ }^{1331}$ Dat betekent dat "alle vormen van levensbeëindigend handelen vooral op hun consequenties beoordeeld moeten worden ${ }^{\mathrm{HI}}$. ${ }^{32}$

Hierover wordt echter verschillend gedacht. Sommigen beschouwen het toedienen van euthanatica als bijzondere categorie van levensbeëindiging. De CAL heeft, om aan deze pluriformiteit van meningen recht te doen, in haar nota uit 1991 de definitie van levensbeëindigend handelen zo rulm gesteld, dat ook deze zienswijze daaronder vallt. Zowel bij actieve levensbeëindiging als bij het niet (verder) behandelen bewerkstelligt de arts de dood wan de patiënt. Het verschil tussen beide gedragingen betreft de subjectieve gesteldhell van de arts. In het eerste geval beoogt hij de dood en in het tweede geval lat hij de dood met opzet toe. ${ }^{83}$

Het toedienen van euthanatica (levensbeëindiging in engere zin) dient uitsluitend door de behandelende arts te geschieden en wel op een "medisch-farmacologisch verantwoorde wijze". ${ }^{\text {334 }}$ Voor het laatste is nodig dat hieraan tijdens opleiding en nascholing meer aandacht wordt geschonken. ${ }^{835}$

\subsection{Verslaglegging}

Met uitzondering van het rapport van de Gezondheidsraad vestigen de rapporten de aandacht op een goede verslaglegging en wel in verband met een mogelijke justitielle toetsing.

Een uitgebreide verslaglegging is vooral van belang in die gevallen waarbij geen verklaring van natuurlijk overlijden mag worden afgegeven en derden, i.c. de gemeentearts. en de OvJ, moeten kunnen nagaan hoe de arts tot zijn uiteindelijke beslissing is gekomen. ${ }^{836}$ Daarom dient in het verslag onder andere te worden opgenomen de (te verwachten) gezondheidstoestand van de patiënt, de mening van de naaste familie en van de bij de behandeling betrokken artsen en verpleegkundigen en gegevens omtrent de geconsulteerde arts. ${ }^{837}$ Al deze gegevens behoren altijd gedocumenteerd, gesigneerd en gedateerd te worden. ${ }^{838}$

829 CAL, 1991, p. 35-36.

$830 \mathrm{CAL}, 1991$, p. 34.

831 CAL, 1991, p. 34.

832 CAL, 1991, p. 34.

833 CAL, 1991, p. 35.

$834 \mathrm{CAL}_{\mathrm{i}}$ 1991, p. 42.

835 CAL, 1991, pu 42.

$836 \mathrm{CAL}, 1991$, p. 43.

837 CAL, 1990, 23; Doen of laten, 1989, p. 47. De werkgroep noemt in dit verband niet een geconsulteerde arts. CAL, 1991, p. 43.

$838 \mathrm{CAL}, 1991$, p. 43 . 


\section{De overlijidensverklaring}

In verband met de huidige situatie brengen zowel de werkgroep Doen of laten als de CAL er begrip voor op dat de arts de overlijdensverklaring onjuist invult.

Anders dan het advies van de Gezondheidsraad besteden de eerste deelnota van de CAL en het rapport van de werkgroep Doen of laten uitgebreid aandacht aan de overlijdensverklaring. Als de arts niet de overtuiging heeft dat de dood ten gevolge van een natuurlijke doodsoorzak is ingetreden, mag hij geen overlijdensverklaring afgeven. Zeker is volgens de rapporten dat het overlijden van een patiërnt ten gevolge van ến wan de drie "schijngestalten" van euthanasie en a fortjori - voor zover van toepassing - voor levensbeëindiging, namelijk levensverkortende pijnbestrijding, het achterwege laten van medisch zinloos geacht handelen of omdat de patiênt toestemming weigert, onder het begrip "natuurlijke doodsoorzaak" valt. ${ }^{840}$

De uitgebreide aandacht voor de overlijdensverklaring vindt zijn reden in een door de CAL en de werkgroep gesignaleerd meningsverschil tussen medici en juristen over de vraag wanneer een overlijdensverklaring zou mogen worden afgegeven en de consequenties die aan de verschillende standpunten vastzitten. ${ }^{841}$

Volgens de CAL en de werkgroep mag vanwege het geldend recht alleen een overlijdensverklaring worden afgegeven als een medisch zinloze levensverlengende handeling achterwege wordt gelaten of deze wordt gestaakt. De juristen zouden daarbij ten onrechte wan mening zijn dat de beslissing niet medisch zinloos te handelen uitsluitend op strikt medische, objectiveerbare criteria benust. $\mathrm{Zij}$ verdedigen een verschil tussen een medisch zinloze en een ethisch zinloze handeling zoals dat in de praktijk niet bestaat, en zij achten overlijden ten gevolge van het nalaten van een ethisch zinloze handeling geen natuurlijke doodsoorzaak. Maar: "Hoe kan een jurist beoordelen wat tot het gebied van ouders en artsen behoort? ${ }^{842}$

In medische kringen zou daarentegen de mening heersen dat zowel het achterwege laten van medisch zinloos als van ethisch zinloos handelen tot de bevoegdheid van de arts behoren. Ook al spelen in de tweede beslissing naast medische indicaties tevens maatschappelijke aspecten een roll, dan nog is de arts "competent" de desbetreffende beslissingen te nemen en dient derhalve een vervroegd overlijden naar aanleiding van diens beslissing als een natuurlijke doodsoorzaak te worden beschouwd. ${ }^{843}$

De bezwaren van de CAL en de werkgroep tegen thet net-afgeven van een overlijdenswerklaring richten zich tegen een justitieel onderzoek dat een zware belasting voor zowel de ouders als de arts kan zijn en tevens een ernstige juridische bedreiging voor de laatste inhoudt. De juridische bedreiging van de arts wordt volgens hen versterkt door het feit dat de criteria die ter toetsing van het handelen van de arts door het $O M$ gebezigd worden,

839 De CAL vestigt er de aandachl op dat de regeling in de (oude) WLB op zichzelf niets zugt over de vraag of het overligden van de patient een strafrechtelijk aspect heef. Met andere woorden: het freitt dot een arts niet de overtuiging heeft dat er sprake is wan een natuurlijke doodsoorzak, witl geenszins zeggen dall de zaak aanleiding zal geven tot strafrechtelijke opsporing of vervolging. Dil element wordt, zo de CAL, nogal eens vergeten in de discussies nond de overlijdenswerklaring.

840 CAL, MC 1988, p. 703 r.k. en Doen of laten, 1989, p. 35. De werkgroep nowin sllechts de eeirste twee schijingestalten, waarschijnlijk ondat in haar rapport meer algement aitspraken achterwege worden gelaten.

841 CAL, MC 1988, p. 703-704, Doen of laten, 1989, p. 35-37:

842 Doen of laten, $1989, p$, 36. Zive hiertoe H. IV A, onder 1.7.14.

843 CAL, 1991, p. 44. 
niet openbaar zijn. De werkgroep Doen of laten stelt dat de huidige praktijk tot "ontsporingen van het besluitwormingsproces" aanleiding kan geven. Zij noemt als zodanig: primair abstineren in plaats van voorwaardelijk behandelen omdat primair abstineren minder toetsbaar is dan het staken op een later tijdstip; ethisch zinloos handelen ten onrechte als medisch zinloos handelen woorstellen en het tegen beter weten in doorzetten van ethisch zinloos handelen. ${ }^{84}$

Zolang er niet in een andere procedure ten aanzien van de overlijdensverklaring wordt voozien die aan de betrokkenen meer zekerheid biedt, acht de CAL het "gerechivaandigd" en de werkgroep het "te verontschuldigen" dat artsen ondanks beter weten een overlijdens* verklaring afgeven. ${ }^{345}$ De CAL wijst daarbij op de "rompslomp en ellende die een eventuele strafrechtelijke vervolging voor alle direct betrokkenen" met zich brengt. Volgens har zou het voldoen aan alle zorgvuldigheidseisen moeten meebrengen, dat men geen risico van een strafrechtelijke vervolging loopt. Daarom dient het $O M$ een duidelijk beleid te voeren, waarbij de "betrokken artsen de garantie krijgen dat indien zij zich aan de bij levensbeëindiging in acht te nemen zorgvuldigheidseisen houden, er geen strafrechtelijke vervolging zal plaatsvinden". Daartoe dienen de Ministers van Justitie en WVC de voorwaarden te scheppen. ${ }^{\$ 46}$

\subsection{De wenselijkheid van een regeling ten aanzien van levensbeëindigend handelen} bij pasgeboremen

Voor de uitsluiting van de strafrechtelijke aansprakelijkheid voor levensbeëindiging acht de Gezondheidsraad de bestaande strafuitsluitingsgronden toereikend. ${ }^{847}$

Actief levensbeëindigend handelen zou naar de mening van de Gezondheidsraad strafbaar moeten blijven. Dit handelen onder bepaalde voorwaarden niet meer strafbaar te stellen zou tot een "gevaarlijk precedent" leiden. Ook is de omschrijving van de voorwaarden uitermate moeilijk, zodat misbruik niet is uit te sluiten. Zelfs als door de zorg voor een draaglijk menselijk lijden bepaalde situaties de overhand kumnen krijgen over de eerbied voor het "puur-biotische" bestaan van de mens, blijft "doden doden, ook wanneer het een zwaar defect en volstrekt weerloos menselijk wezen betreft". ${ }^{448}$

In "uitzonderlijk moeilijke situaties, situaties waarin het zonder meer duidelijk is da"t passieve euthanasie (euthanasie en levensbeëindiging, J.W.) in aanmerking zou komen" acht de Gezondheidsraad het niet uitgesloten dat de arts tot actieve levensbeëindiging overgat. Maar de Raad acht zich niet in staat voor deze gevallen rechtvaardigende regels te geven. Actieve levensbeëindiging kan nooit geoorloofd zijn, wellicht verontschuldigbaar. ${ }^{849}$ Daar voor actieve levensbeëindiging geen "stringente normen" bestaan, kan

844 Doen of laten, 1989, p. 36 .

845 Doen of laten, 1989, Bijlage 2, p. 6 .

846 CAL, 1991, p. 45 .

847 Gezondheidsrand, 1975 , p. 32.

8448 Gronditheidsraad, 1975, p. 27.

849 Gezondheidsraad, 1975 , p. 27-28. In die zin ook de ethische werkgroep; zie Bijage II, p. 8-10. Op p. 9 van Bijlage II wordt opgenerkt, dat het "ethisch verschil nussen de terughowdendheid ten asmzien van het laten sterven en het aktief doden binuen het éne kader wan menseljke zorg woor anderen (...) witteindelijk (berust) op de overiviging dat elk menselijk laven méér waand is dan wij in onze kullnureel bepalde begrip. pen en kriteria aangaande "draaglijk", "wolwardig", "anwaardbaar", "gelukkig" of "wellbesteed" lewen kumen uildrukken" ". 
de rechter de gedraging van de arts daaraan niet toetsen. De enige mogelijkheid die hij heef is tot de overtuiging te komen dat "de arts in alle zorgvuldigheid zijn besluit genomen heeft, na emstige overweging van de pro's en contra's van het onderhavige gewal" ${ }^{850}$ Hieruit blijkt dat de Gezondheidsraad niet af will van een rechterlijke toetsing van levensbeëindigend handelen.

De CAL acht een procedure nodig die toetsbaar en controleerbaar is en "die recht doet aan de belangen van alle in het geding zijnde partijen" ${ }^{* 51}$. Zij denkt daarbij aam "een goede ünterne toetsing vơóraf en, voorzover dan nog noodzakelijk, een tuchtrechtellijke toetsing achteraf". ${ }^{852}$ Daarmee in overeenstemming stelt de werkgroep Doen of laten vast dat een procedure ontbreekt, die aan haar bezwaren tegemoet komt. ${ }^{853}$

Concrete voorstellen voor een procedure geven de CAL en de werkgroep niet. Maar vanuit de nadruk die zij leggen op het casuïstische van elk geval, kan slechts aran een procedure gedacht zijn die eisen stelt ten aanzien van de zorgvuldigheid. Dat blijkt ook uit de hiervoor genoemde opmerking van de CAL dat het OM niet tot vervolging zou mogen overgaan als de arts aan bepaalde zorgvuldigheidseisen heeft voldaan.

Ook de juristen van de werkgroep Doen of laten achten een andere procedure noodzakelijk. Volgens hen zou bereikt moeten worden dat in het algemeen met een verslag van de lijkschouwer kan worden volstaan. De Vereniging voor Kindergeneeskunde dient te streven naar een protocol. Tevens benadrukken deze juristen het belang van een toetsing. "Zonder de mogelijkheid van toetsing komt de rechtsorde, welke de beschermwaardigheid vam elk individu in welke staat deze ook verkeert, erkent, in gevaar." 854

Enkele door de werkgroep geraadpleegde medici, juristen en ethici stellen een dienovereenkomstige procedure voor. Slechts als de besluitworming onzorgvuldig is geweest of het een andere wijze van levensbeëindiging betreft dan staken van levensverlengend behandelen $^{855}$, zal een nader juridisch onderzoek moeten volgen. De aanwezigen erkennen dat het gewenst kan zijn bij de evaluatie van elk geval een vertrouwensarts of de medisch ethische commissie van een ziekenhuis in te schakelen, maar achten dit als regel onpraktisch.

\subsection{Levensbeëindiging bij ernstig geestelijk gehandicapten}

De discussie over levensbeëindiging concentreert zich thans vooral op zwaar-defecte pasgeborenen en langdurig comateuze patiënten. Over willsonbekwamen die niet in één van deze categorieën vallen en die hier worden aangeduid als ernstig geestelijk gehandicapten, zal de derde nota van de CAL gaan. Tot de ernstig geestelijk gehandicapten behoren diep zwakzinnigen en zwaar demente patiënten.

850 Gezondheidsratad, 1975, p. 28.

851 CAL, 1991, p. 45.

852 CAL, 1990, p. 26.

853 Doen of laten, 1989 , p. 36. Zie ook: Bijlage 2, p. 6, waar de geconsulteenden zich uitspreken voor een andere procedure. Slechts bij onzorgvuldige besiluitworming of indien hei geen "staken van levenswerlengend handelen betreft zou een nader juridisch ondenzoek kunien volgent

85.4 Doien of later, 1989, Bijlage 1, p 12 .

855 Waarschijnlijk lijkt dat ook het niet-beginnen hieronder valt, maar daarover wordi in de Bijlage niet gesproken. 
Levensbeëindiging van ernstig geestelijk gehandicapten is het meest precaire onderwerp in verband met llevensbeëindiging en euthanasie. Voor zover levensbeëindiging van deze wilsonbekwamen in de discussie wordt betrokken, gebeurt dat veelal als waarschuwing over het verloop van de discussie. Sommigen voorspelden een acceptatielijn van abortus vanwege andere redenen dan een strikt medische indicatie ${ }_{,}$over de toelaatbaarheid wan euthanasie, naar het doden van wilsonbekwamen. Herinnerd wordt aan het geruchtmakende artikel van Dessaur over - onder andere - het doden van bejaarden, tot welke groep de zwaar demente patiënten behoren. Wat de voorspellingen over het verloop van de discussie betreft, hebben deze critici gelijk gekregen. Juist levensbeëindiging van ernstig geestelijk gehandicapten vestigt de aandacht op "euthanasiepraktijken" in het Derde. Duitse Rijk.

Wanneer de arts Marlet ${ }^{856}$ in 1968 over levensbeëindiging van ernstig geestelijk gehandicapten spreekt, dan doet hij dat binnen het kader van "de vernietiging van leven dat niet levenswaard wordt geacht". ${ }^{857}$

De aanzet tot de eerste stappen van de recente discussie over levensbeëindiging van ernstig geestelijk gehandicapten lijkt niet zozeer zijn oorsprong te hebben in de vooruitgang van de medische technologie en daaruit voortvloeiende problemen, maar in de kostenproblematiek van de gezondheidszorg. ${ }^{858}$ Als dat juist is, dan zou dat een reden kunnen zijn dat medici tot nu toe slechts zeer terughoudend aan deze discussie deelnamen. Een van de weinige artsen die levensbeëindiging van wilsonbekwamen in het algemeen behandelt is Spreeuwenberg. ${ }^{859} \mathrm{Na}$ een algemene benadering bespreekt hij levensbeëindiging bij ernstig defecte pasgeborenen, comateuze patiënten en ernstig demente bejaarden afzonderlijk. Aan de laatste groep besteedt hij de minste aandacht en de literatuurverwijzingen in zijn artikel beperken zich tot euthanasie en levensbeëindiging van pasgeborenen.

Op het niveau van de gezondheidszorg gaat het om de mate van zorg, waarop een patiênt aanspraak kan maken. Voor het eerst werd het begrip "kwaliteit van leven", dat uit de economie afkomstig is, op dat niveau gebezigd. Inmiddels wordt het vaak gebruikt om de (on)leefbaarheid van een individuele patiënt te helpen bepalen. "Kwaliteit van leven" kent een keur van invullingen. Voor levensbeëindiging wordt daaronder steeds vaker begrepen "minimaal mens-zijn". ${ }^{861}$ Is de kwaliteit van leven beneden de grens van minimaal mens-zijn, dan zou - in de opvatting van Musschenga - levensbeëindiging op grond van een moreel vooroordeel geoorloofd zijn. Ook het criterium "minimaal mens-zijn" vereist een nadere invulling. Vaststaat dat dit criterium ruimer is dan "medisch zinloos". De werkgroep Doen of laten spreekt van kwaliteit van leven als synoniem van een "te gering levensperspectief" respectievelijk een in ethisch opzicht zinloos handelen. Daarom is het niet verwonderlijk, dat in het algemeen de factoren die het minimaal mens-zijn dienen te bepalen; dezelfde zijn die binnen het referentiekader voor levensbeëindiging van zwaar-defecte pasgeborenen volgens de CAL en de werkgroep Doen of laten dienst doen ${ }^{862}$ en waarvan de voornaamste zijn de (on)mogelijkheid tot enigerlei vorm van communicatie en de mate van zelfredzaamheid. Daarmee lijken in de tweede helft van de jaren tachtig criteria beschikbaar te komen op grond waarvan een beslissing tot

856 Marlet, in: Recent medisch ethisch denken 1, 1968, p. 157-187.

857 Marlet, in: Recent medisch ethisch denken, 1968, p. 176-178. In origineel cursief, I.W.

$858 \mathrm{Vgl}$. Boon (red), Kwalliteit van leven \& worg, 1988.

859 Spreeuwenberg, in: Handboek Gezondheidsethiek, 1988, p. 481-487.

860 Spreeuwenberg, in: Handboek Gezondheidsethiek, 1988, p. 487.

861. Vgl. Musschenga, 1987.

$862 \mathrm{Vgl.} \mathrm{Musschenga,} 1987$ en Boon (red.), Kwaliteit van leven \& zorg, 1988. 
levenswerlenging of levensbeëindiging genomen kan worken in situaties waarin behandelen niet medisch zinloos is. In 1968 achtte Marlet dit niet mogelijk:

"De waarde en de zin van het leven onttrekken zich goeddeels aan het medisch oordeel, en ook de leefbaarheid laat zich moeilijk meten langs de ons ter beschikking staande maatstaven ${ }^{18}$.

Michells merkte in 1974 op, dat het doden van kinderen met aangeboren afwijkingen, idioten, zwakzinnigen, demente bejaarden en irreversibel comateuze patiếnten, nooit in het belang van de betrokkene zijn kan. "Hier wordt gedood in het belang van de omgeving en de maatsehappij" " wan diep zwakzinnigen. "Is er geen 'tenzij"? Naar onze mening zelden of nooit. Of de diep-zwakzinnige zelf de dood zou verkiezen boven het leven, is een niet te beantwoorden vraag $g^{\prime \prime}$. 65

Voor de concrete toepassing van criteria voor minimaal mens-zijn ontbreken thans nog gegevens. Hoewel soms wordt gesteld dat de problematiek van de verschillende groepen wilsonbekwamen verschilt, geldt dat vermoedelijk in mindere mate voor zwaar-defecte pasgeborenen en ernstig geestelijk gehandicapten.

Uit een voordracht van de arts Pouwels ${ }^{866}$ kan worden afgeleid, dat de diagnose, de behandelingsmogelijkheden en de effecten van behandelen bij wilsonbekwame zwakzinnigen vaak meerduidig zijn. Terwijl de arts naar levensverlenging dient te streven mag deze anderzijds niet slechts lijdensverlenging of lijdensverergering betekenen. Pouwels acht het uitgesloten dat er ooit objectieve criteria aan te geven zijn, die het nemen van de beslissing vergemakkelijken en toetsbaarheid mogelijk maken. Daarom is het voor het verkrijgen van meer duidelijkheid over het handelen van de arts noodzakelijk dat deze specialisten consulteert. De arts is verantwoordelijk voor het medisch handelen, terwijl de verzorgenden en de familie "een sterk beoordelende rol" hebben. Wanneer er voldoende reden is, mag de arts afzien van een levenswerlengende handeling. Actieve levensbeeindiging acht Pouwels slechts toelaatbaar als de patiënt daarom verzoekt.

Van Willigenburg ${ }^{867}$ concentreert zich bij de beoordeling van de morelle toelaatbaarheid van levensbeëindiging van zwakzinnigen op de kwaliteit van leven. Volgens hem wordt het leven van een wilsonbekwame te zeer vanuit belangen beoordeeld. Dan is de vraag welk belang een wilsonbekwame en andere betrokkenen bij het al dan niet levenswerlengend of levensbeëindigend handelen ten opzichte van de wilsonbekwame hebben. Daardoor verliezen morele noties als "respect voor leven of verantwoordelijkheid woor geschonden leven ${ }^{\text {th }}$ hun argumentatieve waarde. ${ }^{868}$ Toch kan het volgens hem soms geboden zijn tot levensbeeindiging over te gaan. Daarvoor noemt hij bepalend "ide bestaanskwaliteit van de patiënt, tezamen met de wensen, de verantwoordelijkheid, en de draagkracht van ouders, familie en zorgverleners" : 869 De genoemde bestaanskwalitelt "kan slechts binnen dat eigen bestaan worden afgemeten", want een "inter-persoonlijke vergelijking" is "uiterst dubieus" 870

863 Marjet, in: Recent medisch ethisch denken I, 1968, p. 178.

864 Michels, in: Menswardig sterven, 1974 , p. 218.

865 Vain der Most, in: Menswarardig sterven, 1974, p. 247.

1866 Pouwels, in: Beslissen over leven \& dood, 1989, p. 77-81.

867 Wan Willigenburg, in: Beslissen over leven dood, 1989, p. 85-88.

868 Wan Willigenburg, in: Beslissen over leven \& dood, 1989, p. 85. In origineel cursief, J.W.

869. Wan Willigenburg, in: Beslissen over leven \& dood, $1989, \mathrm{p} .88$.

870 Van Willigenburg, in: Beslissen over leven dood, 1989, p. 87. 
Sporken ${ }^{871}$ opteert voor een mensbeeld "waarin het mens-zijn omschreven wordt als een wordingsproces van zelfontplooiing in relatie" ${ }^{872}$ Wanneer daarvan wordt uitgegaan dan voldoet de patiënt die niet tot enigerlei relatie of tot zelfontplooiing in staat is, niet aan het mensbeeld, hetgeen zou kunnen betekenen dat diens leven beëindigd zou mogen worden. Voor de ethische rechtvaardiging van levensverlengend handelen bij ouderen acht hij belangrijk, in hoeverre het leven voor de patiënt zelf "redelijk aanvaardbaar en menswaardig is en waar hij nog enige positieve zin aan kan geven"t. ${ }^{873}$

Voor het stoppen met sondevoeding en het op deze wijze beëindigen van het leven van een demente bejaarde, is van belang "de totale conditie van de betrokkene, al of niet aanwezig zijn van andere aandoeningen, terugblik op het leven met de poging te achterhallen wat de betrokkene in het kader van zijn of haar levensontwerp zou gewild hebben". Sporken geeft dit voorbeeld bij de bespreking van levensverlenging, terwijl hij zich onder het kopje "Levensverkorting" beperkt tot gevallen waarbij de bejaarde verdere behandeling of verzorging weigert of om actieve euthanasie verzoekt. ${ }^{874}$

Verderop ${ }^{875}$ merkt hij ten aanzien van zwakzinnigen op, dat actieve levensbeëindiging niet geoorloofd is, waarbij hij een uitspraak van de ethische werkgroep uit 1975 , waarvan hij deel uitmaakte, aanhaalt. "Immers dergelijke regels zouden een handeling voor geoorloofd verklaren, die nooit meer kan zijn dan een stellig niet-onschuldige noodbeslissing". Wel toelaatbaar acht hij "het eerbiedigen van het stervensproces". Vermoedelijk gaat het er daarbij om een patiënt in het stervensproces ongestoord zijn eigen dood te laten sterven.

De morele waardering van levensbeëindiging van Van Willigenburg en van Sporken lijken in elk geval niet uit te sluiten dat de criteria van het genoemde referentiekader voor een concrete toetsing een rol kunnen spelen. Dat hoeft ook niet het geval te zijn in de opvatting van de arts Spreeuwenberg. Maar deze benadert de rechtvaardiging van levensbeëindiging op een thans ongebruikelijke wijze, die doet denken aan de euthanasiediscussie die gedurende de eerste tientallen jaren van deze eeuw eigenlijk uitsluitend buiten Nederland is gevoerd. Spreeuwenberg relativeert de waarde van wilsuitingen aangaande het beëindigen van leven. Het motief voor euthanasie en levensbeëindiging is voor hem gelegen in "compassie" met de patiënt. Bovendien acht hij van belang de waarde die het leven van de patiênt voor anderen heeft. Wel stelt hij als eis voor het beëindigen van het leven van een wilsbekwame patiënt dat daartoe slechts mag worden overgegaan als de patiënt daarom heeft verzocht. ${ }^{876}$

Wanneer als uitgangspunt voor het doen beëindigen van het eigen leven het zelfbeschikkingsrecht wordt gekozen, dan moet voor levensbeëindiging naar criteria worden gezocht, die de wilsuiting kunnen vervangen Daar dat nooit volledig mogelijk is, geeft dit uitgangspunt een buitengrens voor levensbeëindiging aan. ${ }^{5 \pi}$ Wanneer met Spreeuwenberg als grondslag voor levensbeëindiging compassie wordt gekozen, dan zijn meer situaties

871 Sporken, in: Handboek Gezondheidsethiek, 1988, p. 331-341.

872 Sporken, in: Handboek Gezondheidsethiek, 1988, p. 331.

873 Sporken, in: Handboek Gezondheidsethiek, 1988, pu 337.

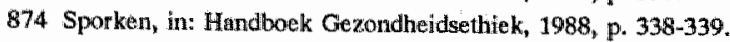

875 Sporken, in: Handboek Gezondheidsethiek, 1988, p. 343-351.

876 Spreeuwenberg, in: Handboek Gezondheldsethielk, 1988, p. 483-484.

877 Leenen, in: Euthanusie, 1977 , p. 108 : Als een patiènt zijn wil niet kan uiten, dan mag met veronderstelde toestemming worden gerwerkt. "De euthanasiebeslissing is echter geen medische beslissing; ondat, .m.. de mens slechts partieel object van het medisch handelen is en daaria si een oordeel over her leven wasi de patiênt niet begrepen, en voorts; omdat de wet dergelijke beslissingen over een ander niet toelata ${ }^{*}$. 
denkbaar waarbij levensbeëindiging geoorloofd kan wordeu geacht. Doordat Spreeuwenberg de noodsituatie centraal stelt en de zelfbeschikking van minder belang acht, ziet hij numere mogelijkheden voor levensbeëindiging. Wel wijst hij levensbeëindiging van emstig demente patiënten zonder wilsverklaring af, omdat "demente patiěnten nog zulke aan het mens-zijn eigen communicatie- en reactiepatronen (vertonen, JW.), dat hier spraike is van een geheel andere toestand dan bij irreversibel comateuze patienten". ${ }^{878}$

\subsection{Samenvating}

De kwestie van levensbeëindiging bij wilsonbekwamen betreft prognoses, waarbij het handelen niet als medisch zinloos kan worden gekwalificeerd, maar doorgaan met behandelen evenmin zonder meer geindiceerd is. Dan is de vraag welke andere factoren in verband met de prognose een medisch-ethische rechtvaardiging voor niet (verder) behandelen kunnen opleveren.

Bij euthanasie wordt vendedigd dat het verzoek om euthanasie in combinatie met een "uitzichtloze noodsituatie" de rechtvaardiging voor levensbeëindiging vormt. Maar een wilsonbekwame patiënt kan noch de behandeling weigeren, noch om euthanasie verzoeken. Evenmin kam hij aandringen op woortzetting van de behandeling. Daarmee zijn de twee beperkingen van het vraagstuk levensbeëindiging bij willsonbekwamen aangegeven. De prognose is wel ongunstig, maar houdt niet in dat handelen medisch zinloos is, en de patiënt kan niet om beëindiging van zijn leven verzoeken, zodat niet achterhaald kan worden wat hij zelf wil. Zou desondanks levensbeëindiging gerechtvaardigd zijn, dan dienen andere factoren de rechtvaardiging te leveren.

Het meest objectief en zeker is de beschrijving van de actuele toestand van de patiënt. Deze betreft bij een pasgeborene de aanwezigheid van zware defecten en bij een comateuze patiënt diens comateuze toestand. De actuele toestand biedt de mogelijkheid een prognose te stellen. Elke prognose is een voorspelling en kan daarom niet meer zijn dan een uitspraak over een waarschijnlijke toekomst van de patiënt.

Juridisch gezien zou bij een gunstige prognose het nalaten te behandelen als moord of doodsllag gekwalificeerd kunnen worden. Daartoe is nodig dat de arts jegens de patiënt een zorgplicht heeft. Die zorgplicht wordt verondersteld in gevallen watrin de patiënt niet tot een willsuiting in staat is. Daarbij word" uitgegaan van hetgeen een patient in dezelfde omstandigheden in het algemeen wil, namelijk te worden behandeld, omdat de behandeling kennelijk in zijn belang is.

De problematiek van levensbeëindiging van wilsonbekwamen betreft patiënten in omstandigheden, waarbij niet zonder meer gezegd kan worden dat een patiënt als hij tot wilsuiting in staat zou zijn, voor een behandeling zou opteren. Dan kan de rechtvaardiging van het behandelen wel in het ethische principe dat een mens niet gedood mag worden, gevonden worden, maar dat principe geldt niet onverkort, zoals uit de discussie over euthanasie en levensbeëindiging blijkt.

Bij het vraagstuk van levensbeëindiging is ten opzichte van euthanasie een verschuiving wan de aandachtspunten te zien. Weliswaar worden de wijze van besluitvorming en zorg- 
vuldighelidseisen beklemtoond, maar de meeste aandacht gaat uit naar de diagnose en de prognose. Vermoedelijk - nu de patiënt zijn wil niet kan uiten - om meer gewicht toe te kennen aan objectieve factoren.

Een wilsonbekwame patiënt is per definitie sterk belemmerd in zijn mogelijkheden tot communicatie. Daarom is het opmerkelijk dat als meest belangrijke factor voor levensbeëindiging de onmogelijkheid tot (enigerlei vorm van) communicatie wordt genoemd. Daarbij wordt wel soms gesteld dat deze onmogelijkheid een organische reden (beschadiging van de hersenen) dient te hebben, maar in elk geval sluiten de betreffende rapporten niet uit, dat het wezenlijk gaat om een niet op te heffen communicatiestoornis. Afgezien van de onmogelijkheid tot communicatie zijn de genoemde criteria factoren, die evengoed ter aanduiding van een "uitzichitloze noodsituatie" bif euthanasie dienst kunnen doen, malar die hier gebezigd worden voor de "onleefbaar leven"

De CAL beschouwt als enige van de drie commissies en pas in haar rapport uit 1991 in het algemeen zowel de "onleefbaar leven"-prognose ais de "geen overlevingskans" prognose als aanwijzingen dat behandelen medisch zinlloos is. Zij voent daartoe aan dat onder artsen ook deze opvatting heerst. Door deze benadering wordt de problematiek van levensbeẻindiging (vooral) een medische kwestie. Dat in elke prognose ook een moellijk te traceren, niet strikt-medische waardering zit, brengt mijns inziens niet zonder meer mee, dat in de benadering van levensbeëindiging tussen een "geen overlevingskans"-prognose en een "onleefbaar leven"-prognose niet onderscheiden behoeft. te worden. Want uitgaande van het standpunt van de CAL kan nog steeds van belang zijn de mate waarin elementen van deze beide prognoses in een bepaalde prognose aanwezig zijn. Bovendien verschuift een vereenzelviging slechts de problematiek. Want de vraag blïft, wanneer een medicus levensbeëindiging mag bewerkstelligen. Als de patiënt binmen afzienbare tijd komt te overlijden of ook als dat niet het geval is. Juist de tweede situatie vraagt om nadere criteria:

Bij de vraag of tot levensbeëindiging mag worden overgegaan kunnen verschillende doelstellingen wan de geneeskunde met elkaar in conflict komen en moet, voor zover niet een bepaalde doelstelling zeer duidelijk overheersend is, mede op grond van niet-medische overwegingen een afweging worden gemaakt.

De morele rechtvaardiging van levensbeëindiging van zwaar-defecte pasgeborenen is volgens de $\mathrm{CAL}$ gelegen in eén van de centrale doelen van de geneeskunde, namelijk het besparen van lijden. Uitgaande van de bij het referentiekader gencemde criteria, betreft "lijden" hier een ruim begrip. Ten aanzien van comateuze patiënten staat niet vast dat deze lijden. De CAL neemt het zekere voor het onzekere en gaat ervan uit dat ook deze patienten lijden. Dat brengt wel mee, dat ook ten aanzien van hen levensbeeindiging eerder geoorloofd wordt geacht.

Het grootste gewicht komt aan de onders bij de beslissing over actieve levensbeẻndiging toe. Als de ouders zich daartegen uitspreken, dan mag de arts het leven niet actief beëindigen.

Reeds in het advies van de Gezondheidsraad wordt - maar meer terloops - gewezen op de noodzaak tot consultatie. Dat geschiedt nadrukkelijker in de twee recentere rapporten. Dat wordt vooral van belang geacht, als de arts omtrent de diagnose in twijfel verkeert. 
Bij de morele waardering van de verschillende vormen van levensbeeindiging wordt een onderscheid gemaakt al naar gelang de medicus met de levensbeëindiging het overlijden van de patient beoogt. Daarbij wordt in plaats van "beoogt" meestal wan "opzettelijk" gesproken. In die opvatting beêindigt de medicus die vanwege een "geen leefbarr lewen"-prognose nalaat te handelen, het leven van de patiënt niet opzettelijk. De CAL erkent daarbij dat de medicus ook in dat geval de dood "bewerkstelligt" en daarom acht zij ook dan de medicus voor het gevolg verantwoordelijk.

Terwijl in het advies van de Gezondheidsraad wetgeving op het gebied van levensbeëindigend handelen bij pasgeborenen niet nodig wordt geacht en zelis gevaarlijk vanwege verlegging van de norm voor de eerbied voor het menselijk leven, wordt in de andere rapporten aangedrongen op een regeling die vooral aan de arts, maar daarnaast ook aan andere bij de levensbeeindiging betrokkenen, waarborgen verschaft en onnodige bedreiging door justitieel optreden voorkomt. In het advies van de Gezondheidsraad wordt niet gesproken over een dreiging die van "justitie" uitgaat.

\section{Voorstellen tot een wettelijke regeling met betrekking tot wilsonbekwame patiènten}

In verband met voorstellen tot een wettelijke regeling voor euthanasile werden ook voorstellen gedaan met betrekking tot comateuze patiënten. De voorzet daartoe gaf de Staatscommissie Euthanasie, die in art. 293 quater als schijngestalten van euthanasie onder meer aangemerkt wilde zien:

"b. het niet instellen, onderscheidenlijk het staken van een behandeling in gevallen waarin een zodanige behandeling naar heersend medisch inzicht zinloos is;

c. het niet behandelen van een bijkomende ziekte of aandoening bij een patiënt die naar heersend medisch inzicht onomkeerbaar het bewustzijn heeft verloren; ...".

Ten aanzien van een comateuze patiënt kunnen beide schijngestalten van toepassing zijn. De behandeling van een comateuze patiënt kan medisch zinloos zijn. In dat geval mag wolgens het onder b bepaalde de behandeling worden nagelaten, ook als dit meebrengt dat de patiënt overlijat. ${ }^{879}$ Het onder c bepalde heeft betrekking op een op het eerste gezicht andere situatie. Als een patiënt zich in een onomkeerbaar coma bevindt, dan mag een behandeling van een bijkomende ziekte of aandoening achterwege blijven, ook wanneer het gevolg daarvan is dat de patiënt overlijdt.

Hoewel er onder c niet wan wordt gesproken dat de behandeling van de bijkomende ziekte of axindoening medisch zinloos is, blijkt uit de toelichting dat de Staatscommissie daarvan wel uitgaat. ${ }^{880}$ Daarom was het beter geweest als de Staatscommissie art. 293 quater onder $c$ haar bedoeling bijvoorbeeld als volgt tot uitdrukking had gebracht:

"c. het behandelen van een bijkomende ziekte of aandoening bij een patiënt die naar

heersend inzicht onomkeerbaar het bewustzijn heeft verloren, wordt als een behandeling beschouwd die naar heersend medisch inzicht zinloos is".

Op deze wijze zou onder cen aanwullende bepaling zijn ten opzichte van het onder $b$ bepaalde.

879 Zie ook: Staatscommissie Euthanaste, Deel 1, 1985, p. 46.

880 Stakiscommissie Euthanasie, Deel 1, 1985, p. 76-77. 
De Staatscommissie beschouwde behandelen van een irreversibel comatewze patient als medisch zinloos: ${ }^{3 a}$ Darom mag de behandeling gestaakt worden ${ }^{382}$ en behoeft een bijkomende zlekte of aandoening niet behandeld te worden.

Voor de problematiek van levensbeëindiging van comateuze patiënten was bovendien van bellang het door de Staatscommissie voorgestelde art. 292 bis:

"1. Hij die opzettelijk het leven van een ander, die niet in staat is zijn wil te uiten, beëindigt wegens ernstige lichamelijke of geestelijke ziekten of aandoeningen, wordt gestraft met ...

2. Het in het eerste lid omschreven feit is niet strafbaar indien de beëindiging van het leven geschiedt door een geneeskundige in het kader van zorgvuldig medisch handelen ten aanzien wan een patiënt die naar heersend medisch inzicht onomkeerbaar het bewustzijn heeft verloren, zulks nadat de behandeling als zijnde zinloos werd gestaakt.

3. Zorgvuldig medisch handelen als bedoeld in het tweede lid houdt in ieder geval in dat de geneeskundige een door Onze Minister van Welzijn, Volksgezondheid en Cultur aangewezen geneeskundige heeft geraadpleegd" ${ }^{\prime 3}$

Art. $292 \mathrm{bis}$ lid 1 betreft de opzettelijke levensbeëindiging van mensen die hun will niet kunnen uiten en dat ook niet eerder hebben gedaan ${ }^{84}$ en waarbij de levensbeëindiging plaatsvindt vanwege "ernstige lichamelijke of geestelijke ziekten of aandoeningen". De Staatscommissie erkende dat deze bepaling in wezen overbodig is, daar de daarin omschreven gedraging ook aan de delictsomschrijving van de art. $287 \mathrm{en} 289 \mathrm{Sr}$ beantwoordt. Met de afzonderlijke strafbaarstelling wilde zij expliciet tot uitdrukking brengen, dat levensbeeindiging uit medelijden niet toelaatbaar is. ${ }^{895}$

Maar art. 292 bis lid 1 kent wel een lager strafmaximum dan moord of doodslag, zodat het een geprivilegieerd delict is. Hiervoor verwijst de Staatscommissie naar de onstandigheden waaronder het feit wordt gepleegd en de motieven die eraan ten grondslag liggen. Het betreft factoren waarmee, bij het ontbreken wan een bijzondere bepaling, de rechter bij de vraag, welke straf of maatregel opgelegd dient te worden, rekening kan houden. ${ }^{866}$ Dat laat echter onverlet dat het de wetgever vrijstaat om daarin bij wet te voorzien, evenals hij van levensberoving op verzoek een geprivilegieerd delict heeft gemaakt. Maar van een benadrukken van de strafbaarheid, zoals de Staatscommissie zegt $^{887}$, kan dan niet meer worden gesproken. ${ }^{888}$

In art: 292 bis lid 2 is een uitzondering op de in lid 1 omschreven strafbaarstelling opgenomen. Het betreft patiënten die geen schriftelijk verzoek tot levensbeëindiging hebben

881 Statscommissie Euthaunsie, Deet 1,1985, p. 77.

$882 \mathrm{Vgl}$. Rang, in: Menswaardig sterver, 1974, p. 267.

883 Startscomanissie Euthanasie, Deel 1, 1985, p. 40-41.

884 Staatscommissie Euthanasie, Deel 1, 1985, p. 99-101.

885 Statscommiss ge Euthanasie, Deel 1, 1985, p. 44.

$886 \mathrm{Vg}$. Minderheidsnota, in: Stantsconmissie Euthanasie, Deel 1, 1985, p. 281.

887 Stadtacommissie Euthanasie, Deell 1, 1985, p. 44.

888 Vgl. Wessal-Tuinstra, "TK, 1985-1986, 18331, m. 9 (Nota n.a.w. het eindverslag), p. 344; Gevers, TwGR 1985 , p. 329 en Josephus Jitta, NJB 1986 , p. 44 4 45 . 
gedaan en die zich in een irreversibel coma bevinden. Dat de comateuze toestand onomkeerbaar is, dient op grond van medische criteria te worden vastgesteld.

Is bij een dergelijke patiënt een behandeling medisch zinloos (art: 293quater onder b) dan mag de medicus vanwege de in art. 292 bis lid 2 geformuleerde rechtvaardigings= grond straffeloos actief en rechtstreeks het leven van een comateuze patiènt beëindigen, maar pas nadat hij de medisch zinloze behandeling heeft gestaakt. Ten onrechte spreekt art. 292 bis lid 2 slechts van "zinloos". Bedoeld is kennelijk een behandeling die "naar heersend medisch inzicht zinloos is", zoals het in art. 293quater onder b is onschreven.

Art. 292 bis lid 2 heeft geen betrekking op comateuze patiënten ten aanzien van wie met de behandeling nog niet is begonnen; vermoedelijk omdat op dat moment nog niet gezegd kan worden dat de comateuze toestand onomkeerbaar is en daarmee niet vaststaat dat een behandeling medisch zinloos is. De formulering van het tweede lid brengt mee dat ook niet tot actieve levensbeềndiging mag worden overgegaan in gevallen waarin een bijkomende ziekte of aandoening van een irreversibel comateuze patiënt niet wordi behandeld (art. 293quater onder c). Dat lijkt me inconsequent, daar niet uit te sluiten is, dat dan de patiënt in een ontluisterende situatie belandt.

De Staatscommissie onderscheidt bij onomkeerbaar comateuze patiënten tussen "patiënten die worden beademd en patiënten bij wie sprake is van een spontane ademhaling". In de toelichting op het tweede lid van art. 292 bis wordt vermeld, dat die bepaling uitsluitend patiënten met een spontane ademhaling betreft.

Als de patiënt wordt beademd dan mag de beademing worden gestaakt daar zij medisch zinloos is $\mathrm{Zij}$ dient immers niet ter verbetering vam de gezondheidstoestand van de patient. ${ }^{850}$ Wanneer de patiënt echter spontaan ademt en er zich geen bijkomende ziekte of aandoening voordoet, dan zou, in de woorden van de Staatscommissie, de "dood van de patiënt ... alleen bewerkstelligd kunnen worden door het niet meer toedienen van vocht en voedsel.". Vanwege de daardoor tot stand komende ontluistering van de patiënt en de belasting van naaststaanden, zou een medicus vanwege art. 292 bis lid 2 gerechtigd. zijn het leven van de patiënt te beëindigen. ${ }^{39}$

De rechtvaardigingsgrond van art. $292 \mathrm{bis}$ lid 2 is derhalve bedoeld voor een irreversibel comateuze patiënt die niet wordt beademd en bij wie zich geen bijkomende ziekte of aandoening voordoet.

De dood wan een comateuze patiênt kan op twee wijzen worden bewerkstelligd: door te stoppen met de toediening van voedsel en vocht en door het toedienen van een euthanaticum. De Staatscommissie is van mening dat in gevallen warin behandelen medisch zinloos is "de gewone verpleegkundige verzorging van de patiênt (wordt) voortgezet".

Het staken van de toediening van voedsel en vocht, door de Staatscommissie aangeduid als "gewone verpleegkundige verzorging", zou tot een "verregaande ontluistering van de patiënt" leiden. Bovendien zou een dergelijke stap ook voor zijn naaste omgeving

889 Staatscommissie Euthanasie, Deel 1,1985, p. 45

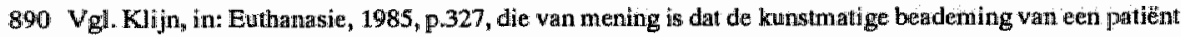
in een irreversibel coma op een gegeven moment als een bwitengewoon middel stopgezet mag worden. Volgens Van Till-d'Aulnis de Bourouill, 1970 $\mathrm{p}_{*}$ 116, is het onduidelijk wat precies buitengewone midatelen zijn. Bovendien mag de vraag of een behamdeling moet worden toegepast of voortgezet naar haar mening niet afhankelijk zijn wan wat voor middelen gebruikt wordem.

891 Staatscommissie. Euthanasie, Deel 1, 1985, p. 46-47. 
een "onhoudbare en ondraaglijke situatie" kunnen beteken. Daarom moet de medicus het leven van deze intewersibel comateuze patiênten op een andere wijze kunnen beëindigen. ${ }^{892}$

Het wetswoorstel Wessel-Tuinstra, dat wóór het verschijnen van het rapport van de Staatscommissie bij de Tweede Kamer werd ingediend, beperkte zich uitdrukkelijk tot een wettelifke regeling van euthanasie. ${ }^{993}$ Het voorzag bovendien niet in een bepaling waarn schijngestalten van euthanasie werden omschreven. ${ }^{84}$ Een amendement van het Tweede Kamerlid Dees (VVD) wilde hierin voorzien. In het amendement werden als schifngestalten onder andere genoemd de in art. 293 quater onder b en c wan de Staatscommissie opgenomen gedragimgen. ${ }^{\text {s9s }}$

De door de Staatscommissie voorgestelde schijngestalten werden wel door de regering in haar "Proeve" overgenomen. In het subamendement van het Tweede Kamerlid Haas-Berger ( $\mathrm{PvdA}$ ) werd voorgesteld de onder $\mathrm{c}$ genoemde schijngestalte te laten vervallen. Het daarin bepaalde betrof immers óf een behandeling die medisch zinloos was, of iets anders. Kon de behandeling als medisch zinloos worden aangemerkt, dan vie] het niet (verder) behandelen onder de schijngestalte wan het afzien van een medisch zinloze behandeling en was de bepaling onder c overbodig. Indien thet onder $\mathrm{c}$ bepaalde echter bedoeld was voor gevallen waarin behandelen niet medisch zinloos is, dan was de bepaling in strijd met het principe van de vrije wilsbeschikking en uit dien hoofde niet acceptabel. De Raad van State was dezelfde mening toegedaan en achtte het daarom wenselijk het onder c bepaalde te schrappen. ${ }^{896}$ Het kabinet voelde voor het standpunt van de Raad van State. In het kabinetswoorstel werd het onder c bepaalde niet overgenomen. ${ }^{897}$.

Van het opnemen van de in art. 292bis lid 2 door de Staatscommissie voorgestelde rechtvaardigingsgrond had de regering reeds bij de Proeve afgezien. In de MvT werd hiertoe overwogen dat actieve en rechtstreekse levensbeeindliging slechts op uitdrukkelijk en ernstig verlangen toelaatbaar kan zijn. Daartoe werd bovendien verwezen naar art. 2 EVRM $^{898}$ Die beptling sluit een regeling ten aanzien van thanatisch handelen niet principieel uit, maar stelt er wel een grens aan. Volgens velen wordt deze overschreden wanneer de wetgever actieve levensbeëindiging van wilsonbekwame patiënten gerechtvaardigd acht: ${ }^{899}$

892 Statiscommissie Euthanasie, Deel 1,1985, p. 46-47.

893 TK, 1983-1984, 18331, nr. 3 (MvT), p. 8.

894 2ie hiertoe: H. IV B , onder 1.7.16.

995 Amendement Dees, TK, 1985-1986, 18331, nr. 25 .

896 TK, 1985-1986, 18331, nr , 43, C en D (Advies van de RvS), p. 3-4. Kenmelijk zag het hoofalbestuur van de KNMG art. 293 quater onder $c$ als een gedeeltelijke doublure wan sub b op. Tevens wees het op hel gevaar van dexe bepaling, doortat via ten achterdeur het uitgangspunt wan de vrijwilligheid voor comateuze patiènten dreigt te worden vertaten, althans als het gaat om bandelingen die blijkbaar niet onder art. 293quater onder b vallen. Zle: KNMG, MC 1986 , p. 208209.

897 TK 1986-1987, 19359, wr. 5, p. 2 en TK 1987-1988, 20383, nrs.1-2, p. 2 voor de tekst van art. 293quater on: 3 (MvT), p. 12 woor de toelichting.

898 TK $_{\text {; }} 1986,19359$, nr. 2 (MwT), p. 13.

899 Minderheidsnota in: Staltscommissie Euthanasie, Deel 1, 1985, p. 281-282. Leenen, 1988, p. 294-295. Zie werder Gevers, TVGR 1985, p. 330; Houben, MC 1985, p. 1205; Til]-d"Aulnis de Bourouill, MC 1985, p. 1347. Zie ook: Sutorius, TVGR 1985, p. 343-344. 
Zoals eerder opgemerkt ${ }^{900}$ stelt het kabinet in zijn standpunt van 8 november 1991 voor "bewust levensbeëindigend handelen" respectievelijk "actief medisch ingrijpen door een arts ter bekorting van het leven zonder uitdrukkelijk verzoek van een patient" in de meldingsprocedure op te nemen. ${ }^{901}$ Hierbij merkt het kabinet op dat "de stand van de jurisprudentie geen algemene aanvaarding van actieve levensbeêndiging in situaties als de door de Commissie-Remmelink onder punt d genoemde ${ }^{902}$ - ... - inhoudt" "Het kabinet acht het gewenst dat de rechter zich hierover uitspreekt en verwacht dat het opnemen van dit handelen in de meldingsprocedure daartoe bijalraagt. Naar mijn mening heeft het kabinet daamee impliciet actieve levensbeëindiging bij wilsonbekwame patiênten in bepaalde situaties erkend. Het doel van de rechterlijke toetsing is kennelijk tot criteria voor de toetsing van dit handelen te komen. Daarmee is het kabinet een stap verder gegaain dan de Staatscommissie.

\section{Strafuitsluiting bị levensbeëindiging}

\subsection{Inleiding}

In dit onderdeel worden eerst de voor levensbeëindiging relevante delictsomschrijvingen besproken. Vervolgens wordt aandacht besteed aan de verschillende wijzen waarop levensbeëindiging kan plaatsvinden. Tenslotte wordt nagegaan in hoeverre via strafuitsluitingsgronden de niet-strafbaarheid van levensbeëindiging door de arts mogelijk is.

Euthanasie kan sinds de acceptatie van schijngestalten slechts via een handelen plaatsvinden. Daarentegen kan levensbeëindiging door een doen of een nalaten geschieden.

Aan levensbeëindiging liggen twee veronderstellingen ten grondslag. Behandelen is miet medisch zinloos, want zou dat wel het geval zijn, dan zou de arts gerechtigd zijn van het behandelen af te zien. Wel is de vraag, of hij in dat geval ook gerechtigd is tot actieve levensbeëindiging.

Ten tweede mag het behandelen niet duidelijk ten voordele van de patiënt strekken, want dan zou de medicus bij llevensbeëindiging een zinvolle medische handeling nalaten. Onder een handeling die niet ten voordele van de patiënt strekt, moet hier worden verstaan een in ethisch opzicht zinloos handelen, omdat de patięnt een te gering levensperspectief heeft of omdat de kwaliteit van zijn leven niet aan een bepaald minimum voldoet. De medisch-ethische rechtvaardiging voor levensbeëindiging ligt derhalve besloten in het oordeel dat medisch handelen ethisch zinloos is.

Bij levensbeëindiging kunnen drie gedragingen worden onderscheiden: Wanneer niet met een behandeling wordt begonnen, dan is de arts het meest passief. Het stoppen of staken van een behandeling heeft elementen van een nalaten en van een doen. Dat blijkt bijwoorbeeld uit het afsluiten van een infus of het uitschakelen van een beademingsmachine. Daarom is het mogelijk het stoppen van de behandeling als actieve of als passieve

900 Zie: HIV B, onder 1.10.

901 Bij een welwillende llezing van de betreffende passage mag aangenomen worden dat het kabinet blechts bedoelt bij wilsonbekwame patienten.

902 "Actieve levensbeëjndiging door een arts in het kuder van stervenshulp zonder uitdrukkelijk verzoelk vain de patiëut in een situatie, wagrin sprake is wan een onomkeerbaar elkaar benwibedend beginnend falen. van vitale functies". 
levensbeëindiging op te vatten. ${ }^{903}$ Onder actieve levensbeëindiging in enge zin kan worden werstaan het rechtstreeks doden van een patiënt door het toedienen van een dodelijk middel.

In medisch-ethische kring wordt tussen deze vormen vaak een moreel verschil gemaakt, waarbij het niet (verder) behandelen (onder bepaalde voorwaarden) wel geoorloofd wordt geacht, maar actiewe levensbeẻindiging in enge zin niet. De vraag is of dit onderscheid in het strafrecht eveneens relevant is. Zoals hierna zal blijken wijkt de heersende medisch-ethische waardering ${ }^{904}$ van levensbeëindiging op sommige punten af van de in het strafrecht gebruikelijke. Een meningsverschil voortvloeiend uit op verschillende wijze: gehanteerde begrippen verwart de discussie en kan tot rechtsonzekerheid leiden. Redenen om hieraan aandacht te besteden.

\subsection{Toepasselijke strafbepalingen}

Bij levensbeëindiging ontbreekt een verzoek van de patiënt. Daarom valt de gedraging niet onder art. $293 \mathrm{Sr}$. Evenmin kan art. $29.4 \mathrm{Sr}$ van toepassing zijn, daar van een zelfdoding door eem wilsonbekwame niet gesproken kan worden. Iemand die tot een rechtens relevant verzoek om levensbeëindiging niet in staat is, kan evenmin als subject van een gedraging worden beschouwd, die zijn dood teweegbrengt.

De delictsomschrijwingen waaraan bij levensbeëindiging vooral gedacht moet worden zijn moord, art. $289 \mathrm{Sr}$, doodslag, art. $287 \mathrm{Sr}$, en dood door schuld, art. $307 \mathrm{Sr}$. Moord is doodslag met voorbedachte raad. Het impulsief doden valt onder doodslag, het geplande doden ondler moord. ${ }^{905}$ Voorbedachte raad heeft geen betrekking op de intentie waarmee wordt gehandeld.

Een derde strafbepaling die bij levensbeëindiging in aanmerking komt, is dood door schuld. Art. $307 \mathrm{Sr}$ heeft ten opzichte van art. 287 en $289 \mathrm{Sr}$ twee voordelen. Dood door schuld is gemakkelijker te bewijzen dan moord of doodslag. Tevens leent art. $307 \mathrm{Sr}$ zich vanwege zijn materiêle omschrijving met een schuldvereiste goed voor vervolging van het teweegbrengen van de dood door een nalaten. ${ }^{907}$ Wie kon en behoorde te handelen, maar heeft nagelaten te handelen, of wie anders heeft gehandeld dan hij kon en behoorde te doen, heeft zich schuldig gemaakt aan dood door schuld, indien zijn gedraging de dood van iemand tot gevolg heeft.

Actieve levensbeëindiging door een medicus is altijd opzettelijke levensbeëindiging en voldoet daarmee, als per definitie zonder verzoek door de patiênt gedaan, aan de delictsomschrijving van doodslag. Bovendien mag ervan worden uitgegaan, dat de medicus de gedraging niet impulsief verricht, maar na besluitvorming, zodat het handelen van de medicus tevens aan de delictsomschrijving van moord beantwoordt.

903 In die zin: Rang, in: Menswaardig sterven, 1974, p. 268 en Nieboer, 1991, p. 130, voor wie telkens doorslaggevend is of zorgplichten worden geschonden.

904 En cok bij snderen. Zie b.w. bij Roscam Abbing, NTwG 1988, p. 1541 en p. 1543.

905 Vgl. Demeersseman, 1989, p. 25-60; Strjjards, 1988, p. 103; Van Bemmellen/Nan Veen, 1, 1989, p. 131-132.

906 Vgl. HR 8 mei 1990, DD $90.291^{*}$. Demeersseman, 1989, p. 53-55.

907 Van Bemmelen/Van Veen, 1,1989 , p. 164-165. 
Een medicus die een behandeling niet begint, kan vervolgd worden vanwege moord of doodslag als de patient ten gevolge van het achterwege blijven van de behandeling komt te overlijden. Hoewel de delictsomschrijvingen van moord en doodslag vooral doelen op een actieve gedraging kan ook door stilzitten iemand gedood worden. Als de medicus bewust de aanmerkelijke kans aanvaardt dat door zijn stilzitten de patiēnt komt te overlijden, dan berooft hijj door nalaten opzettelijk de patiënt van het leven.

Nalaten te handelen is strafbaar als "handelen rechtens is verplicht" " In omissiedelicten wordt uitsluitend nalaten strafbaar gesteld. Voor de medicus zijn in verband met ons onderwerp twee omissitedelicten van belang, omschreven in de artt. 255 (jo 257) en $450 \mathrm{Sr}^{909}$

Bij een omissiedelict stelt de delictsomschrijving een nalaten te handelen strafbaar, bij een commissiedelict een bepaald handelen. Een oneigenlijk omissiedelict is een commissiedelict dat door nalaten wordt gepleegd. Als oneigenlijk omissiedelict komen in aanmerking delicten met een materiële delictsomschrijving. ${ }^{910}$ Tot deze delicten waarin niet een bepaalde handeling is omschreven, maar met de aanduiding van het gevolg wordt volstaan, behoren moord, doodslag en mishandeling. ${ }^{911}$

Behalve dat een delictsomschrijving zich moet lenen voor strafbaar nalaten, is voor een bewezenverklaring nodig, dat de verdachte normadressaat is. ${ }^{912} \mathrm{Bij}$ een eigenlijk omissiedelict geeft de wet expliciet aan wie normadressaten zijn. Dat zijn degenen op wie een zorgplicht rust. ${ }^{913}$ Zo spreekt art: 255 Sr van degene die "krachtens wet of overeenkomst verplicht is" tot onderhoud, verpleging of verzorging van een derde. Wie zijn zorgplicht niet nakomt kan strafrechtelijk aansprakelijk worden gesteld. Van in strijd met zijn zorgplicht handelen is bij art. $255 \mathrm{Sr}$ bijvoorbeeld sprake als een ouder een pasgeborene in hulpeloze toestand brengt of laat ${ }^{914}$ of een arts een patiënt niet behandelt, waardoor deze sterft. ${ }^{\text {.15 }}$

908 Vgl. Van Bemmelem/Van Veen, I, 1989, p. 76.

909 Van Benmelen/Wan Veen, $\mathrm{l}, 1989$, p. 165; Deze eigenijke omissiedelicten zijn formele delicten. Strijards, 1989, p. 94, merkt terecht op dat de zorgplicht bij art. $450 \mathrm{Sr}$ ook kan bestaan als de dood niet intreedt. Miar pas dit gevolgschept de stratrechtelijke aansprakelijkheid. Een voorbeeld. Wanneer A en B getuige zijo wan de ogenblikkelijke levensgevaar wäan $C$ verkeer, dan rust op A en $B$ de zorgplicht in te grijpen. Gript slechts $A$ in en redt hij $C_{3}$ dan is $B$ thiet ansprakelijk. Wetheeft hij in strijd nuet eer torgplicht nagelatiden the handelen.

$910 \mathrm{Vgl}$. Hamewinkel-Suringa/Renmelink, 1991, p. 108. De oneigenlike onissiedelicten worden soms over het hoofd gezien. Zie b.v. Roscam Abbing, NTvG 1988 , p. 1541, die i.v.m. het nalaten van medisch handelen, behalve dood door schuld, art. $307 \mathrm{Sr}$, sleclits onissiedelicten bespreekt.

911 Vgl. Hazewinkel-Suringa/Remmelink, 1991, p. 107. Van Bemmelen/Vart Veen, I, 1989, p. 165. Zie ower materierel omschreven delicten ook: $\mathrm{H}$. II, onder 3.1 .

912 Hazew inkel-Suringa/Remmelink, 1991, p. 176. Nieboer, in: Naar eer en geweter, 1987, p. 455-464.

913 Nieboer, in: Naar cer en geweten, 1987, $p_{n}$ 455-464. Politotf en Koopmans, 1991, p. 137, noot 172: "Omdit de oneigenlijke omissiedelicten (...) alleen kunnen worden gepleegd door hen die wegens hun bijzonderte hoedanigheid (Corankenstellang) de plicht hebben een bepaald gevolg af te wenden, zou het bestaan wan de Garrontenstellung bij dit soort delieten kunnen worden beschouwd als en implicietle bestanddeed van de delictsonsethrijuing". Hazewinkel Suringa/Remmelink, 1991, p. 151: "Zie ik goed, dar gaat de Hoge Raad en thans ook toe over om te eisen, dat de aansprakelijke persoon een bepalde "hoedanigheid" en daarmee een speciale zorgplich ("Garantenstellung") ten aanzien van het betreffende rechtsgoed moet heblent".

914. Vgl. Van Stigt, NJB 1989, p 1152

915 Vgl. Hazewinkel-Suringa/Remmelink, 1991, p. 149. 
Ook bij oneligenlijke omissiedelicten is het noodzakelijk om de kring van de normadressaten af te bakenen. Daartoe wordt eveneens het criterium van de zorgplicht gehanteerd. Slechts degene op wie een zorgplicht rust kan een oneigenlijk omissiedelict plegen.

Terwijl in beginsel een delictsomschrijving met een materiële omschrijving zich tot iedereen richt, kan niet iedereen beschouwd worden als normadressaat van de omissitevariant van dergelijke delictsomschrijwingen. Want dan zou iedereen dader kunnen zijn, die - als hij wist of behoorde te weten wat de gevolgen van nalaten in een specifiekgeval konden zijn - niet heeft gehandeld. Bij een commissiedelict wijst een dader zichzelf door zijn activiteit als normadressaat aan, bij een omissiedelict wordt hij door in strijd met een zorgplicht stil te zitten als normadressaat aangewezen. ${ }^{916}$

De medicus heeft ten opzichte van zijn patiënten een zorgplicht, die inherent is aan zijn beroep en tevens in vele gevallen berust op een behandelingsovereenkomst. ${ }^{9.7}$ Toch, zo is hier eerder geconstateerd, is allgemeen geaccepteerd dat hij zich niet strafbaar maakt als hij een medisch zinloze handeling nalaat. Dat is vanuit de benadering van de omissiedelicten te verklaren üt het feit, dat een medisch zinloze handeling tevens een handeling is die niet in de zorg voor de patiênt voorziet. ${ }^{918}$ Maar ook bij commissiedelicten kan van een handelen in strijd met een zorgplicht worden gesproken, hoewel dat minder gebruikelijk is. ${ }^{919}$

Het in verband met medisch zinloos handelen over de zorgplicht opgemerkte heeft betrekking op een bepaalde handeling. Als ten opzichte van die handeling geen zorgplicht (meer) bestaat, dan volgt daaruit niet dat de medicus ook van ander handelen mag afzien.

Het op natuurlijke wijze toedienen van vocht en voedsel wordt tot de verzorgingsplicht gerekend. ${ }^{920}$ Of het toedienen van voedsel en vocht via sondevoeding een medische zorgplicht of een verzorgingsplicht is, is in medissche kring omstreden, hoewel een tendens

916 Vgl. Strijards, 1987, p. 6-7 en Nueboer, 1991, p. 117. Nieboer, in: Naar cer en geweten, 1987, p. 46:0: "De kwaliteitsdelicten zijn hier iu bepald opzicht een tegenhanger van de oneigenlijke omissiedelicten* bij eerstgenoemdes wordt de zorgplicht wit de adressering afgeleid en bij laatistgenoemde de adresseriag uit de zorgplicht. Adressering en zorgplicht zijn correlaat en het hangt van het delictstype af aan welke kant het startpunt ligt ${ }^{\text {to }}$.

917 Zorgplicht kan volgens Hazewinkel-Suringa/Renmelink, 1991, p. 152-153, worden aangewezen dowr: - de wot, art. $245 \mathrm{BW}$, - eigenian, gebruiker, enz. van bepalde rechisgoederen, - overeenkomst, - beroe $\mathrm{p}_{\text {, }}$ - gratagsvethouding; - zan kwatrnening, - voorafgand gevaarlijk of crimineel handelen. Knigge verdedigh in DD 1992, p. 143, dat een zorgplicht rusi op degene die in ean bepalde situat ise de aragewezen persoon is oni in te grijpen.

918 In H.IV A, onder 3, werd opgenerkt, dat de medious dan niet aansprakelijk is, orndat de nedische exoeptite

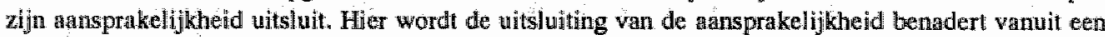
mogelijke zorgplicht.

919 Nieboer, in." Liber Amicorum, 1985, p. 255-270, p. 261: "de strafrechtelijk relevante gedraging heefl alls algemeen kenmerk de schendiryg wan en straffechtelijke zorgplicht (in origineel cursief, J.W.). Strijards, 1988; p. 85; In het alledigage leven lopen commissie wn omissie door elkar heet. "Volgens het moreel beset is er tussen beide opstellingen niet zoweel verschil. ... Voor de soort van zorgplich schending is dat irrelevant. ... Het strafrechtelijke gedragingsbegrip wordt belachelijk als deze onderscheiding wèl principièle betekeniss heeft" Kelk legt in AA 1989, p, $867-868 \mathrm{~m}$ i. met veronachtzaming van de nommadressa at een te grote nadruk op bet verschil tussen cetn wettelijke rechtsplicht bij een ejgenlijk omissiedelict en een zorgplicht bij een onejgenlijk omissiedelict. Ook in het doot hern aangehaalde voorbeeld, art. 444 Sr, is sprake van een nomadressatut (degene die wettelijk als getuige, als deskundige of als tolk is opgeroepen) en cen zorgplicht (nag niet wederrechtelijk wegblijwen).

920 Roscam Abbing, NTVG 1988, p. 1543, "Verzorging moet steeds worden verleend". Zie ook: Hazewinkel-Suringa/Remmellink, 1991, p. 152 . 
warneembaar is de sondevoeding tot de medische behandeling te rekenen. ${ }^{221}$ Naar mijn mening is voor het doorgaan met sondevoeding niet van belang hoe deze wordt gerangschikt, maar in hoeverre zij in een bepaald geval aan hel leven van de patient een bijidrage levert. Daarover dient een medicus een beslissing te nemen. Als deze van oordeel is dat sondevoeding medisch zinloos is, dan kan hij gerechtigd zijn daarmee te stoppen.

\subsection{Levensbeëindiging en strafuitsluiting}

\subsubsection{Inleiding}

Daar dit hoofdstuk analoog aan het voorafgaande is opgebouwd, worden cok de mogelijkheden tot strafuitsluiting zo veel mogelijk op dezelfde wijze besproken. Dat is niet altijd mogelijk. Zo is mij geen geval van levensbeëindiging bekend, waarbij een beroep is gedaan op een bepaalde interpretatie van de desbetreffende delictsomschrijving dan well op het ontbreken van de materiële wederrechtelijkheid. Maar het te dien aanzien bij euthanasie gezegde is ook hier van toepassing.

Gemeenschappelijk aan alle gevallen is dat een verzoek door de patiënt ontbreekt, athans dat daarvan niet is gebleken. Alle patienten waren ernstig ziek, de meesten bejaard en enkelen bevonden zich in coma. De handelende personen waren medici, verpleegkundigen of anderen. Voor zover de levensbeëindiging door anderen dan artsen plaatswond is het niet helemaal juist de betrokkenen als patiënten aan te duiden, daar zij in verhouding tot de anderen geen patiënten waren. Desondanks is voor het woord "patiënt" gekozen. Het woord wijst hier vooral op een gezondheidstoestand van de betrokkene.

De zaken Stinissen ${ }^{922}$ en Baby Ross ${ }^{923}$ worden afzonderlijk besproken. Dat heeft verschilllende redenen. Beide zaken onderscheiden zich van de overige hieronder besproken jurisprudentie, omdat de levensbeëindiging bij baby Ross en bij Stinissen passiever van aard was: De zaak Stinissen betrof de vraag of een arts bij een irreversibel comatteuze patiente de behandeling, in casu de sondewoeding, mag nalaten en of hij op verzoek van de echtgenoot van de patiënte van verdere behandeling moest afzien. Hoewel deze zaak een civielrechtelijk rechtsgeschil betrof, wordt zij verderop besproken, omdat zij voor de strafrechtelijke benadering van deze problematiek verhelderend kan werken. In de zaak baby Ross werd nagelaten een maag- en darmafsluiting van een pasgeborene met het syndroom van Down te verhelpen. Via een bezwaarschriftprocedure berelkte deze zaak de Hoge Raad, die de ongegrondverklaring van het bezwaar in stand liet.

921 Gezondheidsraad, $1975, \mathrm{p}, 20$, Doen of laten, 1989, p. 12; CAL, 1991, p. 28. Als reden wordt opgegeven dat voor deze kunstmatige handeling deskundighejd vereist is. In het onderzok dat in opdracht van de Commissie Medische Praktijk inzake Euthanasie werd verricht, wordt sondevoeding wonder nadere motjvering als mediseb handelen beschiouwd. Zie: Conumissie Medische Praktijk inzake Euthanasie, Ondwrzolk, 1991. p. 13. Het Prof. Dr. G.A. Lindeboom Instituut, MC 1991, p. 1277, platst hierbij een vratghteken. Volgens de CAL, 1991, p. 29, zjjn sommigen artsen van mening dat het staken tot een ontluisterend sterfbed leidt en andere dat de patuënt darardoor op een wardjge wijze kan sterven. Ook wolgens Leenen, 1988 , p. $298-301$, m. n. p. 300 , kan voedsel en vochttoediening kan dermate kunstmatig geschieden, dat zij als medische handeling kan worden beschouwd. Zie ook: Rb. Amelo 1 juli 1987, TvGR $1987 / 50$.

922 Rb. Almelo 1 juli 1987, TvGR $1987 / 50$.

923 Die tot de beschikkingen van de Hoge Raad van 28 april 1989 , NJ 1990, 46 en NJ 1990, 47, leidde. 


\subsubsection{Medische exceptie}

Voor de rechtbank Haarlem ${ }^{924}$ voerde de raadsman van een arts die verdachte werd van moord op een comateuze patiënt aan dat de medische exceptie van de arts meebrengt, dat een arts pas dan strafbaar is, als de motieven die aan zijn handelen ten grondslag liggen niet meer van medische aard zijn en hij zeer onzorgvuldig heeft gehandeld. De verdachte arts zou in casu weliswaar onzorgvuldig, maar niet zeer onzorgvuldig hebben gehandeld.

De rechtbank liet zich niet in het algemeen over de medische exceptie uit. Zij beperkte zich ertoe vast te stellen dat de invulling daarvan op de wijze als de raadsman had gedaan, te ver gaat. Uitgaande van deze invulling zou immers het medisch handelen van de arts in beginsel buiten de werking van de strafwet vallen. Tevens werwees de rechtbank naar een uitspraak van het Medisch Tuchtcollege Amsterdam ${ }^{925}$ in deze zaak. Volgens het tuchtcollege had de arts zich schuldig gemaakt aan de overschrijding van medisch aanvaarde normen. Een medicus die in strijd handelt met medisch aanvaarde normen kan zich, volgens de rechtbank, niet met succes beroepen op de medische exceptie. ${ }^{926}$

\subsubsection{Overmacht in de zin van noodtoestand}

Voor de rechtbank Rotterdam ${ }^{927}$ werd wel een beroep gedaan op noodtoestand-exces, maar niet op noodtoestand. Wil er sprake zijn van een noodtoestand-exces, dan moet degene die in een noodtoestand verkeert verontschuldigbaar de grenzen van noodtoestand overschrijden. Een beroep op noodtoestand-exces is derhalve, anders dan een beroep op noodtoestand, een beroep op een schulduitsluitingsgrond. In deze zaak werd dan ook aangevoerd, dat de verpleegkundige in een noodtoestand verkeerde en dat hij daarin de grenzen van proportionaliteit en subsidiariteit verontschuldigbaar uit het oog had verloren.

De rechter kan op twee wijzen een dergelijk verweer verwerpen. Hij kan owerwegen dat van een noodtoestand niet is gebleken. Hij kan ook vaststellen dat de verdachte zich in een noodsituatie bevond, maar dat hij daarin op niet verontschuldigbare wijze de grenzen heeft overschreden.

Volgens de rechtbank Rotterdam was niet aannemelijk geworden dat de verpleegkundige in een situatie van noodtoestand had gehandeld, daar hij geen keuze hoefde te maken uit twee op hem rustende conflicterende plichten. Op hem rustte wel de plicht niet levensbeëlndigend te handelen. Daarentegen had de verpleegkundige niet de plicht om zonder opdracht van een arts de nood van de patiënt te lenigen op een wijze die voor de patiënt gevaar met zich brengt.

Het standpunt van de rechtbank Rotterdam werd gedeeld door de rechtbank Amster$\mathrm{dam}^{928}$. Ook hiler beriep de verpleegkundige zich op een conflict van plichten. ${ }^{929}$ Het zou tot haar taak behoren het lijden van patiënten te verlichten en daarom achtte zij zich genoodzaakt tot levensbeëindiging over te gaan. De rechtbank Amsterdam overwoog

924 Rb. Haarlem 4 april 1986, NJ 1987, 287.

925 Medisch Tuchtcollege Amsterdam 6 mei 1985 , TvGR 1985/45.

926 De rechtbank spreekt van: "deze zgn. medische exceptie".

927 Rb. Rotterdam 31 maart 1987, TVGR 1988/1.

928 Rb. Ansterdam 30 maart 1988. TVGR 1988/65.

929 Deze werpleegkundige doet een beroep op noodtoestand. 
dat het niet tot de taak van verpleegkundigen behoort "naar verantwoord verpleegkundig inzicht, getoetst aan de in de verpleegkundige ethiek geldende normen "levensbeeindigend the handelen. De verpleegkundige had ter levensbeëindiging van de comateuze patient een geneesmiddel gebruikt. Maar het zelfstandig toedienen van geneesmiddelen komt niet aan verpleegkundigen toe. ${ }^{930}$ Hienut blijkt dat een verpleegkundige niet levensbeëindigend mag handelen, ook al doet hij dit met de bedoeling het lijden van de patient te beëindigen. Dat is in overeenstemming met het in de medische en verpleegkundige wereld heersende standpunt dat een verpleegkundige niet zelfstandig medisch mag handelen.

Voor de rechtbank Haarlem ${ }^{931}$ voerde de verdediging aan dat de arts in een noodtoestand had gehandeld. De arts had een patiënte in coma gebracht en haar vervolgens twee dodelijke injecties toegediend.

Nu voor hem meerdere andere wegen openstonden, kon niet gezegd worden dat hij in een noodtoestand had gehandeld. Voor het handelen in strijd met het subsidiariteitsbeginsel wijst de rechtbank erop dat de medicus de patiênte vit haar coma had kunnen laten bijkomen en vervolgens met haar over euthanasie had kunnen spreken of met haar had kunmen bespreken of zij opnieuw in coma gebracht wilde worden en in die staat het overlijden wilde afwachten. Ook had de arts de patiènte in coma kunnen laten. Bovendien was de situatie aan de arts te verwijten daar hij (zonder verzoek of medleweten van de patiente) deze in een comateuze staat had gebracht, zodat ook vanwege culpa in causa het beroep op noodtoestand werd verworpen.

\subsubsection{Psychische overmacht}

Een beroep op gewetensdrang kan stranden, omdat de dader in strijd met het subsidiariteitsbeginsel heeft gehandeld. Daarvan is sprake als voor hem nog een andere, minder vergaande weg openstond, waarvoor hij ten onrechte niet heeft gekozen. Zo overwoog de rechtbank Alkmaar ${ }^{932}$ ten aanzien van een vader die op gezamenlijk besluit van hem en de moeder zijn ongeneeslijk ziek kind van 15 maanden heeft gedood, dat het lijden van het kind ten tijde van de handeling niet acuut was toegenomen, zodat de vader een andere weg had kunnen en moeten kiezen. Daarbij dacht de rechtbank aan het voeren vain gesprekken met mensen in soortgelijke omstandigheden: Kennelijk verwachtte zij dat de vader naar aanleiding daarvan voor een andere oplossing zou hebben gekozen. Uit de motivering van de straf ${ }^{933}$ valt af te leiden, hoe groot het belang is dat de rechtbank hechtte aan het zoeken naar andere wegen:"

"Zeer grote uitzonderingen daargelaten is het de individuele mens niet gegeven eigenhandig te beslissen over leven en dood van zijn medemens, hetgeen temeer

930 Hiertoe verwijst de rechtbank Amsterdam naar het rapport "De Verpleegkundige en het Medisch Technisch Handellen" van de Cormmissie Beroepsinhoud Verpleegkundigen van de beroepsorganisatie voor verpleegkundigen. Zie woor algemene informatie over de taken van verpleegkundigen: Van der Arend, in: Handboek Gezondheidsethiek, 1988, p. 275-285; Scholten, itr: Ethiek, rechi \&zorg, 1986, p. 91-95; Van der Arend; in: Ethiek, recht \& zorg, 1986, p. 15-18.

931 Rb. Haarlen 4 april 1986 , NJ 1987, 287; TwGR 1986/34.

932 Rb. Alkmatr 8 juli 1986, TvGR 1986/61.

933 De vader werd vanwege moord tot een gevangenisstraf van 1 jaar werocrdeeld. 
klemul als die medemens voor zijn verzorging en opvoeding totaal van die ander afhankelijk is".

De rechtbank Amsterdam ${ }^{934}$ bezigde ter verwerping van het beroep op gewetensdrang: van een verpleegkundige als eerste argument, dat het op grond van de wet, de jurispruden-

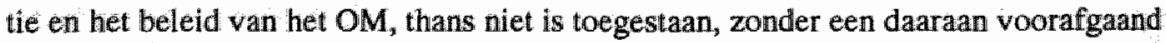
uitdrukkelijk verzoek van de patiennt op actieve wijze het leven van de comateuze patient te beeindigen. Wel onderkende zij in deze zak de druk van buitenaf op de verpleegkundige. Maar daaraan had deze gezien haar Garantenstellung weerstand moeten bieden. Het betrof immers een ervaren verpleegkundige die wist dat deze wijze van levensbeëindiging vain comateuze patienten niet is toegelaten.

Door de verdediging werd in een zaak voor de rechtbank Rotterdam ${ }^{935}$ gesteld dat de verpleegkundige die een ongeneeslijk zieke patiënt door verstikking van het leven had beroofd, in psychische overmacht zou hebben gehandeld. De verpleegkundige zou door het lijden van de patiênt hebben blootgestaan aan een dermate grote psychische druk dat hij daaraan op het moment dat hij de patiënt van het leven beroofde geen weerstand kon bieden.

De rechtbank verwierp het verweer omdat de verpleegkundige zich niet van professionele en ter zake kundige hulp heeft voorzien, om de door hem als dwangsituatie ervaren periode te doorbreken. Dat geldt niet slechts ten aanzien van verpleegkundigen, want de rechtbank voegde eraan toe, dat aan iedere niet-medicus in een soortgelijke situatie de eis gesteld dient te worden, de genoemde hulp te zoeken. Het zoeken van hulp kan en mag juist van de verpleegkundige worden verwacht, die zo nodig voor verandering van zijn werksituatie dient te zorgen en eventueel zelfs deze dient te beëindigen.

Ter verwerping van het beroep op psychische overmacht van de verpleegkundige werd bovendien overwogen, dat van mensen als de verpleegkundige die in hun beroep met dergelijke situaties geconfronteerd worden, verwacht mag worden dat zij tegen de psychische druk beter bestand zijn dan niet in de gezondheidszorg werkenden. Met andere woorden, ook de Garantenstellung voorkomt de honorering van het beroep op psychische overmacht. .396

Door niet de bedoelde hulp te zoeken had de verpleegkundige in strijd met het subsidiariteitsbeginsel gehandeld. Hij had geen gebruik gemaakt van een andere, minder vergaande en voor hem openstaande weg.

Als laatste argument ter verwerping van het beroep op psychische overmacht voerde de rechtbank Rotterdam aan dat niet voldoende aanmemelijk is geworden dat de verpleegkundige blootstond aan een dermate grote psychische druk dat hij daaraan geen weerstand kon bieden. ${ }^{\text {937? }}$

934 Rb. Amsterdam 30 mant 1988, TVOR 1988/65.

935 Rb. Rotterdan 31 maart 1987, TYGR $1988 / 1$.

936. Rb. Almelo 1 mant 1988, TVGR 1988/43. De rechtbank Alntelo benadmukte ter werwerping van het beroep op psychische owermacht van een medicus eveneens diens Garantenstellung.

937 Een zelfide overweging bezigt de Rb. Den Hagg 6 aug. 1985; NJ 1985, 708 ten axuzien van een muedicus. 


\subsubsection{Die omstandigheden}

De hierboven besproken jurisprudentie betreft gevallen van actieve levensbeëindiging. Met ëén uitzondering kwam de rechter telkens tot een veroordeling ${ }^{\text {as }}$ In geen van de uitspraken formuleerde de rechter algemene voonwaarden op grond waarvan de strafrechtelijke aansprakelijkheid bij levensbeëindiging zou zijn uitgesloten. De gedraging werd wooral strafbaar geacht, omdat een verzoek van de patiënt ontbrak. Toch kan uit de benadering van dergelijke situaties door de rechter wel in meer algemene zin afgeleid worden, welk gewicht de rechter aan bepaalde omstandigheden toekende. In plaats van het woord "voorwaarden" is hier gekozen voor het woord "omstandigheden", omdat niet blijkt dat actieve levensbeëindiging onder bepaalde voorwaarden wel geoorloofd zou kunnen zijn.

\section{Arts of niet-arts}

Uit uitspraken van de rechtbank Rotterdam en de rechtbank Amsterdam ${ }^{939}$ blijkt expliciet dat verpleegkundigen niet zelfstandig levensbeëindigend mogen handelen.

De rechtbank Alkmaar ${ }^{940}$ overwoog ten aanzien van een vader die zijn ongeneeslijk ziek kind van 15 maanden had gedood: "Zeer grote uitzonderingen daargelaten is het de individuele mens niet gegeven eigenhandig te beslissen over leven en dood van zijn medemens, hetgeen temeer klemt als die medemens voor zijn verzorging en opvoeding totaal van die ander afhankelijk is".

Bij die uitzonderingen kan gedacht worden aan omstandigheden van het geval en aan omstandigheden gelegen in de patiënt. Van de door de rechtbank genoemde afhankelijkheid kan sprake zijn bij ernstig zieke patiënten. In de aangehaalde zin wordt van "de individuele mens" gesproken. Vanwege deze open aanduiding kan ook een medicus hieronder worden begrepen. Daaruit volgt dat, volgens de rechtbank Alkmaar, ook een medicus slechts bij hoge uitzondering levensbeëindigend mag handelen.

Dat levensbeëindiging door een medicus minder strafwaardig wordt geacht dan door anderen, kan uit de strafmotiveringen worden afgeleid. Het door de vader doden van zijn ongeneeslijk ziek kind heef, zoals de rechtbank Alkmaar opmerkte de rechtsorde zeer geschokt. ${ }^{911}$ Bij een verpleegkundige wordt weleens rekening gehouden met de werkomstandigheden ${ }^{942}$. Daarentegen wordt ten aanzien van een medicus overwogen, dat niet getwijfeld wordt aan diens goede bedoelingen en dat de gebruikelijke motieven voor moord hier ontbreken. ${ }^{943}$

938 De Terp-zaak (Rb. Den Hag 6 aug. 1985, NJ 1985, 708), leidde tot vrijspraak in heger beroep vanwege onrechtmatig verknegen bewijsmateriaal. $\mathrm{Zie}$. Hof Den Haag 12 nov. 1986, TVGR 1987/1, NJ 1987; 609 m.nt. GEM.

939 Rb. Rotterdam 31 maart 1987, TVGR 1988/1 en Rb. Amsterdam 30 maart 1988, TVGR 1988/65.

940 Rb. Alkruaar 8 jult 1986, TvGR 1986/61.

941 Rb. Alkmaar 8 juli 1986, TVGR $1986 / 61$.

$942 \mathrm{Rb}$. Amsterdam 30 maart 1988, TVGR 1988/65 en Rb. Rotterdam 31 maart 1987, TVGR 1988/1 en - in hoger beroep - Hof Den Haag 25 olkt. 1988, TvGR 1989/13.

943 Rb. Almelo 1 malart 1988, TWGR 1988/43; Rb. Haarlem 4 april 1986, NJ 1987, 287 en Rb. Den Hata 6 aug. 1985, NJ $1985,708$. 
Een woorwaarde voor euthanasie is dat đe patiênt (ondraaglijk) pijn lijdt. Volgens de cleskundige in de Terp-zaak wordt door medici in het algemeen aangenomen dat een comateuze patiênt geen (bewuste) pijn lijdt. Derhalve kan bijj een comateuze patiênt naar het oordeel van de rechtbank Den $\mathrm{Haag}^{944}$ niet van een acute noodsituatie worden gesproken. ${ }^{\text {955 }}$ Hierbij zij herinnerd aan het standpunt van de $\mathrm{CAL}$, die ervan uitgaat dat een comateuze patient well pijn lijdt. ${ }^{946}$ Of de arts levensbeeindigend mag handelen ten aanzien van een wilsonbekwame patiënt die ernstig lijdt, valt uit deze uitspraak niet af te leiden. ${ }^{\text {at }}$

In een zaak die voor rechtbank Amsterdam ${ }^{948}$ diende, leed de familie onder de toestand van de patiênt. Maar ook aan dit lijden had de verpleegkundige weerstand moeten bieden.

\section{De rol wan het werzoek}

De rechtbank Den Haag ${ }^{949}$ overwoog dat de patiënten geen uitdrukkelijk en ernstig verzoek tot levensbeëindiging hadden gedaan, terwijl zij vanwege hun comateuze toestand niet (bewust) pijn leden. Volgens de rechtbank Amsterdam ${ }^{550}$ is actieve levensbeëindiging van een comateuze patiënt, zonder een voorafgaand verzoek van deze in strijd met de wet, de jurisprudentie en het beleid van het $O M$.

De rechtbank Almelo ${ }^{951}$ wilde kennelijk niet uitsluiten dat een ander dan de patiënt een verzoek tot levensbeëindiging van deze kan doen. Zij stelde immers ter verwerping van het beroep op noodtoestand vast dat "niemand" de arts om de handelling heeft verzocht en met betrekking tot de straf overwoog zij, dat noch de patiënt, noch de familie een uitdrukkelijk verzoek hadden gedaan of uitdrukkelijk toestemming hadden gegeven.

Nadat de naaststaanden - na de levensbeëindiging van de patiënt - daarvan op de hoogte zijn gebracht, hebben zij zich alsnog met de handelwijze van de arts kunnen verenigen, gelet op het "uitzichtloze" lijden van de patiënt. De rechtbank Almelo liet een goedkeuring door naaststaanden van de levensbeëindiging, na het plegen van het feit, slechts meewegen bij het bepalen van de straf.

944 Rb. Den Hang 6 aug. 1985, NJ 1985, 708.

945 Varn ondranglijke pija sprekt de Rb. Den Haag 6 ang. 1985, NJ 1985, 708, slechts bij de motivering van de straf.

$946 \mathrm{CAL}, 1991, \mathrm{p}, 9 . \mathrm{Zie:} \mathrm{H.} \mathrm{IV} \mathrm{C,} \mathrm{onder} 2.6$.

947 Everumin uit Rb. Haarlem 4 april 1986, NJ 1987, 287.

948 Rb. Amsterdam 30 maart 1988, TVOR 1988/65

949 Rb. Den Haag 6 aug. 1985, NJ 1985, 708.

950 Rb. Amsterdam 30 maart 1988, TVGR 1988/65.

951 Rb. Almelo 1, maart 1988, TwGR 1988/43. 


\subsubsection{Concllusie}

De rechtspraak staat afwijzend tegenover actieve levensbeëindiging. Het grootste struikelblok vormt de afwezigheid van een verzoek van de wilsonbekwame patiènt. Bij comateuze patiënten is bovendien van belang, in hoverre ervan uitgegaan wordt, dat deze pijn lijden.

De rechters overwegen ter verwerping van beroepen op noodtoestand en psychische overmacht bij anderen dan medici onder meer dat voor hen een andere weg openstond en deze begaan had moeten worden. Die weg houdt in het zoeken van professionele hulp en daarmee het inschakelen van medici. Ten aanzien van medici wordt overwogen dat deze onzorgwuldig hebben gehandeld, terwijl zij niet aan een aantal voorwaarden hebben voldaan.

Hoewel in de genoemde zaken de rechters geen algemene voorwaarden formuleerden voor levensbeëindiging, mag vanwege de uitkomst van deze zaken, ervan worden uitgegaan, dat zij ter beoordeling van de toelaatbaarheid van de levensbeëindigende gedraging de in de jurisprudentie ontwikkelde voorwaarden voor euthanasie als leidraad bezigden. Aan twee van die voorwaarden kan bij wilsonbekamen niet worden voldaan: er ontbreekt een verzoek en de waardering van de noodsituatie door de patiënt.

Biji euthanasie kon de toestand waarin de patiënt zich diende te bevinden, het beste aangeduid worden met "uitzichtloze noodsituatie". Die term of een daarmee overeenkomende treffen we in geen van de hier besproken gevallen aan. Er wordt veeleer in meer feitelijke termen ervan gesproken dat de patiënt zeer ziek was, dat hij slechte levenskansen had, dat hij veel pijnen leed en dergelijke. We hebben gezien dat de term "uitzichtloze noodsituatie" naast de aanwezigheid van een objectief-medisch vast te stellen noodsituatie van de patiënt vooral een subjectieve beoordeling van de situatie door de patiënt zelf vereist.

Ten aanzien van comateuze patiènten wordt weleens opgemerkt dat deze geen (ondraaglijke) pijn lijden, althans voor zover dat bekend is, zodat van een ondraaglijke noodsituatie niet gesproken kan worden. Maar diens situatie kan wel uitzichtloos zijn. Toch is het gebruik van de term uitzichtloze noodsituatie bij wilsonbekwame patiënten minder vanzelfsprekend dan bij patiënten die hun wil kenbaar kunnen maken, daar de uitzichtloosheid van de noodsituatie uiteindelijk door de patiënt bepaald wordt en op de een of andere wijze aan derden kenbaar gemaakt moet kunnen worden. Bij comateuze patiênten blijkt dat niet mogelijk te zijn. Terecht wordt daarom in de rechtspraak niet gesproken van een witzichtloze noodsituatie.

\subsubsection{Een uitstap naar de burgerlijke rechter}

De zaak Stinissen betrof medisch zinloos handelen. Mw. Stinissen raakte tijdens een operatie in een coma, waarin zij zich 15 jaar later nog steeds bevond. Het hof Arnhem ${ }^{952}$ sprak van een diep comateuze en een vegetatieve toestand. De patiënte kreeg sondevoeding, maar ademde spontaan. De echtgenoot, tevens curator, achtte de woortzetting van de comateuze toestand "zonder enige zin" en in strijd met haar belang. Daarom wilde hij haar leven " - in ruime zin" begrepen, beëindigd zien. Andere naaste familieleden namen hierover een verdeeld standpunt in. 
Het hof merkte in het algemeen op, dat de situatie van de patiente de vraag oproept: of er nog sprake was van "zinvol medisch, maar vooral ook menselijk handelen" ${ }^{\text {gt }}$. Het achtte een ontkennend standpunt verdedigbaar.

Desondaniks vond het hof het niet op de weg van de rechter liggen om zich in algemene zin over de problematiek uit te latten. Deze betreft immers wragen van levensbeschouwelijke en medisch-ethische aard, warover in de Nederlandse samenleving "diepgaande verschillen van inzicht" bestaan en ten aanzien waarvan "elk duidelij $k$ juridisch kader" ontbreekt. Daarnaast past de rechter terughoudendheid, omdat een oordeel over de "zin van een behandeling in beginsel een medisch oordeel is", dat "in beginsel door de arts (dient, J.W.) te worden beantwoord aan de hand van de medisch professionele standaard".

In casu achtte het hof sprake van medisch handelen, "omdat de situatie waarin mevrouw Stinissen zich bevindt kunstmatig van aard is, door artsen wordt begeleid en gecontroleerd en daarom in overwegende mate onder medische verantwoordelijkheid valt".

De echtgenoot vorderde ten eerste te gelasten dat de sondevoeding werd gestaakt. Volgens het hof wordt in medische kring verschillend gedacht of een arts in zo "n situatie conform zijn "eigen medisch-ethische normen" mag handelen. Zelfs indien zou komen vast te staan, dat in casu, gemeten naar de medisch professionele standaard, sprake zou zijin van medisch zinloos handelen, komt de vordering niet voor toewijzing in aannierking. Voor de behandelende arts was immers, gezien zijn opvatting, levensbeëindiging door onthouden van sondevoeding onaanvaardbaar. Actieve levensbeëindiging achtte het hof niet toegestaan, omdat vanwege "heersende rechtsopvattingen" slechts op "uitdrukkelijk en ernstig vertangen van de patiënt" daartoe mag worden overgegaan. Ten derde is voor de maatstaf kwaliteit van een mensenleven als zelfstandig criterium hier geen ruimte. Daar het hof had geconstateerd dat in medische kring een diversiteit van opvattingen over het al dan niet staken van sondevoeding bestaat, zag het weinig heil in het zich laten voorlichten door deskundigen om het heersend medisch inzicht op te speuren.

De echtgenoot had gesteld dat tot doorgaan met de behandeling toestemming van de patiënte ontbreekt respectievelijk moet geacht worden te ontbreken. Hiertoe merkte het hof op, dat een aanknopingspunt over hoe de patiënte over de situatie zou hebben gedacht, afwezig is en daarom omtrent de wil van de patient geen uitspraak kan worden gedaan. De echtgenoot stelde, volgens het hof terecht, dat zijn wilsuiting hier niet in de plaats kan treden van de ontbrekende willsuiting van de patiënt.

De echtgenoot vorderde ook een verbod medische complicaties te behandelen, anders dan ten behoeve van het woorkomen of verzachten van lijden. Daartoe overwoog het hof, dat dit "behoort tot het door hen (de gedaagden, J.W.) voor die situatie voorgenomen beleid. Dat beleid is - daar gaan beide partijen wan uit en het hof volgt hen daarin overeenkomstig de huidige medisch-professionelle standaard".

Na deze uitspraak werd de behandeling gestaakt, waartegen de Nederlandse Patiënten Vereniging (NPV) in verweer kwam. $Z$ ij vorderde in kort geding voortzetting van de behandeling. Het hof Arnhem ${ }^{953}$ achtte de NPV niet-ontwankelijk. Bovendien overwoog het dat de opvatting

"dat naar Nederlands positief recht het leven van ileder mens, zonder uitzondering, te allen tijde en onder alle omstandigheden, zo lang als mogelijk in stand zou moeten worden gehouden, ... te ongenuanceerd en daarmee niet juist" is. 
Nolgens het hof mag de rechter in een situatie als in casu slechts ingrijpen,

"voorzover deze wan oordeel zou zijn dat een in redelijkheid handelende arts, met inachtneming wan de medisch-professionele standaard, niet tot de beslissing van stopzetting wan het toedienen van voedsel en vocht aan $\mathrm{A}$ heeft kunnen komen".

De beslissingen in de zaak Stinissen zijn in overeenstemming met het door de CAL in 1991 in het interimrapport ten aanzien van langdurig comateuze patienten verwoordde standpant, dat de vaststelling of een behandeling medisch zinloos is een medisch-professioneel oordeel is en derhalve niet afhankelijk van oordelen van derden. Daarbij is wordt ten aanzien van comateuze patiènten dan wel uitgegaan van de veronderstelling dat het doorbehandelen van irreversibel comateuze patiënten medisch zinloos is. Dit uitgangspunt is echter volgens Musschenga een moreel oordeel. ${ }^{954}$

De zaak die in kont geding voor de President van de rechtbank Utrecht diende ${ }^{95 s}$ laat een spiegelbeeld van het geval Stinissen zien.

Een minderjarige had zeer ernstige en onherstelbare beschadiging van de hersenen. Het gevaar bestond dat permanente beademing nodig was. De arts vond de toestand van de patiënt zo ernstig, dat hij beademing als medisch zinloos beschouwde. De ouders vorderden dat bij complicaties tot beademing werd overgegaan. De President overwoog ten aanzien van de vordering:

"Naar algemeen wordt aanwaard zijn artsen met name niet verplicht te achten om over te gaan tot medische handelingen, welke als zinloos moeten worden aangemerkt. ... Bij de beoordelling van deze vraag past de rechter terughoudendheid, nu het antwoord op de vraag of een behandeling medisch zinvol of zinloos te noemen is, op een medisch oordeel berust en ook dient te berusten. Dit antwoord zal dan ook in beginsel door de behandelende arts zèlf dienen te worden gegeven aan de hand van de medische professionele standaard (objectieve medische beroepsnormen)".

\subsubsection{De zaak "baby Ross"}

\section{Inleiding}

Het geval van de ernstig gehandicapte pasgeborene "baby Ross"il leidde tot twee procedures, een tegen de arts en een tegen de secretaris van de Raad voor de Kinderbescherming. ${ }^{956}$

De relevantie van deze zaak is daarin gelegen dat de strafrechter impliciet besliste dat de medicus niet verplicht was om de baby verder te behandelen. Tevens blijkt uit deze zaak hoe moellijk actieve en passieve levensbeëindiging soms wan elkaar te scheiden zijin.

9S4 Zie: H. IV C, onder 2.4.

955 Rb. Utrecht 11 jan. 1991 , TVGR 1991/28.

956. Het betreft de beschikkingen van de Hoge Raad wan 28 april 1989, NI 1990, 46 m.nt. GEM (1egen de medicus) en NJ 1990,47 (tegen de secretaris van de Raad voor de Kinderbescherming) Mulder wijst: in zijo annotatie erop, dat de ouders miet vervolgd werden, thowel dat mogelijk zou zijn geweest. 
Ouders wierden geconfronteerd met de geboorte van een kind met het Down-syndroom en als bijkomende ziekte een maag- en darmafsluiting. Het kind zou overlijden alls de afsluiting niet werd geopereerd. De ouders wendden zich voor advies tot hun huisarts en deelden hem mee dat zij overwogen geen toestemming tot de operatie te verlenen, hetgeen woor de arts aanleiding was om contact op te nemen met het Openbaar Ministerie en de betreffende Inspecteur woor de Volksgezondheid. ${ }^{95 \%}$ Vanwege de OvJ werden de ouders tijdelijk uit de ouderlijke macht ontzet en het kind aan de Raad voor de Kinderbescherming toevertrouwd.

Noch de ouders noch de secretaris van de Raad voor de Kinderbescherming verleenden toestemming tot de operatie. De verantwoordelijke chirurg, het hoofd van de afdeling kindergeneeskunde, besloot daarop niet tot operatie over te gaan. Tevoren had hij advies ingewonnen bij de medisch-ethische commissie van het ziekenhuis waarin hij werkzaam was. De commissie achtte zijn beslissing juist.

Nadat de secretaris wan die beslissing op de hoogte was gebracht, trof hij geen maatregelen om het kind aan de zorg van de geneeskundige te onttrekken. De chirurg staakte

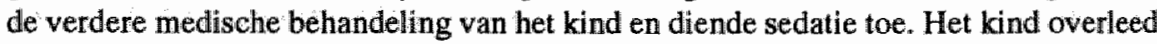
enkelle dagen later.

Zowel de raadkamer van de rechtbank Maastricht als van het hof Den Bosch stelde de verdachten buiten vervolging. Tegen de beschikkingen van het hof tekende het $O M$ cassatie aan. De Hoge Raad zag geen aanleiding de beschikikingen te vernietigen.

In een bezwaarschriftprocedure mag slechts marginaal getoetst worden, of tot een veroordeling kan worden gekomen. Alleen als aan de raadkamer "evident" blijkt dat de feitenrechter niet tot een veroordeling zou kunnen komen, stelt zij de verdachte buiten vervolging. Daarvan is sprake als er onvoldoende aanwijzingen van schuld zijn, waarbij "schuld" opgevat dient te worden in de zin van "gedaan hebben". ${ }^{958}$ In de jurisprudentie wordt daartoe het hoogst-onwaarschijnlijk-criterium gehanteerd. Als het hoogst onwarschijnlijk is dat de verdachte door de feitenrechter zou worden veroordeeld, wordt hij door de raadkamer buiten vervolging gesteld.

Hieronder wordt slechts de zaak tegen de chinurg besproken, omdat de secretaris van de Raad voor de Kinderbescherming geen medicus is. ${ }^{959}$ Aan de chirurg werden meerdere strafrechtelijke verwijten gemakat. Ten eerste doodslag door nalaten, art. $287 \mathrm{Sr}$; ten tweede uitlokking tot doodslag (door nalaten), art. $287 \mathrm{jo} .47 \mathrm{Sr}$; en ten derde iemand, tot wiens onderhoud, verpleging of verzorging men krachtens wet of overeenkomst verplicht is, in hulpeloze toestand brengen of laten; art. $255 \mathrm{Sr}$. Daar opzettelijk iemand van het leven beroven, art. $287 \mathrm{Sr}$, een commissiedelict is, werd derhalve aan de chirurg primair een oneigenlijk omissiedelict verweten, subsidiair een commissiedelict en meer subsidiair een omissiedelict. 
De kritiek die de beslissingen van de Hoge Raad opriepen was strafprocessueel en inhoudelijk van aard. De behandeling door het hof zou enerzijds de grenzen van een bezwaarschriftprocedure hebben overschreden, terwijl het hof anderzijds niet een zo diepgaand onderzoek zou hebben verricht als een latere feitenrechter. ${ }^{960}$

Kritiek ondervond de keuze van het hof voor de verklaring van de in raadkamer gehoorde deskundige Prof. Vos. De verklaring van de andere deskundige tijdens het gerechtelijk vooronderzoek zou daarmee niet in overeenstemming zijn. De P-G stelde dat een dergelijke keuze uit "tegenstrijdige" oordelen slechts door de feitenrechter en niet door de raadkamer in een bezwaarschriftprocedure kan worden gemaakt. In cassatie overwoog de Hoge Raad hiertoe: het "karakter van deze procedure belet ... de rechter niet een keuze te maken uit voorhanden zijnde gegevens".

Ten tweede werd bekritiseerd dat in een bezwaarschriftprocedure een inhoudelijk zo verstrekkende beslissing over een zeer precair onderwerp was genomen. Daarvoor werden twee redenen aangewoerd. De procedure was niet openbaar, zodat de behandeling zich in het verborgene afspeelde, waarmee het - zeker voor omstreden kwesties als deze belangrijke forum-karakter van een procedure voor de feitenrechter achterwege bleef. ${ }^{961}$ De inhoudelijke knitiek hield in dat de rechters grensverleggend hadden gewerkt. $\mathrm{Na}$ erkenning van euthanatisch handelen onder bepaalde voorwaarden was een volgende stap gezet: ook zonder verzoek van de betrokkene en rekening houdend met belangen van derden, in casu de ouders, zou een medicus in bepaalde omstandigheden tot levensbeeindiging door nalaten mogen overgaan.

\section{Het primaire verwijt}

Het primaire verwijt luidde, verkort gezegd: opzettelijke levensberoving, art. $287 \mathrm{Sr}$; doordat de chirurg opzettelijk zou hebben nagelaten alsnog toestemming tot de operatie te verkrijgen. ${ }^{962}$ Van belang is hierbij dat de beslissing om zich te conformeren en niet te opereren, betekende dat het kind ten gevolge van de afsluiting van het maag- en darmkanaal zou overlijden. Daarnaast behelst het primair telastegelegde nog een ander, daarmee samenhangend, verwijt. De chirurg zou opzettelijk de verdere levensverlengende behandeling van het kind hebben gestaakt (en vervangen door sedatie) zodat het kind was overleden.

Het hof, dat die twee verwijten afzonderlijk besprak, kwam tot buitenvervolgingstelling vanwege niet-strafbaarheid van de telastegelegde feiten. Het las het primair telastegelegde als opzettelijke levensberoving door nalaten. Wordt aan een verdachte verweten opzettelijke

960 Vgl. Kelk in AA 1989, p. 874 en Schalken in NRC 1 jun 1989, terwijl, zoals Abbink en Borst, NJB 1989 , p. 1141, opmerken de beslissing van de HR van 23 juni 1987 , NJ 1988,157 m.nt. ThWwW in een w thanasie-zaak, eveneens in het kader van cen bezwaarschriftprocedure werd genomen, zonder dat hierop kritiek werd genit.

961 In die zin: Schalken, NRC 1 juni 1989 en Kelk, AA 1989, p. 869.

962 Mulder geeft onder HR 28 april 1989, NJ 1990, 46, de voorkeur aan een vervolging van de arts varwege dood door schuld in situaties als deze als de zorgplicht de plicht tot opereren meebracht. Tetzijde zij nog opgemerkt dhat vit de beslissingen tewens opmieuw blijkt, welke belangrijke rol de strafrechispraak aan de toestemming tot medjsch handelen toekent. Er blijkt nergens wit dat de chirurg zonder rechtsgeldige touestemming had nogen opereren. 
levensberoving door nalaten dan wordt hem - kwalificatief gezegd - een oneigenlijk omissiedelict ten laste gelegd. Daarom moest het hof eerst nagaan of op de chirurg een zorgplicht rustte en zo ja of de chinurg in strijd met de zorgplicht had gehandeld. ${ }^{63}$ Dat heeft het hof Den Bosch telkens gedaan. Volgens het hof had de chirurg niet in strijd met zijn zorgplicht gehandeld en daarom was niet aan het telastegelegde voldaan.

Tegen de interpretatie van het primair telastegelegde als een dubbel nallaten richtte zich het tweede cassatiemiddel, waarin de $P-G$ van het hof stelde, dat bij staken van levensverlengende behandeling en het sederen sprake is van actief handelen, en ook het zich conforme ren aan het standpunt van de ouders en de secretaris - zij het in mindere mate - enige activiteit vereist. ${ }^{964}$ Daarom zou het hof het begrip "opzettelijk een ander van het leven beroven", art. $287 \mathrm{Sr}$, waarop het primair telastegelegde mikte, onjuist hebben uitgelegd en bowendien de telastelegging onzuiver hebben geïnterpreteerd.

Volgens Hoge Raad was de uitleg door het hof niet in strijd met de bewoordingen van het telastegelegde. Van de door het hof gebezigde lezing uitgaande kon het hof tot het uitgangspunt komen dat alleen dan de gedragingen van de verdachte de in de kennisgeving van verdere vervolging omschreven misdrijven zouden opleveren, indien de verdachte verplicht was anders te handelen dan hem door de OvJ werd verweten.

Het hof toetste de beslissingen van de chirurg terughoudend. Van een verplichting anders te handelen zou volgens het hof sprake zijn: "indien verdachte bij de uitoefening van zijn medisch beroep, alle omstandigheden in aanmerking genomen, in redelijkheid niet heeft kunnen komen tot zijn beslissing". Het gaat erom of de chirurg "in redelijkheid" tot de beslissingen kon komen. Als op hem de verplichting rustte te trachten alsnog toestemming tot de operatie te verkrijgen, dan was hij normadressaat en kon hij tevens niet in redelijkheid tot de beslissing komen zich te conformeren aan het standpunt van de ouders en van de secretaris en zou hij in strijd met zijn zorgplicht hebben gehandeld.

\section{Het materiele uitgangspunt dat het hof hanteerde}

Voor een antwoord op de vraag of op de chirurg de verplichting nustte om alsnog toestemming tot de operatie te verkrijgen en of hij dus in strijd met de zorgplicht heeft gehandeld, is belangrijk welk uitgangspunt ten aanzien van het leven (van wilsonbekwamen) gekozen wordt.

Er kan voor het standpunt gekozen worden dat de chirurg onder de geschetste omstandigheden nooit in redelijkheid tot de betreffende beslissing kon komen, omdat een derde niet over (de beëindiging van) het leven van lemand anders mag beslissen. De maagen darmafsluiting bij dit kind was immers geen dodelijke aandoening. Een operatieve ingreep had die afsluiting kunnen verhelpen. Daarom was er ook geen sprake van medisch zinloos handelen. ${ }^{965}$

Ook kan het standpunt worden ingenomen dat het van de omstandigheden afhangt of de beslissing van de chirurg redelijk is te noemen. Voor dat uitgangspunt koos het hof. De omstandigheid dat het kind door niet geopereerd te worden tengevolge van zijn afwijking zou overlijden "weegt ... niet per definitie het zwaarst". Andere omstandigheden 
dan het overlijden van een mens kunnen in de opvating van het hof kennelijk zwaarder wegen dan het overlijden.

Kritiek op de beschikkingen betreft in wezen meer de keuze van het hof voor dit uiligangspunt dan de nadere motivering van het hof en de goedkeuring van de uitspraken door de Hoge Raad. Binnen de verdere bespreking van de beschikkingen van het hof en van de Hoge Raad wordt uitgegaan van het door het hof gekozen standpunt. Dat standpunt roept de vraag op, aan welke omstandigheden het hof hierbij dacht, nu het bovendien nog oordeelde dat de chirurg vanwege die omstandigheden in redelijkheid had kunnen beslissen zich te conformeren aan de weigering toestemming tot de ingreep te verlenen.

\section{Eem niet te verwalarlozen kans}

De eerste omstandigheid die het hof noemde is de niet te verwaarlozen kans dat door de operatie de weg werd geopend naar een leven van "zeer ernstig lijden" van het kind. Het lijden beschouwde het hof derhalve als zeer ernstig, maar niet als ondraaglijk. Wel achtte het een kans aanwezig dat het lijden ondraaglijk zou kunnen worden.

Volgens de $\mathrm{P}-\mathrm{G}^{966}$, kan uit het - door het hof niet gebezigde - deskundigenbericht voor de $\mathrm{R}-\mathrm{C}$ worden afgeleid, "dat het succespercentage van een operatieve ingreep vrijwel bij $100 \%$ ligt en het kind na een geslaagde operatie - medisch gezien - een volledig normaal leven zou kunnen leiden nu uit de status niet was gebleken van andere afwijkingen", terwijl de deskundige Vos had verklaard dat het statistisch vrijwel zeker is dat 40 tot $60 \%$ van kinderen zoals het kind i.c. een hartafwijking heeft en $85 \%$ van dergelijke kinderen binnen een jaar na de geboorte overlijdt. ${ }^{967}$ Als het hof derhalve met "kans" een statistisch gegeven bedoelde, dan had het wellicht een keuze uit, zoals onder andere de $\mathrm{P}-\mathrm{G}$ stelde, tegenstrijdige deskundigenrapporten gemaakt. De cassatieadvocaat van de chirurg deelt echter mee, dat in het niet gebezigde deskundigenbericht het besluit tot niet opereren een "juist en verantwoord besluit" werd geacht en zelfs "' het enige mogelijke besluit." ".

Brands-Bottema ${ }^{969}$ is van mening dat de zinsnede "een niet te verwaarlozen kans" normathef is bedoeld. Zij wijst ter ondersteuning van deze opvatting op de overeenkomst van die zinsnede met de omschrijving van voorwaardelijk opzet door de Hoge Raad in het Cicero-arrest" 970 waar de Hoge Raad voorwaardelijk opzet omschreef als: de "geenszins als denkbeeldig te verwaarlozen kans".

Naar mijn mening mikte het hof met het begrip kans noch op een invulling aan de hand van statistische gegevens ${ }^{972}$, noch op een normatieve invulling. Het hof is immers

966 De P-G heeft dit gegeven gebruikt on zijn steiling te onderbouwen dat een keuze uit dergelijke tegentutrijdige oordellen door de feitenrechter en niet door de ratadkamer dient te worden gedaan.

967 Daarentegen schrijft Molenaar: "De huidige resultaten wan deze behandeling zijn goed" de letaliteit is lager dan 10\%. De bijkomende aanwezigheid van het syndroom van Down alleen beinvloedt de vesultaten niet" Molenaiar, GHi, Dupuis, NTVG 1988, p. 1914-1915.

968. Zie Van Stigt, NJE 1989, p. 1152 .

969. Brands-Bottema, NJB 1989, p. 1143.

$970 \mathrm{HR} 9$ now. 1954, NJ 1955, 55 m.nt. W.P.

971 Brands-Bottema, NJB 1989, p. 1143.

972. Anders: Kelk, AA 1989, p. 871. 
verder wan mening dat niet wezenlijk is of statistisch gezien de kans dat het kind dit zeer ernstig lijden bespaard blijft en geneest, eventueel aanzienlijk groter is dan de kwade kans op dit lijden. Aan een dergelijk statistisch gegeven kan en mag naar het oordeel van het hof in een individueel geval, waarin diep ingrijpend menselijk lijden op het spel staat, geen doorslaggevende betekenis worden toegekend.

Wat het hof mijns inziens te kennen wilde geven is dat het niet van belang is hoe groot rekenkundig de waarschijnlijkheid op die kans is. Een statistisch gegeven is immers slechts een gemiddelde uit een aantal individuele gevallen. Daarmee is niet gezegd hoe groot de kwade of goede kans van een gegeven bij een bepaald individueel kind is. ${ }^{979}$

Een dergelijk statistisch gegeven is wel van betekenis om te constateren dat een individuele patiënt een niet te verwaarlozen kans op een zeer ernstig lijden loopt, maar het is miet van doorslaggevende betekenis in die zin dat goede en kwade kansen op grond van statistische gegevens tegen elkaar afgewogen worden en a fortiori (reeds) op grond van de uitkomst wan die afweging gezegd kan worden dat een medicus in een concreet geval op een bepaalde wijze had dienen te handelen. Als - in de opvatting van het hof, zoals ik die begrijp - verklaringen van deskundigen niet overeenstemmende kansberekeningen bevatten, dan hoeft daaraan geen gewicht toegekend te worden, zolang evident is dat de kwade kans niet te verwaarlozen is. En in zoverre hoeven de deskundigenrapporten niet als tegenstrijdig beschouwd te worden en zeker niet in verband met de conclusie.

Ik vat samen. De eerste omstandigheid is de niet te verwaarlozen kans van zeer ernstig lijden van dit kind. Die kans mag, statistisch gezien, eventueel aanzienlijk kleiner zijn dan de kans op een goede afloop. Het woord "kwade kans" dient in casu begrepen te worden alls een aanduiding van een zeker risico in een individueel geval.

\section{Het lijden van het kind en van de ouders}

Tegenower het leven van het kind plaatste het hof een toekomstig lijden van dit kind. Als de operatie slaagt, bestaat de mogelijkheid op een toekomstig zeer ernstig lijden. Dat lijden is derhalve niet een mogelijk inherent gevolg van de operatieve ingreep, maat een lijden dat kan optreden vanwege mogelijke latere complicaties bij het kind in verband met zijn algehele gezondheidstoestand. ${ }^{974}$ Of het kind zeer ernstig zal lijjen kan niet met zekerheid gezegd worden; er is "slechts" een niet te verwaarlozen kans aanwezig.

De deskundige Prof. Vos wees op post-operatieve complicaties en verklaarde bovendien: "Lijders aan het syndroom van Down lijden hasst altijd ook aan andere lichamelijke

973 Vgl. Doen of laten, 1989, p. 17: "Toch kan de vertaling van deze gegevens naar een inschatting van de te voorziene handicap bij een individueel kind heel moeilijk zijn, omdat deze gegevens uit onderzoeks,groepen afkomustig zijn en daarom slechts statistische betekenis hebben. ... Indien vaststaal dat de overgrote meerderheid van kinderen in een bepalde klinische situatie emstig gehandicapt zal zijn, kan dit een reden ziju om van verdere levenswerlenging af te zien. Dit liatste geldt ook voor de situatie dat de kans op een minder enistige handicap of zelfs de (geringe) kans op een vrijwel ongestoorde antwikkeling miet met en 100\%-ige zekerheid is wit te sluiten".

974 Enigszins anders Molenaar, Gill en Dupuis, NTwG 1988, p. 1915, die schrijwen: "Maar als ten minste Gen van de afwijkingen zonder behandeling in korte tijd dodelijk verloopt en de andere afwijkingen nujet alle met goed resultaat behandelbaar zijn, dan is een afweging op zijn plaats. ... Bij de behandeling van, zonder die behandelling, dodelijk verlopende anngeboren afwijkingen is het mogelgk dat zo'n behandeling oorzak wordi van verlenging wan leven waraan een onbekende hoeveellheid leed wordt toegevoegd ${ }^{*}$. Hicrtegen: Kljin, MC 1989, p. 919-922. 
gebreken. Dat die gebreken in het geval van Ross M. niet zijn vastgesteld, zegt niets. we andere gebreken treden veelal eerst na enige weken op. Mijn persoonlijke ervaring Is dat er in geval van darmafsluiting altijd sprake is van nog andere afwijkingen". Het lijkt me van belang om te beklemtonen dat volgens deze deskundige het syndroom van Down tot een complex van aandoeningen kan leiden, zodat in deze opvatting het ragelijke toekomstige lijden niet los staat van het syndroom van Down. De prognose had derhalve uitsluitend betrekking op een kind met het syndroom van Down. Als gesteld wordt dat het kind wel geopereerd zou zijn als het dat syndroom niet had gehad ${ }^{975}$, dan wordt daarmee ten onrechte de indruk gewekt, dat het syndroom van Down, de maag- en darmafsluiting en een mogelijk later lijden los van elkaar gezien kunnen worden. ${ }^{976}$

Het mogelijke lijden van het kind beschouwde het hof als zo ernstig, dat van de chirurg "in redelijkheid niet gevergd kan worden dat hij - in afwijking van het oordeel van de ouders van het kind - alsnog toestemming tot de operatie tracht te verkrijgen". Uit deze overweging blijkt dat het hof aan het oordeel van de ouders een groter gewicht toekent dan aan dat van de secretaris, terwijl de secretaris in casu, nadat de ouders voorlopig uit de ouderlijke macht waren ontzet, wel degene was die rechtsgeldig toestemming kon verlenen.

Tegenover het leven van het kind stelde het hof bovendien en zoals het opmerkt "met nadruk" een "dienovereenkomstig lijden van de ouders". Het lijden van de ouders werd door het hof afhankelijk gesteld van het lijden van het kind. ${ }^{977}$ Als het kind zeer ernstig lijdt, dan lijden de ouders dienovereenkomstig zeer ernstig. Met het lijden van de ouders kan niets anders dan een psychisch en mentaal lijden zijn bedoeld. ${ }^{978}$

Kritiek op het meewegen van een (dienovereenkomstig) lijden van derden komt erop neer, dat de belangen van derden, in casu de ouders, bij een beslissing over het leven van iemand nooit een rol mogen spelen, ook niet als deze belangen, zoals hier, afgeleide belangen van de patiënt zijn.

Leenen ${ }^{980}$ makt tussen het lijden van derden als zelfstandig en als afgeleid criterium een duidelijk onderscheid. Slechts ten aanzien van het lijden als zelfstandig criterium spreekt hij terecht van de problemen die een dergelijke erkenning met zich mee zou brengen. Het hof heeft het lijden van de ouders als afgelleid criterium gebezigd. Daarom was hier niet aan de orde het lijden van naaststaanden als zelfstandig criterium.

Tegenover het leven van het kind plaatste het hof derthalve een voor het kind niet te verwaarlozen kans op een "zeer ernstig", "ondraaglijk" respectievelijk "diep ingrijpend menselijk lijden" en, als afgeleid criterium, een dienovereenkomstig ernstig lijden van de ouders van dit kind.

975 In die zin: De Blois, NJB 1989, p. 1148.

976. Vgl. Kelk, AA 1989, p. 871-872 en de A-G Fokkenss vöòr HR 28 april 1989, NJ 1990, 46 m.nt. GEM, en impliciet Mulder onder deze beschikking.

977 Vgl. Leenen, TVGR 1989, p. 400; Kelk, AA 1989, p. 872.

978 Vgl. Abbink en Borst, NJB 1989, p. 1142.

979 Vgl. Brands-Bottema, NJB 1989, p. 1144; Abbink en Borst, NJB 1989, p. 1142.

980 Leener, TVGR $1989, \mathrm{P}_{*} 400$. 
Kennelijk was de P-G van mening, dat de chirurg eerst had moeten trachten alsnog toestemming tot de operatie te verkrijgen en vervolgens had moeten opereren. Zodra zich later een ernstig lijden zou voordoen dan had hij altijd nog, zoals het in de beschikking staat, "medisch" kunnen ingrijpen. Naar mijn mening kan met dit medisch ingrijpen niets anders zijn bedoeld dan een - zo nodig - levensbeëindigend ingrijpen. Het door de OvJ aangevoerde kan juridisch gezien worden als een verwijt dat de chirurg in strijd met het subsidiariteitsbeginsel heeft gehandeld. Nu er nog een andere, minder vergaande weg voor de chirurg openstond, had hij deze (eerst) dienen te bewandelen.

Het hof overwoog hiertoe dat de chirurg "de vrijheld dient te worden gelaten naar eer en geweten te beslissen". Een op het eerste gezicht uitsluitend subjectieve formulering, tenzij men deze leest als de vrijheid van een chirurg om naar eer en geweten handelend, na zorgvuldige afweging van alle bellangen en vanuit verantwoord medisch inzicht, trachten te komen tot een redelijk besluit. ${ }^{981}$ Er blijkt niet naar welke lezing de voorkeur wan het hof uitging. Het hof bracht in elk geval daarmee tot uitdrukking dat in een dergelijke conflictsituatie een chirurg een beslissing moet kunnen nemen, die het bijzondere en specifieke karakter van de zaak benadrukt. De reden die het hof voor deze vrijheid gaf benadrukt dit karakter. Van de chirurg "kan en mag niet worden geëist - ... - dat hij voor zijn verantwoording neemt de kwade kans dat hij voor het kind ... de weg opent naar een leven van een zeer ernstig lijden".

Bovendien wees het hof erop, dat de kwade kans dat de chirurg voor het kind de weg opent naar een leven van een zeer ernstig lijden, voor hem meebrengt een zich schuldig maken aan een misdrijf. Mogelijk heeft het hof hierbij aan mishandeling gedacht. Als het kind \ater zeer ernstig zou lijden, dan zou dat aan de chirurg te verwijten zijn, omdat hij eerder tot operatie is overgegaan terwijl hij wist van de niet te verwaarlozen kans op een zeer ernstig lijden van het kind. Een tweede, vanwege de zinsconstructie minder waarschijnlijke mogelijkheid is, dat het hof hiermee doelde op de door de OvJ geopperde mogelijkheid dat de chirurg altijd nog medisch in kon grijpen als dit lijden zich zou voordoen. Want kennelijk heeft de OwJ daarbij gedacht aan actieve levensbeëindiging. Door nu geen toestemming te verwerven en niet te opereren kon de chinurg voorkomen later misschien nog het leven van het kind actief te (moeten) beëindigen.

\section{Andere omstandigheden}

Het hof heeft de aanmerkelijke kans op een toekomstig lijden van het kind en een dienovereenkomstig lijden van de ouders als belangrijkste omstandigheid beschouwd, die van de chirurg in redelijkheid niet kon vergen alsnog toestemming tot de operatie te verwerven.

Andere omstandigheden die ertoe bijdroegen dat van de chirurg "temeer" niet gevergd kon worden om alsnog toestemming voor de operatie te verkrijgen, waren de weigering van de ouders en van de secretaris en "voorts" het feit, dat de medisch-ethische commissie van het ziekenhuis, waarin de chirurg werkzaam was, de beslissing van de chirurg om niet te opereren, juist heeft geacht. 
In felte was de beslissing van de ouders belangrijker dan uit de nevenschikking blijkt. Uit werschillende verklaringen van medici die te maken hebben met dergelijke situaties komt naar voren, dat in omstandigheden als waarin het kind zich bevond, de wil van de ouders voor de beslissing van de medicus doorslaggevend is. Mulder komt derhalve tot de uitspraak dat medici, die zowrel het belang van het kind als het leed van de ouders moeten incalculteren, "de wens van de ouders mogen respecteren". Daaraan woorafgaande merkte hij op dat: "men" , waarmee hij zowel de ouders, als de medicus en de secretaris van de Raad voor de Kinderbescherming bedoelde, "de 'goede" keus eenvoudig niet kan treffen".

\section{De tweede beslissing: staken en sedatie}

De tweede beslissing van de chirurg hield in de lopende medische behandeling te beëindigen en sedatie toe te dienen. Ook ter beoordeling van die beslissing bezigde het hof het redelijkheidscriterium: de verdachte heeft "in redelijkheid ... kunnen beslissen de medische behandeling van het kind te staken". Want vanaf het moment dat de eerste beslissing genomen was, kon de medische behandeling "geen medisch zinvol doel meer dienen en nog slechts stervensvertragend en leedtoevoegend werken". De tweede beslissing werd derhalve door het hof afhankelijk gesteld van de eerste beslissing. ${ }^{983}$ Nadat de eerste beslissing, die in feite inhield dat opereren ethisch zinloos was, genomen was, stond vast dat verdere medische behandeling van het kind niet meer medisch zinvol was, daar het aan de bijkomstige complicatie, de maag- en darmafsluiting, zou overlijden. Het zou een medisch zinloze behandeling zijn geworden, of zoals het hof zegt: "een behandeling mett een ... heilloos gevolg".

\section{Het subsidiaire en het meer subsidiaire verwijt}

Subsidiair werd de chinurg verweten; dat hij opzettelijk had uitgelokt dat het kind opzettelijk van het leven werd benoofd, omdat hij aan zijn staf opdracht zou hebben gegeven, aithans deze zou hebben bewogen de levensverlengende behandeling van het kind te staken en te vervangen door sedatie, zodat het kind was overleden. Maar doordat het hof ten aanzien van het primaire verwijt had vastgesteld, dat op de chirurg geen zorgplicht rustte, kon het subsidiaire verwijt evenmin slagen.

Meer subsidiair luidde het verwijt tegen de chirurg het kind, tot welks onderhoud, werpleging en/of verzorging hij krachtens wet of overeenkomst verplicht was; in een halpeloze toestand te hebben gebracht en/of gelaten, art. $255 \mathrm{Sr}$. De verplichting rustte,

982 Herover kritisch: Croughs, MC 1989, p.650-651, Zijn kritiek op zowel Molenaar als op de RvdK vlout woor wit het feit dat aan de nening varn de ouders de voorrang werd verleend boven het recht op leven wan de pasgeborene, wiens darmafshluiting immers operabel was. Volgens Molenaar, Gill en Dupu is, NTVG $1988, \mathrm{p} .1916$, werd ongeveer tezelfdertijd bij een pasgelborene met het $\mathbb{D}$ oww-syndronm en een darma fsluj ting op wens wan de ouders de darma fsluiting wel behandeld. "Het lijkt ons echter onjuist on het dringende verzoek van de ouders (tot operatie, J.W. ) te negeren. Wij zoudwit hen hiermee in een grote religieuze en morele nojd bremgen wartegen niemand is opgewassen". Zie ook" Mulder onder HIF 28 aprill 1989, NJ 1990, 46, die naar een interview met de hartchirurg Hazebroek, NRC 11 now. 1989, verwijst.

$983 \mathrm{Vgl}$. Abbink en Borst, NJB 1989, p. 1142. 
volgens de kennisgewing van verdere vervolging, op de chirurg omdat hij hoofd van de afdeling kinderheelkunde en (als zodanig) behandelend geneesheer van het kind was.

Ten aanzien van het meer subsidiair telastegelegde, namelijk iemand in een hulpeloze toestand brengen of laten, merkt het hof op, dat aan de chirurg geen toestemming tot de operatie was gegeven en op hem - zoals het eerder had vastgesteld - niet de verplichting rustte die toestemming alsnog te verkrijgen. Het kind ontving in het ziekenhuis de bulp en verzorging die men hem daar, gegeven zijn afwijking, het beste kon verschaffen. De operatie aan het maag- en darmkanaal behoefde van die hulp en verzorging geen onderdeel uit te maken, omdat daartoe op "respectabele gronden" geen toestemming was verleend en op verdachte niet de verplichting rustte die toestemming alsnog te verkrijgen.

\section{Over de zaak "baby Ross"}

De zaak baby Ross betreft de strafrechtelijke aansprakelijkheid bij medisch handelen dat zinloos wordt geacht. De bijzonderheid hierbij is, dat de wilsonbekwame patient ernstig ziek is en zich op een bepaald moment een bijkomstige complicatie voordoet, die op zichzelf te verhelpen is.

De werkgroep Doen of laten constateerde in een met deze zaak vergelijkbare casuspositie dat onder neonatologen over de behandeling van de bijkomstige complicatie bij weigering van de ouders verschillend wordt gedacht. De ene opvatting houdt in dat behandeld dient te worden, ook al moet daartoe de Raad voor de Kinderbescherming worden ingeschakeld. Volgens de andere opvatting gaat het hierbij om een grenssituatie waarover ook in de samenleving verschillend wordt gedacht. Vanwege de twijfelachtige situatie mag dan niet tegen de wil van de ouders worden behandeld. Een meerderheid van de werkgroep heeft een voorkeur voor de tweede opvatting. ${ }^{985}$

De zaak baby Ross verschilt in zoverre van de casuspositie van de werkgroep, dat de Raad voor de Kinderbescherming zich in de zaak baby Ross aan het standpunt van de ouders conformeerde.

De uitspraken van het hof en van de Hoge Raad in deze zaak zijn niet in strijd met de opvatting van de werkgroep. Bij een ernstig ziek kind behoeft een bijkomende complicatie niet te worden behandeld als er een aanmerkelijke kans op een zeer ernstig lijden van dit kind bestaat en de ouders weigeren tot de operatie toestemming te verlenen, ook al brengt het niet-behandelen het overlijden van het kind mee.

De vraag of er een aanmerkelijke respectievelijk een niet te verwaarlozen kans op een zeer ernstig lijden van het kind bestat is ter beoordeling van de verantwoordelijke arts. Als deze van mening is dat een anmerkelijke kans daarop bestaat, dan heeft hij de vrijlieid naxar eer en geweten te besissen. Van een niet te verwaarlozen kans kan sprake zijn als, statistisch gezien, de kans dat het kind dit zeer ernstig lijden eventueel bespaard blijft en het kind geneest groter is dan de kwade kans van dit lijden. Voldoende is vermoedelijk een gerechtwaardigde twijfel van de medicus omtrent het nut van de

984 Mulder wijst in zign noot onder HR 28 april 1989, NJ 1990,46, op de op de chirurg rustende, van de onders afgeleide zorgplicht.

985 Doen of laten, 1989, p. 32-33. Zje ook: H. IV C, onder 2.7. 
behandeling. ${ }^{986}$ Juist voor twijfelgevallen bevelen de werkgroep en de CAL aan dat de arts tot consultatie overgaat. In deze zaak heeft hij voordat hij zijn beslissing uitvoerde, terst overleg gepleegd met de medisch-ethische commissie van het ziekenhuis. ${ }^{987}$

Zou zeker hebben vastgestaan; dat door de operatie de weg werd geopend naar een leven met zeer ernstig lijden, dan had de operatie als medisch zinloos kunnen worden beschouwd. Het probleem in casu betrof juist het ontbreken van die zekerheid. Afhankelijk van het gewicht dat aan de regel "in dubio abstine" wordt toegekend, kan in een dergelijk twijfelgeval verdedigd worden, dat de medicus al dan niet tot behandelen gehouden is.

Als de ouders geen toestemming tot de operatie van de bijkomstige complicatie verlenen en de chirurg niet gehouden is om te trachten deze alsnog te verkrijgen, dan kan hij in redelijkheid tot het staken van de medische behandeling en tot sedatie beslissen, omdat door het niet-behandelen van de complicatie de medische behandeling geen zinwol medisch doel meer kan dienen. Uit de overwegingen van het hof ten aanzien van het staken van de medische behandeling en het toedienen van sedatie, kan afgeleid worden wanneer er in de ogen van het hof in casu sprake is van medisch zinloos handelen. Daarvan is sprake als de patiënt zich in de stervensfase bevindt en een medische behandeling nog slechts stervensvertragend en leedtoevoegend werkt.

Zowel in de medische als in de juridische ${ }^{989}$ literatuur is omstreden of het hof grensverleggend heeft gewerkt. Vanwege het dillemma waarin zich de medicus bevond, heeft het hof hem het voordeel van de twijfel gegund. Of, zoals Mulder in zijn annotatie onder HR 28 april 1989, NJ 1990, 46 opmerkt: "Een en ander komt erop neer dat er voor het all dan niet behandelen van een (pasgeboren) kind met de hier bedoelde afwijking een 'rechtsfreier Raum' is, waarbinnen plaats is voor een gewetensbeslissing die tot stand komt in onderling overleg tussen arts en ouders". .90

Hoe het strafrecht in dergelijke gevallen dient op te treden en of hier een taak voor de wetgever ligt ${ }^{\$ 1}$, wordt verderop besproken.

986. Vgl. de A-G Fokkens vò̀r HR 28 april 1989, NJ 1990, 46, De opvatting van het hof "acht ik juist en in owereenstemming met de medische ethische regel, dat bij twijfel geen behandeling dient te worden ingesteld". Zie ook: CAL, 1990, p. 18. Van Stigt, NJB 1989, p. 1153, acht het bij een "onleefbaar leven ${ }^{*}$-prognose verdedigbaar, dat de arts verplicht is de behandeling achterwege te laten, ook zonder dat dewettelijke vertegenwoordigers behandeling weigenen.

987 Vgl. Van Stigt, NJB 1989, p. 1153-1154.

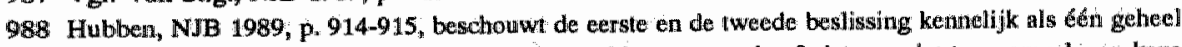
wh leidt daaruit als door het hof additionele gestelde voorwagrde af, dat een niet te verwarlozen kans op ten zeer ernstigilijden van het kind moet bestan. Abbink en Borst, NJB 1989, p. 11.42 , vestigen de aandacht op de eerste beslissing. Voor hen stond in deze zaak central, of besloten mocht worden niet tot operatie over te gan. De tweede beslissing en de daarnee verband houdende gedraging (staken en sedatie) zien rij als dasnit voortvloeiend. Verder ingrijpen was na het nemen van de eerste beslissing medlisch zinloos. Die zienswijze wordt ook hier verdedigd.

989 Wel grensverleggend: Hubben, NJB 1989, p. 915 en p. 1589 en waarschijmlijk ook Leenen, TvGR 1989 , p. 400 . Bij beiden is echter onduidelijk in hoeverre zij de beoordelingen van het hof ten aanzien van de eerste en de tweede beslissing a fronderlijk op hun merïtes waxrderen. Anders Kelk, AA 1989, p. 871-872, die in dit verband spreekt van een carte blanche die het hof in deze zaak het professionele bandelen heeft gegeven. Zie ook: Brandis-Bottema, Iust, $1990, p ; 45$.

990 Zie voor het belang van de ouders bij een ethisch zinloos geachte behandeling: Molenaar, Gill, Dupuis, NTwG 1988, p. 1916. Volgens Spreetwenberg, in: Handbowek Gezondheidsethiek, 1988, p. 485-486, dienen artsen in een dergelijke situatie "hun eigen verantwoordelijkheid te nemen".

991 Zoals Brands-Bottema, NJB 1989, p. 1145, sielt. 


\section{Conclusile}

Euthanasie wordt geoorloofd geacht als de patiënt zich in een uitzichtloze noodsituatie bevindt. Het uitzichtloze van de noodsituatie ligt daarin dat de toestand van de patient niet verbeterd kan worden en de patiënt, uitgaande van die toestand zijn toekomstige levensmogelijkheden als uitzichtloos kenschetst. Darmee kan euthanasie situaties betreffen, die als ethisch zinjoos kunnen worden aangemerkt, omdat het levensperspectief te gering is:

Met een verzoek om levensbeëindiging geeft de patiënt te kennen dat zijn levensperspectief te gering is. Euthanasje kan derhalve plaatsvinden alls het behandelen van de patiënt ethisch zinloos is. Ten opzichte van levensbeëindiging bij wilsonbekwamen zijn twee verschillen van belang: Bij euthanasie oordeelt de patiënt dat zijn leven een te gering levensperspectief heeft. De voornaamste taak van de medicus is te toetsen of de patient dat oordeel op de juiste medische informatie heeft gebaseerd. Het tweede verschil is dat euthanasie actieve levensbeëindiging betreft, terwijl "levensbeëindiging" zowel actief als passief kan plaatsvinden.

Wil men levensbeëindiging geoorloofd achten, dan moet het aan anderen dan de patiënt worden toegestaan over het levensperspectief van de patiënt te oordelen. Daar het uitgangspunt hiertoe de diagnose en de prognose zijn, is het verdedigbaar, dat de medicus ook een oordeel over het levensperspectief van de patiënt toekomt.

De beoordeling van het levensperspectief is echter niet uitsluitend gebaseend op medische gegevens. Het behelst mede een subjectieve waardering van de kwaliteit van het bestaan, bij welke het al dan niet meer zinvol wordt geacht om (verder) te behandelen. Voor de subjectieve waardering is de medicus niet beter toegerust dan anderen die over dezelfde informatie over de medische situatie en de prognostische verwachtingen van de patiënt beschikken. Daarom wordt bij zwaar-defecte pasgeborenen aan de stem van de ouders een groot gewicht toegekend. Om het besluit zoveel mogelijk te objectiveren wordt bij zwaardefecte pasgeborenen voorgesteld met een referentiekader te werken.

Ook bij comateuze patiënten zou werwacht worden dat de naaststaanden een belangrijke rol bij de besluitworming toekomt; mede omdat ten aanzien van deze patiënten geen referentiekader wordt voorgesteld. Toch wordt hier de beslissing over het behandelen primair aan de arts toegekend. Bovendien wordt in verband met deze patiènten gesteld, dat medisch zinloos en ethisch zinloos handelen niet goed van elkaar te scheiden zijn. Daaraan wordt de gevolgtrekking verbondlen dat de medicus derhalve ten aanzien wan beide aspecten beslissingsbevoegd is.

Hier wordt verdedigd aan het onderscheid tussen medisch zinloos en ethisch zinloos vast te houden, ook al bestaat er een grijs gebied, waar dat onderscheid niet goed te maken is. In geval van twijfel zou naar mijn mening niet van medisch zinloos gesproken mogen worden. In dat geval behelst de beslissing van de medicus ook een moreel oordeel over de zin van het leven. Terwijl het in de zaak baby Ross begrijpelijk is dat de arts buiten vervolging werd gesteld, is dat naar mijn mening mede te wijten aan de onduidelijkheid die over de beslissingsbevoegdheid van de arts voor dergelijke situaties bestaat. Hier ligt derhalve een taak voor de wetgever om duidelijkheid te verschaffen.

Een behandeling is medisch zinloos als zekemeid bestaat omtrent de afwezigheid van een positieve uitkomst van de behandeling. De vraag naar de ethische zinloosheid van de behandeling doet zich voor als die zekerheid niet bestaat. $\mathrm{Bij}$ de zwar-defecte pasgeborenen gaat het om toekomstige medische complicaties en bij langdurig comateuzen om 
de wraag, of zij altijd in die toestand zullen verblijven en als dat niet het geval is, in welke staat zij uit de comateuze toestand komen.

In de medisch-ethische discussie over levensbeëindiging wordt een verschil gemalakt tussen actieve en passieve levensbeëindiging, waarbij de medicus voor passieve levensbeeindiging minder of niet verantwoordelijk wordt geacht. Daartoe wordt teruggegrepen op bij de medicus spelende intenties en motieven. Terecht heeft de CAL in haar recent rapport erkend dat wezenlijk is of de ants de dood van de patiënt bewerkstelligt, waarmee eigenlijk de aandacht wordi gevestigd op een causaal verband tussen het doen of niets-doen van de arts en het overlijden van de patiënt. Deze recente opvatting van de CAL sluit aan bij een strafrechtelijke benadering van deze kwestie, waarin de zorgplicht centraal staat en het verschil tussen een handelen en een nalaten op de achtergrond treedt.

Toch is het verschil tussen actief en passief niet helemaal zonder belang. Voor strafuitsluiting is belangrijk in hoeverre voldaan is aan de eisen van proportionaliteit en subsidiariteit. Als met een minder ingrijpende gedraging het doel kan worden bereikt, dan dient met die gedraging te worden volstaan. Dan behoort het doel - in casu de levensbeèindiging - op zichzelf wel gerechtvaardigd te zijn. Dat is bij levensbeëindiging juist omstreden.

Wil levensbeëindiging geoorloofd kunnen worden geacht zonder aan de beslissing van derden over de zin van het toekomstige leven van de patient teveel gewicht toe te kennen, dan zou als vertrekpunt de legitimatie voor het medisch handelen moeten worden gekozen. In die opvatting is medisch handelen geoorloofd als daarvoor goede redenen zijn. Bestaat twijfel omtrent de zin wan het medisch handelen, zoals zich dat voordoet bij de vraag of het handelen ethisch zinloos is, dan ontbreekt een argument om wel te behandelen. Het niet (verder) behandelen vindt dan zijn grondslag in de ontbrekende legitimatie voor een behandeling en in het medisch-ethische adagium: in dubio abstine. Daardoor komt de invulling van de ethische zinloosheid wel in de buurt van die van de medische zinloosheid. Het verschil wordt echter goed zichtbaar bij wilsbekwame patiënten. Is twijfelachtig of een behandeling een positief effect heeft, dan is het aan de patiënt voor of tegen een behandeling te opteren, terwijl de arts in beginsel zelfstandig van een behandeling dient af te zien, als deze medisch zinloos is.

Bij twijfelgevallen verdient het de voorkeur dat de medicus eerst een collega-arts consulteert. Bevestigt deze de twijfel dan zou de arts in overleg met de naaststannden van de patiënt en eventueel in overleg met andere derden tot een beslissing kunnen komen. 



\section{Slotbeschouwing}

\section{Mishandeling}

Het onderzoek wijst uit dat de strafrechtelijke aansprakelijkheid van de medicus in verband met de delictsomschrijvingen van mishandeling niet tot problemen leidt, ondanks dat lange tijd verschil van mening bestond over de juridische grondslag voor de straffeloosheid.

De discussie over de verschillende juridische constructies die voor het bereiken van de straffeloosheid werden voorgesteld heeft niet geleid tot een gevoel van rechtsonzekerheid onder de medici. De reden voor de vanzelfsprekendheid waarmee het toebrengen wan pijn of letsel in het belang van de gezondheid van de patiënt wrerd benaderd, is daarin gelegen dat het behandelingsdoel niet werd betwist. Een dergelijk handelen van de medicus wordt dienovereenkomstig algemeen als gewoon medisch handelen beschouwd. Ook de wetgever voelde zich niet genoodzaakt om langs wettelijke weg het gewone medisch handelen van de formele strafbaarheid uit te sluiten. Hij erkende in dat verband dat voor de strafbaarheid van een feit niet voldoende is dat het feit formeel strafbaar is, maar dat het tevens materieel strafbaar dient te zijn. En bijna terloops heef de Hoge Raad in het tweede euthanasie-arrest overwogen, dat het toebrengen wan pijn of letsel aan een patiènt ten behoeve van de gezondheid in het kader van een medische behandeling vanwege de medische exceptie straffeloos mag geschieden,

In hetzelfde arrest wees de Hoge Raad echter de opvatting van de hand dat de medische exceptie ook ten aanzien van euthanasie zou gelden.

\section{De problematiek van omstreden handelen van de medicus}

Abortus, euthanasie en levensbeëindiging zijn medische handelingen die llevensbeschouwelijke normen en waarden raken. Aan de strafrechtelijke normering van deze handelingen gaat daarom een morele waardering vooraf, die de vraag betreft, of en zo ja, onder welke omstandigheden, een zwangerschap mag worden afgebroken, aan het verzoek van de patiènt om levensbeèindiging mag worden woldaan, het leven van een wilsonbekwame patiënt mag worden beëindigd.

De verscheidenheid van opvattingen over levensbeschouwelijke onderwerpen leidt tot problemen bij het zoeken naar een rechtsgrond voor de straffeloosheid van deze gedragingen, bij het maken van een wettelijke regeling en tot onrust in de samenleving.

Wetgeving voor abortus, euthanasie en levensbeëindiging door een medicus is uitermate moeilijk, omdat de verschillende standpunten zich nauwelijks voor compromissen lenen. Dat kan voor de wetgever aanleiding zijn om van wetgeving af te zien of te trachten zich te beperken tot wetgeving, waarin de nadruk op procedurele aspecten wordt gelegd en materiële normen slechts uit de strekking van de regeling kunnen worden afgeleid. 


\subsection{Abortus}

Vanaf de totstandkoming van het Wetboek wan Strafrecht tegen het eind van de vorige eeuw overheerste het gewoel dat onder bepaalde omstandigheden het belang van de wrow boven het levensbelang van de vrucht uitging. Geen consensus kon echter worden bereikt ten aanzien van de vraag welke omstandigheden van de vrouw abortus konden rechtvaardigen.

In het Wetboek was niet voorzien in een bijzondere rechtsgrond op grond waarvan de medicus op medische indicatie straffeloos een zwangerschap mocht afbreken. De wetgever van 1886 achtte het opnemen van een dergelijke rechtsgrond overbodig en gevaarlijk. Een rechtsgrond was overbodig, omdat de praktijk de noodzaak niet aantoonde. Het gevaar van een rechtsgrond was naar de mening van de wetgever, dat deze tot formee-juridische problemen zou leiden. Ook in werband met abortus erkende de wetgever derhalve dat voor strafbaarheid vereist is, dat een feit zowel formeel als materieel wederrechtelijk is.

Doordat de wetgever naliet aan te geven onder welke omstandigheden de medicus een zwangerschap straffeloos mocht afbreken, bleef onduidelijk welke indicaties de medicus het recht verschaften te aborteren. Een andere gevolg was dat een aantal juristen het standpunt innam dat de medicus formeel gezien ook strafbaar was wanneer hij op medische indicatie aborteerde, bijwoorbeeld om het lewen van de vrouw te redden. Bovendien werden in de loop der tijd in wetsvoorstellen over abortus verschillende standpunten ingenomen over de geoorloofdheid van abortus door een medicus. Die standpunten stoelden op levensbeschouwelijke overtuigingen. Het gevolg van dit alles was, dat onder de medici een gevoel van rechtsonzekerheid bestond, dat voor hen aanleiding was op een wettelijke regeling aan te dringen die hen straffeloosheid kon garanderen.

Hierin ligt een aanwijzing, dat de wetgever ten aanzien van levensbeschouwelijk gevoelige onderwerpen gehouden is tot een regeling te komen, die in overeenstemming is met het gevoelen van de meerderheid in de samenleving.

Toen de wetgever in 1984 erin slaagde ten aanzien van abortus een bijzondere recht= vaardigingsgrond voor de medicus in de strafwet op te nemen, was hij niet zozeer man de eisen van de medici tegemoet gekomen, maar vooral aan de roep vanuit de samenleving om vrouwen toe te staan tot abortus te kunnen overgaan om hen moverende redenen. De wetgever gaf daarmee gevolg aan een vanaf de jaren zestig opkomend gevoel dat het an de vrouw is te beslissen of abortus in haar belang is. De erkerning van dit recht van de vrouw makkte het mogelijk voor de formulering van een inhoudlelijk criterium met de open formulering te volstaan, dat de noodsituatie van de vrouw abortus onontkoombarar dient te maken.

Met de abortuswet van 1984 heeft de wetgever to uitdrukking gebracht dat de beschermwaardigheid van het ongeboren menselijk leven ondergeschikt is aan die van het geboren lewen. Deze wet toont bovendien het gewicht aan dat de wetgever toekent aan de wens van de vrouw om abortus, voor zover de vrucht nog niet zel fstandig levensvatbaar is. Met de erkenning van deze wens heeft de wetgever tevens in zekere zin het zelfbeschikkingsrecht aanvaard ten aanzien van bepaald omstreden medisch handelen. 


\subsection{Thanasie}

\subsection{Algemeen}

In de euthanasiediscussie staan het zelfbeschikkingsrecht en de situatie van de patient centraal. Anders dan bij abortus is bij euthanasie en bij andere thanatische gedragingen geen sprake van een belangenconflict. De morele waardering van euthanasie betreft de vraag of een mens (onder bepaalde omstandigheden) het tijdstip van zijn overlijden mag bepalen en of het de arts geoorloofd is dat overlijden te bewerkstelligen.

Uit het onderzoek blijkt dat de verschillende wegen, waarlangs wordt getracht onder de bestaande wetgeving tot een gedifferentieerde strafrechtelijke aansprakelijkheid voor thanatische gedragingen te komen, niet tot juridisch bevredigende resultaten leiden.

Voor zover in de strafrechtspraak is erkend dat bepaalde vormen van omstreden medisch handelen straffeloos mogen worden verricht, zonder dat de wetgever in een bijzondere uitzonderingsbepaling heeft voorzien, wordt de straffeloosheid bereikt met behulp van de rechtvaardigende noodtoestand, die daartoe met elementen van de medische exceptie word aangevuld. Op deze wijze krijgt noodtoestand echter de kwaliteit van een nieuwe strafuitsluitingsgrond. Bovendien zijn de door de Hoge Raad gebezigde elementen van de medische exceptie, het "wetenschappelijk verantwoord medisch inzicht" en de "in de medische ethiek geldende normen ${ }^{\prime \prime}$, criteria, die vooral ter beoordeling aan de medische stand worden overgelaten.

Hoewel de jurispnidentiële benadering van deze probleemgebieden niet tot ontsporingen heeft geleid, verdient het geen aanbeveling om op grond daarvan op dit gebied van wetgeving af te zien.

Een nadeel van de jurisprudentiele aampak is dat thanatisch handelen niet een zodanig uitzonderlijk karakter heeft als waarvoor de overmacht in de zin van noodtoestand is bedoeld. De medicus wordt immers in zijn beroepsuitoefening structureel met siltuaties geconfronteerd die hem tot een beslissing over het al dan niet verrichten van omstreden medisch handelen nopen. Dat aangetoond te hebben is wellicht de grootste winst van de werkzaamheden van de Commissie Onderzoek Medische Praktijk inzake Euthanasie.

Over de wijze waarop onder de bestaande wetgeving straffeloosheid voor thanatisch handelen het beste te bereiken is, lopen de opvattingen uiteen. Maar in alle relevante strafrechtelijke methoden wordt dit handelen als uitzonderlijk benaderd. Zodra een uitzonderingsgeval echer tot een maatschappelijk verschijnsel wordt dat structurele kenmerken anneemt en in de samenleving over de geoorloofdheid duidelijke positieve geluiden te horen zijn en het Openbaar Ministerie een (impliciet) vervolgingsbeleid voert, dat meebrengt dat onder bepaalde omstandigheden de strafzaak wordt geseponeerd en de rechter in toenemende mate tracht de straffeloosheid voor omstreden medisch handelen een strafrechtelijke grondslag te verlenen, dan mag de wetgever niet langer afzijdig blijwen.

Het is niet de taak van het $O M$ en van de rechter als plantswervangend wetgever op te treden. Het voornaamste bezwar tegen een jurisprudentielle oplossing is dat hel de taak van de rechter zich te beperken tot beslissingen ten aanzien van concrete gevallen. Naarmate de strafrechter meer met algemene criteria gaat werken, treedi hij als pseudowetgever op. Maar dat is niet zijn taak en bovendien zijn de algemene strafuitsluitingsgronden daarvoor niet bedoeld. Daarom heeft de Hoge Raad ook terecht afgezien van een 
opsomming van specifieke voorwaarden voor een succesvol beroep op noodtoestand bil euthanatisch handelen. Toch toont de aanpak van de Hoge Raad juist een nadeel wan de jurisprudentiele benadering, want randwoorwaarden voor een wenselijk geachte toetsing. zoals het raadplegen van een collega-arts en het bijhouden van een journaal, zijn langs deze weg niet dwingend voorgeschreven.

Een principieel bezwaar tegen een jurisprudentiële benadering is dat zij onvoldoende duidelijkheid en daarmee rechtszekerheid verschaft. Rechtşekerheid voor de medicus is modig om te voorkomen dat het handelen zich in het verborgene afspeelt. Zij is evenzeer nodig om aan patiënten rechtsbescherming te waarborgen. Dit klemt des te meer nu het handelen ingrijpt in het zwaarst beschermde rechtsgoed: het menselijk leven. Daar komt nog bij dat over de geoorloofdheid van dit handelen om levensbeschouwelijke redenen in de samenleving verschillend wordt gedacht.

Voor zover de wetgever in gebreke blijft, kan het OM echter beter dan de rechter het gebrek opvangen. Het OM kan immers via vervolgingsrichtlijnen tot een pseudowetgeving komen. Op deze wijze wordt echter de problematiek, die het wetgevingsproces belemmert slechts verplaatst. Daar staat wel tegenover dat het vervolgingsbeleid naar zijn aard llexibeler kan reageren op veranderende omstandigheden dan de wetgeving. Dat is echter niet alleen een voordeel, maar evenzeer een nadeel. Want verantwoordelijk. voor het beleid is de Minister van Justitie en daarmee hangt het van de signatuur van de desbetreffende minister (en uiteindelijk van het kabinet) af welk beleid gevoerd wordt. Bovendien, wanneer geen vervolgingsrichtlijnen voor dit medisch handelen gepubliceerd worden, dan kan het OM te veel in het verborgene opereren. Worden daarentegen de richtlijnen gepubliceerd, dan beschouwt de Hoge Raad deze als recht in de zin van art. 99 Wet RO en verschillen zij in hun praktische werking nog nauwelijks van wetgeving:

De rechtspraak en het OM hebben wel een belangrijke taak ten aanzien van thanatisch handelen door in de fase voorafgaand aan de totstandkoming van wetgeving regelend op te treden. ${ }^{2}$

Het al dan niet geoorloofdheid zijn van thanatisch handelen dient door de wetgever geregeld te worden. Rechtszekerheid en rechtsbescherming vereisen duidelijke inhoudelijke normen, op grond waarvan de scheidslijn tussen geoorloofd en ongeoorloofd thanatisch handelen wordt getrokken. Het is de taak van de wetgever die scheidslijn te bepalen en de randvoorwalarden te formuleren. Bovendien biedt dat de garantie dat een regeling tot stand komt via een democratische bes/uitvormingsprocedure.

De wetgever ziet zich hierbij echter geconfronteerd met verschillende maatschappelijke denkbeelden over de strafwaardigheid van deze gedragingen, waardoor het wetgevingsproces uitermate moelzaam verloopt en consensus over materièle normen nauwelijks te bereiken is. De moeizame weg naar de abortuswetgeving van 1984 heeft dit al eens eerder geillustreerd.

Sommigen wijzen het idee dat de mens een zelfbeschikkingsrecht over het tijdstip van zijn dood heeft principieel af: Voor hen is het eveneens moreel ongeoorloofd aan derden een dergelijk recht toe te kennen. In deze benadering kan thanatisch handelen niet gerechtvaardigd zijn, mar onder omstandigheden wel verontschuldigbaar. Het benadleren van de straffeloosheid voor omstreden medisch handelen via schulduitsluiting leent zich echter niet goed voor een wettelijke regeling, als de wetgever daarin een duidelijke. grens wil trekken tussen geoorloofd en ongeoorloofd handelen. Daarvoor moeten immers

2 Ook Enschede, 1985, p. 76, is er niet principieel tegen on streden medisch handelen wettelijk te regelen. "Later, als zich de zaken consolideren, is het voor wetgeving de tijd". 
objectieve omstandigheden geformuleerd worden op grond waarvan het handelen al dan niet strafbaar is. Ter illustratie zij verwezen naar de Proeve, die formeel een schulduitsluitingsgrond bevat, maar materieel een rechtvaardigingsgrond. Een tweede reden die het moeilijk maakt materiële criteria te formuleren is gelegen in de verscheidenheid van de gevallen. Hieruit blijkt dat de medische beroepsgroep niet in stat is tot een duidelijke normstelling. Het gevolg is dat met open normen moet worden volstaan. Daardoor blijft echter de afbakening tussen geoorloofd en ongeoorloofd handelen voornamelijk een taak van het Openbaar Ministerie en de rechterlijke macht. Voor zover het niet mogelijk is duidelijke materiële normen te formuleren, dient de wetgever de open normen aan controleen toetsingscriteria te koppelen.

De wetgever ziet zich derhalve met betrekking tot thanatisch handelen met een aantal problemen geconfronteerd, die woor zover hij niet zelf in actie komt, bij de rechter en het Openbaar Ministerie terecht komen. Nog enkele woorden over die problemen.

Een rechtsstaat moet als uitgangspunt van rechtsstatelijkheid de bescherming van het leven van zijn burgers warborgen. Dit grondbeginsel is onder andere terug te vinden in art. 2 EVRM en is tevens het centrale doel van de geneeskunde.

Elke regeling, warin thanatisch handelen van de strafbaarheid wordt uitgesloten kan derhalve niets anders zijn dan een als uitzondering op dit uitgangspunt bedoelde regeling. De medici willen rechtszekerheid en dat betekent dat een wettelijke regeling onder meer aan hen duidelijkheid moet verschaffen over welk thanatisch handelen wel en welk niet toelaatbaar is. Het genoemde uitgangspunt brengt immers mede, dat de wetgever het niet aan de medici $\mathrm{kan}$ en mag overlaten te beslissen in welke gevallen zij thanatisch handelen. Daartoe is het rechtsgoed waarom het hier gaat van te grote importantie.

Voor de inhoudelijke afbakening van de geoorloofdheid van omstreden medisch handelen is van belang dat de normering geen specifiek medische kwestie betref, maar berust op levensbeschouwelijke overwegingen. Daar komt nog bij dat de medici onderling verdeeld zijn over de toelaatbaarheid van een aantal omstreden medische gedragingen. $\mathrm{Zij}$ weerspiegelen daarmee de opvattingen die hierover in de samenleving in het allgemeen bestaan.

Het is begrijpelijk dat medici rechtszekerheid bij deze problematiek wensen. Maar anderzijds is van belang dat de rechtsbescherming van de burger gewaarborgd blijft. Daartoe is nodig een wettelijke regeling, waarin met beide aspecten rekening wordt gehouden.

Hierbij speelt echter het probleem dat thanatische gedragingen van medici in het algemeen slechts bekend worden als de medici daaraan medewerking verlenen. Uit het rapport van de Commissie-Remmelink blijkt, dat zij daarvoor bij een strafrechtelijke aanpak weinig voelen: ${ }^{3}$

Dat is éen van de redenen die Schalken brengt tot een pleidooi voor een primair tuchtrechtelijke afdoening. Een belangrijker reden is voor hem dat uit het onderzoek is gebleken, dat voor de arts "de medische conditie van de patiënt ... als, zij het niet de enige, maar wel het voornaamste richtsnoer (is) dat hij bij zijn besluitvorming hanteert". De functie van het strafrecht zou dan naar zijn mening daarin liggen, als wangnet te dienen

3. Commissie Onderzoek Medische Praktijk inzake Euthanasie, Onderzoek, 1991, p. 80*81 en p. 158 . 
"voor de evidente gevallen van incompetentie of misbruilk" "Daarmee kiest hij voor een praktische oplossing. Hoewel het beter is dat zoveel mogelijk medici meewerken aan het bekend worden van thanatische gedragingen, moet naar mijn mening de rechisbescherming van het menselijk leven niet aan beroepsspecifieke handhavingsmechanismen onderworpen zijn. Ook al zou een strafrechtelijke regeling tot gevolg hebben dat medici minder geneigd zijn tot medewerking, dan is het voordeel hierin gelegen dat de wetgever (en daarmee de samenleving) daarmee tot uitdrukking brengt, dat de rechtsbescherming van het leven een aangelegenheid is die de gehele samenleving aangaat. Daar komt nog bij dat $22 \%$ van de artsen onder geen enkele voorw aarde bereid is euthanasie te melden, terwijl $66 \%$ een voorkeur voor een wettelijke regeling in de zin van het initiatiefvoorstel heeft. ${ }^{5}$

Enschedé stelt dat het strafrecht geen normerende taak heeft. ${ }^{6}$ Voor zover hij daarmee bedoelt dat het strafrecht geen nieuwe normen mag stellen, ben ik het daarmee eens. Het straffecht, waarbij ik me hier beperk tot misdrijven, dient echter wel de normen te weerspiegelen, die in de samenleving over fundamentele kwesties bestaan. In die zin geldt nog steeds het uitgangspunt wan de wetgever van 1886 dat als misdrijven te beschouwen zijn die gedragingen die in de samenleving als onrecht gelden.

In de huidige samenleving bestat, in tegenstelling tot die van vroeger, pluriformiteit van opvattingen over wat bij thanatisch handelen recht en onrecht is. Hoe kan de wetgever hieran recht doen?

Verdedigbaar is dat de wetgever ruimte moet bileden aan deze pluriformiteit. Zo stelt bijvoorbeeld Meeuwissen, dat bij controversiële kwesties de wetgever geen regeling moet treffen die slechts tegemoet komt aan het standpunt van de meerderheid, maar dat hij een juridisch kader voor de pluriformiteit moet scheppen. ${ }^{7}$ Waar het om gaat is dan dat een dergelijke regelling de mogelijkheid moet uitsluiten, dat tegenstanders van omstreden medissch handelen aan dat handelen onderworpen kunnen worden.

Het probleem is echter dat de eerbiediging van pluriformiteit ten aanzien van fundamentele vragen ook berust op een bepaalde levensbeschouwing. Kenmerkend voor een levensbeschouwelijke benadering van omstreden medisch handelen is het absolutistisch karakter van de standpunten.

Of de wet ruimte moet bieden aan een pluriformiteit van standpunten is daarmee op zichzelf een opvatting die in een democratische samenleving door de meerderheid beantwoord dient te worden. Wie zich in het resultaat van democratische besluitvorming niet kan vinden, moet proberen het politieke besluitvormingsproces te beïnvloeden en trachten op deze wijze een andere regeling tot stand te brengen.

4 Schalken, DD 1991, p. 837-841, Eerder had hij opgemerkt dat euthanasie in wezen een strafrechtelijk vratagstuk is, omdat het daarbij on de vralg, gat, in hoeverre euthanasie onder een normatief gezichtspunt principiev towatbaar is. "Toetsing door Justitie blijf van essentieel belang, ondat het niet alleen gaat om de juiste naleving wan procedurele voorwaarden wat de besluitworming van de arts betreft, maar oolk en in de eerste plats on de groorloofdheid wan het met zijn handeling beoogde doel, voor zover dat niet tot thet gewone medisch handelen kan worden gerekend". Schalken, in: Euthanasie, 1985, p. 157 en p. 164.

5 Commissie Onderzoek Medische Praktijk imzake Euthanasie, Onderzoek, 1991, p. 80-81 en p. 84-85.

6 Enschedé, 1985 .

7 Meeuwissen, 1982, p. 200-206 en p. 226-227. 
We hebben hiervótr geconcludeerd dat de wetgever geroepen is zich te beraden over een wettelijke regeling voor thanatisch handelen om tot wetgeving op dit terrein over te gaan, woor zover dat handelen (onder bepaalde omstandigheden) geoorloofd wordt geacht.

Uit het onderzoek blijkt dat de wetgever daarvoor meestal niet voelt en dat hij, als

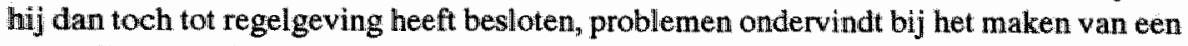
wettelijke regeling voor thanatisch handelen.

De wetgever kan op twee manieren duidelijk laten blijken hoe hij over de strafrechtelijke aansprakelijkheid voor omstreden medisch handelen denkt. De ene houdt in dat hij de medicus in zijn beroepsuitoefening van die aansprakelijkheid voor omstreden medisch handelen in algemene zin uitsluit. De andere mogelijkheid is dat hij met behulp van. materiële normen cen grens trekt tussen geoorloofd en ongeoorloofd omstreden medisch handelen.

Voor de strafuitsluiting van thanatisch handelen in algemene zin kan een open geformuleerde rechtvaardigingsgrond voor de medicus dienen, zoals deze sinds 1881 in Nederland verscheidene malen is voorgesteld. Hij zou kunnen luiden: "De medicus die met inachtneming van de regelen der kunst medische handelingen verricht, is niet strafbaar." Het voordeel van een dergelijk algemene strafuitsluitingsgrond is gelegen in de rechtszekerheid voor de medicus en in de flexibiliteit van een dergelijke rechtsgrond, die meebrengt, dat de rechtsgrond bij veranderende omstandigheden dienst kan doen. Het nadeel is dat een dergelijke rechtsgrond de medicus in wezen vrijlaat in zijn handelen, voor zover dat geschiedt volgens de regelen van de kunst.

Dat met een zodanig open geformuleerde rechtvaardigingsgrond voor medisch handelen tevens aan de pluriformiteit recht wordt gedaan, kan niet zonder meer worden gezegd. Want het toelaatbaar achten van omstreden medisch handelen behoeft niet te betekenen, dat de medici over de geoorloofdheid daarvan mogen beslissen. Naast een dergelijke rechtvaardigingsgrond zouden derhalve nog aanvullende eisen gesteld kunnen worden, die weliswaar geen inhoudielijke, maar wel formele voorwaarden behelzen, die erop neerkomen dat een ander of anderen (mede) beslist/beslissen over de geoorloofdheid. Hoe meer de rechtvaardigingsgrond is geclausuleerd, des te "geslotener' wordt hij.

De wetgever heeft behalve de keuze tussen een open en een 'gesloten' rechtvaardigingsgrond ook de keuze tussen een algemene en een bijzondere rechtvaardigingsgrond.

Bij de abortuswetgeving van 1986 heeft hij voor een bijzondere rechtvaardigingsgrond gekozen, die tevens een open karakter heeft. Strafbaar vanwege art. 296 lid 5 Sr is immers slechts de medicus die abortus verricht in een inrichting, waar volgens de WAZ geen zwangerschap mag worden afgebroken. Op deze wijze raakt echter een van de beide doelstellingen van de abortuswetgeving, namelijk de rechtsbescherming van de vrucht op de achtergrond. ${ }^{8}$ De toen tevens tot stand gekomen procedureregeling, neergelegd in de WAZ zelf en in het BAZ, staat daardoor in wezen los van de strafrechtelijke aansprakelijkheid, terwijl zij juist bedoeld was als uitweg voor de impasse waarin de wetgever

Daarom vroegen de Weine conservatieve partijen on een evaluatie wan de abortuswet. Zie: "ThK, 1990-1991, $18386, \mathrm{nr} .42$. De Stantssectetaris ven WVC zag geen principiële bezwaren tegen een evalluatle. Mar hij merkte tevens op: "Tien jaar gele den heef men na veel discussie een compromis bereikt in cen waardenconflict. Er maeten dan ook wel zwaarwegende politieke argumenten zijn om zo'n wergelijk te evalueren". TK, 1990-1991, 18386, nr.. 42, p. 12 . 
terecht was gekomen, doordat woor een (duidelijk) materieel criterium geen meerderheid in het parlement te vinden was.

Mocht de wetgever in staat zijn een materieel criterum te formuleren, dan is de vraag, of een dergelijk criterium wenselijk is. Voordeel daarvan is, dat evenals bij een algemeen geformuleerde rechtwaardigingsgrond voor omstreden medisch handelen, duidelijkheid bestaat over wat de medicus mag. Nadeel is, dat een materieel criterium al gauw het gevaar in zich bergt, dat het nilet voldoende flexibel is voor zich wijzigende omstandigheden en nieuwe situaties.

Mijns inziens zou de wetgever moeten trachten om tot een algemene regeling voor omstreden medisch handelen te komen. Daarom is onder andere éen procedurele regeling ten aanzien van dit handelen wenselijk, met minimaal in acht te nemen zorgvuldigheidseisen en administratieve verplichtingen. Ten denken valt daarbij met name aan het werplichte consult en aan de journaalwerplichting."

Daarbij mag het niet-naleven van sommige zorgvuldigheidseisen niet leiden tot aansprakelijkheid vanwege het hoofddelict. Wanneer degene die bijvoorbeeld geen journaal bijhoudt of een consult achterwege laat vanwege het hoofddelict zou kunnen worden gestraft, dan zou de proportionaliteit tussen de laakbare gedraging en de reden voor strafbaarstelling van het hoofddelict worden veronachtzaamd. ${ }^{10}$ Terecht heeft de Hoge Raad daarom ook overwogen, dat het nalaten van een consult niet uitsluit dat in een voor noodtoestand vereiste noodsituatie is gehandeld. ${ }^{11}$ Daarentegen verdient het wel aanbeveling om het niet-naleven van (bepaalde) procedurele eisen zelfstandig - en desnoods als misdrijf - strafbar te stellen, omdat dit ter controle van het handelen dienen.

Met een procedurele regeling kan de wetgever echter niet volstaan, als hij het betreffende handelen slechts in bepaalde gevallen wil toestaan. Afgezien van het probleem dat het vanwege levensbeschouwelijke normen en waarden moeilijk is om overeenstemming te bereiken over een materieel criterium, is het zeer lastig een materieel criterium te formuleren, dat enerzijds voldoende houvast biedt en anderzijds voldoende flexibel is, om voor per geval verschillende omstandigheden in aanmerking te komen. Bij euthanasie worden criteria als 'uitzichtloze noodsituatie", "stervensfase" en 'ondraaglijk lijden" als te weinig nauwkeurig aangemerkt.

\subsubsection{Thanasie bij wilsbekwame patienten}

Het meeste houvast voor een regeling van thanatische gedragingen biedt de eis, dat slechts met uitdrukkelljke toestemming van de patiênt gehandeld mag worden. Bovendien wordt deze toestemming geeist in verband met het zelfbeschikkingsrecht. Hierop behoort daarom in nog sterkere mate dan soms geschiedt de nadruk te worden gelegd, voor zover het

9 Volgens de Conmissie Onderzoek Medische Praktijk juzake Euthanasie, rapport, 1991, p. 34, worden door nedici de zorgvuldigheidseisen met name ten arazien wan ander thanatisch handelen dan euthanasie onwoldoende in acht genomen. Dat geldt vooral voor de journaalverplichting.

10 In het oorspronkelijk initiatiefwoorstel leidt het niet-naleven van de journaalverplichting tot anspirakelijkheid vanwege het hoofddelict. In het gewijzigd intiatiefvoorstel en in de Proeve geldt dat ten aanzien van thet consult. Zie: H. IV B, onder 1.7 .10 en onder 1,7.13. Een zo vergaande strafbaarstelling wordt hier dus afgewezen.

11 HIR 23 juni 1987, NJ 1986, 157 mint. ThWvV en HR 3 meil 1988, NJ 1989, 391 m.ni. GEM. 
thanatisch handelen wilsbekwame patienten betreft. ${ }^{12}$ Bovendien is de rechtvaardiging wan het handelen daarin gelegen dat deze in het belang, althans niet tegen het belang van de patiënt plaatsvindt. De patiënt is echter de eerst aangewezene on over dat belang te oondelen.

Of de patiënt toestemming heeft gegeven kan getoetst worden door te eisen dat deze op schrift wordt gesteld. Is de patiënt daartoe niet in staal dan zou geëist moeten worden, dat hijj ten overstaan van de arts en van tenminste éen onafhankelijke derde zijn wil mondeling uit en dat de arts de toestemming en de omstandigheden waaronder die gegeven is schriftelijk vastlegt.

Vanwege de nadruk die mijns inziens op de toestemming moet worden gelegd, verdient het aanbeveling om meer dan thans het geval is gewicht toe te kennen aan een eerdere schriftellike wilsverklaring. Die kan uitkomst bieden in de gevallen, waarin de patient op het moment waarop de beslissing moet worden genomen niet meer in statat is tot een wilsuiting. Zou hiermee onvoldoende relkening worden gehouden, dan wordt de beslissing in handen van derden gelegd en dat is minder wenselijk, dan het gevolg geven aan een eventueel zelfs jaren oude wilsverklaring. ${ }^{13}$ In het laatste geval wordt immers uitgegaan van de zelfbeschikking van de patiënt. Die zelfbeschikking brengt mede dat hij ook verantwoordelijk is voor een eenmaal opgestelde wilsverklaring en de daaraan verbonden gevolgen.

Mijins inziens zou een dergelijk uitgewerkt toestemmingsvereiste gekoppeld aan een procedureregeling voor alle gevallen van thanatisch handelen moeten gelden, voor zover de patiënt tot wilsuiting in staat is. Dat betekent dat een zodanige regeling ook van toepassing zou moeten zijn bij levensverkortende pijnbestrijding en bij het nalaten van medisch zinloos handelen.

Uit het onderzoek dat in opdracht van de Commissie Remmelink is verricht, blijkt immers onder andere, dat euthanasie slechts een zeer klein gedeelte van alle thanatische gedragingen omvat, terwijl levensverkortende pijnbestrijding en nalaten van medisch zinloos handelen veelvuldig voorkomen. Bovendien toont het rapport aan dat daarbij niet altijd bepaalde voorwaarden, die ten aanzien van euthanasie gelden, in acht worden genomen. ${ }^{14}$ Vanwege de omvang van deze zogenaamde schijngestalten alsook vanwege de mogelijkheid dat deze gedragingen ter verhulling van euthanasiepraktijken gebruikt kumnen worden, werdient het daarom eveneens aambeveling dat deze gedragingen aan de door mij voorgestelde wettelijke regeling worden gebonden.

Een reden om de genoemde regeling ook van toepassing te verkllaren op het nalaten van medisch zinloos handelen is daarin gelegen dat uit versehillende uitlatingen van medici blijkt, dat het zeer moeilijk is in algemene zin te bepalen, wanneer het handelen medisch zinloos is. Een andere reden is, dat volgens meer recente uitlatingen uit de medische kring de beoordeling over de medische zinloosheid ook elementen van een ethische wardering en daarmee van de kwaliteit van het leven van te patiënt behelst. Daarvan uitgaande dient er mijns inziens op te worden aangedrongen dat bij een wilsbekwame patiënt het handelen niet wordt nagelaten tegen de wil van de patiënt. Maar zelfs al zou

12 the wooral: Leener, 1988 , hoofdstuk III en hooldstuk XI.

13 Zie o.a: Leener, 1988, p. 283-285 en Sutorius en Jansen, A.A 1991, p 990-997.

14 Commissic Onderzock Medische Praktijk inzake Euthanasie, Onderzoek, 1991, p. 13 . 19 exil p. 34. In 45\% van lewenswerkortende pujnbestrijding werd geen collegiat advies ingewonnen, in 21 o van de gewallen waren er nog alternatieven, in 79\% van de gewallen waten geen alternatiewen meer en in $17 \%$ van de gevallen waren er wel nog alternatieven, matar wilde de patient "nist mear". 
de medische zinloosheid in uitsluitend medisch-technische zin te bepalen zijn; dan nog zou het aanbeveling verdienen om aan de wilsuiting van de patiênt gevolg te geven. Want dan heeft de medisch-technisclj zinloze handeling voor de patiênt en daarmee voor diens leven nog wel zin. Het gaat hierbij immers om de vraag, of het handelen mag worden nagelaten met als gevolg dat de patiënt eerder komt te overlijden en dan moet naar mijn mening de rechtsbescherming vain het leven van de patiënt voorop staan.

Weigert de patiënt toestemming tot een behandeling, dan moet deze worden nagelaten, ook al is het gevolg dat de patient daardoor overlijdt. Het nalaten van medisch thandelen is hierbij slechts afhankelijk van de toestemming. Daarom is een uitvoerige procedurele regeling hier niet op haar plaats. Ter controlle zou echter wel het hierboven over de voorwaarden voor de toestemming gezegde van toepassing kunnen worden verklaard ten aanzlen van de weigering van de patiênt.

\subsubsection{Thanasie bij willsonbelkwame patiënten}

Bij een wilsonbekwame patient kan aan de belangrijkste voorwaarde voor euthanasie niet worden voldaan: hilj kan omtrent dat handelen zijn will niet uiten. Dan treedt het uitgangspunt op de voorgrond, dat het leven beschermd dient te worden. Uitzonderingen hierop zijn slechts te verdedigen met het uitzonderlijk karakter van de omstandigheden. Hierbij moet evenwel worden onderscheiden tussen comateuze patienten en andere wilsonbekwame patienten. Bovendien moet een onderscheid worden gemaakt tussen patiënten die nooit tot een wilsuiting in staat waren en patiënten bij wie dat wel het geval was: Bij patiënten die hun wil konden bepalen en die ün die tijd geen levenstestament hebben opgesteld zou verondersteld kunnen worden dat zij geen levensbeëindiging wensen. Overwogen zou nog kunnen worden om hierover naaststaanden te horen, die over uitlatingen van de patient over thanasie mededelingen zouden kunnen doen. Maar dat bergt een zeker gevaar in zich ten aanzien van de betrouwbaarheid van deze mededelingen. Dat gevaar kan enigszins gerelativeerd worden door te eisen dat minimaal twee naaststaanden overeenkomstige mededelingen doen over uitlatingen van de patiënt. Bij wilsonbekwame patiënten die nooit wilsbekwaam waren zou principieel aan de rechtsbescherming vam het leven voorrang moeten worden gegeven.

Vanwege de nadruk die hier op de rechtsbescherming van het menselijk leven wordit gelegd, zou de medicus slechts tot nalaten van medisch handelen mogen beslissen wanneer het handelen medisch gezien zinloos is. Als aanvullende eisen gelden ook hier dat de prognose door minimaal eên onathankelijke arts bevestigd wordt en dat de behandelende arts een journaal bijhoudt.

Uitgaande van het standpunt dat de kwalificatie "medisch zinloos" niet uitsluitend op grond van medische overwegingen genomen wordt, verdient het arabeveling, dat bij de medicl op consensusbevordering wordt aangedrongen, zoals dat in de rapporten van de CAL en de werkgroep Doen of laten ten aanzien van pasgeborenen wordt voorgesteld. Deze aandachtspunten zouden eventueel ook in een wettelijke regeling kunnen worden opgenomen. Een bezwaar daartegen is, dat de aandachtspunten met de ontwikkeling van de medische mogelijkheden kunnen veranderen.

Bij een comateuze patiênt doet zich nog een bijzonder probleem voor. Kennelijk kunnen comateuze patiënten soms zeer lang in hun comateuze toestand verblijven, terwijl in de comateuze toestand geen verandering behoeft op te treden. Dan is de vraag, wamneer het blijven behandelen van een comateuze patiënt zinloos geacht wordt. Het antwoord 
op dieze vraag heeft een normatief karakter en berust - zoals Musschenga heef gesteld op een wooroordeel over de waarde van menselijk leven. "Comapatiënten die aan een beademingsapparatuur liggen, blijven tenminste nog in leven. ${ }^{115}$ Als een criterium voor het nalaten van de behandeling van irreversibel comateuze patiènten wordt gewenst, dan zou aangesloten kunnen worden bij het voorstell van de CAL door te bepalen dat ten aanzien van een patiënt die een bepaalde tijd in coma verblijft handelen zinloos is en derhalve mag worden nagelaten.

Kan ten aanzien van een wilsonbekwame patiënt thanatisch handelen legitiem zijn, waarbij aan de patiënt een euthanaticum wordt toegediend? Naar mijn mening in het algemeen nïet. Wanneer met het nalaten van medisch zinloos handelen kan worden volstaan, moet daarmee worden volstaan. Dat is ook in overeenstemming met de subsidiariteitseis van het strafrecht en met de eis van de instrumentele doelmatigheid van Leenen. ${ }^{116}$ Slechts wanneer het nalaten van medisch handelen in dat geval tot een vermeerdering van het lijden van de patiënt leidt en daarin niet op een andere wijze adequate hulp kan worden geboden dan door het toedienen van een euthanaticum, zou daartoe mogen worden overgegaan. Voor dergelijke uitzonderlijke situaties is een wetswijziging niet nodig, noch afgezien van het feit, dat een wettelijke regeling waarin actieve levensbeeindiging van wilsonbekwame patiënten onder bepaalde omstandigheden geoorloofd wordt verklaard, in strijd zou komen met art. 2 EVRM. ${ }^{17}$ Voor de straffeloosheid zou in die situaties teruggevallen kunnen worden op de bestaande strafuitsluitingsgronden.

Levensverkortende pijnbestrijding bij wilsonbekwame patiënten is eveneens bijzonder, omdat de patiënt niet uitdrukkelijk toestemming tot de behandeling kan geven. Waar andere mogelijkheden te kort schieten, zou hiertoe mogen worden overgegaan. Daarbij zou nog grotere terughoudendheid betracht moeten worden dan bij wilsbekwame patiënten die immers toestemming tot de handeling verlenen. In een wettelijke regeling zou vastgelegd kunnen worden, dat de behandelende arts een collega dient te consulteren en beiden hun bevindingen ten aanzien van deze handeling schriftelijk vast dienen te leggen.

\section{Samenvatting}

Ik pleit voor een regeling voor thanatisch handelen, waarin de witdrukkelijke toestemming van de patiënt centraal staat. Slechts indien de patiënt toestemming tot levensbeëindiging, levensverkortende pijnbestrijding en nalaten van medisch zinloos handelen verleent, mag daartoe worden overgegaan, voor zover nog aan andere in de wet te formuleren voorwarden ten aanzien van de situatie van de patiënt is voldaan. Bovendien moet ter toetsing aan bepaalde procedurele regels worden voldaan, waarvan de belangrijkste zijn dat zoveel mogelijk schriftelijk dient te worden vastgelegd en dat consult verplicht is.

Is de patiënt niet tot wilsuiting in staat, maar heeft hij voordien een levenstestament opgemaakt, dan zou de medicus gevolg mogen geven aan hetgeen in het levenstestament is beparald.

Is de patiënt wilsonbekwam en heeft hij nooit zijn will omtrent thanasie kenbaar gemaakt, dan mag diens leven slechts dan actief worden beëindigd, wanneer het handelen

$15 \mathrm{Wgl}$. Musschenga, 1987, p. 162-163. Anders: CAL, 1991, p. 20-25, die het verblijwen in een langdurig coma als medisch zinloos kwalificeert. Zie: H. IV $C_{0}$ onder 2.4.

16 Leenem, 1991 , p. 33-34..

17 Vgl. Leenen, "TVGR 1992, p. 6. 
medisch zinloos is en het nalaten van dat handelen tot een vermeerdering wan het lijden leidt.

Ook al komt het tot een wettelijke regeling in de door mij bepleite zin, dan nog zullen er gevallen overblijven die niet daaronder kunnen worden gebracht. In deze gevallen kan en moet de rechter met behulp van de bestaande strafuitsluitingsgronden tot cen rechtvaardige afweging komen. 


\section{Samenvatting}

In dit proefschrift wordt de strafrechtelijke aansprakelijkheid van de medicus voor professioneel uitgevoerde handelingen onderzocht. Daarbij wordt van de veronderstelling uitgegaan dat geen kunstfout wordt gemaakt en zich geen complicatie voordoet. Centraal staat derhalve de vraag of de medicus een bepaald type handeling mag verrichten.

\section{Hoofdstuk I - De Huizer veearts en de medicus}

In het eerste hoofdstuk wordt nagegaan of de Hoge Raad in de Huizer veearts-arresten het ontbreken van de materiële wederrechtelijkheid als algemene rechtvaardigingsgrond danwel de medische exceptie als beroepsspecifieke rechtvaardigingsgrond heeft erkend.

De analyse van deze arresten wijst uit dat de Hoge Raad vermoedelijk het ontbreken van de materiële wederrechtelijkheid heeft aanvaard. Maar deze dient wel beperkt te worden opgevat. Daartoe noopt dat de overwegingen van de Hoge Raad terughoudend zijn en dat bij een te ruime strekking van het ontbreken van de materiële wedierrechtelijkheild deze strafuitsluitingsgrond onvoldoende kan worden afgebakend.

Naar mijn mening moet voor een succesvol beroep op het ontbreken van de materiële wederrechtelijkheid voldaan zijn aan drie voorwaarden. Deze zijn:

- er moet evident in hetzelfde belang gehandeld zijn dat de wetgever met de delictsomschrijving wilde beschermen,

- de wetgever heeft juist de omstreden gedraging niet van de strafbaarheid willen uitsluiten,

- de met de wet in strijd zijnde wijze waarop het belang wordt nagestreefd, dient meer aangewezen te zijn dan conform de wet te handelen.

\section{Hoofdstuk II - Mishandeling}

In het tweede hoofdstuk staat de vraag centraal op welke wijze de uitsluiting van de strafrechtelijke aansprakelijkheid van de medicus voor operatieve ingrepen wordt verdedigd en welke wijze de meest aangewezene is.

Uit de wetsgeschiedenis van 1886 valt af te leiden, dat de wetgever voor de straffeloosheid van de medicus met betrekking tot de delictsomschrijvingen van mishandelingen niet aan een bijzondere rechtsgrond dacht, maar veeleer aan een algemene rechtsgrond, op grond waarvan een handelen met een objectief gerechtvaardigd doel de strafbaarheid uitsluit. Voor de strafbaarheid van de gedraging is in die opvatting nodig dat deze zowel formeel als materieel wederrechtelijk is. Daarbij kan de hoedanigheid van de handelende persoon in zoverre van belang zijn, als zij aangeeft wie tot een bepaald handelen met een gerechtvaardigd doel bevoegd is. Voor de wetgever van 1886 was het kennelijk 
vanzelfsprekend dat de medicus in het algemeen met een gerechtvaardigd doel handelt en derthalve niet strafbaar is.

In de rechtswetensichap zijn werschillende constructies voorgestell om tot uitsluiting van de strafrechtelijke aansprakelijkheid van de medicus voor operatieve ingrepen te komen. Aanleiding daartoe waren enigszins tegenstrijdige uitlatingen van de wetgever over deze problematiek en het feit, dat vooral in de beginperiode na invoering van het huidige Wetboek van Strafrecht weinig belang werd gehecht aan de parlementaire geschiedenis bij de totstandkoming van dit wetboek en des te meer belang aan de wettekst.

Verdedigd werd ondermeer dat bij de medicus het voor mishandeling vereiste (materiele) opzet ontbreekt, omdat deze met het doel zou handelen niet te mishandelen. In deze benadering wordt echter ten onrechte het vereiste materiële opzet (oogmerk) door bet motief bepaald. Vervolgens wordt gesteld dat het oogmerk van de medicus op de genezing is gericht.

Een tweede constructie houdt in dat een medische behandeling geen mishandeling is, omdat de strekking van beide gedragingen verschillend is. Ook deze benadering leidt niet tot bevredigende uitkomsten. Ten eerste is zij beperkt tot de rechtvaardiging van medisch handelen, terwijl voor de wetgever van 1886 het medisch handelen slechts éen van de handelingen was die straffeloos mogen worden verricht. Ten tweede kan zij geen verklaring geven voor de strafuitsluiting bij de zware mishandeling, omdat de delictsomschrijving van de zware mishandeling voor geen ruimte laat woor deze interpretatie

Volgens een derde benadering zou de medicus straffeloos mogen opereren omdat de: patiënt toestemming tot de handeling heeft gegeven. Hoewel in de loop van de tijd aan de werking van de toestemming een ruimere werking in het strafrecht lijkt te worden toegekend, wordt in het algemeen de strafuitsluitende werking van de toestemming terecht beperkt tot relatief eenvoudige vormen van het toebrengen van pijn en/of letsel. De reden dat de toestemming in het algemeen geen strafuitsluitende werking toekomt, voor zover de wetgever daarin niet heeft woorzien, is daarin gelegen, dat een strafbepaling het allgemeen belang dient en de toestemming niet wegneemt dat het algemeen belang wordt geschonden. De toestemming kan derhalve slechts strafuitsluitend werken, ten aanzien van delicten waarbij een individueel belang wordt geschonden en het algemeen belang niet boven het individueel belang uitstijgt.

De eisen die het strafrecht aan een rechtsgeldige toestemming stelt, zijn in de loop van de tijd natwelijks gewijzigd. Nodig is dat toestemming wordt gegeven op grond van een vrije wilsbepaling met het besef van de draagwijdte van de beslissing. Niet vereist is dat de toestemmingsgever meerderjarig is. Veelmeer nadruk wordt gelegd op het inzicht van deze persoon in de draagwijdte van zijn beslissing. Voor het medisch handelen is daarnaast nog van bijzonder belang, dat terecht algemeen wordt verdedigd, dat een rechtsgeldige toestemming een medische ingreep niet kan rechtvaardigen, maar dat deze toestemming wel als éen van de voorwaarden voor geoorloofd medisch handelen wordt beschouwd.

In de vierde opvatting wordt in de delictsomschrijving van de eenvoudige mishandeling het bestanddeel wederrechtelijk ingelezen en vervolgens gesteld dat de medicus niet wederrechtelijk handelt. Tegen deze opvatting spreekt dat deze weg niet openstaat voor een verklaring van de straffeloosheid voor de voor het medisch handelen belangrijker delictsomschrijving van de zware mishandeling.

Volgens sommigen is het medisch handelen straffeloos vanwege de medische exceptie (het beroepsrecht van de medicus). Daartoe worden drie argumenten aangevoerd. De 
medicus handelt in het belang van de maatschappij. Zijn handelen is ook moreel verdedigbaar. De medische exceptie kan uit het gewoonterecht worden afgelleid. Hiertegen werd wooral vroeger ingebracht, dat het gewoonterecht nlet als zodanig is erkend. Bovendien handelen medici niet altijd volgens dezelfde regels, zodat niet voldoende duidelijk kan worden vastgesteld, wanneer de medische exceptie van toepassing is. Sommigen waren daarom van mening dat de grondslag van de medische exceptie in het Wetboek van Strafrecht behoorde te worden opgenomen. Zij accepteerden geen ongeschreven rechtvaardigingsgrond. Anderen, met name Van Hamel, waren van mening dat de erkenning van de medische exceptie berust op de geneeskundige wetten. Hiertegen werd arangevoerd, dat deze wetten bedoeld zijn woor de uitsluiting van onbevoegden.

In het arrest van 21 okt. 1986, NJ 1987, 607 m.nt. GEM heeft de Hoge Raad de medische exceptie als ongeschreven rechtsgrond voor medisch handelen in verband met de delictsomschrijvingen van mishandeling erkend.

\section{Hoofdstuk III - Abortus}

Anders dan bij mishandeling bestaat bij abortus een belangenconflict. Het belang van de vrouw staat tegenover het belang van de wrucht. Slechts in de opvatting dat de vrucht deel is van de vrouw is geen sprake van een belangenconflict. Maar deze opvatting is in het strafrecht nawwelijks verbreid. De constructie van de uitsluiting van de strafrechtelijke aansprakelijkheid stuitte juist vanwege het belangenconflict op grote problemen.

De wetgever van 1886 heeft in de inmiddels vervallen abortusbepalingen, de artt. 295 e.v. geen voor de medicus bevrijdend bestanddeel opgenomen. Hij achtte de medious vanwege het ontbreken van de materiële wederrechtelijkheid niet strafbaar. Naar zijn mening was een bijzondere strafuitsluitingsgrond overbodig en gevaarlijk. Hij was overbodig, omdat het handelen volgens de regelen van de kunst reeds tot strafuitsluiting zou leiden. Hij was gevaarlijk, omdat een wettelijke constructie tot afbakeningsproblemen zou leiden.

Volgens enkele juristen was abortus door een medieus in beginsel strafbaar, omdat de wetgeving niet in een uitzondering voorzag. Overheersend was in het begin van deze eeuw dat overmacht in de zin van noodtoestand vanwege het belangenconflict geen oplossing kon bieden. $\mathrm{Bij}$ de medici bestonden twee tegenstrijdlige opvattingen over de wenselijkheid van de strafbaarstelling van abortus. Volgens de ene dienden de abortusbepalingen in het bellang wan de zedelijkheid zodanig geredigeerd te worden dat abortus beter wervolgd kon worden, ook al zou dit tot een beperking van de vrijheid van het handelen van de medicus leiden. Andere medici spraken zich uit voor het schrappen van de abortusbepalingen, daar deze ertoe bijdroegen dat abortus in het geheim en ten nadele van de gezondheid van de vrouw plaatsvond.

In de novellen Cort van der Linden uit 1900 en Loeff uitt 1904 werd een wijziging van de abortusbepalingen voorgesteld. Volgens de novelle-Cort van der Linden zou in de abortusbepalingen het bevoegde medisch handelen als bevrijdend bestanddeel worden opgenomen. In de toelichting werd opgemerkt, dat de medicus tot abortus bevoegd was als deze ingreep geschiedde in het bellang van het leven of de gezondheid van de vrouw. De voorgestelde wijziging van de bepalingen woorzag niet in een materieel criterium. Kritiek tegen het voorstel hield daarom in, dat de aldus gewijzigde abortusbepalingen geen duidelijkheid zouden verschaffen over de vraag of de medicus in een bepaald geval al dan niet bevoegd was tot de abortieve ingreep. 
In de abortusbepalingen van de novelle-Loeff was geen bevrijdend bestanddeel voon de medicus opgenomen. Daarmee wilde Loeff kenbaar maken dat de medicus evenals andere burgers onderworpen is aan de wetten van de zedelijkheid. Dit voorstel leidde tot een versterkte roep on rechtszekerheid voor de medicus. Enkele katholieke medici konden zich darentegen wel vinden in de voorgestelde beperkingen.

In 1909 beval een door de Nederlandsche Maatschappij tot Bevordering der Geneeskunst ingestelde commissie van medici en juristen aan in het Wetboek van Strafrecht een algemene bepaling op te nemen, op grond waarvan de arts, die een feil begat, dat naar redelijk inzicht is geboden of is toegelaten door de regelen van zijn kunst, niet strafbaar is. Tevens stelde de commissie een bepaling voor die de toestemming tot een medische handeling regelde, want aan het vereiste van toestemming tot een medische handeling hechtte zij veel bellang. De commissie achtte een algemene wettelijke strafuitsluitingsgrond voor medici van belang voor hun rechtszekerheid. Bovendien bood een dergelijke uitsluitingsgrond het voordeel dat hij ook de straffeloosheid van medisch handelen in verband met de strafbepalingen van mishandelling regelde.

In 1911 werd in het WvSr art. 251bis opgenomen. Deze bepaling, die met de invoering van de WAZ is komen te vervallen, breidde de aansprakelijkheid voor abortus sterk uit. In de literatuur is verdedigd dat de wetgever van 1911 de medische exceptie heeft erkend. Uit de parlementaire behandeling van deze bepaling blijkt dat deze analyse niet juist is. De wetgever gaf te kennen dat hij zich niet in staat achtte om in een uitzonderingsbepaling voor de medicus te voorzien en hij vertrouwde voor de strafuitsluiting op de toepassing van het opportuniteitsbeginsel door het Openbalar Ministerie.

Tot in de jaren zestig zijn de artsen in hun uitlatingen terughoudend over de indicaties op grond waarvan abortus volgens hen zou zijn toegestaan. Vanaf het midden van de jaren zestig komt het tot een verruiming van de indicaties. In 1971 aanvaardt de KNMG richtlijnen voor abortus. In deze richtlijnen komt de nadruk te liggen op procedureregels. Van een nawwkeurige opsomming van indicaties wordt afgezien. Daartoe acht de KNMG zich vanwege de verscheidenheid van gevallen niet in staat. De toelaatbaarheid van abortus op ruime indicatie is ook in medische kring omstreden. Als reactie op de tendens om de indicaties te verruimen wordt het Nederlands Artsen Verbond opgericht. Het NAV stelt zich ten doel de levensbescherming van het ongeboren en het geboren menselijk leven.

In de lagere rechtspraak over abortus wordt vanaf het midden van de jaren veertig een verruiming van de indicaties en daarmee van de straffeloosheid van de medicus voor abortus langzaamaan aanvaard. Door medici, politici en strafrechtjuristen wordt vanaf het midden van de jaren zestig erkend dat het begrip medische indicatie een ruimere inhoud heeft gekregen en dat de wetgever van zowel 1886 als van 1911 voor deze verniming van het begrip ruimte heeft gelaten. Verschil van mening heerst over hoeveel ruimte er voor dit begrip bestaat.

Het Openbaar Ministerie stelt zich ten aanzien van de vervolging van abortus door medici terughoudend op. Het Staatstoezicht op de volksgezondheid kwalificeert abortus als een medische handeling. Twee keer treedt het OM tegen de abortuskliniek Bloemenhove op. Deze incidenten, die met instemming van de toenmalige Minister Van Agt plaatsvonden, tonen aam dat de concrete toepassing van het opportuniteitsbeginsel afhankelijk is van de opvatting van de zittende Minister van Justitie. 
Tussen 1970 en 1981 worden tien wetsvoorstellen voor abortus bij de Tweede Kamer aamhangig gemaakt. Slechts in Een van die voorstellen, het voorstel-Lamberts/Roethof, wordt voorgestelld om de strafrechtelijke aansprakelijkheid van de medicus voor abortus op te heffen en de strafrechtelijke aansprakelijkheid voor abortus te beperken tot het handelen van onbevoegden tot de medische beroepsuitoefening. Dit voorstel verschilt ook nog in zoverre van de andere voorstellen dat het niet voorzag in een procedurele regeling voor abortus door een medicus.

In de andere voorstellen komt de nadruk op een procedurele regeling voor de medicus te liggen. Het blijkt immers moeilijk om een politieke meerderheid voor bepalalde indicaties te vinden. Daarom wordt afgezien van duidelijke materièle normen.

In 1981 wordt de Wet Afbreking Zwangerschap (WAZ) aangenomen. Volgens deze wet is abortus een strafbare handeling. Voor de strafuitsluiting van de medicus dient een bijzondere rechtvaardigingsgrond, op grond warvan de medicus niet aansprakelijk is voor zover hij de ingreep in een erkende inrichting heeft uitgevoerd. De eigenlijke WAZ behelst een aantal procedurele en administratieve bepalingen. Voor cle afwezigheid van een materiële normstelling wordt in de MvT op de verscheidenheid van gevallen gewezen, die zich niet leent voor een algemene materiële normstelling. Daarom dient de bescherming van de vrucht via procedurele warborgen bereikt te worden. Behalve dat deze regeling niet in een materieel criterium voorzlet; is zij op meerdere punten onduidelijk. Zo is niet nauwkeurig vastgelegd wanneer de zelfstandige levensvatbaarheid van de vrucht ingaat en blijft onduidelijk of een overtijdsbehandeling al dan niet onder de strafbepaling danwel onder het regime van de eigenlijke WAZ valt.

Vanwege de bijzondere rechtvaardigingsgrond voor abortus door een medicus geldt ten aanzien van abortus door een medicus geen medische exceptie. Bovendien heeft de wetgever van 1981 verklaard, dat ook de artsen aan de wettelijke beperkingen gebonden zijn. Die brengen mee dat de arts in beginsel strafbaar is als hij in strijd met de abortusbepalingen handelt en de rechtvaardigingsgrond van art. 296 lid 5 Sr niet van toepassing is. In dat geval kan hij zich evenwel onder omstandigheden met succes op noodtoestand beroepen.

De abortuswet van 1984, de WAZ, brengt tot uitdrukking dat de beschermwaardigheid van het ongeboren menselijk leven ondergeschikt is aan die van het geboren leven en zelfs aan de wens van de vrouw om geen kind ter wereld te brengen. Met de WAZ heeft de wetgever tevens in zekere zin het zellbeschikkingsrecht van de vrouw ten aanzien van bepaald omstreden medisch handelen aanvaard, door aan het verzoek van de vrouw een doorslaggevende rol toe te kennen.

\section{Hoofdstuk IV - Thanasie}

De wetgever van 1886 heeft art. $293 \mathrm{Sr}$ in het leven geroepen, omdat hil aanleiding zag voor een geprivilegieerde strafbaarstelling als de levensberoving op verzoek van het slachtoffer geschiedt. Art. $294 \mathrm{Sr}$ kwam in het WwSr terecht orndat de (poging tot) zelfmoord zelf niet strafbaar was en derhalve woor de strafrechtelijke aansprakelijkheid van helpers niet op de algemene deelnemingsbepalingen kon worden teruggevallen. Als rechtsgrond voor de strafbaarstelling van beide delictsomschrijvingen noemde hij de eerbied die aan het menselijk leven in het algemeen is verschuldigd. Over euthanasie werd tijdens de totstandkoming van deze artikelen niet gesproken. 
Tot in de jaren zestig is in de geraadpleegde literatuur weinig melding gemaakt wan euthanasie. Uit de enkele mededelingen en artikelen in het NTVG en hei MC valt af te leiden dat een medisch zinloze handeling kan worden nagelaten en dat het in de stervensfase ter pijnbestrijding toegestaan is levensverkortende pijnbestrijders toe te dienen. Actieve levensbeëindiging, waarbij het doel is de dood te bewerkstelligem, werd echter afgewezen, ook wanneer op verzoek van de patient zou worden gehandeld. Volgens de medische ethiek diende de arts primair ten gunste van het behoud van het leven te handelen.

In de jaren zestig wordt een tegenstelling zichtbaar tussen deze "oude" en een nieuwe medische ethiek. De nieuwe medische ethiek houdt in dat het de arts geboden is het menselijk leven te behouden, te sparen en te verlengen, waar en wanneer dat zinvol is. De tegenstelling tussen de oude en de nieuwe medische ethiek betreft vooral de toelaatbaarheid van actief rechtstreeks levensbeeindigend handelen, al dan niet op verzoek.

Na het verschijnen wan het rapport van de Staatscommissie Euthanasie in 1985 lijkt het erop dat levensbeeindiging op verzoek in het algemeen wordt geaccepteerd. Daarna echter krijgen de tegenstanders meer gewicht in de discussie.

In de discussie over euthanasie worden werschillende vormen onderscheiden. Vanaf rond 1985 raakt de volgende terminologie steeds meer ingeburgerd. Onder euthanasie wordt slechts verstaan het opzettelijk levensbeëindigend handelen door een ander dan de betrokkene, op diens werzoek. De levensverkortende pijnbestrijding met instemming van de patient wordt als normaal medisch handelen beschouwd, voor zover andere middelen ontbreken om de pijn te bestrijden. Verder wordt erkend dat een behandeling bij een wilsbekwame patiënt niet zonder diens toestemming mag plaatsvinden. Ook is het aan de arts niet geoorlloofd om een medisch zinloze behandeling te verrichten.

Geconcludeerd wordt dat het nalaten van (verder) handelen op verzoek van de patiënt en het nalaten van medisch zinloos handelen niet strafbaar is, omdat in beide gevallen een zorgplicht ontbreekt. Levensverkortende pijnbestrijding en euthanasie zijn in beginsel strafbaar. Vindt levensverkortende pijnbestrijding met toestemming plaats dan vertoont deze handeling strafrechtelijk gezien overeenkomst met euthanasie. Beide vallen in beginsel onder art. $293 \mathrm{St}$. Levenswerkortende pijnbestrijding bij wilsonbekwame patiënten vertoont overeenkomst met wat genoemd wordt levensbeëindiging. Mogelijke wegen voor strafuitsluiting van deze beide gedragingen worden in het tweede en in het derde onderdeel van dit hoofdstuk onderzocht.

In het tweede onderdeel van dit hoofdstuk worden het initiatiefvoorstel Wesse]Tuinstra/Kohnstam, het rapport van de Staatscommissie Euthanasie, de Proeve, het kabinetsvoorstel en het kabinetsstandpunt besproken. Daarbij wordt ook aandacht geschonken aan het onderzoek voor en het rapport van de Commissie Medische Beslissingen rond het levenseinde.

Het initiatiefvoorstel pleit ervoor euthanasie en hulp bij zelfdoding in het WvSr te regelen. Ter strafuitsluiting van de arts dient een bijzondere rechtvaardigingsgrond. Deze is van toepassing voor zover de arts aan bepaalde zorgvuldigheidseisen heeft voldaan. Nadnk wordt gelegd op het verzoek van de patiënt en op diens situatie, die als uitzichtloze noodsituatie wordt aangeduid.

Ook de Staatscommissie Euthanasie stelt voor euthanasie en hulp bij zelfdoding in het WwSr te regelen. Zij denkt voor de strafuitsluiting eveneens aan een bijzondere rechtvaardigingsgrond en stelt in verband daarmee enkele zorgvuldigheidseisen voor. Van het initiatiefvoorstel onderscheidt zich het voorstel van de Staatscommissie vooral daardoor dat het laatste een negatieve bepaling behelst, waarin gedragingen omschreven worden 
die op euthanasie lijken, maar die naar de mening van de Staatscommissie niet daaronder vallen. Ëen wan de negatieve omschrijvingen heeft betrekking op het nalaten van het behandelen wan een bijkomende ziekte of aandoening bij een comateuze patiènt: Verder voomiet het voorstel van de Staatscommissie in een bijzondere strafuitsluitingsgrond ten aanzien van actieve levensbeëindiging bij een comateuze patiènt die niet kunstmatig beademd wordt.

De Proeve van het kabinet stoelt op het voorstel van de Staatscommissie, maar behelst twee belangrijke verschillen. Strafuitsluiting zou via een bijzondere schulduitsluitingsgrond worden bereikt. Tevens heeft het kabinet de bijzondere strafuitsluitingsgrond ten aanzien van actieve levensbeëindiging bij comateuze patiënten die niet kunstmatig beademd worden, niet overgenomen.

In alle voorstellen wordt groot gewicht toegekend aan het verzoek van de patiënt en aan diens situatie, die in het algemeen als uitzichtloze noodsituatie wordt aangeduid. Tevens wordt van groot belang geacht dat de arts een of meer collega-artsen heeft geraadpleegd en dat hij een journaal bijhoudt. Volgens het initiatiefvoorstel en het voorstel van de Staatscommissie komt aan een schriftelijke euthanasieverklaring bij patiënten die op het moment van de beslissing hum wil niet kunnen uiten even veel waarde toe als aan een mondeling verzoek.

Volgens de toelichtingen op deze drie voorstellen is geen van de voorstellen in strijd met art. 2 EVRM, daar alle voorstellen als hoofddoel hebben de bescherming van het menselijk leven en zij - materieel gezien - geen nieuwe rechtvaardigingsgrond voor levensbeëlndigend handelen creëren. Tevens wordt ervan uitgegaan dat tussen de verboden van art. 2 en art. 3 EVRM een belangenafweging mag plaatswinden. In de Minderheidsnota van de Staratscommissie Euthanasie wordt dit standpunt bestreden. Volgens deze nota is art. 2 EVRM normatief van aard. Euthanasie mag wettelijk slechts dan gerechtvaardigd zijn, wanneer de wetgever ook daadwerkelijk levensbeëindigend handelen tegengaat. In de literatuur worden over de betekenis van de artt. 2 en 3 EVRM voor euthanasie vergelijkbare standpunten ingenomen. In de Memorie van Toelichting op de gewijzigde Proeve wordt meegedeeld, dat volgens de lidstaten euthanasie een strafbaar feit behoort te blijwen. Een wettelijke regeling van euthanasie conform éen van de voorstellen behoeft daarmee niet in strijd te zijn. Hier wordt het standpunt verdedigd, dat een wettelijke regeling van euthanasie niet per se in strijd is met art. 2 ERM.

Naar aanleiding van het advies van de Raad van State over het initiatiefvoorstel en de Proeve komt het kabimet met en nieuw voorstel: het zogenaamde kabinetsvoorstel. Volgens dit voorstel zullen de zorgvuldigheids-en procedurele eisen voor euthanasie en de negatieve bepaling in de WUG worden opgenomen. Ter strafuitsluiting wordt verwezen naar de in art. $40 \mathrm{Sr}$ neergelegde strafuitsluitingsgrond overmacht. Als de zorgvuldigheidseisen worden nageleefd, dan brengt dit volgens het kabinetsvoorstel niet automatisch mee dat de arts vrijuit gaat en als aan (al) deze eisen niet wordt voldaan, dan houdt dit niet zondermeer in dat de arts niet met succes een beroep op art. $40 \mathrm{Sr}$ kan doen. Het kabinetswoorstel ontmoet vanwege de onduidelijkheden die dit voorstel schept en vanwege de ondoorzichtige koppeling met het WvSr terecht kritiek van ondermeer de vereniging van de Procureurs-Generaal en de Gezondheidsraad.

Nadien acht het kabinet het nodig dat een onderzoek naar de euthanasiepraktijken onder artsen plaatsvindt. Dat onderzoek wordt in opdracht van de Commissie Medische Beslissingen rond het levenseinde vericht. Ter waarborging van een goede medewerking wan artsen aan dit onderzoek, wordt een meldingsprocedure vastgelegd, op grond waarvan 
justitie bij gemelde gevallen van euthanasie terughoudend dient op te treden. In het vervolgingsbeleid wordt geen wijziging gebracht.

Uit het onderzoek voor de Commissie blijkt, dat het bij de 130.000 stervensgevallen per jaar in circa 2.300 gevallen per jaar tot euthanasie komt. Opmerkelijk is dat levensverkortende pijnbestrijding en het nalaten van medisch zinloos handelen elk 22,500 keer per jaar plaatsvinden en actieve levensbe ëindiging zonder verzoek rond 1.000 keer. Ten aanzien van het laatste getal en de omstandigheden waaronder de levensbeëindiging plaatsvond, verschaft het onderzoek onvoldoende gegevens. Niet in alle gevallen waarin toestemming van de patiënt tot het levensverkortend handelen gevraagd had kunnen worden, gebeurde dat ook. De artsen geven in verreweg de meeste gevallen van euthanasie, levensbeëindiging en levensverkortende pijnbestrijding een verklaring van natuurlijk overlijden af. Daartoe geven zij als voornaamste redenen op dat zij rompslomp door justitieel optreden willen voorkomen en dat een mogelijk justitieel onderzoek voor de naaststaanden te belastend zou zijn. Over de voorkeur van artsen voor een regeling van euthanasie kan het volgende gezegd worden. Een grote groep artsen heeft een voorkeur voor een regeling in de zin van het initiatiefvoorstel, een andere groep kan zich vinden in het voorstel van de Proeve, een derde groep is van mening dat een bijzondere wettelijke regeling van deze problematiek de weg baant voor een uitbreiding van de euthanasiepraktijken. Circa een kwart van de artsen is onder geen beding bereid euthanasie en levensbeeindiging te melden. In een aantal gevallen werd geen consult verricht en van verslaglegging afgezien.

De Commissie Medische Beslissingen beveett aan de meldingsprocedure te bestendigen en nadruk te leggen op het consult en de verslaglegging. Het kabinet pakt het idee van de meldingsprocedure op en deelt als zijn standpunt aan de Tweede Kamer de volgende procedure voor euthanasie en levensbeëindiging mede.

De Wet op de lijkbezorging wordt zodanig gewijzigd dat de arts euthanasie en levensbeeindiging aan de gemeentelijke lijkschouwer behoort te melden, onder overlegging van een bij AMvB vastgelegde lijst van vraagpunten. De gemeentelijke lijkschouwer dient na te gaan of de arts tot euthanasie of levensbeëindiging mocht overgaan en of hij zorgvildig te werk is gegaan. Vervolgens informeert de lijkschouwer de OvJ die beslist of hij al dan niet tot vervolging wil overgaan. In het laatste geval neemt hij contact op met de geneeskundig inspecteur voor de volksgezondheid. Mede van diens standpunt zal dan kennelijk afhangen of de OvJ daadwerkelijk tot vervolging overgaat. Daarmee zal euthanasie en levensbeëindiging met behulp van een sepotbeleid geregeld worden.

Het kabinet benadrukt dat het met deze meldingsprocedure de toetsbaarheid van levensbeëindigend handelen benadrukt, maar levensverkortende pijnbestrijding vait niet onder deze procedure. Wellicht nog opmerkelijker is dat in de toelichting op het standpunt geen stelling wordt genomen inzake de toelaatbaarheid van actieve levensbeëindiging. Het kabinet spreekt de hoop uit dat langs jurisprudentiële weg de normering voor dit handelen uitkristalliseert. Impliciet heeft het kabinet daarmee de toelaatbaarheid van actieve levensbeëindiging zonder verzoek erkend. Waarover volgens het kabinet nog onvoldoende duidelijkheid bestaat is kennelijk onder welke omstandigheden daartoe mag worden overgegaan.

In het tweede onderdeel van het tweede deel van dit hoofdstuk wordt nagegaan, in hoeverre onder de bestaande bepalingen tot strafuitsluiting vanwege euthanasie kan worden gekomen. Deze vraag heeft vanwege het kabinetsstandpunt niet aan actualiteit verloren. 
De delictsomschrijving van art. $293 \mathrm{Sr}$ leent zich niet voor en interpretatie op grond wiarvan gesteld kan worden dat euthanasie niet aan de delictsomschrijving voldoet. Dat geldt evenzeer voor hulp bij zelfdoding in verband met art. $294 \mathrm{Sr}$.

Voor de strafuitsluiting vanwege het ontbreken van de materiêle wederrechtelijkheid moet tussen twee vormen van deze rechtsgrond worden onderscheiden. In de meest gebruikelijke vorm houdt deze rechtsgrond in dat het handelen conform de bewoordingen van de delictsomschrijving beter voldoet aan de bedoeling van de wetgever dan door van het handelen af te zien. Het is evident dat deze invulling van het ontbreken van de materiele wederrechtelijkheid bij euthanasie en bij hulp bij zelfdoding geen succes kan hebben, varnwege de door de wetgever aangevoerde rechtsgrond voor deze strafbepalingen, namelijk de eerbied voor het menselijk leven in het algemeen verschuldigd. Een andere invulling van deze rechtsgrond houdt in, dat de materiële wederrechtelijkheid ontbreekt vanwege de rechtsontwikkeling. Dan wordt gesteld dat de wettelijke norm van art. $293 \mathrm{Sr}$ (resp. art. 294 Sr) thans onvoldoende steun in de samenleving ondervindt of nog verder, dat een meerderheid in de samenleving thans uitgaat van een contrariërende norm, zodat aan art. $293 \mathrm{Sr}$ (en aan art. $294 \mathrm{Sr}$ ) een verouderde norm ten grondslag ligt.

Terwijl enkele rechtbanken het zelfbeschikkingsrecht inzake het overlijden hebben erkend, heeft de Hoge Raad overwogen dat de eerbiediging wan het zelfbeschikkingsrecht en het hulp verlenen aan de mens in nood maatschappelijk niet zo algemeen aanvaard zijn, dat daarom art. 293 Sr niet van toepassing zou zijn. Daaraan voegde de Hoge Raad toe, dat ook bij voldoende maatschappelijke aanvaarding het de vraag is, of de rechter de vrijhelid heeft de norm van art. 293 Sr terzijde te stellen. Naar mijn mening komt aan de rechter deze vrijheid niet toe. Het gaat hierbij immers niet om een creatieve interpretatie, maar om een interpretatie contra legem. Waar een dergelijk uitzonderlijk rechtsgoed als het menselijk leven in het spel is, dient een verbiedende norm strikt te worden geïnterpreteerd.

In de literatuur zijn de meningen over de erkenning van een zelfbeschikkingsrecht ten aanzien van de eigen dood verdeeld. Mijns inziens zijn er in de loop van de tijd wel meer argumenten aan te wijzen voor een erkenning van dit recht, daar inmiddels algemeen is aanvaard dat een arts een wilsbekwame patiënt niet zonder diens toestemming mag behandelen. Weigert de patiënt de behandeling, dan is de arts gehouden daarvan af te zien, ook brengt dit mede dat de patiënt vanwege het niet-behandelen komt te overlijden. Vanwege de erkenning van dit recht, wordt het verschil met euthanasie zeer klein. Het gaat dan niet langer om de vraag of de betrokkene over het tijdstip van het eigen sterven mag beschikken, maar in hoeverre derden daaraan mee mogen werken. Tegen erkenning van een dergelijk zelfbeschikkingsrecht pleit, dat dan iedereen hulp tot verwezenlijking van dit recht zou mogen verlenen, mits hij voldoende zorgvuldig te werk gaat. Dat is ten eerste contra legem en ten tweede feitelijk niet aanvaardbaar. Terecht wondt daarom in de rechtspraak het zelfbeschikkingsrecht geclausuleerd begrepen. Een mens heeft cen recht op een zachte dood en op een waardig sterven, voor zover dat in zijn macht ligt. Om dat te verwezenlijken is hij de hulp van derden noodzakelijk. Daarom kunnen slechts. die derden met succes een beroep op het ontbreken van de materiële wederrechtelijkheid doen, die tot een zorgvuldige hulpverlening in staat zijn. Volgens de rechtspraak zijn als zodanig artsen aan te merken.

Bij euthanasie gaat het om twee hoofdvoorwaarden, de zelfbeschikking en de noodsituatie. Als het accent op de noodsituatie komt te liggen, dan kunnen op deze wijze beperkingen worden gesteld aan het thanatiseh handelen van derden. Het voordeel van het benadrukken van het zelfbeschikkingsrecht is daarentegen, dat de noodsituatie geen overheer- 
send criteriam wordt en uiteindelijk belangrijker wordt dan de wil van de patiênt. Daar het criterium untzichtloze noodsituatie mede subjectief wordt bepaald, wordt hier bepleit het verzoek van de patient centraal te stellen.

Terwijl onder de genoemdle beperkingen een beroep op het ontbreken van de materiele wederrechtelikheid niet zondermeer kansloos behoeft te zijn, bestaat daaraan geen behoefte, zolang euthanasie afhankelijk wordt gesteld van een wilsuiting gekoppeld aan een noodsituatie. Want de noodsituatie maakt het mogelijk een bercep te doen op noodtoestand en daarmee op een wettelijke strafuitsluitingsgrond.

In de literatuur is verdedigd dat de medicus zich ten aanzien van euthanasie met succes op de medische exceptie kan beroepen. Deze mogelijkheid is door de Hoge Raad uitdnikkelijk verworpen met de overweging dat de wetgever de medische exceptie ten anzien van euthanasie niet heeft erkend. Daartoe verwijst de Hoge Raad terecht ondermeer naar de wetsgeschiedenis van 1886 . Daarin zijn geen aanwijzingen te vinden, dat de wetgever de arts voor enigerlei handelen in strijd met de artt. 293 en 294 Sr straffelloos wilde laten zifin..

Een derde mogelijkheid voor strafuitsluiting biedt overmacht in de zin van noodtoestand. Deze weg is door de Hoge Raad bewandeld. Hij heeft daarbij aangetekend dat dan met het handelen contra legem een objectief meerwaardig belang moet worden nagestreefd. Daarvan ts volgens de Hoge Raad sprake als 'naar wetenschappelijk verantwoord medisch inzicht en naar in de medische ethiek geldende normen, zich een situatiie voordeed welke als noodtoestand aangemerkt mocht worden'. Vanwege het grote belang dat de Hoge Raad aan medisch-ethische normen toekent, kan worden gesteld dat de medische exceptie in de noodtoestand ingang heeft gevonden.

Terwijl in de lagere rechtspraak specifieke voorwaarden voor toelaatbare euthanasie zijn geformuleerd, heeft de Hoge Raad daarvan afgezien. Daarmee heeft hij beklemtoond dat elk geval op zichzelf beoordeeld dient te worden. In het eerste euthanasie-arrest heeft hij erop gewezen dat de vraag of bij euthanasie sprake is van een noodtoestand "afhankelijk is van diverse factoren, welke van geval tot geval kunnen verschillen'. Niet noodzakelijk is dat de geconsulteerde arts objectief en onafhankelijk is van de behandelende arts. In een latere uitspraak heeft de Hoge Raad zelfs bepaald dat het niet-raadplegen van een collega-arts een beroep op noodtoestand niet uitsluit. Daarmee heeft de Hoge Raad aan de open strafuitsluitingsgrond overmacht (noodtoestand) ook voor euthanasie voldoende ruimte willen laten.

Nodig blijft wel dat een noodsituatie van een patiënt de arts tot de keuze "dringt". Vermoedelijk blijven ook de in lagere rechtspraak geformuleerde voorwaarden aan de zijde van de patiënt (verzoek en uitzichtloos lijden) overeind. Deze typeren immers diens noodsituatie en rechtvaardigen een bepaald handelen van de arts. Verder is, zoals voor elk handelen wan de arts nodig, dat hij zorgvuldig te werk gaat. Niet nodig is dat de arts een andere arts consulteert ${ }_{j}$ dat hij familieleden raadpleegt en een journaal bijhoudt. Als daaraan is voldatan dan versterkt dat wel de bewijsrechtelijke positie van de arts, doordat het beroep op noodtoestand eerder aannemelijk maakt.

Wanneer derhalve meer voorw aarden voor de straffeloosheid wenselijk zijn, dan dient de wetgever te spreken.

In het derde deel van dit hoofdstuk wordt de "levensbeëindiging" besproken. Onder "levensbeeindiging" wordt verstaan een levensbeëindigende gedraging ten aanzien van wilsonbekwamen. Deze gedraging kan bestaan uit een doen of een nalaten. Niet onder levensbeëindiging valt het nalaten van medisch zinloos handelen. Uitgangspunt voor de 
geoorloofdheid van "levensbeeindiging" is dat (verder) belhandelen "zinloos" is: Dat woord moet kennelijk in een beperktere betekenis begrepen worden dan het begrip 'medisch zinloos". Voor de vraag of en zo ja, wanneer levensbeèindiging niet strafbaar is, is van belang wat in dit verband onder "zinloos" moet worden verstalan.

Verschillende commissie hebben in de laatste jaren rapporten ten aanzien van levensbeeindiging uitgebracht. Daaruit valt op te maken, dat onder 'medisch zinloos' wordt begrepen dat de patiēnt geen overlevingskans heeft en het resterende leven waarschijnlijk met een ernstig en niet op te heffen lijden gepaard gaat. De prognose dat handelen "medisch zinloos" is wordt genomen aan hand van medische criteria.

Van 'medisch zinloos' moet worden onderscheiden wat hier 'ethisch zinloos' wordt genoemd. Daaronder wordt verstaan dat de prognose voor wat betreft de latere gezondheid zeer slechts is, gezien de geringe kans op een leefbaar leven. Er wordt in dit verband gesproken van een 'ethisch zinloos handelen", een 'te gering levensperspectief", "geen leefbaar leven', "onvoldoende kwaliteit van leven". In de rapporten wordt erkend dat deze prognose sterk subjectief is bepaald.

Daarom stellen de Commissie Aanvaardbaarheid Levensbeëindigend Handelen en de Werkgroep Doen of Laten van de Vereniging voor Kindergeneeskunde voor een referentiekader ter beoordeling van de gevallen te ontwikkelen, waarbij ten aanzien van ernstig gehandicapte pasgeborenen levensbeëindigend mag worden opgetreden, om op deze wijze tot een consensusbevordering te komen. De CAL wil bovendien aan de in het referentiekader opgenomen criteria grenswarden worden toegekend.

Vervolgens wordt ingegaan op levensbeëindiging bij irreversibel comateuze patiënten. Hiervoor stelt de CAL geen referentiekader voor. Haar uitgangspunt is dat bij irreversibel coma het behandelen mag worden nagelaten. Zij merkt het verblijven in een coma niet als overleven aan. Er is nog slechts sprake van een beperkt biologisch leven. Doorbehandelen is in haar opvatting in strijd met de menselijke waardigheid. Volgens de CAL is de grens tussen medisch zinloos en ethisch zinloas handelen bij irreversibel comateuze patuënten niet goed te trekken.

De morele rechtvaardiging voor het nalaten van ethisch zinloos handelen bij wilsonbekwame patiënten wordt gezien in de afweging die gemaakt moet worden tussen een ongunstige prognose ten aanzien van het lijden en een gunstige prognose ten aanzien van het leven. Het leven van de wilsonbekwame kan met de behandeling behouden worden. Maar het willen behouden van het leven kan in strijd komen met een andere doelstelling van het medisch handelen; namelijk het lijden te verzachten. Wanneer zich een dergelijke situatie voordoet, dan kan de medicus gerechtigd zijn om het handelen na te laten. Dat is in overeenstemming met het adagio "in dubio abstine".

De besluitvorming ten aanzien van levensbeëindiging bij zwar-defecte pasgeborenen werschilt van die bij irreversibel comateuze patiënten daardoor, dat in het geval van een pasgeboren patiënt aan de stem van de ouders een belangrijke rol toekomt. Als het handelen ethisch zinloos is en de ouders zich voor behandelen uitspreken, dan vertolken de ouders in beginsel de wil van het kind en kunnen zij een andere arts zoeken die het kind wel wil behandelen. Als echter ook andere artsen zich tegen een behandeling uitspreken, dan gaat de CAL ervan uit dat de ouders niet meer de wil van het kind vertolken.

Tot actieve levensbeèindiging van zwaar-defecte pasgeborenen bij wie behandelen medisch zinloos is, kan slechts met toestemming van de ouders worden overgegaan. 
Wanneer over de toelaatbaarheid van levensbeëindiging wordt gesproken, dan wordt in het algemeen bedoeld de toelaatbaameid van het nalaten te behandelen. Tussen dit nalaten en actieve levensbeeindiging wordt een moreel verschil geconstateerd. Actieve levensbeëindiging is het meest controversieel en wordt slechts toelaatbaar geacht in situaties waarin het moreel geoorlloofd is het handelen na te laten en als bijzondere omstandigheden tot actieve levensbeëindiging nopen. Voor deze situaties achten de commissies zich niet in stat algemene criteria te geven. De Gezondheidsraad was in 1975 van mening dat de bestaande strafuitsluitingsgronden toereikend zijn en dat actieve levensbeëindiging strafbar moet blijven. Voor zover in zeer uitzonderlijke omstandigheden tot actieve levens beëlindiging wordt overgegaan, kan deze eventueel verontschuldigbaar zijn, maar nooit gerechtvaardigd. Uit deze standpunten kan afgeleid worden dat vanuit medische zijde wetgeving ten aanzien van actieve levensbeëindiging niet (dringend) gewenst wordt: Voor andere vormen van levensbeëindiging spreken de CAL en de werkgroep Doen of laten zich üt voor een procedurele regeling, daar naar hun mening vanwege de verscheidenheild van de gevallen geen materie̋le criteria gegeven kunnen worden.

In de medische wereld wordt belang gehecht aan de bedoeling waarmee wordt gehandeld: Onder opzettelijke levensbeeindiging wordt verstaan het beogen van de dood van de patiënt. Actieve levensbeëindiging wordt altijd als opzettelijke levensbeëindiging gezien, omdat de arts dan niet anders dan de dood van de patiënt kan beogen. Als niet-opzettelijk vormen van levensbeëindiging beschouwt de werkgroep Doen of laten het niet (verder) behandelen zonder dat het oogmerk van de arts op het overlijden is gericht. In haar meest

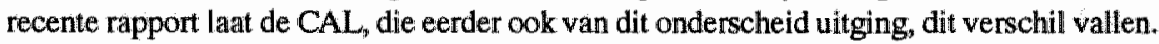
Zij spreekt daarom in plaats van al dan niet beogen van bewerkstelligen en constateert vervolgens dat tussen het nalaten te behandelen en actieve levensbeëindiging geen scherp verschil is te maken. Ook verschilt de verantwoordelijkheid van de arts voor beide vormen van levensbeëindiging niet. Alle vormen van levensbeëindiging moeten voor de $\mathrm{CAL}$ vooral op hun consequenties beoordeeld worden. Deze laatste wijze van het benaderen van de verantwoordelijkheid van de arts voor levensbeëindiging is in overeenstemming met de wijze waarop in het strafrecht het opzet wordt geconstrueerd.

De commissies vestigen de aandacht op het bijhouden van een journaal, vooral in verband met het niet-afgeven van een overlijdensverklaring. Volgens de commissies mag een verklaring van natuurlijk overlijden worden afgegeven bij levensverkortende pijnbestrijding, nalaten van medisch zinloos handelen en het afzien van handelen ondat de patiênt weigert tot de behandeling toestemming te geven. De commissies hebben er begrip voor dat artsen ten onrechte overlijdensverklaringen afgeven. Dat is volgens hen te wijten aan de bestaande rechtsonzekerheid en aan het feit dat juristen ten onrechte denken dat een scherp onderscheid gemaakt kan worden tussen medisch zinloos en ethisch zinloos.

Na de bespreking van de wijze waarop door medici tegen levensbeëindiging wordt aangekeken; wordt ingegaan op de mogelijkheden die het bestaande strafrecht biedt om levensbeeindiging niet strafbaar te achten. Voor een strafrechtelijke benadering is wezenlijk dat niet van belang is of levensbeëindiging bewerkstelligd wordt door niet beginnen; stoppen of staken van een behandeling of dat een 'euthanaticum' wordt toegediend. Voor zover op de medicus een zorgplicht rust om te handellen, leidt het nalaten te handelen evenzeer tot strafrechtelijke aansprakelijkheid ais het verrichten van levensbeëindigende handelingen.

De rechtspraak over levensbeëindiging betreft meestal zaken, waarbij anderen dan artsen tot levensbeëindiging zijn overgegaan. Desondanks kunnen daaruit enkele gevolg- 
trekkingen worden afgeleid voor levensbeeindiging door artsen. Tot nu toe stabit de (lagene) mechter afwijzend tegenover actieve levensbeëindiging. Het grootste struikelblok vormt de afwezigheid van een verzoek van de patiënt. In verschillende uitspraken wordt erop gewezen dat voor de geoorloofdheid van actieve levensbeëindiging wetswijziging nodig is.

Aan twee gevallen in de rechtspraak wordt meer aandacht besteed. De eerste betreft de zaak Stinissen. Hierbij ging het om een patięnt die zich in een irreversibel coma bewond, spontaan ademde en via een sonde werd gevoed. Het hof overwoog ten aanzien van de vraag of de arts de behandeling mocht nalaten, dat de rechter op dit terrein terughoudend dient te zijn, omdat een beslissing daarower vooral de medische vraag betrof of verder behandelen al dan niet medisch zinloos is. In een andere zaak vindt deze overweging bevestiging.

Strafrechtelijk gezien is voor levensbeëindiging vooral de zaak baby Ross belangrijk. In deze zaak werd de arts vervolgd omdat hij bij een mongoloïde pasgeborene niet to: operatie van een maag- en darmafwijking was overgegaan en vervolgens de behandeling had gestaakt. Volgens het hof was de operatie kennelijk ethisch zinloos. De uitspraak van het hof is in overeenstemming met de rapporten van de CAL en de werkgroep Doen of laten. Er bestond twijfel over het nut van de operatie. De operatie had de wreg kunnen openen voor een leven met lijden. In deze situatie heeft het adagio "in dubio abstine" de doorslag gegeven. Van belang daarvoor was bovendien dat de ouders zich tegen de operatie hadden uitgesproken.

\section{Hoofdstuk V - Slotbeschouwing}

In de slotbeschouwing wordt erop gewezen, dat de medische exceptie goed dienst kan doen bij medische ingrepen die pijn of letsel meebrengen, omdat het behandelingsdoel maatschappelijk niet omstreden is.

Voor abortus ligt een bijzondere strafuitsluitingsgrond meer voor de hand, daar het antwoord op de vraag of het leven van de vrucht of het bellang van de vrouw voorrang heeft afhankelijk is van levensbeschouwelijke overtuigingen.

Ook ten aanzien van euthanasie is een wettelijke regeling wenselijk. Ook hierbij wordt een beslissing genomen die llevensbeschouwelijke waarden betreft. Vanwege het gevaar voor misbruik en willekeur verdient daarbij een regeling de voorkeur, waarbij de nadruk op het verzoek van de patiënt komt te liggen en controle en toetsing zo veel mogelijk verzekerd zijn.

Hoewel het nalaten van medisch zinloos handelen, het niet behandelen omdat de patiënt weigert toestemming tot de behandeling te geven en de levenswerkortende pijnbestrijding met toestemming tot het normale medisch handelen worden gerekend, verdient het aanbeveling ook dit handelen aan een regeling ter controle en toetsing te onderwerpen, omdat het in individuele gevallen niet goed af te gremzen zijn is euthanasie en levensbeềindiging en omdat dit handelen als camouflage van euthanasie en levensbeëindiging kan dienen.

Bij wilsonbekwame patiënten, die ook niet eerder een schriftelijke wilswerklaring hebben opgesteld, dient in twijfelgevallen het behoud van het leven op de voorgrond te staan. Bij een patiëmt die eerder wilsbekwaam is geweest en die in die tijd geen levenstestament heeft gemaakt, zou mijns inziens veronderstelt mogen worden dat hij behandeld will worden. Zowel bij deze categorie patiënten als bij duurzaam wilsonbekwame patiënten geeft de doorslag dat in een rechtsstaat de bescherming van het leven centraal staat. Daarop 
is ook de regel gegrondwest dat bij een patiënt die tijdelijk wilsonbekwaam is, verondersteld wordi dat deze behandeld will worden. Uitzonderingen hierop kunnen niet verdedigd worden met de will van de patiënt en dienen derhalve gegrondvest te zijn op de uitzonderlijke comstandigheden waarin de patiënt zich bevindt. Het is goed hierbij te onderscheiden tussen irreversibel comateuze en andere wilsonbelwame patiënten.

De vraag of irreversibel comateuze patiënten moeten worden doorbehandeld is een normatieve vraag en derhalve vereist nalaten van medische behandeling een wettelijke regeling. Voor zover deze tot het oordeel komt, dat de behandeling mag worden nagelaten, zou hij aansluiting kunnen zoeken bij het tijdscriterium dat de CAL in haar rapport uit 1991/1990 geeft.

Voor levensverkortende pijnbestrijding is, zoals voor elke behandeling, toestemming van de patiënt vereist. Is de patięnt daartoe niet in staat, dan wordt ervan uitgegaan dat hij de behandeling wenst, omdat zij in zijn (levens)belang is. Dat is niet het geval bij de levensverkortende pijnbestrijding. Deze verkort immers het leven van de patiënt. Maar daar staat tegenover dat zij de pijn van de patiënt bestrijdt. Naar mijn mening is het daarom ook hier noodizakelijk dat de wetgever over de toelaatbaarheid van de levenswerkortende pijnbestrijding bij wilsonbekwame patiënten een beslissing neemt. Aanknopingspunten voor levensverkortende pijnbestrij ding bij đeze patiënten zouden moeten zijn de mate van lijden (in geobjectiveerde zin), de verwachte levensduur van de patiënt en de toestand waarin de patient zich bevindt en het leven dat hij tegemoet gaat.

Tot actieve levensbeëindiging zou naar mijn mening slechts in het algemeen niet mogen worden overgegaan. Slechts in zeer uitzonderlijke omstandigheden als het nalaten van behandelen tot vermeerdering van het lijden van de patiënt leidt, zou actieve levensbeëindiging gerechtvaardigd kunnen worden geacht. Naar mijn mening zou ten aanzien van actieve levensbeëindiging met de bestäandle strafuitsluitingsgronden kunnen worden volstaan. 


\section{Zusammenfassung}

Die Arbeit untersucht die strafrechtliche Haftung des Arztes. Ausgangspunkt ist dabei ein sorgfältig handelnder Arzt. Es geht in dieser Arbeit also nicht um Kunstfehler, sondern um Fragen der richtigen medizinischen Entscheidung.

Das erste Kapitel analysiert zwei Urteile des niederländischen obersten Gerichts (Hoge Raad) aus der ersten Hälfte der dreiBiger Jahre. An diese Urteile hat sich in der Strafrechtswissenschaft die Diskussion angeschlossen, ob der Hoge Raad hier die Rechtswidrigkeit verneint hat oder ob er eine dem besonderen Berufsrecht des Arztes entstammende sog. medizinische Exzeption anerkannt hat. Die Analyse hier kommt zu dem Ergebnis, daß der Hoge Raad die Rechtswidrigkeit verneint hat, aber innerhalb sehr enger Grenzen. Voraussetzung ist, daß der Arzt zur Wahrung eben des Rechtsgutes gehandelt hat, das durch den verletzten Tatbestand geschützt wird, $\mathrm{daB}$ weiter der Gesetzgeber nicht gerade eine Handlung der vorliegenden Art mit dem Tatbestand erfassen wollte und daß schließlich die Art und Weise mit der der Arzt das Rechtsgut wahren wollte, das Rechtsgut besser schützt als gesetzeskonformes Handeln.

In dieser Arbeit werden vier Typen ärztlicher Handlungen einer strafrechtlichen Betrachtung unterworfen. Das sind zunåchst Handlungen mit denen der Arzt einem Patienten Schmerz oder Schaden zufügt. Im Niederländischen Strafgesetzbuch (WvSr) ist nach Art. 300 f. die vorsătzliche Zufügung von Schmerz oder Schaden als Körperverletzung unter Strafe gestellt. Der Arzt erfüllt an sich den Tatbestand dieses Artikels und begeht damit eine strafbare Handlung. Verschiedene Theorien haben versucht in diesen Fällen die Strafbarkeit auszuschließen. Die Geschichte dieses Artikels läßt erkennen, daß der Gesetzgeber solche ärztlichen Tätigkeiten nicht erfassen wollte. Seiner Meinung nach ist diese Handlung nicht als Körperverletzung anzusehen, weil sie nicht rechtswidrig ist und sie ist nicht rechtswidrig, weil sie gesellschaftlich akzeptiert ist. In einer Entscheidung des Hogen Raads aus jüngster Zeit hat auch dieser zum ersten Mal anerkannt daß eine solche ärztliche Tätigkeit nicht rechtswidrig ist. Seiner Auffassung nach ist Grund hierfür jedoch die besondere medizinische Exzeption.

Die zweite der untersuchten Handlungen ist die Abtreibung. Der Strafgesetzgeber von 1886, dem Jahr in dem das heutige Strafgesetzbuch eingeführt wurde, hat für die Abtreibung durch den Arzt keinen Strafausschließungsgrund in das Strafgesetzbuch aufgenommen. Die Umschreibungen der Tatbestände für Abtreibung waren (1984 sind diese Artikel ersetzt worden) ohne Einschränkungen formuliert, so daß auch die. Abtreibung durch einen Arzt tatbestandlich erfaßt war. Der Gesetzgeber erkannte ein Recht des Arztes, straffrei abzutreiben, wahrscheinlich unter der Voraussetzung an, daß eine Fortsetzung. der Schwangerschaft zum Tode der Frucht oder der Frau führen würde. Ein Strafausschließungsgrund schien ihm jedoch überflüssig und gefährlich. Er erschien ihm überflüssig, weil ein Arzt, der gemäß den Regeln seiner Kunst handelt, sich seiner Ansicht 
nach nicht strafbar machte und er erschien ithm gefährlich, weil der Gesetzgeber nicht in der Lage ist eine Formulierung zu finden, die einerseits ausreichend deutlich und andrerseits genügend flexibel ist. Die Haltung des Gesetzgebers hinsichtlich der Abtreibung steht in Einklang mit seinem Standpunkt hinsichtlich der Körperverletzung.

In der strafrechtlichen Literatur wurde in den ersten Jahren nach Einführung des Strafgesetzbuchs überwiegend die Auffassung vertreten, daß eine Abtreibung, auch wenn sie durch einen Arzt geschieht und auch wenn eine medizinische Indikation vorliegt, strafbar ist. Einige Juristen vertraten die Auffassung, daß der rechtfertigende Notstand die Rechtswidrigkeit der Abtreibung durch einen Arzt ausschließ . Hiergegen wurde vorgebracht, daß der Notstand keinen AufschinßB darüber gibt, ob das Interesse der menschlichen Frucht oder das der Frau Vorrang hat. Ein ungeschriebener StrafausschlieBungsgrund wie die medizinische Exzeption wurde damals im allgemeinen nicht anerkannt.

Die Ärzte hatten sich zu Beginn dieses Jahrhunderts gegen die Abtreibung gestellt, vor allem wenn sie durch Unbefugte vorgenommen wurde. Sie sahen eime Gefahr sowohl für die Volksgesundheil als auch für die Sittlichkeit. In einem Gesetzentwurf der Regierung aus dem Jahre 1900 wurde vorgeschlagen, die Abtreibungsvorschriften in dem Sinne zu verändern, daß auch die Abtreibung einer toten Frucht unter Strafe gestellt wurde. Auf diese Weise wollte man Beweisschwierigkeiten verringern. Daneben sollte die Abtreibung durch einen Arzt, der in Ausûbung seines Berufes handelte, vom Tatbestand nicht erfaßit werden.

1904 wurde ein neuer Giesetzentwurf der Regienung eingebracht. Er ähnelte dem von 1900 insofern, als die Abtreibung einer toten Frucht unter Strafe stehen sollte, aber anders als im Entwurf von 1900 war Abtreibung durch den Arzt nicht vom Tatbestand ausgenommen. Der Justizminister erklärte, daß die Ärzte ebenso wie andere Bürger den Gesetzen der Sittlichkeit unterworfen seien. Der Entwurf von 1904 führte zu Protesten bei den Ärzten. Sie verlangten Rechtssicherheit. Sowohl der Entwurf von 1900 als auch der Entwurf von 1904 kamen infolge eines Regierungswechsel nicht bis ins Parlament.

1909 schlug eine Kommission aus Ärzten und Juristen der Niederländïschen Gesellschaft zur Beförderung der Heilkunst (Nederlandsche Maatschappij ter bevordering van de Geneeskunst, NMG) vor, in das Strafgesetzbuch einen allgemeinen Strafausschließungsgrund für Ärzte aufzunehmen. Danach sollten vernünftigerweise gebotene oder von den Regeln der Kunst zugelassene Handlungen der Ärzte nicht strafbar sein. Außerdem entwarf die Kommission eine Vorschrift, in der die Zustimmung des Patienten zu einer medizinischen Handlung geregelt wird.

Im Rahmen der sogenannten Sittlichkeitsgesetzgebung von 1911 wurde dem bestehenden Abtreibungsartikel ein neuer hinzugefügt: Strafbar war es schon, bei einer Frau die Vorstellung hervorzurufen, daB eine Abtreibung ausgeführt werde. Diese Vorschrift verlangte nicht einmal, daB die Frau wirklich schwanger war. In der Erörterung dieser Vorschrift im Parlament wurde nach der Meinung mancher Juristen die medische Exzeption anerkannt, auf Grund einer medizinischen Indikation eine Schwangenschaft straffrei abzubrechen zu dürfen. Die vorliegende Arbeit kommt zu dem Ergebnis, daß diese Auffassung nicht richtig ist; die Straffreiheit des Arztes wurde vielmehr mit dem in den Niederlanden auch im Sirafrecht geltenden Opportunitätsprinzip begründet.

Ab der Mitte der vierziger Jahre ist in der Rechtsprechung eine Tendenz nachzuweisen, dem Begriff der medizinischen Indikation der Abtreibung einen immer weiteren Inhalt zul geben. Eine neue Phase in der Diskussion um die Abtreibung durch einen Arzt setzte erst der Mitte der sechziger Jahre ein. Viele Ärzte sprachen sich damals für eine Ausweitung der Indikation aus. Die Ärateorganisation KNMG brachte 1971 Richtlinien heraus, 
in denen der Nachdruck auf Verfahrensregeln liegt. Zu einer Definition der zulässigen Indikationen kam es dabei jedoch nicht.

Die Auffassung, daB Abtreibung aufgrund medizinischer Indikation die Rechtswidrigkeit ausschlleBt, war in den sechziger und siebziger Jahren weit verbreitet. Unterschiedliche Auffassungen bestanden, wie der Begriff der medizinischen Indikation zu verstehen ist. Die Staatsanwaltschaft verhielt sich hinsichtlich der Abtreibung durch Ärzte zurückhaltend, obwohl es zweimal mit Wissen des damaligen Justizministers zu einer Aktion gegen die Abtreibungsklinik Bloemenhove gekommen war.

Zwischen 1970 und 1981 wurden zehn Gesetzentwürfe zur strafrechtlichen Regelung der Abtreibung (durch einen Arzt) eingebracht. Nur in einem der Entwürfe wurde vorgeschlagen, den Arzt grundsätzlich von der strafrechtlichen Verantwortung auszunehmen. Die anderen Entwürfe hielten an einer strafrechtlichen Verantwortlichkeit des Arztes fest. Sie konzentrierten sich vor allem auf eine Regelung des Verfahrens für Abtreibungen durch einen Arzt.

1981 wurde das Gesetz zum Abbruch der Schwangerschaft (Wet Afbreking Zwangerschap, WAZ) verabschiedet. Abtreibung bleibt eine strafbare Handlung. Zur Strafausschließung für den Arzt ist ein besonderer Rechtfertigungsgrund in das Strafgesetzbuch aufgenommen. Ausführliche Verfahrens- und Verwaltungsbestimmungen regeln den ärztlichen Schwangerschaftsabbruch. Der Gesetzgeber sah sich nicht in der Lage, ein materielles Kriterium zu formulieren und hat darum den Nachdruck auf das Verfahren gellegt. Der besondere Rechtfertigungsgrund bringt es mit sich, daß nunmehr feststeht, daß für die ärztliche Abtreibung keine besondere medizinische Exzeption gilt.

Das vierte Kapitel trägt den Titel "Thanasie". Unter "Thanasie" werden alle Handlungen des Arztes verstanden, die zum Tode des Patienten führen und die nicht durch einen Kunstfehler verursacht sind. In diesem Kapitel wird die strafrechtliche Haftung des Arztes für verschiedene thanatische Handlungen untersucht. Im ersten Teil wird zunächst die Gesetzesgeschichte der relevanten Artikel untersucht mit der Feststellung, daß der Gesetzgeber von 1886 zur Euthanasie nicht Stellung genommen hat. Danach wird die Niederländische Geschichte der Euthanasie kurz beschrieben. Anders als in Deutschland findet die Euthanasiediskussion erst in jüngster Zeit statt. Eine ausführliche Diskussion gibt es erst seit den sechziger Jahren. Dabei hat sich seit dem Anfang der achtziger Jahren in den Niederlanden ein Begriffsrathmen mit den folgenden Unterscheidungen gebildet:

Es wird unterscheiden zwischen Sterbehilfe (Euthanasie), Handlungen die der Euthanasie ähneln, aber nicht als solche zu qualifizieren sind und der sogenannten "Lebensbenehmung". Unter Euthanasie wird ausschließlich ein beabsichtigtes lebensbenehmendes Handeln durch einen Dritten auf ausdrücklichen Wunsch des Betroffenen verstanden. "Lebensbenehmung" im engeren Sinne ist Lebensbenehmung von Patienten die ihren Wunsch nicht äußern können. Diese Lebensbenehmung kann durch Tun oder Unterlassen geschehen. Zu den Handlungen die der Euthanasie ähneln, aber nicht dazu gerechnet werden, gehören die Bekämpfung des Schmerzes mit Mitteln die als Nebeneffekt das Leben verkürzen, die sogenannte lebensverkürzende Schmerzbekămpfung; das Nichtbehandeln des willensfähigen Patienten, weil dieser zu der Behandlung keine Zustimmung gibt und das Unterlassen einer medizinisch sinnlosen Behandlung.

Strafrechtlich gesehen ist das Unterlassen einer medizinisch sinnlosen Behandlung nicht strafbar, weil der Arzt keine Fürsorgepflicht verletzt. Aus demselben Grund ist das Nichtbehandeln des willensfähigen Patienten nicht strafbar. In diesem Falle setzt sich das Recht des willensfähigen Patienten durch, daß medizinische Eingriffe nur mit 
seiner Zustimmung geschehen düfen. Strafrechtlich gesehen ist die lebensverkürzende Schmerzbekämpfing problematisch. Geschieht diese mit dem Eunvernehmen des Patienten, dann gleicht sie der Euthanasie. Geschieht sie bei willensunfähigen Patienten und deshalb ohne Zustimmung des Patienten, dann ähnelt sie der Lebensbenehmung.

Im zweiten Teil dieses Kapitels steht die Euthanasie im Mittelpunkt. Ersi werden verschiedene Entwürfe zu einer gesetzlichen Regelung der straffreien Euthanasie durch einen

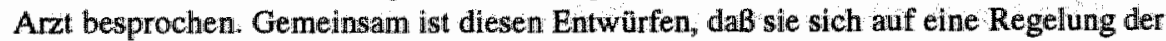
Euthanasie beschrãnken und daß großer Nachdruck auf dem Ersuchen des Patienten liegt, der sich in einer aussichtslosen Notsituation befinden muB. Alle Entwürfe enthalten auBerdem ausführliche Verfahrens- und Verwaltungsregeln.

Unterschiedlich sind die Wege, auf denen die StrafausschlieBung erreicht werden soll. Im Inttiativentwurf Wessel-Tuinstra/Kohnstamm und im Entwurf der Staatskommission Euthanasie wird ein Rechtfertigungsgrund worgeschlagen, während in die hierzu ergangene sog. "proeve" (Probe) der Reglerung ein SchuldausschlieBungsgrund aufgenommen ist. In eimem zweiten Entwurf der Regierung wird vorgeschlagen, die prozeduralen und administrativen Vorschriften in das Gesetz zur Ausübung der Heilkunde (WUG) aufzumehmen und von einem besonderen Strafausschließungsgrund abzusehen. Als Strafausschließungsgrund soll der rechtfertigende Notstand dienen.

Nach dem zweiten Gesetzentwurf hat die Regienung vorgeschlagen, erst eine Untersuchung der bestehenden Euthanasiepraktiken der Ärzte durchführen zu lassen. Diese Untersuchung weist aus, daß ca. 2.300 der ca. 130.000 jährlichen Sterbefällen in den Niederlanden als Euthanasiefălle bezeichnet werden können. Außerdem ist hiernach in circa 22.500 Fällen der Tod die Auswirkung einer schmerzbekämpfenden Therapie. In gleichvielen Fällen wird nicht (weitter)behandelt, weil die Behandlung als medizinisch sinnlos angesehen wird. In ca. 1000 Fällen jährlich wird das Leben von Patienten, die zu einer Äußerung nicht fähig sind, aktiv beendet. Vor allem hinsichtlich der letzten Kategorie weist die Untersuchungsgruppe auf die Möglichkeit hin, daß die angegebene Zahl die Tatsachen nicht korrekt wiedergibt.

Die Untersuchung folgte einem Meldungsverfahren. Die Justiz verhielt sich in den gemeldeten Fällen zurückhaltend. Dadurch konnten die Ärzte für eine Mitarbeit an der Untersuchung gewonnen werden. Die Kommission " Ärtliche Entscheidungen beim Ende des Lebens" "in deren Auftrag die Untersuchung stattfand, empfahl, das Meldungsverfahren zu einer dauerhaften Einrichtung zu machen: Diese Empfehlung wurde von der Regierung übernommen. In ilher Standortbestimmung schlug sie vor, das Gesetz zur Leichenbestattung (WBL) so abzuändern, daß der Arzt, der keine natürliche Todesursache feststellt, verpflichtet ist, einen Fragebogen auszufüllen. Diesen muB er dem Leichenbeschauer übergeben, der nach seiner Tätigkeit den Staatsanwalt informiert. Wenn der Staatsanwalt den Arzt verfolgen will, dann muß er erst mit dem Medizinischen Inspektor für die Volksgesundheid $\mathbb{K}$ ontakt aufnehmen. Dieses Meldungsverfahren wird bei Euthanasie und bei Lebensbenehmung angewandt. In der Erläuterung teilt die Regienung mit; daß die Rechtsprechung noch keine Kriterien für die Straffreiheit bei Lebensbenehmung entwickelt hat. Auch hierzu soll das Meldungsverfahren beitragen. Da aber der Arzt der die Lebensbenehmung mitteilen soll, unsicher sein $\mathrm{mu}$, ob er nicht strafrechtlich verfolgt wird, ist seine Mitwirkungsbereitschaft vermutlich gering. Materiell gesehen liegt die Besonderheit dieses Melidungsverfahrens darin, daß es eine mögliche Straffreiheit der Lebensbenehmung impliziert. Das Verfahren dient ja gerade der Feststellung der Kriterien, bei deren Vorliegen die Lebensbenehmung nicht strafbar sein soll. Das Meldungsverfahren 
gill nicht für Fälle lebensverkürzender Schmerzbekämpfung und des Unterlassens medizinisch sinnloser Biehandlung.

Neben dem Meldungsverfahren bleiben die gegenwärtigen Vorschriften des Strafgesetzbuchs unverändert. Über die Haftung des Arztes bei Eutharasie nach heutigem Rechtszustand ist in den letzten Jahren eine ausgedehnte Rechtsprechung entstanden. Daraus kann geschlossen werden, daB der Tatbestand des Artikel 293 WvSr (absichtliche Tötung auf Verlangen) eine strafausschließende Auslegung nicht zulläBt.

Eine Strafausschließung ist auch nicht dadurch zu erreichen, daß man die Tatigkeit als nicht rechtswidrig ansieht. Jedoch ist in der heutigen Rechtsprechung im allgemeinen anerkannt, daß Euthanasie aufgrund eines Notstandes nicht strafbar ist, wenn auf ausdrücklichen Wunsch des Patienten, der sich in einer ausweglosen Notsituation befindet, gehandelt wird. Nicht nötig ist hierfür, daB der behandelnde Arzt einen Kollegen zu Rate ziehnt oder daB er Aufzeichnungen macht. Der Notstand wird in diesem Fall materiell durch Elemente der "medizinischen Exzeption" ergänzt. Der Hoge Raad verwendet dabei die Formulierung, daß "nach wissenschaftlich verantwortlicher medizinischer Einsicht und nach in der medizinischen Ethik geltenden Normen eine als Notstand anzusehende Situation vorliegt". Anders als die Rechtsprechung der unteren Gerichte hat der Hoge Raad besondere Kriterien nicht formuliert. Die Kriterien sind - mit Ausnahme der Konsultation eines zweiten Arztes und der Aufzeichnungspflicht - dieselben, die sich in den verschiedenen Gesetzentwürfen finden. Der Hoge Raad hat darauf verwiesen, daß die Umstände unter denen eine Euthanasie in Frage kommt, so unterschiedlich sind, daß es nicht ratsam ist, allgemeine Kriterien zu formulieren. Diese Entscheidung des Hogen Raads steht mit der offenen Formulierung des rechtfertigenden Notstands in Einklang. Daraus läBt sich schließen, daß genauere Kriterien einem Gesetz vorbehalten bleiben müssen.

In den Niederlanden besteht auch die Möglichkeit, daß die Staatsanwaltschaft aufgrund des Opportunitätsprinzips Euthanasie unter bestimmten Bedingungen nicht verfolgt. Dazu können Richtlinien aufgestellt werden, die, soweit sie öffentlich bekanntgemacht sind, durch den Hoge Raad als Rechtssātze angesehen werden. Der Vorteil einer Regelung der Euthanasie mit Hilfe des Opportunitătsprinzipes ist die Flexibilität mit der auf verănderte Umstände regiert werden kann. Ein Nachteil ist, daß die Anwendung des Opportunitätsprinzipes von der Haltung des jeweilligen Justizministers abhängig ist. Ein anderer Nachteil ist, daß die Öffentlichkeit kaum erfährt, wie die Staatsanwaltschaft in einem bestimmten Fall entscheidet.

Im dritten Teil dieses Kapitels wird die "Lebensbenehmung" besprochen. Unter "Lebensbenehmung" wird in diesem Zusammenhang verstanden ein Handeln oder Nachlassen, das den Tot des Betroffen bewirkt und das weder eine Euthanasie ist, noch eine der Euthanaš̈e ähnelnde Handlung. Darum ist das Unterlassen der medizinisch sinnlosen Behandlung keine "Lebensbenehmung". Die Suche nach Gründen, warum die "Lebensbenehmung" erlaubt ist, kann von der Voraussetzung ausgehen, daß eine medizinische Behandlung sinnlos ist. Das Wort "sinnlos" muß hier jedoch in einer beschränkteren Bedeutung aufgefaßt worden als der Begriff "medizinisch sinnlos" . Unter "medizinisch sinnlos" wird yon der Medizin heute im allgemeimen verstanden, daB der Patient keine Chance hat zu Überleben, wobei ihn in der verbleibenden Lebenszeit wahrscheinlich ein ernstes und nicht zu beseitigendes Leiden begleiten wird. Die Prognose, daß eine Behandlung medizinisch sinnlos ist, wird auf Grund medizinischer Kriterien gestellt. Von der medizinisch sinnllosen Handlung muB die ethisch sinnlose Handlung unterschieden werden. Unter "ethisch sinnlos" wird in diesem Zusammenhang verstanden, daß die Prognose hinsichtlich der künfti- 
gen Gesundheit ein seht schlechtes Bild ergibt mit einer nur sehr kleinen Chance eimes lebenswerten (oder ertrẩglichen) Lebens. Anstelle von "ethisch sinnlos" wird auch von "einer zu geringen Lebenspenspektive" gesprochen und von "ungenügender Lebensqualitat". In verschieden Rapporten wird erkannt, daB diese Prognose stark subjektiv bestimmt ist. Darum wird eine stärkere Konsensbildung unter den Ärzten vorgeschlagen. Auch müssen die so herausgebildeten globalen Kriterien gesellschafflich akzeptiert werden.

Die moralische Rechtfertigung der Unterlassung ethisch sinnloser Behandlung bei willensunfähigen Patienten liegt in der Abwägung zwischen einer günstigen Prognose thinsichtlich des Überlebens und einer ungünstigen Prognose hinsichtlich der Milderung des Leidens. Wenn diese beiden Prognosen in Widerspruch geraten, dann kann der Arzt befugi sein, die Behandlung zu unterlassen. In diesem Fall folgt er dem Satz "in dubio abstine".

Über Lebensbenehmung beï ìrreversibel komatösen Patienten hat eine Kommission des Niederländischen Ärztebundes einen Report ausgebracht. Nach diesem Report ist davon auszugehen, daß ein Patient der sich in einem irreversiblen Koma befindet, nicht weiter behandelt werden darf, da dies mit der menschlichen Würde nicht zu vereinbaren sein soll. Deshalb schlägt die Kommission vor, nach einer gewissen Zeit die Behandlung eines irreversibel komatösen Patienten zu beendem.

Der EntscheidungsprozeB hinsichtlich der Lebensbenehmung von Neugeborenen mit schweren Defekten und von irreversibel komatôsen Patienten unterscheidet sich dadurch, daß im ersten Fall die Stimme der Eltern eine wichtige Rolle spielt.

Im auBersten Fall ist es nach dem Rapport dem Arzt erlaubt, wenn eine Situation vorliegt, in der er die Behandlung eines willensunfähigen Patienten unterlassen darf, dessen Leben auch durch das Verabreichen eines Euthanaticums (aktive Lebensbenehmung) zu beenden: Dazu benötigt er bei einem Neugeborenen jedoch die Zustimmung der Eltern.

In dem Rapport wird auf den Nutzen eines Tagebuches hingewiesen, das vor allem dann wichtig ist, wenn keine Todesurkunde ausgestellt wird. Eine Todesurkunde darf nach der Meinung der Kommission beil der lebensverkürzenden Schmerzbekämpfung, wenn eine medizinisch Behandlung sinnlos ist und wenn der Patient die Zustimmung zur Behandlung verweigert hat, ausgestellt werden. In den Berichten klingt jedoch auch Verständnis für unzulässig ausgestellte Todesurkunden an. Die Ursache soll in der Rechtsunsicherheit liegen und ist außerdem eine Folge der juristischen Ansicht, daß die Feststellungen eine Behandlung sei medizinisch sinnlos oder ethisch sinnlos, deutlich zu unterscheiden sind.

Auf dle Lebensbenehmung bei geistig ernstlich behinderten Patienten wird nur kurz eingegangen. Es handelt sich um ein empfindliches und wissenschaftlich kaum bearbeitetes Thema.

Bei der Frage, welche Möglichkeiten bestehen, eine Lebensbenehmung straffrei zu lassen, ist von Bedeutung, daßB die Fälle der Lebensbenehmung durch Nichtbeginnen, Beenden, Abbrechen einer Behandlung oder durch das Zusplelen eines "Euthanatîcums" gleich behandelt werden. Soweit der Arzt eine Behandlungspflicht hat, führt das Unterlassen einer Behandlung genauso zu strafrechtlicher Verantwortlichkeit wie ein aktives Handeln.

Die Rechtsprechung zur Lebensbenehmung betrifft Fälle in denen Personen, die keine Ärte waren, sich vor Gericht verantworten mußten. Es kann trotzdem auf eine grundsätzliche Ablehnung der aktiven Lebensbenehmung durch die Rechtsprechung geschlossen werden. Wesentlicher Punkt ist, daß der Wunsch des Patienten fehlt. Bei irreversibel komatösen Patienten kommt noch hinzu, daß die Rechtsprechung davon ausgeht, daß 
diese Patienten nicht leiden. In verschiedenen Entscheidungen wird darauf hingewiesen, $\mathrm{daB}$ für die Straffreiheit der aktiven Lebensbenehmung eine Änderung der heutigen Gesetzgebung nötig ist.

Zwei Rechtsprechungsfalle werden ausführlicher besprochen, der zivilrechtliche Fall der Patientin Stinissen und der strafrechtliche Fall des Babys Ross. Im Falle Stinissen ging es um eine Patientin, die sich seit siebzehn Jahren in einem Koma befand und deren Ehemann die Ärzte mit Hilfe einer richterlichen Entscheidung zwingen wollte, die Behandlung zu beendigen. Der Richter wies den Antrag des Ehemanns ab. Zugleich machte er deutlich, daß sich der Richter hinsichtlich der Frage, ob ein Arzt eine Behandlung beendigen darf, weil sie nach seiner Meinung medizinisch sinnlos sel, zurückhaltend âußern muB, da hierbei vor allem eine medizinische Frage betroffen ist. In einem anderen zivillechtlichen Fall wird in gleichen Sinne geurteilt.

Strafrechtlich gesehen ist für die Lebensbenehmung vor allem der Fall des Babys Ross wichtig geworden. In diesem Fall wurde ein Arzt gerichtlich verfolgt, weil er bei einem mongoloiden Baby eine Magen- und Darmabweichung nicht operierte und nach diesem Entschluß die Behandlung beendete. Nach dem Urteill des Richters war die Operation offensichtlich ethisch sinnlos. Das Urtell steht in Übereinstimmung mit Rapporten der Kommissionen des Niederländïschen Ärztebundes und der Niederländischen Vereinigung für Kindermedizin. Obwohl die Operation selbst sehr wahrscheinlich erfögreich verlaufen wäre, wurde es dem Arzt zugestanden diese nicht auszuführen, weil die Möglichkeit bestand, daß das Kind nur einen langen Leidensweg gegangen wäre. In dieser Situation gab der Satz "in dubio abstine" den Durchschlag. Von Bedeutung war außerdem, daB die Eltern die Zustimmung zur Operation verweigerten.

In letzten Kapitel, der Schllußbetrachtung, wird vor allem die Frage untersucht ob Thanasie auch weitterhin einer strafrechtlichen Kontrolle unterworfen bleiben muß und wie eine mögliche strafrechtliche Regelung aussehen sollte.

Bei einer medizinischen Behandlung die - formal gesehen - den Tatbestand der Konrperverletzung erfüllt, ist das Ziel der Behandlung weder medizinisch noch gesellschaftlich umstritten. Der Arzt darf auf Grund der medizinischen Exzeption handeln.

Bei Abtreibung ist das Ziel der Behandlung umstritten, da dabei im Interesse der Frau die menschliche Frucht getötet wird. Im Abtreibungsgesetz von 1984 wird der Schutz des Lebens der Frucht dem des geborenen menschlichen Lebens untergeordnet und sogar dem Wunsch der Frau, die Schwangerschaft abbrechen zu lassen. Mit diesem Gesetz hat der Gesetzgeber in gewissem Sinne das Selbstbestimmungsrechts der Frau hinsichtlich umstrittenen medizinischen Handelns akzeptiert.

Bei der Euthanasie steht das Selbstbestimmungsrechts des Patienten über sein Leben Im Mittelpunkt, obwohl es begrenzt wird durch die Umstände in denen er sich befindet. Anders als bei der Abtreibung liegt hierbei kein Interessenkonflikt vor. Die untersehiedlichen Weisen worauf unter dem heutigen Strafrecht Euthanasie straffrei gelassen wird, sind nicht zufriedenstellend. Die Aufgabe des Richters ist es in konkreten Fallen zu einer Entscheidung zu kommen, jedoch nicht als eine Art Pseudo-Gesetzgeber aufzutreten, wor allem nicht, wenn fundamentale Rechtsgüter auf dem Spiel stehen. In diesen Fällen darf der Gesetzgeber nicht untätig bleiben. Rechtssicherheit und Rechtsschutz für alle Betroffenen verlangen deutliche materielle Normen.

Die Ärte erklären sich außerstande, diese Normen geben zu können. Ausgangspunkt der Rechtstaatlichkeit ist es daß der Gesetzgeber das Leben seiner Bürger beschirmt. Bei einer solch fundamentalen Frage darf es nicht den Ärzten überlassen werden, über 
die Zulassung von Thanasie zu beschlieben und es geht auch nicht an, daB ausschlieblich das medizinische Disziplinarrecht regulierend auftritt.

Bel willensfahigen Pathenten und damit im Hinblick auf eine gesetzliche Regelung der Euthanasie; ist vor allem die Willensäußenung des Patienten ausschlaggebend. Wenn der Patient zu dem Zeitpunkt zu đem er um Euthanasie bitten könnte, dazu nicht in der Lage ist, dann sollte eine durch ihn aufgestellte frühere Erklärung des Willens den Platz der mündlichen Außerung einnehmen. Für die Kontrolle ist es nützlich das verlangt wird das die mündliche Erklärung des Willens im Beisein von mehreren Personen stattfindet und für die schriftliche Erklärng daB diese durch mehrere andere Personen unterzeichnet ist.

Eine Erklärung des Willens in diesem Sinne scheint mir auch sinnvoll bei der lebensver-

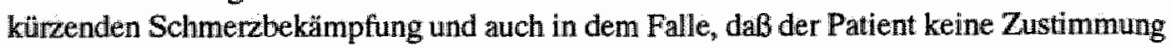
zur Behandlung gibt, oder eine gegebene Zustimmung zurückzieht. Wenn nach der Meinung des Arztes eine Behandlung medizinisch gesehen sinnlos ist, der Patient jedoch diese will, dann sollte möglicherweise der Wille des Patienten den Ausschlag geben. Denn anscheinend will dann der Patient ungeachtet der durch den Arzt gegebenen Information noch länger leben bleiben.

Bel Patienten die ihrén Willen nicht äuBern können und die auch früher ihren Willen nicht schriftlich erklärt haben, muß nach meiner Meinung Ausgangspunkt sein, daß eine Behandlung begonnen oder fortgesetzt wird. Das steht in Übereinstimmung mit der anerkannten Regel, cla B bei einem zeitlich willensunfähigen Patienten der Behandlungswille angenommen wird.

Ausnahmen von dieser Regel können sich nicht auf den Willen des Patienten berufen und können sich darum nur auf außerordentliche Umstände, in denen der Patient sich befindet, stützen. Hierbei muß zwischen irreversibel komatösen Patienten und anderen willensunfahigen Patienten unterschieden werden.

Bell willensunfahigen Patienten darf der Arzt in der Regel die Behandlung unterlassen, wenn diese medizinisch sinnlos ist. Weil Ärzte selbst erklären, daß medizinisch sinnlos nicht gut von ethisch sinnlos zu unterscheiden ist, sollte hier die Konsensbildung geforddert werden.

Die Frage ob irreversibel komatöse Patienten weiterbehandelt worden müssen, ist eine normative Frage und darum ist hinsichtlich der Unterlassung eine gesetzliche Regelung nötig.

Für lebensverkürzende Schmerzbekämpfung ist, so wie für jede andere Behandlung, die Zustimmung des Patienten nötig. Wenn dieser zu einer Willensäußerung nicht in der Lage ist, dann wird angenommen, daB er eine Behandlung will, weil sie in seinem (Lebens)interesse liegt. Wenn aber auf der einen Seite das Leben des Patienten durch die Behandlung verküzt wird, auf der anderen Seite der Schmerz bekämpft wird, dann ist auch in diesen Konflikt eine Entscheidung des Gesetzgebers über die lebensverkürzende Sohmerzbekämpfung bei willensunfähigen Patienten erforderlich. Dazu müssen das Ausmaß des Leidens, die zu erwartende Lebensdauer und der akute und künftige Zustand des Patienten berücksichtigt werden.

Aktive Lebensbenehmung bei willensunfähigen Patienten solite meiner Meinung nach nur unter sehr außergewöhnlichen Umstầnden straffrei sein. Auf jeden Fall wăre zu fordern, daß eine Situation vorliegt, in der es erlaubt wäre die Behandiung zu unterlassen, in der aber ein Unterlassen der Behandlung zugleich das Leiden vergrößert. 


\section{Lijst van aangehaalde Literatuur}

Abbink, H. en W.L. Borst, Rechtsbescherming van het leven verder onder druk, NJB 1989 , p. $1141-1142$

Abortuswetgeving. PUNT X. van de Beschrijiningsbrief voor de 168ste Algemene Vergadering van de K.N.M.G. op vrijdag 17 september 1976, MC 1976, p. 1071

Afdeeling Amsterdam van de NMG, NTvG 1895, I, p. 892

Afdeeling Amsterdam van de NMG, voorstel, NTvG 1905, I, p. 867-868

Agt, A.A.M. van, Recht op leven en sterven, Katholiek Artsenblad 1968, p. 369-379 Aletta H. Jacobs, De strijd tegen de facultatieve steriliteit, NTvG 1898, I, p. 656-663 Algemene Vergadering, NMG, NTvG 1895, Il, p. 126

Algemene Vergadering stemt vooralsnog niet in met aanvulling richtlijnen abortus provocatus, MC 1975 , p. $519-520$

Alkema, E.A., Studies over Europese Grondrechten, Deventer 1978

Alphen e.a., H.A.M. van, Euthanasie, recht en medische ethiek, NJB 1986, p. 311-313 Alphen c.s., H.A.M. van, Zorg dragen voor een rustig sterven is niet synoniem met actieve levensbeëindiging, MC 1988, p. 1389-1390

Arend, A.J.C. van der, Ontwikkelingen van verpleegkundig-ethische codes, in: L. Boon (samensteller), Ethiek, recht \& zorg, (Ontwikkelingen in de gezondheidszorg: deel 4), Amstelveen 1986, p. 15-18

Arend, A.J.G. van der, Verpleegkundigen, in: I.D. de Beaufort en H.M. Dupuis (red.), Handboek Gezondheidsethiek, Assen/Maastricht 1988, p. 275-285

Baas, A.R., Levensberooving op verzoek en zelfmoord, Amsterdam 1910 (diss.)

Batenburg, M., NTvG 1905, II, p. 898-905

Bemmelen, J.M. van, De beteekenis van het strafrecht voor den normalen mensch, Rede uitgesproken na de aanvaarding van het ambt van hoogleraar aan de Rijks-Universiteit te Leiden op vrijdag 2 october 1931, 's-Gravenhage 1931

Bemmellen, J.M. van, volgens: Ca.M. Schenk, NTvG 1933, III, p. 3909-3910

Bemmelen, J.M. van en W.F.C. van Hattum, Hand- en leerboek van het Nederlandse strafrecht; deel I - Algemene leerstukken, door W.F.C. van Hattum, Amhern/s-Gravenhage 1953

Bemmelen, J.M. van en W.F.C. van Hattum, Hand- en leerboek van het Nederlandse strafrecht; deel II, Bijzondere delicten, door J.M. van Bemmelen, Arnhem/"s-Gravenhage 1954

Bemmelen, J.M. van, Initiatief-ontwerp inzake abortus, NJB 1970, p. 997-1000

Bemmelen, J.M. van, Ons strafrecht 1; het materiële strafrecht algemeen deel, Alphen aan den Rijn, $1975^{5}$

Bemmelen, J.M. van, Ons strafrecht 1; het materiële strafrecht algemeen deel, Alphen aan den Rijn $1989^{10}$, (bewerkt door Th.W. van Veen)

Bemmelen, J.M. van, Ons strafrecht 3; bijzondere delicten, Alphen aan den Rijn, $1981^{\text {s }}$ 
Bemmelen, J.M. van, Ons strafrecht 3; bijzondere delicten, Alphen aan den Rijn $1990^{\text {git; }}$ (bewerkt door Th.W. van Veen)

Beneditty, N. de, De strafrechtelijke begrenzing der vivisectie, TvS 1935, p. 173-180

Berg, J.H. wan den, Medische macht en medische ethiek, Nijkerk $1970^{12}$

Bergkamp, L., Het arrest van de Hoge Raad. Een oplossing voor het euthanasievraagstuk?, MC 1985, p. $91-93$

Berkestijn, Th.M.G. van, Hoofdlijnen KNMG-discussienota inzake aanvaardbaarheid levensbeëindigend handelen bij zwaar-defecte pasgeborenen, in: L. Boon (red.), Beslissen over leven \& dood, (Ontwikkelingen in de gezondheidszorg, deel 8), Amstelveen 1989 , p. 32-36

Bijleveld, P.J., Art. 293 Wetboek van Strafrecht, Leiden 1883 (diss.)

Binding, $K$ en $A$. Hoche, Die Freigabe der Vernichtung levensunwerten Lebens. Ihr Mass und thre Form, Leipzig 1920

Bins, J., Dessaur als bevlogen regelaar, DD 1986 , p. 208-213

Binsbergen, W.C. van, Euthanasie - een aantal kanttekeningen, DD 1974, p. 459-471

Blois; M. de, Het recht op persoonlijke integriteit in het internationale recht, Haarlem 1989, (diss.)

Blois, M. de, Het recht op leven van gehandicapte babies, NJB 1989, p. 1146-1148

Boekelman, W.A., Nota der minderheid, Bijlage bij Rapport der commissie in zake het instellen wan een onderzoek naar de strafrechtelijke verantwoordelijkheid van den geneesheer, ingevolge besluili der Algemeene Vergadering van Dinsdag 2 juli 1907 te Utrecht; NTVG 1909 , I, p. $81-83$

Boon, L. (red.), Kwaliteit van leven \& zorg, (Ontwikkelingen in de gezondheidszorg, deel 6), Amstelveen 1988

Boon, L. (red.), Beslissen over leven \& dood, (Ontwikkelingen in de gezondheidszorg; deel 8), Amstelween 1989

Boon, J.M., Levensbeëindigend handelen bij pasgeborenen, MC 1989, p. 1299-1301

Brands-Bottema, G.W., Een kind hoeft niet zeer ernstig te lijden ... gelukkig!? NJB 1989, p. 1143-1145

Brands-Bottema, G.W., Juridische aspecten van de besluitvorming in de neonatologie, Iust 1990 , p. 44-50

Bronkhorst, C., Overmacht in het strafrecht, Utrecht/Nijmegen 1952, (diss.)

Bronkhorst, $\mathrm{C}$, Het regeringsontwerp betreffende het afbreken van zwangerschap, NJB 1972, p. $810-815$

Brouns, P.J.H.M., Opzet in het wetboek van strafrecht, Arnhem 1988 (diss.)

Bruij $_{,}, \mathbf{J}$. de, Geschiedenis van de abortus in Nederland, Amsterdam 1979 (diss.)

Burger, H., Nabetrachting, NTVG 1904, II, p. 145-146

Burger, H., Abortus juste provocatus, NTvG 1904, II, p. 1573-1575

Burger, H., Het programma voor de Algemeene Vergadering te Leeuwarden, NTvG 1909 , 1. p. $1478-1481$

CAL, zie: KNMG-Commissie Aanvaardbaarheid levensbeèindigend handelen

Commissie Abortuswraagstuk, Interimrapport, HTK 1971, 11321

Commissie van de Nederlandse Vereniging voor Psychiatrie en Neurologie, MC 1970, p. $143-154$

Commissie Onderzoek Medische Praktijk inzake Euthanasie, Medische beslissingen rond het llevenseinde. Het onderzoek voor de Commissie Onderzoek Medische Pralktijk inzake Euthanasie, 's-Gravenhage 1991 
Commissie Onderzoek Medische Praktijk inzake Euthanasie, Medische beslissingen rond het levenseinde. Rapport van de Commissie onderzoek medische praktijk inzake euthanasie, "s-Gravenhage 1991

Corstens, G.J.M., Richtlijnen: recht in de zin van art. 99 RO, DD 1991, p. 1-6

Croughs, R.W.M., Recht op leven van emstig gehandicapte pasgeborenen, MC 1989, p. $647-651$

Dam van Isselt, E.W. van, De strafrechtelijke aansprakelijkheid van den medicus, Utrecht 1902, (diss.)

Damoiseaux, V., Patiëntenvoorlichting, een nadere begripsbepaling, in: V. Damoiseaux en A.Ph. Visser (red.), Patiēntenvoorlichting. Een interdisciplinaire benadering, Assen/Maastricht 1988, p. 3-25

Davelaar-Van Tongeren, V.H. en U. van de Pol, Een krampachtig werkstuk. Het abortuswetsontwerp van Ginjaar-De Ruiter, NJB 1979, pi $560-571$

Demeersseman, H.A., De autonomie van het materiële strafrecht, Amhem 1985 (diss.)

Derksen, Th.W.J., in: Enthoven, L., Op sterven na dood - Euthanasie in Nederland, Utrecht-Antwerpen/Deventer 1987, p. 39-42

Dessaur, C.I., Euthanasie: de zelfmoord op zieken en bejaarden, DD 1985 , p. 913-918

Dessaur, C.I. en C.J.C. Rutenfrans, Mag de dokter doden?, Amsterdam 1986

Dijk, J.V. van, in: G.A. van Hamel, Inleiding tot de studie van het Nederlandsche strafrecht, Haarlem/'s-Gravenhage $1927^{4}$, bijgewerkt door J.V. van Dijck

Dijk, P. van en G.J.H. van Hoof, De Europese Conventie in theorie en praktijk, Nijmegen 1990 (Arts Aequil Libri)

Districtsafgevaardigden stellen hoofdbestuursbeleid inzake het abortusvraagstuk ter discussie, Brief aan de minister van Volksgezondheid en Milieuhygiëme, MC 1972, p. 714715; De voorzitter der Maatschappij Geneeskunst heeft de volgende tekst verstrekt aan het A.N.P., MC 1972, p. 715-716

Doelder, H. de en A.J.A. van Dorst, Sport en Strafrecht, NJB 1977, p. 164-170

Doelder, H. de en A.C. 't Hart, Medicus en mishandeling, TvGR 1978, p. 57-68

Doen of laten, zie: Nederlandse Vereniging voor Kindergeneeskunde, Doen of laten?

Does de Willebois, Jhr. J.A. van der, in: Enthoven, L., Op sterven na dood - Euthanasie in Nederland, Utrecht-Antwerpen/Deventer 1987, p. 55-64

Domela Nieuwenhuis, J., Opmerkingen over de vrije en de onbevoegde uittoefening der geneeskunde, TvS 1917, p. 349-362

Doorn, J.K van, Ingezonden. Abortus en levensrecht, MC 1966, p. 21

Dorbeck, AJ.F.M.N., Strafrechterlijke studie over de vraag: 'An injuria fit volenti?', Alkmaar 1893 (diss.)

Dörner, $K$, Euthanasie gisteren - stervenshulp vandaag, V(r)ijvertaal(d), 1988, nr. 3, p. 12 en nr. 4 , p. 12

Drooge, A.C. van, Strafbaarheid van abortus provocatus, TvS 1900, p. 1-13

Dupuis, P.J.F, Discussie over abortus provocatus. Overwegingen inzake de abortus arte provocatus, MC 1970 , p. 783-785

Dupuis, H.M., Dilemma's voor de arts .... en hoe er mee om te gaan. Een commentaar vanuit ethisch perspectief, in: I.D.de Beaufort en H.M. Dupuis (red.), Handboek Gezondheidsethiek, Assen/Maastricht 1988, p. 367-370

Dupuis, H.M., Mag er nog gestorven worden? Het toenemende imperatief van de medische technologie, in: L. Boon (red.), Beslissen over leven en dood, (Ontwikkelingen in de gezondheidszorg, deel 8, Amstelveen 1989, p. 13-18 
Eikema-Hommes, H.J. van, De materiële wederrechtelijkheid in het strafrecht, in: Strafrecht in Perspectief, Arnhem 1980, p. 161-178

Elders, J.L.M., Euthanassie en burgerlijk recht, in: J. Elders, H. Keasberry, G. Kootstra, I. Michiels van Kessenich-Hoogendam, Euthanasie, recht en praktijk, Assen/Maastricht 1985, p. 38-47

Enschede, Ch. J., Abortus op medische indicatie en strafrecht, NTVG 1966, p.1349-1353

Enschede, Ch.J., Abortus op medische indicatie en strafrecht, NJB 1966, p.1109-1118

Enschede, Ch.J., Over abortus, Seminarium "Van Hamel" Cahier no. 6, Amsterdam 1970

Enschede, Ch.J., Over abortus, NJB 1970, p. 718-721

Enschedé, Ch.J, Taboe en abortus, NJB 1970, p. 1398

Enschede, Ch.J., Abortus op medische indicatie en strafrecht, NJB 1978, p. 1002

Enschede, Ch.J, Euthanasie rechtswetenschappelijk beschouwd, in: Euthanasie - Recht, ethiek en medische praktijk (Beschouwingen woor een gezamenlijke vergadering van de Rechtskundige Afdeling van het Thijmgenootschap en de Calvinistische Juristen Vereniging op vrijdag 1 maart 1985 te Amsterdam), Amsterdam 1985, p. 85-106

Enschede, Ch.J., De Arts en de Dood - Sterven en Recht, Deventer 1985

Enischedé, Ch.J., Kanttekeningen bij het advies van de Staatscommissie Euthanasie, NJB 1986, p. 37.42

Enthoven, L., Op sterven na dood, Utrecht-Antwerpen/Deventer 1987

Enthoven, L., Het recht op leven en dood, Deventer 1988

Es, J.C. van, Ieder sterft zijn eigen dood, in: G. Beckers e.a. (red.), Mensw aardig sterven, Baarn $1974^{3}$, p. 59-72

Feber, H.R.G., Het beleid van het openbaar ministerie bij de behandeling van strafzaken met medische aspecten, Preadvies uitgebracht ten behoeve van de jaarvergadering van de Vereniging voor Gezondheldsrecht op 14 april 1989

Frenkel, F.E., Abortus provocatus: het foetus en de wet, De Gids, 1969, p. 283

Frenkel, F.E., Achtergronden en perspectieven van de Nederlandse abortuswetgeving, MC 1970 , p. $805-813$

Frenkel, F.E., De sociale indicatie bij abortus provocatus, NJB 1970, p. 1399-1401

Frenkel, F.E., Sociale indicatie bij abortus provocatus naar geldende Nederlandse rechtspraak wel degelijk toegestaan, MC 1971, p. 51-52

Frets, G.P., NTvG 1921, II, p. 1330-1332

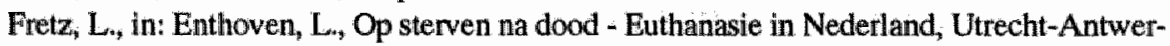
pen/Deventer 1987, p. $43-48$

Gemengde Commissie van 1909, Rapport der commissie in zake het instellen van een onderzoek naar de strafrechtelijke verantwoordelijkheid van den geneesheer, ingevolge beslunt der algemeene vergadering van dinsdag 2 juli 1907 te Utrecht, NTVG 1909 , I. p. $71-83$

Gevers, J.KM., Euthanasie: het rapport van de Staatscommissie euthanasie, TvGR 1985 , p. 328-332

Gevers, J.K.M., m.m.v. E.H.L.M. Randag, De rechter en het medisch handelen, Deventer $1991^{2}$

Gevers, J.K.M., Gewetensbezwaren en hulpverlening, TvGR 1988, p. 356-364

Gewin, B., Beginselen van Strafrecht, Leiden 1907

Gezondheidsraad, Advies inzake euthanasie, (Interim-advies), 's-Gravenhage 1972

Gezondheidsraad, Advies inzake euthanasie bij pasgeborenen, tweede interimadvies, Rijswijk 1975

Gezondheidsraad, Advies inzake euthanasie, 's-Gravenhage 1982 
Gezondheidsraad, Advies inzake zorgvuldigheidseisen euthanasie, 's-Gravenhage 1987 Greeve, M., Zelfmoord (Met ideeên betreffende eene wettelijke regeling), Den Haag 1923

Griffiths, J., Een toeschouwerperspectief op de euthanasie, NJB 1987, p. 681-693 p. $682-683$

Haak, B. van der, Mishandeling, Leiden 1883 (diss.)

Hallie, D.J., Discussie over abortus provocatus, MC 1970, p. 199-200

Hamel, G.A. van, Inleiding tot de studie wan het Nederlandsche strafrecht, Haarlem/'s-

Gravenhage $1907^{2}$

Hamel, G.A. van, Inleiding tot de studie van het Nederlandsche strafrecht, Haarlem/sGravenhage $1913^{3}$

Hamel, G.A. van, Inleiding tot de studie van het Nederlandsche strafrecht, Haarlem/'s-

Gravenhage $1927^{4}$, bijgewerkt door J.V. van Dijck

Hamel, G.A. van, NTvG 1911, I, p. 986-989

Haspels, A.A. en A.W. Mante, Discussie over abortus provocatus, MC 1971, p. 105-106 Hazebroek, NRC 11 now. 1989

Hazelhoff, K., Th. Heemskerk en B.J. Polenaar, Het Wetboek van Strafrecht in doorloopende aantekeningen verklaard, Amsterdam 1886

Hazewinkel-Suringa, D., Inleiding tot de studie van het Nederlandse strafrecht, Haarlem $1964^{3}$

Hazewinkel-Suringa, D., Inleiding tot de studie van het Nederlandse strafrecht, Alphen aan den Rijn $1991^{11}$, (bewerkt door J. Remmelink)

Heering, M.J., Discussie over abortus provocatus, MC 1969, p. 289-290

Hertogh, C.M.P.M., Ethische weging van dilemma's ontstaan door selectieve behandeling

van de pasgeborene met spina bifida, NTvG 1988 , p. 2070-2073

Heijnsbergen, P. van en G.C. van Balen Blanken, Abortus Criminalis, Amsterdam 1925 Het rondschrijven over de richtlijnen inzake abortus provocatus, MC 1971, p. 1197-1198 Hirsch, S.J., Hulp en aanzetting tot zelfmoord, Tiel 1882 (diss.)

Hirsch Ballin, E.M.H., Over het leven beschikken - Naschrift, RR 1985, p. 72-75 Hoche, A., Vom Sterben. Kriegsvortrag, Jena 1919

Hoeven, H. van der, De geneesheer en de strafivet, NTvG 1905, 1, p. 1598-1601

Hoeven, H. van der, Mag het Wetboek van Strafrecht ongewijzigd worden ingevoerd?, Leiden 1884

Holland, W.A., Gewetensbezwaren en strafuitsluitingsgronden, Arnhem 1989 (diss.) Hoofdbestuur KNMG, Het abortusvraagstuk, MC 1969, p. 19-23

Hoofdbestuur KNMG, Hulpverlening bij ongewenste zwangerschap, MC 1970, p. 1012 1014

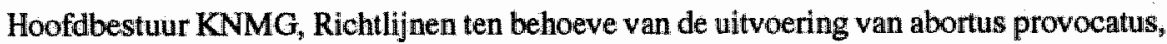
MC 1971, p. 1025-1027

Hoofdbestuur KNMG, Open brief van het hoofdbestuur, MC 1971, p. 1167-1169

Hoofdbestuur KNMG, Het Euthanasie-vraagstuk, MC 1973, p. 587-588

Hoofdbestuur KNMG, Richtlijnen abortus provocatus, MC 1975, p. 350-354

Hoofdbestuur KNMG, MC 1984, p. 7-8

Hoofdbestuur KNMG, Standpunt inzake euthanasie, MC 1984, p. 990-998

Hoofdbestuur NMG, NTvG 1904, I, p. 669

Houben, G.M.M., Rapport Staatscommissie Euthanasie. Coherent werk met enkele zwakkere onderdelen, MC 1985 , p. 1205 
Hubben, J.H., Gezondheidsrecht: Beginselen of belangenafweging? - De zaken baby Ross en Stinissen, NJB 1989, p. 1588-1590

Hubben, J.H., Levensbeëindiging bij ernstig gehandicapte pasgeborenen. Geen grensverlegging door Hoge Raad, NBB 1989, p. 914-915

Hubben, J.H., Gezondheidsrecht: beginselen of belangenafweging? De zaken baby Ross en Stinissen, NJB 1989, p. 1588-1590

Hubben, J.H., Kwaliteit en recht in de gezondheidszorg, Preadvies uitgebracht ten behoeve van de Vereniging voor Gezondheidsrecht op 12 april 1991

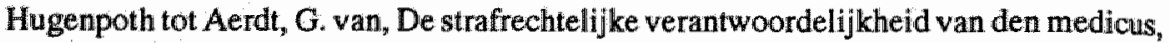
in: De verantwoordelijkheid van den geneesheer, Leiden z.j. (1908), p. 39-81

Hulsman, L.H.C., Een nieuwe ronde in het abortusdebat, DD 1979, p. 213-217

Hulst, J.P.L., NTvG 1923, II, p. 2751-2753

Hylkema, B.S., Beademen en bedenken, MC 1985, p. 1185-1190

Indewey Gerlings-Huurman, Th, De milde dood. Tien jaar strijd voor vrijwillige euthanasie, Lochem 1983

Jager, L. de, NTvG 1905, 1, p. 1523-1525

Jongsma, M.W., Verlenging en verkorting van het leven, in: E.H. Hermans (red.), Recent medisch ethisch denken I, Nederlandse Bibliotheek der Geneeskunde, Deel 40, Leiden 1968 , p. $122-138$

Josephus Jitta, A.N.A., in: B. van Aken, Euthanasie: tussen wet en geweten, Utrecht 1986, p. 127-141

Josephus Jitta, A.N.A., Het rapport van de Staatscommissie Euthanasie, NJB 1986, p. 42-46

Kastelein, W.R., Levensbeëindigend handelen bij zwaar-defecte pasgeborenen, MC 1990, p. 49-51

Kastelein, W.R., De wil van de wils-onbekwame patiënt. De juridische aspecten van de wilsverklaring van de langdurig comateuze patiënt, MC 1991, p. 653-655

Kastelein, W.R., De WGBO: moet en kan dal zo?, MC 1991, p. 1027-1029

Katholieke Vereniging voor Ziekeninrichtingen, Principiële zaken in het geding, MC 1989 , p. 19-23

Kelk, C., Euthanasie-arrest, bespreking van HR 27 nov. 1984, nr. 77091, AA 1985, p. 330-342

Kelk, $C$, De levensbeëindiging van een gehandicapte mongoloïde pasgeborene, (Bespreking van HR 28 april 1989 , nr. 2238), AA 1989, p. 862-874

Kelk $k_{f}$., Aan de grens van het bestaan. Beschouwingen over euthanasie, in: J.KM. Gevers en J.H. Hubben (red), Gremzen aan de zorg; zorgen aan de grens, 1990, p. 149-169

Ketting, E., Van misdrijf tot hulpverlening. Een analyse van de maatschappelijke betekenis van abortus provocatus in Nederland, Alphen aan den Rijn/Brussel 1978 (diss.)

Keuller, J.M.I., De verantwoordelijkheid van den medicus, in: De verantwoordelijkheid van den geneesheer, Leiden z.j. (1908), p. 1-15

Kinjn, W.C.M., Euthanasie. Ethische analyse en waardering, in: Euthanasie - recht, ethiek ea medische praktijk, (Beschouwingen voor een gezamenlijke vergadering van de Rechtskundige Afdeling van het Thijmgenootschap en de Calvinistische Juristen Vereniging op vrijdag 1 maart 1985 te Amsterdam), Amsterdam 1985, p. 17-68

Klijn, M., Hoge Raad: wetenschap en levensbeèindiging, MC 1989, p. 919-922

Klijn, W.C.M., 'Euthanasie' en kabinet, NJB 1987, p. 233-235

Kloosterman, G.J., Prof. Enschede en de legalisatie van abortus provocatus in Nederland, in: Ad personam, Zwolle 1981, p. 155-160 
Knigge, G., Doen en nalaten; enkele opmerkingen over daderschap, DD 1992, p. 128-154. $\mathrm{KNMG}$, Medische Ethiek en Gedragsleer, Amsterdam $1959^{3}$

$\mathbb{K N M G}$, Brief ower euthanasie aan regering en Kamer, MC 1986, p. 2

$\mathrm{KNMG}_{\mathrm{g}}$ Gedragsregels voor artsen. Gebaseerd op datgene wat door de medische professie verstaan wordt onder zorgvuldig handelen, de beroepsuitoefening in nuime zin betreffende, Utrecht 1978

KNMG-Commissie Aanvaardbaarheid levensbeëindigend handelen, Levensbeëindigend handelen bij wils-onbekwame patiênten, Deel $1:$ Zwaar-defecte pasgeborenen, Discussienota, MC 1988, 697-704

KNMG-Commissie Aanvaardbaarheid levensbeëindigend handelen, Interim-rapport inzake lewensbeëindigend handelen bij wils-onbekwame patiênten, Deel 1: zwaar-defecte pasgeborenen, Utrecht 1990

KNMG-Commissie Aanvaardbaarheid levensbeëindigend handelen, discussienota - levensbeëindigend handelen bij wilsonbekwame patiënten, Deel II - langdurig comateuze patiënten, Utrecht 1991

Koch, J.D.C., NTvG 1905, I, p. $491-493$ en p. 628

Kortbeek, L.H.Th.S., Inleiding - aard en doel van het geneeskundig handelen,in: E.H. Hermans (red.), Recent medisch ethisch denken 1, Nederlandse Bibliotheek der Geneeskunde, Deel 40, Leiden 1968, p. 11-49

Kortmann, M.G.J.M., De redelijkheid van abortus provocatus, MC 1970, p. 1284-1285

Kouwer, B.J., NTvG 1917, II, p. 1488-1493

Kouwer, B.J., Afdrijving der vrucht op gronden van geneeskundigen aard, NTvG 1928, II, p. $5886-5892$

Kouwer e.a., B.J., NTVG 1931, II, p. 2009-2011

Kruyver, G.P.M., Discussie over abortus provocatus, MC 1970, p. 283-285

Kuijper, C.M. de, Het begrip wederrechtelijk in het Nederlandsch Wetboek van Strafrecht, Amsterdam 1905 (diss.)

Kuitert, H.M., Een gewenste dood - euthanasie en zelfbeschikking als moreel en godsdienstig probleem, Baarn 1981

Kuitert, H.M., Mag alles wat kan? ethiek en medisch handelen, Baarn 1989

Lange, S.A. de, Het staken van medische behandeling en non-reanimatie, in: Grenzen. aan de zorg; zorgen aan de grens (Liber amiconm voor Prof. Dr. H.J.J. Leenen), Alphen aan den Rijn, 1990

Langemeijer, G.E., Reanimatie, MC 1960, p. 188-191

Langemeijer, G.E., Verdient het abortusontwerp wet te worden?, NJB 1981, p. 341

Langemeijer, G.E., Ch.J. Enschedé en Th.W. van Veen, Beroepsrecht en medisch handelen in de euthanasiediscussie, NJB 1987, p. 50-51

Leenen, H.J.J., Euthanasie in het gezondheidsrecht, in: P. Muntendam (red.), Euthanasie, De Nederlandse Bibliotheek der Geneeskunde, Deel III, nr. 111, Leiden 1977, p. 72-146

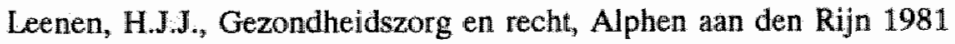

Leenen, H.J.J., De Wet Afbreking Zwangerschap en de toepassing van die wet, NJB 1985 , p. 1357-1361

Leenen, H.J.J., Handboek Gezondheidsrecht - Rechten van mensen in de gezondheidszorg, Alphen aan den Rijn $1988^{2}$

Leenen, H.J.J., Levensbeëindiging bij ernstig gehandicapte passgeborenen. Van neonatologie naar neothanatologie?, MC 1988 , p. 1050-1052

Leenen, H.J.J., Handboek Gezondheidsrecht - Gezondheidszorg en recht, Alphen aan den Rijn $1991^{2}$ 
Leenen, H.J.J., Onderzoek Medische Beslissingen rond het levenseinde, TvGR 1991, p. $462-463$

Leenen, HJJ., Het standpunt van het kabinet inzake regeling van euthanasie, TvGR 1992, p. 2-8

Lette van Oostwoorne, N.J.C., Het veroorzaken van den dood of wan lichamelijk letsel door schuld, Leiden 1882 (diss.)

Lier, E.H.D. van, NTVG 1930, II, p. 6201

Lindeboom, G.A., Opstellen over medische ethiek, Kampen 1960

Lindeboom, G.A., Euthanasie in historische perspectief, Amsterdam 1978

Lindeboom, G.A., Tegen de stroom in, Tien jaar Nederlands Artsenverbond, Voordracht, in verkorte vorm uitgesproken op 26 november 1982 te Noordwijkerhout aan het begin van het congres ter herdenking van het tienjarig bestaan van het Nederlands Artsenverbond

Loghtem Sr, J.J. van, NTvG 1959, I, p. 113-114

Loon, W. van, Mishandeling, Amsterdam 1910, (diss.)

Marlet, J.J.C., Euthanasie, in: E.H. Hermans (red.), Recent medisch ethisch denken I, Nederlandse Bibliotheek der Geneeskunde, Deel 40, Leiden 1968, p. 157-187

MC 1969, p. 1015: De oprichting van een abortus-kliniek (mededeling)

MC 1971, p. 104: Stichting voor het ongeboren kind opgericht. Mededeling

Meer, C. van der, De arts in confrontatie met de stervende, in: G. Beckers e.a. (red.), Menswaardig sterven, Baarn 1974", p. 13-31

Meer, C. van der, Euthanasie en medisch handelen, in: Euthanasie - recht, ethiek en medische praktijk, Amsterdam 1985, p. 69-83, (Beschouwingen voor een gezamenlijke vergadering van de Rechtskundige Afdeling van het Thijmgenootschap en de Calvinistische Juristen Vereniging op vrijdag 1 maart 1985 te Amsterdam)

Meerman, D, Goed doen door dood te maken, Kampen 1991 (diss.)

Meeuwissen, D.H.M., Recht en vrijheid. Inleiding in de rechtsfilosofie, Utrecht/Antwerpen 1982

Meijers, L.C.M., Een ongewone strafuitsluitingsgrond, in: Verantwoordle]ijk voor mensen (Goudsmit-bundel), Arnhem 1985, p. 121-128

Michels, J.J.M., Euthanasie, begripsomschrijving, in: G. Beckers e.a., Mensw aardig sterven, Baarn $1974^{3}$, p. $217-219$

Michels, J.J., De patiênt in coma - dilemma"s voor de arts, in: I.D. de Beaufort en H.M. Dupuis (red.), Handboek Gezondheidsethiek, Assen/Maastricht 1988, p. 361-366

Michiels-van Kessenich-Hoogendam, I.P., Euthanasie en het strafrecht, in: J. Elders, H. Keasberry, G. Kootstra, 1. Michiels van Kessenich-Hoogendam, Euthanasie, recht en praktijk, Assen/Maastricht 1985, p. 22-37

Minderheidsnota (Klijn, W.C.M. en W. Nieboer), in: Staatscommissie Euthanasie, Rapport, Advies, Deel 1, 1985, p. 191-334

Minderhoud, J.M., De arts en levensbeëindigend handelen bij comapatiënten, in: L. Boon (red.), Beslissen over leven \& dood, (Ontwikkelingen in de gezondheidszorg, deel 8) Amstelveen 1989 , p. $69-71$

Mol, J. en P. Mol, Over het staken van de behandeling bij ernstig gehandicapte pasgeboremen, MC 1988, p. 1535-1537

Molenaar, A.J., Is gedwongen abortus mogelijk?, NJB 1973, p. 384-385

Molenaar, J.C., K. Gill, H.M. Dupuis, Geneeskunde, dienares der barmhartigheid, NTwG 1988, p. 1913-1917

Molenaar, J.C., Het nalaten van medisch handelen, NTvG 1988 , p. 1925-1926 
Most, G. van der, Luisteren naar fluisteren, in: G. Beckers e.a. (red.), Menswaardig sterven, Baarn $1974^{3}$, p. 236-252

Mulder, G.E., De abortusproblematiek in het spaniningsveld van administratief recht en strafrecht, in: H.J.A.M. van Geest et al. (red.), Regel en praktijk: opstellen aangeboden aan prof. mr. S.F.L. baron wan Wijubergen ter gelegenheid van zijn 25 -jarig ambtsjubileum als hoogleraar staats- en bestuursrecht van de Katholieke Universiteit te Nijmegen, Zwolle 1979, p. 87-100

Mulder, J.H., Niet-behandelen en euthanasie in cen kankerkliniek, MC 1988, p. 1417-1419 Muntendam, P., Enkele sociaal-geneeskundige aspecten van abortus provocatus, NTvG 1966, II, p. 1337-1341

Musschenga, A.W., Kwaliteit van leven: criterium voor medisch handelen?, Baarn 1987 NAV, Vita Humanae, 1984, p. 165-168

Namens de Stuurgroep van het Abortus Protest, Open antwoord op een open brief, MC 1971, p. 1331-1332; De Stuurgroep, Memorandum van de "Stuurgroep van het Abortus Protest" inzake de eerbiediging van het menselijk leven, MC 1971, p. 1333

Nederlands Genootschap voor Medische Sexuologie over het abortusvraagstuk, MC 1970 , p. $279-281$

Nederlands Gesprek Centrum, Euthanasie, Baarn 1975

Nederlandse Gynaecologische Vereniging, Rapport - Abortus arte provocatus, MC 1969, p. 59-64

Nederlandse Vereniging van Anthroposolische Artsen wendt zich tot de Commissie-Abortusvraagstukken, MC 1970, p. 1285-1286

Nederlandse Vereniging voor Kindergeneeskunde, Doen of laten? - Het al of niet beginnen met en staken van levensverlengend handelen in de neonatologie, Interimrapport, 1989

Nederlandse Vereniging voor Psychiatrie en Neurologie, Rapport abortus-vraagstuk, MC 1970, p.143-154

Nederlandse Staatscourant, 29 sept. 1972, nr. 190.3 Gedragslijn Staatstoezicht Volksgezondheid

Nieboer, W., Willens en wetens, Arnhem 1978

Nieboer, W., Strafrechtelijke zorgplichten, in: Liber Amicorum (Van Veen-bundel), Leiden 1985

Nieboer, W., Verzuim, in: Naar eer en geweten (Liber Amiconum J. Remmelink), Arnhem 1987, p. $455-464$

Nieboer, W., Schets materieel strafrecht, Arnhem 1991

Nijhoff, G.C., NTvG 1895, 1, p. 1120-1124

Nijhoff, G.C., NTvG 1895,1, p. 1165

Nijhoff, G.C., NTvG 1905 , I, p. 130-131

Nijhoff, G.C, De verloskundige en de strafrechtsnovelle 1904 (Ontwerp Loeff), NTvG $1905, I$, p. 126-133

Nijhoff, G.C., NTvG 1905, 1, p. 1073-1075

Nijhoff, G.C., NTvG 1905 , II, p. 1691

Nijhoff, G.C., NTvG 1909, I, p. 1924-1926

Nijhoff, NTwG 1930, II, p. 4606-4609

Noyon, T.J., Het wetboek wan strafrecht, eerste deel, Arnhem $1904^{2}$

Noyon, T.J., Het wetboek van strafrecht, eerste deel en tweede deel, Arnhem 1926 $6^{4}$, derde deel, Arnhem $1927^{4}$

Noyon, T.J., Het Wetboek van Strafrecht, eerste deel, (bewerkt door G.E. Langemeijer), Arnhem $1947^{5}$ 
Noyon, T. I., Het Wetboek van Strafrecht, (bewerkt door G.E. Langemeijer), Amhem $1954^{\circ}$

Noyon, T.J., Het Wetboek van Strafrecht, (bewerkt door J. Remmelink), Arnhem 19717

NTvG 1928, I, p. 142-144; p. 486-488

NTVG 1930, I, p. 1303; p. 1811; p. 2053; p. 2298-2299; p. 2603-2604

NTVG 1930, II, p. $3983-3985$; p. $4601-4609$; p. 4628-4634; p. 6015

NTvG 1930, II, p. $4628-4634$

NTVG 1931,1, p. $168-169$

NTVG 1958, II, p. 2029

NTvG $1962, I$, p. 140

NTVO 1964,1, p. $484-485$

NTVG 1965,1, p. 672

NTVG 1965, II, p. 1448

NTVG 1971,1, p. 83

Nysingh, A., Iets over de werking der toestemming in het strafrecht, Leiden 1888 (diss.)

Ogilvie, HJ., Discussie over abortus provocatus, MC 1967, p. 1201-1202

Oidtman, A., De strafrechtelijke verantwoordelijkheid van den geneesheer, in: De verantwoordelijkheid van den geneesheer, Leiden z.j. (1908), p. 16-38,

Oostvogel, F.J.G., Stervensbegeleiding van oude(re) mensen, in: G. Beckers e.a. (red.), Menswaardig sterven, Baarn $1974^{3}$, p. 184-191

Outshoorn, J, De politieke strijd rondom de abortuswetgeving in Nederland 1964-1984, "s-Gravenhage 1986 (diss.)

Pannekoek, M.G., Discussie over abortus provocatus, MC 1970, p. 281-283

Passier-Meijer, H.C., Discussie over abortus provocatus, MC 1968, p. 352

Persoon, J. en F. Sturmans, Hoe artsen denken over abortus provocatus. Meningen van de Nederlandse artsen over abortus provocatus in relatie met godsdienstige ep politieke overtuiging, MC 1976, p. 649-655

Peters, A.A.G., Opzet en schuld in het strafrecht, Deventer 1966 (diss.)

Pijls, H.M., Criminele abortus, Algemeen Politieblad 1968, p. 171-175, p. 204-207, p. $225-227$, p. $252-255$, p. $276-280$, p. $295-298$

Pinkhof, H., De geneeskunst en de willekeurige onvruchtbaarheid, NTvG 1898, I, p. 523531

Pinkhot, H., NTrG 1898 , 1, p. $720-722$

Pinkhof; H., NTvG 1904, I, p. 1479-1480

Pinkhof, H., NTvG 1905 , II, p. 874

Pinkhof, H., NTvG 1910, 1, p. 62-63

Pinkhof, H., NTvG 1915, II, p. 526

Pinkhof, H., NTvG 1918, $\mathbb{1}$, p. 44

Pinkhof, H., NTvG 1918, I, p. 1018

Pinkhof, H., NTvG 1919, II, p. 532-533

Pinkhof, H., NTvG 1921, II, p. 1598

Pinkhof, H., NTvG 1921, II, p. 1012

Pinkhof, H., NTvG 1921, II, p. 1897-1898

Pinkhof, H., NTvG 1922, I, p. 232-236

Pinkhof, H., NTwG 1922, II, p. 2970

Pinkhof, H., NTvG 1925 , II, p. 2328-2329

Pinkhof, H., NTvG 1928 , I, p. 253

Pinkhof, H., NTvG 1929, I, p. 2563 
Pinkhof, H., NTvG 1930, II, p. 4581

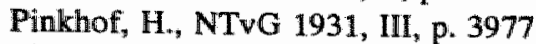

Pinkhof:, H., NTvG 1933 , III, p. 3402

Pinkhof, H., NTvG 1936,1 , p. 88-89

Pinkhof, H, NTvG 1936, 1, p.336-337

Pinkhof, H., NTvG 1936, 1.II, p. 1147

Pinkhof, H., NTvG 1937, II, p. 1487

Politoff, S.I. en F.A.J. Koopmans, Schuld, Arnhem $1991^{2}$

Pols, J., Discussie over abortus provocatus. Arts en menselijk leven, MC 1970, p. 977-981

Pompe, W.P.J., Handboek van het Nederlandse strafrecht, Zwolle $1959^{5}$

Postmes, A.J., Aanvaardbaarheid levensbeëindigend handelen, MC 1988, p. 806

Pouwels, T., Beslissingen over het levenseinde van wilsonbekwame zwakzinnigen, in:

L. Boon (red.), Beslissen over leven \& dood, (Ontwikkelingen in de gezondheidszorg; deel 8) Amstelveen 1989

Praag, J. van, Misdrijf in nood gepleegd, Amsterdam 1885 (diss.)

Prof. Dr. G.A. Lindeboom Instituut, Medische beslissingen rond het levenseinde - reactie Prof. Dr. G.A. Lindeboom Institunt op rapport-Remmelink, MC 1991, p. 1276-1278

Rang, J.F., Juridische vragen rondom euthanasie, in: G. Beckers e.a. (red.), Menswaardig sterven, Baarn $1974^{3}$, p. 261-270

Rapport van de Nederlandse Gynaecalogische Vereniging, Abortus arte provocatus, $\mathrm{MC}$ 1969 , p. $59-64$

Rapport abortus-vraagstuk van de Nederlandse Vereniging voor Psychiatrie en Neurologie, MC 1970 , p. $143-154$

Rapport van het Nederlands Genootschap voor Medische Sexuologie over het abortusvraagstuk, MC 1970 , p. 279-281

Rasker, J.J. en G.D.M. van Hellemond, Euthanasie een stap terug; visie van medici op recente rechterlijke uitspraken, NJB 1984 , p. $823-827$, p. 824

Redactie MC, Abortus, MC 1965, p. 909-910

Redactie NTvG, NTvG 1966 , I, p. 253-254

Reitsma, F.E., Discussie over abortus provocatus, MC 1968, p. 77-79

Remmelink, J., Onbevoegde uitoefening van beroepen in het Nederlands strafrecht, Utrecht 1951 (diss.)

Rijnbeek, G. van, Dr. H. Pinkhof. 1888-25 Februarij-1929. Een medisch-journalistiek jubilaeum, NTvG 1929, I, p. 898-900

Roessingh, I., Wederrechtelijk, TvS 1891, p. 308-331

Roest, F., Discussie over abortus provocatus, MC 1970, p. 426-428

Roethof, $\mathrm{H}_{\text {, }}$ De abortuskwestie en meer dan dat, "s-Gravenhage 1982

Romijn; H.J., Abortus provocatus; een neuro-biologisehe wisie, NJB 1973, p. 917-919

Roscam Abbing, H.D.C., Euthanasie en mensenrechten, in: J. Elders, H. Keasberry, G. Kootstra, I. Milchiels van Kessenich-Hoogendam, Euthanasie, recht en praktijk, Assen/Maastricht 1985 , p. $48-56$

Roscam Abbing, H.D.C., Medisch handelen bij het begin van het leven; enkele juridische kanttekeningen, NTvG 1988 , p. $1540-1543$

Rascam Abbing, H.D.C., Pasgeborenen, een commentaar naar aanleiding van een rapport van de KNMG-commissie; TvGR 1988, p. 467-475

Roscam Abbing, H.D.C en H.J.J. Leenen, MC 1988, p. 1265

Rutenfrans, CJ.C., Euthanasie: volg het spoor terug, Intermediair, 5 december 1986 , p. 3-7 en p. 59-61 
Rutgers, J., NTvG 1895, I, p. 1201-1203

Rutgers, J., NTVG 1903, II, p. 52-53

Schaffmeilster, D. en Heijder, A., Concretisering van de wrederrechtelijkheid in het strafrecht, in: Bij deze stand van zaken, Arnhem 1983, p. 441-474

Schalken, T.M. (A-G), Euthanasie en de rechtspolitieke betekenis van het gewetensconflict, NJB 1984, p. 38-50

Schalken, T.M., Euthanasie en handhaving van recht. Normatieve, procedurele en strafrechtspolitieke aspecten van het verwolgingsbeleid, in: Euthanasie - Recht, ethiek en medische praktijk, (Beschouwingen woor een gezamenlijke vergadering van de Rechtskundige Afdeling van het Thijmgenootschap en de Calvinistische Juristen Vereniging op vrijdag 1 maart 1985 te Amsterdam, Amsterdam 1985, p. 107-179

Schalken, T.M., Euthanasie een moratorium voor de wetgever?, DD 1986, p. 661-665 Schalken, T.M.; in: NRC 1 juni 1989

Schalken, T.M., Euthanasie of de ontluistering van een mythe, DD 1991, p. 837-841 Scheltens, D.F., rubriek: Besprekingen en aankondigingen, RR 1986, p. 176-180

Schlichting, Th.H., MC 1950, p. 321

Scholten, E.G., Greinzen van verpleegkundigen bij de zorgverlening, in: L. Boon (samensteller), Ethiek, recht \& zorg, (Ontwikkelingen in de gezondheidszorg, deel 4), Amstelveen 1986, p. $911-95$

Schouwen, H.P.A. van, NTvG 1969, II, p. 1861

Schreuder, J.Th.R., Het recht om te sterven, in: E.H. Hermans (red.), Recent medisch ethisch denken I, Nederlandse Bibliotheek der Geneeskunde, Deel 40, Leiden 1968, p. $146-156$

Schucking Kool, P.A., Discussie over abortus provocatus, MC 1967, p. 933-934

Schuckink Kool, P.A., MC 1968, p. 241-244

Schulte, J.E., MC 1950, p. 321-322, reactie op AE.S. Sluyterman, Euthanasie, MC 1950, p. $201-205$

Schulte, J.E., Discussie over abortus provocatus, MC 1967, p. 989-990

Schulte, J.E., NTvG 1969, II, p. 1704

Schulte, J.E., Discussie over abortus provocatus. Abortus provocatus in een nieuwe fase, MC 1970 , p. $781-782$

Schulte, J.E., MC 1975, p. 230-232

Schuurmans Stekhoven, W., Op weg naar de volledige vruchtverwijderingsvrijheid, NJB $1969, p_{2} 1007-1010$

Schuurmans Stekhoven, W., Medisch-juridische analyse wetsontwerp afbreking zwangerschap, MC 1972 , p. 417-421 en MC 1972, p. 770-771

Schuurmans Stekhoven, TrGR 1978 , p. 159

Semplonius, A., Dierenmishandeling (Artt. 254 en 455 W.v.S.), Utrecht 1920 (diss.)

Simons, D., Kritiek van den hoogleraar Mr. D. Simons te Utrecht op het voorstel A. van de Afdeeling Amsterdam, NTvG 1905, I, p. 1305-1315

Simons, D., Leerboek van het Nederlandsche Strafrecht, Eerste deel. Algemeene leerstukken, Groningen $1927^{5}$

Simons, D., Leerboek van het Nederlandsche Strafrecht, Tweede deel. Bijzondere strafbare feiten, Groningen $1923^{\text {th }}$

Simons, D., Problemen van het strafrecht, Amsterdam 1929

Singer-Dekker, H., De wet afbreking zwangerschap op de keper beschouwd of zullen we het dan nooit leren?, in: Liber Amicorum Van Veen, Arnhem 1985, p. 333-358 
Sluis, I. van der, Het recht om grootmoeder te doden. Korte geschiedenis van de enthanasiebeweging sinds 1870 , Amsterdam 1977

Sluyterman, AE, S., Euthanasie, MC 1950, p. p. 201-205

Sluyters, B., Geknipt verband, Rede uitgesproken bij de aanvaarding van het ambt van bijzonder hoogleraar in het gezondheidsrecht aan de Rijksuniversiteit te Leiden op 11 jamuari 1985, Deventer 1985

Smelt e.a., W.L.H., Geen actieve levensbeëindiging door de arts, MC 1989, p. 17-19

Smidt, H.J., Geschiedenis van het Wetboek van Strafrecht. Volledige verzameling van regeeringsontwerpen, gewisselde stukken, gevoerde beraadslagingen, enz., Eerste en Tweede Deel, Haarlem $1891^{2}$

Smidt, J.W., Vrije uitoefening der geneeskunde en het strafwetboek, Leiden 1889 (diss.)

Snijders-Borst, H., Wetje belAZer, NJB 1986 , p. 187-189

Soetenhorst-de Savornin Lohman, J., In droeve verwachting. Enkele sociaall-culturele en wetshistorische aspecten van de abortusproblematiek, NJB 1979, p. 553-560

Sporken, C.P., Katholieke moraal en abortus, MC 1967, p. 385-389

Sporken, $\mathrm{P}$, Actief doden van ernstig gehandicapte pasgeborenen. Ethische kanttekeningen, MC 1988 , p. $1238-1240$ en MC 1988 , p. 1554

Sporken, C.P., Zwakzinnigenzorg en ethiek, in: I.D. de Beaufort en H.M. Dupuis (red.), Handboek Gezondheidsethiek, Assen/Maastricht 1988, p. 343-351

Spreeuwenberg, C., Levensbeëindiging buiten aanwezigheid van een uitdrukkelijk verzoek van de betrokkene, in: I.D. de Beaufort en H.M. Dupuis (red.), Handboek Gezondheidsethiek, Assen/Maastricht 1988, p. 481-487

Stigt, A.J.N. van, Levensbeëindigend handelen bij zwaar defecte pasgeborenen, NJB 1989 , p. $1150-1154$

Staatscommissie Euthanasie, Rapport, Deel 1, 2, 3, 's-Gravenhage 1985

Steendijk, H.L., Geoorloofde euthanasie?, MC 1959 , p. 310

Strijards, G.A.M., Strafuitsluitingsgronden, Zwolle 1987 (Studiepockets strafrecht nr. 14)

Strijards, G.A.M., Aansprakelijkheidsgronden, Zwolle 1988 (Studiepockets strafrecht nr. 16)

Strijards, G.A.M., Het nieuwste wetsvoorstel inzake euthanasie, TvGR 1988, p. 138-147 Struycken, H.J.L., NTvG 1905, II, p. 873

Stuurgroep inzake abortus: MC 1971, p. 1331-1333

Sutorius , E.Ph.R. en D.J. Jansen, De juridische status van het levenstestament, AA 1991, p. $990-997$

Sutorius, E.Ph.R., Abortus en euthanasie: medisch handelen tussen het respect voor menselijk leven en de vrijheid tot zelfbeschikking, in: 100 jaar Wetboek van Strafrecht, Arnhem 1986, p. 395-423

Sutorius, E.Ph.R., Een antwoord op euthanasie vanuit het recht - vragen aan de jurist, in: C. Spreeuwenberg (red.), Verantwoorde levensbeëlndiging? Medische, ethische en juridische aspecten, Delft 1986, p. 35-55

Sutorius, E.Ph.R., Vrijwillige euthanasie of de gewetensfunctie van een rechtspolitiek conflict, NJB 1984 , p. $50-57$

Sutorius, E.Ph., De voorstellen van de Staatscommissie euthanasie in het licht van de jurisprudentie, TvGR 1985, p. 334-345

Tideman, W, Discussie over abortus provocatus, MC 1967, p. 1201

Tielboel van den Ham, M.G., De regel: "volenti non fit injuria' ten aanzien van klachtdelicten, TvS 1893, p. 101-113 
Tilled'Aulnis de Bourouill, H.A.H. van, Euthanasiediscussie 186e Algemene Vergadering, MC 1985, p. 560

Till-d'Aulnis de Bourouill, H.A.H. van, Patiëntenrecht en het artikel 292 bis van de Staatscommissie Euthanasie, MC 1985, p. 1347

Till-d'Aulnis de Bourouill, H.A.H. van, Medisch-juridische aspecten van het einde van het menselijk leven, Deventer 1970 (Serie Medisch Recht nr. 3) (diss.)

Treub, H., Abortus provocatus en strafwet, TwS 1896, p. 1-24

Treub, H., De geneesheer tegenover de facultatieve steriliteit, NTvG 1898, I, p. 745-755

Treub, H., Art. 307bis van het Wetboek wan Strafrecht, TvS 1902, p. 167-175

Treub, H., Nogmaals: abortus provocatus en Strafwet, TvS 1904, p. 475-481

Treub, H., NTVG 1905, II, p. 869-872

Treub, H. en A. Tak, Leerboek der gerechtelijke verloskunde, Haarlem 1908

Treub, H., Het jongste abortus-artikel in de Tweede Kamer, NTwG 1911, I, p. 849-852

Trommel, M.J. van, Discussie over abortus provocatus. De indicatiestelling door de huisarts, MC 1970, p. 1031-1033

Urk, G. van, Discussie over abortus provocatus, MC 1968, p. 209-213

Urk, G.R. van, Discussie over abortus provocatus, MC 1969, p. 383-385

Urk, G.R. van, Discussie over abortus provocatus, MC 1969, p. 485-486

Urk, G.R. van, Discussie over abortus provocatus. Persoonlijke verantwoordelijkheid, MC 1970 , p. $425-426$

Valkhoff, J., Abortus provocatus. Een juridies-sociologies onderzoek naar de doelmatigheid van de bestraffing der vruchtafdrijving, Haarlem 1933

Valkhoff, J., Ten gelleide, in: R.E. de Winter, Enkele aspecten van de aborius provacatus, Deventer 1966

Veen, Th.W. van, Ontbreken van materiële wederrechtelijkheid (1), DD 1975, p. 189-207

Veen, Th.W. van, Ontbreken van materiële wederrechtelijkheid (2), DD 1975, p. 274-290

Veen ${ }_{*}$ Th.W. van, Ontbreken van materiëlle wederrechtelijkheid, Nederlands Tijdschrift voor Rechtsfilosofie en Rechtstheorie (RR) 1980, p. 1-22 (preadvies)

Veen, Th.W. van, De 'Proeve' op de keper beschouwd, DD 1986, p. 876-889

Veen, Th.W. van, Euthanasie en de artikelen 293 en 294 . Het initiatief-ontwerp WesselTuinstra, NJB 1984, p. 1067-1070

Vermeulen, B.P., De vrijheid van geweten, een fundamenteel rechtsprobleem, Arnhem 1989 (diss.)

Vermunt, D., Nogmaals: de veearts van stall (I) en (II), DD 1984, p. 109-120 en p. 712-724

Vermunt, D. "De veearts' leent zich miet voor euthanasie ..., NJB 1985, p. 809-810

Versluys, C., Levensbeëindiging bij ernstig gehandicapte pasgeborenen, neonatologie met het oog op de toekomst: levensverlenging is geen doel op zich, MC 1989, p. 606607

Versluys, C., co-referent bij: Hoofdlijnen KNMG-discussienota inzake aanvaardbaarheid levensbeëindigend handelen bij zwaar-defecte pasgeborenen, in: $\mathbb{L}$. Boon (red.), Beslissen over leven \& dood, (Ontwikkelingen in de gezondheidszorg, deel 8), Amstelveen 1989 , p. $37-40$

Vlaming, Th.M., Prof. Hector Treub als strafwetgever, in: H. Treub, H. van Oppenray en Th.M. Vlaming, Het levensrecht der ongeboren vrucht, Haarlem 1901, p. 17-42 Voozitter van de KNMG, MC 1972, p. 715-716

Vos, H.B., Leerboek van Nederlandsch Strafrecht, Haarlem $1947^{2}$

Vroom-Kastelein, W.R. Wetsvoorstellen inzake euthanasie, Metamedica 1986, p. 85-97 W 2041, 2064, 2066, 2067, 8893, 9108, 10109, 10105 
Wall Amemann, R.W.C. van den, De Misdaad van Abortus, Amsterdam 1879 (diss.)

Werkgroep ad hoc van het Prof. Dr. G.A. Lindeboom Instituut, Zorg voor comapatiënten.

Bespreking KNMG-discussienota 'Levensbeëindigend handelen bij wils-onbekwame patiênten', MC 1991, p. 1481-1483

Werkgroep Euthanasie van de $\mathrm{KNMG}_{\text {, }}$ Discussienota, MC 1975, p. 7-16

Werkgroep Euthanasie van het Katholiek Studiencentrum, Vragen om de dood - Beschouwingen over euthanasie, Baarn 1983 (red. G. Dierick)

Wibaut, F., NTvG 1933, III, p. 3809-3810

Wibaut c.s., P., De overtijdbehandeling - Zeer vroege abortus artificialis of late interceptie?, MC 1987, p. 683-685

Wijmen, F.C.B. van, Gezondheidsrecht en euthanasie, in: J. Elders, H. Keasberry, G. Kootstra, I. Michiels van Kessenich-Hoogendam, Euthanasie, recht en praktijk, Assen/Maastricht 1985 , p. 12-21

Wijmen, F.C.B. van, Juridische aspecten van patiëntenvoorlichting, in: V. Damoiseaux en A.Ph. Visser (red.), Patiëntenvoorlichting. Een interdisciplinaire benadering Assen/Maastricht 1988 , p. 26-45

Wijmen, F.C.B. van, Een menswaardig leven, een menswaardige dood, V(r)ijvertaal(d), nr. 6,1988 , p. 11

Wijmen, F.C.B. van, Artsen en het zelfgekozen levenseinde; verslag van een onderzoek onder artsen naar opvattingen en gedragingen ten aanzien van euthanasie en hulp bij zelfdoding, Vakgroep Gezondheidsrecht Rijksuniversiteit Limburg 1989

Wijmen, F.C.B. van, Driehoeksverhoudingen - gezondheidsrechtelijke beschouwingen over vertegenwoordiging van meerderjarige onbekwamen, Preadvies voor de Vergadering voor Gezondheidsrecht ten behoeve van de jaarvergadering op 27 april 1990

Willigenburg, T. van, Levensbeëindiging bij zwakzinnigen en ethiek, in: $\mathbb{L}$. Boon (red.), Beslissen over leven \& dood, (Ontwikkelingen in de gezondheidszorg, deel 8), Amstelveen 1989 , p. $85-88$

Winter, R.E. de, Enkele aspecten van de abortus provocatus, Deventer 1966

Witsen, H.M., Rechtskundige beschouwingen over vivisectie, Amsterdam 1888 (diss.)

Wttewaall, G., Opzet bij dierenmishandeling, TvS 1898, p. 118-126

Zeben, W. van, Euthanasie en de kinderarts, in: P. Muntendam (red.), Euthanasie, De Nederlandse Bibliotheek der Geneeskunde, Deel III, nr. 111, Leiden 1977, p. 169-176 

Jurisprudentieregister

HR 13 april 1852, W 1326129

HR 31 okt. 1887, W 548926

HR 30 april 1888, W 555526

HR 23 febr. 1891, W 599936

HR 25 juni 1894, W 653431

HR 24 mei $1897, W 697863,69$

HR 1 nov. 1897, W 703869

HR 12 april 1898, W 711363

HR 12 dec. 1898, W 721626

HR 21 meil 1900, W 746134

HR 5 nov. 1900 , W 751336

HR 10 febr. 1902 , W 772336,37

HR 11 maart 1907, W 851069

HR 29 juli 1907, W 858069

HR 26 okt. 1908, W 875935

HR 15 maart 1909 , W 884234

HR 24 juni 1912, W 936789

HR 26 juni 1916, NJ 1916, 703227

HR 13 mei 1918, W 10252 m.nt. D.S. 27

HR 11 nov. 1918, W 10347 m.nt. D.S., NJ 1918, 124527

HR 13 jan. 1919, W 10385 m.nt. D.S. 27

HR 11 okt. 1920, W 10635, NJ 1920, 109627

HR 16 jan. 1922, W 10870, NJ 1922, 34528

HR 25 juni 1923, NJ 1923, 129696

HR 10 juni 1924, W 1129937

HR 28 juni 1926, NJ 1926, 785 m.nt. L.B. 37

HR 25 nov. 1929, NJ 1930, 14196

HR 27 juni 1932, NJ 1933, 60 m.nt. W.P., W 12545 m.nt. M.P.V. 11, 53

HR 20 febr. 1933, NJ 1933, 918 m.nt. T., W 12600 m.nt. J.M.v.B. 12, 53

HR 15 jan. 1934, NJ 1934, 403 m.nt. W.P. 37

HR 5 febr. 1934, NJ 1934, 68289

HR 14 okt. 1940 , NJ 1941, 8734

HR 27 april 1942, NJ 1942, 59389

HR 8 febr. 1944, NJ 1944, 314203

HR 9 nov. 1954, NJ 1955, 55 m.nt. W.P. 297

HR 9 mei 1961, N.J 1962, 83 m.nt. B.V.A.R. 117

HR 16 jan. 1968, NJ 1969, 2 m.nt. Bronkhorst 227

HR 11 mei 1976, NJ 1976, 538 m.nt. ThWvV 14

HR 28 nov. 1978, NJ 1979, 93 m.nt. ThWvV 17, 42 
HR 11 mei 1982, NJ 1982, 583 m.nt. A.C. 't Hart 207

HR 15 juli 1983 , NJ 1984,63 m.nt. GEM 230

HR 11 okt. 1983, NJ 1984, 111 m.nt. A.C. 't Hart 207

HR 10 april 1984, NJ 1984, 612 m.nt. 'tH 207

HR 27 nov. 1984, NJ 1985, 106 m.nt. ThWwV 17, 20, 121, 130, 166, 167, 174,

$205-213,221,222,223,227,229,230$

HR 18 juni 1985, NJ 1986,183207

HR 21 okt. 1986, NJ 1987, 607 m.nt. GEM 15, 53, 61, 77, 121, 190, 213, 217, 218, $220,221,223,224,237,309$

HR 23 juni 1987, NJ 1988, 157 m.nt. ThWwV 232, 237, 295, 314

HR 15 dec. 1987 , NJ 1988, 811 m.nt. C $18,157,186$

HR 3 mei 1988, NJ 1989, 391 m.nt. GEM $220,227,226,231,237,314$

HR 21 febr. 1989 , NJ 1989, 668 m.nt. 'tH 47

HR 28 april 1989, NJ 1990, 46 m.nt. GEM 260, 293, 285, 295, 299, 301-303

HR 28 april 1989, NJ 1990, 47285,293

HR 8 mei 1990 , DD 90.291282

HR 29 mei 1990, NJ 1991, 217 m.nt. Schalken 120

HR 19 juni 1990 , NJ 1991, 119 m.nt. ThWvV en MS 240

HR 5 maart 1991, NJ 1991, 694 m.nt. C 240

HR 28 meil 1991 , NJ 1991,789 m.nt. 'tH 233

Hof Amsterdam 17 nov. 1983, NJ 1984, $43205,208-210,213,218,222$

Hof Arnhem 19 okt. 1976, NJ 1977, 1098

Hof Arnhem 27 febr. 1987, TvGR 1987/35 220

Hof Arnhem 31 okt. 1989, TvGR 1990/18 291

Hof Arnhem 16 jan. 1990, TvGR 1990/39; NJ 1990, 470292

Hof Den Bosch, 22 dec. 1953, NJ 1954, 16197

Hof Den Haag 9 april 1979, TvGR 1979/95 98

Hof Den Haag 10 juni 1985 en 11 sept. 1986, NJ 1987, 608 m.nt. GEM 223

Hof Den Haag 12 nov. 1986, NJ 1987, 609 m.nt. GEM. TvGR 1987/11 166, 289

Hof Den Haag 25 okt. 1988, TvGR 1989/13 289

Hof Den Haag 23 maart 1989, NJ 1989, 808120

Hof Leeuwarden 11 okt. 1984, NJ 1985, 241209,220

Rb. Alkmaar 10 mei 1983, NJ 1983, $407205,208-210,215,231-236$

Rb. Alkmaar 8 juli 1986, TvGR 1986/61 287, 289

Rb. Almelo 1 juli 1987, TvGR $1987 / 50285$

Rb. Almelo 1 maart 1988, TvGR 1988/43 288-290

Rb. Almelo 26 sept. 1989, TvGR 1990/5 226, 234

Rb. Amsterdam 21 sept. 1909, PvJ 1910, nr. 978203

Rb. Amsterdam 27 april 1938, NJ 1939, 55438

Rb. Amsterdam 5 febr. 1942, NJ 1942, 24497

Rb. Amsterdam 20 jan. 1949, NJ 1949, 59697

Rb. Amsterdam 26 maart 1953, NJ 1953, 37798

Rb. Amsterdam 8 juli 1976, NJ 1977, 47798

Rb. Amsterdam 30 maart 1988 , TvGR $1988 / 65 \quad 286,288-290$ 
Rb. Den Bosch 7 jan. 1938, NJ 1938, 23138

Rb. Den Haag 21 juni 1985, NJ 1985, 709 221, 222

Rb. Den Haag 6 aug. 1985, NJ 1985, 708 219, 232, 288-290

Rb. Groningen 1 maart 1984, NJ 1984, 450 209, 217, 221, 226, 231-235

Rb. Haarlem 8 febr. 1984, NJ 1986, 13347

Rb. Haarlem 4 april 1986, NJ 1987, 287, TvGR 1986/34 217, 219, 222, 286, 287, 289,290

Rb. Leeuwarden 21 febr. 1973, NJ 1973, 183 141, 221, 225, 230-234

Rb. Rotterdam 20 okt. 1925, NJ 1925, 1175 m.nt. L.B. 38

Rb. Rotterdam 1 dec. 1981, NJ 1982, 63, TvGR 1982/7 209, 210, 215, 221, 229-236, 240

Rb. Rotterdam 31 maart 1987, TVGR 1988/1 286, 288, 289

Rb. Utrecht 19 febr. 1938, NJ 1938, 33396

Rb. Utrecht 11 maart 1952, NJ 1952, 275 203, 228

Rb. Utrecht 21 dec. 1982, NJ 1983, 264 208, 222, 226, 228

Rb. Utrecht 5 juli 1985, TvGR 1986/22 234

Rb. Utrecht 11 jan. 1991, TvGR 1991/28 293

Rb. Zwolle 13 dec. 1989, TvGR 1990/63 182

Gerecht in eerste aanleg Aruba van 14 maart 1980, NJ 1981, 9798

CMT 29 maart 1990, TvGR 1990/77 233

Medisch Tuchtcollege Amsterdam 6 mei 1985, TvGR 1985/45 286 

Register aangehaalde auteurs

Abbink, H. 294, 295, 299, 301, 303

Agt, A.A.M. van 155, 157

Alkema, E.A. 168, 169

Alphen, H.A.M. van 172, 175, 247, 250, 263

Arend, A.J.C. van der 287

Baas, A.R. 129, 131

Balen Blanken, G.C, van $89,90,96$

Batenburg, M. 73

Bemmelen, J.M. van $28,32,35,42,44,47,99,105,138$

Beneditty, $\mathbf{N}$. de 26

Berg, J.H. van den 140,144

Bergkamp, L. 223

Berkestijn, Th.M.G. van 246,250

Besier, L.Ch. 38

Bijleveld, P.J. 49, 129, 130, 134

Binding, K. 138

Bins, J. 149

Binsbergen, W.C. van 187, 205, 224

Blois, M. de 169, 299

Boekelman, W.A. 76, 134, 135

Boon, J.M. 246, 261, 263

Borst, W.L. 294, 295, 299, 301, 303

Brands-Bottema, G.W. 297, 299, 303

Bronkhorst, C. $67,68,105,219,225,238$

Brouns, P.J.H.M., 33-37, 117

Bruiǰn, J. de $57,59,92,97,103,112$

Burger, $\mathbb{H} .71-74,134,136$

Corstens, G.J.M. 186,240

Croughs, R.W.M. 250, 252, 259, 265, 301

Dam van Isselt, E.W. van $36,39,40,44,45,49-51,63,65,67,69,74,75,96$

Damoiseaux, V. 177

Davelaar-Van Tongeren, V.H. $105,114,118$

Demeersseman, H.A. 282

Derksen, Th.W.J. 134, 140,142, 155

Dessaur, C.I. 149

Dijk, J.V. van 87

Dijk, P. van 167-169

Doelder, H. de $23,36,40,47$

Does de Willebois, Jhr. J.A. van der 141 
Domela Nieuwenhuis, J. 39, 51

Doorn, JK van 94

Dorbeck, A.J.F.M.N. 41, 42, 44, 45, 51, 134, 135

Dörner, K. 150

Dorst, A.J.A van 47

Drooge, A.C. van 67

Dupuis, H.M. 6, 255, 261, 263, 297, 298, 301, 303

Dupuis, P.J.F, 94

Eikema-Hommes, H.J. van 15, 19, 211, 214

Elders, J. 187

Enschedé, Ch.J. 18, 19, 30, 51, 77, 97.99, 131, 153, 157, 185, 190, 216, 224, 238, 310,312

Enthoven, L. 129, 131, 141

Es, J.C. van 141

Feber, H.R.G. $128,239,240$

Fokkens, J.W. 299, 303

Frenkel, F.E. 97.99, 105

Frets, G.P. 138

Fretz, L. 142

Gevers, J.K.M. 9, 156, 173, 174, 192, 278, 280

Gewin, B. 36

Gill, K 255, 297, 298, 301, 303

Greeve, M. 133

Griffiths, J. 195

Haak, B. van der 43

Hallie, D.J. 94

Hamel, G.A. van $26,32,34,37,41,43,44,51,68,84,87$

Hart, A.C. 't $23,36,39,40,47,207,233$

Haspels, A.A. 94

Hattum, W.F.C. van $30,32,40,44,68,88$

Hazelhoff, $\mathrm{K} .35,36,38$

Hazewinkel-Suringa, D. $34,37,39,41,44-46,68,88$

Heemskerk, Th. 35, 36, 38

Heering, M.J. 94

Heljder, A. 14-17, 211

Heijinsbergen, P. van $63,89,90,96$

Hellemondt, G.D.M. van 154

Hertogh, C.M.P.M. 260

Hirsch, S.J. 49,131

Hirsch Ballin, E.M.H. 151

Hoche, A. 138

Hoeven, H. van der 30,68

Holland, W.A. 228

Hoof, G.J.H. van 167-169

Hoofdbestuur KNMG 93, 95, 96, 143, 146-148, 150, 151, 155, 173

Houben, G.M.M. 142, 174, 280

Hubben, J.H. 296, 303

Hugenpoth tot Aerdt, G. van 44, 47, 49-51 
Hulsman, L.H.C. 114

Hulst, I.P.L. 138

Hylkema, B.S. 251

Indewey Gerlings-Huuman, Th. 141

Jacobs, Aletta H. 74

Jager, L. de 62

Jansen, D.J. $180,182,315$

Jongsma, M.W. 140

Josephus Jitta, A.N.A. 153, 154, 188, 240, 278

Kastelein, W.R. $167,180,182$

Katholieke Vereniging voor Ziekeninrichtingen $246,250,252,263$

Kelk, C. 207, 214, 284, 294-297, 299, 303

Ketting, E. 57, 90, 92-94

Keuller, J.M.I. 73, 134, 135

Klijn, W.C.M. $128,151,153,155,157,158,164,165,192,279,298$

Kloosterman, G.J. 99

Knigge, G. 284

KNMG $6,92,139,143,155,280$

Koch, J.D.C. 72

Koopmans, F.A.J. 33, 34, 224, 227, 283

Kortbeek, L.H.Th.S. 140

Kortmann, M.G.J.M. 99

Kouwer, B.J. 90,91

Kruyver, G.P.M. 94, 95

Kuijper, C.M. de 87

Kuittert, H.M. 249, 261, 264

Lange, S.A. de $249,251,252$

Langemeijer, G.E. $42,44,68,99,114,157,216$

Leenen, H.J.J. $4,5,8,18,23,36,40,45,47,52,88,99,115,118,123,124,150-152$, $154,155,156-158,164,180,181,183,185,187,191,197,214,263,274,280$, $285,299,303,315,317$

Lette van Oostvoorne, N.J.C. $42,44,48$

Lier, E.H.D. van 91

Lindeboom, G.A. 96, 133, 140, 141, 150

Loghem Sr, J.J. van 139

Loon, W, van $40,43,51$

Mante, A.W. 94

Marlet, J.J.C. $153,155,272,273$

Meer, C. van der $3,128,141,151,153,155,157,181,187$

Meerman, D. 133

Meeuwissen, D.H.M. 312

Meijers, L.C.M. 118

Michels, J.J.M. 157, 251, 252, 273

Michiels-van Kessenich-Hoogendam, I.P. 188

Minderhoud, J.M. 252

Mol, J, en P. 258

Molenaar, A.j. 94

Molenaar, J.C. $255,297,298,301,303$ 
Most, G. wan der 273

Mulder, G.E. $15,30,64,88-89,227,293,295,299,301,302$

Mulder, J.H. 263

Muntendam, P. 92

Musschenga, A.W. 244, 252, 253, 261, 264, 272, 317

Namens de Stuurgroep van het Abortus Protest 96

Nederlands Genootschap voor Medische Sexuologie 95

Nederlands Gesprek Centrum 153, 154

Nederlandse Gynaecollogische Vereniging 58,94

Nederlandse Vereniging van Anthroposofische Artsen 95

Nederlandse Vereniging voor Psychuatrie en Neurologie 95, 99

Nieboer, W. $16,27,29,32,33,35,37,46,155,158,165,213,223,282-284,296$

Nijhoff, G.C. $58,62,66,67,70-73,76,78,79,91$

NLR $26,28,33,88,98,116-118,120,121,129,131,188$

Noyon, T.I. 26, 28, 34-37, 40,42, 43, 68, 69, 89, 129

Nysingh, A. 41-44, 48, 129

Ogilvile, H.J. 94

Oidtman, A. $73,134,135$

Oostvogel, F.J.G. 141

Outshoorn, J. $57,92,96,101,103,104,112,114$

Pannekoek, M.G. 95

Passier-Meijer, H.C. 94

Persoon, J. 94

Peters, A.A.G. 33

Pijls, H.M. 63, 88, 97-99

Punkhof, H. $45,66,73,74,89,91,134-139$

Poll, U. van de $105,114,118$

Polenaar, B.J, 35, 36, 38

Pollitoff, S.I. 33, 34, 224, 227, 283

Pols, J. 94

Pompe, W.P.J. 51, 63

Postmes, A.J. 265

Pouwels, T. 273

Praag, J. van 67, 87

Prof. Dr. G.A. Lindeboom Instituut 285

Rang; J.F. $153,155,157,278,282$

Rasker, Ji. 154

Redactie MC 92

Redactie NTvG 92

Reitsma, F.E. 93

Remmelink, J. 9, 17-19, 23, 30, 32-35, 37, 38, 42-44, 47, 63, 88, 117, 118, 120, 130 , $131,209-211,213,219,221,226,227,229,283,284$

Rijnbeek, G. van 136

Roessingh, I. 48

Roest, F. 94

Roethof, H. 57

Romijn, H.J. 94

Roscam Abbing, H.D.C. 156, 157, 251, 258, 263, 282-284 
Rutenfrans, C.J.C. $133,149,150$

Rutgers, J. 66, 134

Schaffmeister, D. 14-17, 211

Schalken, T.M. $16,17,121,132,154,157,169,181,195,205,207,208,211,213$, $214,221,224,225,227,228,239,240,295,312$

Scheltens, D.F. 164

Schlichting, Th.H. 139

Scholten, E.G. 287

Schouwen, H.P.A. van 94

Schreuder, J.Th.R. 140, 153

Schucking Kool, P.A. 94

Schulte, J.E. 94, 105, 139, 140

Schuurmans Stekhoven, W. 23, 93, 105, 107

Semplonius, A. $26,27,30$

Simons, D. $25,26,28,31,40,42,43,50,52,63,67-69,71,74,75,88,91,96$

Singer-Dekker, H. 115,119

Sluis, I. van der 133,150

Sluyterman, AE., S. 139

Sluyters, B. 214

Smelt, W.L.H. 246, 250, 265

Smidt, J.W. $36,48,50,59,65$

Snijders-Borst, H. 115

Soetenhorst-de Savornin Lohman, J. 114

Sporken, C.P. 73, 263, 274

Spreeuwenberg, C. $272,274,275,303$

Staatscommissie $150,151,154,158$

Steendijk, H.L. 140

Stigt, A.J.N. van 283,297, 300, 303

Strijards, G.A.M. 17, 21, 30, 32-34, 39, 42, 43, 46, 170, 214, 227, 282-284

Struycken, H.J.L. 73

Sturmans, F. 94

Stuurgroep inzake abortus 96

Sutorius, E.Ph.R. 151, 152, 174, 176, 180, 182, 205, 224, 280, 315

Tak, A. 63, 64, 66, 69

Taverne, B.M. 13

Tideman, W. 94

Tielboel van den Ham, M.G. 42

Till-d'Aulnis de Bourouil.", H.A.H. 223, 279, 280

Treub, H. $58,63,64,66,67,69,71-76,84$

Trommel, M.J. van 105

Urk, G.R. van 94,95

Valkhoff, J. 90,98

Veen, Th.W. van $14,15,67,125,133,153,157,171-173,176,179,182,185,187$, $188,192,194,204,207,208,214,216,225,227,228,282,283$

Vermeulen, B.P. 227

Vermunt, D. $14-16,19,208$

Versluys, C. $244,246,250,265$

Vlaming, Th.M. 73, 134, 135 
Vos, H.B. $34,35,44,87$

Vroom-Kastelein, W.R. 159, 174, 176, 194

Wall Arnemann, R.W.C. van den 58, 59

Werkgroep ad hoc van het Prof. Dr. G.A. Lindeboom Instituut 266

Werkgroep Euthanasie 144-146, 151, 155

Werkgroep Euthanasie van het Katholiek Studiencentrum 141, 152

Wibaut, F. 121, 122, 138

Wijmen, F.C.B. van $153,155-157,177,181,182,230$

Willigenburg, T. van 273

Winter, R.E. de 93

Witsen, H.M. $47-49,51$

Wttewaall, G. 26, 27

Zeben, W. van 244 


\section{Curriculum vitae}

De auteur werd 4 mei 1947 te Datteln in Duitsland geboren. Hij studeerde aan de Universiteit Bochum Sociale Wetenschappen en behaalde in 1973 het Kandidaatsdiploma. Van 1977 tot 1983 studeerde hij Rechten aan de Rijksuniversiteit Groningen.

Sinds november 1983 is hij aan de Juridische Faculteit der Rijksuniversiteit Lïmburg verbonden; eerst als wetenschappelijk medewerker en vanaf 1987 als universitair docent. In de jaren 1984 tot 1991 was hij tevens plaatsvervangend griffier bij de rechtbank Roermond. 